\title{
Grens en gezin : beleidsvorming inzake gezinsmigratie in Nederland, 1955-2005
}

Citation for published version (APA):

Bonjour, S. A. (2009). Grens en gezin : beleidsvorming inzake gezinsmigratie in Nederland, 1955-2005. [, Maastricht University]. Maastricht University. https://doi.org/10.26481/dis.20090619sb

Document status and date:

Published: 01/01/2009

DOI:

10.26481/dis.20090619sb

Document Version:

Publisher's PDF, also known as Version of record

\section{Please check the document version of this publication:}

- A submitted manuscript is the version of the article upon submission and before peer-review. There can be important differences between the submitted version and the official published version of record.

People interested in the research are advised to contact the author for the final version of the publication, or visit the DOI to the publisher's website.

- The final author version and the galley proof are versions of the publication after peer review.

- The final published version features the final layout of the paper including the volume, issue and page numbers.

Link to publication

\footnotetext{
General rights rights.

- You may freely distribute the URL identifying the publication in the public portal. please follow below link for the End User Agreement:

www.umlib.nl/taverne-license

Take down policy

If you believe that this document breaches copyright please contact us at:

repository@maastrichtuniversity.nl

providing details and we will investigate your claim.
}

Copyright and moral rights for the publications made accessible in the public portal are retained by the authors and/or other copyright owners and it is a condition of accessing publications that users recognise and abide by the legal requirements associated with these

- Users may download and print one copy of any publication from the public portal for the purpose of private study or research.

- You may not further distribute the material or use it for any profit-making activity or commercial gain

If the publication is distributed under the terms of Article $25 \mathrm{fa}$ of the Dutch Copyright Act, indicated by the "Taverne" license above, 
GRENS EN GEZIN 
Deze uitgave is mede tot stand gekomen dankzij een financiële bijdrage van:

J.E. Jurriaanse Stichting

M.A.O.C. Gravin van Bylandt Stichting

SNS REAAL Fonds

SNS REAAL Fonds

Omslagontwerp: Frits van Hartingsveldt, Amsterdam Opmaak: Ellen Bouma, Alkmaar 


\title{
Grens en gezin \\ Beleidsvorming inzake gezinsmigratie in \\ Nederland, 1955-2005
}

\author{
PROEFSCHRIFT \\ Ter verkrijging van de graad van doctor \\ aan de Universiteit Maastricht
}

op gezag van de Rector Magnificus, Prof. mr. G.P.M.F. Mols, volgens het besluit van het College van Decanen, in het openbaar te verdedigen

op vrijdag 19 juni 2009 om 14.00 uur

door

Saskia Anne Bonjour 


\section{Promotores}

Prof. dr. Arnold Labrie

Prof. dr. Ton Nijhuis (Universiteit van Amsterdam)

\section{Beoordelingscommissie}

Prof. dr. Tannelie Blom, voorzitter

Prof. dr. Ad Knotter

Prof. dr. Leo Lucassen (Universiteit Leiden)

Prof. dr. Rinus Penninx (Universiteit van Amsterdam)

Prof. dr. Hildegard Schneider 


\section{Dankwoord}

Ik prijs mezelf gelukkig met mijn promotoren, Arnold Labrie en Ton Nijhuis: met de ruimte die ze me gunden, met hun scherpzinnige en constructieve kritiek, en met hun steun waarvan ik me steeds verzekerd wist. Voor de ingewikkelde evenwichtstoer die het begeleiden van een promotieonderzoek is zijn Arnold en Ton wat mij betreft met vlag en wimpel geslaagd.

Het Nationaal Archief is een fantastische plek om onderzoek te doen, en dat is grotendeels te danken aan de vriendelijkheid en hulpvaardigheid van de mensen die er werken. Ook bij het ministerie van Justitie en de IND ben ik hartelijk ontvangen. Voor het speurwerk dat zij voor mij hebben willen doen dank ik in het bijzonder Cees Rooyakkers, Maarten van Rijn en de beleidsmedewerkers van het ministerie van Algemene Zaken. Ik ben positief verrast door de bereidheid van de Nederlandse overheid om ook recente interne beleidsstukken ter beschikking te stellen voor onderzoek: een openheid die in internationaal perspectief niet vanzelfsprekend is.

Voor hun opmerkingen bij mijn teksten, hun antwoorden op mijn vragen, en de bron van inspiratie en plezier in mijn onderzoek die zij voor mij vormden dank ik Evelyn Ersanilli, Kees Groenendijk, Betty de Hart, Tessel de Lange, Leo Lucassen, Rinus Penninx, Klaartje Peters, Marlou Schrover, Maarten Vink en Sarah van Walsum.

De Faculteit der Cultuur- en Maatschappijwetenschappen was een inspirerende uitvalsbasis, waar ik me thuis voelde. Voor de praktische en inhoudelijke tips, de onmisbare morele steun en de zalige aio-soepen dank ik mijn collega-aio's: Alissa, Babette, Cornelia, Elissaveta, Hendrik-Jan, Johannah, Josje, Julia, Leen, Ludo, Maaike, Martijn, Maud, Merel, Mieneke, Niki, Patrick, Roel, Serge, Sophie, Thijs en Vivian. Tom Sintobin was mijn kamergenoot op de faculteit in de eerste twee jaar van mijn promotieonderzoek, en heeft me met picknicks in het park en verhalen over dichters en vissen door die niet altijd eenvoudige jaren heen geholpen. Dat $\mathrm{ik}$ in de laatste twee jaar geen boekenwurm met tunnelvisie ben geworden is grotendeels te danken aan de mensen van Provum: Mariolina, Gjalt-Jorn, Kees, Erik en de anderen.

Bij mijn tante en oom Aukje van Roessel en René Dekeling vond ik - maanden aan een stuk - onderdak tijdens mijn archiefonderzoek in Den Haag. Ik heb genoten van hun gastvrijheid en voel me al sinds de middelbare school gesterkt door hun betrokkenheid bij al wat ik onderneem. 
Ik kan hier met geen mogelijkheid recht doen aan de steun, uitdaging, troost, afleiding en aanmoediging die ik bij mijn familie- en vriendenkring vond en vind. Ik noem daarom alleen Floor Manschot en Karin de Kroes, twee prachtige mensen en dierbare vriendinnen. Zij zijn mijn paranimfen en ik ben blij dat zij bij de verdediging van dit proefschrift achter me zullen staan, zoals ze altijd achter, naast of voor me staan als het er toe doet.

Ik draag dit boek op aan het gezin waarin ik heb geleerd om over grenzen heen te reiken: aan mijn moeder Brechje van Roessel, à mon père Richard Bonjour, aan mijn zus Maeva en aan mijn broer Yovan, die ik mis. 


\section{Inhoudsopgave}

Dankwoord

Afkortingen

1. Inleiding

1.1 Waarom gezinsmigratiebeleid maken ingewikkeld is

1.2 Constructivistische kijk op politiek en beleidsvorming

1.3 Probleemstelling en afbakening

Beleidsvorming in Nederland inzake gezinsmigratie tussen 1955 en $2005 \quad 20$

Institutionele structuur en invloedsverhoudingen

Fasen en breuklijnen in de beleidsontwikkeling in context

1.4 Academische positionering

Een blinde vlek op de kaart van migratiestudies in Nederland

Invloedsverhoudingen in Nederlandse beleidsvormingsprocessen

De paradox van het migratiebeleid in liberale democratieën

1.6 Opzet van dit boek

2. Ambtelijke onmin over gezinnen van gastarbeiders, 1955-1975

2.1 Inleiding

2.2 Immigratie in Nederland tussen 1945 en 1975

Buitenlandse gezinsleden van Nederlandse staatsburgers

Migranten uit voormalig Nederlands-Indië

Vluchtelingen

Arbeidsmigranten

2.3 Institutionele structuur

2.4 Drie beleidsperspectieven op gezinsmigratie 54

Eén gemeenschappelijk uitgangspunt 54

De vitale belangen van de Nederlandse volkshuishouding 55

Maatschappelijke gevolgen op de lange termijn 60

Het morele gewicht van het gezin 
2.5 De eerste jaren van de werving 64

Verbod op gezinshereniging (1955-1960) 64

Gezinshereniging voor Gemeenschapsonderdanen 66

Gezinshereniging voor arbeidsmigranten van buiten de EEG 68

2.6 Wachten op welkom: geschillen over de wachttijd 70

$\begin{array}{ll}\text { Van } 2 \text { naar } 1 \text { jaar voor Spanjaarden } & 70\end{array}$

Verdere verlaging van de wachttijd 73

$\begin{array}{ll}\text { Justitie als hoeder van homogeniteit } & 74\end{array}$

2.7 Ruzie over Spaanse echtgenotes 78

$\begin{array}{ll}\text { Uitzondering voor werkzame echtgenotes } & 79\end{array}$

$\begin{array}{ll}\text { Publiek rumoer } & 81\end{array}$

2.8 Radicale voorstellen $\quad 85$

Politisering $\quad 85$

De Nota Buitenlandse Werknemers $\quad 87$

De brief van minister Polak 88

Op voorstel van Justitie: een rotatie-systeem 89

De Memorie van Antwoord 92

2.9 Macht en onmacht in een beleidsdebat $\quad 94$

Justitie's twijfel aan tijdelijkheid 94

De overtuigingskracht van argumenten 96

$\begin{array}{ll}2.10 \text { Besluit } & 101\end{array}$

3. Een open gezinsmigratiebeleid in krappe tijden, 1975-1989 107

3.1 Inleiding 107

3.2 Einde van de werving, maar niet van immigratie 108

$\begin{array}{ll}3.3 \text { Institutionele structuur } & 111\end{array}$

Het parlement $\quad 111$

De rechtspraak 113

Verhoudingen binnen en tussen de ministeries $\quad 116$

3.4 Revolutie in de zeden $\quad 117$

Homo- en heteroseksuele niet-huwelijkse partners 119

Echtgenoten van Nederlandse vrouwen $\quad 121$

Echtgenoten van buitenlandse vrouwen 123

$\begin{array}{lr}\text { Schijnhuwelijk en schijnrelatie } & 125\end{array}$

$\begin{array}{ll}\text { Verruimde gezinshereniging } & 126\end{array}$

3.5 Nieuwe vreemdelingen: de onafhankelijkheid van Suriname 128

De overeenkomst van $1975 \quad 130$

De overeenkomst van $1980 \quad 132$ 
3.6 Paradigmawisseling: van gasten naar volwaardige medeburgers 134 Het tijdelijkheidsdenken onder druk 134

Het minderhedenbeleid 137

Gezinsmigratiebeleid, minderhedenbeleid en de 'rechten'van migranten 138

De omslag bij Justitie 142

3.7 De Tweede Kamer op de bres voor vrouwenemancipatie 148

Gelijke behandeling van mannen en vrouwen in het vreemdelingenbeleid 150

De afhankelijke verblijfsstatus 153

Gelijkstelling van mannen en vrouwen in het nationaliteitsrecht 161

3.8 Restrictieve tendensen in de jaren tachtig 162

Een voorzichtige omslag 162

De feitelijke gezinsband 165

Een nieuwe beleidscategorie: 'gezinsvorming' 167

$\begin{array}{ll}3.9 \text { Besluit } & 177\end{array}$

4. De restrictieve wending in het Nederlands gezinsmigratiebeleid, 1989-2005 183

4.1 Inleiding 183

4.2 De institutionele structuur $\quad 184$

Invloedsverhoudingen in Den Haag 184

Een nieuwe beleidsarena: het Europees asiel- en migratiebeleid 186

De rechtspraak: het Europees Verdrag voor de Rechten van de Mens 189

DEEL I: DE JAREN NEGENTIG 192

4.3 Verantwoord burgerschap: een nieuwe kijk op migratie en integratie 192

Optimisme maakt plaats voor zorg 192

Rechten en plichten 194

Van minderhedenbeleid naar integratiebeleid 196

4.4 Een eerste restrictieve stap: de hervormingen van $1993 \quad 198$

$\begin{array}{ll}\text { Worsteling binnen de regering } & 199\end{array}$

De parlementaire behandeling 207

Overige hervormingen in de jaren negentig: blauwe kaart,

$\begin{array}{ll}\text { schijnhuwelijken en mvv } & 213\end{array}$

4.5 Evaluatie van het gezinsmigratiebeleid: het recht op gezinshereniging

$\begin{array}{ll}\text { ter discussie } & 216\end{array}$

$\begin{array}{ll}\text { De evaluatie } & 216\end{array}$

De motie Verhagen/Rijpstra: gezinshereniging van vluchtelingen 
4.6 De Vreemdelingenwet $2000 \quad 224$

De verhoging van het inkomensvereiste 225

Gezinshereniging voor vluchtelingen $\quad 227$

4.7 Vrouwen in het vreemdelingenrecht 229

Voortgezet verblijf na verbreken van huwelijk of relatie 230

$\begin{array}{ll}\text { Indirecte discriminatie } & 234\end{array}$

DEEL II: NA DE EEUWWISSELING 237

$\begin{array}{ll}4.8 \text { Cultuur, cohesie en 'zeggen wat je denkt' } 237 & 237\end{array}$

Nationale identiteit, culturele diversiteit en politieke legitimiteit 238

$\begin{array}{ll}\text { Scheffer, 9-11 en Fortuyn } & 241\end{array}$

De Nederlandse politiek en het migratie- en integratievraagstuk na de Fortuyn-revolte 244

4.9 De nadagen van Paars: integratievereisten voor huwelijksmigranten? 246

Het voorstel van GSI: een inburgeringsbijdrage bij gezinsvorming 247

De bezwaren van Justitie $\quad 249$

Justitie weggestemd 252

4.10 Hervormingen onder het tweede kabinet Balkenende 255

Het probleem van gezinsmigratie volgens het tweede kabinet Balkenende 256

Aanscherping van de voorwaarden voor gezinsvorming 259

De Wet Inburgering in het Buitenland 261

Tentatieve interpretatie van de verhoudingen binnen het ministerie van Justitie 265

4.11 Het criterium 'feitelijke gezinsband' in Europees perspectief 267

De hervorming van $2001 \quad 268$

De hervorming van $2006 \quad 270$

4.12 Enkeltje Brussel? De Europese gezinsherenigingsrichtlijn 273

De Nederlandse inbreng in de onderhandelingen 274

Invloed op beleidsvorming en beleid in Nederland 277

De toekomst van het Nederlands gezinsmigratiebeleid 279

4.13 Besluit 282

Continuïteit en discontinuïteit in het perspectief op het

$\begin{array}{ll}\text { gezinsmigratievraagstuk } & 282\end{array}$

Continuïteit in de invloedsverhoudingen: de politiek beslist 284

De hypothese van de 'control gap' 287 


\section{Besluit}

5.1 De ontwikkeling van het Nederlands gezinsmigratiebeleid, 1955-2005

5.2 Haagse machten

De rol en invloed van ambtenaren

De rol en invloed van bewindspersoon en kabinet

De rol en invloed van het parlement

De invloed van partijpolitieke verhoudingen

5.3 De these van de control gap

Macht of onmacht van nationale beleidsmakers

De keuzes van politici en ambtenaren

Kritische reflecties op de vraagstelling van een academisch debat

\section{English summary}

The making of Dutch family migration policies, 1955-2005

The powers that be in The Hague

The thesis of the control gap

\section{Literatuur}

\section{Bijlagen}

1. Kabinetten, betrokken bewindslieden en hervormingen gezinsmigratiebeleid, 1955-2005

2. Bevolking van Nederland naar nationaliteit en herkomstgroepering, 1955-2007

3. Buitenlandse immigratie per jaar naar nationaliteit, geboorteland en herkomstland, 1950-2005

Index van namen 
Voor Brechje, Richard, Maeva en Yovan 


\title{
Afkortingen
}

\author{
ACVZ \\ Adviescommissie Vreemdelingenzaken \\ CRM \\ (ministerie van) Cultuur, Recreatie en Maatschappelijke Werk \\ DCM \\ Directoraat Coördinatie Minderhedenbeleid \\ DCIM \\ Directoraat Coordinatie Integratiebeleid Minderheden \\ DVB \\ Directie Vreemdelingenbeleid \\ DVZ \\ Directie Vreemdelingenzaken \\ EEG \\ Europese Economische Gemeenschap \\ EG \\ Europese Gemeenschap \\ EU \\ Europese Unie \\ EVRM \\ GSI \\ HVG \\ IND \\ Europees Verdrag tot Bescherming van de Rechten van de Mens en \\ Fundamentele Vrijheden \\ (ministerie van) Grote Steden- en Integratiebeleid \\ ISI \\ JOVD \\ MVV \\ Hoofdafdeling Vreemdelingenzaken en Grensbewaking \\ Immigratie- en Naturalisatiedienst \\ Interdepartementale Stuurgroep Immigratie \\ Jongeren Organisatie Vrijheid en Democratie \\ machtiging tot voorlopig verblijf \\ NCB Nederlands Centrum Buitenlanders \\ OC\&W (ministerie van) Onderwijs, Cultuur en Wetenschappen \\ RVD Rijksvreemdelingendienst \\ VN Verenigde Naties \\ vtv-hum vergunning tot verblijf humanitair \\ vvtv vergunning tot voorlopig verblijf \\ VZI \\ (ministerie van) Vreemdelingenzaken en Integratie \\ WIB Wet Inburgering in het Buitenland \\ WRR Wetenschappelijke Raad voor het Regeringsbeleid
}

In noten:

\begin{tabular}{|c|c|}
\hline AO & Algemeen Overleg \\
\hline $\mathrm{AZ}$ & (ministerie van) Algemene Zaken \\
\hline вiza & (ministerie van) Binnenlandse Zaken \\
\hline CBS & Centraal Bureau voor de Statistiek \\
\hline DG & directoraat-generaal \\
\hline EHRM & Europees Hof voor de Rechten van de Mens \\
\hline EK & Eerste Kamer \\
\hline OCV & Openbare Commissievergadering \\
\hline o\&w & (ministerie van) Onderwijs en Wetenschappen \\
\hline SG & secretaris-generaal \\
\hline szw & (ministerie van) Sociale Zaken en Werkgelegenheid \\
\hline TK & Tweede Kamer \\
\hline $\mathrm{UCV}$ & Uitgebreide Commissievergadering \\
\hline $\mathrm{vc}$ & Vreemdelingencirculaire \\
\hline
\end{tabular}


Jij bent de Vreemdeling die ik het best ken, Van wie ik het meeste hou.

Uit Walter de la Mare's Under the Rose (The Song of the Wanderer) (1944) Vertaald door Tonke Dragt 


\section{Inleiding}

\subsection{Waarom gezinsmigratiebeleid maken ingewikkeld is}

Dit boek gaat over hoe Nederlandse politici en ambtenaren in de afgelopen vijftig jaar de regels hebben vastgesteld voor gezinsmigratie. Mocht $u$ of ik morgen verliefd worden op een Venezolaan, een Russische of een Tunesiër en met hem of haar in Nederland willen leven, wat moeten we dan doen om voor onze geliefde vreemdeling een visum en een verblijfsvergunning te regelen? Of iemand die naar Nederland is gekomen om te werken, dan wel om een veilig heenkomen te zoeken, en kinderen in het buitenland heeft achterlaten: aan welke voorwaarden moet zo iemand voldoen om zijn of haar kinderen naar Nederland te mogen laten komen?

De laatste jaren is het gezinsmigratiebeleid boven aan de politieke agenda komen te staan. Het klimaat waarin Nederlandse debatten over migratie en integratie plaatsvonden was beladen, na de aanslagen in New York en Washington in september 2001 en de moord op Pim Fortuyn enkele maanden later. Nederlandse politici maakten zich ernstige zorgen over de gevolgen van gezinsmigratie voor de betrokken gezinnen en voor de Nederlandse maatschappij. Die bezorgdheid mondde uit in een serie aanscherpingen van de voorwaarden voor gezinsmigratie, waarvan de toets waarmee gezinsmigranten voortaan hun kennis van de Nederlandse taal en maatschappij moeten aantonen alvorens zij naar Nederland mogen komen, in binnen- en buitenland het meeste stof heeft doen opwaaien.

Gezinsmigratie is als beleidsvraagstuk echter geen recent fenomeen. In de jaren vijftig werden beleidsmakers reeds geconfronteerd met de vraag of en onder welke voorwaarden buitenlandse gezinsleden van Nederlandse inwoners in Nederland mochten komen wonen. Het vaststellen van die voorwaarden was ook toen al buitengewoon complex, al lag de kwestie maatschappelijk en politiek bij lange na niet zo gevoelig als tegenwoordig.

Het vraagstuk van gezinsmigratie plaatst politici en ambtenaren namelijk voor een in wezen onoplosbaar dilemma. Aan de ene kant hecht bijna iedereen die in Nederland woont een bijzonder grote waarde aan het kunnen samenleven met degenen die hem of haar het meest nastaan; aan de 
mogelijkheid om van dag tot dag zorg en steun te geven aan en ontvangen van levenspartner en kinderen. De meesten van ons kunnen zich levendig voorstellen wat een verdriet en frustratie het teweegbrengt als man en vrouw, of ouders en kinderen, door overheidsregels van elkaar gescheiden moeten blijven. Misschien is er in Nederland geen andere morele waarde die zo breed gedeeld en diep gevoeld wordt als de waarde van het gezinsleven. Zo bekeken is het moeilijk te begrijpen dat de Nederlandse overheid ooit belemmeringen heeft opgelegd aan de komst van buitenlandse gezinsleden naar Nederland.

Aan de andere kant heeft Nederland nooit een immigratieland willen zijn. In de eerste decennia na de Tweede Wereldoorlog werden Nederlanders juist aangemoedigd om te emigreren uit een land dat zo dichtbevolkt was, en waarvan de bevolking zo schrikbarend snel groeide. Van de jaren vijftig tot de dag van vandaag is de permanente vestiging van grote aantallen vreemdelingen in Nederland steeds als onwenselijk beschouwd, evenzeer uit economisch en sociaal als uit demografisch perspectief. De bevolkingsstructuur, de werkgelegenheid, het bedrijfsleven, de infrastructuur, de sociale zekerheid, de maatschappelijke samenhang: niets van dit alles werd of wordt geacht gebaat te zijn bij grootschalige vestigingsmigratie. Toch heeft de overheid sinds de jaren vijftig honderdduizenden vreemdelingen toestemming verleend om zich in Nederland te vestigen. Een groot deel van hen heeft die toestemming gekregen vanwege de gezinsband die hen met een Nederlands inwoner verbond. Gezinsmigratie is bijna altijd vestigingsmigratie: een vreemdeling die naar Nederland komt om zich bij een familielid te voegen zal in de regel blijvend deel uit gaan maken van de Nederlandse samenleving. Zo bezien is het verwonderlijk dat de Nederlandse overheid gezinsmigratie ooit heeft toegestaan. Gezinsmigratiebeleid voeren betekent dus een afweging maken tussen het belang van individuen bij het samenleven met hun gezin enerzijds, en het belang van de Nederlandse samenleving bij migratiebeperking anderzijds: zwaarwegende belangen waaraan nooit gelijktijdig volledig recht kan worden gedaan.

Immigratiebeleid - of het nu gaat om arbeids-, asiel- of gezinsmigratie - draait om het maken van onderscheid tussen mensen: tussen hen die er bij mogen horen en hen die wij buitensluiten. In liberale democratieën met een hoogontwikkelde verzorgingsstaat, zoals Nederland, worden politieke en sociale rechten over de leden van de gemeenschap verdeeld. Deze verdeling is alleen aanvaardbaar als een zeker gevoel van solidariteit de leden van de gemeenschap met elkaar verbindt: die solidariteit is op haar beurt 
alleen mogelijk in een gemeenschap die begrensd is. De overheid bewaakt namens de gemeenschap de grenzen van die gemeenschap: zij bepaalt wie mag delen in onze rechten, vrijheden en welvaart en wie niet. ${ }^{1}$ Migratiebeleid voeren betekent dus bepalen wie 'wij' zijn en wie 'de ander' is, en vooral hoe wij omgaan met de grens tussen 'ons' en 'de ander'. De manier waarop de overheid zich van die taak kwijt is, zeker in recenter jaren, van grote betekenis geweest voor de legitimiteit van de overheid in de ogen van haar burgers.

Wanneer immigratiebeleid in het algemeen beleidsmakers reeds voor complexe vraagstukken stelt, geldt dit in versterkte mate voor gezinsmigratiebeleid. Het vaststellen van het onderscheid tussen 'wij' en 'de ander' wordt in het gezinsmigratiebeleid bemoeilijkt doordat niet alleen vreemdelingen die om toegang vragen door de beslissing worden geraakt, maar ook inwoners van Nederland die de overkomst van hun gezinsleden wensen. Deze ingezetenen mogen van de Nederlandse overheid een zekere zorg voor hun welzijn verwachten, onder andere voor de bescherming van hun gezinsleven. In het gezinsmigratiebeleid dient niet alleen een afweging te worden gemaakt tussen het individueel belang van een 'buitenstaander' en het collectief Nederlands belang, maar ook tussen het algemeen belang van de gemeenschap en het belang van een individu dat deel uitmaakt van die gemeenschap. Daarmee doen zich vragen voor rond mogelijke breuklijnen binnen de gemeenschap: weegt de morele waarde van gezinseenheid voor sommige inwoners van Nederland zwaarder dan voor andere? Heeft een Nederlands staatsburger sterkere aanspraken op hereniging met buitenlandse gezinsleden in Nederland dan een vreemdeling die zich in Nederland gevestigd heeft? Maakt het verschil hoe lang iemand in Nederland woont, hoeveel hij of zij verdient, hoe goed iemand is geïntegreerd in de Nederlandse gemeenschap? ${ }^{2}$

Nederlandse politici en ambtenaren hebben zich de afgelopen vijftig jaar voortdurend een weg moeten banen door dit labyrint van conflicterende collectieve en individuele belangen, van gewichtige morele waarden, en van economische, sociale, politieke en demografische overwegingen. De vraag hoe zij erin geslaagd zijn om daarin een standpunt te bepalen en tot bindende besluiten te komen is de drijvende kracht geweest achter het promotieonderzoek waarvan ik in dit boek verslag doe.

1 Vgl. Joppke 1999: 5-6.

2 Zie Bonjour 2007. 


\subsection{Constructivistische kijk op politiek en beleidsvorming}

Aan dit onderzoek ligt de theoretische veronderstelling ten grondslag dat beleidsvorming niet een proces is waarin op rationele wijze de optimale oplossing wordt vastgesteld van een objectief gegeven probleem. ${ }^{3}$ Beleidsproblemen zijn sociale constructies: in de interacties tussen de verschillende deelnemers in het besluitvormingsproces wordt bepaald of er sprake is van een probleem, wat de aard van het probleem is, welke belangen en normatieve waarden op het spel staan, welke oorzaken aan het probleem ten grondslag liggen en in welke richting de oplossing dus moet worden gezocht. ${ }^{4} \mathrm{Zo}$ is gezinsmigratie in de afgelopen vijftig jaar, op verschillende momenten en door verschillende beleidsmakers, onder meer gedefinieerd als een probleem van welzijn van migranten, van vrouwenemancipatie, van verkapte arbeidsmigratie en van maatschappelijke samenhang.

Ik voeg mij daarmee naar de aansporing waarmee Bekke in I99o zijn oratie afsloot:

Meer dan bij enig andere kennistheoretische conceptie is de bestuurskundige gebaat bij een opvatting van de bestuurskunde als cultuurwetenschap. Processen van sturing, beleidsvorming en beleidsuitvoering door de overheid zijn zingevingsprocessen, waarbij te hanteren waarden door een variëteit van actoren centraal moeten staan bij onderzoek en prescriptie. ${ }^{5}$

Beleidsvorming kan als zingevingsproces worden geanalyseerd door de 'denkkaders' ${ }^{6}$ of 'beleidsparadigma's" ${ }^{7}$ te identificeren waarbinnen de standpunten die besluitvormers in beleidsdebatten innemen vorm krijgen. Deze denkkaders zijn clusters van percepties, veronderstellingen, waardeoordelen en causale interpretaties, die veelal onuitgesproken blijven maar wel bepalen welke aspecten van een beleidsprobleem als relevant worden beschouwd en welk normatief oordeel eraan wordt verbonden. De selectieve, ordenende en normatieve werking van denkkaders stelt besluitvormers in staat 'zin, betekenis en doel te onderkennen' in een complexe en polyvalente werkelijkheid. ${ }^{8}$

3 Fischer 2003: 1-17.

4 Hisschemöller 1993: 14-16.

5 Bekke 1990: 22.

6 Schön \& Rein 1994: 23.

7 Hall 1993: 279.

8 Hoppe 1998: 40. 
Dergelijke beleidsvisies zweven niet in de ruimte: zij krijgen vorm binnen een specifieke politiek-institutionele context. ${ }^{9}$ Zo kunnen politieke partijen, vanuit verschillende ideologische achtergronden of politiek-strategische overwegingen, onderscheiden visies ontwikkelen op de aard van een beleidsvraagstuk en de normatieve implicaties ervan. Maar ook ministeries, of zelfs afdelingen binnen ministeries, opereren vanuit een bepaalde definitie van hun maatschappelijke taak, die de 'bril' bepaalt waardoor zij de werkelijkheid zien en interpreteren. ${ }^{10}$ Omgekeerd vormt de institutionele structuur een neerslag van beleidsparadigma's die op een zeker moment dominant zijn of zijn geweest: of de verantwoordelijkheid voor het gezinsmigratiebeleid wordt toegekend aan het ministerie van Justitie, Sociale Zaken of Binnenlandse Zaken hangt af van de manier waarop gezinsmigratie als beleidsprobleem wordt gedefinieerd.

Beleidskaders komen eveneens tot stand binnen een specifieke politiekculturele context. Besluitvormers zijn niet immuun voor de 'tijdgeest': maatschappelijke verhoudingen, politieke en economische structuren en praktijken, en dominante opvattingen inzake private en publieke moraal zijn aan verandering onderhevig en beïnvloeden de percepties en waardeoordelen van beleidsmakers.

Wanneer besluitvormers conflicterende standpunten innemen in beleidsdebatten, komt dat veelal doordat zij vanuit verschillende beleidsparadigma's naar een vraagstuk kijken. Macht uitoefenen in een besluitvormingsproces betekent niet in de laatste plaats bepalen vanuit welk perspectief een beleidsprobleem dient te worden bezien. In die zin moeten ambtelijke en politieke conflicten worden begrepen als strijd over de interpretatie van de werkelijkheid. ${ }^{11}$

De definitie van een beleidsprobleem, de identificatie van relevante oorzaken en gevolgen, de formulering van beleidsdoelen en de keuze voor specifieke beleidsinstrumenten worden bepaald door het beleidsparadigma dat op een zeker moment dominant is. Heroriëntaties van beleid, anders dan marginale wijzigingen, komen tot stand wanneer dat dominante paradigma verandert. Veranderingen in het dominante beleidsperspectief komen op hun beurt weer voort uit de wisselwerking tussen enerzijds ontwikkelingen in de bredere politiek-culturele context, en anderzijds verschuivende machtsverhoudingen tussen de betrokkenen in het besluitvormingsproces.

9 Vgl. Schön \& Rein 1994: 29.

10 Ringeling 1993: 161-162.

11 Zie Hajer 1989: 244; Fischer 2003: 55-58. 
De taak die ik mijzelf in dit onderzoek heb gesteld is dan ook de ontwikkeling van het Nederlands gezinsmigratiebeleid in de afgelopen vijftig jaar inzichtelijk te maken door te achterhalen hoe Nederlandse ambtenaren en politici sinds de jaren vijftig gezinsmigratie als beleidsprobleem hebben geconstrueerd. Dat betekent dat in kaart moet worden gebracht welke actoren invloed hebben uitgeoefend op de beleidsontwikkeling en vanuit welke beleidsperspectieven zij dat hebben gedaan. Om deze perspectieven of beleidsparadigma's te identificeren heb ik, bij mijn analyse van beleidsdocumenten, in de eerste plaats aandacht besteed aan woordkeus. Of beleidsmakers bijvoorbeeld over 'buitenlandse werknemers', 'minderheden' of 'allochtonen' spreken en schrijven, zegt zeer veel over hun visie op het migratie- en integratievraagstuk. Daarnaast heb ik zowel interpretaties van oorzaak en gevolg, als normatieve evaluaties uitgelicht. ${ }^{12}$ Zo wordt duidelijk welke percepties, veronderstellingen en waardeoordelen aan de beslissingen van beleidmakers ten grondslag hebben gelegen.

\subsection{Probleemstelling en afbakening}

Beleidsvorming in Nederland inzake gezinsmigratie tussen 1955 en 2005

In dit boek zoek ik een antwoord op de vraag, hoe de beleidsvorming in Nederland op het gebied van gezinsmigratie zich tussen I955 en 2005 ontwikkeld heeft en hoe dat te verklaren is. Doel is de ontwikkeling van het gezinsmigratiebeleid niet alleen in kaart te brengen maar ook te duiden, door inzicht te bieden in de dynamiek van de besluitvormingsprocessen waarin het beleid tot stand kwam.

Onder 'gezinsmigratiebeleid' versta ik de wet- en regelgeving waarin de voorwaarden zijn vastgelegd waaronder een vreemdeling toelating en verblijf in Nederland wordt toegestaan op grond van zijn familierelatie met een inwoner van Nederland. Andere gronden waarop de Nederlandse overheid visa en verblijfsvergunningen verleent zijn bijvoorbeeld arbeid, asiel, studie en stage, of medische verzorging. Ik richt mij dus op een specifiek subveld binnen het algemeen Nederlands vreemdelingenbeleid.

12 Vgl. Scholten 2007: 59. 
Dit onderzoek betreft de voorwaarden voor gezinsmigratie zoals die in Nederlandse wet- en regelgeving zijn vastgelegd. Sinds I96I valt de overkomst van gezinsleden van arbeidsmigranten uit de Europese Gemeenschap niet onder nationaal, maar onder Europees recht, als onderdeel van het vrij verkeer van werknemers binnen de interne markt. ${ }^{13}$ Dit Europees beleid inzake gezinsmigratie binnen de Gemeenschap blijft hier buiten beschouwing. ${ }^{14} \mathrm{Wel}$ zal worden bezien of, hoe en wanneer de ontwikkeling van het Europese migratierecht invloed heeft uitgeoefend op de beleidsvorming in Nederland.

Ik gebruik de term 'beleidsvorming' om aan te geven, dat mijn onderzoek zich richt op een specifieke fase in het beleidsproces, namelijk die waarin wet- en regelgeving tot stand komt. Wanneer wordt gezinsmigratie op de beleidsagenda geplaatst en door wie, wie spreken er mee over mogelijke beleidsopties en op grond van welk denkkader bepalen zij hun standpunten, hoe is de interactie tussen de betrokken spelers in het proces dat in een beslissing uitmondt? De beleidsprocessen die volgen op het moment dat een algemeen bindend besluit gevallen is, laat ik buiten beschouwing. Mijn onderzoek strekt zich dus niet uit tot de implementatie van beleid, of tot de effectiviteit van beleid. Ik ben mij er scherp van bewust dat de implementatie een cruciale fase is in het beleidsproces en dat ook in de uitvoeringspraktijk vorm en invulling wordt gegeven aan beleid, vooral wanneer de wet- en regelgeving ruimte laat voor interpretatie. Onderzoek naar implementatieprocessen en naar effectiviteit van beleid vergt echter een geheel andere vraagstelling en aanpak dan die aan dit boek ten grondslag liggen. Ik richt mij hier daarom nadrukkelijk op een analyse van de besluitvormingsprocessen waarin de formele voorwaarden voor gezinsmigratie zijn vastgesteld.

Mijn keuze voor een onderzoeksperiode van vijf decennia maakt het mogelijk om continuïteit en verandering in de beleidsontwikkeling te identificeren, deze in politiek-historisch context te plaatsen en daarmee te duiden en, niet in de laatste plaats, een zekere kritische afstand te nemen van actuele debatten en perspectieven op het gezinsmigratievraagstuk. Zoals ik later in dit inleidend hoofdstuk zal betogen, is er in de academische literatuur weinig analytische reflectie voorhanden op de manier waarop

13 In 1961 werd de eerste Europese verordening over het vrij verkeer van werknemers aangenomen. Zie ook paragraaf 2.5 .

14 Zie hierover bijvoorbeeld Sewandono 1998: 149-175; Carlier 2007: 61-70; Barnard 2004: 284289; Toner 2004. 
de Nederlandse overheid met toelating en verblijf van vreemdelingen is omgegaan. De studies die er zijn richten zich overwegend op het heden, of op de korte termijn. Door de middellange termijn in ogenschouw te nemen, worden nieuwe verbanden, continuïteiten en discontinuïteiten zichtbaar. De immigratiestromen van de afgelopen halve eeuw hebben het aanzien van Nederland voorgoed veranderd: gezinsmigratie was van die stromen niet de minste. Mijn streven is begrijpelijk te maken hoe de beleidskaders waarbinnen die gezinsmigratie plaatsvond tot stand zijn gekomen. Ik begin daarom bij het begin, niet van de omvangrijke gezinsmigratiestromen of van het publiek debat over gezinsmigratie, maar van de beleidsvorming op dit gebied.

Deze studie vangt dus aan in I955, toen de minister van Sociale Zaken een circulaire verzond aan de Nederlandse werkgevers en werknemers, waarin hij zijn voornemen aankondigde om de mogelijkheden voor de tewerkstelling van buitenlandse arbeidskrachten te verruimen. Met deze circulaire werd een periode ingeluid van grootschalige arbeidsmigratie naar Nederland. De conflictueuze besluitvorming over de voorwaarden die in deze periode aan de gezinshereniging van arbeidsmigranten werden gesteld vormt het onderwerp van mijn tweede hoofdstuk. De periode van onderzoek eindigt in 2005, met de goedkeuring door de Tweede Kamer van de Wet Inburgering in het Buitenland. Deze wet verplicht gezinsmigranten om aan te tonen over een basale kennis van de Nederlandse taal en samenleving te beschikken, alvorens zij tot Nederland worden toegelaten. De Wet Inburgering in het Buitenland vormt de 'kroon' op een serie hervormingen van het gezinsmigratiebeleid die door het tweede kabinet Balkenende zijn doorgevoerd in de woelige jaren na de eeuwwisseling, hervormingen die op hun beurt in het verlengde lagen van de aanscherpingen van de regelgeving waarvoor de kabinetten onder Lubbers en Kok in de jaren negentig hebben gekozen. Over die restrictieve wending in het Nederlands gezinsmigratiebeleid gaat mijn vierde hoofdstuk.

Om mijn hoofdvraag te beantwoorden, zullen twee deelvragen als leidraad dienen. De eerste heeft betrekking op de constellatie van betrokken beleidsactoren, de tweede op de samenhang tussen beleidsontwikkelingen en de brede politiek-historische context. 


\section{Institutionele structuur en invloedsverhoudingen}

Inzicht in de beleidsvorming op het gebied van gezinsmigratie vereist dat in kaart wordt gebracht, hoe de institutionele structuur waarbinnen dit beleid wordt gemaakt is veranderd tussen 1955 en 2005 . Ik vat het concept 'institutionele structuur' breed op, zodat het niet alleen de formele verdeling van competenties omvat, maar ook informele verhoudingen en invloedsstructuren. De vraag wordt dan: wie waren de spelers in het besluitvormingsproces, wie spraken er mee? Vanuit welk beleidsparadigma bepaalden deze spelers hun standpunten ten opzichte van het gezinsmigratievraagstuk? Hoe lagen de machts- en invloedsverhoudingen tussen deze spelers, welke stem of stemmen waren beslissend?

De hoofdrolspelers in de vorming van het gezinsmigratiebeleid zijn ambtenaren in ministeries, bewindspersonen in het kabinet en Kamerleden in het parlement. Doel is dan ook in de eerste plaats te achterhalen, hoe de 'verticale' verhoudingen zich hebben ontwikkeld, dat wil zeggen de verhoudingen tussen deze drie categorieën van beleidsmakers. Waar lag het zwaartepunt van de besluitvorming, op ambtelijk, kabinets- of parlementair niveau? Hoe was de verhoudingen tussen ambtenaren en bewindspersonen enerzijds, en tussen kabinet en parlement anderzijds? Waren institutionele of ideologische perspectieven doorslaggevend voor de beleidsontwikkeling? In de tweede plaats dient duidelijk te worden hoe de 'horizontale' verhoudingen lagen, i.e. de verhoudingen binnen iedere categorie van besluitvormers. Welke ministeries waren betrokken bij debatten over het gezinsmigratiebeleid, welke standpunten namen zij in en hoe invloedrijk waren zij? Hoe was de verhouding tussen politici van verschillende politieke partijen, zowel binnen het kabinet als in het parlement? In de derde plaats zal ik bezien, in hoeverre er sprake is van continuïteit en discontinuiteit in zowel de 'horizontale' als de 'verticale' verhoudingen.

Buiten deze kring van direct en formeel betrokkenen, speelt natuurlijk nog een grote verscheidenheid aan actoren een meer of minder grote rol in het besluitvormingsproces. De rechtspraak neemt hier een bijzondere plaats in: de rechter is de enige instantie, naast politici en ambtenaren, die bevoegd is om bindende besluiten te nemen op het gebied van gezinsmigratie, zij het uitsluitend in individuele gevallen. Aangezien dit geen juridische studie is maar een politiek-historische analyse van de totstandkoming van algemeen bindende wet- en regelgeving, zal ik geen jurisprudentie-onderzoek doen. Wel zal ik nagaan of, hoe en wanneer de rechtspraak invloed 
heeft uitgeoefend op de beleidsvorming. Verder hebben ook journalisten, opiniemakers, belangenorganisaties en wetenschappers zich betrokken getoond bij het gezinsmigratiebeleid. Ook hier geldt dat ik zal aangeven in hoeverre zij een stempel hebben weten te drukken op de standpunten van ambtenaren, bewindslieden en Kamerleden.

\section{Fasen en breuklijnen in de beleidsontwikkeling in context}

Om niet alleen institutioneel maar ook inhoudelijk tot een beter begrip van de dynamiek van de beleidsvorming te komen, dient te worden onderzocht welke fasen en breuklijnen kunnen worden onderscheiden in de ontwikkeling van het Nederlands gezinsmigratiebeleid, hoe wijzigingen in de beleidstendens te herleiden zijn tot verschuivingen in de beleidsperspectieven van de betrokken besluitvormers, en hoe die verschuivingen op hun beurt samenhangen met ontwikkelingen in de bredere politiek-culturele context.

Het gezinsmigratiebeleid is een subveld van het algemene vreemdelingenbeleid. De voorwaarden die aan toelating en verblijf van vreemdelingen worden gesteld houden nauw verband met de manier waarop beleidsmakers tegen de integratie van vreemdelingen in de samenleving aankijken. Het beleidsperspectief op het gezinsmigratievraagstuk in engere zin krijgt dan ook in belangrijke mate vorm in de context van het perspectief op het migratie- en integratievraagstuk in bredere zin, zoals dat in ambtelijke en politieke kringen en in de Nederlandse samenleving leeft. Hoe wordt er tegen de komst van vreemdelingen naar Nederland aangekeken? Welke immigratiestromen hebben de aandacht van politiek en publiek? Hoe wordt er gedacht over de positie van migranten in de Nederlandse samenleving en over de invloed van migratie op de Nederlandse maatschappij? Welke rol wordt de overheid toegedicht in het reguleren van de maatschappelijke gevolgen van immigratie? Het antwoord op al die vragen is direct van invloed op de manier waarop gezinsmigratie als beleidsprobleem wordt gedefinieerd. Ik zal dan ook laten zien dat de breuklijnen in de ontwikkeling van het Nederlands gezinsmigratiebeleid nauw samenhangen met fundamentele verschuivingen in het dominante perspectief onder Nederlandse beleidsmakers op het migratie- en integratievraagstuk.

Ambtelijke en politieke debatten over migratie en integratie vinden op hun beurt weer plaats in de bredere context van maatschappelijke, economische en politieke structuren en praktijken. Opvattingen over de manier 
waarop de Nederlandse samenleving moet worden ingericht en over de rol van de staat daarin, over de verhouding tussen staat, markt en samenleving en tussen burger en politiek, zijn aan verandering onderhevig en beïnvloeden in meer of mindere mate de wijze waarop beleidsmakers zich verhouden tot het vreemdelingenvraagstuk.

Een specifiek aspect van de politiek-culturele context dat een rol speelt in besluitvormingsprocessen inzake het gezinsmigratiebeleid, zijn normen en waarden op het gebied van gezin, seksualiteit en de verhouding tussen man en vrouw. Hoe wordt een 'gezin' gedefinieerd? Welke morele en maatschappelijke betekenis wordt aan gezin en gezinsleven toegekend? Welke rollen in gezin en samenleving worden aan mannen en vrouwen toegeschreven? De 'culturele revolutie' van de jaren zestig en zeventig bracht een fundamentele verschuiving teweeg in de dominante gezinsmoraal in Nederland, die zijn weerslag op het gezinsmigratiebeleid niet heeft gemist. Expliciete en impliciete opvattingen over genderrollen spelen voortdurend, van de jaren vijftig tot de dag van vandaag, een rol in politieke en ambtelijke debatten over het gezinsmigratiebeleid.

Opvattingen over gezin, seksualiteit en de positie van man en vrouw zijn bovendien van doorslaggevend belang in de constructie van het onderscheid tussen 'Wij' en 'de Ander' ${ }^{15}$ Zo wordt in actuele debatten over de plaats van moslims in de Nederlandse samenleving voortdurend gerefereerd aan thema's als opvoeding en vrouwenemancipatie, en vooral ook aan kwesties als uithuwelijking, eerwraak, huiselijk geweld en vrouwenbesnijdenis. Juist op deze vlakken wordt zichtbaar, of zichtbaar gemaakt, wat 'de Nederlandse opvattingen' zijn en waarin 'wij Nederlanders' van 'migranten' verschillen. Juist op deze vlakken worden de verschillen als bijzonder problematisch en pijnlijk ervaren. De intimiteit van het gezin speelt dus een cruciale rol in de constructie van de eigen identiteit en van het beeld van 'de Ander'. Ik heb eerder uiteengezet dat vreemdelingenbeleid voeren draait om het bewaken van de grenzen van de gemeenschap: de bijzondere betekenis van gezin en gender in het definiëren van die grenzen geeft het gezinsmigratiebeleid een uitermate complexe lading. De manieren waarop het 'anders-zijn' van migranten op deze vlakken wordt gedefinieerd en gewaardeerd maken een cruciaal onderdeel uit van het beleidsparadigma voor migratie en integratie in het algemeen, en voor gezinsmigratie in het bijzonder.

15 Vgl. Stoler 2002: 32-78, 112-139; Anthias \& Yuval Davis 1989: 9-10. 


\subsection{Academische positionering}

De bijdrage die ik beoog te leveren aan het academisch debat is drieledig. In de eerste plaats wil ik een blinde vlek op de kaart van de bestaande kennis inzake migratie en migratiebeleid in Nederland opvullen. In de tweede plaats zal ik bezien hoe de bevindingen van deze studie zich verhouden tot inzichten en hypotheses van bestuurswetenschappers en politicologen over hoe politiek en beleidsvorming in Nederland in hun werk gaan, met bijzondere aandacht voor invloedsverhoudingen tussen beleidsactoren. In de derde plaats ten slotte zal ik deze studie positioneren in het internationaal debat in het veld van migratiestudies, gericht op theorievorming over migratiebeleid in liberaal-democratische landen.

\section{Een blinde vlek op de kaart van migratiestudies in Nederland}

Penninx e.a. hebben recentelijk geconstateerd dat wetenschappelijke publicaties die politieke en beleidsmatige ontwikkelingen in Nederland in het veld van migratie en integratie analyseren, dun gezaaid zijn. Er is te weinig 'literature that analyses the making of policies itself: that is analyses, not of the content of policies per se, but of the process that has led to these policies, the actors involved and the levels at which they are made'. ${ }^{16}$ Met deze studie wil ik in een deel van die leemte voorzien.

Het veld van migratiestudies in Nederland werd lange tijd gedomineerd door enerzijds sociologen, antropologen en sociaal geografen, en anderzijds juristen. De eerste categorie onderzoekers onderhield nauwe banden met beleidsmakers en was er sterk op gericht hen via beleidsadvies en -evaluatie te ondersteunen bij het ontwikkelen van beleidsinstrumenten ter verbetering van de positie van migranten in de Nederlandse maatschappij. ${ }^{17} \mathrm{De}$ juridische expertise op het gebied van vreemdelingenrecht is ontstaan in de jaren zeventig, als gevolg van de toegenomen behoefte aan en toegankelijkheid van rechtsbijstand voor vreemdelingen. ${ }^{18}$ Tot op heden blijven Nederlandse onderzoekers van het vreemdelingenrecht zich betrokken tonen bij de versterking van de rechtspositie van vreemdelingen in Nederland. ${ }^{19} \mathrm{De}$

16 Penninx e.a. 2005: 2.

17 Penninx e.a. 2005: 2; Scholten 2007: 77-250.

18 Groenendijk 1980.

19 Zie bijvoorbeeld Van Walsum 2004b, 2004c; Groenendijk 1981; 1983; 2005, 2006; Groenendijk \& Barzilay 2001; Lodder 2007; Boeles \& Lodder 2005; Boeles 2005, 2007; Spijkerboer 2002 . 
positie van Nederlandse onderzoekers ten opzichte van beleidsvormingsprocessen in het veld van migratie en integratie is er tot voor kort dan ook veeleer één geweest van kritisch betrokken medespelers, dan van waarnemers op afstand. Politiek wetenschappers en bestuurswetenschappers hebben zich pas laat op het terrein van migratiestudies begeven. ${ }^{20}$ Dit verklaart het gebrek aan analytische reflectie op de manier waarop het Nederlands migratie- en integratiebeleid tot stand komt en is gekomen, waar Penninx e.a. op duiden.

Penninx e.a. constateren bovendien, dat waar beleidsvoering op het gebied van integratie wél enige academische aandacht heeft genoten, de literatuur over het Nederlands immigratiebeleid zeer schaars en gefragmenteerd is. ${ }^{21}$ Eén van de eerste studies van ambtelijke en politieke besluitvorming inzake toelating en verblijf van vreemdelingen was het proefschrift van Ringeling uit 1978 over het spijtoptantenbeleid dat Nederland in de jaren vijftig en zestig voerde. ${ }^{22}$ Pas in 1986 volgde Groenendael met een proefschrift over de regularisatie van buitenlandse werknemers in de jaren zeventig en tachtig. ${ }^{23}$ Recentelijk is de literatuur over naoorlogse Nederlandse beleidsvorming inzake toelating en verblijf van vreemdelingen uitgebreid, in het bijzonder op het gebied van asiel- ${ }^{24}$, arbeids- ${ }^{25}$ en (post) koloniale migratie. ${ }^{26}$ Vermeldenswaard zijn ook de studie van Willems en Lucassen naar het beleid van de Nederlandse overheid jegens buitenlandse zigeuners in de jaren zeventig en tachtig, en het werk van Schuster waarin hij de vertogen analyseert die aan het Nederlandse en Britse vreemdelingenbeleid tussen 1945 en 1980 ten grondslag lagen. ${ }^{27}$ De vooroorlogse ontwikkelingen zijn in beeld gebracht in de proefschriften van Van Eijl en Leenders over het vreemdelingenbeleid in de $19^{\mathrm{e}}$ en de eerste helft van de $20^{\mathrm{e}}$ eeuw, evenals in het proefschrift van Lucassen over de geschiedenis van zigeuners in Nederland tussen 1750 en 1944. ${ }^{28}$

De geschiedenis van de beleidsvorming in Nederland inzake gezinsmigratie is echter nog niet geschreven. Dat is verrassend, niet alleen gezien de politieke lading die het gezinsmigratievraagstuk in recente jaren gekregen

\footnotetext{
20 Penninx e.a. 2005: 2.

21 Penninx e.a. 2005: 10.

22 Ringeling 1978.

23 Groenendael 1986.

24 Ten Doesschate 1993; Berghuis 1999; Geuijen 2004. Zie ook hoofdstuk 5 in Alink (2006).

25 De Lange 2007. Zie ook hoofdstuk 6 in Alink (2006) over het witte-illegalenbeleid.

26 Jones 2007.

27 Willems \& Lucassen 1990; Schuster 1999.

28 Van Eij1 2005; Leenders 1993; Lucassen 1990.
} 
heeft, maar ook gezien het feit dat gezinsmigratie sinds de jaren zeventig in kwantitatieve termen één van de meest belangrijke migratiestromen naar Nederland is geweest. Volgens Kofman is gezinsmigratie niet alleen in Nederlandse migratiestudies maar ook in het internationale onderzoeksveld onderbelicht gebleven. Doordat migratieprocessen overwegend in economische en individuele termen werden begrepen viel gezinsmigratie buiten het academisch blikveld. Kofman wijst erop dat gezinsmigratie veelal is beschouwd als volgmigratie, als afgeleide van 'autonome' migratieprocessen als arbeidsmigratie en asiel. ${ }^{29}$ Wellicht verklaart dit ook waarom het Nederlands gezinsmigratiebeleid tot nog toe nauwelijks zelfstandig onderwerp van wetenschappelijk onderzoek is geweest.

Belangrijke uitzondering op deze regel vormen de rechtssociologische studies van Betty de Hart en Sarah van Walsum. ${ }^{30}$ Waar De Hart zich richt op de implicaties van het gezinsmigratiebeleid voor Nederlandse vrouwen met een buitenlandse partner, houdt Van Walsum zich bezig met de invloed van dominante normen op het gebied van huwelijk en gezin op het gezinsmigratiebeleid. Beide auteurs hebben aandacht besteed aan de historische ontwikkeling van het Nederlands gezinsmigratiebeleid en aan de politiekmaatschappelijke context waarin die ontwikkeling plaats vindt. De Hart noch Van Walsum hebben zich echter ten doel gesteld om de mechanismes die de besluitvorming hebben bepaald bloot te leggen en inzichtelijk te maken. Dat is wel het doel van deze politiek-historische studie.

\section{Invloedsverhoudingen in Nederlandse beleidsvormingsprocessen}

Anders dan men wellicht zou verwachten, is er tot op heden relatief weinig empirisch onderzoek gedaan naar de mate waarin ambtenaren, kabinet en parlement in Nederland erin slagen hun stempel te drukken op het beleidsvormingsproces. ${ }^{31}$ Historische studies van verandering en continuïteit in deze invloedsverhoudingen zijn nog schaarser. In dit boek beoog ik nader inzicht te bieden en bestaande hypotheses te toetsen, waar het gaat om de vraag wie beslist, in Nederland.

Wat de verhouding tussen ambtenaren en politiek betreft, is uit onderzoek van Van Putten, Koppenjan e.a. en Peters gebleken dat ambtenaren een zeer wezenlijke invloed uitoefenen op de beleidsvorming, maar dat

29 Kofman 2004: 247-249.

30 De Hart 1997, 2000a\&b, 2003a\&b; Van Walsum 2002, 2004a, 2005, 2008.

31 Peters 1999: 18-19. Volgens 't Hart (1992: 199-200) genoot invloedsonderzoek met name in de jaren zeventig en tachtig de aandacht van Nederlandse onderzoekers. 
van een 'allesoverheersende vierde macht' geen sprake is. De macht van ambtenaren wordt beperkt door hun loyaliteit aan en afhankelijkheid van politiek gezagdragers, evenals door externe actoren. ${ }^{32}$ Genoemde studies beperken zich tot de korte termijn: de ontwikkeling van politiek-ambtelijke verhoudingen op de middellange termijn is tot op heden niet empirisch onderzocht. Desalniettemin bestaat in de literatuur het beeld dat de machtsbalans sinds de Tweede Wereldoorlog is verschoven ten gunste van ambtenaren. Als gevolg van de uitbreiding van het ambtelijk apparaat, de toegenomen expertise van ambtenaren, en hun contacten met belangengroepen zouden zij zich hebben ontwikkeld 'van loyale uitvoerders tot mondige meedenkers'. 33

Ik zal in mijn analyse van de casus van het gezinsmigratiebeleid nagaan of en zo ja in welke mate en onder welke omstandigheden ambtenaren invloed hebben uitgeoefend op de beleidsontwikkeling, en of de macht van het ambtelijke ten opzichte van het politieke inderdaad is toegenomen in de loop van de afgelopen vijftig jaar.

Het is onder bestuurswetenschappers en politicologen een algemeen aanvaard gegeven dat 'de overheid' niet bestaat. ${ }^{34}$ Het Nederlands ambtenarenapparaat is in de woorden van Glasbergen 'geen monoliet' ${ }^{35}$ : verschillende ministeries, en verschillende afdelingen binnen ministeries, opereren vanuit onderscheiden visies op hun maatschappelijke taak en op de waarden en belangen die zij dienen te behartigen. ${ }^{36} \mathrm{Ik}$ zal onderzoeken of fragmentatie en pluraliteit van de overheid ook in het veld van gezinsmigratie een bepalende rol spelen. Zo ja, dan is de vraag hoe en waarom ambtelijke organisaties onderscheiden standpunten innemen ten opzichte van eenzelfde beleidsvraagstuk, en wanneer en hoe dergelijke institutionele conflicten het verloop en de uitkomst van een beleidsvormingsproces beïnvloeden.

Verder is de verhouding tussen parlement en regering van belang. Het is een feitelijk gegeven dat de activiteit van het parlement in de tweede helft van de jaren zestig significant is toegenomen. Er werden meer vragen gesteld, meer moties ingediend, er waren meer interpellaties en meer ver-

32 Van Putten 1980: 248-252; Koppenjan e.a. 1987: 294-295; Peters 1999: 242-244.

33 Bovens e.a. 2007: 360-361, 371-374; Bekke 1994: 14-19; Hoppe 1998: 15-19. Zie ook Peters 1999: 36.

34 Zie bijvoorbeeld Koppenjan e.a. 1987: 279; Visscher 1994: 764-765.

35 Glasbergen 1984: 91.

36 Vgl. Van Putten 1980: 250. 
gaderingen in plenair en commissieverband. ${ }^{37}$ De vraag is echter, of deze toegenomen parlementaire betrokkenheid zich heeft vertaald in een gezaghebbender stem in de besluitvorming. In 1980 constateerde Van Putten dat de volksvertegenwoordiging 'betrekkelijk weinig invloed' uitoefende op de beleidsvorming, ondanks haar sterk toegenomen activiteit. ${ }^{38}$ Bevindingen van onderzoek uit de jaren negentig wijzen in een andere richting. Visscher komt tot de conclusie dat de parlementaire invloed in de loop van de jaren zestig, zeventig en tachtig 'veeleer is toegenomen dan afgenomen'. Hij beschouwt daarbij de periode van het kabinet Den Uyl als een breekpunt. Visscher wijst in het bijzonder op de belangrijke rol van de Tweede Kamer bij het bepalen van de politieke agenda. ${ }^{39}$ Peters vond evenmin bewijs voor een structureel overwicht van de regering op het parlement: in haar ogen houden parlement en regering elkaar in evenwicht. ${ }^{40}$ Zowel Peters als Van Putten wijzen nadrukkelijk op de kabinetsformatie als een moment waarop de politieke partijen in de Tweede Kamer, althans de partijen die een coalitie zullen vormen, uitzonderlijk grote invloed uitoefenen op de beleidsontwikkeling. ${ }^{41}$

Wat de verhoudingen binnen het parlement betreft, stellen Visscher en Peters eensgezind dat de rol van de Eerste Kamer in vergelijking met die van de Tweede Kamer verwaarloosbaar is. ${ }^{42}$ Visscher stelt vast dat vooral de grote fracties in de Tweede Kamer - PvdA, CDA en VVD - veel invloed op de besluitvorming uitoefenen, ook wanneer zij vanuit de oppositie opereren. ${ }^{43}$ Peters daarentegen concludeert dat oppositiepartijen in de Tweede Kamer 'machteloos' zijn, omdat het hen aan stemmacht én aan toegang tot bewindspersonen en hun ambtenaren ontbreekt. ${ }^{44}$

Ik zal bezien in hoeverre ook op het beleidsveld van gezinsmigratie sprake is van een significante toename van de parlementaire betrokkenheid sinds de late jaren zestig en of de invloed van het parlement op de beleidsvorming daarmee ook toegenomen is. Bovendien zal ik onderzoeken of en zo ja hoe de verhoudingen binnen het parlement zijn veranderd van de jaren vijftig tot op heden.

37 Van Schendelen 1974; 't Hart e.a. 2002: 124-129.

38 Van Putten 1980: 268-270.

39 Visscher 1994: 784-786, 789.

40 Peters 1999: 227-228, 263.

41 Peters 1999: 236-237; Van Putten 1980: 258-259.

42 Visscher 1994: 773; Peters 1999: 226-227.

43 Visscher 1994: 782-784.

44 Peters 1999: 232-233. 


\section{De paradox van het migratiebeleid in liberale democratieën}

Nederland heeft nooit een immigratieland willen zijn. In de periode die hier wordt onderzocht is de grootschalige en permanente vestiging van vreemdelingen door de overheid steeds als ongewenst beschouwd. Tot de jaren negentig ontkende de regering zelfs met enige regelmaat nadrukkelijk dat Nederland een immigratieland was of mocht worden. Desalniettemin hebben zich in de afgelopen vijftig jaar vele duizenden vreemdelingen in Nederland gevestigd. Een groot deel van hen is als gezinsmigrant gekomen. Het begrijpelijk maken van deze tegenstrijdigheid is één van de centrale doelstellingen van dit onderzoek.

Nederland is niet het enige land met een dergelijke paradoxale migratiegeschiedenis, en ik ben niet de enige onderzoeker die op zoek is gegaan naar een oplossing voor deze paradox. Al vijftien jaar woedt onder Europese en Noord-Amerikaanse wetenschappers een debat dat gericht is op theorievorming over migratiebeleid in liberale democratieën. Onderwerp van dat debat is de verklaring van het fenomeen dat Cornelius, Martin en Hollifield, in de inleiding van hun standaardwerk Controlling Immigration uit 1994, hebben benoemd als hun beroemde 'gap hypothesis': 'the gap between the goals of national immigration policy (laws, regulations, executive actions etc.) and the actual results of policies in this area (policy outcomes) is wide and growing wider'. ${ }^{45}$ Die paradox wordt in het internationaal academisch debat enerzijds benaderd als een beheersingsprobleem, waarbij de vraag is waarom overheden er niet in slagen hun beleidsdoelen te realiseren. Anderzijds wordt de vraag gesteld, waarom regeringen van liberale democratieën een veel opener en inclusiever migratiebeleid blijven voeren dan hun - overwegend tot restrictie geneigde - publieke opinies graag zouden zien. ${ }^{46}$

In de jaren negentig zijn een aantal invloedrijke publicaties verschenen waarin deze paradox van het migratiebeleid in de context werd geplaatst van het debat over verval of voortbestaan van de natiestaat in een globaliserende wereld. Twistpunt was de vraag of natiestaten de zeggenschap over toegang en verblijf van vreemdelingen op hun grondgebied - traditioneel een kernelement van nationale soevereiniteit - hadden verloren.

Soysal behoort tot diegenen die betogen dat externe processen de relevantie van de natiestaat als regulator van migratiestromen hebben aangetast.

45 Cornelius e.a. 1994: 3.

46 Boswell 2007: 75. 
Zij stelt dat na de Tweede Wereldoorlog het traditioneel staatsburgerschap heeft plaatsgemaakt voor een nieuwe vorm van burgerschap, die zij 'postnational membership' noemt en die gebaseerd is op 'universal personhood rather than national belonging'. De natiestaat vormt nog steeds het kader waarin individuele rechten worden verwezenlijkt, maar is niet langer de bron van legitimiteit van die rechten. Die legitimiteit vloeit nu voort uit een transnationaal vertoog waarvan universele mensenrechten het organiserend principe vormen, en dat is vastgelegd in internationale conventies en mensenrechtenverdragen. De rechten van de mens zijn op iedereen gelijkelijk van toepassing, of die nu vreemdeling of staatsburger is. Natiestaten kunnen vreemdelingen die zich op hun grondgebied bevinden dus niet meer zomaar uitsluiten van rechten en privileges, niet alleen op politiek, sociaaleconomisch en cultureel gebied, maar ook op het gebied van toegang en verblijf. ${ }^{47}$

Sassen heeft eveneens betoogd dat globalisering de autonomie van de staat bij het voeren van migratiebeleid heeft ingeperkt. Economische globalisering heeft geleid tot deregulering en tot machtsverlies van de staat ten gunste van private actoren. Bovendien is de beleidsruimte waarover nationale regeringen beschikken steeds verder beperkt. Net als Soysal wijst Sassen op de opkomst van het internationaal mensenrechtenregime, waardoor het onderscheid tussen staatsburger en vreemdeling is vervaagd en de vrijheid van staten om vreemdelingen toegang te verlenen of te weigeren is afgenomen. Daarnaast is de zeggenschap over migratiebeleid deels overgeheveld van natiestaten naar supranationale organisaties als de Europese Unie of de Wereld Handelsorganisatie. Volgens Sassen is de staat zelf ook getransformeerd door globalisering. Er zijn nu meer overheidssectoren betrokken bij het migratiebeleid dan voorheen het geval was en daarmee is er meer aanleiding voor conflicten binnen de staat. Veel meer dan voorheen tonen publiek en parlement zich betrokken bij het migratiebeleid, zodat de bewegingsruimte van de uitvoerende macht nog verder afneemt. ${ }^{48}$

Tegenover Soysal en Sassen staan auteurs die de verklaring voor het voortduren van migratie die als ongewenst wordt beschouwd zoeken in mechanismen binnen de natiestaat. Zo stelden Cornelius, Martin en Hollifield in 1994 dat liberale democratieën er niet in slagen immigratie te beheersen, in de eerste plaats doordat economische push- en pull factoren die migratie veroorzaken aan de controle van de staat ontsnappen en in de

47 Soysal 1994: 1-3, 32-36, 142-143, 164-165.

48 Sassen 1996; 1999: 177-179, 181, 183-187, 192-193; 2006: 351-352. 
tweede plaats door wat zij 'rights based liberalism' noemen. De beleidsruimte van regeringen is beperkt door de expansie van rechten van individuen en minderheden, een expansie die het gevolg is van juridisch activisme van belangenorganisaties en politieke partijen maar vooral ook van rechtbanken. Waar Sassen een opkomend internationaal mensenrechtenregime als voornaamste machtsbron van de rechtspraak tegenover de uitvoerende macht beschouwt, leggen Cornelius e.a. de nadruk op binnenlandse processen van 'rights-based politics' in de jaren zestig, zeventig en tachtig, die rechtbanken de middelen in handen hebben gegeven om de bewegingsruimte van de uitvoerende macht aan banden te leggen. ${ }^{49}$

De analyse van Joppke (1998) heeft een vergelijkbare strekking. Hij verwerpt eveneens de stelling van Sassen dat westerse staten ongewenste immigratiestromen hebben moeten aanvaarden doordat globalisering de nationale soevereiniteit in deze heeft aangetast. Tegenover de hypothese van 'globally limited sovereignty' stelt Joppke die van 'self-limited sovereignty'. Net als Cornelius e.a. beschouwt Joppke de rechtspraak als een cruciale factor in de beperking van de mogelijkheden waarover regeringen beschikken om voornamelijk gezinsmigratie en asielmigratie aan restricties te onderwerpen. De rechtspraak baseert zich daarbij niet op internationale mensenrechtenverdragen, maar op nationale rechtsprincipes en grondwettelijke normen. Daarnaast verklaart Joppke het voortduren van immigratie in West-Europese landen als een gevolg van morele verplichtingen die regeringen ervaren zowel jegens arbeidsmigranten die op uitnodiging van de staat zijn gekomen, als jegens post-koloniale migranten. ${ }^{50}$

Ook Freeman zoekt - net als Cornelius e.a. en Joppke - de oplossing voor de paradox van het migratiebeleid in nationale processen. Hij poneert dat migratiebeleid in liberale staten in het algemeen inclusief en expansief zal zijn, als gevolg van de dynamiek van binnenlandse politiek. De publieke opinie is weliswaar vrijwel steeds gekant tegen immigratie, maar dit collectieve belang is diffuus en veelal slecht gearticuleerd. Daarentegen zijn er kleine, georganiseerde belangengroepen in de samenleving, in het bijzonder het bedrijfsleven, die belang hebben bij een soepel immigratiebeleid. Deze belangengroepen ontwikkelen nauwe banden met beleidsmakers en slagen erin om, buiten het zicht van de publieke opinie, het beleid naar hun hand te zetten: 'the typical mode of immigration politics, therefore, is 
client politics'. ${ }^{51}$

Guiraudon ten slotte heeft onderzocht hoe en waarom in Frankrijk, Duitsland en Nederland na 1974 hervormingen zijn doorgevoerd die de rechtspositie van migranten hebben versterkt, en daardoor de mogelijkheden van nationale overheden om toegang en verblijf van vreemdelingen in te perken hebben verzwakt. Zij concludeert dat ontwikkelingen op internationaal niveau zoals die waar Soysal op wijst de versterking van de rechtspositie van vreemdelingen niet kunnen verklaren. Haar these is dat aan vreemdelingen rechten zijn toegekend wanneer besluitvorming zich buiten het blikveld van het brede publiek heeft kunnen afspelen. Zij wijst in de eerste plaats - net als Joppke en Cornelius e.a. - op de rechtspraak als een dergelijk 'besloten' institutioneel kader, in de tweede plaats op bureaucratische besluitvorming en in de derde plaats op parlementaire debatten die niet of nauwelijks worden verslagen in de media. Guiraudon laat zien dat actoren in het beleidsvormingsproces strategisch gebruik maken van de mogelijkheden die verschillende institutionele 'venues' bieden. Juist doordat Nederlandse politici en beleidsmakers in de jaren tachtig bewust het publieke debat wisten te vermijden, zo stelt Guiraudon, was het Nederlands beleid ten aanzien van vreemdelingen significant soepeler dan in Duitsland of Frankrijk. Hoe opener het debat, hoe minder rechten aan vreemdelingen worden verleend.

Bovenstaande bijdragen aan de zoektocht naar inzicht in de paradox van het migratiebeleid van liberaal-democratische staten zijn overwegend gebaseerd op beleidsontwikkelingen in de Verenigde Staten, Frankrijk, Duitsland en het Verenigd Koninkrijk. Alleen Guiraudon heeft de Nederlandse casus in het debat betrokken. In het Nederlands veld van migratiestudies is De Lange de enige auteur die haar onderzoek in het perspectief van dit internationaal debat heeft gepositioneerd. ${ }^{52} \mathrm{Zij}$ heeft onderzocht in hoeverre de theses van Sassen op het arbeidsmigratiebeleid dat Nederland tussen 1945 en 2006 voerde van toepassing zijn. De Lange concludeert dat de Nederlandse staat inderdaad zeggenschap heeft verloren aan supranationale organisaties, maar alleen aan de instellingen van de Europese Unie. Andere internationale verdragen en organisaties hebben de soevereiniteit van de staat niet noemenswaard ingeperkt. De bevindingen van De Lange

51 Freeman 1995: 881-887; 2002: 77-82.

52 De tweede editie van Controlling Immigration van Cornelius e.a bevat wel een bijdrage van Muus (2004) over het Nederlands asiel- en migratiebeleid. Deze bijdrage biedt echter niet zozeer een empirische toetsing van de in het internationaal debat geformuleerde hypotheses, als een overzicht van beleidsontwikkelingen. 
duiden er evenmin op dat de invloed van private actoren of de rechter op de beleidsvorming is toegenomen in de mate die Sassen veronderstelt. ${ }^{53}$

Het is verrassend en betreurenswaardig dat tot op heden zo weinig aandacht is besteed aan de vraag, hoe beleidsontwikkelingen in Nederland zich tot de in het internationaal debat geformuleerde hypothesen verhouden. De paradox die aan dat debat ten grondslag ligt is immers ook in de Nederlandse casus onmiskenbaar aanwezig. Door de hierboven geschetste verklaringsmodellen op de beleidsvorming in Nederland inzake migratie toe te passen, wordt ons analytisch inzicht in de Nederlandse beleidsontwikkeling verscherpt. Bovendien constateert De Lange terecht dat in het internationaal debat te vaak voorbij wordt gegaan aan verschillen tussen westerse landen, en tussen de manieren waarop onderscheiden categorieën van migratie worden benaderd. ${ }^{54}$ Empirische studies naar beleidsvorming in Nederland op een specifiek subveld van het vreemdelingenbeleid, zoals de onderhavige en die van De Lange, maken een gefundeerde en zorgvuldige evaluatie van bestaande hypotheses mogelijk. Daarmee kan een wezenlijke bijdrage worden geleverd aan het internationaal debat in migratiestudies.

Ik zal daarom in de eerste plaats bezien, of het gezag van de Nederlandse staat over toelating en verblijf van buitenlandse gezinsleden aan erosie onderhevig is, en of die erosie kan verklaren waarom Nederland zoveel gezinsmigranten heeft toegelaten. Heeft de Nederlandse regering, zoals Sassen veronderstelt, soevereiniteit in deze verloren aan supranationale organisaties als de Europese Unie? Is de beleidsruimte van de regering beperkt door internationale verdragsverplichtingen?

Dat er sprake is van een 'control gap' in westerse landen is inmiddels niet meer onomstreden. De restrictieve hervormingen van het immigratiebeleid die veel westerse staten in de jaren negentig hebben doorgevoerd hebben veel onderzoekers tot de conclusie gebracht dat liberale staten wel degelijk - en wellicht zelfs in toenemende mate - in staat zijn om migratie te beheersen. ${ }^{55}$ De auteurs van de tweede editie van Controlling Immigration, die in 2004 verscheen, handhaafden daarentegen de 'gap hypothesis' die zij tien jaar eerder hadden geponeerd. ${ }^{56}$ De discussie over de vraag of er sprake is van machtsverlies van liberale democratieën over migratiestromen duurt dus voort: wij zullen zien welk licht de beleidsontwikkelingen in Nederland op die vraag werpen.

53 De Lange 2007: 401-405, 407-409.

54 De Lange 2007: 4.

55 Brochmann 1999: 298; Joppke 2002: 262; Geddes 2003: 20.

56 Cornelius \& Tsuda 2004: 4-5. 
Alle hierboven besproken auteurs, behalve Freeman, wijzen met nadruk op de rol van de rechtspraak in het beleidsvormingsproces. Rechtbanken zouden, op grond van internationaal of nationaal recht, de belangen van individuele vreemdelingen hebben verdedigd ten opzichte van de belangen van de staat. Daarmee zouden de mogelijkheden van beleidsmakers om migratie aan beperkingen te onderwerpen significant zijn verzwakt, hetgeen verklaart waarom westerse staten meer migranten hebben toegelaten dan zij wenselijk achtten. Ook bij die stelling zijn recentelijk enige vraagtekens gesteld. Zo meent Messina dat het immigratiebeleid dat een land als Duitsland - volgens Jopkke een “"extreme” case of self-limited sovereig$n t y$ ' - sinds de jaren zeventig voerde niet het resultaat was van rechterlijk ingrijpen, maar van welbegrepen eigenbelang van de Duitse regering. ${ }^{57}$ In de tweede editie van Controlling Immigration schrijven Cornelius en Tsuda ter verklaring van de 'gap hypothesis' een veel bescheidener rol toe aan de rechtspraak, en een grotere invloed aan politieke beperkingen en aan de pressie die door belangengroepen wordt uitgeoefend. ${ }^{58} \mathrm{Ik}$ zal dus nagaan, in hoeverre rechterlijke uitspraken invloed hebben uitgeoefend op de beleidsvorming inzake gezinsmigratie in Nederland, in hoeverre die invloed uitwerkte als een beperking van de beleidsopties waarover Nederlandse politici en ambtenaren beschikten, en of deze rechterlijke inbreng kan verklaren waarom de Nederlandse overheid de afgelopen vijftig jaar de vestiging van vele duizenden gezinsmigranten heeft toegestaan.

Zowel Freeman als Guiraudon wijzen op het 'open' of 'besloten' karakter van de besluitvorming, dat wil zeggen de aard en het aantal van de betrokken actoren, als een factor die restrictieve of liberale tendensen in het migratiebeleid kan verklaren. Freeman legt de nadruk op de 'diffuse' of 'geconcentreerde' aard van de maatschappelijke belangen die bij het migratiebeleid in het geding zijn. De staat is in zijn visie de passieve bemiddelaar van die maatschappelijke belangen. Guiraudon daarentegen besteedt meer aandacht aan de interactie tussen de verschillende actoren binnen de staat en aan de invloed van de specifieke institutionele fora waarin beleidsvorming plaats vindt op de uitkomst van de besluitvorming. Joppke heeft ten slotte geponeerd dat Europese overheden de overkomst van gezinnen van arbeidsmigranten en post-koloniale migranten hebben aanvaard omdat zij zich hiertoe 'moreel verplicht' voelden. In hoeverre bieden deze verklaringsmodellen inzicht in de ontwikkeling van het Nederlands

57 Messina 2004: 235-236.

58 Cornelius \& Tsuda 2004: 11-14. 
gezinsmigratiebeleid? Kunnen er op grond van de Nederlandse casus kanttekeningen worden geplaatst bij deze hypotheses?

Juist doordat ik heb gekozen voor analyse van de besluitvorming op een specifiek beleidsveld op de middellange termijn, waar in het internationaal debat veelal wordt gesproken over de ontwikkeling van het immigratiebeleid in algemene zin en niet verder wordt teruggekeken dan de jaren zeventig, biedt deze studie gelegenheid om enerzijds inzicht te verwerven in de paradox van het Nederlands gezinsmigratiebeleid en anderzijds te bezien in hoeverre bestaande verklaringsmodellen nuancering of wijziging behoeven.

\subsection{Bronnen}

Ik heb de beleidsvorming inzake gezinsmigratie gereconstrueerd aan de hand van stukken uit enerzijds het parlementair archief en anderzijds het beleidsarchief van het ministerie van Justitie. Mijn bronnenonderzoek in deze twee archieven was erop gericht een zo compleet mogelijk beeld te krijgen van wat Nederlandse ambtenaren, bewindslieden en parlementariers de afgelopen vijftig jaar hebben gezegd en besloten over gezinsmigratie. Ook van de inbreng van externe actoren - media, belangenorganisaties, enzovoorts - in het beleidsvormingsproces heb ik in deze archieven de weerslag teruggevonden in de vorm van krantenknipsels, opmerkingen in nota's en debatten, en correspondentie met ministeries en Kamerleden.

Het parlementair archief bevat alle verslagen van parlementaire en commissievergaderingen, alle regeringsstukken die door het parlement zijn behandeld, alle Kamervragen, amendementen en moties. Vanaf 1995 is dit archief gedigitaliseerd, hetgeen het onderzoek significant eenvoudiger maakt: zo bestaat in het digitaal archief niet alleen de mogelijkheid om te zoeken op Kamerstuknummer, titel of indiener, maar ook op woorden in de volledige tekst. ${ }^{59}$ Voor het onderzoek van de periode 1955-1995 heb ik gebruik gemaakt van registers op de handelingen voor zover die beschikbaar zijn, van de serie parlementaire jaarboeken die onder de titel Parlement en Kiezer is uitgebracht, en van verwijzingen naar kamerstukken in

59 Het parlementair archief vanaf 1995 is beschikbaar op Parlando (www.parlando.sdu.nl). Recentelijk zijn de Tweede Kamer en de Koninklijke Bibliotheek begonnen met een project om het gehele parlementaire archief vanaf 1814 te digitaliseren. Dit project moet in 2010 afgerond zijn: op dit moment is het parlementair archief van 1990 tot 1995 online te raadplegen (www.statengeneraaldigitaal.nl). 
secundaire literatuur of andere primaire bronnen.

De formele verantwoordelijkheid voor toelating en verblijf van vreemdelingen in Nederland, en dus ook voor het gezinsmigratiebeleid, heeft in de periode onder studie steeds bij het ministerie van Justitie gelegen. Daarom heb ik naast het parlementair archief ook het beleidsarchief van het ministerie van Justitie onderzocht. Wanneer andere ministeries betrokken waren in de besluitvorming op het gebied van gezinsmigratie, vind ik daarvan in het archief van Justitie de sporen terug in de vorm van verslagen van interdepartementaal overleg, correspondentie met ambtenaren en bewindspersonen van andere ministeries en interne ambtelijke nota's van die andere ministeries. Op basis van het beleidsarchief van het ministerie van Justitie heb ik dus een beeld kunnen vormen van de standpuntbepalingen en verhoudingen niet alleen binnen de direct verantwoordelijke ambtelijke organisatie, maar ook binnen en tussen andere ministeries.

Voor de periode 1945-1985 is het archief van het ministerie van Justitie dat betrekking heeft op het vreemdelingenbeleid overgebracht naar het Nationaal Archief. Aangezien het mij ging om de totstandkoming van de algemene wet- en regelgeving, niet om beslissingen in individuele gevallen, heb ik alleen onderzoek gedaan in het beleidsarchief. De persoonsgebonden dossiers, die zich ook in het Nationaal Archief bevinden, heb ik buiten beschouwing gelaten.

De beleidsontwikkeling na 1985 heb ik onderzocht aan de hand van de lopende beleidsarchieven van zowel de Immigratie- en Naturalisatiedienst (IND) als het ministerie van Justitie. Ik heb toestemming gekregen om archiefstukken in te zien uit de periode van 1985 tot 2003. Mijn analyse van de beleidsontwikkelingen vanaf het aantreden van het tweede kabinet Balkenende is dus uitsluitend gebaseerd op parlementaire stukken. Het doen van archiefonderzoek in deze lopende beleidsarchieven was in die zin anders dan in het Nationaal Archief, dat ik zelf geen directe toegang had tot de registers. Op basis van een door mij zo nauwkeurig mogelijk geformuleerde zoekopdracht zijn de archivarissen van de IND en het ministerie van Justitie op zoek gegaan in de inventaris van hun archieven, en hebben ze dossiers voor me gelicht. In het Nationaal Archief heb ik vrij kunnen grasduinen, hetgeen soms verrassende vondsten heeft opgeleverd.

Tot op heden hebben onderzoekers van het naoorlogs Nederlands migratiebeleid zelden gebruik gemaakt van de beleidsarchieven van het ministerie 
van Justitie. ${ }^{60}$ De lopende beleidsarchieven van de IND en het kerndepartement, waarin zich de stukken van 1985 tot op heden bevinden, zijn zelfs nog niet eerder door politicologen, bestuurswetenschappers of historici onderzocht. ${ }^{61}$ Ik hoop met deze studie te laten zien dat de beleidsarchieven van Justitie een uitzonderlijk vruchtbare bron zijn voor wie inzicht in de totstandkoming van het Nederlands migratiebeleid nastreeft, en daarmee andere onderzoekers aan te moedigen deze archieven verder te ontsluiten.

Ter aanvulling heb ik ten slotte op beperkte schaal onderzoek gedaan in de archieven van de ministerraad en het ministerie van Algemene Zaken. De agenda's, notulen en vergaderstukken van de ministerraad tot 1984 zijn te raadplegen op het Nationaal Archief. Documenten van minder dan 25 jaar oud zijn niet voor inzage beschikbaar. Mijn onderzoek in het archief van Algemene Zaken beperkte zich tot de dossiers die betrekking hebben op de onderhandelingen over de regeerakkoorden van 1998, 2002 en 2003. Ik heb die dossiers zelf niet ingezien: een medewerker van het ministerie heeft voor mij die stukken geselecteerd die inzicht boden in wat er in de coalitieonderhandelingen over het gezinsmigratiebeleid besloten is.

\subsection{Opzet van dit boek}

Dit boek brengt volgens een chronologische lijn de ontwikkeling van de beleidsvorming in Nederland op het gebied van gezinsmigratie tussen 1955 en 2005 in kaart. Ik onderscheid binnen die ontwikkeling drie fases, die ieder het onderwerp vormen van een hoofdstuk.

Het tweede hoofdstuk gaat over het tijdvak van 1955 tot 1974. Dit waren de jaren van grootschalige werving van arbeidsmigranten door het Nederlands bedrijfsleven en de overheid. Een besloten kring ambtenaren van de ministeries van Justitie en Sociale Zaken bepaalde - in vérgaande mate beschut tegen inmenging van rechter, parlement en zelfs bewindspersonen - de voorwaarden voor toelating en verblijf van arbeidsmigranten én hun gezinsleden. Aangezien Sociale Zaken en Justitie er heel verschillende visies op het migratievraagstuk op na hielden, leidde dat twintig jaar lang vrijwel voortdurend tot felle conflicten. Die meningsverschillen spitsten

60 Onderzoekers als Willems \& Lucassen (1990), Berghuis (1999) en De Lange (2007) vormen in die zin een uitzondering.

61 Met uitzondering van Willems \& Lucassen (1990) die ook archiefdossiers uit 1986-1989 hebben ingezien. 
zich toe op de voorwaarden voor overkomst van gezinsleden van arbeidsmigranten. In de discussies over gezinshereniging stond namelijk de tijdelijkheid van het verblijf van arbeidsmigranten op het spel, dat sleutelelement in de rechtvaardiging van de keuze om de overkomst van duizenden buitenlandse arbeiders aan te moedigen, terwijl niemand wilde dat Nederland een immigratieland werd.

In het derde hoofdstuk behandel ik de periode van 1975 tot 1989. In deze jaren werd de kring van besluitvormers in het beleidsveld van gezinsmigratie aanzienlijk vergroot. De veranderingen in de dominante Nederlandse moraal met betrekking tot gezin, huwelijk en verhoudingen tussen mannen en vrouwen vonden hun vertaling in ingrijpende wijzingen van het gezinsmigratiebeleid. In de loop van de jaren zeventig zagen Nederlandse beleidsmakers zich bovendien genoodzaakt te erkennen dat de aanwezigheid van migranten in Nederland niet van tijdelijke maar van permanente aard was. Vanaf de vroege jaren tachtig richtte de overheid zich daarom op het bevorderen van de gelijkwaardige en volwaardige participatie van migranten in de Nederlandse samenleving. Deze ontwikkelingen tezamen resulteerden in de meest soepele voorwaarden voor toelating en verblijf van buitenlandse gezinsleden die Nederland na de Tweede Wereldoorlog heeft gekend.

Het vierde hoofdstuk bespreekt de beleidsontwikkelingen tussen 1989 en 2005. De positie van migranten in de Nederlandse samenleving werd een steeds dringender en zorgelijker thema voor Nederlandse politici: het migratie- en integratievraagstuk raakte in toenemende mate gepolitiseerd. De oplossing werd deels gezocht in het verder terugbrengen van het aantal immigranten dat naar Nederland kwam, met als gevolg een graduele restrictieve wending in het gezinsmigratiebeleid. Na de eeuwwisseling kwam gezinsmigratie bovenaan de politieke agenda te staan, en zijn een aantal vérgaande en innovatieve aanscherpingen van het gezinsmigratiebeleid doorgevoerd. Verder zijn sinds de jaren negentig zowel het Europees Hof voor de Rechten van de Mens in Straatsburg als de Europese Unie een steeds belangrijker rol gaan spelen in de beleidsvorming inzake gezinsmigratie. De opkomst van deze Europese actoren komt eveneens in het vierde hoofdstuk aan de orde.

In het afsluitend hoofdstuk zal ik de hoofdlijnen van de beleidsvorming op het gebied van gezinsmigratie in Nederland in de afgelopen vijftig jaar samenvatten, en bezien welke kanttekeningen en aanvullingen op basis hiervan kunnen worden geplaatst bij enerzijds bestaande visies op de aard 
en ontwikkeling van beleidsvormingsprocessen binnen de Nederlandse overheid, en anderzijds hypotheses over hoe de paradox van het migratiebeleid van liberale democratieën kan worden verklaard. 



\section{Ambtelijke onmin over gezinnen van gastarbeiders, 1955-1975}

\subsection{Inleiding}

Deze studie van de Nederlandse beleidsvorming op het gebied van gezinsmigratie begint in de jaren vijftig. Dat is niet vanzelfsprekend. In de migratieliteratuur wordt de periode van arbeidsmigratie vóór 1974 veelal gecontrasteerd met de periode van gezinshereniging daarna. Daarbij wordt het beeld geschetst, dat gezinshereniging pas vanaf de jaren zeventig een plaats kreeg op de beleidsagenda. Zo beschrijven Van Amersfoort en Penninx 'het beperken of onaantrekkelijk maken van gezinshereniging' als een 'nieuwe invalshoek' die na 1973 een rol ging spelen in beleidsdiscussies. Bovenkerk beweert dat de Nederlandse regering vanaf het begin van de jaren zeventig de overkomst van gezinnen heeft toegestaan. Hooghiemstra schrijft: 'Specifiek beleid met betrekking tot gezinshereniging bestond al sinds de invoering van de Vreemdelingenwet in 1967'. En Spijkerboer stelt dat in 1974 'voor het eerst bezorgdheid over gezinshereniging wordt geformuleerd'. ${ }^{1}$

Uit mijn onderzoek blijkt echter dat gezinsmigratie al vanaf de jaren vijftig een bijzonder saillant beleidsthema was, niet zozeer op politiek als wel op ambtelijk niveau. De voorwaarden voor toelating van gezinsleden van arbeidsmigranten vormden twintig jaar lang het onderwerp van voortdurende en felle conflicten - de secretaris-generaal van Justitie sprak van 'geacharneerde gevechten'2 - tussen de betrokken ministeries.

Hoofdrolspelers in die beleidsconflicten waren het ministerie van Sociale Zaken en het ministerie van Justitie, die gezamenlijk de verantwoordelijkheid

1 Van Amersfoort \& Penninx 1993: 57-84, 61; Bovenkerk 1979: 118-132, 129; Hooghiemstra 2003: 73; Spijkerboer 2007: 113.

2 De term 'geacharneerd' die de secretaris-generaal hier gebruikt is een incorrecte, letterlijke vertaling van het Franse 'acharné', dat zoveel betekent als: 'verbeten, hardnekkig'. Nota SG aan hoofd HVG,15 februari 1968. NA IND 1202. 
droegen voor de regulering van de arbeidsmigratie: Sociale Zaken verleende de arbeidsvergunningen, Justitie de verblijfsvergunningen. De twee ministeries hielden er echter een heel verschillende kijk op de migratieproblematiek op na en juist in debatten over gezinshereniging leidden die verschillen steeds weer tot confrontaties. Justitie achtte de immigratie van gezinsleden ongewenst en pleitte daarom steeds voor zo strikt mogelijke regelgeving. Sociale Zaken daarentegen streefde naar een soepeler gezinsherenigingsbeleid. Het verloop van deze ambtelijke twisten is grotendeels bepalend geweest voor de ontwikkeling van het beleidskader voor gezinsmigratie in de eerste decennia na de Tweede Wereldoorlog.

Dat dit slepende beleidsconflict tot nu toe nogal eens over het hoofd is gezien in de migratieliteratuur, komt waarschijnlijk doordat het zich grotendeels achter gesloten deuren heeft afgespeeld. De discussies over de toelating van Spaanse echtgenotes tussen 1962 en 1964, die wél aanleiding waren tot publiek en parlementair debat, vormen dan ook vrijwel het enige moment in de beleidsontwikkeling tot de jaren zeventig dat wel besproken is in de literatuur. ${ }^{3}$ Verder besteedt De Lange aandacht aan de discussies in de ministerraad over gezinshereniging. ${ }^{4}$ In deze studie wordt echter voor het eerst, aan de hand van de archieven van het parlement en het ministerie van Justitie, dat formeel verantwoordelijk was voor het gezinsmigratiebeleid, de beleidsvorming gedurende de gehele periode van grootschalige arbeidsmigratie in kaart gebracht.

Daarbij staat de vraag centraal, welke conflicterende visies op het gezinsmigratievraagstuk de ontwikkeling van het beleid hebben bepaald. Om de dynamiek van de beleidsvorming, de invloedsverhouding tussen de betrokken besluitvormers en de logica en continuïteit van hun argumentaties inzichtelijk te maken, worden een aantal debatten uitgelicht die voor de beleidsontwikkeling van belang zijn geweest. De aandacht gaat primair uit naar de hoofdrolspelers, dat wil zeggen de ambtenaren en bewindslieden van Justitie en Sociale Zaken, en waar relevant ook naar de vertegenwoordigers van andere ministeries. Hoewel de invloed van het parlement op de beleidsvorming tot de jaren zeventig beperkt bleef, kan deze hier niet buiten beschouwing blijven. Kamerleden brachten namelijk een geheel eigen perspectief te berde in de beleidsdebatten.

Deze reconstructie van de beleidsdebatten over gezinshereniging van arbeidsmigranten tussen 1955 en 1974 biedt nieuwe inzichten, niet alleen

3 Schuster 1999: 177-181; Tinnemans 1994 39-41; Van Walsum 2008: 123-125.

4 De Lange 2007: 155-158. 
in de geschiedenis van het gezinsmigratiebeleid in engere zin, maar ook in manier waarop Nederlandse politici en ambtenaren zich in deze periode tot het brede migratievraagstuk verhielden. In de Nederlandse migratieliteratuur wordt namelijk algemeen aangenomen dat de 'veronderstelling van tijdelijk verblijf' de cruciale factor was die beleid en debat over migratie in Nederland tot het einde van de jaren zeventig heeft bepaald. Dat de overheid ervan uitging dat arbeidsmigranten na korte tijd weer terug zouden keren naar hun land van herkomst, verklaart waarom tienduizenden 'gastarbeiders' met open armen werden verwelkomd, ook al wilde Nederland 'geen immigratieland' zijn. Zo wordt ook geduid, waarom de overheid pas eind jaren zeventig een actief integratiebeleid ontwikkelde: pas toen de permanente aard van het verblijf van migranten werd erkend, zouden beleidsmakers oog hebben gekregen voor de maatschappelijke consequenties van migratie. ${ }^{5}$ Uit mijn onderzoek blijkt echter dat de tijdelijkheidsgedachte in overheidskringen niet zo algemeen en onbetwist domineerde als wel wordt aangenomen. In de discussies over het gezinsherenigingsbeleid stond vanaf de jaren vijftig juist die tijdelijkheid op het spel. Het verzet van Justitie kwam voort uit de verwachting dat gezinshereniging zou leiden tot langdurig verblijf en uit vrees voor de gevolgen die dit zou kunnen hebben voor de Nederlandse samenleving. In het hart van de Nederlandse regering leefden dus al twintig jaar eerder dan verondersteld zorgen over de permanente en grootschalige vestiging van vreemdelingen in Nederland en over de consequenties hiervan voor het Nederlands maatschappelijk bestel. Dit werpt een nieuw licht op deze cruciale episode in de Nederlandse migratiegeschiedenis, die het aanzien van de Nederlandse samenleving definitief heeft veranderd.

\subsection{Immigratie in Nederland tussen 1945 en 1975}

De gezinsleden van arbeidsmigranten maakten maar een klein deel uit van de honderdduizenden vreemdelingen die in de eerste drie decennia na de Tweede Wereldoorlog hun weg vonden naar Nederland. In het hiernavolgende schets ik kort de overige immigratieontwikkelingen in deze periode, en zet ik uiteen waarom ik mij in dit hoofdstuk richt op beleidsvormingsprocessen omtrent de gezinnen van 'gastarbeiders'.

5 Zie bijvoorbeeld Penninx 1979: 163-165; Bovenkerk 1979: 118; Entzinger 1985: 57; Obdeijn 1987: 470; Van Amersfoort \& Surie 1987: 180; Van Amersfoort 1999: 136; Snel \& Scholten 2005: 168 . 


\section{Buitenlandse gezinsleden van Nederlandse staatsburgers}

Toelating en verblijf van buitenlandse gezinsleden van Nederlanders waren tot de jaren zeventig grotendeels gereguleerd in het nationaliteitsrecht. Centraal in dat recht stond de morele norm van eenheid van het gezin, die tot uitdrukking kwam in het principe dat alle leden van het gezin één en dezelfde nationaliteit dienden te delen. Uit de heersende opvattingen over genderrollen vloeide logisch voort dat de man, als hoofd van het gezin, de nationaliteit van zijn vrouw en kinderen bepaalde. Tot 1964 verkreeg de buitenlandse echtgenote van een Nederlandse man bij haar huwelijk dan ook automatisch de Nederlandse nationaliteit. Omgekeerd verloor een Nederlandse vrouw die met een vreemdeling trouwde haar Nederlands staatsburgerschap. Het was vanzelfsprekend dat een Nederlander het recht had om, met zijn gezin, op Nederlands grondgebied te verblijven. Het sprak evenzeer voor zich dat een Nederlandse die koos voor een huwelijk met een buitenlander haar echtgenoot in zijn nationaliteit en domicilie diende te volgen. ${ }^{6}$

In een wijziging van de rijkswet op het Nederlanderschap van 1964 werd deze ongelijke behandeling van mannen en vrouwen enigszins getemperd. Een Nederlandse die met een vreemdeling trouwde verloor haar staatsburgerschap niet langer en de buitenlandse echtgenote van een Nederlander kreeg niet meer automatisch de Nederlandse nationaliteit. Deze vreemdelinge had echter wel de mogelijkheid om bij haar huwelijk direct voor de Nederlandse nationaliteit te opteren. Koos zij daar niet voor, dan verkreeg zij vanaf 1967 na één jaar huwelijk en verblijf de zogenaamde 'blauwe kaart', een status die haar verblijfsrecht in Nederland garandeerde zolang het huwelijk voortduurde. Kinderen van een Nederlander kregen bij geboorte de Nederlandse nationaliteit. ${ }^{7}$ Uitgangspunt bleef dus, dat de gezinseenheid en het gezinsleven van een Nederlandse man in Nederland gewaarborgd moesten zijn. Voor Nederlandse vrouwen lag dat anders. Zij gaven hun Nederlanderschap niet automatisch door aan hun kinderen. Hun

6 De Hart 2003a: 78-81. Tot 1936 hadden buitenlandse echtgenoten van (voormalig) Nederlandse vrouwen wel een bijzondere positie in het vreemdelingenrecht. Op grond van de Vreemdelingenwet van 1849 mochten deze mannen, wanneer zij in Nederland woonden en uit het huwelijk kinderen waren geboren, in principe niet worden uitgezet. In de context van de economische crisis van de jaren dertig werd deze geprivilegieerde status echter afgeschaft, uit angst voor schijnhuwelijken van 'armlastige' buitenlanders met Nederlandse vrouwen. De Hart 2003a: 90.

7 De Hart 2003a: 81, 101. De 'blauwe kaart', of 'artikel 10 lid 2 status', is geïntroduceerd in de nieuwe Vreemdelingenwet van 1965 die in 1967 in werking trad. 
buitenlandse echtgenoten hadden niet de mogelijkheid om voor de Nederlandse nationaliteit te opteren, maar kwamen net als andere vreemdelingen pas na vijf jaar voor naturalisatie in aanmerking. Zij verkregen geen 'blauwe kaart'. Ook na 1964 gold voor de buitenlandse gezinsleden van Nederlandse vrouwen dus geen bijzonder recht op toelating en verblijf in Nederland. De verlening van een vergunning 'voor verblijf bij echtgenote' was afhankelijk van de algemene criteria van openbare orde en voldoende inkomen. ${ }^{8}$ Dankzij het liberale arbeidsmigratiebeleid in die jaren bracht dit echter relatief weinig problemen met zich mee: buitenlandse echtgenoten van Nederlandse vrouwen bezaten veelal een vergunning voor arbeid. ${ }^{9}$

De toelating van buitenlandse gezinsleden van Nederlanders was in de jaren vijftig en zestig dus geen problematisch vraagstuk voor de makers van het Nederlands vreemdelingenbeleid. ${ }^{10}$ Zoals we in hoofdstuk 3 zullen zien, komt in deze situatie vanaf de jaren zeventig verandering.

\section{Migranten uit voormalig Nederlands-Indië}

De meest omvangrijke groep migranten die in de eerste decennia na de Tweede Wereldoorlog naar Nederland kwam was afkomstig uit NederlandsIndië. Tussen 1945 en 1970 zijn naar schatting 300 duizend mensen vanuit de jonge Indonesische Republiek naar Nederland vertrokken. ${ }^{11}$ Aangezien zij in grote meerderheid het Nederlands staatsburgerschap bezaten, kon hen het recht niet worden ontzegd zich in Nederland te vestigen: het vreemdelingenbeleid was niet op hen van toepassing. ${ }^{12}$ Uitzondering op deze regel vormde een groep van ruim 10 duizend Molukkers, in meerderheid KNIL-militairen en hun gezinnen, die in 1951 naar Nederland kwamen. ${ }^{13} \mathrm{Zij}$ hadden toen

8 Deze toelatingsgrond werd geïntroduceerd in de Vreemdelingenwet van 1965.

9 De Hart 2003a: 81, 102-103.

10 In de eerste jaren na de Tweede Wereldoorlog is wel gedebatteerd over Nederlandse mannen en vrouwen die met Duitsers getrouwd waren; zie Van Walsum 2008: 93-97. In de jaren zestig waren huwelijken van Nederlandse vrouwen met arbeidsmigranten onderwerp van overheidszorg, echter niet zozeer in het kader van het vreemdelingenbeleid als vanuit welzijnswerk. Zie Hondius 2001: 156-166.

11 Ellemers \& Vaillant 1987: 429.

12 Zie over de toescheiding van Nederlands en Indonesisch staatsburgerschap: Heijs 1994: 120133; Jones 2007: 73-87; zie over het 'ontmoedigingsbeleid' van de Nederlandse regering jegens 'Nederlands-Indische' migranten: Schuster 1999: 85-111; Jones 2007: 137-183.

13 Manuhutu 1987: 432-436. 
veelal de Indonesische nationaliteit. ${ }^{14}$ Daarnaast kwamen in de jaren zestig nog enkele duizenden spijtoptanten naar Nederland: mensen van veelal gemengd Nederlands-Indische afkomst die bij de onafhankelijkheid voor de Indonesische nationaliteit hadden geopteerd, maar later alsnog voor migratie naar Nederland kozen. ${ }^{15}$ Zowel voor de Molukkers als voor de spijtoptanten gold dat zij in gezinsverband migreerden. De beslissing tot toelating werd voor het gehele gezin genomen: getoetst werd of het hoofd van het gezin - de man - aan de toelatingscriteria voldeed. ${ }^{16} \mathrm{Net}$ als in het nationaliteitsrecht gold ook hier dat de man de verblijfplaats van het gezin bepaalde. De overkomst van Nederlandse staatsburgers, Molukkers en spijtoptanten uit voormalig Nederlands-Indië, is dus voor de Nederlandse overheid geen aanleiding geweest om beleidsregels op te stellen voor toelating van buitenlandse gezinsleden. ${ }^{17}$

\section{Vluchtelingen}

In de directe nasleep van de Tweede Wereldoorlog nam Nederland enkele duizenden vluchtelingen op, met name Poolse ex-militairen en ontheemden uit kampen in Duitsland. ${ }^{18}$ Welbegrepen eigenbelang speelde daarbij een belangrijker rol dan humanitaire overwegingen. Nederland wenste vooral 'volwaardige arbeidskrachten' toe te laten. Met het oog op de woningnood die in Nederland heerste was de overkomst van gezinnen ongewenst: alleen ongehuwde ontheemden waren welkom. ${ }^{19}$

Tot halverwege de jaren tachtig zou het aantal vluchtelingen dat zijn weg naar Nederland vond beperkt blijven. In 1956 werden zo'n 3 duizend Hongaarse vluchtelingen toegelaten. In de nasleep van de 'Praagse lente' in 1968 kwamen iets minder dan duizend Tsjechen naar Nederland, en

14 Bij de onafhankelijkheid van Indonesië kregen Molukkers - veelal tegen hun zin - automatisch de Indonesische nationaliteit. Het verkrijgen van het Nederlands staatsburgerschap was voor Molukkers niet eenvoudiger dan voor andere vreemdelingen. Indonesische staatsburgers die meer dan vijf jaar in het buitenland verbleven verloren de Indonesische nationaliteit, tenzij zij deze verlengden bij het Indonesisch consulaat. Een zeer ruime meerderheid onder de Molukkers in Nederland liet dat na. In 1978 had 10\% van de Molukkers de Indonesische en 30\% de Nederlandse nationaliteit en was 60\% stateloos. Jones 2007: 99-102, 129-130.

15 Ringeling 1978: 71-87.

16 Van Walsum 2008: 109-110.

17 Zie over de rol van gender- en familienormen in beleid en rechtspraak ten aanzien van migranten uit voormalig Nederlands-Indië tussen 1945 en 1970: Van Walsum 2008: 97-116. Zie over de 'gendered disciplinering van Indische gezinnen' in de assimilatiepolitiek van de jaren vijftig en zestig: Jones 2007: 174-177.

18 De Lange 2007: 23.

19 Berghuis 1999: 82-103. 
in de eerste helft van de jaren zeventig nog enkele honderden Portugese, Oegandese en Chileense vluchtelingen. ${ }^{20} \mathrm{Ik}$ heb in de literatuur noch in de beleidsarchieven van het ministerie van Justitie tot de jaren zeventig verwijzingen gevonden naar debat of regelgeving inzake de toelating van gezinsleden van vluchtelingen. ${ }^{21}$

\section{Arbeidsmigranten}

Zoals ook voor de oorlog gebruikelijk was geweest, kregen werkgevers in sectoren die met arbeidstekorten kampten na 1945 in de regel toestemming van de overheid om buitenlandse werknemers in dienst te nemen. In de eerste naoorlogse jaren waren bijvoorbeeld Italiaanse vrouwen werkzaam in de chocolade-industrie en Fransen en Italianen in de hoogovens en chemie-grafische industrie. In 1947 werkten zo'n 30 duizend vreemdelingen in Nederland, waaronder 10 duizend grensarbeiders. ${ }^{22}$ In 1948 sloot de Nederlandse regering voor het eerst een bilaterale wervingsovereenkomst, met het oog op de tewerkstelling van Italianen in de Nederlandse steenkoolmijnen. ${ }^{23}$ In die overeenkomst met de Italiaanse regering had de Nederlandse delegatie haar voorkeur vastgelegd voor ongehuwde arbeidsmigranten. Alleen wanneer voldoende huisvesting beschikbaar was, zou de werving van gehuwde mijnarbeiders in overweging worden genomen. ${ }^{24}$

In 1960 waren 24 duizend vreemdelingen in het bezit van een werkvergunning: minder dus dan in 1947. Ruim een derde van die vergunningen was verleend aan Duitsers, waaronder naar alle waarschijnlijkheid een groot aantal grensarbeiders. ${ }^{25}$ In de tweede helft van de jaren vijftig waren Nederlandse werkgevers daarnaast in toenemende mate arbeiders gaan werven in Italië. ${ }^{26}$ In 1960 waren ruim 2700 Italianen werkzaam in

20 Ten Doesschate 1993: 40-88.

21 Ten Doesschate (1993: 210-211) laat het gezinshereningsbeleid voor vluchtelingen in zijn analyse van het Nederlands asielbeleid tussen 1968 en 1982 buiten beschouwing. Hij geeft wel aan dat bij beslissingen omtrent het aantal en de selectie van uitgenodigde vluchtelingen, zoals de Chilenen, de gezinssamenstelling een belangrijke rol speelde: kleine gezinnen genoten de voorkeur, opdat het aantal vluchtelingen dat overkwam beperkt bleef. Op grond daarvan lijkt het mij aannemelijk dat voor vluchtelingen - net als voor Molukkers en spijtoptanten - de beslissing om verblijf toe te staan niet alleen de aanvrager, maar ook zijn gezin gold.

22 De Lange 2007: 24-25.

23 De Lange 2007: 68-70.

24 Artikel 7, Italiaans-Nederlandse Overeenkomst betreffende de aanwerving van Italiaanse arbeiders voor de ondergrondse bedrijven der Nederlandse steenkolenmijnen, oktober 1948. NA IND 5.023.5026243.

25 De Lange 2007: 91.

26 Goedings 2005: 368. 
Nederland. Vanaf het begin van de jaren zestig ging het economisch echter snel beter met Italië, zodat het aantal Italianen dat werk in het buitenland zocht sterk afnam. ${ }^{27}$

Na 1960 namen de tekorten op de Nederlandse arbeidsmarkt scherp toe. ${ }^{28}$ Tussen 1960 en 1975 maakten buitenlandse arbeiders de overgrote meerderheid uit van de migranten die naar Nederland kwamen. ${ }^{29}$ In 1965 verbleven bijna 40 duizend vreemdelingen uit het Middellandse Zeegebied in Nederland, in 1970 waren dat er bijna 93 duizend, en in 1973 ruim 128 duizend. ${ }^{30}$ In de eerste helft van de jaren zestig was die groei met name afkomstig uit Spanje: in 1960 verbleven 309 Spanjaarden met een verblijfsvergunning in Nederland, in 1965 was dat aantal gestegen tot ruim 21 duizend. De omvang van de Spaanse populatie in Nederland zou in 1974 een maximum bereiken, met bijna 32 duizend. ${ }^{31}$ In de loop van de jaren zestig sloot de Nederlandse regering een achttal wervingsovereenkomsten met landen in het Middellandse Zeegebied, namelijk met Italië (1960), Spanje (1961), Portugal (1963), Turkije (1964), Griekenland (1966), Marokko (1969), Joegoslavië (1970) en Tunesië (1970). ${ }^{32}$ In de tweede helft van de jaren zestig zou de samenstelling van de arbeidsmigrantenpopulatie in Nederland dus steeds diverser worden, waarbij met name de instroom uit Turkije en Marokko sterk toenam.

De wervingsovereenkomsten vormden het belangrijkste instrument voor de Nederlandse regering om de arbeidsmigratie te reguleren. In de overeenkomsten was vastgelegd dat de landen van herkomst zorg zouden dragen voor een voorselectie van arbeiders, terwijl de definitieve selectie, op basis van leeftijdscriteria, gezondheid en beroepsvaardigheden, aan Nederland toeviel. De Nederlandse regering zou erop toezien dat werkgevers aan buitenlandse werknemers dezelfde arbeidsvoorwaarden boden als aan Nederlandse arbeiders in dezelfde sector. Verder hadden werkgevers de plicht om in het eerste jaar in de kosten van huisvesting en levensonderhoud van de arbeidsmigranten te voorzien.

De effectiviteit van de wervingsovereenkomsten als reguleringsinstrument bleef echter lange tijd zeer beperkt. Tot 1968 kwam een meerderheid

27 De Lange 2007: 91; Goedings 2005: 29, 368-369; Federici 1979: 150.

28 Berg 1967: 16.

29 De Lange 2007: 91.

30 Penninx 1979: 95. Deze cijfers betreffen vreemdelingen uit Griekenland, Joegoslavië, Portugal, Spanje, Turkije, Marokko en Tunesië.

31 Penninx 1979: 95.

32 Penninx 1979: 99; De Lange 2007: 144-154. 
van de arbeidsmigranten 'spontaan' naar Nederland, dat wil zeggen buiten de officiële wervingskanalen om. ${ }^{33}$ 'Spontane' migranten kwamen op een toeristenvisum naar Nederland, zochten en vonden gemakkelijk een baan, en vroegen vervolgens een werk- en verblijfsvergunning aan. Tot 1968 werd deze 'spontane' migratie niets in de weg gelegd, omdat zo de kostbare en tijdrovende wervingsprocedures werden vermeden. ${ }^{34}$

Zoals wij later zullen zien was het arbeidsmigratiebeleid dat de Nederlandse regering tot 1975 voerde gebaseerd op de veronderstelling dat het verblijf van buitenlandse werknemers in Nederland tijdelijk zou zijn. In de jaren zestig lijkt er inderdaad verloop te zijn geweest in de buitenlandse arbeidspopulatie, hoewel nauwkeurige gegevens over verblijfsduur en terugkeer niet voorhanden zijn. Op basis van eigen berekeningen schat Penninx het percentage van de buitenlandse werknemers dat terugkeerde tussen 1960 en 1967 op ongeveer 30 procent. Daarna zou dat aandeel snel teruglopen, van 16 procent in 1969 tot 4,5 procent in $1973 .{ }^{35}$ De Spaanse populatie in Nederland zou na 1974 inderdaad afnemen. De Spanjaarden waren echter de enigen onder de arbeidsmigranten die in grote aantallen terugkeerden naar hun herkomstland. De omvang van de overige ZuidEuropese groepen consolideerde zich in de jaren zeventig, terwijl het aantal Turken en Marokkanen gestaag toe zou blijven nemen. ${ }^{36}$

De arbeidsmigranten die tussen 1955 en 1975 op grote schaal naar Nederland kwamen, waren in grote meerderheid mannen, en zij kwamen

33 De Lange 2007: 91-93.

34 Van Amersfoort \& Penninx 1993: 59-60; Tinnemans 1994: 64-5, 87; De Lange 2007: 113116.

35 Penninx 1979: 108. Penninx baseert zijn berekening op cijfers inzake het aantal arbeidsvergunningen die de regering aan het parlement verstrekte.

36 Lindo 1994: 119-120. Meer dan 80 procent van de Italiaanse arbeiders is met een Nederlandse vrouw getrouwd. (Lindo 1994: 127) De Italianen kwamen vooral vóór 1960. Volgens De Lange (2007: 76) werden toen voornamelijk vrijgezellen geworven, omdat werkgevers aan gehuwde Italianen een extra vergoeding moesten bieden. Waarom de Spanjaarden - als enigen onder de arbeidsmigranten - wél in substantiële mate naar hun herkomstland terugkeerden, is niet bekend. Volgens Lindo (1994: 130-131) bieden economische factoren geen verklaring: de sociaal-economische positie van Spanjaarden in Nederland was relatief goed - velen namen ontslag om te remigreren - en de situatie in Spanje waarnaar zij terugkeerden zeer onzeker. De politieke veranderingen in Spanje na de dood van Franco in 1975 zouden een rol kunnen hebben gespeeld: ook daarvóór waren de terugkeerpercentages onder Spanjaarden echter al relatief hoog, en onder Grieken en Portugezen zou het aantal remigranten na de val van de dictatoriale regimes in hun herkomstlanden niet substantieel toenemen. 
in eerste instantie alleen. ${ }^{37}$ Over de vraag of en onder welke voorwaarden deze arbeidsmigranten hun gezinsleden naar Nederland mochten laten overkomen, zouden twintig jaar lang felle debatten worden gevoerd. Deze debatten vormen het begin van de beleidsvorming in Nederland inzake de toelating van buitenlandse gezinsleden, en zijn daarom het onderwerp van dit hoofdstuk.

\subsection{Institutionele structuur}

Over de beginjaren van het Nederlands gezinsmigratiebeleid is, zoals in de inleiding van dit hoofdstuk gesteld, tot nu toe niet veel bekend. Dit heeft waarschijnlijk te maken met het feit dat deze beleidsvormingsprocessen zich grotendeels buiten het zicht van politiek en parlement hebben afgespeeld. ${ }^{38}$ In de eerste decennia na de Tweede Wereldoorlog werd de inhoud van het gezinsmigratiebeleid in vérgaande mate op ambtelijk niveau bepaald.

Tot de dag van vandaag zijn de voorwaarden voor toelating en verblijf van buitenlandse gezinsleden niet neergelegd in de vreemdelingenwet, maar in lagere regelgeving. Tussen 1955 en 1975 lag de formele bevoegdheid voor het vaststellen van die voorwaarden bij de Hoofdafdeling Vreemdelingenzaken en Grensbewaking (HVG) van het ministerie van Justitie. ${ }^{39}$ De uitvoering van het vreemdelingenbeleid was tot 1994 de taak van de Hoofden van Plaatselijke Politie. ${ }^{40}$ Wijzigingen in regelgeving werden door het hoofd HVG aan de politiediensten meegedeeld door middel van circulaires, die het karakter hadden van 'geheime' interne instructies: zij werden niet gepubliceerd. Voor zover deze circulaires betrekking hadden op toelating

37 Tussen 1960 en 1975 werden ook vrouwelijke arbeidsmigranten geworven, onder meer uit Spanje, Joegoslavië en de Filippijnen. Het precieze aantal is niet bekend. (De Lange 2007: 171172; Chotkowski 2000: 80-82). Vrouwelijke arbeidsmigranten speelden in de debatten over het gezinsmigratiebeleid geen enkele rol. Formeel werden alleen ongehuwde buitenlandse vrouwen geworven. Chotkowski (2000: 87-91) heeft aangetoond dat in de praktijk wel degelijk gehuwde arbeidsters naar Nederland kwamen. Voor zover gewenst zullen hun echtgenoten, net als de buitenlandse mannen van Nederlandse vrouwen, gemakkelijk toegang tot Nederland hebben gekregen via het arbeidsmigratiekanaal.

38 Volgens zowel Daalder (1995: 19-20) als Lijphart (1979: 124-127) was de 'neiging tot geheimhouding' tot in de jaren zestig kenmerkend voor de Nederlandse politieke cultuur.

39 Vanaf 1956. Daarvóór droeg de desbetreffende afdeling de titel 'Rijksvreemdelingendienst' (RVD). Berghuis e.a. 1994: 47.

40 Berghuis e.a. 1994: 11-12. Sinds 1994 valt die taak aan de Immigratie- en Naturalisatiedienst (IND) toe. 
en verblijf van arbeidsmigranten en hun gezinnen, werd de formulering ervan vastgesteld in nauw overleg met het Directoraat-Generaal voor de Arbeidsvoorziening van het ministerie van Sociale Zaken en eventueel ook met ambtenaren van andere betrokken ministeries. De kring Justitie-ambtenaren die zich met het toelatingsbeleid bezig hield was beperkt en besloten. Een handvol ambtenaren van de HVG bepaalde in onderling overleg het standpunt van Justitie, dat door de secretaris-generaal van het ministerie werd bekrachtigd of aangepast. ${ }^{41}$

De betrokkenheid van bewindspersonen bij de beleidsvorming was gering, zeker in vergelijking met later jaren. De inbreng van de minister van Justitie bleef beperkt tot een enkele krabbel op een ambtelijke nota. Interdepartementale controverses werden grotendeels door ambtenaren uitgevochten: veelal werd een beleidsvoorstel pas aan de minister voorgelegd als op ambtelijk niveau overeenstemming was bereikt. In dergelijke 'uitonderhandelde' compromissen konden nauwelijks meer wijzigingen worden aangebracht. Hervormingen van de regelgeving werden soms, maar lang niet altijd, voorgelegd aan de ministerraad.

De vérgaande autonomie waarmee ambtenaren opereerden resulteerde in een uitgesproken continuïteit in de standpunten die door de ministeries van Justitie en Sociale Zaken werden ingenomen. De politieke kleur van het kabinet had geen invloed op de beleidsontwikkeling. ${ }^{42}$ Tussen 1955 en 1975 werd Nederland afwisselend geregeerd door centrum-linkse, confessionele en centrum-rechtse coalities. De post van minister - later staatssecretaris - van Justitie werd bekleed door politici van PVdA, KVP, CHU, VVD, ARP en D66; die van Sociale Zaken door PVdA, KVP, ARP, CHU en VVD. ${ }^{43}$ Deze politieke verschuivingen leidden niet tot wijzigingen in het beleid, of in de termen waarin het debat over gezinsmigratie werd gevoerd. ${ }^{44}$

De rol van het parlement was eveneens veel beperkter dan in later jaren het geval zou zijn. Wijzigingen in de regelgeving werden doorgevoerd zonder dat het parlement daarover werd geraadpleegd. Dit betekent echter niet dat Kamerleden zich geheel afzijdig hielden van de problematiek rond de

41 In 1955 waren bij de Rijksvreemdelingendienst 11 ambtenaren werkzaam; in 1960 werkten bij wat toen de Hoofdafdeling Vreemdelingenzaken en Grensbewaking was gaan heten 15 ambtenaren; in 1965 22, in 196829 en in 1971 25. (Staatsalmanak)

42 Uit onderzoek van De Lange (2007: 235) blijkt dat de politieke kleur van de betrokken bewindslieden in het veld van arbeidsmigratie tot de jaren zeventig evenmin invloed had op de beleidsontwikkeling.

43 Zie bijlage I.

44 Tot op zekere hoogte vormt het kabinet Den Uyl, dat in 1973 aantrad, hierop een uitzondering. Ik kom daar later in dit hoofdstuk, maar vooral in hoofdstuk 3, op terug. 
overkomst van gezinnen van arbeidsmigranten. Er werden met enige regelmaat kritische vragen gesteld over het regeringsbeleid, met name in het kader van de jaarlijkse begrotingsdebatten en naar aanleiding van berichtgeving in de media.

De rechtspraak speelde in deze periode geen enkele rol in de beleidsvorming. Tot 1967, toen de Vreemdelingenwet van 1965 in werking trad, bestonden er binnen het Nederlands vreemdelingenrecht geen mogelijkheden tot beroep. ${ }^{45}$ Het uitgebreide netwerk van rechtshulp aan vreemdelingen, dat wij heden ten dage kennen, heeft zich pas halverwege de jaren zeventig ontwikkeld. ${ }^{46}$ Tot die tijd waren er in Nederland nauwelijks juristen met expertise in het vreemdelingenrecht. ${ }^{47}$ Gevolg was dat arbeidsmigranten en hun gezinnen de beslissingen van de Nederlandse overheid over hun toelating en verblijf in Nederland niet aanvochten bij de rechtbank. Pas vanaf de jaren zeventig zouden rechters worden gevraagd om zich uit te spreken over de conformiteit van het Nederlands gezinsmigratiebeleid met nationale en internationale rechtsnormen.

\subsection{Drie beleidsperspectieven op gezinsmigratie}

\section{Eén gemeenschappelijk uitgangspunt}

De geschiedenis van beleid en beleidsdebatten over gezinsmigratie tussen 1955 en 1975 is een verhaal van conflicten en botsende zienswijzen, maar er was één fundamenteel uitgangspunt waar iedereen het over eens was: Nederland was geen immigratieland en kon en mocht dat ook niet worden.

Dit standpunt werd in de eerste plaats ingegeven door ernstige zorgen over de vermeende overbevolking van Nederland. In de eerste naoorlogse decennia kende de Nederlandse bevolking de hoogste groeicijfers in Europa. In 1947 telde Nederland 9,6 miljoen inwoners; in 1960 waren dat er 11,4 en in 1971 13,2. Prognoses uit de vroege jaren zestig schatten het inwonertal in 2000 op 20 miljoen. Vooraanstaande demografen vroegen zich af hoe Nederland al die monden zou voeden en al die handen aan werk

45 Ook na 1967 stond beroep alleen open als de vreemdeling minstens een jaar in Nederland verbleef, en slechts in specifieke, scherp afgebakende gevallen. Pas in de tweede helft van de jaren zeventig zou daarin verandering komen. Groenendijk 1996: 120-121.

46 Groenendijk 1980.

47 Groenendijk 1996: 124-25. 
zou helpen. Schuyt en Taverne spreken van het 'spook van de overbevolking' dat de Nederlandse gemoederen jarenlang bezig hield en zelfs van een 'overbevolkingspsychose' ${ }^{48}$

Deze perceptie van overbevolking werd in de vroege naoorlogse periode nog versterkt door een ernstig huisvestingstekort. In 1947 werd het tekort geschat op 300 duizend woningen. Mensen moesten jaren wachten op een huis en inwoning werd 'een heel normaal verschijnsel': in 1947 woonde $26 \%$ van de huishoudens van twee of meer personen met anderen samen. Daarmee werd volkshuisvesting een prioriteit van de regering: de woningnood werd tot 'volksvijand nr. 1' verklaard en er kwam een apart ministerie voor Volkshuisvesting en Openbare Werken. De woningbouw werd fors gesubsidieerd. Eind jaren vijftig werden meer dan 80 duizend nieuwe woningen per jaar gebouwd. In 1963 bedroeg het huisvestingstekort echter nog steeds bijna 300 duizend. De bevolking bleef immers groeien en bovendien waren als gevolg van de zogenaamde 'huishoudensverdunning' voor hetzelfde aantal mensen steeds meer woningen nodig. ${ }^{49}$

Dit beeld van een overbevolkt land, waar bovendien woningnood heerste, leidde tot een conclusie die door alle betrokken partijen werd onderschreven: vestigingsmigratie in Nederland was ongewenst en zelfs onverantwoord.

\section{De vitale belangen van de Nederlandse volkshuishouding}

Tussen 1955 en 1975 was het dominante perspectief op het gezinsmigratievraagstuk een economisch perspectief. Na de vernietigende ervaring van de oorlog, en met het schrikbeeld van de misère van de jaren dertig nog scherp voor ogen, nam de Nederlandse regering in de jaren vijftig expliciet de verplichting op zich om bestaanszekerheid voor iedere Nederlander te garanderen. Dat moest in de eerste plaats gebeuren door alles op alles te zetten om de Nederlandse economie te doen gedijen, zodat er voor iedereen werk zou zijn. De overheid zette in op modernisering en forse uitbreiding van de industrie. Middels een gematigde loonpolitiek werden de productiekosten laag gehouden en het bedrijfsleven gestimuleerd om voor arbeidsintensieve productiemethoden te kiezen, zodat zoveel mogelijk

48 Schuyt \& Taverne 2000: 223-227, 231.

49 Jansen 2006: 47-53. 
arbeidsplaatsen werden geschapen. ${ }^{50}$ Dankzij dit ambitieuze economische project zou Nederland een moderne natie worden waarin niemand meer honger leed. Het belang dat hieraan werd toegekend kan nauwelijks worden overschat. De Rooy geeft aan dat 'economie een allesoverheersende waarde werd in de samenleving. Vrijwel alles werd onderworpen aan het "economisch primaat", vrijwel alles moest wijken voor werkgelegenheid, industrialisatie en groei', ${ }^{51}$

Begin jaren vijftig zette een explosieve groei van de Nederlandse economie in die tot 1973 zou duren, met een gemiddeld groeicijfer van bijna 5 procent per jaar. In deze periode werd vrijwel volledige werkgelegenheid bereikt, verdrievoudigde het reëel nationaal inkomen en verdubbelde het reëel inkomen per hoofd van de bevolking. ${ }^{52}$ De industriële productiecapaciteit steeg bijzonder snel, zo snel zelfs dat de vraag naar arbeidskrachten het aanbod op de Nederlandse arbeidsmarkt oversteeg. Halverwege de jaren vijftig bedroeg het arbeidstekort ruim 80 duizend. ${ }^{53}$ Bedrijven konden niet op volle kracht draaien omdat ze mensen tekort kwamen. Er ontstond concurrentie om werknemers en daarmee kwam de loonmatiging, een essentieel onderdeel van het industrialisatiebeleid, in gevaar.

Om deze situatie het hoofd te bieden kozen bedrijfsleven en overheid gezamenlijk voor de werving van arbeiders in het buitenland. ${ }^{54}$ De werving was dus een instrument van het economisch beleid, in het bijzonder van de industrialisatiepolitiek. Arbeidsmigranten werden noodzakelijk geacht voor het goed functioneren van de economie: zonder hen zou het Nederlands bedrijfsleven het niet redden. Toen Kamerleden in 1965 vroegen, wat de maatstaven van het arbeidsmigratiebeleid van de regering waren, antwoordden de bewindslieden van Sociale Zaken en Economische Zaken dat het beleid uitging van 'de vitale belangen van de Nederlandse volkshuishouding' ${ }^{55}$ In een tijd waarin de economie, in de woorden van De Rooy, een

50 Blom 1999: 345; Schuyt \& Taverne 2000: 41-45; De Rooy 2005: 215; Berg 1967: 19-22; Righart 1995: 36-40.

51 De Rooy 2005: 216.

52 De Rooy 2005: 215; Schuyt \& Taverne 2000: 42, 45.

53 Schuster 1999: 167; Berg 1967: 16.

54 Schuster (1999: 165) wijst erop dat Nederlandse werkgevers al wervings-delegaties naar Italië stuurden, voordat de minister van Sociale Zaken officiële toestemming voor de werving had gegeven. In die zin werd de keus voor arbeidsmigratie gestuurd door het bedrijfsleven, en was de formele regulering ervan een poging van de regering om 'greep te krijgen op een proces dat reeds in gang was gezet'. De Lange (2007: 403) constateert dat het ministerie van Sociale Zaken in de jaren zestig weinig succesvol was in zijn streven arbeidsmigratie te controleren.

55 TK 1964-1965 Aanhangsel van de Handelingen nr. 467. De schriftelijke vragen werden gesteld door leden van de PSP. 
'allesoverheersende waarde' was, woog dit argument bijzonder zwaar. ${ }^{56}$

In overheidskringen was de directie-generaal voor de Arbeidsvoorziening van Sociale Zaken de belangrijkste voorstander van deze visie op arbeidsmigratie als een tijdelijke oplossing voor de nijpende arbeidstekorten. In interdepartementale discussies werd Sociale Zaken nogal eens gesteund door Economische Zaken. Voor deze ministeries stonden de belangen van het Nederlands bedrijfsleven voorop. Uit onderzoek van De Lange is gebleken, dat de standpunten van Sociale Zaken in de jaren vijftig en zestig naadloos overeenkwamen met die van het bedrijfsleven ${ }^{57}$ Ook de vakbonden zagen arbeidsmigratie als een economische noodzaak. ${ }^{58}$

Het ministerie van Sociale Zaken was niet alleen verantwoordelijk voor het verlenen van arbeidsvergunningen aan buitenlandse werknemers, maar ook voor het emigratiebeleid dat Nederland tussen 1952 en 1962 voerde. Om de druk van de bevolkingsgroei te verzachten, bood de overheid financiële steun bij vertrek; uitvoering en ondersteuning werden gedelegeerd aan verzuilde organisaties. Tussen 1946 en 1960 vertrokken 377 duizend Nederlanders naar Australië, Nieuw-Zeeland, Canada en de Verenigde Staten. ${ }^{59}$ Nederland beschouwde zichzelf niet als een immigratieland, maar als een emigratieland..$^{60}$

Vanuit het perspectief van Sociale Zaken, Economische Zaken en werkgevers- en werknemersorganisaties conflicteerde de werving van arbeidsmigranten niet met het axioma dat Nederland geen immigratieland was, en evenmin met het emigratiebeleid. De emigratie van Nederlanders werd immers als permanent beschouwd: het verblijf van arbeidsmigranten in Nederland daarentegen nadrukkelijk als tijdelijk. ${ }^{61}$ Arbeidsmigratie voor beperkte tijd werd geïnterpreteerd als een logisch gevolg van de ontwikkeling van de Europese economie en arbeidsmarkt: de staatssecretaris van

56 De Rooy 2005: 215.

57 De Lange 2007: 87, 115.

58 Roosblad 2002: 42-43.

59 Schuyt \& Taverne 2000: 229-231; Van Faassen 2001.

60 Ellemers 1987: 322.

61 Van Faassen 2001: 51. In de tweede helft van de jaren vijftig en vroege jaren zestig, toen arbeidsmigratiebeleid en emigratiebeleid overlapten, werd de werving als de oplossing voor een tijdelijk probleem beschouwd. Schuster (1999: 166) spreekt van een 'tijdelijke noodmaatregel'. Pas later zou men de behoefte aan buitenlandse arbeidskrachten op de Nederlandse arbeidsmarkt als een structureel verschijnsel gaan zien. (Zie paragraaf 2.8) De Lange (2007: 26-27) plaatst echter een kritische noot bij het argument dat arbeidsmigratie de oplossing voor een tijdelijk, en emigratie de oplossing voor een structureel probleem was: de emigranten waren vooral boerenarbeiders, terwijl er tekort was aan mijnarbeiders. Dat zei de minister van Sociale Zaken er tegenover het parlement niet bij. 
Sociale Zaken sprak van 'de moderne vorm van migratie voor tijdelijke tewerkstelling (...) in Europa' ${ }^{62}$ Deze visie kwam overeen met de wetenschappelijke inzichten van de jaren zestig. Zo sprak professor Wentholt, hoogleraar sociale psychologie in Rotterdam, in zijn invloedrijke werk Buitenlandse arbeiders in Nederland (1967) niet van migranten maar van 'internationale forensen'. De internationale forens, zo betoogde Wentholt, was het product van een tijd waarin arbeidsmarkten internationaliseerden en de mobiliteit toenam. Hij verplaatste zijn verblijf tijdelijk naar een land waar de lonen hoger waren en liet zijn gezin daarbij achter om de kosten van het levensonderhoud tot een minimum te beperken. Aangezien de internationale forens niet de intentie had zich te vestigen, zou hij zich tijdens zijn verblijf in het buitenland in sociaal en cultureel opzicht niet méér aanpassen dan strikt noodzakelijk. Met betrekking tot de specifieke Nederlandse situatie voorspelde Wentholt dat in het slechtste geval acht procent van de buitenlandse werknemers zich permanent zou vestigen. ${ }^{63}$

De veronderstelling van tijdelijk verblijf was het sleutelelement in de rechtvaardiging van de keuze voor arbeidsmigratie als een instrument van het economisch beleid. De vertaling van dit uitgangspunt in de beleidspraktijk was echter met enige ambiguïteit omgeven. Zo wijst De Lange erop dat er nooit enige regelgeving is ingevoerd om verlenging van arbeidscontracten te belemmeren en zo de tijdelijkheid van het verblijf te waarborgen. Afhankelijk van de stand van de arbeidsmarkt kon het verblijf 'zo lang duren als gewenst'. ${ }^{64}$ Ook hierin speelden de belangen van het bedrijfsleven een doorslaggevende rol. Werkgevers hadden er namelijk baat bij dat een arbeidsmigrant zijn verblijf in Nederland verlengde. Een geworven arbeidsmigrant bracht voor de werkgever vrij hoge kosten met zich mee: de wervingskosten voor een Italiaan of Spanjaard bedroegen ruim honderd gulden. Bovendien was een werkgever in het eerste jaar dat een arbeidsmigrant in Nederland verbleef tussen de 2500 en 3000 gulden kwijt aan huisvesting, levensonderhoud, reiskosten en dergelijke. Vanaf het tweede jaar verviel de onderhoudsplicht van de werkgever. Door het arbeidscontract van een buitenlandse werknemer te verlengen, bespaarde een werkgever dus zowel wervings- als onderhoudskosten. Daar kwam nog bij, dat een arbeidsmigrant na een jaar in het algemeen goed ingewerkt was en dus pro-

62 TK 1964-1965 Aanhangsel van de Handelingen nr. 467.

63 Wentholt 1967a: 88-91, 95. Professor Wentholt werd door staatssecretaris De Meijer van Sociale Zaken met instemming geciteerd. EK 1965-1966 H15 Handelingen 3 mei 1966: 709.

64 De Lange 2007: 85, 112, 156, 171. 
ductiever. ${ }^{65}$ Werkgevers zagen dus graag dat buitenlandse werknemers hun verblijf in Nederland verlengden en de Nederlandse regering faciliteerde dat. De veronderstelling van tijdelijk verblijf rustte dan ook geheel op de overtuiging, dat de overgrote meerderheid van de arbeidsmigranten zelf geenszins de wens koesterde om zich permanent in Nederland te vestigen. ${ }^{66}$ Die overtuiging was niet uit de lucht gegrepen. Veruit de meeste arbeidsmigranten hadden inderdaad de intentie om, zodra zij voldoende geld hadden gespaard om in hun land van herkomst een beter leven op te bouwen, naar huis terug te keren. ${ }^{67}$ In de jaren zestig was het verloop onder buitenlandse arbeiders bovendien daadwerkelijk relatief hoog, hoewel het terugkeerpercentage ook toen, volgens de eerder geciteerde schattingen van Penninx, niet boven de 30 procent uitsteeg. ${ }^{68}$

Dit economisch perspectief op arbeidsmigratie bracht een specifiek standpunt inzake het vraagstuk van gezinshereniging met zich mee. Op basis van het beeld van de arbeidsmigrant als 'internationale forens' ging Sociale Zaken er vanuit, dat het percentage arbeidsmigranten dat de wens koesterde om gezinsleden te laten overkomen zeer beperkt was. Zelfs wanneer wel om toelating van het gezin werd verzocht, werd de veronderstelling van tijdelijk verblijf niet verlaten: de verwachting bleef dat de overgrote meerderheid van deze gezinnen naar het land van herkomst terug zou keren. ${ }^{69}$

65 Tinnemans 1994: 43.

66 Of het werkelijk om een oprechte overtuiging ging of om strategische retoriek, is nauwelijks vast te stellen. De Lange (2007: 85, 112) noemt het uitgangspunt van tijdelijke tewerkstelling 'louter retorisch' wanneer zij de periode 1945-1960 bespreekt, maar duidt de aard van dat uitgangspunt niet in haar hoofdstuk over het tijdvak 1960-1975. In zijn onderzoek naar de geschiedenis van arbeidsmigratie in Deventer wijst Van der Horst (2005: 108-109) erop dat personeelsfunctionarissen in het bedrijfsleven zich er zeer wel van bewust waren dat het verblijf van hun buitenlandse werknemers van blijvende aard was. Vasthouden aan het uitgangspunt van tijdelijk verblijf was voor hen een 'strategische keuze'. De ambtenaren van Sociale Zaken die Van der Horst interviewde zeggen niet te hebben getwijfeld aan de tijdelijkheid van arbeidsmigratie. In een gesprek met Tinnemans (1994: 165) gaf een hoge ambtenaar van het directoraat Arbeidsvoorziening van Sociale Zaken aan dat ervaringen in de vroege periode van de werving de verwachting wekten dat migranten niet zouden blijven, althans bij 'optimisten' waaronder hij zichzelf en zijn collega's schaart. De bevindingen van Tinnemans en Van der Horst lijken er dus op te duiden dat de ambtenaren van Sociale Zaken oprecht van de tijdelijkheid van het verblijf van arbeidsmigranten overtuigd waren.

67 Tuskan \& Vogel 2004: 13; Lindo 1994: 119, 125; Van Amersfoort \& Van der Wüsten 1975: 39; Del Campo 1979: 158.

68 Penninx 1979: 108; Lindo 1994: 119; Böcker 1994: 149.

69 Zo wijst Sociale Zaken erop dat ook arbeidsmigranten wier gezinnen over zijn gekomen, vaak liever niet verhuizen naar een duurdere zelfstandige woning. Zij zijn immers nog steeds aan het sparen voor een betere toekomst in het thuisland. (TK 1964-1965 Aanhangsel van de Handelingen nr. 467). 
Het ministerie van Sociale Zaken zag dus weinig argumenten om gezinshereniging strenge beperkingen op te leggen. Het had daarentegen wel een aantal zwaarwegende redenen om de voorwaarden voor gezinshereniging te versoepelen. In de eerste plaats waren arbeidsmigranten in deze periode een schaars goed: het Nederlands bedrijfsleven moest bij de werving van buitenlandse werknemers concurreren met Duitse, Franse en Belgische bedrijven. In deze wervingscompetitie werd de positie van Nederlandse bedrijven benadeeld door strenge regelgeving voor gezinshereniging, aangezien Nederland hierdoor een minder aantrekkelijke bestemming was voor arbeidsmigranten. Daarbij kwam dat buitenlandse werknemers er soms, tot teleurstelling van hun werkgevers, voor kozen om hun contract niet te verlengen, omdat zij naar hun gezin terug wilden keren. Kortom, het Nederlands bedrijfsleven ondervond bij de tewerkstelling van de buitenlandse arbeidskrachten, die het zo nodig had om te kunnen groeien, hinder van het streng gezinsherenigingsbeleid. Het ministerie van Sociale Zaken zette dus zwaar in op versoepeling van de voorwaarden voor gezinshereniging.

\section{Maatschappelijke gevolgen op de lange termijn}

De belangrijkste opponent van het economisch beleidsperspectief en van Sociale Zaken was de Hoofdafdeling Vreemdelingenzaken en Grensbewaking (HVG) van het ministerie van Justitie. In meest algemene zin had dit ministerie de taak om de openbare orde en veiligheid in Nederland te beschermen. Als onderdeel daarvan droeg het de verantwoordelijkheid voor het reguleren van toegang en verblijf van vreemdelingen op Nederlands grondgebied.

Glastra van Loon geeft, in een terugblik op zijn ervaringen als staatssecretaris van Justitie in het kabinet Den Uyl, een beeld van de manier waarop die taak binnen de HVG werd geïnterpreteerd. Het 'departementaal standpunt' was, aldus Glastra van Loon, 'bezwaren te hebben tegen iedere uitbreiding van de kategorieën vreemdelingen die aanspraak hebben op toelating tot ons land en tegen iedere beperking van de toch al beperkte middelen om vreemdelingen uit ons land te weren of te verwijderen' ${ }^{70} \mathrm{De}$ HVG vatte haar opdracht dus primair op als het zoveel mogelijk beperken en waar mogelijk voorkomen van immigratie.

70 Glastra van Loon 1976: 43. 
Deze taakopvatting kwam voort uit het directe verband dat door HVG ambtenaren werd gelegd tussen het beschermen van de openbare orde en het beheersen van de immigratie. De ongebreidelde instroom van vreemdelingen zou de harmonieuze maatschappelijke verhoudingen in Nederland kunnen ondermijnen, en vormde daarmee een bedreiging voor de sociale rust en openbare orde. Waar Sociale Zaken arbeidsmigratie bezag vanuit het profijt dat er voor het bedrijfsleven en daarmee voor het welvaartspeil in Nederland mee te behalen viel, was Justitie bevreesd voor mogelijke negatieve maatschappelijke consequenties. Daarom was het vanuit het oogpunt van Justitie ambtenaren cruciaal om immigratiestromen onder controle te houden. Zij waren veel minder genegen om aan de wensen van het Nederlands bedrijfsleven tegemoet te komen dan hun collega's van Sociale Zaken. Botsingen tussen Justitie en Sociale Zaken waren gedurende de twintig jaar van grootschalige arbeidsmigratie naar Nederland dan ook meer regel dan uitzondering.

Deze interdepartementale conflicten spitsten zich toe op het vraagstuk van gezinshereniging. Anders dan Sociale Zaken toonde het ministerie van Justitie zich namelijk steeds voorstander van een zo strikt mogelijk gezinsmigratiebeleid. Als het aan Justitie had gelegen, was de overkomst van gezinnen van buitenlandse arbeiders zelfs nooit toegestaan. Dit standpunt vloeide voort uit de twijfels die binnen het ministerie leefden bij de veronderstelling van tijdelijk verblijf. Vanaf het begin van de werving in de jaren vijftig waren de ambtenaren van Justitie ervoor beducht dat een groot deel van de arbeidsmigranten, wanneer zij eenmaal van de Nederlandse welvaart geproefd hadden, niet meer terug zou keren naar hun land van herkomst. ${ }^{71}$ Al rond 1960 bleek bovendien dat substantiële aantallen gehuwde arbeidsmigranten werden geworven en dat deze, met steun van hun regeringen en de ministeries van Sociale Zaken en Economische Zaken, aandrongen op de overkomst van hun gezin. Daarmee werd de vrees van Justitie voor definitieve vestiging in Nederland groter dan ooit. Anders dan bij Sociale Zaken, gingen ambtenaren van Justitie er namelijk vanuit dat wanneer een arbeidsmigrant zijn gezin liet overkomen, van terugkeer naar het land van herkomst geen sprake meer zou zijn. Dit was de belangrijkste reden voor het verzet van Justitie tegen gezinshereniging.

De ambtenaren van Justitie stonden in hun weerstand tegen het dominante economische perspectief op de komst van arbeidsmigranten en hun

71 Jansen 2006: 160. 
gezinnen niet altijd alleen. In de ministerraad en in interdepartementaal overleg vond Justitie geregeld bijval bij de ministeries van Volkshuisvesting en van Maatschappelijk Werk, die zich eveneens zorgen maakten over de maatschappelijke gevolgen van gezinshereniging. Voor Volkshuisvesting was de overkomst van gezinnen bezwaarlijk omdat die de druk op de toch al overbelaste woningmarkt verder op zou voeren. Ook voor Maatschappelijk Werk was de woningnood een belangrijke factor: dit ministerie was verantwoordelijk voor de opvang en huisvesting van repatrianten uit voormalig Nederlands-Indië en zag niet graag dat de toch al moeizame taak om deze mensen te huisvesten werd verzwaard door extra concurrentie op de woningmarkt van arbeidsmigranten en hun gezinnen. ${ }^{72}$ Geen enkel ministerie heeft zich echter zo fel en verbeten verzet tegen gezinshereniging als het ministerie van Justitie.

\section{Het morele gewicht van het gezin}

Het derde perspectief op het gezinsmigratievraagstuk dat in de beleidsvorming tussen 1955 en 1975 een rol speelde was ethisch van aard. Centraal stond de morele waarde van het gezinsleven.

In de jaren vijftig en zestig werd het traditionele gezin als 'dè centrale eenheid in de samenleving' beschouwd. Niet alleen bij de confessionelen maar ook bij de liberalen en sociaaldemocraten leefde de fundamentele overtuiging, dat man en vrouw van nature bestemd waren om verschillende rollen in het gezin te vervullen: hij als kostwinner, zij als huismoeder. ${ }^{73}$ Deze traditionele gezinsmoraal maakte deel uit van de ideologische fundamenten waarop Nederland, na de traumatische ervaringen van oorlog en dekolonisatie, opnieuw een positieve nationale identiteit opbouwde. In die zin spreekt Van Walsum over het gezin als 'the normative core of the nation'. ${ }^{74}$ Blom beschrijft het nationaal besef in de naoorlogse jaren als 'een bezonken tevredenheid over de uniekheid en voorbeeldigheid van de Nederlandse samenleving, die als bij uitstek vreedzaam en van hoge

72 In de tweede helft van de jaren zestig raakte CRM steeds nauwer betrokken bij het welzijnswerk voor arbeidsmigranten. Daardoor veranderden de standpunten die dit ministerie innam: zie paragraaf 2.8 .

73 Blom 1993: 33, 36; De huwelijkspatronen en rolverdeling van de Nederlanders voegden zich in de jaren vijftig ook naar deze 'puriteinse moraal'. De Rooy 2005: 218, Righart 1995: 44; Streek 1993: 197.

74 Van Walsum 2008: 133-135. 
morele kwaliteit werd gezien'. ${ }^{75}$ Het sterk verzuilde Nederland van de jaren vijftig en zestig vond een gemeenschappelijke grondslag in een burgerlijk normen- en waardenpatroon, waarvan het gezin als hoeksteen van de samenleving een kernelement uitmaakte. ${ }^{76}$

In ambtelijke debatten over het gezinsmigratiebeleid werd aan deze morele norm echter nauwelijks gerefereerd. Binnen en tussen de departementen overheersten materiële belangen de argumentaties. In parlementaire debatten daarentegen was het ethisch perspectief dominant. Zoals eerder vermeld bleef de bemoeienis van het parlement met het gezinsherenigingsbeleid in de jaren vijftig en zestig beperkt, in vergelijking met latere perioden. Wanneer parlementariërs echter wel over gezinshereniging spraken, had hun betoog een sterke morele lading. Alle politieke partijen kenden een groot gewicht toe aan bescherming van de eenheid van het gezin. Voor de confessionele partijen woog deze norm nog het zwaarst. De christendemocraten - vooral de katholieken ${ }^{77}$ - waren dan ook het meest uitgesproken in hun kritiek op het strenge gezinsherenigingsbeleid van de regering, dat tot 'gedwongen gezinssplitsing' leidde en daarmee moreel verwerpelijk was. ${ }^{78}$ Christelijke parlementariërs pleitten dan ook consequent voor een versoepeling van de voorwaarden voor gezinshereniging.

Zij werden daarin gesteund door de VvD. De liberale Kamerleden behartigden daarmee de belangen van het bedrijfsleven, dat immers bij de werving hinder ondervond van de strenge regelgeving voor gezinsmigratie. In hun argumentatie verwezen de liberalen eveneens geregeld naar de gezinsmoraal die door de confessionelen zo nadrukkelijk werd ingebracht. In het vertoog van de VVD was het ethisch perspectief dus vervlochten met het eerder geschetst economisch perspectief.

Linkse parlementariërs ten slotte besteedden relatief weinig aandacht aan gezinshereniging. Als verklaard vertegenwoordigers van de Nederlandse arbeidsklasse waren zij er primair op gericht te voorkomen dat de tewerkstelling van buitenlandse arbeidskrachten oneerlijke concurrentie voor hun kiezers opleverde. Wanneer sociaaldemocraten - of de kleine

\footnotetext{
75 Blom 1993: 33-34.

76 Blom 1999: 343.

77 Tot het einde van de jaren zestig waren de meeste arbeidsmigranten katholieke Spanjaarden en Italianen. De KVP zal zich bij hun welzijn bijzonder betrokken hebben gevoeld, niet in de laatste plaats door contacten met het katholiek maatschappelijk werk en het bedrijfapostolaat die in die tijd het welzijnswerk voor de arbeidsmigranten op zich namen. De KVP was van 1959 tot 1971 de grootste partij in het parlement. 78 TK 1962-1963 B 6900 H15 Handelingen: 3392.
} 
partijen op hun linkerflank - bij gelegenheid wel de gezinsmigratieproblematiek aan de orde stelden, deden zij dat vanuit dezelfde morele zorg als de andere politieke partijen.

Kamerleden waren niet de enigen die het ethisch belang van gezinseenheid inbrachten in de debatten over gezinshereniging. Bijstandsstichtingen voor buitenlandse werknemers entten hun kritiek op het regeringsbeleid eveneens primair op deze morele norm. De Spaanse regering refereerde eraan wanneer zij een genereuzer gezinshereningsbeleid voor haar onderdanen in Nederland bepleitte. De toon van de mediaberichtgeving ten slotte lijkt ook door dit moreel perspectief te zijn gekleurd. ${ }^{79}$

\subsection{De eerste jaren van de werving}

Verbod op gezinshereniging (1955-1960)

In juni 1955 verzond minister Suurhoff (PvdA) van Sociale Zaken een circulaire aan de Nederlandse werkgevers en werknemers, waarin hij een verruiming aankondigde van de mogelijkheden om buitenlandse arbeidskrachten te werven. Nederland had al geruime tijd te kampen met een 'sterk overspannen arbeidsmarkt'. Het tekort aan arbeidskrachten was zo nijpend, dat het 'de continuïteit van de Nederlandse economie ernstig bedreigt'. Sociale Zaken beschouwde de werving van arbeidsmigranten dus als onontbeerlijk om de voorspoedige ontwikkeling van het Nederlands bedrijfsleven zeker te stellen. De circulaire vermeldt nadrukkelijk dat het om tijdelijke tewerkstelling zou gaan: werkvergunningen zouden worden verleend voor één of twee jaar. Verlenging was echter wel mogelijk, 'afhankelijk van de dan bestaande toestand van de nationale arbeidsmarkt'. De werving zou plaats vinden onder supervisie van het Rijksarbeidsbureau, onder voorwaarde dat van de kant van de Rijksvreemdelingendienst geen bezwaar bestond. ${ }^{80} \mathrm{Zo}$ vond de grootschalige werving van buitenlandse arbeiders voor de Nederlandse arbeidsmarkt haar aanvang. Tussen 1955 en 1960 bleef de omvang van arbeidsmigratiestromen uit de landen rond de Middellandse Zee echter nog relatief beperkt: het ging om enkele duizenden arbeiders, in grote meerderheid Italianen. ${ }^{81}$

79 Zie paragraaf 2.7 .

80 Circulaire DG voor Arbeidsvoorziening, 29 juni 1955. NA IND 483.

81 TK 1963-1964 B 7400 H15 (2): 13; Goedings 2005: 368. 
Van 1955 tot 1960 was gezinshereniging categorisch uitgesloten. Steeds wanneer de Rijksvreemdelingendienst toestemming verleende voor een wervingsproject, verbond zij daaraan nadrukkelijk de voorwaarde dat al tijdens de werving op ondubbelzinnige wijze aan de arbeiders zou worden meegedeeld dat zij hun gezin moesten achterlaten. ${ }^{82}$ Deze stringente beleidslijn werd door de Tweede Kamer bekritiseerd als een 'uit menselijk oogpunt harde bepaling'. ${ }^{83}$ Arbeidsmigranten werden immers gedwongen een aantal jaren gescheiden van hun gezinnen te leven, hetgeen moeilijk te verenigen was met het bijzondere morele gewicht van gezinseenheid. De regering antwoordde dat zij in eerste instantie alleen ongehuwden had willen werven, maar op aandringen van de autoriteiten in Rome had besloten ook gehuwden toe te laten tot de Nederlandse arbeidsmarkt. Daarbij was bedongen dat arbeidsmigranten van tevoren duidelijk zouden worden geïnformeerd over de voorwaarden van hun tewerkstelling. ${ }^{84}$ Wanneer de arbeiders een bewuste en weloverwogen keuze maakten om voor zekere tijd hun gezin in het thuisland achter te laten, woog de morele verantwoordelijkheid voor deze situatie minder zwaar op de schouders van de Nederlandse overheid. ${ }^{85}$ Weliswaar besloot de ministerraad in 1960 alsnog dat alleen ongehuwde arbeiders zouden worden geworven, maar de raad kwam daar - op verzoek van Sociale Zaken en ondanks bezwaar van Justitie en Maatschappelijk Werk - binnen een maand alweer op terug, omdat het aantal beschikbare ongehuwde Italianen ontoereikend bleek. ${ }^{86}$

In maart 1960 presenteerde Sociale Zaken een voorstel om de werving uit te breiden tot 2000 Italianen. Ambtelijk Justitie vond dit een 'nogal griezelige geschiedenis' maar ging toch akkoord, onder voorwaarde dat de arbeiders ongetrouwd zouden zijn en dat contracten voor maximaal twee jaar zouden worden getekend, zonder mogelijkheid tot verlenging. ${ }^{87}$ Vier maanden later tekenden ambtenaren van Sociale Zaken een ontwerpwervingsovereenkomst met Italië. Tot grote verontwaardiging van het hoofd HVG was deze overeenkomst niet beperkt tot de eenmalige werving van hoogstens 2000 arbeiders, zoals in het oorspronkelijke voorstel van

82 Correspondentie RVD met procureurs-generaal, betreffende correspondentie met verschillende werkgevers. NA IND 3363-3357-3353-3348.

83 TK 1956-1957 B 4500 H12 (8): 11. Welke parlementariërs deze vragen stelden is niet bekend: tot 1966 schreef het reglement van orde van de Tweede Kamer voor dat in voorlopige verslagen en eindverslagen de naam en politieke kleur van Kamerleden niet werd genoemd.

84 TK 1956-1957 B 4500 H12 (9): 33.

85 TK 1962-1963 B6800 H15 Handelingen: 3420-3421. Zie noot 36 in hoofdstuk 2.

86 Notulen ministerraad, 9 september en 7 oktober 1960. NA IND 551.

87 Nota HVG aan SG, 9 maart 1960. NA IND 551. 
Sociale Zaken. In plaats daarvan was een open overeenkomst getekend, die bepaalde dat kwaliteit en aantallen arbeiders ieder half jaar zouden worden vastgesteld en dat arbeidscontracten na een jaar konden worden verlengd. Eind juli werd de wervingsovereenkomst door de ministerraad goedgekeurd. ${ }^{88}$

Het hoofd HVG was ontdaan dat de Nederlandse regering zich aldus de middelen uit handen sloeg om de tijdelijkheid van het verblijf van arbeidsmigranten te garanderen. Hij verwachtte dat 'deze Italianen na een jaar van voorspoed zich niet spoedig opnieuw in de Italiaanse armoede zullen storten'. Tot nog toe ging het merendeel van de Italianen inderdaad na een aantal jaren terug naar Italië, maar:

dat er zo velen terugkeren is (...) ongetwijfeld te danken aan de stringente voorwaarden, welke ten aanzien van de overkomst van gezinnen worden gesteld. Aan deze stringente voorwaarden (...) zal - wil men inderdaad kunnen spreken van een tewerkstelling voor beperkte tijd (...) - onverminderd de hand moeten worden gehouden. ${ }^{89}$

Voor Justitie was het verbod op gezinshereniging dus een instrument om migratie te beheersen: het enige beschikbare middel om te waarborgen dat arbeidsmigranten Nederland na korte tijd weer zouden verlaten.

\section{Gezinshereniging voor Gemeenschapsonderdanen}

Vanaf 1960 kwam het verbod op gezinshereniging, waar Justitie zo aan hechtte, in toenemende mate onder druk te staan. Die druk kwam in de eerste plaats uit Brussel. In 1957 hadden Duitsland, Frankrijk, Italië en de Benelux-landen de Europese Economische Gemeenschap (EEG) opgericht. Eén van de doelstellingen van de jonge EEG was het totstandbrengen van het vrij verkeer van werknemers tussen de lidstaten. In 1959 presenteerde de Europese Commissie een voorstel voor een Europese verordening, die de eerste fase zou inluiden van de implementatie van dit vrij verkeer. Onderdeel van het voorstel van de Commissie was een bepaling die werknemers

88 Nota HVG aan SG, 28 juli 1960. NA IND 551. De Lange (2007:79-80) constateert dat bij de totstandkoming van het wervingsakkoord alleen de controle van politiek antecedenten aanleiding gaf tot debat. Verder heeft 'geen inhoudelijke discussie' plaatsgevonden. Uit de stukken die ik heb ingezien blijkt evenmin dat de kritiek van HVG aanleiding is geweest tot interdepartementaal overleg, op ambtelijk noch op ministerieel niveau. 89 Nota HVG aan SG, 5 oktober 1960. NA IND 551. 
het recht gaf om zich, wanneer zij in een andere lidstaat gingen werken, door hun gezin te laten vergezellen. Beperking van de mogelijkheid van gezinshereniging, zo stelde de Commissie, zou de mobiliteit van werknemers binnen de Gemeenschap belemmeren. ${ }^{90}$ In de lente van 1960 vond in Den Haag interdepartementaal overleg plaats over deze voorstellen uit Brussel. Daarbij bleek het ministerie van Justitie fel tegenstander van enige vorm van Europese verplichting tot toelating van gezinnen van arbeidsmigranten. Andere ministeries, met name Sociale Zaken en Economische Zaken, zouden graag een inschikkelijker standpunt innemen.

In de maanden die volgden vonden in Den Haag discussies tussen de ministeries plaats, die niet minder moeizaam verliepen dan de onderhandelingen tussen de lidstaten in Brussel. In eerste instantie wist Justitie te bedingen dat de Nederlandse delegatie er in Brussel voor zou pleiten dat de lidstaten zouden toezeggen gezinshereniging te bevorderen, zonder echter een verplichting tot toelating van gezinnen vast te leggen. In ruil voor deze concessie van Sociale Zaken en Economische Zaken was Justitie ermee akkoord gegaan dat de nationale beleidslijn zou worden aangepast, zodat EEG-burgers die tenminste twee jaar in Nederland hadden gewerkt en gewoond hun gezinnen mochten laten overkomen. Voorwaarde was wel dat zij beschikten over passende huisvesting. Het hoofd HVG schreef aan zijn minister: 'Waar bekend is dat met name Economische Zaken voorstander is van directe toelating van de gezinnen van vreemde werknemers biedt het onderhavige punt weinig ruimte voor een compromis in de ministerraad dat op een groter aantal jaren is afgestemd dan de voorgestelde 2 jaar als wachttermijn voor de overkomst van de gezinnen. Ik moge u dan ook adviseren dit zo moeizaam bereikte resultaat te willen aanvaarden' ${ }^{91}$ Op 23 december 1960 ging de ministerraad met dit compromis akkoord. ${ }^{92}$ Onder druk van Sociale Zaken en Economische Zaken besloot Justitie diezelfde maand om, vooruitlopend op de nieuwe Europese regelgeving, gezinshereniging toe te staan aan Italianen die tenminste drie jaar werkzaam waren in Nederland. ${ }^{93}$

Het Nederlands voorstel werd in Brussel echter slecht ontvangen, met name door de Europese Commissie. Den Haag besloot daarom toch de verplichting tot toelating van gezinnen te accepteren, maar daarbij vast te

90 Goedings 2005: 139-153; 162-166.

91 Nota HVG aan SG, 26 oktober 1960. NA IND 47.

92 Nota minister van Justitie aan SG, 3 januari 1961. NA IND 47.

93 Nota HVG aan SG, 13 december 1960. NA IND 47. 
leggen dat Nederland een wachttijd mocht aanhouden. Daarbij voelde Justitie, dat zich in een minderheidspositie geplaatst zag tegenover Economische Zaken en Sociale Zaken, zich opnieuw gedwongen concessies te doen: de wachttijd voor EEG-burgers werd teruggebracht van twee naar één jaar. ${ }^{94}$ Dit ambtelijk compromis stuitte aanvankelijk op verzet bij minister Beerman (CHU) van Justitie, die op de nota van zijn ambtenaar aantekende dat hij zich 'beslist niet [kon] verenigen!' met de reductie van de wachttijd tot één jaar. ${ }^{95}$ Deze kritiek kwam echter te laat: het beleidsvoorstel dat aan het bewindslid werd voorgelegd was een 'uit-onderhandeld' compromis waarin nauwelijks meer wijzigingen konden worden aangebracht. Beerman werd in wezen met een voldongen feit geconfronteerd en heeft zij daarbij moeten neerleggen. ${ }^{96}$ Dit is een sprekend voorbeeld van de autonomie ten opzichte van bewindslieden waarmee ambtenaren in de jaren zestig opereerden. Het is eveneens indicatief voor de stempel die de ontwikkelingen in Brussel op de interdepartementale verhoudingen in Den Haag drukten.

De Europese verordening 15, zoals die uiteindelijk in december 1961 werd aanvaard, bepaalde dat gezinshereniging bij arbeidsmigratie binnen de EEG was toegestaan zodra passende huisvesting voorhanden was. In een aantekening in de notulen werd echter vermeld dat Nederland, als enige onder de lidstaten, de gezinnen van EEG-arbeiders pas zou toelaten nadat ze één jaar werkzaam en woonachtig in Nederland waren geweest en indien zij over een werkgarantie beschikten voor nog een jaar. ${ }^{97}$

\section{Gezinshereniging voor arbeidsmigranten van buiten de EEG}

In de tussentijd bleek het Italiaanse aanbod van arbeiders onvoldoende om aan de behoeften van het Nederlandse bedrijfsleven te voldoen. In februari 1961 tekenden ambtenaren van Sociale Zaken daarom een ontwerp-wervingsovereenkomst met Spanje, een land dat geen lid was van de Europese Gemeenschap. ${ }^{98}$ De ambtenaren van Vreemdelingenzaken constateerden misnoegd dat 'weer de vanouds beproefde tactiek van het voldongen feit is

94 Nota HVG aan SG, 22 maart 1961. NA IND 47.

95 Nota's HVG aan SG, 9 en 22 maart 1961. NA IND 47.

96 Nota aan hoofd HVG, 17 maart 1970. NA IND 612.

97 Nederland had, met het oog op de woningnood, al in het officiële verslag van de onderhandelingen over het Verdrag van Rome een verklaring laten opnemen over een mogelijke Nederlandse uitzondering op gezinshereniging voor EG-arbeidsmigranten gedurende de transitiefase van de gemeenschappelijke markt. Goedings 2005: 164-166.

98 Spanje zou in 1986 toetreden tot de EG. 
gevolgd' en dat daarbij alle wensen van Justitie terzijde waren geschoven. ${ }^{99}$ In de ministerraad was in oktober 1960 - nog geen vier maanden eerder besloten het aantal gehuwde arbeidsmigranten beperkt te houden en arbeiders tijdig te informeren dat hun gezin niet mee zou mogen komen. ${ }^{100}$ Noch de voorkeur voor ongehuwden, noch het verbod op gezinshereniging waren in de overeenkomst vastgelegd. Erger nog: aan de overeenkomst was een protocol toegevoegd, waarin Spanje de Nederlandse autoriteiten vroeg om gezinshereniging waar mogelijk te bevorderen. ${ }^{101}$ Het akkoord was echter al getekend en Justitie zag geen mogelijkheid meer om er nog significante wijzigingen in aan te brengen.

In de maanden die volgden oefende Sociale Zaken druk uit op Justitie om tegemoet te komen aan de wens van de Spaanse regering. ${ }^{102}$ In maart 1961 besloot de minister van Justitie om de overkomst van Spaanse gezinnen toe te staan, "indien gebleken is dat de werknemer voortdurend in Nederland te werk wordt gesteld, welk ogenblik niet geacht wordt te zijn aangebroken binnen drie jaar na de datum van tewerkstelling' ${ }^{103}$ Daarmee was gezinshereniging niet alleen voor Gemeenschapsonderdanen, maar ook voor arbeidsmigranten uit landen buiten de EEG mogelijk. Vanuit de veronderstelling dat de overkomst van het gezin betekende dat van terugkeer geen sprake meer zou zijn, wilde Justitie gezinshereniging echter pas toe staan wanneer Nederland de permanente - of tenminste langdurige vestiging van een arbeidsmigrant had aanvaard. Daarom werd een wachttermijn van drie jaar ingesteld.

Voor staatssecretaris Roolvink (ARP) van Sociale Zaken was dit echter geen bevredigende oplossing: 'De werving in het buitenland is zinloos indien slechts na 3 jaar gezinshereniging wordt toegestaan' ${ }^{104}$ Liefst zou hij de wachttijd teruggebracht zien tot één jaar, zoals dat voor EEG-burgers

99 Nota HVG aan SG, 2 februari 1961. NA IND 1.

100 Notulen ministerraad 7 oktober 1960. NA IND 551.

101 Brief Spaanse Delegatie aan Nederlandse Delegatie, 27 januari 1961. NA IND 1. De Spaanse regering zou gedurende de gehele periode van grootschalige arbeidsmigratie blijven ijveren voor ruimere voorwaarden voor gezinshereniging voor haar onderdanen. Dit is in die zin verrassend, dat het Spaans emigratiebeleid er niet alleen op gericht was de structurele werkeloosheid te verlichten, maar ook de betalingsbalans te verbeteren dankzij geldzendingen van emigranten. (Del Campo 1979: 158)Van gezinshereniging mocht een nadelig effect op die geldstromen worden verwacht. Volgens Fernández Vicente (2004: 100) heeft de Katholieke Kerk er een doorslaggevende rol in gespeeld dat de Spaanse regering het bevorderen van emigratie in gezinsverband desalniettemin als centraal element in haar beleid opnam.

102 Nota DG voor Arbeidsvoorziening aan minister voor Sociale Zaken, 28 juni 1961. NA IND 1.

103 Nota's HVG aan SG, 9 februari 1961, 6 en 9 maart 1961; Nota SG aan minister, 7 maart 1961. NA IND 1.

104 Notulen ministerraad 1 en 4 december 1961. NA MR 653. 
was afgesproken. ${ }^{105}$ Minister Beerman van Justitie hield echter vast aan drie jaar wachttijd. Een geïrriteerde ambtenaar bij Sociale Zaken schreef aan zijn minister: 'Het liefst zou hij de toelating van deze gezinnen weigeren.' In november 1961 werd bij wijze van compromis besloten dat voor arbeidsmigranten van buiten de EEG een wachttijd van twee jaar zou gelden. ${ }^{106}$

\subsection{Wachten op welkom: geschillen over de wachttijd}

\section{Van 2 naar 1 jaar voor Spanjaarden}

In de vroege jaren zestig lieten vooral confessionele Kamerleden zich bij herhaling kritisch uit over het gezinsherenigingsbeleid van de regering. Al in 1960 beschreef KVP-politicus Zwanikken de scheiding van arbeidsmigranten van hun gezinnen als 'uiterst pijnlijk' ${ }^{107}$ Een jaar later verklaarde zijn partijgenoot Brouwer dat 'waar wij hier met mensen van doen hebben, een menselijke en niet strikt economische oplossing gezocht dient te worden'. ${ }^{108}$ Bij de parlementaire behandeling van de Rijksbegroting voor 1963 kwam met name de wachttijd voor gezinshereniging de staatssecretaris van Sociale Zaken en de minister van Justitie op veel kritiek te staan. ${ }^{109}$ KVP-lid Baeten noemde het 'ietwat stroef, ietwat rigide en in veel gevallen ook weinig bevredigend' dat arbeidsmigranten van buiten de EEG 'ten minste twee jaren gescheiden moeten blijven van hun gezin'. ${ }^{110}$ Maenen, ook van de KVP, vroeg om aandacht voor 'het zeer menselijke, maar ook morele aspect van dit probleem' en pleitte voor 'enige verzachting van de thans geldende harde richtlijnen'. ${ }^{111}$ Linkse parlementariërs hielden zich afzijdig van deze discussies over het gezinsherenigingsbeleid. De liberalen

105 De voorkeursbehandeling van Gemeenschapsonderdanen ten opzichte van andere vreemdelingen was in deze eerste jaren van Europese integratie nog niet vanzelfsprekend. Vgl. De Lange 2007: 157.

106 Nota DG voor Arbeidsvoorziening aan minister voor Sociale Zaken, 28 juni 1961. NA IND 1; Nota aan Hoofd HVG, 17 maart 1970. NA IND 612.

107 TK 1960-1961 B6100 H16 Handelingen: 3655.

108 TK 1961-1962 B6500 H15 Handelingen: 3309.

109 Deze begrotingsdebatten vonden plaats op een moment dat in de media uitgebreid werd bericht over Spaanse echtgenotes van arbeidsmigranten die irregulier in Nederland verbleven en met uitzetting werden bedreigd. (Zie paragraaf 2.7) Vandaar ook de parlementaire aandacht voor het gezinsherenigingsvraagstuk.

110 TK 1962-1963 B6900 H6 Handelingen: 2080.

111 TK 1962-1963 B 6900 H15 Handelingen: 3392. 
daarentegen lieten fel van zich horen: VvD-Kamerlid Corver noemde het regeringsbeleid 'onbevredigend en eigenlijk onverantwoord'. Hij sloot zich aan bij het moreel perspectief dat door de KVP met zoveel nadruk werd ingebracht: 'Hier worden gezinnen voor lange tijd uit elkaar gehaald, iets dat m.i. nauwelijks past in een christelijk-sociaal beleid'. De vvD had daarbij ook de belangen van het bedrijfsleven voor ogen. Corver meende dat het 'heel veel waard [zou] zijn, wanneer wij een aantal buitenlanders aan onze bedrijven (...) kunnen binden'. ${ }^{112}$ Hier blijkt opnieuw de ambiguïteit van het discours van tijdelijkheid: werkgevers en hun belangenbehartigers zagen graag dat arbeidsmigranten hun verblijf in Nederland verlengden.

In hun verweer verwezen zowel de staatssecretaris van Sociale Zaken als de minister van Justitie steeds naar het huisvestingstekort. Het morele aspect waaraan de parlementariërs appelleerden werd echter wel erkend: 'Hoezeer uit algemeen menselijk standpunt gezien een bestendiging van het gezinsverband van migrerende arbeiders ook wenselijk geacht mag worden, de in Nederland heersende woningnood maakt een integrale aanpassing van het beleid aan deze overweging helaas nog onmogelijk'. ${ }^{113}$

Naar het parlement toe trokken Sociale Zaken en Justitie dus één lijn. Binnenshuis ging dat er heel anders aan toe. Gesterkt door de steun van een meerderheid in het parlement, legde minister Veldkamp (KVP) van Sociale Zaken in november 1963 een nota voor aan de ministerraad, waarin hij voorstelde de wachttijd voor arbeidsmigranten van buiten de EEG terug te brengen van twee tot één jaar. Deze nota stelde dat de wervingen van arbeidsmigranten 'aanzienlijke moeilijkheden' ondervonden. De vraag oversteeg het aanbod en de concurrentie met andere wervingslanden was groot. Vooral door zijn relatief stringente gezinsherenigingsbeleid was Nederland voor arbeidsmigranten een minder aantrekkelijk land van bestemming. Nederlandse bedrijven ondervonden verder hinder van de strenge regelgeving, doordat 'waardevolle arbeidskrachten, die de moeilijke periode van inwerking en acclimatisatie achter zich hebben', na een jaar besloten hun contract niet te verlengen omdat zij niet nog een jaar van hun gezin gescheiden wensten te zijn. Daar kwam bij, dat de voorkeursbehandeling van EEGburgers, voor wie maar één jaar wachttijd gold, door de Spaanse autoriteiten als 'discriminatoir' werd beschouwd. ${ }^{114}$ Volgens Sociale Zaken hoefde men niet te vrezen dat arbeidsmigranten niet meer naar hun herkomstland

112 тк 1962-1963 В 6900 H15 Handelingen: 3401-2.

113 тк 1962-1963 B6900 H15 (13): 19-20.

114 Zie noot 105 in hoofdstuk 2. 
zouden terugkeren: 'het zij met nadruk gesteld - (...) verreweg de meeste migrerende werknemers hebben geen plannen zich blijvend in het land van aanwerving te vestigen'. ${ }^{115}$

Bij de bespreking in de ministerraad stuitte het voorstel van Sociale Zaken op bezwaren van de ministers van Justitie, Maatschappelijk Werk en Volkshuisvesting, die vreesden voor een verdere belasting van de woningmarkt. Minister Veldkamp was bij de verdediging van zijn voorstel buitengewoon fel. Daarbij uitte hij openlijk zijn irritatie over de belemmeringen die binnen de Nederlandse regering werden opgeworpen tegen een arbeidsmigratiebeleid dat in zijn ogen cruciaal was voor het welvaren van de Nederlandse economie. Minister Veldkamp stelde de indruk te hebben, 'dat er ministers zijn, die tegen de aanwerving van vreemde arbeidskrachten principieel bezwaar hebben. (...) Spreker meent, dat men het wervings- en toelatingsbeleid moet versoepelen of ermee op moet houden'. Het voorstel van Sociale Zaken kreeg steun van premier Marijnen (KVP). Uiteindelijk stemde de ministerraad ermee in, de wachttijd te verkorten. ${ }^{116}$

Daarmee was de kous echter niet af. Over de precieze strekking van het besluit van de ministerraad ontstond namelijk een vreemde verwarring. Volgens minister Scholten ( $\mathrm{CHU}$ ) van Justitie had de raad besloten om de wachttijd alléén voor Spanjaarden te verkorten. ${ }^{117}$ De officiële notulen van de ministerraad vermeldden echter dat het oorspronkelijke voorstel van Sociale Zaken was aanvaard, en dat de wachttijd dus voor alle nietEEG landen tot één jaar werd teruggebracht. ${ }^{118}$ Bij navraag bij de secretaris van de ministerraad bleek, dat de oorspronkelijke notulen inderdaad overeenkwamen met de opvatting van minister Scholten. Op verzoek van staatssecretaris De Meijer (KVP) van Sociale Zaken was de tekst van de notulen gewijzigd. ${ }^{119}$ Zo werd de strijd tussen Sociale Zaken en Justitie over het gezinsherenigingbeleid tot in de formulering van de notulen van de ministerraad uitgevochten. Het duurde vijf maanden voordat de zaak was opgehelderd, maar in april 1964 schreef staatssecretaris De Meijer aan de minister van Justitie dat hij akkoord ging met 'Uw interpretatie van het op 22 november jl. behandelde'. Helemaal van harte ging dat echter niet, want de staatssecretaris voegde daaraan toe: 'Ik hoop evenwel dat gij

115 Nota minister van Sociale Zaken en Volksgezondheid aan ministerraad, 12 november 1963. NA IND 1.

116 Notulen ministerraad, 22 november 1963. NA IND 1.

117 Notitie minister van Justitie op nota HVG, 19 november 1963. NA IND 952.

118 Nota SG aan minister., 16 januari 1964. NA IND 1.

119 Nota HVG aan SG, 5 februari 1964. NA IND 1. 
oog zult blijven houden voor de wenselijkheid ontspanning te brengen op de arbeidsmarkt'. ${ }^{120}$ Op 5 augustus 1964 verscheen de circulaire, waarin werd medegedeeld dat voor niet-EEG burgers een wachttijd van twee jaar bleef gelden, maar dat deze voor Spanjaarden werd teruggebracht tot één jaar. $^{121}$

\section{Verdere verlaging van de wachttijd}

In de tweede helft van de jaren zestig zou de wachttijd het onderwerp blijven van soortgelijke debatten tussen Sociale Zaken en Justitie. In 1966 werd de wachttijd verlaagd van twee naar één jaar voor Portugezen, Grieken en Turken. Minister Samkalden (PvdA) van Justitie had minister Veldkamp (KVP) van Sociale Zaken zover gekregen, in te stemmen met zijn voorstel om tijdelijk niet meer dan 5 duizend arbeidsmigranten per half jaar toe te laten tot Nederland. In ruil voor die inschikkelijkheid van Sociale Zaken ging Justitie ermee akkoord de wachttijd te verlagen voor arbeidsmigranten uit landen waarmee Nederland een wervingsakkoord had gesloten. ${ }^{122} \mathrm{Na}$ 1968 steeg de vraag naar buitenlandse werknemers echter weer, en het toelatingsbeleid van de Nederlandse overheid plooide zich opnieuw naar de behoeften van het bedrijfsleven. In 1970 en 1971 zou de werving zelfs een hoogtepunt bereiken, met meer dan 16 duizend nieuw afgegeven arbeidsvergunningen per jaar. ${ }^{123}$ De quotum-regeling is dus nooit in de praktijk gebracht. ${ }^{124}$ Het gezinsherenigingsbeleid daarentegen is wel aangepast.

In 1968 werd de wachttijd voor Gemeenschapsonderdanen afgeschaft. ${ }^{125}$ In 1970 ten slotte werd, opnieuw op voorstel van Sociale Zaken, de wachttijd voor Joegoslaven en Marokkanen teruggebracht naar één jaar. Justitie had liever aan twee jaar vastgehouden, 'in ieder geval voor niet in Europa gelegen landen'. Uit schaarse beschikbare gegevens bleek dat arbeidsmigranten doorgaans niet meer dan twee of drie jaar in Nederland bleven. Het zou daarom beter zijn om gezinshereniging die eerste jaren niet

120 Brief staatssecretaris van Sociale Zaken aan minister van Justitie, 14 april 1964. NA IND 1.

121 Circulaire, 5 augustus 1964. NA IND 804.

122 Nota minister van Justitie aan minister-president, 15 juni 1966. NA MR 793; Notulen ministerraad 24 juni 1966. NA MR 814, fiche 223; De Lange 2007: 118-123.

123 Penninx 1979: 93.

124 Enkele maanden nadat voor de quotum-regeling gekozen was, viel het kabinet Cals. In 1967 werd Roolvink (ARP) minister van Sociale Zaken: hij achtte de quotum-regeling 'niet meer opportuun'. De Lange 2007: 123.

125 Nota HVG, 17 maart 1970. NA IND 612; Goedings 2005: 244-247. 
toe te staan, 'wil men het sedentaire karakter althans niet versterken'. ${ }^{126}$ Zowel de werkgevers- en werknemersverbonden als een Kamermeerderheid hadden echter te kennen gegeven het niet gerechtvaardigd te vinden dat onderscheid werd gemaakt tussen arbeidsmigranten van verschillende nationaliteiten. ${ }^{127}$ Het hoofd HVG constateerde dat Justitie in deze kwestie 'steeds meer geïsoleerd komt te staan'. ${ }^{128}$ De ambtelijke top van Justitie adviseerde de minister, met tegenzin, om het voorstel van Sociale Zaken goed te keuren. Minister Polak (VVD) van Justitie reageerde daarop in een aantekening aan zijn ambtenaren: "'t Zal wel moeten. Ik vind het jammer. We worden steeds meer een immigratieland'. ${ }^{29}$

Deze opmerking van de minister is buitengewoon veelzeggend. Formeel zou de Nederlandse regering nog tot in 1989 nadrukkelijk blijven ontkennen dat Nederland een immigratieland was of kon zijn. ${ }^{130}$ Binnen het ministerie van Justitie werden al twintig jaar daarvoor vraagtekens gesteld bij de realiteit van dit axioma. Het fundamentele uitgangspunt, dat vestigingsmigratie ongewenst was, werd in de ogen van Justitie door elke versoepeling van het gezinsmigratiebeleid verder ondermijnd. Het ministerie zag zich echter steeds opnieuw gedwongen te buigen voor de overmacht van de tegenpartij. In de jaren zeventig zou gezinsmigratie substantiële vormen aan gaan nemen. Met de regelgeving zoals die aan het begin van dat decennium werd vastgesteld, was de Nederlandse regering slecht toegerust om die migratiestromen aan banden te leggen. Vanaf 1970 was gezinshereniging voor arbeidsmigranten uit wervingslanden toegestaan wanneer zij één jaar in Nederland hadden gewerkt en gewoond en beschikten over passende huisvesting en een arbeidscontract voor nog één jaar.

\section{Justitie als hoeder van homogeniteit}

De opmerking van de HVG ambtenaar, dat de wachttijd vooral voor 'niet in Europa gelegen landen' niet mocht worden verlaagd, verdient nadere beschouwing. Justitie zag voor zichzelf de taak weggelegd, ervoor te waken dat Nederland een immigratieland werd. Het ministerie beschouwde de grootschalige, permanente vestiging van vreemdelingen als een potentiële

126 Nota aan hoofd HVG, 17 maart 1970. NA IND 612.

127 Advies van Raad voor Arbeidsmarkt inzake Nota buitenlandse werknemers, 12 januari 1970. NA IND 2468; TK 1970-1971 10504 (5).

128 Notitie hoofd HVG aan SG, 22 juni 1970, op nota aan hoofd HVG, 19 juni 1970. NA IND 612

129 Notitie minister van Justitie aan SG, niet gedateerd. NA IND 612.

130 TK 1989-1990 21132 (8H): 42. 
bron van maatschappelijke problemen. Dat risico werd echter niet voor alle vreemdelingen in dezelfde mate voorvoeld: de vraag hoe een groep immigranten in de Nederlandse samenleving zou passen speelde een belangrijke rol. Met andere woorden, hoe 'vreemder' of 'afwijkender' de arbeidsmigrant, hoe huiveriger Justitie stond tegenover zijn komst.

$\mathrm{Nu}$ is 'vreemd' een relatief begrip. Begin jaren zestig waren ook de Italianen 'vreemd': men constateerde verontrust dat 'de verhoudingen der sexen hier te lande (...) vooral bij de Italianen aanleiding geeft tot misverstanden'. ${ }^{131}$ Justitie sprak over de 'spoedig verhitte gemoederen van de Spanjaarden' ${ }^{132}$ en over de 'zeer stugge en trotse Zuidslaven' ${ }^{133}$ De Spaanse cultuur werd 'folklore' genoemd, de Spaanse familie een 'clan'. ${ }^{134}$ Met de snel stijgende toestroom van arbeiders uit Turkije en Marokko vanaf de tweede helft van de jaren zestig gingen culturele verschillen echter een nog veel centraler rol spelen in de overwegingen van Justitie. ${ }^{135}$

In 1964 maakte het hoofd HVG deel uit van een Nederlandse delegatie, die in Turkije ging onderhandelen over een wervingsakkoord. In zijn verslag schreef hij:

Er heerst daar te lande een armoede die voor Westerlingen nauwelijks voorstelbaar is. De wijze van wonen zou zelfs de Nederlandse Minister van Volkshuisvesting tot een pessimist maken. De positie van de vrouw in Turkije doet middeleeuws aan. (...) Men vertelde mij - ik heb het niet kunnen verifiëren - dat de situatie van de vrouw in Turkije nog rechtstreeks voortvloeit uit een passage in de Koran, die in volgorde van waarde vermeldt de man, dan een hele tijd niets, dan de kameel dan tweemaal een hele tijd niets en vervolgens de vrouw. (...) Islamitische godsdienst en daaruit voortvloeiende levensopvattingen schijnen in Turkije nog bepaald algemeen aanvaard. (...)

Het schijnt mij dat een Turk, die uit Turkije wordt opgevist en in een westers land gaat werken een ongelukkige toekomst tegemoet gaat. Indien hij na 2 jaar werkzaamheid weer naar zijn dorp teruggaat, zal hij daar bepaald moeilijk weer kunnen aarden. Indien hij in het Westen

131 Rapport inzake de buitenlandse arbeidskrachten in Overijssel, december 1962. NA IND 844.

132 Nota HVG aan SG, 24 mei 1963. NA IND 1.

133 Nota aan hoofd HVG, 7 juli 1969. NA IND 1237.

134 Notitie hoofd HVG aan SG, 24 maart 1966. NA IND 1066.

135 In 1965 waren ruim 7000 Turken en 5.500 Marokkanen in Nederland werkzaam. Tegen 1973 was het aantal Turkse arbeiders verdrievoudigd en het aantal Marokkaanse arbeiders ruim verdubbeld. Obdeijn 1987: 461. 
blijft zal zijn afwijkend leefpatroon voor hem ongetwijfeld ook diepgaande moeilijkheden meebrengen. ${ }^{136}$

In een nota van 1970 wees de HVG op het gevaar dat een 'afzonderlijk "vreemd" proletariaat' zou ontstaan:

Dit gevaar is des te meer aanwezig nu - zeker waar het niet-Europeanen betreft - wel van een zeer afwijkend maatschappij-, cultuur- en religieus patroon sprake is, die integratie in onze samenleving, zo niet een illusie, dan toch - zeker in verhoudingsgetallen - een zeer moeilijk te verwezenlijken ideaal doet zijn. ${ }^{137}$

In een interdepartementale vergadering van datzelfde jaar verklaarde een HVG ambtenaar:

Laten we de zaak op zijn beloop, dan is een toeneming te verwachten. Dit zal allicht een verminderde aanpassing met zich meebrengen. Zo kunnen binnen onze samenleving groepen ontstaan met een geheel andere levensstijl; hierbij speelt ook de godsdienst een belangrijke rol.

Daarom stelde hij voor de werving te beperken tot 'voor onze samenleving zoveel mogelijk aanvaardbare mensen' ${ }^{138}$ Justitie stond dus bijzonder huiverig tegenover de immigratie van mensen van buiten Europa, vooral wanneer hun religieuze achtergrond niet christelijk was. Zolang het alleen om mannen ging voorzag Justitie geen onoverkomelijke problemen, maar men verwachtte dat 'een sterk afwijkend leefpatroon meer gewicht in de schaal gaat leggen zodra ook de gezinnen van deze arbeidskrachten herwaarts komen'. ${ }^{139}$ Justitie vroeg bij de toelating van gezinnen om aandacht voor 'aanpassingsverwachtingen. Het lijkt weinig zinvol een Turks gezin, misschien met een aantal opgroeiende kinderen waarvan niemand een syllabe Nederlands kent van een bergdorp in Anatolië over te poten naar b.v.

136 Het hoofd HVG stelde daarom voor niet meer dan 2000 Turken naar Nederland te laten komen. Dat voorstel werd niet overgenomen. Nota HVG aan SG, 14 maart 1964. NA IND 952.

137 Concept-nota HVG voor Commissie toekomstig beleid vreemde werknemers, niet gedateerd. NA IND 2468.

138 Verslag vergadering commissie toekomstig beleid vreemde werknemers, 22 januari 1970. NA IND 2468.

139 Nota aan hoofd Algemene Juridische Zaken, 30 januari 1964. NA IND 779. 
een woning driehoog-achter in de Utrechtse binnenstad'. ${ }^{140}$

Ann Stoler heeft laten zien dat het gezin, de opvoeding van de kinderen, de rol en het gedrag van de vrouw, een cruciale rol speelden in het creëren en behouden van de raciale hiërarchie - het onderscheid tussen 'wij' en 'zij' - waarop koloniale regimes in Zuidoost-Azië waren gebaseerd. ${ }^{141}$ In zijn analyse van recente Britse debatten over huwelijksmigratie constateert Ralph Grillo eveneens dat het gezin wordt beschouwd als 'the institution par excellence within which "difference" is produced and sustained'.142 Ook in de weerstand van Justitie tegen gezinsmigratie in de jaren zestig wordt zichtbaar dat vrouwen en kinderen bij uitstek als dragers worden gezien van het cultureel afwijkende, het Andere. De migratie van mannelijke arbeiders uit Turkije en Marokko werd in economische termen begrepen: zolang zij op de werkvloer goed functioneerden en in afgezonderde pensions en huurkazernes bleven wonen deed hun culturele achtergrond er weinig toe. Met de overkomst van Turkse en Marokkaanse gezinnen drong het 'vreemde' echter veel verder door in de samenleving: in woonwijken, scholen, ziekenhuizen, enzovoort. Daarmee stak de angst de kop op dat de cultuur die deze gezinnen met zich meebrachten de samenhang van de Nederlandse maatschappij zou kunnen aantasten. ${ }^{143}$

Deze vrees vertaalde zich echter niet in stringentere toelatingsvoorwaarden voor Turkse en Marokkaanse gezinnen. In de late jaren zestig deed de invloed zich reeds gelden van de norm van gelijke behandeling, dat kernelement van de 'culturele revolutie' die ook in Nederland woedde. Juist daarom was de wens van Justitie om voor Marokkanen en Joegoslaven een hogere wachttijd aan te houden dan voor migranten uit andere

140 Nota aan hoofd Vreemdelingenzaken, 19 november 1964. NA IND 1.

141 Stoler 2002: 32-78 en 112-139.

142 Grillo 2007.

143 Het kan ook andersom: Lucassen (2005: 106-107) stelt vast dat de ongehuwde staat van veel Italianen die voor de Tweede Wereldoorlog in Frankrijk werk kwamen zoeken de angst voor 'violent and unpredictable behavior' versterkte. Men zag liever dat Italianen zich met hun gezin in Frankrijk vestigden: gezinnen werden als stabiel en dus minder bedreigend ervaren. Ook met betrekking tot de Nederlandse naoorlogse casus is geopperd dat deze angst voor 'mannen alleen' een rol zou hebben gespeeld in het gezinsherenigingsbeleid. Groenendijk (1990: 85), De Hart (2003a: 101) en Van Walsum (2008: 123-125) suggereren dat rellen in Twente tussen Nederlanders en Italiaanse en Spaanse arbeidsmigranten in 1961 over toegang tot dansavonden (lees: tot Nederlandse vrouwen) de Nederlandse overheid ertoe hebben gebracht gezinshereniging toe te staan. We weten inmiddels echter dat gezinshereniging, anders dan deze auteurs veronderstellen, niet vanaf 1962 maar vanaf 1960 was toegestaan. De Lange (2007: 119) oppert nog dat de rellen in Twente een rol zouden kunnen hebben gespeeld in de verlaging van de wachttijd in 1967. Ik heb daar in de beleidsdocumenten geen aanwijzingen voor gevonden. Vooral binnen het ministerie van Justitie werden gezinnen veel meer als een bedreiging van de publieke orde beschouwd dan arbeidsmigranten die alleen kwamen. 
wervingslanden in 1970 door parlement en vakbonden als discriminatoir van de hand gewezen. Hoeveel bedenkingen Justitie ook had, voor Turkse en Marokkaanse mannen golden dezelfde voorwaarden voor gezinshereniging als voor andere arbeidsmigranten.

Het ministerie van Justitie zag voor zichzelf de taak weggelegd, te voorkomen dat migranten zich permanent in Nederland zouden vestigen op een schaal die het 'absorpsievermogen' ${ }^{144}$ van de Nederlandse samenleving te boven ging. Hoe 'afwijkender' de culturele achtergrond van de migrant, hoe sterker de vrees dat de sociale cohesie in Nederland zou lijden onder diens blijvende aanwezigheid. Deze analyse bevestigt de bevindingen van andere auteurs die zich hebben gebogen over de taakopvatting van Justitie in de eerste naoorlogse decennia. Wentholt schreef al in 1967 dat 'een vrij grote mate van cultureel etnocentrisme' de 'kringen van justitie en politie' niet vreemd was. Schuster stelt dat de Hoofdafdeling Vreemdelingenzaken en Grensbewaking zich opwierp 'als hoeder van de etnische samenstelling van de Nederlandse bevolking'. In een interview met Willems en Lucassen verklaarde een oud-ambtenaar van diezelfde afdeling, dat het vreemdelingenbeleid erop gericht was Nederland 'schoon te houden'. ${ }^{145}$ De parallellen tussen de visies van deze HVG ambtenaren en recente publieke en politieke discussies zijn opmerkelijk. Volgens Entzinger draaide het Nederlands debat over integratie vanaf de jaren negentig om de spanning tussen diversiteit en eenheid: 'What should all members of a society have in common in order to make that society function'? ${ }^{146}$ Dertig jaar eerder was die vraag al leidend voor de standpuntbepaling van Justitie in het gezinsmigratievraagstuk.

\subsection{Ruzie over Spaanse echtgenotes}

In de loop van de jaren zestig gingen Spanjaarden de grootste groep buitenlandse arbeiders uitmaken. ${ }^{147}$ Meer nog dan de Italiaanse arbeiders hadden gedaan, verzetten Spaanse arbeiders zich tegen de strenge Nederlandse regelgeving betreffende gezinshereniging. Dit verzet kwam vooral tot uiting in een eenvoudigweg negeren van de regels: Spaanse echtgenotes

144 Nota HVG aan SG, 12 maart 1964. NA IND 357.

145 Wentholt 1967b: 198; Schuster 1999: 178; Willems \& Lucassen 1990: 158.

146 Entzinger 2003: 81-82.

147 Zie paragraaf 2.2. 
voegden zich bij hun mannen, ook als zij niet aan de voorwaarden voldeden. Dit zorgde binnen de Haagse ministeries herhaaldelijk voor de nodige opschudding.

\section{Uitzondering voor werkzame echtgenotes}

In januari 1962 werd bij Vreemdelingenzaken voor het eerst aan de bel getrokken, omdat echtgenotes van Spaanse arbeidsmigranten zich bij hun man hadden gevoegd vóórdat de twee jaar wachttijd om waren. Het geval was bijzonder complex, omdat de Spaanse vrouwen in Nederland werk hadden gezocht en gevonden. Sterker nog: Sociale Zaken had aan vijftien vrouwen een werkvergunning verleend. Gevolg was een zoveelste frontale botsing tussen de ambtenaren van Justitie en Sociale Zaken, die in dit geval deels voortkwam uit een fundamenteel verschillend perspectief op genderrollen. De uitvoeringsinstanties van Sociale Zaken verkeerden in de veronderstelling dat het arbeidsmigratiebeleid zowel op mannelijke als op vrouwelijke arbeidsmigranten van toepassing was en dat de strenge regelgeving voor gezinshereniging alleen gold voor vrouwen die niet werkten. ${ }^{148}$ Justitie was het daar niet mee eens. Het hoofd Vreemdelingenzaken en Grensbewaking stelde:

$\mathrm{Nu}$ staat wel vast - en dit schijnt mij voor het vinden van het te voeren beleid een goed uitgangspunt - dat de dames hier komen om zich bij hun mannen te voegen en bepaald niet om hier op dezelfde voet als dezen te werken. Zij doen dit slechts om een basis te verschaffen aan hun verblijf (plus eventueel dat der kinderen) hier te lande. ${ }^{149}$

In de ogen van Sociale Zaken betekende de komst van de Spaanse echtgenotes in de eerste plaats een welkome aanvulling van het arbeidsaanbod waaruit het Nederlands bedrijfsleven kon putten. Justitie ging echter uit van het traditionele rolpatroon binnen het gezin: de man werkt, de vrouw volgt. Wanneer de echtgenote van een arbeidsmigrant naar Nederland kwam en hier werk zocht, dan stond niet haar werkzaamheid, maar haar hereniging met haar man centraal. Daarom diende op hen niet de soepele regelgeving voor arbeidsmigratie maar het strenge gezinsherenigingbeleid van toepassing te zijn. In hele specifieke gevallen zou Justitie wel een uitzondering 
willen maken, bijvoorbeeld voor kooksters voor ploegen buitenlandse werknemers, verpleegsters en huishoudelijke hulpen. ${ }^{150}$

Op basis van dit standpunt werd ambtelijk overleg gevoerd met Sociale Zaken. Vijf maanden later, in juni 1962, werd overeenstemming bereikt: aan de wachttijd zou streng de hand worden gehouden, behalve voor vrouwen die kinderloos waren en werk vonden in 'de huishoudelijke sfeer dan wel in een instelling met een sociaal karakter'. In die gevallen mocht de echtgenote naar Nederland komen zodra de proeftijd van haar man was verstreken en deze over passende huisvesting beschikte. Werk in de 'winstgevende sfeer' viel in eerste instantie dus niet onder de uitzondering. ${ }^{151}$ In het parlement verklaarden de bewindslieden van Sociale Zaken en Justitie dat de uitzondering beperkt was tot de 'sociale sfeer' omdat in de industrie geen behoefte was aan vrouwelijke arbeidskrachten. ${ }^{152}$ In feite hadden arbeidsmarktoverwegingen geen rol gespeeld in deze beslissing. Het waren de ambtenaren van HVG die erop hadden aangedrongen, vanuit de wens om de reikwijdte van de uitzondering zo beperkt mogelijk te houden. ${ }^{153}$ Het is tekenend voor het traditionele perspectief van ambtelijk Justitie dat daarbij gedacht werd aan typisch 'vrouwelijke' beroepen.

Deze beperking werd echter scherp bekritiseerd, in de eerste plaats door de werkgeversverbonden. Zij lieten de regering weten dat er 'in vele bedrijfstakken (...) een dringend tekort aan vrouwelijk personeel' bestond. Ze benadrukten nog eens dat Spaanse arbeiders 'ten hoogste enkele jaren in Nederland' wilden werken en dat hun echtgenotes kwamen om hen 'te helpen in deze korte tijd zoveel mogelijk te verdienen'. 'De geringe soepelheid' van de overheid, zo stelden de werkgevers, schaadde 'de economische concurrentiepositie van vele van onze bedrijven'. ${ }^{154}$ Ook de vvD had voor de gekozen beleidslijn geen goed woord over. Kamerlid Berkhouwer verklaarde door de maatregel 'eigenaardig getroffen' te zijn. Het argument van de regering dat in commerciële sectoren geen vraag was naar vrouwelijke arbeidskrachten sneed geen hout en bovendien was de maatregel een laakbare beperking van de keuzevrijheid van vrouwen. ${ }^{155}$ Gesterkt door

150 Nota HVG aan SG, 15 februari 1962. NA IND 1.

151 Nota HVG aan SG, 3 juli 1962; Circulaire 17 juli 1962. NA IND 1.

152 TK 1962-1963 B6900 H15 Handelingen: 2107, 3420.

153 Nota HVG aan SG, 15 februari 1962. NA IND 1.

154 Brief Raad van Nederlandse Werkgeversbonden aan minister-president, 15 november 1962. NA IND 1.

155 тK 1962-1963 B6900 H15 Handelingen: 3402; EK 1962-1963 B6900 H15 Handelingen: 3234. 
deze steunbetuigingen wist Sociale Zaken Justitie er in juli 1963 van te overtuigen de uitzondering te verbreden tot echtgenotes die werk vonden in het bedrijfsleven. ${ }^{156}$

Werklustige echtgenotes van arbeidsmigranten mochten dus al na enkele maanden overkomen, in plaats van na één of twee jaar. Die soepele regeling was echter alleen van toepassing op kinderloze vrouwen, en dat zinde Sociale Zaken niet. Staatssecretaris Roolvink (ARP) betoogde in de ministerraad dat de kinderen in het herkomstland konden worden achtergelaten: de sterke familiebanden in Spanje stonden ervoor garant, dat voor deze kinderen goed werd gezorgd. Het verruimen van de toelatingsvoorwaarden voor echtgenotes zou niet alleen het tekort aan vrouwelijke arbeidskrachten verzachten, maar ook de werving van gehuwde mannelijke arbeiders vergemakkelijken. Dit voorstel vond echter onvoldoende steun in de ministerraad. Beerman (CHU) van Justitie stelde dat het verbod op overkomst van de kinderen moeilijk te handhaven zou zijn omdat 'de praktijk leert dat (...) het bloed kruipt waar het niet gaan kan'. Premier De Quay (KVP) had moeite met de 'morele aspecten' ${ }^{157}$ Het kwam zelden voor dat het morele gewicht van het gezinsleven een rol speelde in ambtelijke of ministeriële besluitvorming, maar voor de bewindslieden was scheiding van moeder en kinderen blijkbaar problematischer dan scheiding van mannen van hun gezin. De uitzondering voor werkzame echtgenotes bleef beperkt tot kinderloze vrouwen. ${ }^{158}$

\section{Publiek rumoer}

Ondanks deze versoepeling bleek het gezinsherenigingsbeleid moeilijk te handhaven. Tot tweemaal toe zag Justitie zich gedwongen op grote schaal verblijfsvergunningen te verlenen aan Spaanse echtgenotes die niet aan de voorwaarden voor gezinshereniging voldeden. In september 1962 vernam Justitie dat in de omgeving van Utrecht zeventien Spaanse vrouwen

156 Nota HVG aan SG, 24 mei 1963; Circulaire 10 juli 1963. NA IND 1.

157 Nota minister van Justitie, mede namens Volkshuisvesting en Bouwnijverheid, Maatschappelijk Werk en Sociale Zaken en Volksgezondheid, aan ministerraad, 17 oktober 1962; Notulen ministerraad, 19 oktober 1962. NA IND 1.

158 Sociale Zaken zou het voorstel om ook werkzame echtgenotes mét kinderen onder de uitzondering te doen vallen nog twee keer (in 1963 en 1965) ter tafel brengen, zonder succes. Nota HVG, 20 februari 1963; verslag interdepartementale bespreking, 27 februari 1963. NA IND 1. De Lange (2007: 121) stelt dat de voorwaarde van kinderloosheid niet neergelegd was in regelgeving. Dat was echter wel het geval, namelijk in de circulaire van de secretaris-generaal van Justitie aan de uitvoerende diensten van 10 juli 1963. 
woonden en werkten die niet aan de voorwaarden voor verblijf voldeden: zij werkten bij een bedrijf. Daarbij beschikte een aantal van hen niet over passende huisvesting. Justitie wilde deze vrouwen daarom uitzetten. ${ }^{159}$ Het geval werd uitgebreid en kritisch besproken in de media. ${ }^{160}$ In de tweede helft van september vond in Spanje bovendien een overstroming plaats, die juist de textielstreken waaruit veel van de Spaanse arbeidsmigranten afkomstig waren, ernstig trof. Daarom werd besloten de uitzetting van de Spaanse echtgenotes voorlopig op te schorten. ${ }^{161}$ In oktober bleek dat het bericht van de opschorting was doorgesijpeld via de pers en dat honderden Spaanse vrouwen zich op het geval beriepen. Het merendeel van deze vrouwen was bij hun man op bezoek - bezoek was voor hoogstens drie maanden toegestaan - en wenste nu dus te blijven. ${ }^{162}$ De media-belangstelling voor de mogelijke uitzetting van de Spaanse vrouwen had inmiddels ook de aandacht getrokken van het parlement. Zo vroeg Baeten (KVP) de minister van Justitie 'of het wel juist [was] een zo rigoureuze maatregel te nemen'. Ambtenaren van Justitie en Sociale Zaken bogen zich over de situatie, maar het overleg verliep moeizaam. ${ }^{163}$ Pas een half jaar later, in mei 1963, kon een compromis kon worden bereikt. Er kwam een bijzonder soepele overgangsregeling: alle Spaanse echtgenotes die op het moment van de inwerkingtreding van de regeling - 15 juli 1963 - in Nederland zouden zijn, kregen een verblijfsvergunning. ${ }^{164}$

In november 1963 won Justitie voor één keer het pleit. Veertien Spaanse vrouwen hadden zich bij hun echtgenoten in Utrecht gevoegd en daarbij hun kinderen in Spanje achtergelaten. Dat was in strijd met de regelgeving en daarom wilde Justitie de vrouwen uitzetten. Anders dan voorheen werd aan dit geval geen aandacht besteed in parlement of pers. De Spaanse autoriteiten hadden er echter bij Sociale Zaken op aangedrongen de uitzetting op te schorten en de algemene regelgeving te versoepelen. Sociale Zaken toonde zich gevoelig voor dit verzoek. Justitie was echter volstrekt

159 Nota HVG aan SG, 27 september 1962. NA IND 1.

160 Zie Schrover (2008) voor het enige mij bekende onderzoek naar deze 'mediahype' rond de uitzetting van gezinnen van arbeidsmigranten. Dat deze mediaberichtgeving in de besluitvorming een belangrijke rol heeft gespeeld blijkt uit bezorgde opmerkingen van HVG-ambtenaren en van de Voorlichtingsdienst van Justitie over negatieve berichtgeving in de pers. Nota's Voorlichtingsdienst aan SG, 26 en 27 september 1962; Nota HVG aan SG, 27 september 1962. NA IND 1.

161 Nota's HVG aan SG en minister, 28 september 1962. NA IND 1.

162 Nota HVG aan SG, 8 oktober 1962. NA IND 1.

163 Notulen ministerraad, 19 oktober 1962; Nota aan hoofd HVG, 20 februari 1963; Verslag interdepartementale bespreking, 27 februari 1963. NA IND 1.

164 Nota aan hoofd HVG, 1 november 1963; Nota HVG aan SG, 24 mei 1963. NA IND 1. 
niet genegen eraan te voldoen: 'De ervaring met de Spanjaarden is, dat zij niet ophouden te chicaneren; tot dusver met vrij veel succes, mede dankzij de steun van Sociale Zaken'. Wanneer opnieuw een uitzondering werd gemaakt, kon men er vanuit gaan dat die niet beperkt zou blijven tot deze veertien vrouwen. ${ }^{165}$ Op 4 november stemde de ministerraad in met onmiddellijke uitzetting naar Spanje. ${ }^{166}$ Dat Justitie ditmaal steun vond voor zijn standpunt zal in de eerste plaats te maken hebben met het uitblijven van parlementaire of publicitaire druk. Bovendien betrof het vrouwen die hun kinderen in Spanje hadden achtergelaten en we hebben eerder gezien dat dit in de ministerraad op morele gevoeligheden stuitte.

In december 1964 zorgden voornemens van Justitie om Spaanse echtgenotes uit te wijzen echter opnieuw voor opschudding. Dit keer ging het om Spaanse vrouwen die bij een tabaksbedrijf in Amsterdam werkten. Zij voldeden niet aan de eisen omdat zij woonden in gehuurde kamers en pensions, terwijl alleen een zelfstandige woning als 'passende huisvesting' werd aangemerkt. Het probleem bleek al snel breder: de ambtenaren van HVG constateerden dat verschillende gemeenten, waaronder naast Amsterdam ook Utrecht en Rotterdam, het 'niet zo nauw [namen]' met de beoordeling van wat passende woonruimte was. $\mathrm{Zij}$ vonden dit onaanvaardbaar, omdat het huisvestingsvereiste als een - in de ogen van deze ambtenaren zéér wenselijke - rem op de toestroom van buitenlandse gezinnen werkte. Daarom wilde Justitie vrouwen die niet aan het huisvestingsvereiste voldeden terug naar Spanje sturen. ${ }^{167}$

Deze opstelling stuitte echter op aanzienlijke weerstand. Justitie kreeg scherpe kritiek te verduren, niet alleen van katholieke Kamerleden, maar zelfs van de PvdA die zich zelden in discussies over gezinshereniging mengde. ${ }^{168}$ De Hoofdaalmoezenier van Spanje noemde het beleid van de regering 'immoreel'. ${ }^{169}$ De Spaanse Ambassade verzocht de Nederlandse regering een 'menselijker' benadering te kiezen: gezinshereniging bracht de arbeiders 'la chaleur humaine nécessaire pour un meilleur rendement dans leur labeur'. ${ }^{170}$ En de minister van Economische Zaken schreef: 'Het brengt mij in een weinig aangename situatie tegenover het bedrijfsleven,

165 Nota aan hoofd Vreemdelingenzaken, 1 november 1963. NA IND 1.

166 Aantekening minister aan SG, 4 november 1963. NA IND 1.

167 Nota's aan hoofd HVG en SG, 15 en 16 december 1964. NA IND 1.

168 TK 1964-1965 Aanhangsel bij de Handelingen, vraag 127 en 128.

169 Brief Hoofdaalmoezenier aan minister van Justitie, 17 december 1964. NA IND 1.

170 'de menselijke warmte die noodzakelijk is voor een hogere arbeidsproductiviteit'. Brief Spaanse Ambassade aan minister van Buitenlandse Zaken, 24 december 1964. NA IND 1. 
dat in een tijd dat van regeringswege steeds weer gehamerd wordt op de noodzaak van verhoging van de produktie (...) als gevolg van bepaalde overheidsmaatregelen de produktie en de export van een belangrijk bedrijf ernstig worden belemmerd. ${ }^{171}$ Uiteindelijk bezweek Justitie voor zoveel druk. Het ministerie ging akkoord met een speciale regeling, waarbij aan de echtgenotes van arbeidsmigranten die zich op 1 januari 1965 in Nederland bevonden en die aan alle voorwaarden voldeden behalve aan het huisvestingsvereiste, voortgezet verblijf werd toegestaan. De ambtenaren van HVG stelden als voorwaarde, dat in de toekomst een strak beleid zou worden gevoerd. De aantekening van de secretaris-generaal daarbij is typerend voor de cynische sfeer die inmiddels bij Justitie leek te heersen waar het gezinshereniging betrof: 'We zullen daarvan dan maar het beste hopen!' 172

Onder druk van het Nederlands bedrijfsleven en diens belangenbehartigers in regering en parlement moest Justitie er dus mee instemmen dat kinderloze echtgenotes zich al vóór het verstrijken van de wachttijd in Nederland mochten vestigen, indien zij een baan vonden. Zelfs die versoepelde regelgeving bleek in de praktijk echter dusdanig moeilijk te handhaven, dat tot twee keer toe tot een grootschalige 'regularisatie' werd overgegaan. Er lijkt in de jaren zestig bijzonder veel ruimte te hebben gezeten tussen de formele regelgeving en de concrete implementatie van het gezinsherenigingsbeleid. ${ }^{173}$ Deze uitvoeringspraktijk verdient nader onderzoek. Hetzelfde geldt voor de wisselwerking tussen mediaberichtgeving en publieke en politieke meningsvorming. Er wordt in wetenschappelijke publicaties over het migratiebeleid vrijwel algemeen aangenomen, dat er zoiets bestaat als 'an Iron Law of the mass public in immigrant-receiving states to be negatively disposed to new migration'. ${ }^{174}$ De opinie van de media kan zeker niet gelijk worden gesteld met de publieke opinie, maar hangt er wel nauw mee samen. De Nederlandse media van de jaren zestig lijken wezenlijk te hebben bijgedragen aan de druk op Justitie om gezinsleden van arbeidsmigranten die in overtreding van de regelgeving in Nederland verbleven, bij

171 Brief minister van Economische Zaken aan minister van Justitie, 22 december 1964. NA IND 1.

172 Nota HVG aan SG, 28 december 1964. NA IND 1.

173 Zie voor een beeld van hoe weinig gewicht de formele regelgeving in de schaal legde de aflevering Nederland is vol (Andere Tijden, 14 januari 2003), waarin Spaanse arbeidsmigranten - mannen en vrouwen - en Nederlandse werkgevers van toen worden geïnterviewd. (http://geschiedenis.vpro.nl/).

174 Joppke 2002: 262. Zie ook Guiraudon 2000: 22; Freeman 2002: 78. 
hun vader en echtgenoot te laten blijven. ${ }^{175}$ Dit zou erop kunnen duiden dat de 'ijzeren wet' dat het brede publiek altijd tegen de toelating van migranten is, minder bikkelhard is dan wordt verondersteld.

\subsection{Radicale voorstellen}

\section{Politisering}

Vanaf het einde van de jaren zestig veranderde de politiek-institutionele constellatie waarbinnen het arbeids- en gezinsmigratiebeleid gevormd werd in een aantal wezenlijke opzichten. Het beleidsdebat werd verbreed, zowel in termen van deelnemers als inhoudelijk.

In 1966 en 1967 werd Nederland voor het eerst in lange tijd getroffen door een economische recessie. Tot dan toe was het dominant perspectief dat arbeidsmigranten als een 'buffer' werkten, die ingezet kon worden in tijden van arbeidstekort en die zich vanzelf weer op zou lossen wanneer het Nederlands arbeidsaanbod voldoende bleek. De recessie leidde echter nauwelijks tot hogere werkloosheid bij arbeidsmigranten in Nederland. De overheid trok daaruit de conclusie, dat in bepaalde sectoren van de arbeidsmarkt blijvend behoefte was aan arbeidsmigranten, doordat Nederlandse werknemers bepaalde soorten werk niet konden of wilden doen. De veronderstelling bleef dat individuele arbeidsmigranten tijdelijk in Nederland waren, maar de aanwezigheid van een - zich steeds vernieuwende - migrantenpopulatie op de Nederlandse arbeidsmarkt werd nu als een structureel fenomeen beschouwd. ${ }^{176}$ Daarmee ontstond de behoefte aan het ontwikkelen van een omvattende politieke visie op het arbeidsmigratiebeleid.

Daarbij kwam dat het economisch perspectief op arbeidsmigratie als een noodzakelijk instrument van het industrialisatiebeleid steeds meer op tegenstemmen stuitte. Zo waren de vakbonden er niet langer van overtuigd dat de werving van arbeidsmigranten bevorderlijk was voor de werkgelegenheid en dus voor de belangen van hun achterban. Zij verlangden van

175 De voorlopige resultaten van het onderzoek van Marlou Schrover (2008) wijzen ook in die richting. Daalder (1995: 36-37, 46, 66-68) wijst erop dat de pers tot midden jaren zestig nauw verbonden was aan gevestigde (verzuilde) partijen en zich in die zin volgzaam opstelde. Het lijkt er inderdaad op dat de pers deelde in het morele perspectief op het gezinsmigratievraagstuk van de politieke partijen in de Tweede Kamer. Daarmee stelde de pers zich echter wel kritisch op ten opzichte van het regeringsbeleid.

176 Bovenkerk 1979: 128-129; Tinnemans 1994: 85. 
de regering een betere controle over de toelating en tewerkstelling van buitenlandse werknemers. Gevolg was dat Sociale Zaken niet langer op één lijn met het bedrijfsleven naar 'zo vrij mogelijke arbeidsmigratie' kon streven. ${ }^{177}$

Ook ambtenaren van Cultuur, Recreatie en Maatschappelijk Werk (CRM) gingen zich hardop afvragen of de welvaart niet ten koste ging van welzijn, zowel van de Nederlanders als van de buitenlandse werknemers, en of niet gekozen moest worden voor beperking van de economische groei. ${ }^{178}$ CRM was in de tweede helft van de jaren zestig steeds meer betrokken geraakt bij het welzijnswerk voor arbeidsmigranten. ${ }^{179}$ Daardoor werden de ambtenaren van CRM zich bewust van de 'sociale konsekwenties' van de aanwezigheid van arbeidsmigranten en hun gezinnen in Nederland. Zij introduceerden een nieuw geluid in interdepartementale beraadslagingen door aandacht te vragen voor kwesties als 'geconcentreerde vestiging', het 'tweede generatie-probleem', en in bredere zin het risico dat in Nederland een samenleving zou ontstaan 'waarin een vaste associatie bestaat tussen ethnische achtergrond en sociale positie', zodat 'conflicten (...) zich langs ethnische lijnen afspelen' ${ }^{180}$ Anders dan bij Justitie leidden deze zorgen bij CRM echter niet zozeer tot de roep om een restrictiever toelatingsbeleid, als wel om een actievere houding van de overheid in het opvangen van de implicaties van immigratie.

De Tweede Kamer ging vanaf 1970 een steeds actiever en invloedrijker rol spelen. ${ }^{181}$ Tot dan toe hadden Kamerleden zich slechts incidenteel in het beleidsdebat gemoeid. In 1970 werd het arbeidsmigratiebeleid voor het eerst expliciet en uitgebreid onderwerp van parlementaire discussie, naar aanleiding van de Nota Buitenlandse Werknemers waarin de regering

177 De Lange 2007: 169. Zie ook Roosblad 2002: 46-47. Dit vertaalde zich concreet in de invoering van het 'mvv-vereiste' in 1968, waarmee een einde werd gemaakt aan de 'spontane' arbeidsmigratie. Vreemdelingen die niet vooraf toestemming hadden gekregen om naar Nederland te komen, in de vorm van een 'machtiging tot voorlopig verblijf' waren voortaan 'illegaal'. De Lange 2007: 123-124.

178 Verslag vergadering commissie toekomstig beleid vreemde werknemers, 22 januari 1970. NA IND 2468. Deze stellingname van CRM past in een bredere tendens in de Nederlandse maatschappij om vraagtekens te zetten bij 'de waarde van economische groei zelf'. Daalder 1995: 43.

179 Het welzijnswerk voor buitenlandse werknemers is in eerste instantie ontstaan vanuit lokaal particulier initiatief, met name uit katholieke hoek. Vanaf 1964 werden deze bijstandsstichtingen deels door CRM gesubsidieerd: deze subsidie werd geleidelijk verhoogd totdat CRM in 1975 de gehele begroting van de stichtingen voor zin rekening nam. Penninx 1979: 147-148.

180 Nota CRM voor commissie toekomstig beleid buitenlandse werknemers, 1 november 1970 . NA IND 2468.

181 Dat gold niet alleen voor het gezinsherenigingsvraagstuk maar voor het arbeidsmigratiebeleid in het algemeen. De Lange 2007: 169. 
haar beleidskader aan de Tweede Kamer voorlegde. ${ }^{182}$ Deze toenemende betrokkenheid van de Tweede Kamer past in een algemene tendens van stijgend parlementair activisme vanaf de tweede helft van de jaren zestig, maar is eveneens een teken van het groeiende politieke en maatschappelijke gewicht van het vraagstuk van arbeidsmigratie. ${ }^{183}$ In nauwe samenhang daarmee werd aan het ministerie van Justitie een staatssecretarispost toegevoegd. ${ }^{184}$ Grosheide (ARP) werd in 1971 de eerste staatssecretaris van Justitie belast met de portefeuille vreemdelingenzaken: een duidelijk signaal dat migratie een te gewichtig thema aan het worden was om aan ambtenaren te worden overgelaten.

Dit alles leidde ertoe dat er in interdepartementaal overleg op zowel ambtelijk als ministerieel niveau voor het eerst een discussie over arbeidsen gezinsmigratie werd gevoerd die niet volkomen overheerst werd door het economisch perspectief, maar waarin ruimte was om bredere maatschappelijke implicaties op de langere termijn aan de orde te stellen.

\section{De Nota Buitenlandse Werknemers}

De nota die minister Roolvink (ARP) van Sociale Zaken in 1970 aan de Tweede Kamer presenteerde bevatte geen voorstellen voor nieuw beleid, maar zette slechts het bestaande beleid op het gebied van toelating, tewerkstelling en opvang van arbeidsmigranten uiteen. Ook wat gezinshereniging betreft bleef de nota geheel in lijn met het formele standpunt waar de regering in haar communicatie naar publiek en parlement al tien jaar aan vast hield:

Nederland is beslist geen immigratieland. Met alle begrip voor de menselijke aspecten, kan men niet anders dan vaststellen, dat ons land behoefte heeft aan arbeidskrachten uit andere landen en niet aan nieuwe

182 TK 1969-1970 10504 (2). Kamerleden vroegen al sinds het begin van de jaren zestig om een dergelijke 'omvattende' nota. тK 1960-1961 B6100 H16 Handelingen: 3653-3655; тK 1962-1963 B6900 H15 Handelingen: 3392.

183 Zie over toename parlementair activisme: Van Schendelen 1974; 't Hart e.a. 2002: 124-129. 184 De eerste staatssecretaris van Justitie was Wiersma (VVD), die in de laatste maanden van de zittingsperiode van het kabinet De Jong werd aangesteld om de werklast van minister Polak van Justitie, die met gezondheidsproblemen kampte, te verlichten. Polak stond de portefeuille van het vreemdelingenbeleid echter nog niet af aan zijn nieuwe staatsecretaris. (Groeneveld 1989: 240-241) In het kabinet van Biesheuvel, die De Jong in 1971 als premier opvolgde, werd de post van staatssecretaris gehandhaafd en werd diens portefeuille gedefinieerd als vreemdelingenzaken, kinderbescherming en het gevangeniswezen. 
gezinsvestigingen vanuit het buitenland. ${ }^{185}$

De reactie van het parlement op de nota was zeer kritisch. Het stuk zou te beschrijvend zijn en 'toekomstvisie' ontberen. Bovendien hadden Kamerleden bezwaar tegen de eenzijdig economische benadering van de arbeidsmigratie: de nota zou blijk geven van een 'uiterst zakelijke, soms zelfs harde aanpak'. De regering toonde onvoldoende besef van haar verplichtingen jegens de arbeidsmigranten die zij geworven had. ${ }^{186}$

De bewindspersonen en hun ambtenaren bogen zich daarom opnieuw over het arbeidsmigratievraagstuk, in een streven een omvattende politieke visie te ontwikkelen en deze te vertalen in concreet beleid. In deze discussies - die vier jaar zouden duren - liet het ministerie van Justitie zich nadrukkelijk gelden.

\section{De brief van minister Polak}

In 1969 zond minister Polak (VVD) van Justitie een lange brief aan de ministerraad, waarin hij kritisch reageerde op het Nederlands arbeidsmigratiebeleid, zoals dat in de Nota Buitenlandse Werknemers door Sociale Zaken uiteen was gezet. ${ }^{187}$ Voor het eerst ging de minister van Justitie direct de confrontatie aan met het dominante instrumenteel-economische paradigma waarop dat beleid gebaseerd was. Polak gaf aan dat het aantal arbeidsmigranten nog niet verontrustend was, maar dat de steeds toenemende vraag naar vreemde arbeidskrachten hem zorgen baarde:

Van heinde en ver komende vreemdelingen, werkend op het laagste niveau, zullen mèt hun gezinnen een nieuw industrieel proletariaat gaan vormen zonder voldoende vertakkingen met de Nederlandse samenleving. Door hun sterke onderlinge bindingen en door de eigen plaats die zij in onze economie innemen zullen zij gemakkelijk een vreemd lichaam gaan vormen binnen onze bevolking met alle gevolgen van dien.

De minister bekritiseerde het beleid dat Nederland tot nu toe voerde als 'van zuiver economische, zo men wil arbeidstechnische aard'. Hij wees op

185 TK 1969-1970 10504 (2): 9.

186 TK 1970-1971 10504 (5).

187 De brief was geschreven door het hoofd HVG, dat hier reageerde op een concept-versie van de Nota Buitenlandse Werknemers. 
de toename van gezinshereniging, die leidde tot 'langer zo niet voortdurend verblijf op grote schaal' en op de maatschappelijke problematiek die hiervan het gevolg was. De minister stelde dat de Nederlandse regering haar vermogen om die maatschappelijke gevolgen door opvang en begeleiding te ondervangen overschatte en voegde zijn collega's toe 'helder voor ogen [te] houden dat import van vreemde arbeidskrachten beslist geen korte termijn politiek is'. Hij drong er op aan onverwijld in te grijpen, bijvoorbeeld door de verblijfsduur tot één of twee jaar te beperken, zowel het totaal aantal arbeidsmigranten als het aantal herkomstlanden aan een maximum te verbinden, en arbeidsparticipatie door gehuwde vrouwen en automatisering te bevorderen. Het was nu immers nog niet te laat om te voorkomen dat 'een sociaal probleem [zou] groeien, waarvan latere geslachten de wrange vruchten zouden plukken'. ${ }^{188}$

De brief maakte echter niet de gewenste indruk in de ministerraad. De ministers van Sociale Zaken en Economische Zaken wuifden de zorgen van minister Polak weg. Het aantal buitenlandse werknemers in Nederland was in vergelijking met andere landen immers zeer beperkt. Het verblijf van arbeidsmigranten in Nederland was van tijdelijke aard. Een restrictief toelatingsbeleid zou de concurrentiepositie van het Nederlands bedrijfsleven beschadigen en voor bepaalde bedrijfssectoren zelfs levensbedreigend zijn. ${ }^{189}$ Kortom, Polak was er met zijn brief niet in geslaagd het dominante economisch perspectief te doen wankelen.

\section{Op voorstel van Justitie: een rotatie-systeem}

De bespreking van Polaks brief in de ministerraad resulteerde wel in de oprichting van de 'interdepartementale commissie toekomstig beleid vreemde werknemers', die de taak kreeg een nieuwe versie van de Nota Buitenlandse Werknemers voor te bereiden. ${ }^{190}$

Het belangrijkste voorstel dat HVG ambtenaren in deze commissie deden, was een rotatie-systeem in te voeren. ${ }^{191} \mathrm{Om}$ 'afzonderlijke proletariaatvor-

188 Brief minister van Justitie aan ministerraad, 29 september 1969. NA IND 1463.

189 Schuster 1999: 184; De Lange 2007: 130-131.

190 Verslag vergadering commissie toekomstig beleid vreemde werknemers, 22 januari 1970. NA IND 2468 .

191 Het voorstel om de verblijfstermijn van arbeidsmigranten aan een maximum te verbinden was al een aantal keren eerder ter tafel gebracht, tot dusver zonder succes: door het ministerie van Justitie in de aanloop naar de wervingsovereenkomst met Italië van 1960 (zie paragraaf 2.5), in datzelfde jaar nogmaals door minister Klompé van Maatschappelijk Werk, en opnieuw door ambtelijk Justitie in 1965. De Lange 2007: 117, 156. 
ming' te voorkomen moest de verblijfstermijn van nieuw te werven migranten aan een maximum worden verbonden en diende de mogelijkheid te worden gecreëerd om arbeidsmigranten onvrijwillig terug te zenden. ${ }^{192}$ Dit bleek al snel een complex punt, waarover ambtenaren van Sociale Zaken en Justitie, buiten de algemene commissievergaderingen om, nader overleg pleegden. De twee ministeries waren het erover eens, dat een beleid dat gericht was op verplichte terugkeer alleen politiek haalbaar en praktisch uitvoerbaar zou zijn, indien het gepaard ging met een financiële bonus bij vertrek. Het overleg tussen Sociale Zaken en Justitie richtte zich daarom op de vraag, hoe zo'n vertrekpremie er precies uit zou moeten zien. ${ }^{193}$

De respons op de Nota Buitenlandse Werknemers, zowel vanuit het parlement als van de kant van de vakbonden, beloofde echter weinig goeds voor de ontvangst van een dergelijk gedwongen terugkeerbeleid. In die respons klonk namelijk de invloed door van de 'culturele revolutie' die Nederland, net als de rest van de westerse wereld, sinds de tweede helft van de jaren zestig in zijn greep had. Kernelement van die culturele revolutie was de emancipatie van het individu, de zelfontplooiing van ieder mens. ${ }^{194}$ Deze visie kwam terug in de nadruk die parlementariërs en vakbondsleden legden op de morele verplichting van de Nederlandse overheid jegens arbeidsmigranten, op het recht op gelijke behandeling en op de afwijzing van iedere vorm van dwang. ${ }^{195}$

In eerste instantie hielden Justitie èn Sociale Zaken echter vast aan hun voornemen om een maximum verblijfstermijn van twee jaar in te stellen. ${ }^{196}$ Voor Justitie was de gestaag in omvang toenemende gezinshereniging de belangrijkste aanleiding om te blijven aansturen op een rigoureus rotatiebeleid. Het hoofd HVG merkte bezorgd op,

dat de problemen ons thans reeds aardig boven het hoofd dreigen te groeien. Het aantal vreemdelingen in Nederland dat hier met een verblijfsvergunning vertoeft neemt maandelijks met bijna 1000 toe. Ruim de helft van dit aantal betreft vrouwen en kinderen van buitenlandse werknemers die in het kader van gezinshereniging overkomen. ${ }^{197}$

192 Nota HVG voor commissie toekomstig beleid vreemde werknemers, besproken op 3 december 1970. NA IND 2468.

193 Nota Sociale Zaken, 25 april 1972; Nota HVG aan SG, 4 mei 1972. NA IND 1576.

194 Blom 1999: 352-358; De Rooy 2005: 238-247.

195 TK 1970-1971 10504 (5); Verslag vergadering CABA, 29 november 1972. NA IND 1475.

196 Nota aan hoofd HVG, 19 mei 1972. NA IND 1576.

197 Nota HVG aan SG, 19 oktober 1973. NA IND 817. 
In augustus 1972 schreef staatssecretaris Grosheide (ARP) van Justitie een brief aan de burgemeester van Oss, die te kennen had gegeven zich ernstige zorgen te maken over de toename van gezinshereniging. De staatssecretaris gaf aan die bezorgdheid over de 'ongebreidelde toelating van gezinsleden' te delen, maar stelde de burgemeester gerust met de vertrouwelijke mededeling dat de regering overwoog om de toelating van arbeidsmigranten aan een tijdslimiet te verbinden: 'Wordt dit punt (...) goedgekeurd dan zal van gezinshereniging in het geheel geen sprake meer zijn.' ${ }^{198}$

Het zou echter anders uitpakken dan Justitie had gehoopt en verwacht. In mei 1973 trad het progressieve kabinet Den Uyl aan en daarmee kwam de 'nieuwe politieke cultuur, die tot dan toe grotendeels in de straten van Amsterdam (...) bloeide', aan de macht. ${ }^{199}$ De nieuwe staatssecretaris van Justitie Glastra van Loon (D66) lag, anders dan zijn voorganger Grosheide, niet op één lijn met zijn ambtenaren. ${ }^{200}$ In november 1973, een aantal maanden voor het verschijnen van de Memorie van Antwoord, vernam ambtelijk Justitie dat de ministeries van CRM en Sociale Zaken in overleg met de minister en staatssecretaris van Justitie overeen waren gekomen, dat arbeidsmigranten na twee jaar de keuzemogelijkheid zou worden geboden, ofwel met een vertrekpremie naar huis terug te keren, of een arbeidscontract voor onbepaalde tijd aan te gaan. De mogelijkheid om na één jaar het gezin te laten overkomen zou blijven bestaan. ${ }^{201}$ Daarmee werd de mogelijkheid tot gedwongen terugkeer dus uit het beleidsinstrumentarium geschrapt en werd gezinshereniging geen verdere rem opgelegd. Het hoofd HVG vroeg zich verontwaardigd af, hoe deze beslissing geheel buiten zijn afdeling om tot stand had kunnen komen. ${ }^{202}$ Begin februari 1974 bevestigde de ministerraad deze hem onwelgevallige beslissing: verplichte terugzending werd afgewezen. In plaats daarvan werd gekozen voor het stimuleren van vrijwillige terugkeer door middel van een financiële premie. Op deze manier, zo verklaarde de minister van Sociale Zaken, kon 'het principe dat Nederland geen immigratieland is [worden] gehandhaafd, zonder daarvan een dogma te maken' ${ }^{203}$

198 Brief staatssecretaris van Justitie aan burgemeester van Oss, 14 augustus 1972. NA IND 612.

199 De Rooy 2005: 259-260.

200 Zie paragraaf 3.4.

201 Brief minister van CRM aan minister van Sociale Zaken, 23 november 1973. NA IND 817.

202 Nota hoofd HVG aan staatssecretaris, 6 december 1973. NA IND 817.

203 Notitie minister van Sociale Zaken, ter bespreking in ministerraad van vrijdag 1 februari 1974. NA IND 818. 


\section{De Memorie van Antwoord}

De Memorie van Antwoord, waarin deze beleidslijn uiteen werd gezet, werd nog datzelfde jaar aan de Tweede Kamer aangeboden. Al snel bleek dat zelfs de door het kabinet Den Uyl zo afgezwakte voorstellen voor een strenger arbeidsmigratiesysteem op zeer fel en zeer breed gedeeld verzet stuitten. De Raad voor de Arbeidsmarkt liet de regering weten, bezwaar te hebben tegen het voorstel van een terugkeerpremie, omdat deze zowel de maatschappelijke integratie van arbeidsmigranten als hun carrière-kansen belemmerde. De vakbondsleden in de Raad vonden het zelfs 'verwerpelijk' om met een terugkeerpremie een 'niet gerechtvaardigde aandrang' op arbeidsmigranten uit te oefenen om Nederland te verlaten. ${ }^{204}$ In het parlement werd het voorstel om een terugkeerpremie in te voeren over de volle breedte van het politieke spectrum verworpen. Het parlementair vertoog was in dit opzicht ambigu: enerzijds werd de stelling van de regering dat Nederland geen immigratieland was volmondig onderschreven. Het werd uitgesproken wenselijk gevonden dat zo veel mogelijk arbeidsmigranten naar hun herkomstlanden zouden terugkeren. Terugkeer stimuleren door middel van een financiële bonus werd echter onaanvaardbaar geacht. Opvallend hierbij is dat zowel de KVP als de PvdA als voornaamste bezwaar te kennen gaven, dat een terugkeerpremie een mentale barrière voor gezinshereniging zou opwerpen en zo zou kunnen resulteren in een nòg langduriger gezinsscheiding. ${ }^{205}$ Geconfronteerd met een zo brede en felle oppositie, zag de regering zich gedwongen haar voorstel voor een vertrekbonus - die in de media al snel 'oprot-premie' werd genoemd - in te trekken.

Van een rotatiesysteem zou dus geen sprake zijn. Van een aanscherping van het gezinsherenigingsbeleid evenmin: Justitie had geen voorstellen in die richting gedaan. Het onderdeel van de Memorie van Antwoord dat betrekking had op gezinshereniging was door Justitie geschreven. ${ }^{206}$ Hierin werd duidelijk gesteld dat aan gezinshereniging ernstige bezwaren kleefden: de Memorie spreekt van een risico op 'ghettovorming', 'ontworteling',

204 Brief Coördinatiecommissie Raad voor de Arbeidsmarkt aan minister van Sociale Zaken, 15 oktober 1974. NA IND 2222. In dit stuk worden de meest kritische opmerkingen over de terugkeerpremie toegeschreven aan 'een aantal leden van de Raad'. Dat het hier gaat om de mening van de vakbondsvertegenwoordigers, blijkt uit het verslag van de vergadering van de CABA, 11 oktober 1974, in dezelfde dossiermap.

205 TK 1974-1975 Handelingen 16 oktober 1974: 535-582.

206 Brief staatssecretaris van Justitie aan minister van Sociale Zaken, 7 november 1973. NA IND 817. 
'fricties' en 'isolement'. Hieruit werd echter niet de conclusie getrokken dat het gezinsherenigingsbeleid moest worden verstrakt:

Vanuit het gezichtpunt van de buitenlandse werknemer zelf en van de cultuur waaruit hij stamt bezien is het daarentegen niet redelijk om gezins- en familieleden te weren wier overkomst hij vraagt omdat hij zich nauw met hen verbonden en verantwoordelijk voor hen voelt. (...) De Regering acht het - mede ook vanuit moreel oogpunt - niet gerechtvaardigd om een restrictief beleid te voeren ten aanzien van de toelating van gezins- en familieleden van buitenlandse werknemers, die zelf immers in het Nederlands belang herwaarts gekomen zijn. Veeleer dient - mede in het licht van recente ervaringen op het gebied van gezins- en familiehereniging - het toekomstig beleid gericht te zijn op beperking van het aantal buitenlandse werknemers. ${ }^{207}$

In het sterk ethisch geladen politieke klimaat dat sinds het aantreden van het kabinet Den Uyl niet alleen het parlementair discours maar ook de regering domineerde, was verdere inperking van de mogelijkheden tot gezinshereniging niet bespreekbaar. De verklaring van het katholieke Kamerlid Hermsen in de plenaire behandeling van de Memorie van Antwoord is in dit opzicht typerend. Hermsen pleitte voor sterke 'mentale beïnvloeding, voorlichting en vorming' om terugkeer te bevorderen. Daarbij mocht aan de keuzevrijheid van de arbeidsmigrant echter niets worden afgedaan. Wanneer een migrant ervoor koos zijn gezin over te laten komen, moest Nederland dit accepteren 'als de consequentie van onze verantwoordelijkheid voor hun welzijn' ${ }^{208}$

Het staat buiten kijf dat juist de instroom van gezinnen van arbeidsmigranten ambtelijk Justitie zorgen baarde. Aangezien voorstellen om gezinshereniging te beperken echter al vijftien jaar op onoverkomelijk verzet stuitten en vanuit de veronderstelling dat aan de behoefte aan arbeidsmigranten op de Nederlandse arbeidsmarkt voorlopig geen einde zou komen, zette Justitie in op een rotatiesysteem, waarbij aan nieuw te werven arbeidsmigranten in ieder geval geen gezinshereniging meer zou worden toegestaan. Ook die poging mislukte.

207 тк 1973-1974 10504 (9): 16.

208 TK1974-1975 10504 Handelingen 16 oktober 1974: 536-537. Overigens ging Hermsen er vanuit dat het verblijf van arbeidsmigranten, ook wanneer zij hun gezinnen lieten overkomen, heel goed tijdelijk kon zijn. 
In 1974 werd de Nederlandse economie ernstig getroffen door de oliecrisis, en daalde de werkgelegenheid zo sterk dat de behoefte aan buitenlandse werknemers bijna geheel verdween. Dit keer werden namelijk juist de sectoren en beroepsgroepen waar arbeidsmigranten werkten zwaar getroffen. De regering nam maatregelen om toelating verder te beperken en zo kwam de instroom van arbeidsmigranten al snel vrijwel tot stilstand. Daarmee waren de afgelopen vijf jaar van discussie over de invoering van een rotatiesysteem ineens irrelevant. De omvang van de gezinshereniging zou in de loop van de jaren zeventig echter gestaag toenemen.

\subsection{Macht en onmacht in een beleidsdebat}

De machtsstrijd over het arbeidsmigratiebeleid die twintig jaar lang woedde tussen Sociale Zaken en Justitie en waarin de toelating van gezinnen van arbeidsmigranten een centraal twistpunt vormde, werd 'gewonnen' door Sociale Zaken. ${ }^{209}$ Justitie wist wel een rem op de overkomst van gezinnen te bedingen in de vorm van de wachttijd en het huisvestingsvereiste. In die zin weerspiegelt de beleidsontwikkeling tussen 1955 en 1975 de compromissen die tussen de betrokken overheidsgeledingen werden gesloten. Justitie had gezinshereniging echter liefst in het geheel niet toegestaan maar zag zich steeds opnieuw gedwongen significante concessies te doen. Dit roept de vraag op, waarom de argumenten van Justitie niet meer gewicht in de schaal legden.

\section{Justitie's twijfel aan tijdelijkheid}

Het verzet van Justitie tegen gezinshereniging kwam voort uit de overtuiging dat daarmee de tijdelijke aard van het verblijf van arbeidsmigranten te niet werd gedaan. Al in 1947 weigerde minister Van Maarseveen (KVP) van Justitie ontheemde gezinnen uit Duitse kampen in Nederland toe te laten omdat 'we ermee blijven zitten, als de conjunctuur omslaat' ${ }^{210}$ Exact hetzelfde argument werd in 1960 door minister Beerman van Justitie ingebracht tegen de werving van gehuwde Italiaanse arbeidsmigranten. ${ }^{211}$

209 Vgl. De Lange 2007: 82, 168.

210 Aantekening minister op rapport Interdepartementale commissie tewerkstelling verplaatste personen in Nederland, 13 mei 1947. NA IND 5.023.5026 174.

211 Notulen ministerraad, 7 oktober 1960. NA IND 551. 
Waarom Justitie gezinsmigratie als vestigingsmigratie beschouwde, werd slechts zelden expliciet gemaakt. Eén enkele keer, in een ministerraadvergadering in 1962, verklaarde minister Beerman dat uitzetting van gezinnen onmogelijk was, 'omdat sociale verdragen, vestigingsverdragen etc. zich daartegen verzetten'. ${ }^{212}$ Deze opmerking dient echter als strategische retoriek van de minister te worden beschouwd. ${ }^{213}$ Beerman maakte niet duidelijk om welke internationale verdragen het precies zou gaan. ${ }^{214}$ In interne discussies over gezinsmigratie tussen ambtenaren van Justitie speelden internationale verdragsverplichtingen, met uitzondering van het Europees Gemeenschapsrecht, geen enkele rol. Internationale verdragen zouden pas invloed gaan uitoefenen op het Nederlands vreemdelingenbeleid vanaf het moment dat er door Kamerleden, belangenorganisaties en vooral juristen een beroep op werd gedaan. ${ }^{215}$ In de jaren vijftig en zestig gebeurde dat nog niet. Het appèl van de minister op internationaalrechtelijke beperkingen maakte dan ook weinig indruk in de ministerraad.

Overigens bleek de uitzetting van vrouwen en kinderen inderdaad problematisch, maar niet vanwege juridische obstakels. Steeds wanneer publieke ruchtbaarheid werd gegeven aan het voornemen van Justitie om gezinsleden van arbeidsmigranten die hier onrechtmatig verbleven de grens over te zetten, brak er zo'n storm van protest uit, niet alleen in de pers maar ook in het parlement, dat Justitie van zijn voornemen af moest zien. De politieke en publieke steun voor het strenge gezinsherenigingsbeleid was zeer zwak. Vanuit het gewicht dat aan het gezin werd toegekend, als hoeksteen van de samenleving en 'normative core of the nation'216, werd aan vrouwen en kinderen een moreel recht toegekend om bij hun man of vader te zijn. ${ }^{217}$ Waarschijnlijk droegen deze ervaringen ertoe bij dat Justitie veronderstelde dat de tijdelijkheid van het verblijf van gezinnen niet zou kunnen worden afgedwongen.

212 Nota minister van Justitie, mede namens ministers van Volkshuisvesting en Bouwnijverheid, Maatschappelijk Werk en Sociale Zaken en Volksgezondheid, aan ministerraad, 17 oktober 1962. NA IND 1.

213 De Lange (2007: 84) wijst erop dat bewindslieden vaker 'hun beleid, waarvoor zij om andere redenen gekozen hadden, legitimeerden als verplichtingen volgens (...) internationale afspraken'. 214 Artikel 8 van het Europees Verdrag voor de Rechten van de Mens, dat dateert uit 1950, garandeert weliswaar het recht op gezinsleven van ieder mens, dus ook van arbeidsmigranten, maar het Hof van Straatsburg zou dit artikel pas in 1985 van toepassing verklaren op het nationaal gezinsmigratiebeleid. Zie paragraaf 3.3 en 4.2 .

215 De Lange 2007: 403-404.

216 Van Walsum 2008: 133-135.

217 Wellicht kwam daar nog bij, dat het oppakken en uitzetten van kinderen, zo kort na de Tweede Wereldoorlog, bijzonder gevoelig lag. In mediaberichten over de uitzetting van Italiaanse vrouwen en kinderen in 1965 werd verwezen naar deportaties tijdens de oorlog. Schrover 2008: 15. 
Minstens zo belangrijk echter in de standpuntbepaling van Justitie was de veronderstelling, dat met gezinshereniging de wens van de arbeidsmigrant om naar zijn land van herkomst terug te keren verloren ging. Het uitgangspunt was 'dat gehuwde buitenlanders, voor zover hun gezin zich ook in Nederland bevindt, zekere attaches hebben op grond waarvan het aannemelijk is dat zij niet zo spoedig terugkeren naar het land van herkomst'. ${ }^{218}$ Zeker wanneer kinderen in Nederland opgroeiden, vrienden maakten, naar school gingen, werd terugkeer steeds minder waarschijnlijk. Dit was cruciaal, omdat de veronderstelling van tijdelijk verblijf geheel rustte op de intenties van de arbeidsmigranten zelf. In wet of regelgeving was niets vastgelegd dat hen verplichtte na een zeker aantal jaren Nederland te verlaten. Sterker nog, omdat het hoge verloop onder arbeidsmigranten veel kosten met zich mee bracht voor het bedrijfsleven, werd verlenging van verblijf en arbeidscontract verwelkomd. Sociale Zaken en het bedrijfsleven benadrukten steeds opnieuw dat het overgrote deel van de migranten volstrekt niet van plan was om zich definitief in Nederland te vestigen en dat het dus in orde was om toelating en verblijfsduur te laten afhangen van de vraag op de arbeidsmarkt. Justitie was er echter van overtuigd dat gezinshereniging een dynamiek in gang bracht die leidde tot permanente vestiging.

Die redenering lijkt zo zinnig, dat de vraag rijst waarom Justitie haar niet met meer kracht heeft ingebracht in de beleidsdebatten. Iedereen was het er immers over eens dat Nederland geen immigratieland was of kon worden: waarom heeft Justitie zijn tegenspelers er niet van weten te overtuigen dat dit fundamentele axioma werd ondermijnd door gezinshereniging?

\section{De overtuigingskracht van argumenten}

In interdepartementale debatten tot het midden van de jaren zestig gaf Justitie nog geregeld uiting aan de angst dat gezinshereniging zou leiden tot langdurig verblijf. Daarna legde het dit argument steeds minder vaak op tafel. Een argument dat Justitie wel twintig jaar lang nadrukkelijk voorop stelde, wanneer het zijn afwijzende standpunt inzake gezinsmigratie moest verdedigen tegenover publiek, parlement of andere ministeries, was de woningnood. Gezien de ernst van het huisvestingstekort - 'volksvijand nr. 1'219 - zou het onverantwoord zijn, zo betoogde Justitie, om de druk op de woningmarkt nog verder te vergroten door vreemde gezinnen toe te laten. Er was met

218 Nota HVG, 7 mei 1968. NA IND 1162.

219 Nota HVG aan SG, 8 oktober 1962. NA IND 1. Zie ook Jansen 2006: 48. 
het argument van de woningnood echter iets vreemds aan de hand. Het is niemand minder dan de secretaris-generaal van het ministerie van Justitie, die ons hierop al in 1962 wijst:

Het merkwaardige van de betrokken constellatie is, dat het beleid van Justitie tot handhaving van de bestaande regelingen inzake de overkomst van gezinnen van Spaanse en andere contractarbeiders als uitgangspunt heeft de krappe woningmarkt in ons land. Dit is echter een onderwerp, dat speciaal behoort tot het ressort van de Ministers van Volkshuisvesting en Bouwnijverheid en van Maatschappelijk Werk, die echter niet aan de bel trekken. Een gevolg is, dat de Minister van Justitie wederom in deze zaak tegenover de Kamer en de publieke opinie (...) moet opdraaien. ${ }^{220}$

De secretaris-generaal heeft gelijk, dit is inderdaad merkwaardig. Justitie was veruit het felst en het meest actief in het verzet tegen een soepel gezinsherenigingsbeleid. Dankzij het huisvestingsargument vond het hierbij steun van Maatschappelijk Werk en Volkshuisvesting. In wezen was de woningnood echter niet het belangrijkste bezwaar van Justitie tegen de overkomst van gezinnen. De HVG en haar bewindslieden verwachtten dat gezinshereniging ertoe zou leiden dat vreemdelingen zich massaal en blijvend in Nederland vestigden en vreesden dat de maatschappelijke samenhang daardoor zou worden aangetast. Waarom hebben zij dat niet gezegd, in plaats van twintig jaar lang te hameren op de woningnood?

Macht uitoefenen in een besluitvormingsproces betekent niet in de laatste plaats bepalen vanuit welk perspectief een beleidsvraagstuk dient te worden bezien. ${ }^{221}$ Juist in dat opzicht had Sociale Zaken de overhand op Justitie. In een tijd dat economische groei een 'allesoverheersende waarde'222 was, was er weinig ruimte om vraagtekens te plaatsen bij de tewerkstelling van arbeidsmigranten in Nederland, die door het bedrijfsleven als 'van levensbelang voor zeer vele van onze ondernemingen' werd omschreven. ${ }^{223}$ Het economisch perspectief domineerde de interdepartementale besluitvorming volledig. De veronderstelling van tijdelijk verblijf was het sleutelelement in de rechtvaardiging van de keuze voor arbeidsmigratie als

220 Notitie SG aan minister, 11 oktober 1962, op nota HVG aan SG, 8 oktober 1962. NA IND 1.

221 Hajer 1989: 244; Fischer 2003: 55-58.

222 De Rooy 2005: 216.

223 Brief van Raad van Nederlandse werkgeversverbonden aan minister-president, 3 december 1965. Annex in Wentholt (Red.) (1967): 225. 
economisch beleidsinstrument. Arbeidsmigranten waren hier in zoverre en voor zolang als er op de arbeidsmarkt vraag naar hen was. Zij koesterden zelf niet de wens om in Nederland iets anders te doen dan werken, dus mocht men er op vertrouwen dat zij zouden vertrekken als er geen werk meer was. Vanuit diezelfde perceptie van de belangen en wensen van de arbeidsmigranten zelf was Sociale Zaken ervan overtuigd dat slechts weinigen onder hen van de mogelijkheid tot gezinshereniging gebruik zou maken. Zelfs wanneer het gezin naar Nederland was overgekomen, bleef de veronderstelling van tijdelijk verblijf in stand. Dit gold niet alleen voor de ministeries van Sociale Zaken en Economische Zaken, maar ook voor het parlement en, belangrijker nog, voor de arbeidsmigranten zelf. Uit onderzoek onder Zuid-Europese, Turkse en Marokkaanse migranten is gebleken dat het besluit om het gezin te laten overkomen slechts zelden betekende dat weloverwogen voor een toekomst in Nederland gekozen was. Veruit de meesten van hen waren oorspronkelijk van plan om met hun gezin terug te keren naar hun herkomstland en bleven nog jaren aan dat plan vasthouden. ${ }^{224}$

Het perspectief dat op een zeker moment dominant is bepaalt ook welke argumenten als relevant, valide en overtuigend worden beschouwd. Fischer stelt: to be understood and considered relevant, a speaker has to situate his remarks in - or relate them to - the recognised discourses at the time'.225 In de jaren vijftig en zestig werd het beleidsdebat zozeer beheerst door het economisch perspectief, dat de bezwaren van Justitie als niet ter zake doende en zelfs als irritant terzijde geschoven. Dat arbeidsmigranten ervoor zouden kunnen kiezen om niet terug te keren naar hun herkomstland, werd eenvoudigweg niet aannemelijk gevonden. Het was daarom veel strategischer om naar de woningnood te verwijzen, die immers alom als een ernstig probleem werd beschouwd. Met behulp van het woningnood-argument wist Justitie de versoepeling van het gezinshereningsbeleid weliswaar niet terug te draaien of te stoppen, maar toch in ieder geval te remmen.

In het boek waarin hij met zijn theorie van het 'internationaal forensisme' de wetenschappelijke onderbouwing leverde voor het arbeidsmigratiebeleid van Sociale Zaken, geeft Wentholt ook een indruk van de manier waarop de bezwaren van Justitie werden ontvangen. De arbeidsmigratie van het Middellandse Zeegebied naar West-Europa was voor

224 Lindo 1994: 125; Van den Berg-Eldering 1978: 243; Van Amersfoort \& Van der Wüsten 1978: 40; Böcker 1994: 149-150.

225 Fischer 2003: 83. 
Wentholt een modern fenomeen, resultaat van een tijd waarin afstanden en landsgrenzen werknemers er niet langer van weerhielden om daar te gaan werken waar het loon het hoogst was. 'In sommige beleidskringen' - en daarmee bedoelde Wentholt Justitie - had men moeite met die moderne ontwikkelingen. Wentholt observeert

een vrij grote mate van onzekerheid als gevolg van de snelle maatschappelijke veranderingen waardoor ons tijdperk wordt gekenmerkt. Deze onzekerheid leidt bij sommigen tot hardnekkige pogingen om de maatschappelijke status quo zonder meer te handhaven op al die fronten die men denkt nog in de hand te kunnen houden. Hieruit kan een versterkte vrees ontstaan voor vreemde en daarmee mogelijkerwijze (...) evenwichtsverstorende elementen in onze samenleving. ${ }^{226}$

De kritische houding van Justitie werd dus geïnterpreteerd als een angstige en behoudende reactie op een snel veranderende wereld.

Vanaf 1970 begon de dominantie van het economisch perspectief te wankelen, en daarmee kwam er meer ruimte voor Justitie om de bredere maatschappelijke gevolgen van arbeids- en gezinsmigratie aan de orde te stellen. Voor het eerst vond het pleidooi van Justitie voor een verplichte beperking van de verblijfstermijn van arbeidsmigranten weerklank bij andere ministeries. Op hetzelfde moment deed de invloed van de 'culturele revolutie' van de jaren zestig, met haar nadruk op vrijheid en gelijkheid, zich echter gelden in de Nederlandse politiek. Dit ethisch perspectief versterkte het moreel gewicht van het gezinsleven dat in het parlement toch al sterk leefde, en maakte iedere vorm van dwang of druk tot terugkeer onhaalbaar.

Freeman heeft betoogd, dat het migratiebeleid van westerse staten begrepen moet worden als 'client politics'. Georganiseerde actoren met een 'geconcentreerd' belang bij een soepel toelatingsbeleid slagen er, dankzij nauwe banden met beleidsmakers, beter in om de besluitvorming te beïnvloeden dan de publieke opinie, die weliswaar vrijwel steeds tegen immigratie gekant is maar waarvan de belangen diffuus en slecht gearticuleerd zijn. ${ }^{227}$ Het onderscheid dat hij maakt tussen 'geconcentreerde' en 'diffuse' belangen biedt inzicht in de dynamiek van de Nederlandse beleidsdebatten over gezinsmigratie in de jaren zestig. Sociale Zaken behartigde het belang 
van het bedrijfsleven en daarmee van de welvaart en werkgelegenheid in Nederland: de positieve consequenties van arbeidsmigratie waren helder gedefinieerd en op korte termijn duidelijk zichtbaar. De negatieve gevolgen voor de Nederlandse maatschappij waar Justitie voor vreesde speelden op de lange termijn en waren inderdaad 'diffuus': moeilijk te concretiseren en niet te verbinden aan één specifieke belangengroep. Ook daardoor stond Sociale Zaken in beleidsdebatten sterker dan Justitie. Dit verklaart eveneens waarom Justitie zich zo vaak op het argument van woningnood beriep: het belang van de Nederlandse bevolking bij een toereikend huisvestingsaanbod was veel minder 'diffuus' dan de vrees voor ontwrichting van de Nederlandse maatschappij.

Of de publieke opinie in Nederland tegen gezinsmigratie gekant was, zoals Freeman veronderstelt, is echter de vraag. Voor het parlement en de media gold dat niet. Zolang het gezinsmigratievraagstuk niet gepolitiseerd werd en de besluitvorming zich in besloten regeringskringen afspeelde, was er inderdaad sprake van client politics, in die zin dat de het bedrijfsleven een enorme invloed uitoefende op het beleidsproces. Zodra de kring van beleidsvormers verbreed werd ging een andere factor een rol spelen, die Freeman niet meeneemt in zijn analyse. Parlement en pers brachten een moreel perspectief in, op grond waarvan zij de scheiding van arbeidsmigranten van hun gezinnen verwerpelijk achtten. Voor de invloed van dergelijke ethische overwegingen, naast materiële belangen, heeft Freeman weinig oog. ${ }^{228}$

Het verzet van Justitie tegen gezinshereniging kwam dus voort uit diffuse, moeilijk te concretiseren bezwaren, die geen enkele weerklank vonden binnen het dominant economisch perspectief. In interne stukken gaven ambtenaren van HVG dan ook geregeld te kennen dat ze zich eenzame roepers in de woestijn voelden. Zo verzuchtte een ambtenaar in 1963: 'Thans gaat Sociale Zaken (...) voort op de weg naar zo volledig mogelijke vrijheid. Slechts Justitie steekt een spaak in dit lustig draaiende wiel'. ${ }^{229}$ Justitie had de indruk 'geïsoleerd' te raken, tegenover een 'gesloten front' te

228 Freeman (1995: 883-884) wijst wel op de smalle 'boundaries of legitimate discussion of immigration policy', waarmee hij bedoelt dat de vraag om restrictief of (etnisch) selectief beleid nogal eens tot beschuldigingen van racisme leidt. Met deze erkenning van de beperking tot 'politiek correcte' discoursen geeft hij zich echter nog geen rekenschap van de zelfstandige rol die ethische normen kunnen spelen in het besluitvormingsproces.

229 Nota aan hoofd HVG, 26 juli 1963. NA IND 203. 
staan en 'steeds gedwarsboomd' te worden. ${ }^{230}$ Tegenover het gewicht van de economische en morele perspectieven op gezinsmigratie stond Justitie inderdaad vrijwel machteloos.

\subsection{Besluit}

Het Nederlandse beleid inzake gezinshereniging voor gastarbeiders is ondanks verzet van het ministerie van Justitie tot stand gekomen. In 1955 werd besloten om overkomst van gezinnen van mannelijke arbeidsmigranten te verbieden. Vanaf 1960 was gezinshereniging toegestaan, onder voorwaarde dat de arbeidsmigrant over passende huisvesting en over een arbeidscontract voor nog tenminste een jaar beschikte. Bovendien werd een wachttijd ingevoerd. Gemeenschapsonderdanen moesten tenminste één jaar in Nederland hebben gewoond voordat hun gezin mocht overkomen; voor andere arbeidsmigranten was de wachttijd twee jaar. In de eerste helft van de jaren zestig werd bepaald, dat echtgenotes die kinderloos waren en werk vonden, al vóór het verstrijken van de wachttijd naar Nederland mochten komen. In de loop van de jaren zestig werd de wachttijd geleidelijk verlaagd: in 1970 was deze voor alle wervingslanden één jaar en gold voor Gemeenschapsonderdanen geen wachttijd meer. Iedere versoepeling van de voorwaarden vond plaats op voorstel van Sociale Zaken en onder protest van Justitie.

De weerstand van Justitie kwam voort uit de invulling die de ambtenaren van Vreemdelingenzaken gaven aan hun verantwoordelijkheid voor het beschermen van de openbare orde in Nederland. Vanaf het begin van de werving ging Justitie er vanuit, dat gezinsmigratie als vestigingsmigratie moest worden beschouwd. Het veronderstelde bovendien dat de grootschalige vestiging van vreemdelingen, vooral als zij een 'afwijkende' culturele achtergrond hadden, de maatschappelijke verhoudingen zou kunnen verstoren. Justitie beschouwde gezinshereniging als een bedreiging voor de orde en samenhang van de Nederlandse samenleving en dus als ongewenst.

Justitie verloor echter het pleit van Sociale Zaken, dat vanuit een instrumenteel-economisch perspectief naar een zo vrij mogelijk gezinsherenigingsbeleid streefde omdat dat de tewerkstelling van arbeidsmigranten die het Nederlands bedrijfsleven zo nodig had vergemakkelijkte. De cruciale

230 Respectievelijk: Nota HVG aan SG, 22 juni 1970. NA IND 612; Nota HVG aan SG, 14 januari 1964. NA IND 952; Notitie SG aan minister, 14 maart 1963. NA IND 844. 
plaats die in deze jaren aan het waarborgen van economische groei werd toegekend, gaf aan dat argument een bijzonder gewicht. De onderhandelingen over het vrij verkeer van werknemers binnen de Europese Gemeenschap hebben de positie van het ministerie van Justitie ten opzichte van Sociale Zaken verder verzwakt. Ook de inbreng van het parlement, dat zich vanuit een moreel perspectief tegen de 'gedwongen gezinsscheiding' van arbeidsmigranten verzette, werkte in het nadeel van Justitie.

Wie 'de overheid' als één en ondeelbaar beschouwt, verliest het zicht op een wezenlijk deel van beleidsvormingsprocessen: de cruciale rol die de conflicten tussen de ambtenaren van Justitie en Sociale Zaken in de besluitvorming speelden laat dat duidelijk zien. Pluraliteit is een wezenlijk kenmerk van het openbaar bestuur in Nederland. ${ }^{231}$ Bovendien blijkt de manier waarop deze ambtenaren de maatschappelijke taak van hun ministerie opvatten - hun institutionele 'bril' - niet alleen bepalend voor hun beleidsvoorkeuren maar ook, op een fundamenteler niveau, voor hun perceptie van het vraagstuk waarvoor zij zich gesteld zagen. ${ }^{232}$ Ambtenaren van Justitie en Sociale Zaken hadden zeer verschillende verwachtingen over het verloop van migratiestromen en over de gevolgen daarvan voor de Nederlandse samenleving.

De parlementaire invloed op de beleidsontwikkeling was beperkt en indirect. De inbreng van Kamerleden richtte zich op de principes die aan het beleid ten grondslag dienden te liggen: over de precieze formulering van de regelgeving voor gezinshereniging lieten zij zich niet uit. Dit past in het beeld van de verhoudingen tussen kabinet en parlement tot de late jaren zestig, dat Lijphart bondig heeft samengevat als: 'de regering regeert'. De verantwoordelijkheid voor het bestuur lag bij het kabinet, dat van het parlement de ruimte diende te krijgen om die taak te vervullen. ${ }^{233}$ De bescheiden bemoeienis van het parlement met het gezinshereniginsbeleid weerspiegelt echter evenzeer het geringe politieke gewicht van dit vraagstuk in de jaren zestig. Pas vanaf de jaren zeventig zou de Tweede Kamer een actievere rol gaan spelen. Desalniettemin heeft het pleidooi van Kamerleden voor een soepeler gezinsherenigingsbeleid zijn weerslag gehad op de interdepartementale verhoudingen en daarmee uiteindelijk ook op de beleidsontwikkeling.

231 Vgl. Koppenjan e.a. 1987; Glasbergen 1984: 91; Van Putten 1980: 250; Veenswijk 1996: 252-253.

232 Vgl. Ringeling 1993: 161-162; Veenswijk 1996: 58; Glasbergen 1984: 89-92.

233 Lijphart 1979: 127. 
Ook de ruimte die bewindspersonen aan hun ambtenaren lieten om de voorwaarden voor gezinshereniging vast te stellen duidt erop dat dit beleidsveld tot de jaren zeventig politiek geen hoge prioriteit genoot. De ambtenaren van Justitie vochten hun conflicten met Sociale Zaken goeddeels op eigen houtje en naar eigen goeddunken uit: hun minister - later staatssecretaris - was daar nauwelijks bij betrokken. Zelfs de ministerraad kwam er weinig aan te pas. Als voorstellen voor beleidswijzigingen al aan de raad werden voorgelegd, dan ging het vaak om een compromis waarover op ambtelijk niveau al uitgebreid was onderhandeld en waaraan het kabinet slechts nog zijn goedkeuring hoefde te hechten. Slechts bij uitzondering werden in de ministerraad inhoudelijke keuzes gemaakt. Wanneer zich meningsverschillen voordeden in het kabinet, waren die niet zozeer politiek als institutioneel van aard: de standpunten van de bewindslieden kwamen naadloos overeen met die van hun ambtenaren. Partijpolitiek speelde in de besluitvorming binnen het kabinet tot de jaren zeventig geen rol. Wellicht wordt hier, naast de bescheiden belangstelling van de politiek voor het gezinsmigratievraagstuk, ook een attitude zichtbaar die Daalder in 1964 beschreef als kenmerkend voor de Nederlandse politieke cultuur: ministers behielden in de regel 'een bewuste afstand tot het parlement en de fracties'. ${ }^{234}$ De politieke kleur van het kabinet had dan ook geen invloed op de beleidsontwikkeling.

Het waren dus vooral ambtenaren die bepaalden welke voorwaarden aan de overkomst van gezinsleden van arbeidsmigranten werden gesteld. Deze constatering weerspreekt de stelling van onderzoekers als Bekke, Hoppe en Bovens dat het Nederlands ambtenarenapparaat tot de jaren zeventig 'klassiek weberiaans' functioneerde en dat ambtenaren pas later een autonome rol zijn gaan spelen in het beleidsproces. ${ }^{235}$ Verder empirisch onderzoek naar de praktijk van beleidsvorming in Nederland vóór de jaren zeventig is wenselijk om vast te stellen of de casus van het gezinsmigratiebeleid in deze een uitzondering vormt, of dat ons beeld van de historische rol van ambtenaren fundamenteel moet worden gewijzigd.

De ontwikkeling van het Nederlands gezinsmigratiebeleid tussen 1955 en 1975 werpt een interessant licht op de vraag die West-Europese en Amerikaanse onderzoekers al vijftien jaar bezig houdt: waarom hebben landen die geen migratieland wilden zijn, toch grootschalige vestigingsmigratie toegestaan? Vrijwel algemeen wordt een doorslaggevend belang toegekend 
aan de rechtbanken, die op grond van nationaal of internationaal recht de ruimte hebben ingeperkt waarover democratische rechtstaten beschikken om het verblijf van migranten te beëindigen of te voorkomen. ${ }^{236}$ Deze hypothese komt echter voort uit onderzoek waarin de periode vóór 1975 buiten beschouwing blijft. In dit hoofdstuk is gebleken, dat de strijd om de toelating van gezinnen van arbeidsmigranten - en in nauwe samenhang daarmee om hun blijvende vestiging - in Nederland al grotendeels in de jaren zestig is gestreden. De rechtbanken hebben daarin geen enkele rol gespeeld. Ambtenaren en politici beschikten over schier onbeperkte beleidsruimte en hebben er dus uit eigen beweging voor gekozen om gezinshereniging toe te staan.

De enige auteur die handvaten biedt om die keuze te verklaren is Freeman. Zijn stelling dat migratiebeleid als client politics moet worden beschouwd is inderdaad van toepassing op de hier besproken casus, in zoverre dat het bedrijfsleven uitzonderlijke invloed heeft uitgeoefend op de beleidsvorming. Bovendien voorspelt hij terecht dat het 'geconcentreerde' profijt van migratie op de korte termijn meer gewicht in de schaal legt dan de 'diffuse' maatschappelijke kosten op de lange termijn. ${ }^{237}$ Freemans analyse is echter geheel geënt op materiële belangen, waardoor de invloed van morele overwegingen zoals die door het parlement met zoveel nadruk werden ingebracht buiten beschouwing blijft. Vanaf de jaren zeventig, wanneer het migratievraagstuk gepolitiseerd raakt, doet die blinde vlek van Freeman zich steeds sterker gelden. Het falen van de voorstellen voor een rotatiesysteem en een terugkeerbonus kan niet worden verklaard vanuit materiële economische belangen: deze voorstellen ketsten af op ethische overwegingen. Joppke schreef in 1998 al, dat - in ieder geval in Europa - Freeman's model moet worden aangepast om ruimte te creëren voor de invloed van 'morele verplichtingen' op keuzes in migratiebeleid. ${ }^{238}$

Een vergelijkbare kritische kanttekening kan worden geplaatst bij de analyse van Guiraudon. Zij concludeert op basis van onderzoek naar de ontwikkeling van de rechtpositie van migranten in Nederland, Duitsland en Frankrijk sinds de jaren zeventig, dat aan migranten rechten worden

236 Cornelius e.a. 1994: 9; Joppke 1998: 271; Soysal 1994: 149-152; Sassen 1996: 11-13; 1999: 181, 184-185; Guiraudon 2000: 224-225.

237 Freeman 1995: 881-887; 2002: 77-82. Cornelius en Tsuda (2004: 12) veronderstellen dat ambtenaren veel minder gevoelig zijn voor de pressie van belangengroepen dan gekozen vertegenwoordigers. De manier waarop de ambtenaren van Sociale Zaken tussen 1955 en 1974 de belangen van het bedrijfsleven behartigden weerspreekt die these.

238 Joppke 1998: 271, 287, 292. 
toegekend wanneer hervormingen in besloten fora tot stand komen. Hoe opener het beleidsdebat, hoe groter de kans op restrictie. ${ }^{239}$ De dynamiek van de Nederlandse beleidsvorming inzake gezinshereniging vóór 1975 was echter andersom. Het openbreken van het beleidsdebat, zodat parlement en pers meespraken, versterkte toen de positie van degenen die voor soepeler voorwaarden pleitten. In publieke discussies werd aan het welzijn van arbeidsmigranten veel meer aandacht besteed dan in besloten beleidskringen. In die discussies woog het moreel belang van gezinseenheid zeer zwaar. De stelling van Guiraudon, dat debatten die zich in het blikveld van het brede publiek afspelen steeds resulteren in restrictieve beleidskeuzes, ging in het Nederland van vóór 1975 dus niet op.

Migratiewetenschappers die de paradoxen van het naoorlogs migratiebeleid van liberale rechtstaten willen verklaren, dienen zich meer dan tot nu toe is gebeurd te buigen over de keuzes die beleidsmakers onafhankelijk van externe pressie of beperkingen hebben gemaakt. Die keuzes kunnen wij alleen verklaren wanneer we ons niet alleen rekenschap geven van de materiële belangen die op het spel stonden, maar ook van de ethische overwegingen die - zonder dat juridische verplichtingen daartoe noopten - in de besluitvorming een rol hebben gespeeld. 



\section{Een open gezinsmigratiebeleid in krappe tijden, 1975-1989}

\subsection{Inleiding}

Het Nederlands gezinsmigratiebeleid is, sinds de Tweede Wereldoorlog tot de dag van vandaag, op geen enkel moment zo genereus geweest als tijdens de jaren tachtig. ${ }^{1}$ In vergelijking met eerdere en latere jaren waren de voorwaarden die aan toelating en verblijf van buitenlandse gezinsleden werden gesteld bijzonder coulant.

Dat juist in deze periode zo'n soepel beleid werd gevoerd ligt bepaald niet voor de hand. Na de oliecrisis van 1973 raakte de Nederlandse economie ernstig in het slop. De economische groei, die zo lang vanzelfsprekend leek, nam drastisch af. De zwaarste klappen vielen in de industrie, vooral in arbeidsintensieve sectoren zoals textiel, scheepsbouw en mijnbouw. In de jaren zeventig hielden zij het hoofd nog boven water dankzij overheidssubsidies, maar begin jaren tachtig gingen naar schatting 27 duizend bedrijven failliet, ten koste van zo'n 150 duizend arbeidsplaatsen. ${ }^{2}$ De werkloosheid steeg na de eerste oliecrisis tot 5 procent van de beroepsbevolking en nam na 1980 scherp toe, tot bijna 14 procent in 1984 . Wie werkloos werd, bleef dat gemiddeld veel langer dan voorheen: in 1988 zat meer dan de helft van de werklozen al ruim een jaar zonder baan. Bovendien lag het aantal mensen dat vervroegd uitgetreden of arbeidsongeschikt was bijna net zo hoog als het aantal werklozen. ${ }^{3}$ In het buitenland gold de Dutch disease als het 'schoolvoorbeeld' van een verzorgingsstaat die aan zijn eigen succes ten onder ging. ${ }^{4}$ Het financieringstekort van de overheid liep op tot 10 procent en vanaf het aantreden van het eerste kabinet Lubbers in 1982 werd er continu gesneden in de overheidsuitgaven. ${ }^{5}$

1 Vgl. Van Walsum 2005: 13.

2 Van Zanden 1998: 162, 171; Blom 1999: 362.

3 Visser \& Hemerijck 1998: 21; Van Zanden 1998: 171.

4 Visser \& Hemerijck 1998: 21.

5 De Rooy 2005: 268; Van Zanden 1998: 171. 
Ook wat het reilen en zeilen van de politiek in de jaren tachtig betreft lag een genereus gezinsmigratiebeleid op het eerste gezicht niet in de lijn der verwachting. Tussen 1973 en 1977 werd Nederland weliswaar geregeerd door het progressieve kabinet Den Uyl, maar in de twaalf jaar die volgden werden de progressieve partijen - op een korte onderbreking van september 1981 tot november 1982 na - naar de oppositiebanken verwezen. Een aanzienlijk deel van de versoepelingen van het gezinsmigratiebeleid is doorgevoerd en geconsolideerd door coalities van $\mathrm{CDA}^{6}$ en VVD, onder de premiers Van Agt (1977-1981) en Lubbers (1982-1989).

Midden jaren zeventig nam het kabinet Den Uyl inderdaad het besluit dat, gegeven de weinig rooskleurige economische omstandigheden, voor de hand lag: voortaan zou de instroom van migranten in Nederland tot een minimum worden beperkt. Desalniettemin versoepelden niet alleen dit kabinet maar ook zijn minder progressieve opvolgers de voorwaarden voor gezinsmigratie aanzienlijk. In de jaren zeventig en tachtig maakten buitenlandse gezinsleden, naast Surinaamse migranten, het leeuwendeel van de immigratiestroom uit.

Migratieonderzoekers debatteren al meer dan tien jaar over de vraag waarom westerse landen die geen immigratielanden wilden zijn, toch grootschalige immigratie hebben toegestaan. Als er één episode is die deze paradox illustreert, dan is dat het gezinsmigratiebeleid dat Nederland tussen 1975 en 1989 voerde. Dit hoofdstuk beoogt inzichtelijk te maken hoe het mogelijk is dat het meest genereuze gezinsmigratiebeleid in Nederland is gevoerd in een tijd van ernstige economische recessie en van langdurige centrum-rechtse dominantie in de politiek, terwijl de noodzaak van een restrictief toelatingsbeleid niet ter discussie stond.

\subsection{Einde van de werving, maar niet van immigratie}

Na jaren van schijnbaar eindeloze economische groei werd Nederland in de jaren zeventig geconfronteerd met ernstige economische tegenslag. Daarmee kwam een einde aan de grootschalige arbeidsmigratie naar Nederland.

6 Het CDA is in 1980 opgericht als fusie van ARP, CHU en KVP. Deze partijen werkten al sinds 1973 samen in federatief verband. 
In 1970 en 1971 werden jaarlijks nog meer dan 16 duizend arbeidsmigranten geworven. In 1974 waren dat er nog maar 5 duizend. ${ }^{7}$ De economische recessie die volgde op de oliecrisis van 1973 vormde een definitief keerpunt. Waar halverwege de jaren zestig werkgevers nog met elkaar vochten om arbeiders, ontstond nu werkloosheid: tussen 1975 en 1980 zocht gemiddeld vijf procent van de beroepsbevolking, ofwel 200 duizend mensen, vergeefs naar werk. ${ }^{8}$ In Duitsland, Frankrijk en België reageerde de regering op de recessie door een algehele wervingsstop af te kondigen. In Nederland gebeurde dat niet. De regering beperkte zich ertoe te verklaren dat het bestaande beheersingsinstrumentarium strenger zou worden toegepast. ${ }^{9}$ Desalniettemin kwam de werving van arbeidsmigranten vrijwel volkomen tot stilstand. Buitenlandse werknemers waren immers voornamelijk tewerkgesteld in de industrie, in arbeidsplaatsen waarvoor zeer weinig opleiding vereist was. Juist daar nam de werkgelegenheid het sterkst af. ${ }^{10}$ In 1975 was het aantal werklozen onder buitenlandse werknemers nog lager dan onder de Nederlandse bevolking. In 1981 was de situatie omgekeerd, met een werkloosheidspercentage van 11,4 onder Turken en Marokkanen, tegen 3,7 voor autochtone Nederlanders. ${ }^{11} \mathrm{Na} 1974$ was er dan ook nauwelijks meer vraag naar nieuwe arbeidsmigranten. Er werd nog wel geworven voor specifieke sectoren zoals de scheepsbouw, maar slechts sporadisch. Vanaf 1976 betrof het minder dan 100 geworven arbeiders per jaar. Tussen 1976 en 1980 werden jaarlijks minder dan 10 duizend nieuwe arbeidsvergunningen verleend: een substantieel deel daarvan was voor vreemdelingen die omwille van gezinshereniging naar Nederland waren gekomen, evenals voor bijzondere categorieën als musici en sporters. Voor zover verder nog vreemdelingen toe werden gelaten met als doel het verrichten van arbeid ging het in toenemende mate om hooggeschoolden uit Amerika en Azië. ${ }^{12}$

Daarmee kwam een einde aan de grootschalige trek van arbeiders uit de landen rond de Middellandse Zee naar Nederland, maar niet aan de immigratie uit deze streken. De overkomst van gezinsleden van arbeidsmigranten ging door en nam zelfs in omvang toe, zodat het aantal vreemdelingen uit wervingslanden gestaag bleef stijgen, van bijna 139,5 duizend in 1974

7 Penninx 1979: 93.

8 De Lange 2007: 175.

9 Tinnemans 1994: 129.

10 Penninx 1988: 78.

11 Penninx 1988: 68, 70.

12 De Lange 2007: 177-180. 
tot ruim 185 duizend in 1977. Die instroom kwam nauwelijks meer uit de landen ten noorden van de Middellandse Zee; het leeuwendeel van de nieuwkomers was afkomstig uit Turkije en Marokko. ${ }^{13}$ De werknemers uit Italië, Spanje, Portugal, Griekenland en Joegoslavië hadden, voor zover zij getrouwd waren en niet terugkeerden naar hun herkomstland, hun gezin merendeels al vóór 1974 naar Nederland laten komen. ${ }^{14}$ De hereniging van Turkse en Marokkaanse gezinnen daarentegen kwam pas halverwege de jaren zeventig echt op gang.

Van 1970 tot 1987 migreerden ieder jaar tussen 45 en 70 duizend mensen die in het buitenland waren geboren naar Nederland, met pieken van 100 duizend in 1975, 80 duizend in 1979 en 90 duizend in 1980. Van 1987 tot 1990 lag deze instroom jaarlijks tussen 70 en 80 duizend. ${ }^{15}$ De toestroom was enerzijds voor een belangrijk deel afkomstig uit Suriname. In 1972 verbleven ruim 50 duizend mensen van Surinaamse herkomst in Nederland; in 1975 was hun aantal al toegenomen tot ruim 85 duizend, om verder te stijgen tot ruim 155 duizend in 1980 en ruim 232 duizend in $1990 .{ }^{16}$ Daarnaast bestond het leeuwendeel van de instroom van migranten uit Marokkanen en Turken. In 1970 bevonden zich ruim 17 duizend mensen met de Marokkaanse en ruim 23,5 duizend mensen met de Turkse nationaliteit in Nederland. In 1980 waren dat er respectievelijk bijna 72 duizend en bijna 120 duizend, in 1990148 duizend en ruim 191 duizend. ${ }^{17}$ Vanaf het midden van de jaren zeventig bestond deze instroom vrijwel geheel uit echtgenoten en kinderen. ${ }^{18}$ En dat alles in een land waarvan de regering met nadruk bleef verklaren dat het geen immigratieland was en geen immigratieland mocht worden. ${ }^{19}$

13 Penninx 1979: 95.

14 Lindo 1994: 221.

15 Website van het CBS, Historie bevolking: immigratie naar geboorteland, statline.cbs.nl. Totale immigratie minus personen die in Nederland geboren zijn. Ik gebruik hier de migratiecijfers naar geboorteland, niet naar nationaliteit, vanwege het belang van de migratie uit Suriname in deze periode: Surinamers hadden tot 1975 de Nederlandse nationaliteit. In 1975 kregen alle Surinamers die in Suriname verbleven de Surinaamse nationaliteit. Zie paragraaf 3.5.

16 Website van het CBS, Allochtonen op 1 januari naar herkomstgroepering, statline.cbs.nl. 17 Website van het CBS, Historie bevolking: bevolking op 1 januari naar nationaliteit, statline.cbs.nl. 18 In 1972 bestond de bevolking van Marokkaanse afkomst in Nederland voor 3,9\% uit vrouwen en 2,9\% uit jongeren tot 21 jaar. Van de Turkse allochtonen was datzelfde jaar 17,2\% vrouw en $9 \%$ minder dan 21 jaar oud. In 1980 maakten vrouwen 35,5\% van de Marokkaanse allochtonen uit, en jongeren tot 21 jaar 23,4\%. Van de Turkse allochtonen was toen $43 \%$ vrouw en $25,7 \%$ minder dan 21 jaar oud. Website van het CBS, Allochtonen op 1 januari; herkomstgroepering, geslacht en leeftijd, statline.cbs.nl.

19 Zie тк 1973-1974 10504 (9): 4; тк 1989-1990 281132 (8H): 42. 


\subsection{Institutionele structuur}

De beleidsvorming op het gebied van gezinsmigratie werd in de loop van de jaren zeventig en tachtig veel complexer dan ze tot dan toe was. Er kwamen meer spelers op het veld en de regelgeving werd ingewikkelder. Dit was enerzijds het gevolg van de stijging van de gezinsmigratiestromen en, in nauw verband daarmee, van het groeiende maatschappelijke en politieke belang van het migratie- en integratievraagstuk. Anderzijds vloeide deze ontwikkeling voort uit het streven naar democratisering, naar participatie, transparantie en verantwoording, dat sinds het midden van de jaren zestig zo ferm voet had gevat in Nederland. ${ }^{20}$ Het paste eenvoudigweg niet meer dat een handvol ambtenaren beslissingen nam buiten zicht van het publiek, zonder inspraak van de volksvertegenwoordiging en zonder controle van de rechter, zeker niet op een beleidsveld dat geleidelijk een steeds groter gewicht kreeg.

\section{Het parlement}

Tot 1970 bleef de parlementaire bemoeienis met het gezinsmigratiebeleid beperkt tot incidentele vragen en opmerkingen. In de loop van de jaren zeventig en tachtig zou de Tweede Kamer zich steeds actiever en intensiever gaan bezig houden met migratievraagstukken. Deze ontwikkeling past in een algemene tendens van stijgend parlementair activisme vanaf de tweede helft van de jaren zestig, als gevolg van processen van democratisering en ontzuiling in de Nederlandse samenleving. ${ }^{21}$ Tot het midden van de jaren zestig was de zetelverdeling in de Tweede Kamer uitzonderlijk stabiel. Geloof en klasse waren zo bepalend voor partijvoorkeur dat een verkiezing, in de woorden van De Rooy, 'niet zozeer een opinieonderzoek als wel een soort volkstelling' was. ${ }^{22}$ Vanaf 1967 werd dat anders: in de parlementaire verkiezingen van dat jaar stemde een derde van de kiezers op een andere partij dan in $1963 .{ }^{23}$ Verkiezingsuitslagen werden veel wisselvalliger en minder voorspelbaar. ${ }^{24}$ Daarmee nam de electorale competitie tussen politieke partijen toe en gingen Kamerleden en -fracties zich

20 Zie Daalder 1995: 252-267.

21 Van Schendelen 1974; 't Hart e.a. 2002: 124-129.

22 De Rooy 2005: 221; zie ook Lijphart 1979: 36.

23 Kennedy 1995: 181-182.

24 Daalder 1995: 49-55, 84-87. 
actiever profileren. ${ }^{25}$ In plaats van wetsvoorstellen van de regering af te wachten plaatste de Tweede Kamer steeds vaker zelf onderwerpen op de politieke agenda. ${ }^{26}$

De groeiende parlementaire aandacht voor het vreemdelingenbeleid dient ook begrepen te worden als een gevolg van de bredere maatschappelijke relevantie van het migratievraagstuk. Waar buitenlandse werknemers voorheen afgezonderd in pensions en woonoorden hadden geleefd, werden zij nu met hun gezinnen zichtbaar, niet alleen op het werk maar ook in de wijk en op school. Daarbij kwam de plotselinge en grootschalige toestroom vanuit Suriname naar Nederland in de jaren rond de Surinaamse onafhankelijkheid. ${ }^{27}$ In 1974 deed Joop Glimmerveen namens de Nederlandse VolksUnie (NVU) mee aan de gemeenteraadverkiezingen in Den Haag. Hij kreeg net niet genoeg stemmen voor een zetel in de raad. In 1977 nam de NVU, onder het motto 'Hou Nederland Blank', deel aan de Kamerverkiezingen, opnieuw zonder succes. ${ }^{28}$ De NVU was de eerste Nederlandse partij die zich exclusief profileerde als een anti-migrantenpartij. Haar verschijning op het politiek toneel is indicatief voor de toegenomen urgentie van migratie als maatschappelijk en politiek vraagstuk.

De Nota Buitenlandse Werknemers van 1970, waarin de regering voor het eerst haar arbeidsmigratiebeleid uiteen had gezet ten behoeve van een gericht debat met het parlement, was een eerste omslagpunt. ${ }^{29}$ In 1979 volgde de Notitie Vreemdelingenbeleid, waarin de staatssecretaris van Justitie het beleid inzake toelating en verblijf van vreemdelingen aan de Tweede Kamer voorlegde. Deze notitie vormde het startsein voor een sterk toegenomen bemoeienis van de Kamer niet alleen met het vreemdelingenbeleid in het algemeen, maar vooral ook met het gezinsmigratiebeleid in het bijzonder. Vóór 1979 was het gezinsmigratiebeleid nooit een afzonderlijk onderwerp van debat geweest tussen de Kamer en de regering. Tussen 1979 en 1985 werden twee regeringsnotities gepresenteerd die geheel aan het gezinsmigratiebeleid gewijd waren, vonden vier commissievergaderingen plaats die uitsluitend over toegang en verblijf van gezinsleden gingen en werd in vijf andere vergaderingen zeer uitgebreid aandacht aan gezinsmigratie besteed. Daarmee werd de Tweede Kamer een speler waarmee het ministerie van Justitie bij het bepalen van de beleidsregels voor

25 Van Schendelen 1974: 119-120.

26 Visscher 1994: 29, 789.

27 Van Amersfoort 1987: 476. Zie paragraaf 3.5.

28 Tinnemans 1994: 134-135, 249-250; Lucardie 1998: 17-19.

29 Zie paragraaf 2.8 . 
gezinsmigratie terdege rekening moest houden.

\section{De rechtspraak}

In de eerste decennia na de Tweede Wereldoorlog werd de beleidsruimte waarover ambtenaren en bewindslieden beschikten om de voorwaarden voor gezinsmigratie te bepalen, niet ingeperkt door de rechtspraak. In het algemeen was het, tot de 'revolutie' van de jaren zestig, eigen aan de Nederlandse politieke cultuur om erop te vertrouwen dat 'wat de overheid doet, zij goed doet'. ${ }^{30}$ Dit gold in versterkte mate voor het vreemdelingenbeleid, dat bij uitstek als een 'domaine réservé' van de staat werd beschouwd. Hierin kwam in de jaren zeventig verandering. De nieuwe Vreemdelingenwet van 1965, die in 1967 in werking trad, had vreemdelingen al beperkte mogelijkheden gegeven om tegen een besluit van de Nederlandse regering in beroep te gaan bij de Raad van State. Dankzij de democratiseringsbeweging van de jaren zestig "verminderde de bereidheid om ongecontroleerde machtsuitoefening door overheidsinstanties te accepteren'. ${ }^{31}$ In 1976 trad de Wet administratieve rechtspraak overheidsbeschikkingen (AROB) in werking, in 1978 de Wet openbaarheid van bestuur. Als gevolg daarvan nam de toegang van vreemdelingen tot de Nederlandse rechtspraak toe.

Daarbij speelde ook de ontwikkeling van de rechtshulp aan vreemdelingen een cruciale rol. Begin jaren zeventig waren in Amsterdam maar vier advocaten werkzaam die ervaring hadden met vreemdelingenzaken; ook in de rest van Nederland waren nauwelijks juristen met kennis van het vreemdelingenrecht. ${ }^{32}$ In 1973 werd de Werkgroep Rechtsbijstand aan Vreemdelingen opgericht, met als doel de expertise in vreemdelingenrecht onder advocaten te stimuleren en die expertise toegankelijk te maken voor vreemdelingen. In 1980 had de Werkgroep 200 leden, waaronder 140 advocaten. Dankzij de werkgroep verbeterde de rechtshulp aan vreemdelingen aanzienlijk, zowel in kwantitatief als in kwalitatief opzicht. ${ }^{33}$

Het gevolg was een sterke toename van rechterlijke uitspraken in vreemdelingenzaken. Daarbij bleven rechters zich terughoudend opstellen waar het bemoeienis met de inhoud van het beleid betrof. In een democratische rechtsorde is het immers niet aan de rechter, maar aan

30 Ik ontleen deze formulering aan een gesprek met professor Kees Groenendijk, 27 juni 2007, CMR Nijmegen.

31 Groenendijk 1996: 120-121, 124.

32 Groenendijk 1996: 124-125.

33 Ten Doesschate 1993: 184-185; Groenendijk 1980: 167; Groenendijk 1978: 14. 
volksvertegenwoordiging en politiek gelegitimeerd bestuur om wet- en regelgeving vast te stellen. De bestuursrechter ziet erop toe dat de toepassing van het beleid in overeenstemming is met algemene beginselen van behoorlijk bestuur, zoals rechtszekerheid, zorgvuldigheid, gedegen motivatie en redelijke belangenafweging. ${ }^{34}$ Rechters gunden de Nederlandse regering dan ook de ruimte om met het oog op het algemeen belang voorwaarden te stellen aan gezinsmigratie, zoals het inkomens- en huisvestingsvereiste. Meer dan op de inhoud is de rechtspraak in de jaren zeventig van doorslaggevende invloed geweest op de vorm van het beleid..$^{35}$ In de jaren zestig werd de Vreemdelingencirculaire, waarin het overgrote deel van de beleidsregels voor toelating en verblijf van vreemdelingen was vastgelegd, niet gepubliceerd. Onder staatssecretaris Glastra van Loon is besloten, dat de Vreemdelingencirculaire ter inzage moest liggen bij alle gerechten, bureaus van consultatie en universiteitsbibliotheken. ${ }^{36}$ Pas in 1983 werd de Vreemdelingencirculaire algemeen verkrijgbaar. ${ }^{37}$ Daarbij had de rechtspraak een belangrijke rol gespeeld. In rechtzaken werd de regering verzocht om het beleid voor toelating en verblijf van vreemdelingen, zoals dat was vastgelegd in de regelgeving, uiteen te zetten. In de uitspraken van de rechters, die werden gepubliceerd, werden die beleidsregels geciteerd. Vervolgens konden andere vreemdelingen en hun advocaten op basis van deze uitspraken om een gelijke toepassing van de regels vragen. ${ }^{38}$ Zo ontwikkelde de Vreemdelingencirculaire zich, dankzij de rechtspraak, van een interne instructie van het departement aan de uitvoerende diensten, tot een serie 'waarborgnormen' waaraan burgers juridisch afdwingbare aanspraken kunnen ontlenen. ${ }^{39}$

34 Polak 2006: 356-360; Dijkstra 1996: 58. Het reikt hier te ver om in te gaan op de vraag hoe indringend de toetsing van de bestuursrechter mag zijn, een vraag die juristen en bestuurders blijft bezig houden.

35 Op specifieke punten hebben rechterlijke uitspraken wel geleid tot beleidswijzigingen, of tot wijzigingen in de uitvoeringspraktijk. Zo bepaalde de rechter in 1979 dat niet alleen erkende vluchtelingen maar ook asielgerechtigden (aan wie niet op grond van het Vluchtelingenverdrag maar om humanitaire redenen verblijf werd toegestaan) niet-huwelijkse buitenlandse partners moesten kunnen laten overkomen naar Nederland. Naar aanleiding van deze uitspraak werd de Vreemdelingencirculaire aangepast. (Groenendijk \& Swart 1980: 26-27) Ook heeft de rechter vastgesteld dat het ontbreken van een machtiging tot voorlopig verblijf (mvv) op zichzelf niet voldoende grond bood om een vergunning tot verblijf te weigeren. (Groenendijk \& Swart 1979b: 70-71) De rechtspraak heeft tevens een rol gespeeld in het gelijkstellen van de voorwaarden voor gezinsmigratie voor mannen en vrouwen, en in het beleid ten aanzien van controle op schijnhuwelijken (zie paragraaf 3.7).

36 Groenendijk 1996: 124.

37 Koens 1983a: 17.

38 Groenendijk 1980: 171.

39 Koens 1983b: 950. 
In de jaren zeventig en tachtig deed ook, heel geleidelijk, het internationaal recht zijn intrede in de Nederlandse vreemdelingenrechtspraak. Voor het gezinsmigratiebeleid is daarbij vooral artikel 8 van het Europees Verdrag voor de Rechten van de Mens (EVRM) van belang, waarin het recht op gezinsleven is vastgelegd. Het EVRM dateert uit 1950, maar Nederlandse rechters en beleidsmakers gingen er lange tijd vanuit dat de bepalingen van het verdrag niet van toepassing waren op het vreemdelingenbeleid, dat immers als een zaak van nationale soevereiniteit werd beschouwd. In de vroege jaren zeventig werd een beroep op artikel 8 EVRM in vreemdelingenzaken nog als een 'zwaktebod' gezien: een teken dat de advocaat in kwestie ernstig om overtuigende argumenten verlegen zat. ${ }^{40}$ In de loop van de jaren zeventig oordeelde de Europese Commissie voor de Rechten van de Mens, het voorportaal van het Hof van Straatsburg dat op de naleving van het EVRM toeziet, dat in vreemdelingenzaken sprake zou kunnen zijn van inbreuk op het recht op gezinsleven, met name wanneer buitenlandse gezinsleden toegang of verblijf werd ontzegd terwijl hereniging van het gezin in een ander land niet mogelijk was. ${ }^{41}$ Tot een uitspraak van het Hof van Straatsburg kwam het echter pas in 1985. In de 'zaak-Abdulaziz' bepaalde het Hof dat artikel 8 EVRM van toepassing was op het vreemdelingenbeleid, in die zin dat een redelijke afweging moest worden gemaakt tussen het individuele belang van betrokkenen om hun gezinsleven te kunnen uitoefenen, en het algemene belang van de staat. Eind 1986 verbood de Nederlandse Hoge Raad voor het eerst de uitzetting van een vreemdeling met verwijzing naar artikel 8 EVRM. ${ }^{42}$ In 1988 kwam het Hof van Straatsburg voor de eerste keer tot de conclusie dat het recht op gezinsleven geschonden was in een migratiezaak: het betrof een klacht tegen Nederland. ${ }^{43}$ Pas vanaf dat moment ging artikel 8 EVRM direct invloed uitoefenen op de Nederlandse beleidsvorming. ${ }^{44}$ Tot het einde van de jaren tachtig bestond over de precieze betekenis van het EVRM voor het Nederlands gezinsmigratiebeleid weinig duidelijkheid. Dat weerhield belangenbehartigers van migranten zowel juristen als volksvertegenwoordigers - er echter niet van om steeds

\footnotetext{
40 Groenendijk 1989: 191-192, 223.

41 Groenendijk \& Swart 1979a: 599; Groenendijk \& Swart 1979b: 302-303; Bolten 1981: 604.

42 Groenendijk 1989: 223; Boeles 2004a: 98-99.

43 Het Hof oordeelde dat een Marokkaanse man die van zijn Nederlandse vrouw gescheiden was niet mocht worden uitgezet, vanwege zijn recht op gezinsleven met de uit dat huwelijk geboren dochter. De Nederlandse regering trok de conclusie dat artikel 8 zwaarder woog in geval van voortgezet verblijf dan bij eerste toelating. Boeles 2004b: 103-104; Boeles 2004c: 114. Zie ook Steenbergen 1989, 1990.

44 Zie paragraaf $4.2,4.5$ en 4.11 .
} 
vaker aan het recht op gezinsleven te refereren in debatten over gezinshereniging.

\section{Verhoudingen binnen en tussen de ministeries}

De toenemende betrokkenheid van parlement en rechtspraak bij het vreemdelingenbeleid had natuurlijk vérstrekkende gevolgen voor de beleidsvoering binnen het ministerie van Justitie. De veelal globale richtlijnen uit de Vreemdelingencirculaires van de jaren zestig, die veel ruimte lieten aan de uitvoerende diensten, voldeden niet meer. Niet alleen rechters maar ook Kamerleden drongen aan op uniformiteit van beleid en rechtszekerheid voor de vreemdeling. ${ }^{45}$ Het steeds toenemende aantal vreemdelingen in Nederland versterkte de behoefte aan gedetailleerde beleidsregels nog verder. In de loop van de jaren zeventig werden de aanwijzingen in de Vreemdelingencirculaire dan ook steeds specifieker en uitgebreider. Koens maakte begin jaren tachtig een inventarisatie van de bepalingen die op gezinshereniging van toepassing waren: dit leverde zeventig verschillende gezinsherenigingsvoorwaarden op, onder te verdelen in vijfentwintig rubrieken. ${ }^{46}$ Deze differentiatie en specificatie had echter een averechts effect: de Vreemdelingencirculaire werd almaar onoverzichtelijker en dat kwam de consistentie en transparantie van de uitvoeringspraktijk niet ten goede. In 1983 trad daarom een geheel herschreven Vreemdelingencirculaire in werking. ${ }^{47}$

Parallel aan deze ontwikkelingen groeide ook de personeelsbezetting aanzienlijk. In 1971 waren bij de Hoofdafdeling Vreemdelingenzaken en Grensbewaking (HVG) van het ministerie van Justitie 25 ambtenaren werkzaam; in 1987 werkten bij die afdeling, die in 1976 was omgedoopt tot Directie Vreemdelingenzaken (DVZ), 127 mensen. ${ }^{48}$ Daarmee veranderde ook de stijl van de ambtelijke nota's. Waar ambtenaren in de jaren vijftig en zestig heel persoonlijke meningen formuleerden en uitwisselden, werden de interne nota's van Justitie vanaf de jaren zeventig aanmerkelijk

45 Zie bijvoorbeeld тк 1979-1980 ocv 28 januari 1980: 747; тK 1981-1982 UVC 8 februari 1982.

46 Koens 1983b: 950.

47 Koens 1983a: 18; Koens 1983b: 950. Volgens Glastra van Loon (1976: 44) beschreven de ambtenaren van HVG de in de circulaires neergelegde richtlijnen zelf als een 'ongeordende, onoverzichtelijke en ondoorzichtige massa'. Voor deze ambtenaren was dat een argument om de circulaires niet te publiceren.

48 Overzicht personeelsbezetting HVG, n.d. NA IND 1463; Tinnemans 1994: 164; Berghuis e.a. 1994: 47-48. 
formeler. Naarmate de rechtspraak meer invloed uitoefende op het vreemdelingenbeleid gingen juridische overwegingen en argumentaties ook een belangrijker rol spelen.

De autonomie van ambtenaren werd niet alleen door volksvertegenwoordiging en rechtbank ingeperkt, maar ook door bewindslieden die nu, veel nadrukkelijker dan in de jaren vijftig en zestig, een stempel drukten op de beleidsvorming. Het meest uitgesproken voorbeeld daarvan was Glastra van Loon, staatssecretaris van Justitie in het kabinet Den Uyl, maar ook de politiek gezagdragers die hem in die functie opvolgden zouden meer dan voorheen beleidslijnen uitzetten, of een beslissend oordeel uitspreken wanneer op ambtelijk niveau controverse bestond. Desalniettemin bleef het voorkomen dat ambtenaren op eigen initiatief significante beleidswijzigingen doorvoerden.

In één opzicht werd de beleidsruimte van ambtenaren en bewindslieden van Justitie juist vergroot in vergelijking met de jaren vijftig en zestig. Ze hadden niet langer te maken met inmenging van andere ministeries in het vreemdelingenbeleid. Met het einde van de grootschalige arbeidsmigratie in 1974 kwam ook aan de aanzienlijke invloed van Sociale Zaken op het migratiebeleid een einde. Vanaf dat moment was er consensus over de noodzaak om een restrictief vreemdelingenbeleid te voeren en werd die taak ook daadwerkelijk aan Justitie overgelaten. Dat de overkomst van buitenlandse gezinsleden buiten deze restrictieve doelstelling viel was evenmin aanleiding voor meningsverschillen tussen de ministeries. De hervormingen van het gezinsmigratiebeleid die in dit hoofdstuk worden besproken zijn, met uitzondering van de voorwaarden voor toelating van Surinamers, geen onderwerp van discussie geweest in de ministerraad. ${ }^{49}$

\subsection{Revolutie in de zeden}

De culturele revolutie van het einde van de jaren zestig gooide een aantal fundamentele normen en waarden volledig op zijn kop. Nederland veranderde van een behoudende, burgerlijke samenleving in een land dat zowel in het buitenland als door de Nederlanders zelf beschouwd werd als een

49 Agenda's en besluitenlijsten vergaderingen ministerraad $1978 \mathrm{t} / \mathrm{m} 1984$. NA MR 2653, 2671, 2975, 3242, 3499, 3512, 3765, 3752, 4066, 4079, 4080; Notulen ministerraad 26 juni 1979. NA MR 2664. Het archief van de ministerraad in het Nationaal Archief reikt niet verder dan 1984. Vgl. Scholten (2007: 128) die concludeert dat over het minderhedenbeleid evenmin substantiële discussies plaatsvonden in de ministerraad. 
progressief en tolerant 'gidsland': land van coffeeshops, abortusklinieken en gay parades, het land waar alles mocht. ${ }^{50}$

Deze revolutie in de zeden betrof niet in de laatste plaats het gezin, de hoeksteen van de burgerlijke moraal in het Nederland van de jaren vijftig en zestig. Het gezin bleef voor veruit de meeste Nederlanders 'de vanzelfsprekende en hooggewaardeerde samenlevingsvorm', maar werd veel pluriformer gedefinieerd. Het traditionele gezin, met de echtgenoot als kostwinner en gezinshoofd en de echtgenote als moeder en huisvrouw, was niet langer normgevend. In de permissive society diende ieder individu de ruimte te krijgen om naar eigen inzicht en behoefte vorm en invulling te geven aan zijn of haar gezinsleven. Anti-conceptie, ongehuwd samenleven, echtscheiding en homoseksualiteit raakten in rap tempo ingeburgerd. ${ }^{51}$

De ambtenaren van de Hoofdafdeling Vreemdelingenzaken en Grensbewaking (HVG) liepen in deze morele kentering bepaald niet voorop. In mei 1973 trad Jan Glastra van Loon echter aan als staatssecretaris van Justitie in het kabinet Den Uyl, een kabinet dat waarschijnlijk meer dan enig ander kabinet in de Nederlandse geschiedenis de ambitie had om van Nederland een ander land te maken. Glastra van Loon was lid van de jonge progressieve partij D66, een links-liberale rechtsfilosoof die een leidende rol had gespeeld in het studentenverzet. ${ }^{52}$ Met hem kwam de revolutie het ministerie van Justitie binnen.

In het boek waarin hij terugkijkt op zijn ervaringen als staatssecretaris beschrijft Glastra van Loon zijn allereerste stafvergadering met de ambtenaren van HVG. In een somber zaaltje in Scheveningen constateerde hij dat onder zijn ambtenaren het 'departementaal standpunt' leefde, dat het hun opdracht was de toelating van vreemdelingen binnen de perken te houden en dat aan de 'toch al beperkte middelen' die hen daartoe ter beschikking stonden niet mocht worden getornd. Gezien de moeilijkheden waarmee deze ambtenaren bij het reguleren van immigratiestromen - een 'nauwelijks te behappen taak' - voortdurend werden geconfronteerd had Glastra van Loon begrip voor die positie. Hij meende echter dat ze moest worden afgewogen tegen een 'meeromvattend', 'algemener gezichtspunt'. De staatssecretaris wierp meteen die eerste ochtend de knuppel in het hoenderhok. Hij besloot dat vrouwen onder dezelfde voorwaarden hun buitenlandse echtgenoot mochten laten overkomen als mannen, en dat niet alleen

50 Vgl. Kennedy 1995: 10.

51 Blom 1999: 361: Zie ook Righart 2006: 62-67.

52 In dit boek schrijf ik steeds over D66, al noemde de partij zich tot 1981 D'66. 
een huwelijk, maar ook een heteroseksuele of homoseksuele relatie met een Nederlands staatsburger reden was voor toelating. Glastra van Loon zag 'geen enkele grond' om het onderscheid tussen mannen en vrouwen te rechtvaardigen, en meende dat het weigeren van verblijf aan niet-huwelijkse partners 'onevenredig groot leed' veroorzaakte in verhouding tot 'het belang van ons land', gezien de 'relatief zeer kleine aantallen waar het (...) om gaat'. Zijn beslissingen stuitten echter bij 'iedereen om de tafel' op bezwaar en veroorzaakten 'zichtbare emotionele onrust bij het toenmalige hoofd van de afdeling. Het was alsof het gebeurde hem in zijn eer had aangetast'. ${ }^{53}$

De spanning van die slechte start werd al gauw doorbroken en Glastra van Loon beschrijft het verder verloop van zijn samenwerking met HVG als 'uitstekend'. ${ }^{54}$ Dat de voortvarendheid van de nieuwe staatssecretaris zijn ambtenaren in het verkeerde keelgat schoot is echter niet verrassend, gezien de traditie van beleid en meningsvorming waarin zij stonden.

\section{Homo- en heteroseksuele niet-huwelijkse partners}

In de jaren zestig was ongehuwd samenleven een 'contra-indicatie' voor het toestaan van verblijf van een vreemdeling in Nederland. Een buitenlander die al in Nederland was toegelaten kon zelfs worden uitgezet, wanneer 'het concubinaat leidt tot aanstoot in de omgeving van de samenlevenden' ${ }^{55}$ Aan het einde van het decennium begon deze benadering te schuiven. In 1969 deelde minister Polak (VvD) van Justitie aan de Tweede Kamer mee dat 'concubinaat', zoals het nog steeds werd genoemd, niet langer een reden was om een vreemdeling te weigeren die aan de overige voorwaarden voor toelating voldeed en dus bijvoorbeeld voor een verblijfsvergunning als arbeidsmigrant in aanmerking kwam. ${ }^{56}$

Het besluit van staatssecretaris Glastra van Loon in 1973 ging nog verder. Bepaald werd dat verblijf kon worden toegestaan als en voor zolang er sprake was van een serieuze relatie met een Nederlander, die de verantwoordelijkheid voor de kosten van het levensonderhoud van de ander op zich nam. ${ }^{57}$ Daarmee was ongehuwd samenleven dus veranderd van een

53 Glastra van Loon 1976: 42-45.

54 Glastra van Loon 1976: 49.

55 Nota HVG aan SG, 12 augustus 1964; Notitie minister op nota SG, 2 november 1964. NA IND 931.

56 Notitie overleg DVZ met chefs vreemdelingendiensten van grote steden, 1970. NA IND 3392.

57 Notitie staatssecretaris op nota hoofd HVG, 3 oktober 1979. NA IND 2608. 
reden om een vreemdeling uit Nederland te weren, in een formele toelatingsgrond.

Met Glastra van Loons beslissing om ook homoseksuele relaties als toelatingsgrond te aanvaarden voltrok zich een nog radicaler omslag in het Nederlands toelatingsbeleid. In de jaren zestig waren toelating en verblijf van homoseksuele vreemdelingen nog het onderwerp van enkele gloedvolle nota's van het hoofd HVG. Ter illustratie van de toon en strekking van die nota's moge deze passage dienen, waarmee hij een nota uit 1964 inleidde:

Eerst enige algemene opmerkingen. Het schijnt dat homofiele neigingen toenemen. Het ligt uiteraard niet op mijn weg te pogen het verschijnsel te verklaren. Is het te wijten aan een voortschrijdende desintegratie van het verantwoordelijkheidsgevoel in de welvaartsstaat? Komt het door toenemende organisatie van homofielen? Is het de wassende litteraire behoefte de nood bijkans als een deugd te presenteren? Is er bij niet homofielen in hun waarderingsgevoel sprake van een afnemend normbesef? Neigt onze beschaving ter kimme? Hoe dit ook zij, men kan alle begrip opbrengen (...) voor deze sexuele afwijking, dat neemt niet weg dat het verschijnsel een afwijking blijft, daargelaten of het nu toeneemt of niet.

Het hoofd HVG zag homoseksualiteit als een 'onmaatschappelijke afwijking' die een bedreiging vormde voor de openbare orde en had daarom 'principiele bezwaren tegen toelating van welke homo-seksueel dan ook' ${ }^{58}$

Vanaf het midden van de jaren zestig raakten in Nederland de opvattingen over homoseksualiteit in een stroomversnelling: nog sneller dan in andere landen zwakte de medische, religieuze en maatschappelijke afkeuring af. ${ }^{59} \mathrm{Al}$ in 1965 werd het principieel afwijzende standpunt van Justitie onhoudbaar. Minister Samkalden (PvdA) bepaalde - volgens zijn ambtenaren 'niet con amore' - dat homoseksualiteit niet langer reden was om een vreemdeling te weren die aan de reguliere voorwaarden voor toelating voldeed, tenzij hij 'opspraak' veroorzaakte door met zijn homoseksuele partner samen te leven. ${ }^{60}$ Nog geen twee jaar later moest ambtelijk Justi-

58 Nota's HVG aan SG, 28 juli en 12 augustus 1964. NA IND 931.

59 Hekma 2004: 114-122; Tielman 1982: 225-227.

60 Nota HVG, 14 oktober 1967; nota HVG aan SG, 31 oktober 1967. NA IND 931. 
tie erkennen dat samenleving van een succesvol Spaans couturier met zijn Nederlandse vriend 'in een grote stadswijk in Rotterdam' niet tot opspraak zou leiden, 'gezien de - blijkbaar zeer snel evoluerende - inzichten hieromtrent'. De ambtenaar besloot daarom, 'ik wil gaarne bekennen contrecoeur', dat er geen reden was om de Spanjaard te weigeren. ${ }^{61}$ Het hoofd HVG stribbelde nog even tegen:

zelfs áls de neiging zou bestaan de normbakens te verzetten, ook dan zou er voor de Overheid alle aanleiding bestaan de kracht van die neiging af te tasten door zich op het standpunt van de norm te blijven stellen, zo lang nog een kleine, zij het luidruchtige minderheid op bakenverzetting aandringt.

Hij merkte echter op dat tussen de Spaanse couturier en zijn partner 'een liefdesgrondslag bestaat waarop normaliter een huwelijk tussen man en vrouw wordt gebaseerd'. In zulk een 'uitzonderlijk' geval wilde het hoofd wel tot toelating overgaan. ${ }^{62}$

Begin jaren zeventig boekte de homo-emancipatiebeweging een reeks politieke successen: in 1971 verdween het artikel dat 'ontucht met minderjarigen van hetzelfde geslacht' strafbaar stelde uit de strafwet en in 1973 werd het COC rechtspersoonlijkheid en subsidie verleend. ${ }^{63}$ Het besluit van staatssecretaris Glastra van Loon in 1973 dat een homoseksuele relatie met een Nederlander niet alleen geen grond tot weigering mocht zijn, maar zelfs een reden tot toelating was, past in deze politieke doorbraak. De aanwijzing van de staatssecretaris werd door zijn ambtelijk apparaat overgenomen, maar helemaal van harte ging dat niet. Toen de nieuwe beleidslijn aan de chefs van de vreemdelingendiensten werd meegedeeld, voegden de ambtenaren daaraan toe: 'Indien toepassing van deze norm tot vreemde situaties zou leiden, dan kan voorlegging aan het ministerie volgen' ${ }^{64}$

\section{Echtgenoten van Nederlandse vrouwen}

Het Nederlands vreemdelingen- en nationaliteitsrecht is lange tijd gebaseerd geweest op de idee dat de man, als gezinshoofd, de nationaliteit en

61 Nota HVG aan SG, 31 oktober 1967. NA IND 931.

62 Nota HVG aan SG, 2 november 1967. NA IND 931.

63 Hekma 2004: 69; Tielman 1982: 226.

64 Verslag overleg DVZ met chefs vreemdelingendiensten, 27 november 1973. NA IND 3392. 
de verblijfplaats van zijn gezin bepaalde en dat het recht van een Nederlandse man om met zijn gezin in Nederland te leven gewaarborgd moest zijn. Sinds 1964 kon de buitenlandse echtgenote van een Nederlander daarom bij haar huwelijk opteren voor de Nederlandse nationaliteit. Een Nederlandse vrouw die met een vreemdeling trouwde werd echter geen bijzondere aanspraak toegekend op verblijf in Nederland met haar man en kinderen. Haar echtgenoot moest aan de reguliere voorwaarden voor verblijf voldoen, waaronder het inkomensvereiste, en kwam net als andere vreemdelingen pas na vijf jaar voor naturalisatie in aanmerking. ${ }^{65}$

De culturele revolutie van de jaren zestig en de tweede feministische golf brachten fundamentele veranderingen teweeg in de denkbeelden over de positie van mannen en vrouwen in gezin en samenleving. Vanaf 1973 vond de vrouwenbeweging gehoor in Den Haag: het kabinet Den Uyl nam vrouwenemancipatie als een belangrijk punt op in zijn beleidsagenda. ${ }^{66}$ Daarmee deed de norm van gelijke behandeling van man en vrouw ook in overheidskringen zijn intrede.

In het vreemdelingenbeleid betekende dat in de eerste plaats, dat aan Nederlandse vrouwen net als aan Nederlandse mannen het recht moest worden verleend, om zonder belemmeringen of beperkingen met hun gezin op Nederlands grondgebied te verblijven. De ambtenaren van HVG beseften dat het bestaand beleid niet te rijmen was met de tijdgeest, maar waren desalniettemin terughoudend uit vrees voor 'schijnhuwelijken'. Impliciet bleven zij er vanuit gaan dat een vrouw volgt waar haar man leidt en dat een man zijn levenskeuzes op materiële en niet op affectieve gronden maakt. Vreemdelingen die ervoor kozen om hun echtgenote naar haar land van herkomst te volgen, wekten hun argwaan. Er was een besluit van staatssecretaris Glastra van Loon voor nodig om die weerstand te overwinnen. ${ }^{67}$ De inkomenseis voor toelating van huwelijkspartners van Nederlandse vrouwen werd aanmerkelijk versoepeld: het inkomensvereiste was niet langer op hen van toepassing, tenzij de betrokkenen hadden geweigerd om passend werk te aanvaarden. ${ }^{68}$ Daarmee was de positie van Nederlandse vrouwen niet gelijkgesteld aan die van Nederlandse mannen, wier echtgenotes immers de Nederlandse nationaliteit konden krijgen en dus een onvoorwaardelijk recht op verblijf in Nederland hadden, maar zij was wel aanzienlijk verbeterd.

65 De Hart 2003a: 78-81, 101-103. Zie paragraaf 2.2.

66 Prins 1989: 39, 53.

67 Nota HVG aan staatssecretaris, met daarop notitie van staatssecretaris, 3 oktober 1973. NA IND 2608.

68 Verslag overleg DVZ met chefs vreemdelingendiensten, 27 november 1973. NA IND 3392. 


\section{Echtgenoten van buitenlandse vrouwen}

Inmiddels kwam ook een debat op gang over de toelating van huwelijkspartners van buitenlandse vrouwen die in Nederland woonden. Vóór de jaren zeventig is daarover in beleidskringen niet gesproken. Er waren niet veel buitenlandse werkneemsters in Nederland. ${ }^{69}$ Voor zover er onder hen vrouwen zijn geweest die een echtgenoot hadden die zij over wilden laten komen naar Nederland, zullen hun echtgenoten gemakkelijk toegang hebben kunnen krijgen via de arbeidsmigratiekanalen. Dat laatste veranderde na de economische crisis begin jaren zeventig, toen arbeidsmigratie aan steeds strengere voorwaarden werd onderworpen. Tegelijkertijd ontstond een nieuwe vorm van gezinsmigratie: de kinderen van arbeidsmigranten, die zelf in het kader van gezinshereniging naar Nederland waren gekomen, bereikten de huwbare leeftijd en kozen vaak voor een partner uit het land van herkomst, voor wie zij om toelating in Nederland verzochten. Met name waar het dochters van migranten betrof, werd dat problematisch gevonden.

De weerstand in beleidskringen blijkt al uit de term die werd gebruikt voor gevallen waarin om toelating van een vreemdeling voor hereniging met zijn echtgenote werd verzocht: 'omgekeerde gezinshereniging'. Gezinshereniging waarbij de man de vrouw volgt was omgekeerd, verkeerdom: verkeerd. Deze term duikt voor het eerst op in beleidsstukken in 1972, toen ambtenaren bezorgd constateerden dat 'de omgekeerde gezinshereniging hand over hand toeneemt'. ${ }^{70}$

Eén van de eerste beslissingen die Glastra van Loon als staatssecretaris van Justitie nam was, dat voor mannen en vrouwen dezelfde voorwaarden moesten gelden voor gezinshereniging. Dit stuitte echter op weerstand bij de Adviescommissie Vreemdelingenzaken (ACVZ): ${ }^{71}$

69 Zie over vrouwelijke arbeidsmigranten in de jaren zestig en zeventig: De Lange 2007: 171; Chotkowski 2000.

70 Verslag overleg DVZ met chefs grootste vreemdelingendiensten, 17 april 1972. NA IND 3392. De voorganger van Glastra van Loon, staatssecretaris Grosheide, had in 1972 al besloten dat op vrouwen dezelfde voorwaarden van toepassing moesten zijn als voor mannen, maar had daarbij gestipuleerd dat aan mannelijke huwelijksmigranten geen arbeidsvergunning mocht worden verleend. Die aanwijzing is nooit formeel vastgelegd in een circulaire: of en hoe ze is toegepast heb ik uit de jurisprudentie niet kunnen achterhalen. Verslagen overleg DVZ met chefs grootste vreemdelingendiensten, 17 april 1972 en 23 januari 1973. NA IND 3392.

71 De ACVZ is in 1967 ingesteld en functioneert tot op heden als permanent extern adviesorgaan van de regering. Berghuis e.a. 1994: 61. 
Men meent dat in de grote meerderheid van de gevallen de situatie geheel anders is wanneer de vrouw zich bij de man voegt dan wanneer de man zich bij de vrouw voegt. In het eerste geval zal het de vrouw er doorgaans om te doen zijn, het huishouden te gaan verzorgen, kinderen groot te brengen enz. In het tweede geval gaat het de man erom als "hoofd van het gezin" een baan te vinden, de kost voor z'n gezin te verdienen. Krijgt hij geen arbeidsvergunning - en de kans daarop is vaak groot - dan zal hij clandestien gaan werken, zeker als z'n vrouw kinderen krijgt en daarvoor wil gaan zorgen. Men vindt dus dat er door het toestaan van "omgekeerde gezinshereniging" een oneigenlijke toestand geschapen of in de hand gewerkt wordt. ${ }^{72}$

De secretaris-generaal accepteerde het uitgangspunt van gelijke behandeling van man en vrouw, maar deelde de bedenkingen van de Adviescommissie. Op zijn voorstel werd besloten om, bij wijze van 'logische verfijning van de uitgangspunten', naast de gangbare voorwaarden - tenminste één jaar werk en verblijf in Nederland, een arbeidscontract voor nog een jaar en passende huisvesting - de aanvullende eis te stellen dat het huwelijk minstens een jaar bestond. ${ }^{73}$ Pas dan kon worden aangenomen, dat het huwelijk niet was gesloten 'met de bedoeling langs die weg in Nederland te kunnen verblijven' ${ }^{74}$ Praktisch gevolg was dat pasgetrouwde stellen het eerste jaar van hun huwelijk niet in Nederland konden samenleven. Wel werd de 'feitelijke anomalie' aanvaard dat de man een arbeidsvergunning kreeg. ${ }^{75}$

Het is opvallend dat bij het formuleren van die voorwaarden voor 'omgekeerde gezinshereniging' expliciet gerefereerd werd aan het gelijkheidsbeginsel. Zonder blikken of blozen werden vervolgens voor vrouwen eisen gesteld, die niet op mannen van toepassing waren. Als abstract principe werd de norm van gelijkheid van man en vrouw niet bestreden. Feitelijk werd de meningsvorming op het departement echter nog dusdanig bepaald door het traditioneel rolpatroon, dat de immigratie van mannelijke huwelijkspartners vanzelfsprekend als verkapte arbeidsmigratie werd

72 Nota HVG aan SG, 1 oktober 1973. NA IND 1658.

73 Nota SG aan staatssecretaris, 3 oktober 1973. NA IND 1658; Verslag overleg DVZ met chefs vreemdelingendiensten, 27 november 1973. NA IND 3392.

74 22e Wijziging Vc, 7 juli 1975. NA IND 474.

75 Nota SG aan staatssecretaris, 3 oktober 1973. NA IND 1658. In 1979 werd de 'witte kaart' ingevoerd, die vreemdelingen aan wie op grond van gezinshereniging een verblijfsvergunning was verleend direct toegang gaf tot de Nederlandse arbeidsmarkt. De Lange 2007: 181. 
beschouwd. Vandaar dat Justitie er geen been in zag enerzijds de gelijkheid van man en vrouw te belijden, en anderzijds strengere eisen te stellen aan de toelating van mannelijke partners. In de ogen van het ambtelijk Justitieapparaat was het feit dat deze vreemdelingen überhaupt werden toegelaten al meer dan voldoende invulling van het gelijkheidsbeginsel. ${ }^{76}$

\section{Schijnhuwelijk en schijnrelatie}

Op 7 juli 1975 werden alle hierboven beschreven beleidshervormingen verwerkt in de Vreemdelingencirculaire. Het is geen toeval dat de uitvoerende diensten in diezelfde circulaire voor het eerst werden geïnstrueerd om bij de toelating van buitenlandse partners te toetsen of er sprake was van een schijnhuwelijk of een schijnrelatie. ${ }^{77}$

We hebben in hoofdstuk 2 al gezien dat de ambtenaren van HVG hun opdracht primair interpreteerden als het beperken van de toestroom van vreemdelingen naar Nederland. De situatie op de arbeidsmarkt in de jaren zeventig maakte die taak des te urgenter. Juist op dat moment werden zij door hun politiek gezagdrager gevraagd om het gezinsmigratiebeleid significant te versoepelen, om aansluiting te zoeken bij de 'revolutie in de zeden' die zich in de Nederlandse maatschappij voltrok. Aangezien gezinshereniging sinds 1974, naast asiel, vrijwel de enige grond was om Nederland legaal binnen te komen, was de verdenking van misbruik echter voortdurend aanwezig. De argwaan van ambtelijk Justitie werd gevoed door nog steeds sterk aanwezige traditionele genderopvattingen. Een man werd in de eerste plaats als kostwinner beschouwd: een buitenlandse man dus in de eerste plaats als - verkapte - arbeidsmigrant. Deze achterdocht jegens mannen die ervoor kozen om hun vrouw naar Nederland te volgen resulteerde in de introductie van preventieve controle op misbruik van het

76 Wat Glastra van Loon daarvan vond, heb ik uit de archiefstukken niet op kunnen maken. In zijn boek van 1976 schrijft hij besloten te hebben dat voor omgekeerde gezinshereniging dezelfde voorwaarden dienden te worden gesteld als voor 'gewone gezinshereniging'; uit niets blijkt dat hij zich er van bewust was dat zijn aanwijzing tot op dat moment niet naar de letter was opgevolgd. Wellicht was hij tevreden met de interpretatie die zijn ambtenaren aan het gelijkheidsbeginsel hadden gegeven, of was hij er niet nauwkeurig van op de hoogte.

77 De Hart 2000b: 247. Uit jurisprudentie blijkt dat ook vóór het verschijnen van deze circulaire de huwelijken van Nederlandse vrouwen en buitenlandse mannen werden gecontroleerd. De Hart (2003a: 91) verwijst naar een drietal rechterlijke uitspraken uit 1974. Verder beschrijft De Hart (2003a: 89-90) dat er in de jaren dertig ook zorg was over schijnhuwelijken van buitenlandse mannen met Nederlandse vrouwen. In de archiefstukken uit de jaren vijftig en zestig die ik heb ingezien wordt de term 'schijnhuwelijk' maar één keer genoemd, met betrekking tot immigratie van Indonesische vrouwen. Nota HVG aan SG, 29 april 1960, NA IND 618. 
gezinsmigratiekanaal. ${ }^{78}$

De circulaire van 1975 schreef voor dat huwelijkspartners van Nederlandse vrouwen dienden te worden geweigerd, indien het geen 'reëel' huwelijk betrof, dat wil zeggen als het was gesloten 'met de kennelijke bedoeling om langs die weg in Nederland te kunnen blijven'. Aanwijzing daarvoor zou bijvoorbeeld kunnen zijn, dat op het moment dat het huwelijk werd gesloten bekend was dat de man het land uit zou worden gezet. Bestond de relatie echter al langere tijd, dan kon er toch sprake zijn van een reëel huwelijk. De tweede categorie waarbij de circulaire controle op misbruik voorschrijft, is toelating van huwelijkspartners van vrouwelijke vreemdelingen, ofwel 'omgekeerde gezinshereniging'. Hier werd zoals eerder vermeld als toelatingsvoorwaarde gesteld dat het huwelijk een jaar had bestaan, omdat 'in dit geval kan worden aangenomen dat het om een reële verbintenis gaat'. Op de derde en laatste plaats stipuleerde de circulaire dat toelating op grond van een niet-huwelijkse relatie kon worden geweigerd, als de relatie 'alleen is aangegaan om verblijf in Nederland af te dwingen' ${ }^{79}$ Alleen dit laatste voorschrift was gender-neutraal geformuleerd.

\section{Verruimde gezinshereniging}

Een laatste versoepeling die in de circulaire van juli 1975 werd opgenomen, had betrekking op familieleden buiten het kerngezin. In de jaren zestig was gezinshereniging strikt beperkt tot de wettige echtgenote en minderjarige kinderen. Het enige andere familielid wiens toelating kon worden overwogen, was de alleenstaande ouder of schoonouder van een arbeidsmigrant, die in het land van herkomst geen kinderen meer had die de zorg op zich konden nemen. ${ }^{80}$

In 1973 werd besloten dat voortaan ook andere familieleden voor verblijf in Nederland in aanmerking konden komen, indien zij 'in het land van herkomst reeds feitelijk deel hebben uitgemaakt van het gezin van de buitenlandse werknemer', dat wil zeggen bij hem hebben ingewoond, en 'van hem ook afhankelijk zijn'. ${ }^{81}$ Daarbij werd bijvoorbeeld gedacht aan meerderjarige dochters, behoeftige ouders, maar 'ook in bijzondere geval-

78 Vgl. De Hart 2003a: 90-91; Van Walsum 2008: 162.

79 22e wijziging Vc, 7 juli 1975. NA IND 474.

80 Brief hoofd HVG aan Directeur Regionaal Welzijnsoverleg Noordelijk Limburg, 18 november 1971. NA IND 1501.

81 Verslag overleg DVZ met chefs vreemdelingendiensten, 27 november 1973. NA IND 3392. 
len andere familieleden' ${ }^{82}$ Als argument voor deze versoepeling werd naar voren gebracht, dat 'achterlating van de afhankelijke gezins- of familieleden immers een onaanvaardbare hardheid [zou] kunnen betekenen', ${ }^{83}$

Ook deze beleidswijziging past in de nieuwe gezinsmoraal die door het kabinet Den Uyl in het regeringsbeleid werd ingebracht. Nu het traditioneel gezin steeds minder normgevend was in de Nederlandse maatschappij, werd ook ruimte gemaakt voor vormen van gezinsleven die afweken van wat in Nederland gebruikelijk was. Voor deze nieuwe openheid gold echter evenzeer dat ze met waarborgen werd omkleed: de uitvoerende diensten dienden gevallen van verruimde gezinshereniging steeds voor te leggen aan het ministerie. ${ }^{84}$

De tolerantie voor afwijkende gezinsvormen strekte zich bovendien niet uit tot polygamie. In 1969 was besloten, dat indien een arbeidsmigrant meer dan één wettige echtgenote had, slechts één echtgenote en de uit háár geboren kinderen voor verblijf in Nederland in aanmerking kwamen. ${ }^{85}$ In de circulaire van 1975 stond die beleidslijn echter niet vermeld: gesteld werd slechts dat de uitvoerende diensten, indien polygame gezinnen toestemming vroegen voor verblijf in Nederland, een aanwijzing dienden te vragen aan het ministerie. ${ }^{86}$ Dit zou op enige openheid kunnen duiden: wellicht behield het departement zich voor, in individuele gevallen toch verblijf toe te staan. Uit de jurisprudentie blijkt echter, dat de bestaande beleidslijn werd gehandhaafd: niet meer dan één echtgenote en háár kinderen. ${ }^{87}$ Eind jaren zeventig werd die regel opgenomen in de Vreemdelingencirculaire: tot de dag van vandaag wordt slechts aan één buitenlandse echtgenoot of partner en aan de kinderen van die vreemdeling een verblijfsvergunning verleend. ${ }^{88}$

De circulaire van 1975 betekende desalniettemin een aanzienlijke versoepeling van het gezinsmigratiebeleid: Nederlandse vrouwen met een

82 22e wijziging Vc, 7 juli 1975. NA IND 474.

83 TK 1975-1976 13600 H6 (2): 47; Zie ook 22e wijziging Vc, 7 juli 1975. NA IND 474.

84 22e wijziging Vc, 7 juli 1975. NA IND 474.

85 Nota HVG 8 april 1969; notulen ministerraad 18 april en 2 mei 1969, NA IND 1202; Nota HVG aan SG, 22 oktober 1970. NA IND 1469.

86 22e wijziging Vc, 7 juli 1975. NA IND 474.

87 Groenendijk \& Swart 1979b: 94-96, 165-167; Groenendijk \& Swart 1980: 103-107, 124-127. Het gaat om rechtszaken uit 1978 en 1979, waarin het Nederlands toelatingsbeleid voor polygame gezinnen werd aangevochten. Het zou dus kunnen dat het beleid tussen 1975 en 1978 inderdaad soepeler werd toegepast: ik heb dat niet kunnen achterhalen.

88 31e wijziging Vc, deel G4, p. 16. Documentatie Database CMR; Vreemdelingenbesluit 2000, artikel 3.16 . 
buitenlandse echtgenoot werden vrijgesteld van het inkomensvereiste, buitenlandse vrouwen mochten hun echtgenoot laten overkomen, heteroseksuele én homoseksuele relaties met een Nederlander werden als toelatingsgrond erkend en er werd ruimte gemaakt voor toelating van familieleden buiten het kerngezin. Deze hervormingen waren niet het gevolg van juridische druk. ${ }^{89}$ Wellicht nog opvallender: Tweede Kamerleden hadden er evenmin een rol in gespeeld. Deze beleidswijzigingen waren het resultaat van een politieke keuze, niet van het parlement, maar van Glastra van Loon, staatssecretaris van Justitie in het progressieve kabinet Den Uyl. Zijn voortvarend ingrijpen, dwars door de bezwaren van zijn ambtenaren heen, bracht de aanpassing van het Nederlands gezinsmigratiebeleid aan de nieuwe gezinsmoraal in een stroomversnelling. ${ }^{90}$ Daarmee tekent zich een aanmerkelijke breuk af met de jaren vijftig en zestig, toen de bewindslieden van Justitie nauwelijks zichtbare invloed uitoefenden op de ontwikkeling van het gezinsmigratiebeleid.

\subsection{Nieuwe vreemdelingen: de onafhankelijkheid van Suriname}

Op 25 november 1975 werd Suriname onafhankelijk. Het tijdstip en de manier waarop Suriname het Koninkrijk verliet zijn onlosmakelijk verbonden met de problematiek van de migratie vanuit Suriname naar Nederland, om precies te zijn met de steeds dringender wens van Nederland om die migratie een halt toe te roepen. ${ }^{91}$ Doelstelling van de Nederlandse regering was om Surinamers de Nederlandse nationaliteit te ontnemen, zodat de restrictieve voorwaarden van het vreemdelingenbeleid konden worden toegepast op het personenverkeer tussen Nederland en Suriname. Van Amersfoort zegt over de Nederlandse handelwijze: 'Zelden zal een politiek succes een zo averechts resultaat gehad hebben'. ${ }^{92}$

Sinds de inwerkingtreding in 1954 van het Statuut voor het Koninkrijk, dat aan alle onderdanen van het Koninkrijk volwaardig burgerschap

89 Zo observeert Van Walsum (2008: 152) in de Nederlandse rechtspraak van de jaren zeventig eenzelfde weerstand tegen toelating van volwassen mannelijke vreemdelingen via het gezinsmigratiekanaal als in beleidskringen.

90 De opvattingen en handelwijze van Glastra van Loon leidden niet alleen op het veld van vreemdelingenzaken tot botsingen met zijn ambtenaren. Al na twee jaar, in 1975, moest hij aftreden vanwege een conflict met de ambtelijke top over het gevangeniswezen, dat minister van Justitie Van Agt er toe bracht het vertrouwen in hem op te zeggen. (Erpecum 1998: 103-106)

91 Jones 2007: 241-242.

92 Van Amersfoort 1987: 490. 
verleende, stond het iedere Surinamer die zich de reis van Paramaribo naar Schiphol kon veroorloven vrij om in Nederland te komen wonen. Wat voorheen een elite-migratie geweest was nam in omvang en diversiteit geleidelijk toe. Tussen 1950 en 1965 bleef het aantal migranten dat jaarlijks vanuit Suriname naar Nederland kwam onder de 5 duizend. Vanaf dat moment begon het te stijgen, om in 1973 voor het eerst de 10 duizend per jaar te bereiken; in 1974 ging het om 17 duizend migranten en 1975 was een historisch piekjaar met 38 duizend migranten uit Suriname..$^{93}$

In het progressieve politieke klimaat dat Nederland in de jaren zeventig kenmerkte gingen steeds meer stemmen op om het koninkrijksverband met Suriname te verbreken. Die 'dekolonisatie-agenda' raakte vervlochten met de wens om de toestroom uit Suriname aan banden te leggen, vooral gezien de tanende werkgelegenheid in Nederland. ${ }^{94} \mathrm{Al}$ sinds 1970 zocht de Nederlandse regering naar manieren om de migratie uit Suriname aan beperkingen te onderwerpen. Toen dat binnen het Statuut voor het Koninkrijk niet mogelijk bleek, richtte het kabinet Den Uyl zijn pijlen op Surinaamse onafhankelijkheid. ${ }^{95}$ De wens om het reguliere vreemdelingenbeleid te kunnen toepassen op Surinamers was volgens Van Amersfoort 'niet de enige, maar wel de meest dringende reden' om te streven naar een onafhankelijk Suriname..$^{96}$

Nederland stelde dan ook voor om bij de onafhankelijkheid alle Surinamers, ook degenen die al lange tijd in Nederland woonden, de Surinaamse nationaliteit te geven. In Suriname daarentegen gingen stemmen op om alle Surinamers een dubbele nationaliteit te verlenen. ${ }^{97}$ Resultaat was een compromis, waarbij alle Surinamers die in Suriname verbleven de Surinaamse nationaliteit verkregen en daarmee de Nederlandse verloren; Surinamers die in Nederland woonden behielden in principe de Nederlandse nationaliteit maar konden opteren voor het Surinaams burgerschap..$^{98}$ Daarmee kreeg de Nederlandse regering in november 1975 grotendeels haar zin: de inwoners van Suriname verloren het Nederlands burgerschap en daarmee het recht zich vrij in Nederland te vestigen. In de haast waarmee de onafhankelijkheid tot stand was gebracht, had Nederland echter ingestemd met een overeenkomst met betrekking tot toelating en verblijf van Surinamers

93 Website van het CBS, Historie bevolking: buitenlandse migratie naar geboorteland, statline.cbs.nl. 94 Jones 2007: 222-224, 238-239.

95 Jones 2007: 229-234; Schuster 1999: 133-153.

96 Van Amersfoort 1987: 481.

97 Van Amersfoort 1987: 485; Dew 1978: 179; Jones 2007: 244-252.

98 Ahmad Ali 1998. 
die zo soepel was, dat de migratie uit Suriname voor de duur van de overeenkomst - tot 25 november 1980 - nauwelijks kon worden ingedamd. Tussen 1975 en 1980 zouden ruim 40 duizend Surinamers op grond van de overeenkomst in Nederland worden toegelaten. ${ }^{99}$ Met name waar het de voorwaarden voor gezinshereniging betrof was de Nederlandse regering zeer ver aan de Surinaamse wensen tegemoet gekomen.

\section{De overeenkomst van 1975}

In 1974 bracht de Koninkrijkscommissie, waarin delegaties uit Nederland, Suriname en de Nederlandse Antillen zitting hadden, een rapport uit ter voorbereiding van de onafhankelijkheid van Suriname. ${ }^{100}$ Dit rapport stelde onder meer:

Gegeven de bijzondere banden die tussen de volken van het Koninkrijk bestaan, en die zullen blijven bestaan ook nadat Suriname onafhankelijk is geworden, spreekt het vanzelf dat het bezit van de Surinaamse nationaliteit geenszins met zich medebrengt dat Surinamers met willekeurig andere vreemdelingen zullen worden gelijkgesteld. Bij overeenkomst zal moeten worden geregeld in welke opzichten de bezitter van de Surinaamse nationaliteit in Nederland en in de Nederlandse Antillen een voorkeursbehandeling geniet. ${ }^{101}$

Ambtenaren van Justitie waren van mening, dat deze 'voorkeursbehandeling' geen betrekking had op de toelating van Surinamers in Nederland. De Nederlandse regering hield daarom in eerste instantie vast aan zijn wens om na de onafhankelijkheid een visum-vereiste in te voeren voor Surinaamse onderdanen. Om toch een invulling te geven aan die bevoorrechte positie, stelde Justitie voor om de wachttijd bij gezinshereniging - in het regulier vreemdelingenbeleid twee jaar voor niet-wervingslanden - buiten beschouwing te laten voor Surinaamse migranten. ${ }^{102}$

Tijdens het bilateraal overleg dat in mei 1975 in Paramaribo plaatsvond, bleken de Nederlandse voorstellen slecht in de smaak te vallen bij de Surinaamse delegatie. ${ }^{103}$ Met name het voornemen een visum-regime in

99 Schuster 1999: 161.

100 Ahmad Ali 1998: 18.

101 Rapport Koninkrijkscommissie, geciteerd in nota HVZ aan minister-president, 12 maart 1975. NA IND 909.

102 Nota HVZ aan minister-president, 12 maart 1975. NA IND 909.

103 Verslag bilateraal overleg Suriname-Nederland in hotel Torarica te Paramaribo, 21 mei 1975. NA IND 909. 
te voeren was tegen het zere been van de Surinamers. Uiteindelijk zou de Nederlandse regering op dit punt toegeven: tot 1980 hadden Surinamers geen visum nodig om Nederland binnen te komen. Ook de verplichting om vóór vertrek een machtiging tot voorlopig verblijf (mvv) aan te vragen werd bijzonder soepel gehanteerd. ${ }^{104}$ Een ander punt van kritiek van de Surinaamse onderhandelaars waren de voorwaarden voor de toelating van niet-huwelijkse partners en van familieleden die niet tot het kerngezin behoren, die te stringent werden gevonden. De Nederlanders brachten daartegenin dat 'op het stuk van gezinshereniging (...) het toelatingsbeleid in Nederland in het algemeen reeds zeer ruim' was. ${ }^{105}$ Justitie suggereerde dat de criteria 'nog eens opnieuw geformuleerd kunnen worden zodat wellicht nog iets beter dan voorheen blijkt hoe ruim zij zijn'. ${ }^{106}$

Dat herformuleren resulteerde in juni 1975 in een ontwerp-vestigingsovereenkomst, waarin in artikel 5 werd gesteld dat Surinaams staatsburgers hun gezinsleden naar Nederland mochten laten overkomen op voorwaarde dat zij over passende huisvesting beschikten. Dit was in zoverre al een ruime bepaling, dat geen afzonderlijk inkomensvereiste werd gesteld: een Surinamer die een verblijfsvergunning had gekregen om in Nederland te werken en vervolgens werkloos werd, mocht desondanks zijn gezin laten overkomen. ${ }^{107}$ Met name in de definitie van 'gezinsleden' week de overeenkomst verder af van het reguliere vreemdelingenbeleid:

Onder gezinsleden worden verstaan:

- de echtgenoot;

- degene met wie de betrokken persoon een duurzame en exclusieve persoonlijke relatie onderhoudt;

- feitelijk tot het gezin van de personen behorende minderjarige kinderen over wie een der ouders het gezag uitoefent;

- andere familieleden, die feitelijk tot het gezin van de betrokken persoon behoren en die van hem afhankelijk zijn. ${ }^{108}$

104 Ahmad Ali 1998: 33-34.

105 Nota interdepartementale werkgroep voorkeursbehandeling Surinamers aan minister-president, 1 mei 1975. NA IND 909.

106 Nota stafafdeling wetgeving publiekrecht aan interdepartementale ambtelijke werkgroep toelating Surinamers, 23 april 1975. NA IND 909.

107 Zie verslag overleg DVZ met chefs grootste vreemdelingendiensten, 28 januari 1977. NA IND 3392.

108 Artikel 5 lid 2 van Overeenkomst tussen het Koninkrijk der Nederlanden en de Republiek Suriname inzake het verblijf en de vestiging van wederzijdse onderdanen, Paramaribo 25 november 1975. Tractatenblad, jaargang 1975, Nr. 133. 
Bij het 'herformuleren' van de voorwaarden was de Nederlandse regering, zoals een ambtenaar van vreemdelingenzaken enigszins verontrust constateerde, aanmerkelijk verder aan de Surinaamse wensen tegemoet gekomen dan zij vooraf van plan was. In 1975 was hereniging met een niet-huwelijkse partner alleen aan Nederlands staatsburgers toegestaan en dan nog alleen als aan een inkomensvereiste was voldaan. Voor Surinamers zou op dit punt dus een soepeler beleid gelden dan voor Nederlanders. De bepalingen voor verruimde gezinshereniging weken in die zin af van het regulier vreemdelingenbeleid, dat de Vreemdelingencirculaire stelde dat toelating van 'andere familieleden' kon worden overwogen, terwijl de vestigingsovereenkomst een verplichting tot toelating vastlegde. ${ }^{109}$ De bedenkingen van ambtelijk Justitie werden echter weggewuifd en in de definitieve versie van de overeenkomst tussen Nederland en Suriname werd artikel 5 ongewijzigd opgenomen. ${ }^{110} \mathrm{Bij}$ de behandeling van de vestigingsovereenkomst in de Tweede Kamer verklaarde staatssecretaris Zeevalking(D66) van Justitie dat voor deze ruime formulering was gekozen om rekening te houden met 'de bijzondere familierelaties en gezinssamenstellingen die in Suriname bestaan'. Hij gaf echter ook aan dat dergelijke verruimde gezinshereniging alleen 'in bijzondere omstandigheden' zou worden toegestaan. ${ }^{11}$

\section{De overeenkomst van 1980}

Staatssecretaris Zeevalking lijkt niet te hebben onderkend hoe ruim de overgangsregeling was waarmee hij had ingestemd. De bedoeling was om de migratie uit Suriname te stoppen, maar de Nederlandse regering had zichzelf de middelen uit handen geslagen om dat te doen. Vijf jaar later spraken gefrustreerde ambtenaren van Justitie over 'de zeer ruimhartige en lacuneuze bepalingen van de huidige overeenkomsten' ${ }^{112}$ en over een 'taxatiefout omtrent de ontwikkeling van Suriname die in 1975 heeft geleid tot aanvaarding van voor Nederland omineuze voorwaarden'. ${ }^{113}$

In april 1979, toen het einde van de looptijd van de vestigingsovereenkomst in zicht kwam, verklaarde de ministerraad onder voorzitterschap van premier Van Agt dat hij 'mede in het belang van Suriname een

109 Nota HVG, 1 juli 1975. NA IND 909.

110 Nota stafafdeling wetgeving publiekrecht aan HVZ, 3 juli 1975. NA IND 909.

111 TK 1975-1976 Handelingen 23 oktober 1975: 602.

112 Nota HVG aan loco-sG, 18 januari 1980. NA IND 871.

113 Nota privaatrecht aan staatssecretaris, 17 januari 1980. NA IND 871. 
veel restrictiever toelatingsbeleid van Surinamers wenselijk acht' ${ }^{114}$ Een interdepartementale werkgroep kwam tot dezelfde conclusie, niet alleen omdat deze 'een zware wissel trekt op het absorptievermogen van de Nederlandse bevolking' maar vooral omdat 'de belangen van de in Nederland verblijvende Surinamers en van de Nederlanders van Surinaamse afkomst ermede gediend zijn dat hun aantal niet nog meer toeneemt' ${ }^{115}$ Wat gezinshereniging betrof adviseerde de werkgroep om de voorwaarden van het reguliere vreemdelingenbeleid toe te passen. ${ }^{116}$ Het hoofd HVG sloot zich daar van harte bij aan, 'in de hoop dat er op 25 november 1980 nog iemand in Suriname is achtergebleven'. 117

In de herfst van 1980 werd in Paramaribo overleg gepleegd over een nieuwe vestigingsovereenkomst. Van Surinaamse zijde werd gevraagd om in het gezinsmigratiebeleid rekening te blijven houden met 'Surinaamse maatstaven'. ${ }^{118}$ Dit keer weigerde de Nederlandse delegatie echter om voor niet-huwelijkse partners en verruimde gezinshereniging van Surinamers af te wijken van het regulier vreemdelingenbeleid. ${ }^{119}$ In november 1980 leidde de harde opstelling van de Nederlandse delegatie in deze bijna tot een breuk in de onderhandelingen, maar ze hield voet bij stuk. ${ }^{120}$ In de vestigingsovereenkomst die op 24 november 1980 werd ondertekend was van bijzondere voorwaarden voor de toelating van gezinsleden van Surinamers geen sprake. ${ }^{121}$

In 1980 kwamen nog meer dan 18 duizend Surinamers naar Nederland. Vanaf 1981 was het migratieregime voor Surinamers vrijwel gelijk aan dat voor andere vreemdelingen. Datzelfde jaar al zakte het aantal migranten uit Suriname tot onder de 5 duizend. Op een incidentele stijging tot 6 duizend

114 Notulen ministerraad, 6 april 1979. NA IND 871.

115 De werkgroep sloot daarmee expliciet aan bij het eerder dat jaar verschenen rapport van de WRR, waarin een restrictief toelatingsbeleid als randvoorwaarde voor een succesvol minderhedenbeleid werd beschouwd (zie paragraaf 3.6).

116 Rapport werkgroep immigratie vanuit Suriname, 23 augustus 1979. NA IND 871.

117 Nota hoofd HVG aan loco-SG, 18 januari 1980. NA IND 871.

118 Motie ingebracht door Suriname tijdens ambtelijk overleg over migratievraagstukken in Paramaribo, 27-28 oktober 1980. NA IND 870.

119 Conclusies ambtelijk overleg over migratievraagstukken te Paramaribo, 27-31 oktober 1980. NA IND 870.

120 Notulen Bewindsliedenoverleg Suriname, 20 november 1980. NA IND 870.

121 Toelichtende nota minister van Buitenlandse Zaken voor ministerraad bij Overeenkomst met Suriname inzake de binnenkomst en het verblijf van wederzijdse onderdanen, 8 december 1980. NA IND 870. Het gezinsmigratiebeleid voor Surinamers week in één opzicht af van het regulier beleid: in een bijlage bij de overeenkomst was vastgelegd, dat 'in bijzondere gevallen' toelating kon worden overwogen van gezinsleden die in het land van herkomst niet bij de aanvrager hadden ingewoond, zoals 'moeders die weduwe worden of kinderen die wees worden, en voor wie er in Suriname geen enkele opvang mogelijk is'. 
in 1987 en 8 duizend per jaar tussen 1990 en 1993 na is de jaarlijkse migratie vanuit Suriname sindsdien onder de 5 duizend gebleven. ${ }^{122}$

Waarom het kabinet Den Uyl in 1975 ondanks haar dringende wens om migratie te beperken met dusdanig soepele voorwaarden voor toelating en verblijf van Surinamers heeft ingestemd, is niet met zekerheid te zeggen. ${ }^{123}$ Tijdsdruk zal daarin een rol hebben gespeeld, maar ook de wens om iedere verdenking van racisme of cultureel vooroordeel te vermijden. Zeker voor een kabinet dat in het regulier vreemdelingenbeleid al ruimte had geschapen voor nieuwe gezinsvormen, lag het voor de hand om Surinaamse familieverhoudingen te respecteren. ${ }^{124}$ Dat het kabinet Van Agt in 1980 voor een andere benadering koos, zal wellicht niet alleen te maken hebben met de ervaring van voortdurende migratie vanuit Suriname sinds 1975, maar ook met de minder sterke behoefte van deze centrum-rechtse regering om iedere zweem van moreel of cultureel superioriteitsgevoel ten opzichte van de voormalige kolonie verre van zich te werpen.

\subsection{Paradigmawisseling: van gasten naar volwaardige mede- burgers}

\section{Het tijdelijkheidsdenken onder druk}

We hebben in hoofdstuk 2 gezien, dat het parlementair debat over de Memorie van Antwoord van 1974 nog werd beheerst door de veronderstelling, dat arbeidsmigranten spoedig terug zouden keren naar hun landen van herkomst. Enerzijds was men het er over de volle breedte van het politieke spectrum over eens dat de grootschalige, permanente vestiging van vreemdelingen in Nederland ongewenst was. Anderzijds was er de sterke morele overtuiging dat de Nederlandse politiek verantwoordelijkheid droeg voor het welzijn van de arbeidsmigranten in Nederland, een morele overtuiging die zich vertaalde in het standpunt dat aan gezinshereniging niets in de weg mocht worden gelegd. ${ }^{125}$

122 Website van het CBS, Historie bevolking: buitenlandse migratie naar geboorteland, statline.cbs.nl.

123 Zie Schuster 1999: 161.

124 Van Walsum (2008: 150-151) suggereert dat de gang van zaken rond de Surinaamse onafhankelijkheid de erkenning van niet-huwelijkse relaties in het regulier vreemdelingenbeleid heeft versneld. Uit mijn archiefonderzoek blijkt echter dat tot die erkenning al in 1973 was besloten en dat het verband dus veeleer andersom moet worden gelegd.

125 Zie paragraaf 2.8 . 
Deze ambiguïteit bleef ook in de tweede helft van de jaren zeventig het vertoog van regering en parlement kenmerken. Ondanks het regeringsbesluit om de immigratie naar Nederland tot een minimum terug te brengen, lieten de migratiecijfers jaar na jaar een positief saldo zien. Schwarz (D66) concludeerde in 1976: 'Wij zijn dus eigenlijk al die jaren voor het lapje gehouden, denkend dat er een restrictief beleid zou worden gevoerd'. De minister van Justitie en staatssecretaris van Sociale Zaken dienden hem van repliek door te wijzen op de omvang van gezinshereniging, die zij beschreven als een 'feitelijk gegeven'. ${ }^{126}$ Het gezinsherenigingsbeleid stond klaarblijkelijk niet ter discussie: de wens om een restrictief toelatingsbeleid te voeren strekte zich niet uit tot deze vorm van migratie.

In het welzijnswerk van de jaren zeventig kwam diezelfde spanning tot uiting in het 'tweesporenbeleid' dat het ministerie van CRM voerde. Onder het motto 'integratie met behoud van eigen identiteit' moest enerzijds integratie in de Nederlandse maatschappij worden bevorderd en anderzijds terugkeer worden gestimuleerd. ${ }^{127}$ Uitgangspunt was dat migranten in staat moesten worden gesteld om in vrijheid een keuze te maken tussen blijven of terugkeren. Zo werden er faciliteiten voor onderwijs in eigen taal en cultuur opgezet, opdat kinderen van migranten na hun terugkeer weer in konden stromen in het onderwijs in het land van herkomst. ${ }^{128}$

Naarmate de gezinshereniging van Turkse en Marokkaanse arbeidsmigranten in omvang toenam en de maatschappelijke implicaties daarvan zichtbaar werden, kwam de veronderstelling van tijdelijk verblijf steeds sterker onder druk te staan. Dit werd nog versterkt door de steile stijging van de immigratie vanuit Suriname. ${ }^{129}$ Het tijdelijkheidsdenken was echter zo stevig verankerd in de percepties en verwachtingen van Nederlandse politici, dat het niet van de ene op de andere dag zijn betekenis verloor. Pas eind jaren zeventig vond een fundamentele paradigmawisseling plaats in de visie van de Nederlandse politiek op het migratievraagstuk: van een

126 EK 1975-1976 Handelingen 2 maart 1976: 528; TK 1976-1977 Handelingen 21 oktober 1976: 618.

127 De leus 'integratie met behoud van eigen identiteit' wordt tegenwoordig vooral geassocieerd met het minderhedenbeleid dat in de jaren tachtig werd gevoerd. In feite namen zowel de WRR in zijn rapport van 1979 als de ambtenaren die verantwoordelijk waren voor het minderhedenbeleid expliciet afstand van deze gedachte, die zij associeerden met de veronderstelling van tijdelijk verblijf, ten gunste van een streven naar actieve participatie van minderheden en van actief overheidsbeleid om dat te bevorderen. (Molleman 1978: 332-333; wRR 1979: 20-21; Molleman 2004: 42; Vink 2007: 344)

128 Entzinger 1984: 87, 117; Hoppe 1987: 43; Scholten 2007: 78-80.

129 Ook het verblijf van Surinamers in Nederland werd tot eind jaren zeventig als tijdelijk beschouwd. Van Amersfoort 1987: 487-488. 
'tijdelijkheids-' of 'gastarbeiders-paradigma' naar een 'minderheden-paradigma'. Waar migranten voorheen als tijdelijke gasten werden beschouwd, zouden zij nu worden aanvaard als permanente leden van de Nederlandse samenleving, wier volwaardige positie en participatie door de overheid moest worden gewaarborgd.

In het totstandbrengen van die omslag heeft een strategische coalitie van beleidsmakers van CRM en sociaal wetenschappers een doorslaggevende rol gespeeld. Vanuit hun betrokkenheid bij de opvang en begeleiding van vreemdelingen werden ambtenaren van CRM direct geconfronteerd met de maatschappelijke gevolgen van de toename van migrantengezinnen in Nederland. In de tweede helft van de jaren zeventig ging CRM steeds krachtiger pleiten voor een coherent overkoepelend beleid ten aanzien van migranten, een beleid dat uit zou moeten gaan van het blijvend karakter van hun verblijf in Nederland. ${ }^{130} \mathrm{Om}$ de overtuigingskracht van dat pleidooi tegenover andere ministeries te versterken, deed CRM een beroep op de expertise van sociologen en antropologen inzake migratie en migranten. ${ }^{131}$ Het ministerie ontwikkelde zich tot de belangrijkste financier van migratieonderzoek in Nederland en richtte in 1978 de Adviescommissie Onderzoek Culturele Minderheden (АСОМ) op, waarin 'almost all researchers involved in the immigration domain' bijeen werden gebracht. ${ }^{132}$ Onder hen waren onderzoekers als Hans van Amersfoort en Han Entzinger, die in wetenschappelijke publicaties al sinds 1973 de vloer aanveegden met het officiele regeringsstandpunt dat Nederland 'geen immigratieland' was. ${ }^{133}$

In 1979 schreef Rinus Penninx, ook lid van de ACOM, in opdracht van de Wetenschappelijke Raad voor het Regeringsbeleid (WRR), een rapport dat de kroon vormde op de wetenschappelijke inspanningen om de maatschappelijke positie van migranten op de politieke agenda te krijgen. ${ }^{134}$ Penninx leverde onomwonden kritiek op wat hij 'de fictie van de tijdelijkheid en het ontbreken van lange-termijn-denken' noemde en pleitte voor een actief en gecoördineerd 'minderhedenbeleid' ${ }^{135}$ Het rapport werd integraal opgenomen in het advies van de WRR aan de regering en lag aan de wieg van het minderhedenbeleid, zoals dat in de jaren tachtig zou worden gevoerd.

130 Jansen 2006: 161-162; Penninx 1979: 155; De Hart \& Prins 2005: 183; Zie ook verslag vergadering Commissie Beleid Buitenlandse Werknemers, 27 april 1978. NA IND 2468.

131 Scholten 2007: 134; Rath 1991: 169-174; De Hart \& Prins 2005: 183.

132 Scholten 2007: 101; Zie ook Penninx 1988: 16.

133 Van Amersfoort 1973, 1974; Entzinger 1975.

134 Scholten 2007: 90-92, 102-105, 131.

135 Penninx 1979: 163-173. 


\section{Het minderhedenbeleid}

Het pleidooi vanuit welzijnswerk en sociale wetenschappen voor een actief migrantenbeleid viel zowel in de Nederlandse politiek als bij het bredere publiek in steeds vruchtbaarder aarde. Eind jaren zeventig waren de immigratiecijfers, door instroom van Surinamers en gezinsleden van arbeidsmigranten, ongekend hoog. De opkomst van de extreem-rechtse NVU en etnische rellen in Rotterdam en Schiedam in 1972 en 1976 droegen ertoe bij dat migratie een gepolitiseerd vraagstuk werd, dat om een beleidsrespons vroeg. Een laatste aanzet tot verandering kwam met de schok die de Molukse treinkapingen veroorzaakten. ${ }^{136}$ In de parlementaire debatten over de gijzelingsacties, in 1978, diende Henk Molleman ( $\mathrm{PvdA}$ ) een motie in om een consistent minderhedenbeleid in te voeren, dat gecoördineerd zou moeten worden vanuit het ministerie van Binnenlandse Zaken. Op uitnodiging van minister van Binnenlandse Zaken Hans Wiegel (VvD) werd Molleman in 1979 hoofd van de nieuwe Directie Coördinatie Minderhedenbeleid. ${ }^{137}$

Datzelfde jaar presenteerde de WRR haar rapport, Etnische minderheden, waarin zij stelde dat het beleid 'zal uit moeten gaan van de mogelijkheid van een permanent verblijf in Nederland' en zich daarom diende te richten op 'gelijkwaardige deelneming van de minderheden aan de Nederlandse samenleving' ${ }^{138}$ In maart 1980 gaf het kabinet Van Agt een eerste reactie op het rapport, waarin het de belangrijkste conclusies overnam. ${ }^{139}$ Daarmee was een cruciale omslag gemaakt: migranten werden niet langer als tijdelijke gasten gezien, maar als permanente inwoners van Nederland, die volwaardig en gelijkwaardig moesten kunnen participeren in de maatschappij. Deze nadrukkelijke insluiting van migranten is het meest fundamentele aspect van het nieuwe dominante beleidsperspectief op het migratievraagstuk.

De regering werkte haar beleidsvoornemens verder uit in de ontwerp-minderhedennota van 1981 en de definitieve Minderhedennota van 1983..$^{140}$ Doelgroepen van het minderhedenbeleid waren Molukkers, Surinamers, Antillianen, arbeidsmigranten en hun gezinnen, zigeuners,

136 Scholten 2007: 98-99.

137 Hoppe 1987: 42; Scholten 2007: 107-110; Molleman 2004: 38, 41.

138 WRR 1979: 39.

139 тк 1980-1981 16102 (6).

140 тK 1982-1983 16102 (21); De ontwerp-minderhedennota is niet als Kamerstuk gepubliceerd, maar zie daarover: Entzinger 1984: 121-131; Fermin 1997: 165-167. 
woonwagenbewoners en vluchtelingen. De doelstelling van het beleid was drieledig: maatschappelijke emancipatie en participatie van minderheden, het verminderen van sociaal-economische achterstanden, en het voorkomen van discriminatie en verbeteren van de rechtspositie. De beleidsinstrumenten waarmee dit moest worden gerealiseerd varieerden van tolken in de gezondheidszorg, grotere woningen en aangepaste vakopleidingen tot lokaal stemrecht, verbetering van de rechtsbijstand en anti-discriminatiewetgeving. ${ }^{141}$

Het minderhedenbeleid gaf geen aanleiding tot verhitte politieke debatten. Er waren wel meningsverschillen, maar op de kleine christelijke partijen en de Centrumpartij van Janmaat na steunden alle politieke partijen het regeringsbeleid. ${ }^{142}$ Thränhardt stelt: 'an attitude of pragmatic compromise became prevalent, with rising optimism about the possibility [of] solving existent problems, and a sense of pride about The Netherlands as an open and tolerant country'. ${ }^{143}$ Die politieke consensus is ook beschreven als een strategische keuze van Nederlandse politici en beleidsmakers om, in de woorden van Guiraudon, 'onnodige provocatie van de publieke opinie te vermijden'. ${ }^{144}$ Het feit dat de in 1980 opgerichte Centrumpartij in 1982 voor het eerst een zetel in het parlement behaalde, heeft er waarschijnlijk toe bijgedragen dat de Nederlandse politiek de rijen sloot. ${ }^{145}$ Uit onwil om xenofobe tendensen in de Nederlandse samenleving te voeden, werden politieke conflicten over het minderhedenbeleid vermeden of binnenskamers gehouden. ${ }^{146}$

Gezinsmigratiebeleid, minderhedenbeleid en de 'rechten' van migranten

Al in het rapport van de WRR in 1979 was een expliciet verband gelegd tussen het toekomstige minderhedenbeleid en het toelatingsbeleid. De WRR stelde:

141 Fermin 1997: 165; Entzinger 1984: 121, 123; Bruquetas-Callejo e.a. 2006: 15.

142 Fermin 1997: 152-153, 179-188, 242-243.

143 Thränhardt 2000: 171.

144 'éviter de provoquer inutilement l'opinion publique'. Guiraudon 2000: 141.

145 Penninx 1988: 168-169; Scholten 2007: 125-126.

146 Guiraudon 2000: 139-153; Thränhardt 2002: 237-238; De Beus 1998; Scholten 2007: 139140. 
De bevordering van gelijkwaardige deelneming van de aanwezige etnische minderheden in onze samenleving vergt grote en kostbare inspanningen. Grote nieuwe immigrantenstromen zouden deze tot onoverzienbare proporties doen uitgroeien. Een belangrijk element van het te voeren beleid, namelijk verbetering van de positie op de arbeidsmarkt (...), zou door de toevloed van nieuwe buitenlandse arbeidskrachten niet tot uitvoering gebracht kunnen worden. Aldus zou allengs een naar verhouding groot proletariaat ontstaan, dat grotendeels is samengesteld uit leden van minderheidsgroepen (...). Een actief beleid gericht op gelijkwaardige deelneming van etnische minderheden vergt derhalve een restrictief immigratiebeleid..$^{147}$

De regering nam dit standpunt van de WRR over. In de Minderhedennota noemde de regering het voeren van een restrictief toelatingsbeleid een 'randvoorwaarde voor het realiseren van het minderhedenbeleid'. ${ }^{148}$ Het parlement steunde het standpunt dat de instroom van nieuwe vreemdelingen tot een minimum moest worden beperkt, om de vreemdelingen die al in Nederland waren de kans te geven zich een plaats te veroveren in de maatschappij. Al in haar eerste reactie op het wRR-rapport maakte de regering echter duidelijk, dat gezinshereniging 'buiten het beperkende beleid [zou] worden gehouden' ${ }^{149}$ De Nederlandse politiek was het er over eens dat de komst van gezinsleden van migranten niet mocht worden belemmerd.

Deze stellingname hing nauw samen met de insluiting van migranten als permanente en volwaardige leden van de Nederlandse samenleving. Daaruit vloeide het streven voort om gevestigde vreemdelingen waar mogelijk gelijk te behandelen aan Nederlandse staatsburgers, ook waar het de voorwaarden voor overkomst van buitenlandse gezinsleden betrof. Het versterken van de rechtspositie van migranten en het vermijden van discriminatie behoorden tot de primaire doelstellingen van het minderhedenbeleid. De Асом had er in 1978 al op gewezen, dat een sterke rechtspositie - in de eerste plaats zekerheid over het recht om in Nederland te blijven - een noodzakelijke voorwaarde was voor de integratie van migranten in Nederland. ${ }^{150}$ Bovendien was gelijke behandeling, sinds de culturele revolutie van de jaren zestig, een norm die de Nederlandse politiek zeer

147 WRR 1979: 35.

148 тK 1982-1983 16102 (21): 144.

149 тк 1980-1981 16102 (6): 14.

150 Van Walsum 2008: 168. 
hoog in het vaandel droeg. Nieuw Links, een groep jonge PvdA-leden die streefde naar vernieuwing van partij, politiek en samenleving, drukte het in 1966 zo uit: 'Vrijheid, gelijkheid en broederschap. De meeste van deze is gelijkheid'. ${ }^{151}$ Niet iedereen deelde dit revolutionair elan, maar 'gelijkheid van kansen en rechten op ontplooiing' nam bij zowel sociaaldemocraten als liberalen en christendemocraten 'een vooraanstaande plaats in'. ${ }^{152}$ Aan gevestigde migranten dienden dus dezelfde rechten te worden toegekend als aan Nederlanders, ook op het gebied van gezinshereniging.

De term 'rechten' verdient nadere beschouwing. Nederlandse politici spraken in de jaren zeventig en tachtig veelvuldig over het 'recht op gelijke behandeling' en het 'recht op gezinshereniging'. Het is echter van belang te onderkennen dat het hier niet zozeer ging om juridische normen, die door de rechtbanken werden afgedwongen, als om politiek-ethische normen. Zo is ongelijke behandeling op grond van nationaliteit vanuit juridisch perspectief toelaatbaar, zolang deze gerechtvaardigd is. Nederlandse en Europese rechtbanken lieten en laten het democratisch gelegitimeerd bestuur hierbij de nodige ruimte, bijvoorbeeld om staatsburgers een geprivilegieerde positie toe te kennen ten opzichte van vreemdelingen. Wanneer Nederlandse politici spraken over het 'recht op gelijke behandeling' verwezen zij dus niet naar uitspraken van de rechter, maar naar hun eigen normatieve overtuiging.

Iets vergelijkbaars geldt voor het 'recht op gezinshereniging': een dergelijk ongeclausuleerd recht was noch in de Nederlandse wet, noch in internationale verdragen vastgelegd. Staten hebben het recht om te beschikken over toelating en verblijf van vreemdelingen op hun grondgebied: individuen hebben recht op gezinsleven. De rechter maakte daartussen een afweging, die slechts bij uitzondering uitmondde in een verplichting voor de staat om buitenlandse gezinsleden verblijf toe te staan. Rechtbanken toonden zich zeer terughoudend bij het inperken van de soevereiniteit van staten over het vreemdelingenbeleid. ${ }^{153}$ Het 'recht op gezinshereniging' waarover in de jaren zeventig en tachtig gesproken werd verschilde niet

151 Manifest Tien over rood, geciteerd in Lucardie 1989: 126.

152 Lucardie 1989: 132-133. Volgens Hondius (2001: 173-174) was er sprake van een 'nationale consensus' rond afkeer van discriminatie en racisme, die direct verbonden was aan de herinnering aan de Jodenvervolging tijdens de Tweede Wereldoorlog. (Vgl. Vuisje 1986: 7-8; Tinnemans 1994: 251-258; Daalder 1995: 77) Ik ben noch in ambtelijke, noch in parlementaire stukken verwijzingen naar de oorlog tegengekomen, maar het is zeer wel mogelijk dat dit verband, dat in het maatschappelijk debat wel werd gelegd, het belang dat beleidsmakers hechtten aan gelijke behandeling van Nederlanders en migranten heeft versterkt.

153 Zie paragraaf 3.3 en 4.2 . 
wezenlijk van de morele norm van gezinseenheid waar Kamerleden in de jaren vijftig en zestig zoveel waarde aan hechtten. Het verwoorden van dergelijke normen in termen van 'rechten' maakte deel uit van de manier van spreken die Nederlandse politici zich sinds de late jaren zestig hadden eigengemaakt.

De norm van gelijke behandeling mondde, zoals wij zullen zien, uit in een aantal wezenlijke versoepelingen van het gezinsmigratiebeleid. Dat het 'recht' op gelijke behandeling en gezinshereniging in de ogen van Nederlandse beleidsmakers zwaarder woog dan het algemeen belang bij een restrictief toelatingsbeleid, had niet alleen te maken met het gewicht van deze morele normen, maar ook met de manier waarop de gevolgen van gezinsmigratie voor de Nederlandse maatschappij werden ingeschat. Scholten heeft laten zien hoezeer de politici en ambtenaren die rond 1980 het nieuwe minderhedenbeleid ontwierpen erop vertrouwden, de maatschappelijke gevolgen van immigratie te kunnen opvangen. Dat optimisme vloeide voort uit de overtuiging dat het mogelijk was om door overheidsingrijpen maatschappelijke verandering tot stand te brengen. De betrokken beleidsmakers, Molleman voorop, veronderstelden dat wanneer het 'jojoeffect' van het politieke spel kon worden vermeden en zij de ruimte kregen om op basis van wetenschappelijke expertise een rationeel beleid op te zetten, het vraagstuk van de integratie van minderheden in de Nederlandse samenleving effectief kon worden opgelost. ${ }^{154}$

Dit vertrouwen vond deels zijn grondslag in de overtuiging dat de grootschalige vestiging van (post)koloniale migranten en arbeidsmigranten een accident of history was, dat zich niet zou herhalen. ${ }^{155}$ Voortaan zouden de Nederlandse grenzen gesloten zijn: het minderhedenbeleid zou de maatschappelijke integratie van de aanwezige minderheden bewerkstellingen en zichzelf zo binnen afzienbare tijd overbodig maken. ${ }^{156}$ Ook gezinsmigratie werd in de late jaren zeventig en vroege jaren tachtig als een eenmalige en eindige migratiestroom beschouwd. Wanneer de reeds in Nederland verblijvende migranten hun gezin zouden hebben laten overkomen, zou de gezinshereniging 'afgerond' zijn. De verwachting was dat de stroom gezinsherenigers tegen het einde van de jaren tachtig zou zijn

154 Scholten 2007: 125-128.

155 Snel \& Scholten 2005: 166; Molleman 2004: 38; Bruquetas-Callejo e.a. 2006: 4.

156 Scholten 2007: 126. 
opgedroogd. ${ }^{157}$ Binnen het ministerie van Justitie werden bij die veronderstelling reeds in de vroege jaren tachtig vraagtekens gesteld, toen bleek dat ook de kinderen van migranten veelvuldig kozen voor een partner uit het land van herkomst. Wij zullen later zien dat die constatering aanleiding was voor één van de schaarse restrictieve hervormingen die in de jaren tachtig zijn doorgevoerd, een hervorming die echter na minder dan twee jaar alweer werd teruggedraaid. ${ }^{158}$

In de jaren tachtig stond het liberaal gezinsmigratiebeleid dus politiek niet ter discussie, ondanks de algemeen aanvaarde doelstelling om immigratie tot een minimum terug te brengen, omdat aan de norm van gelijke behandeling en het recht op gezinshereniging een bijzonder gewicht werd toegekend en omdat de gevolgen van gezinsmigratie voor de Nederlandse maatschappij met optimisme en vertrouwen tegemoet werden gezien. ${ }^{159}$

\section{De omslag bij Justitie}

In 1979 presenteerde Haars (CDA), staatssecretaris van Justitie in het eerste kabinet Van Agt, de Notitie Vreemdelingenbeleid aan de Tweede Kamer. Deze notitie beoogde een overzicht te bieden van het bestaand beleid, dat als basis kon dienen voor een 'zinvolle discussie' met de Kamer over de voorwaarden voor toelating en verblijf van vreemdelingen in Nederland. Hiermee werd een wezenlijke stap gezet richting toenemende parlementaire betrokkenheid bij het vreemdelingenbeleid. Daarnaast bevatte de notitie een aantal beleidswijzigingen, die Justitie gewenst achtte met het oog op 'veranderingen in de feitelijke omstandigheden', met name 'het gegeven, dat het verblijf van buitenlandse werknemers in Nederland meer dan vroeger verondersteld werd van niet-tijdelijke aard is' ${ }^{160}$ Voor het eerst

157 TK 1981-1982 UVC 8 februari 1982: 38; TK 1982-1983 17984 (2): 9-10; Verslag beleidsbespreking staatssecretaris met DVZ, 16 april 1982. NA IND 2775; Nota aan hoofd DVZ, 25 april 1984, NA IND 2522.

158 Zie paragraaf 3.8 .

159 Van Walsum (2008: 173; 2002: 140) voegt daaraan toe, dat gezinshereniging als bevorderlijk werd beschouwd voor de integratie van migranten in de Nederlandse samenleving. In het minderhedenbeleid werd verondersteld dat inbedding in sociaal-culturele collectieve structuren, zoals het gezin, de individuele migrant beter in staat zou stellen zijn plaats te vinden in het nieuwe thuisland. Ook De Hart (2003a: 140) schreef dat men verwachtte dat de vrouw een 'sleutelrol' zou spelen in de integratie van het migrantengezin. Ik ben het argument dat gezinshereniging een positief effect zou hebben op de integratie echter in ambtelijke noch in parlementaire stukken uit de jaren zeventig en tachtig tegengekomen. Het is mogelijk dat het op de achtergrond wel een rol heeft gespeeld. In de jaren negentig werd het wel ingebracht door de PvdA in een debat met het CDA over gezinshereniging van vluchtelingen. Zie paragraaf 4.5.

160 тк 1978-1979 15649 (2): 4. 
werd in een officieel regeringsdocument erkend, dat de aanwezigheid van migranten in Nederland als permanent moest worden beschouwd.

Het ministerie had behoefte aan een 'zinvolle discussie' met het parlement omdat het vreemdelingenbeleid, dat 'nog niet lang geleden aan de uitvoerende instanties voorbehouden scheen', steeds meer in de publieke schijnwerpers was komen te staan. ${ }^{161}$ In hun streven om de instroom van vreemdelingen te beheersen stuitten ambtenaren van Justitie steeds vaker op kritiek van Kamerleden, belangengroepen en media. Zij weten dit aan het 'klimaat' in de Nederlandse samenleving, dat zich tegen een stringente opstelling jegens vreemdelingen verzette:

Waar het in feite om gaat is, om in het licht van enerzijds de huidige en te verwachten economische en sociale omstandigheden, het sociale klimaat in Nederland (soft state, permissive society en een "zacht" sociaal klimaat) en anderzijds de influx van vreemdelingen en de toekomst van de hier toegelaten vreemdelingen en hun familie, beleidslijnen te ontwikkelen die op zodanig brede consensus (in de parlementaire en publieke opinie) kunnen rekenen dat een effectief en consistent beleid gevoerd kan worden. ${ }^{162}$

Justitie wilde het vreemdelingenbeleid zo inrichten en presenteren, dat er voldoende draagvlak zou zijn om het beleid consequent te kunnen uitvoeren. In de eerste plaats moesten de argumenten om een restrictief toelatingsbeleid te voeren helder en overtuigend uiteen worden gezet. Justitie stelde daarbij de bevolkingsdichtheid, die 'tot de hoogste ter wereld behoort', voorop. ${ }^{163}$ Gezien 'de huidige transportfaciliteiten' vormde geografische afstand nauwelijks meer een belemmering voor migratie: nu wereldwijd zoveel mensen in staat waren om naar Nederland te komen, kon niet iedere vreemdeling die daarom vroeg worden toegelaten. De 'traditionele gastvrijheid' diende veeleer tot uitdrukking te komen in een zorgvuldige behandeling van toelatingsverzoeken en in een goede ontvangst na toelating. ${ }^{164} \mathrm{Het}$ is veelbetekenend dat Justitie daarbij opmerkte, dat 'er rekening mee [moet] worden gehouden, dat vele hier verblijvende vreemdelingen te eniger tijd

161 TK 1978-1979 15649 (2): 4.

162 Notitie ten behoeve van beleidsbespreking DVZ met staatssecretaris, 22 januari 1979. NA IND 2861.

163 тк 1978-1979 15649 (2): 6.

164 тк 1978-1979 15649 (2): 8. 
ook hun gezinsleden naar Nederland willen laten overkomen. Dit leidt op zichzelf al tot een niet onbelangrijke immigratie'. ${ }^{165}$ Juist omdat gezinshereniging niet zou worden ingeperkt moest overige migratie des te strenger worden gereguleerd.

In de tweede plaats probeerde Justitie namelijk het draagvlak voor het vreemdelingenbeleid te versterken door de voorwaarden voor toelating en verblijf van gezinsleden te versoepelen. ${ }^{166}$ Belangrijkste grond voor deze hervormingen was een streven naar gelijke behandeling en versterking van de rechtspositie van migranten die al in Nederland waren en wier aanwezigheid nu als blijvend werd beschouwd. ${ }^{167}$

Zo stelde de Notitie Vreemdelingenbeleid dat vluchtelingen voortaan onder dezelfde voorwaarden als Nederlanders hun niet-huwelijkse partners mochten laten overkomen. Die verruiming gold ook houders van een vestigingsvergunning, maar dat vermeldde de notitie niet. ${ }^{168}$ De vestigingsvergunning was een verblijfsstatus die was ingevoerd door de Vreemdelingenwet van 1965. Anders dan de verblijfsvergunning, die jaarlijks verlengd moest worden, was de vestigingsvergunning voor onbepaalde tijd geldig. Deze status bood grote verblijfszekerheid: hij kon bijvoorbeeld niet worden ingetrokken wegens werkloosheid. ${ }^{169}$ In 1981 was het overgrote deel van de migranten uit wervingslanden in het bezit van een vestigingsvergunning. ${ }^{170}$

Ambtelijk Justitie had in 1978 besloten dat niet-huwelijkse partners van vreemdelingen met een 'harde verblijfstitel' zouden worden toegelaten. ${ }^{171}$ Het overwoog daarbij:

165 Persbericht Notitie Vreemdelingenbeleid, 28 juni 1979. NA IND 2862.

166 Alleen op het punt van gezinsmigratie bevat de Notitie concrete beleidswijzigingen. Daarnaast wordt aangekondigd dat aanpassingen worden overwogen op het punt van adoptie van buitenlandse kinderen, vreemdelingen die met het strafrecht in aanmerking komen, illegale arbeid en beroepsmogelijkheden binnen het vreemdelingenrecht. TK 1978-1979 15649 (2): 35-36.

167 Ik bespreek hier de beleidswijzigingen die direct voortvloeiden uit de aanvaarding van migranten als permanente leden van de Nederlandse samenleving. Op andere hervormingen van het gezinsmigratiebeleid die in de Notitie werden gepresenteerd kom ik in paragraaf 3.7 terug.

168 тK 1978-1979 15649 (2): 16.

169 Boeles 1984: 88. Een vreemdeling kon aanspraak maken op een vestigingsvergunning wanneer hij tenminste vijf jaar in Nederland verbleef, duurzaam over voldoende middelen van bestaan beschikte en geen ernstige inbreuk had gemaakt op de openbare orde. Na tien jaar was alleen het openbare orde criterium nog van toepassing. Koens 1983a: 21-22.

170 Groenendijk 1981: 533.

171 Circulaire, 29 juni 1978. NA IND 2635; Aanwijzing vreemdelingenvoorschriften nr. 14, 26 oktober 1978. NA IND 2608. 
Het verblijf van deze categorie vreemdelingen kan en mag men veelal niet als tijdelijk beschouwen en met hun definitieve vestiging in ons land zal rekening moeten worden gehouden. Een behandeling, gelijk aan die welke in overeenkomstige omstandigheden aan Nederlanders wordt gegeven, lijkt voor deze groep vreemdelingen gerechtvaardigd. ${ }^{172}$

Het is verrassend dat de ambtenaren van Vreemdelingenzaken, die in de regel steeds naar restrictie en beheersing van immigratie streefden, een dergelijk standpunt innamen. Kennelijk sijpelde de 'tijdgeest', zoals die in parlement en samenleving leefde en waarin non-discriminatie zo zwaar woog, ook door binnen het ministerie van Justitie.

Vanuit hetzelfde principe van gelijke behandeling werd ook tot een significante versoepeling van het inkomensvereiste besloten. Sinds 1973 werd toelating van de buitenlandse echtgenoot van een Nederlandse vrouw alleen geweigerd vanwege onvoldoende inkomen, indien dit aan henzelf te wijten was. In 1978 werd dit zogenaamde 'verwijtbaarheidscriterium' ook op vluchtelingen en vestigingsvergunninghouders van toepassing. ${ }^{173}$ De betekenis van deze beleidswijziging kan nauwelijks worden overschat. Arbeidsmigranten werden disproportioneel zwaar getroffen door de economische crisis van de jaren tachtig: de werkloosheid onder Turken en Marokkanen steeg van 11,4 procent in 1981 tot 40 procent in 1987. ${ }^{174}$ De versoepeling betekende dat een vreemdeling die onvrijwillig werkloos was, toch zijn gezin naar Nederland kon laten komen. De werkloosheidcijfers laten zien, voor hoeveel mensen deze regeling relevant was. Opvallend genoeg vermeldde de Notitie Vreemdelingenbeleid alleen dat vluchtelingen hun gezin zouden mogen laten overkomen als zij 'niet-verwijtbaar' over onvoldoende inkomen beschikten: dat die regeling ook op houders van een vestigingsvergunning - een veel omvangrijker groep - van toepassing was stond er niet bij. ${ }^{175}$ Dat een zo wezenlijke beleidswijziging werd

172 Nota DVZ, 9 maart 1978. NA IND 2635.

173 Aanwijzing vreemdelingenvoorschriften nr. 14, 26 oktober 1978. NA IND 2608.

174 Penninx 1988: 68, 70.

175 тK 1978-1979 15649 (2): 16. Ik kan dit niet verklaren. Deze beleidslijn is pas in 1980, dus een jaar na het verschijnen van de Notitie Vreemdelingenbeleid, opgenomen in de Vreemdelingencirculaire. (32e wijziging Vc, 9 januari 1980. Documentatie Database CMR) In 1978 was slechts een losse aanschrijving uitgegaan. Zoals eerder opgemerkt, was de regelgeving van het vreemdelingenbeleid eind jaren zeventig bepaald onoverzichtelijk. Wellicht hebben de ambtenaren die de Notitie hebben opgesteld de vrijstelling voor vestigingsvergunninghouders over het hoofd gezien. Zo niet, dan hebben ze deze beleidswijziging bewust verzwegen voor de Kamer: gezien de steun van de Kamer voor een liberaal gezinsherenigingsbeleid zou ik echter niet weten waarom. 
doorgevoerd zonder inspraak van het parlement is op zijn zachtst gezegd opmerkelijk en toont aan dat de parlementaire invloed op het vreemdelingenbeleid weliswaar toenam, maar ambtenaren nog veel ruimte liet om naar eigen goeddunken te handelen.

Verder kondigde de Notitie Vreemdelingenbeleid een substantiële versterking van het verblijfsrecht van de zogenaamde 'tweede generatie' aan. Tot die tijd kleefden aan het recht van kinderen van migranten om in Nederland te blijven de nodige onzekerheden. Zolang zij deel uitmaakten van het gezin was hun verblijfsrecht vrijwel verzekerd, met name als hun vader in het bezit was van een vestigingsvergunning. In dat geval hadden zij na één jaar verblijf in Nederland recht op de zogenaamde '10-lid-2-status' of 'blauwe kaart', een verblijfsstatus die ook gezinsleden van Nederlanders en vluchtelingen kregen en die niet kon worden ingetrokken zolang de gezinsband bestond. ${ }^{176}$ Zodra zij echter meerderjarig werden of om een andere reden het gezin verlieten, was het reguliere vreemdelingenbeleid op hen van toepassing. Dit betekende dat verlenging van hun verblijf geweigerd kon worden als zij niet over voldoende inkomen beschikten of een bedreiging vormden voor de openbare orde. ${ }^{177}$ In de praktijk kon een jonge vreemdeling die in Nederland was opgegroeid dus, wanneer hij of zij 21 werd en werkloos was, het land uit worden gezet. In de Notitie Vreemdelingenbeleid gaf staatssecretaris Haars van Justitie aan, hier verandering in te willen brengen. Het is opvallend, hoezeer Justitie migrantenkinderen definieerde als leden van de Nederlandse samenleving en niet van het land waar zij of hun ouders vandaan kwamen:

Het gaat hier dus om de rechtspositie en het beleid ten aanzien van diegenen die hier in zekere zin reeds geboren en getogen, althans geworteld zijn, wier banden met het land van herkomst vrijwel geslaakt zijn doch die nochtans niet de Nederlandse nationaliteit hebben en op wie de Nederlandse vreemdelingenwet derhalve formeel nog steeds van toepassing is. ${ }^{178}$

Een dergelijke nadrukkelijke insluiting van jeugdige vreemdelingen moest wel leiden tot een substantiële versterking van hun verblijfsrecht. De notitie stelde dat buitenlandse kinderen van de tweede generatie 'alleen dan nog

176 Boeles 1984: 84-85; 92.

177 Koens 1983b: 953.

178 тк 1978-1979 15649 (2): 32. 
voor verwijdering uit ons land in aanmerking kunnen komen in het zeer uitzonderlijke geval waarin sprake zou zijn van een ernstig gevaar voor de nationale veiligheid dan wel van een veroordeling bij gewijsde ${ }^{179}$ wegens een bijzonder ernstig misdrijf, waardoor de betrokkene een bedreiging vormt voor de Nederlandse gemeenschap'. Wanneer de zoon of dochter van een migrant meerderjarig werd, zou deze in aanmerking komen voor een vestigingsvergunning. Indien hij of zij vijf jaar of langer in Nederland verbleef zouden de reguliere 'weigeringsgronden' niet van toepassing zijn. De slotzin van deze passage laat iets zien van de spanning die bestond tussen de insluiting van migranten en hun kinderen als volwaardige leden van de Nederlandse samenleving enerzijds en het streven naar beheersing en controle van ambtelijk Justitie anderzijds: 'ook mogelijke nadelige consequenties verbonden aan de aanwezigheid in ons land van reeds langdurig in onze samenleving opgenomen vreemdelingen [zullen] in verregaande mate worden aanvaard'. ${ }^{180}$

In de Tweede Kamer oogstte de Notitie Vreemdelingenbeleid brede bijval. vVD-Kamerlid Kappeyne van de Coppello complimenteerde de staatssecretaris met 'haar werkelijkheidszin, nu eindelijk te erkennen dat het verblijf van de buitenlandse werknemers meer van blijvende aard is dan tot nog toe werd aangenomen'. Alle partijen, van CDA tot PPR, stemden in met de noodzaak om, 'in een dichtbevolkt land als het onze', een restrictief immigratiebeleid te voeren. De versoepelingen van het gezinsmigratiebeleid passeerden vrijwel zonder commentaar, op een pluim van D66 na. Alleen Van den Broek vroeg zich namens het CDA af, of de toelating van niet-huwelijkse partners van vreemdelingen het niet moeilijk zou maken om misbruik binnen de perken te houden. Wat lette vreemdelingen om zich simpelweg op één adres in te schrijven? Hier wordt het begin zichtbaar van een omslag in de standpunten van de christendemocraten, die tot het midden jaren zeventig immers steeds hadden gepleit voor een soepel gezinsherenigingsbeleid, vanuit hun zorg voor de 'gezinseenheid' van migranten. Van den Broeks twijfels gingen echter niet zover, dat hij om scherpere regelgeving vroeg. ${ }^{181}$

Eind jaren zeventig zette Justitie dus de stap naar aanvaarding van migranten als permanente leden van de Nederlandse samenleving. Dat resulteerde in een versterking van de verblijfspositie van kinderen van

179 Een 'veroordeling bij gewijsde' kan juridisch niet meer worden bestreden.

180 TK 1978-1979 15649 (2): 33-34.

181 тк 1979-1980 oCv 28 januari 1980. 
migranten enerzijds, en in het streven naar gelijke behandeling van Nederlanders en vreemdelingen met een 'harde' verblijfsstatus anderzijds. Met name de vrijstelling van het inkomensvereiste in geval van onvrijwillige werkloosheid was van grote betekenis. Daarbij valt op dat de beleidsversoepeling niet het gevolg was van rechterlijke druk: de rechtbanken aanvaardden het inkomensvereiste, ook wanneer dat niet aan Nederlanders maar wel aan vreemdelingen werd gesteld. ${ }^{182}$ Kamerleden hadden vooraf evenmin om deze hervorming gevraagd. De ambtenaren en staatssecretaris van Justitie hadden de stemming in het parlement echter wel goed aangevoeld.

Op één punt waren houders van een vestigingsvergunning namelijk niet gelijkgesteld aan Nederlanders. Het vereiste van passende huisvesting, dat voor Nederlanders en vluchtelingen niet gold, bleef onverkort op hen van toepassing. Gezien de situatie op de woningmarkt vormde dat in de praktijk een belangrijke belemmering voor gezinshereniging. ${ }^{183}$ Dit stuitte in het parlement op breed protest: in 1980 nam de Tweede Kamer met algemene stemmen een motie aan, waarin zij verzocht om 'aan buitenlandse werknemers die langer dan drie jaar op een woning hebben moeten wachten gezinshereniging toe te staan, ongeacht de kwaliteit van de woning' en om 'kinderen die na een wachttijd van drie jaar meerderjarig zijn geworden en daarom moesten achterblijven, alsnog toe te laten'. ${ }^{184}$ Alleen de tweede helft van de motie werd echter uitgevoerd. ${ }^{185}$ Het huisvestingsvereiste zou tot 2001 blijven bestaan. In de loop van de jaren tachtig verbeterde de toegang van migranten tot de woningmarkt echter, zodat het een minder groot struikelblok opwierp. ${ }^{186}$

\subsection{De Tweede Kamer op de bres voor vrouwenemancipatie}

Vanaf het midden van de jaren zeventig kreeg de emancipatie van de vrouw een officiële plaats op de politieke en ambtelijke agenda in Den Haag. In 1974 werd door het kabinet Den Uyl voor het eerst een coördinerend minister voor emancipatiebeleid aangewezen - minister Van Doorn van CRM - en er werd een extern adviescollege ingesteld om de regering te adviseren

182 Zie bijvoorbeeld Groenendijk \& Swart 1982: 66-68.

183 Nota DVZ, 11 februari 1980. NA IND 2812; Jansen 2006: 210-217, 248-249.

184 тк 1979-1980 oCV 28 januari 1980; тK 1979-1980 15649 (6).

185 Brief staatssecretaris aan voorzitter Vaste Commissie Justitie, 3 juni 1980. NA IND 446.

186 Jansen 2006: 240. 
bij het voeren van een samenhangend emancipatiebeleid, de zogenaamde Emancipatiecomissie, die in 1981 werd omgedoopt tot Emancipatieraad. In juni 1976 stond het emancipatiebeleid voor het eerst officieel op de agenda van de Tweede Kamer. Emancipatie, van oudsher een 'links' onderwerp, werd nu een doelstelling die partij-politieke verschillen oversteeg. Het regeerakkoord van het eerste kabinet Van Agt uit 1977 was het eerste in de geschiedenis dat een paragraaf aan het emancipatiebeleid wijdde. Bij het aantreden van het tweede kabinet Van Agt in 1981 werd Hedy d'Ancona benoemd tot de eerste staatssecretaris voor Emancipatie, op het ministerie van Sociale Zaken. ${ }^{187}$ Deze krachtige politieke agendering van vrouwenemancipatie kon niet anders dan zijn weerslag vinden in discussies over het vreemdelingenbeleid.

De Tweede Kamer speelde daarin een actieve rol. Anders dan in voorgaande decennia namen Kamerleden nu het initiatief tot debat over het gezinsmigratiebeleid en stelden zij concrete beleidswijzigingen voor. Daarbij valt op dat de posities van de politieke partijen in de Kamer begonnen te verschuiven. In de jaren zestig en vroege jaren zeventig waren de christendemocraten en de VVD de meest uitgesproken voorstanders van een soepel gezinsmigratiebeleid. Vanaf de jaren tachtig gingen CDA en VVD voorzichtig enige bedenkingen uiten, vooral waar het misbruik van het gezinsmigratiekanaal betrof. De kleine linkse partijen en de PvdA daarentegen, die zich voorheen veelal afzijdig hielden van discussies over gezinshereniging, ontpopten zich nu als felle behartigers van het belang van migranten bij genereuze voorwaarden voor gezinsmigratie. Dankzij contacten met geëngageerde juristen en belangenorganisaties waren de linkse partijen ook goed op de hoogte van ontwikkelingen in beleid en uitvoeringspraktijk. ${ }^{188}$ De Kamer als geheel, met inbegrip van CDA en VVD, koos in de jaren tachtig echter steeds veeleer voor soepeler dan voor stringenter voorwaarden voor gezinsmigratie. Gezinshereniging werd immers als een recht beschouwd, dat migranten met het oog op het belang van emancipatie en gelijke behandeling niet kon worden ontzegd. 
Gelijke behandeling van mannen en vrouwen in het vreemdelingenbeleid

Sinds 1975 mochten vrouwelijke vreemdelingen die in Nederland woonden een buitenlandse huwelijkspartner over laten komen. Omdat 'omgekeerde' gezinshereniging - mannen die hun vrouw volgden in plaats van andersom - bij Justitie de verdenking van oneigenlijke, economische motieven deed rijzen, was voor vrouwen een vereiste ingevoerd dat voor mannen niet gold: het huwelijk moest tenminste één jaar hebben bestaan.

Tot twee keer toe stelden linkse Kamerleden schriftelijke vragen over deze ongelijke behandeling. In 1977 antwoordde De Gaay Fortman (ARP), minister van Justitie in het kabinet Den Uyl, op vragen van PvdA-Kamerlid Haas-Berger, dat de aanvullende eis werd gesteld om 'misbruik van het huwelijk' te voorkomen, en gerechtvaardigd was omdat dit misbruik 'hoofdzakelijk bij de zogeheten omgekeerde gezinshereniging een rol' speelt. ${ }^{189}$ Zelfs dit progressieve kabinet redeneerde dus vanuit de veronderstelling, dat een man zich in zijn levenskeuzes liet leiden door economische motieven en een vrouw door affectieve overwegingen: een vrouw kwam om bij haar echtgenoot te zijn, een man kwam om te werken. In 1979 concludeerde Beckers-de Bruijn namens de PPR 'dat de wetgever kennelijk nog steeds van mening is, dat een buitenlandse vrouw sneller een onbezonnen huwelijk of zelfs een schijnhuwelijk sluit dan een buitenlandse man'. Zij vroeg de regering, 'in het kader van de emancipatie van de vrouw', het beleid op dit punt te wijzigen. Staatssecretaris Haars (CDA) van Justitie bracht daar opnieuw tegenin dat misbruik van het huwelijksmigratiebeleid door 'een buitenlandse werknemer die niet via de officiële kanalen hier te lande kan worden te werk gesteld' vooral bij de omgekeerde gezinshereniging voorkwam. Desalniettemin toonde de staatssecretaris zich bereid de kwestie te heroverwegen. ${ }^{190}$

Naar aanleiding van deze toezegging van de staatssecretaris werd 'omgekeerde gezinshereniging' aan de orde gesteld tijdens de ambtelijke voorbereiding van de Notitie Vreemdelingenbeleid. DVZ constateerde dat de huidige beleidslijn onhoudbaar was geworden, niet alleen vanwege de Kamervragen, maar ook omdat ze moeilijk te verenigen was met de voorschriften van internationale mensenrechtenverdragen van de VN en de Raad van Europa. Ambtelijk Justitie stelde daarom voor om de vereisten gelijk 
te trekken: ook voor mannelijke vreemdelingen zou voortaan gelden dat de echtgenote pas werd toegelaten als het huwelijk één jaar had bestaan. Aangezien de meeste arbeidsmigranten al lang getrouwd waren, zou dat voor een meerderheid van de mannen geen nadelige gevolgen hebben. Vreemdelingen die pas nadat zij in Nederland waren komen wonen met een buitenlandse vrouw trouwden, zouden echter het eerste jaar van hun huwelijk gescheiden van hun echtgenote moeten leven. DVZ stelde voor om dit aspect in de notitie aan het parlement niet te vermelden. ${ }^{191}$

Voor de andere mogelijkheid, namelijk het geheel laten vallen van het vereiste van één jaar huwelijk, voelde Justitie niets. Een huwelijk met een hier levende vreemdelinge was een al te 'aantrekkelijke manier om te werk gesteld te kunnen worden'. Aan dat bekende motief werd bovendien nog een argument toegevoegd: 'de bescherming van vrouwelijke huwelijkskandidaten'. Jonge migrantendochters zouden onder druk staan van hun familie om met een partner uit het land van herkomst te trouwen, vanwege de 'financiële tegemoetkoming' die daar tegenover stond. ${ }^{192}$ Hier doet een nieuw element zijn intrede in het beleidsdebat over gezinsmigratie: de problematisering van de huwelijkspraktijken van migranten. Ook in de jaren zestig en zeventig leefden bij ambtelijk Justitie zorgen over de 'afwijkende' culturele achtergrond van migranten, maar eind jaren zeventig werden voor het eerst juist de manieren waarop migranten hun huwelijks- en gezinsleven inrichtten benoemd als een cruciaal aspect van dat 'anders-zijn'. De ambtenaren van DVZ meenden dat het in migrantengezinnen niet ongebruikelijk was dat ouders zich bij de keuze van huwelijkspartners voor hun dochters lieten leiden door financieel gewin, en wilden jonge vrouwen daartegen in bescherming nemen door een streng toelatingsbeleid te voeren. In de eerste helft van de jaren zeventig zagen we dat het streven naar restrictie van ambtelijk Justitie versterkt werd door traditionele gendernormen, om uit te monden in controle op schijnhuwelijken en -relaties; hier wordt de wens om migratie te beheersen opnieuw gevoed door een normatieve kijk op het gezin, op grond waarvan de huwelijkspraktijken van migranten als afwijkend en onwenselijk worden beschouwd.

Justitie stuitte echter op weerstand. Ten eerste bleek Sociale Zaken zich in het voorstel om een jaar wachttijd in te voeren voor jonggehuwden absoluut niet te kunnen vinden. ${ }^{193}$ Daar kwam bij dat al meerdere malen een kort

191 Nota hoofd DVZ aan staatsecretaris, 23 april 1979. NA IND 2862.

192 Nota hoofd DVZ aan staatsecretaris, 23 april 1979. NA IND 2862.

193 Nota DVZ, 14 mei 1979. NA IND 2862. 
geding was aangespannen tegen een afwijzing van 'omgekeerde gezinshereniging'. De rechtbanken bleken aarzelingen te hebben ten opzichte van de voorwaarde van één jaar huwelijk: het vereiste mocht worden beschouwd als 'een controlemogelijkheid' in het onderzoek naar de 'realiteit' van het huwelijk, maar 'het niet vervuld zijn van de jaar-termijn behoeft op zichzelf nog niet te betekenen dat er geen reëel huwelijk zou kunnen zijn' ${ }^{194}$ Het is opvallend dat de rechters niet zozeer kritiek hadden op de ongelijke behandeling van mannen en vrouwen, als wel op de deugdelijkheid van de jaartermijn als middel om misbruik te bestrijden. ${ }^{195}$ Dit droeg ertoe bij dat gelijkstelling tot stand werd gebracht door de jaartermijn af te schaffen, in plaats van hem op mannen én vrouwen toe te passen.

In de Notitie Vreemdelingenbeleid van 1979 stond dat met het oog op de gelijke behandeling van man en vrouw gekozen was voor opheffing van het vereiste dat het huwelijk een jaar bestond voordat de echtgenoot van een vreemdelinge werd toegelaten. De notitie stelde daarbij, in navolging van de rechtspraak, de vraag 'of het juist is om de realiteit van een huwelijk te beoordelen aan de hand van een door de overheid vast te stellen termijn gedurende welke het huwelijk moet hebben voortgeduurd'. De regering liet haar achterdocht jegens huwelijksmigratie niet varen, maar nam zich voor voortaan bij de toelating van mannen en vrouwen dezelfde criteria te gebruiken bij het onderzoek of het een 'reëel huwelijk' betrof. ${ }^{196}$

Zo werd het laatste element van ongelijke behandeling van mannen en vrouwen in 1979 uit het Nederlandse vreemdelingenbeleid verwijderd. ${ }^{197}$ Bij de parlementaire behandeling van de notitie werd de staatssecretaris beloond met een compliment van Haas-Berger (PvdA). ${ }^{198}$ Ook de christendemocraten steunden de versoepeling waarmee het beleid in overeenstemming werd gebracht met de norm van gelijke behandeling van man en vrouw. Bij monde van Van den Broek uitte het CDA echter zorgen over 'mogelijkheden om misbruik binnen aanvaardbare grenzen te houden':

194 Nota DVZ, 17 mei 1979. NA IND 2862, onderstreping in origineel; Zie ook Bolten 1981: 609. 195 Zie bijvoorbeeld Groenendijk \& De Swart 1980: 169-171.

196 TK 1978-1979 15649 (2): 15.

197 In 1977 was een andere ongelijkheid opgeheven: de 'blauwe kaart', een vrijwel onaantastbare verblijfsstatus die tot dan toe aan gezinsleden van mannen was voorbehouden, zou ook aan de buitenlandse echtgenoot en kinderen van een vrouw worden toegekend. Wijziging vreemdelingenbesluit en vreemdelingenvoorschrift, 17 december 1977. Documentatie Database CMR.

198 TK 1979-1980 oCV 28 januari 1980: 743. 
Men had die discriminatie natuurlijk ook kunnen opheffen door de termijn van één jaar voor beide categorieën van toepassing te verklaren. $\mathrm{Nu}$ staan wij beslist geen verstrakking op dit punt voor, maar de vraag rijst, hoe de uitvoerende instanties tot een redelijke beoordeling moeten komen. Door een huwelijk met een in Nederland werkende buitenlandse vrouw zal een vreemdeling nu rechtstreeks aanspraak op een verblijfstitel kunnen maken. ${ }^{199}$

Het CDA deelde dus het wantrouwen van Justitie jegens de zuiverheid van de motieven van een buitenlandse man die bij zijn vrouw in Nederland wilde komen wonen, maar wilde daaruit niet de conclusie trekken dat het beleid moest worden aangescherpt. De sterke en eenduidige weerstand in het parlement tegen een restrictieve benadering van gezinshereniging verklaart - meer nog dan de rechterlijke druk - waarom ambtelijk Justitie zich genoodzaakt zag om mannen en vrouwen gelijk te stellen door de vereisten voor vrouwen te versoepelen, in plaats van die voor mannen te verstrakken.

\section{De afhankelijke verblijfsstatus}

Naarmate de gezinshereniging van met name Turkse en Marokkaanse migranten toenam, kwam er in de jaren zeventig meer aandacht voor de positie van 'de buitenlandse vrouw' in Nederland, getuige een toenemend aantal publicaties van welzijnswerk en sociaal wetenschappers dat aan deze kwestie gewijd was. ${ }^{200}$ Lutz heeft laten zien dat in deze publicaties een stereotype werd gecreëerd dat tot op heden een centrale rol speelt in debatten over migratie en integratie: dat van 'de' moslimcultuur als een patriarchale cultuur waarin de vrouw wordt onderdrukt, geweerd uit de publieke ruimte, waarin haar iedere zeggenschap over haar seksualiteit wordt ontzegd omdat die de kern vormt van de familie-eer. Voor Lutz is dit statische, simplistische beeld van de Islamitische maatschappij als traditionalistische tegenpool van de moderne westerse samenleving een vorm van oriëntalisme, die zij fel bekritiseert omdat de buitenlandse vrouw erdoor wordt opgesloten in

199 TK 1979-1980 ocv 28 januari 1980: 752.

200 Zie bijvoorbeeld Mak 1976; Gaikhorst e.a. 1979; Vreede-de Stuers 1979. 
de rol van passief slachtoffer. ${ }^{201}$

Juist op grond van deze beeldvorming werd de integratie van vrouwelijke migranten in de Nederlandse samenleving als een problematisch proces beschouwd, dat om gericht overheidsingrijpen vroeg. In de Nota Emancipatie, proces van verandering en groei van 1977, waarin de regering haar voornemens voor het emancipatiebeleid uiteen zette, werd de oprichting van een ambtelijke Werkgroep Buitenlandse Vrouwen aangekondigd. De ontwikkeling van concreet beleid in deze werd echter belemmerd doordat politici en ambtenaren worstelden met wat zij ervoeren als een spanning tussen respect voor de cultuur en identiteit van migranten enerzijds en de emancipatie van de vrouw anderzijds. ${ }^{202}$

Binnen het vreemdelingenbeleid bestond echter een element dat direct betrekking had op de positie van de buitenlandse vrouw en dat buiten dit spanningsveld viel: de afhankelijke verblijfsstatus van vrouwen van buitenlandse werknemers. Misschien juist omdat dit een beleidsthema was met een uitgesproken emancipatoir aspect dat formeel uitsluitend betrekking had op de relatie tussen overheid en migrantenvrouw, zonder actieve inmenging in de gezinsverhoudingen, grepen niet alleen belangenorganisaties maar ook parlementariërs dit thema met beide handen aan om uitdrukking te geven aan hun betrokkenheid bij de emancipatie van de vreemdelinge. Waar Kamerleden zaken als de handhaving van het huisvestingsvereiste hadden laten passeren, hoewel dat voor veel mannelijke én vrouwelijke migranten eveneens een aanzienlijke belemmering opleverde, plaatsten zij hun volle gewicht achter de versterking van het verblijfsrecht van buitenlandse vrouwen in Nederland.

Het begrip 'afhankelijke verblijfsstatus' had, in strikt juridische zin, betrekking op de verblijfsrechtelijke positie van alle vreemdelingen die in het kader van gezinshereniging naar Nederland kwamen. Zij kregen een verblijfsvergunning met als doel 'verblijf bij ouder of partner' en de overheid behield zich het recht voor om hun verblijf, wanneer het niet meer aan dat doel beantwoordde, te beëindigen. Na vijf jaar verblijf kwamen

201 Lutz 1991: 5-28. Niemand zal ontkennen dat dergelijke problemen zich inderdaad voordeden in moslimgezinnen in Nederland. Het probleem met dit beeld, zoals met alle stereotiepen, is echter dat het een veelheid aan mensen opsluit in een enkelvoudige en onveranderlijke rol: vrouwen in die van passief slachtoffer, mannen in die van vrouwonvriendelijke en zelfs gewelddadige tiran. De vraag is gerechtvaardigd hoeveel moslims en moslima's in Nederland zich in die beeldvorming herkennen, en of het de meest constructieve insteek is om vrouwen met een migratie-achtergrond in hun emancipatie te steunen.

202 Saharso 1995: 244-245, 252, 255-256; Imbos 2006: 54-57. 
gezinsleden, net als andere vreemdelingen, in aanmerking voor een vestigingsvergunning indien zij over voldoende inkomen beschikten. Werd de gezinsband vóór die tijd verbroken, dan verviel hun verblijfsrecht.

In juridische zin was de verblijfsrechtelijke positie van alle buitenlandse gezinsleden dus een afhankelijke, of zij nu mannen of vrouwen waren, kinderen of partners. De maatschappelijke en politieke discussies over de 'afhankelijke verblijfsstatus' spitsten zich echter toe op de positie van de buitenlandse echtgenote tijdens de eerste vijf jaar van haar verblijf in Nederland. ${ }^{203}$ In die discussies verwees het woord 'afhankelijk' niet alleen naar de juridische aard van haar verblijfsvergunning, maar ook en vooral naar de positie van de vreemdelinge binnen haar huwelijk. Koos zij ervoor om haar man te verlaten, of verliet hij haar, dan kon zij het land worden uitgezet. Dit aspect van het vreemdelingenbeleid werd fel bekritiseerd als bekrachtiging door de overheid van de afhankelijke positie van de buitenlandse vrouw ten opzichte van haar echtgenoot. Daarbij speelde de gedachte dat de positie van de vrouw in een islamitisch gezin toch al een beklagenswaardige was op de achtergrond voortdurend een rol.

In de debatten over de afhankelijke verblijfsstatus stond, net als in de discussies over omgekeerde gezinshereniging, het streven van parlementariërs naar emancipatie van de vrouw tegenover de vrees voor schijnhuwelijken van het ministerie van Justitie. In 1979 stelde Beckers-de Bruijn (PPR) deze kwestie aan de orde in schriftelijke vragen. Zij wees erop dat het voor buitenlandse vrouwen bijzonder moeilijk was om werk te vinden, zodat zij na een eventuele scheiding geen verblijfsvergunning konden krijgen vanwege onvoldoende middelen van bestaan. Het gevolg was, zo stelde Beckers-de Bruijn, 'dat zij hun huwelijk noodgedwongen moeten laten voortduren, hetgeen vaak ondraaglijke spanningen met zich meebrengt' en 'dat sommige buitenlandse mannen hun echtgenotes vanuit deze machtspositie het leven zuur maken'. Daarom vroeg zij de staatssecretaris om vrouwen die zich in Nederland bij hun echtgenoot hadden gevoegd, na zekere tijd een zelfstandige verblijfstitel te geven. Staatssecretaris Haars (CDA) antwoordde dat soepeler toegang tot een zelfstandig verblijfsrecht schijnhuwelijken in de hand zou werken, aangezien het aantrekkelijker zou worden om met een Nederlands inwoner te trouwen, 'uitsluitend om (voortgezet) verblijf in Nederland te verkrijgen.' Desalniettemin stemde de staatssecretaris ermee in om haar beleid aanzienlijk te versoepelen. Voortaan zouden buitenlandse

203 In discussies over de verblijfsrechtelijke positie van kinderen werd niet over 'afhankelijkheid' ten opzichte van hun ouders maar over 'emancipatie' gesproken. 
huwelijkspartners na drie jaar verblijf in Nederland een zelfstandige verblijfsvergunning krijgen, omdat dan 'een zodanige band met Nederland verondersteld kan worden dat het afhankelijke karakter van de verblijfstitel wordt opgeheven'. Inbreuk op openbare orde zou nog wel een grond kunnen zijn om het verblijf te beëindigen, maar onvoldoende inkomen zou niet worden tegengeworpen, 'tenzij zulks aan de betrokkene verwijtbaar is'. ${ }^{204}$

Ondanks deze versoepeling kwam er in de jaren die volgden steeds meer kritiek op het beleid van Justitie. De staatssecretaris ontving in 1980 brieven van de FNV en de Emancipatiecommissie. ${ }^{205}$ De Stichting 'Blijf van mijn lijf' zocht de media op om aandacht te vragen voor de situatie van migrantenvrouwen die in steeds groter getale in haar huizen terecht kwamen. ${ }^{206}$ In het kader van de inspraakronde over de ontwerp-minderhedennota kwam vanuit zeer brede kring, variërend van de Twents Turkse Arbeidersvereniging tot het Interprovinciaal Overleg voor maatschappelijk werk, de gemeente Amsterdam en de Raad van Kerken, de vraag om sneller dan wel gemakkelijker een zelfstandige verblijfsvergunning te verlenen aan buitenlandse echtgenotes. ${ }^{207}$ Ook in de pers kwam het thema regelmatig aan de orde. ${ }^{208}$ En dan kwam er nog druk uit het parlement. De Kamer nam met zeer ruime meerderheid een motie aan die was geïnitieerd door Wessel-Tuinstra (D66), waarin de regering werd verzocht om zeker te stellen 'dat de partner, vrouw of man, die in het kader van gezinshereniging 3 jaar legaal in Nederland verblijft, een eigen niet-afhankelijke verblijfsvergunning kan verkrijgen, ongeacht of het gezin na 3 jaar al dan niet uiteen is gevallen'. ${ }^{209}$ Verder stelden zowel Haas-Berger en Buurmeijer (PvdA) als Beckers-de Bruijn (PPR) schriftelijke vragen over de verblijfsstatus van buitenlandse vrouwen. ${ }^{210}$

De PvdA-politici vroegen nadrukkelijk aandacht voor het 'cultuurpatroon' in de landen van herkomst, dat terugkeer voor alleenstaande vrouwen 'zeer bezwaarlijk' maakte. ${ }^{211}$ Het argument dat het leven voor een vrouw

204 TK 1978-1979 Aanhangsel van de Handelingen nrs. 1464 en 968; TK 1978-1979 15649 (2): 17. Het 'verwijtbaarheid'-criterium was identiek aan de inkomenseis die voor toelating in het kader van gezinshereniging werd toegepast.

205 Brief Federatiebestuur FNV aan staatssecretaris, 1 juli 1980; Brief Emancipatiekommissie aan staatssecretarissen van Justitie en CRM, 1 december 1980. NA IND 2774.

206 Van Walsum 2008: 167; TK 1980-1981 Aanhangsel bij de Handelingen nrs. 226 en 227.

207 TK 1981-1982 17501 (2): 4.

208 Nota DVZ aan minister, 31 juli 1981. NA IND 2775.

209 тK 1979-1980 oCV 28 januari 1980: 748; тK 1979-1980 15649 (8), aangenomen op 12 februari 1980: SGP en GVP stemden tegen.

210 TK 1980-1981 Aanhangsel bij de Handelingen nrs. 226 en 227.

211 TK 1980-1981 Aanhangsel bij de Handelingen nr. 226. 
alleen in islamitische samenlevingen buitengewoon moeilijk was werd ook door advocaten ingebracht die migrantenvrouwen bijstonden wier verblijfsrecht in Nederland tegelijk met hun huwelijk was geëindigd. ${ }^{212}$ De rechtbanken toonden zich gevoelig voor dit argument, zodat Justitie in de beoordeling van individuele gevallen rekening ging houden met de situatie van alleenstaande vrouwen in het land van herkomst. ${ }^{213}$

In mei 1981 wijdde de Tweede Kamer een mondeling overleg aan het vraagstuk van de afhankelijke verblijfsstatus. Dat hierover een afzonderlijke vergadering werd belegd, toont aan hoe zwaar het onderwerp voor de Kamerleden woog. Linkse politici pleitten ervoor sneller een zelfstandige verblijfstitel te verlenen: de PvdA na twee jaar, de PSP liefst direct of anders na zes maanden. Staatssecretaris Haars hield echter vast aan de termijn van drie jaar, die ze noodzakelijk vond om schijnhuwelijken tegen te gaan. Zij beloofde wel dat 'een zeer humaan beleid zal worden gevoerd jegens vrouwen die werkelijk in ernstige moeilijkheden zijn geraakt'. De staatssecretaris probeerde dus een algemene versoepeling van het beleid te voorkomen, door de nadruk te leggen op haar bevoegdheid om in individuele gevallen van de algemene beleidsregels af te wijken. ${ }^{214} \mathrm{Zij}$ vond steun bij CDA en VVD, die eveneens vonden dat 'de individuele omstandigheden van de betrokken vrouwen doorslaggevend moeten zijn'. ${ }^{215}$

Een jaar later namen christendemocraten en liberalen een ander standpunt in. De Emancipatieraad had een rapport uitgebracht over de rechtspositie van buitenlandse vrouwen, dat indruk had gemaakt op CDA en VVD. Nijpels verklaarde namens de VVD dat 'het [...] in de meeste gevallen onmenselijk [is] om een buitenlandse vrouw terug te sturen naar het moederland, waar zij immers door de veelal islamitische samenleving niet wordt geaccepteerd'. Ook CDA-woordvoerder Buikema sloot zich aan bij de kritiek van de linkse partijen: 'Met de afhankelijke verblijfstitel van deze vrouwen bezegelt het vreemdelingenbeleid de afhankelijkheid die de maatschappelijke positie van gehuwde vrouwen nog steeds veelal kenmerkt'. Anders dan voorheen verwierp het CDA het meewegen van humanitaire aspecten in individuele gevallen nu als 'een kwestie [...] van casuïstiek,

212 Zie bijvoorbeeld Groenendijk \& Swart 1979a: 124-126; zie ook Van Walsum 1997: 32, 35.

213 TK 1980-1981 Aanhangsel bij de Handelingen nr. 226. Van Walsum (2008: 190; 1997: 32-37) wijst erop dat advocaten van migrantenvrouwen zo onbedoeld hebben bijgedragen aan de stereotiepe beeldvorming van de moslimcultuur als patriarchaal en vrouwonvriendelijk.

214 Deze argumentatie keert steeds terug in het vertoog van de bewindspersonen van Justitie: alle opvolgers van staatssecretaris Haars, tot en met minister Verdonk, zouden er gebruik van maken. 215 TK 1980-1981 16102 (9). 
die weinig rechtszekerheid biedt'. Buikema diende daarom, mede namens PvdA en D66, een motie in waarin de regering werd verzocht 'te onderzoeken of en in hoeverre aan de partner van de hier te lande verblijvende vreemdelingen in plaats van een afhankelijke verblijfstitel een zelfstandige verblijfstitel kan worden verleend.' De motie werd met algemene stemmen aangenomen. ${ }^{216}$ Staatssecretaris Scheltema (D66) van Justitie verklaarde de zorg van de Kamer over de positie van "vrouwen van de "eerste generatie" van buitenlandse werknemers uit de mediterrane gebieden' te delen, maar stelde daarbij: 'Wanneer je maatregelen neemt - en dat is een groot probleem waarmee ik zit - dan neem je zo vlug maatregelen die veel verder gaan dan alleen maar de groep waarom het gaat'. De versoepeling waar de Kamer om vroeg zou immers niet alleen van toepassing zijn op vrouwelijke maar ook op mannelijke huwelijkspartners, wier terugkeer naar het land van herkomst 'zeker niet' zo problematisch was. ${ }^{217}$

In beleidsbesprekingen op het departement over de uitvoering van de motie Buikema bleken de ambtenaren van DVZ niet genegen om de afhankelijke verblijfsstatus op te heffen. Zij braken een lans voor handhaving van het huidige beleid, dat ze logisch en gerechtvaardigd achtten in het kader van een restrictief toelatingsbeleid. Staatssecretaris Scheltema meende daarentegen dat bij ontbinding van het huwelijk een zelfstandige verblijfsvergunning kon worden verleend als het huwelijk tenminste drie jaar bestond en de vreemdeling tenminste één jaar in Nederland verbleef. Aangezien het beleid niet alleen vrouwen maar ook mannen zou gelden, vond de staatssecretaris echter dat de reguliere voorwaarden voor de verlening van een verblijfsvergunning moesten worden toegepast: 'Met name (en in tegenstelling tot het huidige beleid) het vereiste van voldoende middelen van bestaan dient te worden gehanteerd, in die zin dat in schrijnende gevallen het ontbreken van voldoende middelen niet zal worden tegengeworpen'. ${ }^{218}$ De ambtenaren van DVZ steunden hun staatssecretaris in dezen van harte. Zij vonden dat in de Kamer 'een onterecht accent [kwam] te liggen op de positie van (buitenlandse) vrouwen', terwijl in feite het 'merendeel van de zaken waarbij zich huwelijksontbinding voordoet en de vraag naar verblijfsbeëindiging actueel wordt betrekking [heeft] op huwelijken

216 тK 1981-1982 17100-XV (37), met algemene stemmen aangenomen op 9 maart 1982.

217 тк 1981-1982 UvC 8 februari 1982: 36-37.

218 Verslag beleidsbespreking DVZ met staatssecretaris, 14 mei 1982. NA IND 2775. 
van buitenlandse mannen met Nederlandse vrouwen' ${ }^{219}$ Het wantrouwen jegens mannelijke huwelijksmigranten bleef de weerstand tegen versoepeling van het gezinsmigratiebeleid voeden.

Het voorstel van staatssecretaris Scheltema betekende een significante versoepeling van de vereiste verblijfsduur, van drie naar één jaar. Voor echtgenotes van migranten wier huwelijk al geruime tijd bestond voordat zij naar Nederland kwamen, was dit een reële verbetering. Door het vereiste dat het huwelijk al drie jaar bestond, had deze versoepeling echter geen enkel effect voor buitenlandse huwelijkspartners van Nederlanders of van tweede generatie migranten, die meestal direct na hun huwelijk naar Nederland kwamen. ${ }^{220}$ Bovendien werd het inkomensvereiste opnieuw ingevoerd. Juist de meest kwetsbare vrouwen - laag opgeleid, ouder, de taal niet machtig en dus weinig kansrijk op de arbeidsmarkt - werden hierdoor misschien nog afhankelijker van hun echtgenoot dan zij voorheen waren.

Vanuit het ministerie van Sociale Zaken, dat ook verantwoordelijk was voor het emancipatiebeleid, kwam kritiek op de beleidsvoornemens van Justitie: het was 'emancipatoir onjuist' om de zelfstandige verblijfstitel pas te verlenen als huwelijksontwrichting zich voordeed, en niet zodra de termijn van drie jaar huwelijk en één jaar verblijf was verstreken. ${ }^{221}$ Hoe zorgvuldig Justitie ieder individueel geval ook beoordeelde, het was van tevoren moeilijk in te schatten hoe dat oordeel zou uitvallen, zeker voor een vreemdelinge die het Nederlandse systeem niet goed kende. De zorg was immers dat vrouwen die bij hun echtgenoot weg wilden, dat nalieten omdat zij bang waren het land te worden uitgezet. Alleen door de zelfstandige titel al tijdens het huwelijk te verlenen, kon die angst worden weggenomen. Aan de eerdergenoemde motie van Wessel-Tuinstra (D66), die de Kamer in 1980 had aangenomen, lag dezelfde redenering ten grondslag. Op ambtelijk Justitie, dat de zaak vanuit een eng juridisch perspectief bekeek, maakte dit argument echter geen indruk. Zolang het huwelijk duurde was het verblijfsrecht van de vreemdelinge immers verzekerd. Vóór verbreking van het huwelijk een zelfstandige verblijfsvergunning verlenen 'levert veel werk op en is zonder juridisch effect'.222

219 Nota hoofd DVZ aan staatssecretaris, 13 mei 1982. NA IND 2782. Op welke gegevens DVZ deze laatste stelling baseerde heb ik niet kunnen achterhalen: ik acht het niet onwaarschijnlijk dat het om een niet met harde cijfers te staven 'indruk' ging.

220 Van Walsum 2008: 178.

221 Nota DVZ, 15 juli 1982. NA IND 2775.

222 Nota hoofd DVZ aan staatssecretaris, 13 mei 1982. NA IND 2782. 
In de Notitie Afhankelijke Verblijfsstatus (1982) zette staatssecretaris Scheltema (D66) het nieuwe beleid uiteen. Buitenlandse huwelijkspartners zouden na drie jaar huwelijk en één jaar verblijf aanspraak kunnen maken op een zelfstandige verblijfsvergunning, indien hun huwelijk stuk liep. Mochten zij niet over zelfstandige huisvesting en inkomsten beschikken, dan kregen zij - net als arbeidsmigranten - één jaar de tijd om aan de voorwaarden te voldoen. Het inkomensvereiste zou niet worden toegepast op vreemdelingen van wie 'niet redelijkerwijs kan worden gevergd dat deze zich ter beschikking stelt van de arbeidsmarkt', zoals arbeidsongeschikten of ouders van jonge kinderen. Voor vreemdelingen die onder deze nieuwe regels geen verblijfsvergunning konden krijgen, zou nog steeds van geval tot geval worden bezien of 'klemmende redenen van humanitaire aard' zich tegen verblijfsbeëindiging verzetten. ${ }^{223}$

De notitie werd in de Tweede Kamer gemengd ontvangen. Kamerbreed werd de beleidswijziging verwelkomd als een versterking van de rechtspositie van buitenlandse vrouwen. CDA, PvdA, D66 en PSP stelden vragen over de toepassing van het inkomensvereiste. Buikema (CDA) en Van Es (PSP) kwamen opnieuw met het voorstel om steeds na één jaar een zelfstandige titel te verlenen, ook als het huwelijk niet ontbonden was. Pas dan zou het vreemdelingenbeleid 'een echt emancipatoir karakter krijgen'. In haar respons benadrukte staatssecretaris Korte-van Hemel (CDA) van Justitie dat de nieuwe regeling zowel op mannen als op vrouwen van toepassing was en dat 'derhalve het arbeidscriterium is gesteld'; 'de specifieke bescherming van mediterrane vrouwen dient gevonden te worden in de humanitaire gronden'. De staatssecretaris legde de kritische opmerkingen van de Kamer naast zich neer en handhaafde het beleid zoals dat in de notitie uiteen was gezet. ${ }^{224}$

Het is mij niet duidelijk waarom de Kamer, die de afhankelijke verblijfsstatus zo nadrukkelijk op de agenda had geplaatst, hiermee genoegen heeft genomen. De staatssecretaris kwam immers zeer beperkt aan haar wensen tegemoet. Misschien hebben Kamerleden zich zand in de ogen laten strooien door de cryptische formuleringen waarin Justitie het voorstel presenteerde. Zo sloeg Van Es (PSP) de plank volkomen mis met haar stelling dat het inkomensvereiste 'nu ruimer geformuleerd [is] dan het was'. ${ }^{225}$ Het zou ook kunnen dat de Kamer in 1983, op het dieptepunt van

223 тк 1981-1982 17501 (2): 8-12.

224 TK 1982-1983 17501 (4).

225 TK 1982-1983 17501 (4). 
de economische crisis, gevoeliger was voor de vrees voor verkapte arbeidsmigratie en Justitie daarom de ruimte gunde om controle uit te oefenen op voortgezet verblijf van vreemdelingen wier huwelijk was verbroken.

\section{Gelijkstelling van mannen en vrouwen in het nationaliteitsrecht ${ }^{226}$}

In 1979 waren de laatste elementen van ongelijke behandeling van mannen en vrouwen uit het vreemdelingenrecht verwijderd. In 1985 werden mannen en vrouwen ook in het nationaliteitsrecht gelijkgesteld. Tot die tijd konden buitenlandse vrouwen die met een Nederlander trouwden meteen voor de Nederlandse nationaliteit opteren. Buitenlandse echtgenoten van Nederlandse vrouwen daarentegen kwamen, net als andere vreemdelingen, pas na vijf jaar voor naturalisatie in aanmerking. In de manier waarop deze ongelijkheid werd opgeheven speelde de wens om misbruik te voorkomen een belangrijke rol.

Het feit dat de verdenking van 'schijnhuwelijken' zich vooral op mannelijke huwelijkspartners richtte betekende namelijk niet dat huwelijken van Nederlandse mannen met buitenlandse vrouwen nooit met achterdocht werden bezien. Vanaf 1975 werd geregeld bezorgdheid geuit over al dan niet 'georganiseerde praktijken' waarbij vrouwen uit den vreemde - Thailand, de Filippijnen, Ghana, de Caraiben - door een huwelijk toegang tot Nederland verkregen.27 Steeds vaker werd de klacht vernomen dat het nationaliteitsrecht schijnhuwelijken in de hand werkte doordat een huwelijk met een Nederlandse man een al te makkelijke weg naar het Nederlanderschap bood. ${ }^{228}$ In 1985 werd een nieuwe wet op het Nederlanderschap aangenomen. Nederlandse vrouwen kregen - net als Nederlandse mannen - het recht om hun nationaliteit door te geven aan hun kinderen. ${ }^{229}$ Verder zouden echtgenoten van Nederlandse mannen en vrouwen voortaan na drie jaar huwelijk de Nederlandse nationaliteit aan kunnen vragen.

226 Aangezien het nationaliteitsrecht geen deel uit maakt van mijn onderzoek, ga ik beknopt op dit onderwerp in. Zie voor een uitgebreider behandeling Van Walsum 2008: 179-183; De Hart 2003a: 81-83; Heijs 1995: 180-197.

227 Brief en codebericht ambassadeur in Bangkok aan minister van Buitenlandse Zaken, 1 december 1975 en 4 maart 1977. NA IND 1394; Uittreksel notulen vergadering Permanente Commissie van advies voor de zaken van de burgerlijke stand en voor nationaliteitsaangelegenheden, 8 juni 1982. NA IND 1801; Brief burgemeester en wethouders van Rotterdam aan staatssecretaris en vaste kamercommissies van Justitie en Emancipatie, 11 mei 1983. NA IND 2775.

228 Zie bijvoorbeeld verslag overleg DVZ met chefs vreemdelingendiensten, 18 september 1980. NA IND 3393.

229 Van Walsum 2008: 182. 
Voor echtgenoten van Nederlandse vrouwen was dit een kleine verbetering: zij kwamen nu na drie jaar in plaats van vijf jaar in aanmerking voor naturalisatie. De echtgenotes van Nederlandse mannen gingen er echter aanzienlijk op achteruit. Anders dan bij het opheffen van de ongelijkheid tussen 'omgekeerde' en 'gewone' gezinshereniging in 1979 koos men hier dus niet alleen voor positieve maar ook voor negatieve gelijkstelling. De regering gaf hiervoor expliciet als argument dat 'getracht wordt de schijnhuwelijken van Nederlandse mannen met buitenlandse vrouwen tegen te gaan'. ${ }^{230}$

Opmerkelijk genoeg werd een jaar later de controle op schijnhuwelijken opgeheven. ${ }^{231}$ Van Walsum beschouwt dit als een direct resultaat van de wijziging van het nationaliteitsrecht, waardoor Nederlandse mannen met een buitenlandse echtgenote voor het eerst werden geconfronteerd met het vreemdelingenbeleid. Tot 1985 waren zij, als enigen, gevrijwaard van controle op de 'realiteit' van hun huwelijk, doordat hun echtgenote direct Nederlandse kon worden. Daarna vochten zij aantijgingen dat hun huwelijk slechts 'schijn' was aan bij de rechtbanken. Nederlandse vrouwen hadden dat eerder ook al gedaan, soms met succes. Pas nadat Nederlandse mannen de strijd aanbonden tegen deze inmenging van de staat in hun privéleven besloot de Raad van State echter dat de criteria in de Vreemdelingencirculaire afzonderlijk noch tezamen voldoende bewijs leverden dat van een schijnhuwelijk sprake was. De circulaire werd aangepast: voortaan werd een formeel huwelijk met een Nederlands inwoner steeds als voldoende grond voor toelating beschouwd, zonder dat werd nagegaan of en hoe het paar invulling gaf aan zijn huwelijksleven. Alleen niet-huwelijkse relaties werden nog gecontroleerd op 'schijn'.232

\subsection{Restrictieve tendensen in de jaren tachtig}

\section{Een voorzichtige omslag}

Sinds het midden van de jaren zeventig voerde Nederland een restrictief immigratiebeleid, vanwege de 'hoge bevolkingsdichtheid' ${ }^{233}$ In 1979 reikte

230 тK 1982-1983 17501 (4): 9-10.

231 Zie over de controle op schijnhuwelijken en schijnrelaties sinds 1975: paragraaf 3.4.

232 Van Walsum 2008: 185-187; zie ook De Hart 2003a: 91.

233 Persbericht Notitie Vreemdelingenbeleid, 28 juni 1979. NA IND 2862. 
de WRR een nieuw argument aan: wilde de regering de migranten die al een in Nederland waren een volwaardige plaats in de samenleving bieden, dan moest verdere immigratie tot een minimum worden beperkt. ${ }^{234}$ De regering besloot dat een restrictief toelatingsbeleid als een 'randvoorwaarde' voor het minderhedenbeleid moest worden beschouwd. ${ }^{235}$ Nederland zou alleen nog vreemdelingen toelaten indien internationale verplichtingen, een wezenlijk Nederlands belang of humanitaire aspecten daartoe noopten. ${ }^{236}$

Onder die 'humanitaire' toelatingsgrond werd naast het vluchtelingenbeleid in de eerste plaats gezinshereniging begrepen. Zoals staatssecretaris Haars het in 1980 in de Tweede Kamer formuleerde: 'Gezinshereniging is dringend nodig. Men heeft er, als men gedurende langere tijd in Nederland is en men denkt hier te blijven, ook recht op'. ${ }^{237}$ De voorwaarden voor de overkomst van buitenlandse gezinsleden werden aanzienlijk versoepeld. Dit genereuze gezinsmigratiebeleid stond steeds op gespannen voet met de algemene restrictieve doelstelling van het vreemdelingenbeleid. In de jaren zeventig kwam dat reeds tot uiting in zorgen over misbruik van het gezinsmigratiekanaal. In de jaren tachtig liep die spanning echter verder op. De verontrustende economische situatie zal daarin een rol hebben gespeeld.

In een bewindsliedenoverleg in 1980 vestigde premier Van Agt de aandacht op 'het dilemma dat het kabinet gaat zeggen dat de WRR gelijk heeft (...), terwijl intussen 30.000 immigranten per jaar blijven binnenstromen'. Minister Wiegel van Binnenlandse Zaken voegde daaraan toe het 'afschuwelijk' te vinden 'dat steeds weer blijkt dat de overheid de immigratie niet onder controle kan krijgen'. Staatssecretaris Haars van Justitie antwoordde 'dat de overheid hieraan weinig zal kunnen doen tenzij men het criterium gezinshereniging zou durven schrappen'. ${ }^{238}$ In de ontwerp-minderhedennota van 1981 probeerde de regering voorzichtig enige ruimte te creëren om het gezinsherenigingsbeleid aan te scherpen. De nota stelde:

Het welslagen van het minderhedenbeleid zoals dat de Regering voor ogen staat zal worden bevorderd wanneer dit gepaard gaat met nog verdere inperking van de immigratie. Daarbij moet men zich ervan bewust zijn, dat inperkingen voor een niet onbelangrijk deel de vreemdelingen zullen treffen die onder het huidige beleid om humanitaire redenen

234 WRR 1979: 35.

235 TK 1980-1981 16102 (6): 14; тK 1982-1983 16102 (21): 144.

236 TK 1978-1979 15649 (2): 7-8; Nota DVZ, 5 november 1981. NA IND 349.

237 TK 1979-1980 ocv 28 januari 1980: 776.

238 Notulen bewindsliedenoverleg migratie, 7 maart 1980. NA IND 870. 
kunnen worden toegelaten. ${ }^{239}$

De voornaamste humanitaire toelatingsgrond was gezinshereniging. De regering voegde daar weliswaar aan toe, dat gezinshereniging "niet wezenlijk' zou worden ingeperkt, maar dat was toch anders dan haar belofte van een jaar eerder, dat gezinshereniging 'buiten het beperkende beleid [zou] worden gehouden'. ${ }^{240}$ Aanscherping van de voorwaarden werd nu niet langer categorisch uitgesloten.

In maart 1982 werd door ambtelijk Justitie gedebatteerd over de vraag wat de plaats van het gezinsmigratiebeleid moest zijn, in het kader van een restrictief toelatingsbeleid als randvoorwaarde voor een actief minderhedenbeleid. De discussies waren niet op concrete beleidswijzigingen gericht, maar de overwegingen waren veelzeggend:

Hoever willen wij gaan met onze humanitaire beginselen in de praktijk in daden om te zetten en hoever staat de bevolking de overheid toe hierin te gaan. Ieder die emigreert weet of komt er wel achter als hij het nog niet wist toen hij vertrok, dat je veel achterlaat in je land van herkomst. Men kan moeilijk toestaan dat iemand zijn gehele sociale context op zijn rug meeneemt naar Nederland dan wel die later onder welke titel dan ook naar Nederland tracht over te brengen. De vraag is: waar willen wij de grenzen trekken en in hoeverre zijn die grenzen maatschappelijk aanvaardbaar? (...)

Is het humanitair om mensen naar een land te laten komen door toelaters die weten dat zij geen kansen zullen hebben omdat zij zich nimmer met hun autochtone leeftijdsgenoten zullen kunnen meten of daarmee concurreren op de arbeidsmarkt? ?41

Zelfs in het parlement waren kritischer geluiden te horen, en wel uit onverwachte hoek. PvdA-politica Haas-Berger, die zo vaak in de bres was gesprongen voor een liberaal gezinsmigratiebeleid en een sterke rechtspositie voor migrantenvrouwen en -kinderen, uitte in 1982 zorgen over misbruik van het gezinsherenigingsbeleid. $\mathrm{Zij}$ verwees naar de omvang van de instroom van gezinsmigranten en concludeerde: 'wij moeten ons op dit beleid bezinnen':

239 Geciteerd in TK 1982-1983 17984 (2): 4.

240 Ontwerp-minderhedennota, geciteerd in Koens 1983b: 949; тK 1980-1981 16102 (6): 14.

241 Nota Subcommissie Toelatings- en Vreemdelingenbeleid, 10 maart 1982. NA IND 2629. 
een vader die hier zit, wil zijn zonen hierheen halen, terwijl de moeder met de dochters in het land van herkomst verblijven. Wij menen dat dit geen zuivere gezinshereniging is, maar dat dit om puur economische motieven gebeurt. Men kan kijken naar de maximale leeftijd waarop kinderen naar Nederland kunnen en moeten overkomen. Men kan ook kijken naar een minimumtermijn van verblijf in ons land, voordat gezinshereniging kan plaatsvinden.

Dit zijn vragen, geen stellingen..$^{242}$

Wij zullen zien dat de staatssecretaris van Justitie de opening die de PvdA hier bood met beide handen heeft aangegrepen.

\section{De feitelijke gezinsband}

In 1975 was een bepaling in de Vreemdelingencirculaire opgenomen die stelde dat niet alleen de echtgenote en minderjarige kinderen maar ook andere familieleden voor gezinshereniging in aanmerking konden komen indien zij 'in het land van herkomst reeds feitelijk deel hebben uitgemaakt van het gezin van de buitenlandse werknemer en van hem ook afhankelijk zijn' ${ }^{243}$ De bepaling was bedoeld om de overkomst mogelijk te maken van meerderjarige dochters, behoeftige ouders of andere familieleden wier 'achterlating (...) een onaanvaardbare hardheid' zou kunnen betekenen. ${ }^{244}$ Daarmee werd ook ruimte gemaakt voor invullingen van gezins- en familieleven die afweken van wat in Nederland gebruikelijk was. ${ }^{245}$

Begin jaren tachtig bleek dat de uitvoerende diensten niet goed raad wisten met het vereiste dat een vreemdeling 'feitelijk' deel moest hebben uitgemaakt van het gezin. In de praktijk verleenden zij, wanneer het een minderjarig kind was dat om toelating verzocht, steeds een verblijfsvergunning. ${ }^{246}$ Daarom boog de ambtelijke Werkgroep Bijstelling Beleid zich over de interpretatie van het criterium. Eén ambtenaar in die werkgroep had een uitgesproken mening over de zaak. Het Nederlands gezinsherenigingsbeleid was gebaseerd op het 'humanitaire' principe, zo stelde hij,

242 TK 1981-1982 UVC 1 maart 1982: 13-14.

243 Verslag overleg DVZ met chefs vreemdelingendiensten, 27 november 1973. NA IND 3392; 22e wijziging Vc, 7 juli 1975. NA IND 474.

244 тк 1975-1976 13600 н6 (2).

245 Zie paragraaf 3.4.

246 Verslag overleg DVZ met chefs vreemdelingendiensten, 28 september 1983 NA IND 3393; Verslag overleg DVZ met chefs vreemdelingendiensten, 3 oktober 1984. NA IND 3395. 
dat moest worden voorkomen dat de gezinsband verbroken werd. 'In de praktijk' bleek echter, dat dat principe voor betrokkenen zelf veel minder gewicht in de schaal legde: 'Kinderen worden nogal eens jarenlang, soms zelfs vanaf één maand na de geboorte, bij een oom of oma gestald, zonder dat de biologische ouder(s) er verder naar omzien'. In de ogen van deze ambtenaar behoorden kinderen in zo'n geval niet langer tot het gezin van de ouders. Immers, als een kind duurzaam was opgenomen in het gezin van bijvoorbeeld een oom en die oom zou naar Nederland verhuizen, dan zou het kind voor verblijf in aanmerking komen omdat het feitelijk tot het gezin van de oom behoorde. Het sprak voor deze ambtenaar vanzelf dat een kind niet van meer dan één gezin tegelijk deel kon uitmaken. ${ }^{247}$ Uitgangspunt moest dus zijn, dat de gezinsband 'zonder onderbreking' werd voortgezet in Nederland. In de meeste gevallen waarin ouders na langdurige gezinsscheiding alsnog verblijf aanvroegen voor hun - in veel gevallen inmiddels bijna meerderjarige - kinderen, lagen aan die aanvraag economische motieven ten grondslag. De ambtenaar vond daarom dat aan kinderen die door de ouders lange tijd aan de zorg van anderen waren overgelaten, geen verblijf moest worden verleend. Deze lijn vond bijval bij een collega, die meende dat na meer dan vier jaar gezinsscheiding niet langer gezinshereniging moest worden toegestaan. Andere ambtenaren in de werkgroep stonden een minder stringente lijn voor. Zij meenden dat alleen als 'duidelijk blijkt' dat de gezinsband was verbroken verblijf kon worden geweigerd, of zelfs dat het criterium 'feitelijk behoren' niets anders kon betekenen dan dat het kind bij aankomst in Nederland in het gezin zou verblijven. ${ }^{248}$

De stringente interpretatie won het pleit. ${ }^{249}$ In 1986 werd de nadere invulling van het criterium 'feitelijk behoren' opgenomen in de Vreemdelingencirculaire. Gesteld werd dat de gezinsband als 'definitief' verbroken diende te worden beschouwd indien sprake was van:

- duurzame opneming in een ander gezin en de ouder(s) niet meer met het gezag zijn belast of niet (meer) in de kosten van opvoeding en verzorging voorzien;

- het zelfstandig gaan wonen en in het eigen onderhoud gaan voorzien;

- het vormen van een zelfstandig gezin door het aangaan van een

247 Dit is op zichzelf een normatief uitgangspunt. Zie Van Walsum 1999.

248 Brief secretaris werkgroep bijstelling beleid aan voorzitter en leden, 29 oktober 1984. NA IND 2638.

249 Conclusies vergadering werkgroep bijstelling beleid, 31 oktober 1984.; Verslag stafvergadering vZ, 5 november 1984. NA IND 1638. 
huwelijk of relatie..$^{250}$

Zo werd de formulering van 'feitelijk behoren tot het gezin', die oorspronkelijk bedoeld was om familieleden buiten het kerngezin in te sluiten, op ambtelijk niveau geherinterpreteerd om minderjarige kinderen uit te sluiten van gezinshereniging met hun ouders. Waar de bepaling was ingevoerd om rekening te kunnen houden met gezinsvormen die afweken van de Nederlandse norm, lag aan de nieuwe interpretatie een scherp normatief oordeel ten grondslag over de manier waarop aan ouderschap invulling moest worden gegeven. Ouders die hun kind voor langere tijd aan de zorg van een ander hadden overgedragen, konden geen aanspraak meer maken op een bijzondere band met hun kind. Deze invulling van het criterium 'feitelijke gezinsband' bleef ongewijzigd tot in 2001. Pas halverwege de jaren negentig zou zij voor het eerst onderwerp zijn van debat in het parlement. ${ }^{251}$ Dit is dus een treffend voorbeeld van de ruimte waarover ambtenaren ook in de jaren tachtig nog beschikten om naar eigen oordeel invulling te geven aan het beleid.

\section{Een nieuwe beleidscategorie: 'gezinsvorming'}

Vandaag de dag is het in Nederland gebruikelijk om onderscheid te maken tussen 'gezinshereniging' en 'gezinsvorming'. De term 'gezinshereniging' wordt gebruikt voor gevallen waarin het huwelijk al bestond toen beide partners in het buitenland verbleven; 'gezinsvorming' verwijst naar die gevallen waarin één van beide partners al in Nederland verbleef op het moment dat het huwelijk werd gesloten. Dat onderscheid wordt gemaakt in beleidsstukken en in parlementaire discussies, maar ook in de pers en in wetenschappelijke publicaties; het is een vanzelfsprekend onderdeel van het Nederlands begrippenapparaat op het gebied van migratie. Dat is echter niet altijd zo geweest. 'Gezinsvorming' als beleidscategorie is ontstaan, ik zou willen zeggen 'uitgevonden', in de vroege jaren tachtig.

Begin jaren zeventig werd op het ministerie van Justitie voor het eerst gesproken over gezinshereniging door migranten van de tweede generatie. In eerste instantie richtten die discussies zich op de huwelijkspartners van migrantendochters: 'omgekeerde gezinshereniging' was onderwerp van debat omdat voor de toelating van mannelijke huwelijkspartners een

250 Vc 1982, B19 2.2.2 (Vc Suppl. 3 juni 1986). Documentatie Database CMR.

251 Zie paragraaf 4.11 . 
geheel nieuwe beleidslijn moest worden uitgestippeld. In 1973 kwam voor het eerst gezinshereniging door migrantenzonen ter sprake: het ging om jonge Turken die hier opgroeiden, 'tijdens vakantie in Turkije huwen en dan hun vrouw meebrengen' ${ }^{252}$ Dit werd echter aanvankelijk niet als een probleem beschouwd, maar als 'het logisch gevolg van het aantrekken van buitenlandse arbeidskrachten'. Op deze jongemannen waren de reguliere voorwaarden voor gezinshereniging van toepassing. ${ }^{253}$

In 1981 vond er op het departement voor het eerst een discussie plaats over 'gezinshereniging van jeugdige vreemdelingen', naar aanleiding van onduidelijkheid bij de uitvoerende diensten over de toepassing van het inkomensvereiste bij vreemdelingen tussen de 16 en 23 jaar. Moest de nadruk liggen op 'het fundamenteel recht op gezinshereniging' en daarom genoegen worden genomen met het minimum-jeugdloon? Of diende het principe dat vreemdelingen niet ten laste mochten komen van de openbare kas zwaarder te wegen en gezinshereniging dus alleen te worden toegestaan als het inkomen van de aanvrager tenminste op bijstandsniveau lag? Voor jongeren onder de 20 jaar was het 'praktisch onmogelijk' om die norm te halen, voor jongeren tussen de 20 en 23 jaar alleen als zij meerdere banen tegelijk hadden. ${ }^{254}$ Ambtelijk Justitie neigde meteen al naar het vasthouden aan de bijstandsnorm, maar een vlammend betoog van één der DVZ-ambtenaren gaf hierbij de doorslag. Hij vroeg zich af of 'het fundamenteel recht op gezinshereniging' wel op deze vorm van migratie van toepassing was:

Vraag: is hier sprake van gezinshereniging? M.i. niet. In het gunstigste geval kan worden gesproken van gezinsvorming door zeer jeugdigen; als zodanig een geheel nieuw vraagstuk, samenhangend met de problematiek van de tweede generatie. (...)

Problemen veroorzaakt door een laag minimum jeugdloon doen zich alleen voor ten aanzien van hen die nog moeten beginnen. Maar dan is er ook geen sprake van gezinshereniging (...).

De conclusie is dat we de huwelijksproblematiek van de zeer jeugdigen wel serieus moeten nemen, maar niet op dezelfde wijze dienen te honoreren als kwesties rond de hereniging van in het land van herkomst achtergebleven gezinnen van oudere werknemers in Nederland. Zeker niet door candidaat-partners hierheen te trekken.

252 Verslag overleg DVZ met chefs vreemdelingendiensten, 13 september 1973. NA IND 3392. 253 Verslag overleg DVZ met chefs vreemdelingendiensten, 27 november 1973. NA IND 3392. 254 Nota DVZ, 10 april 1981. NA IND 2648. 
En zo deed het woord 'gezinsvorming' zijn intrede in de Nederlandse taal. Vanaf dit eerste begin was de term omgeven door tal van zeer problematische connotaties. De DVZ-ambtenaar schreef verder:

Daarbij dient ook voor misbruiken te worden gewaakt. Van gezinshereniging is in elk geval geen sprake wanneer Turkse of Marokkaanse jongelui, kersvers uit hun land komend, graag op baantjes zich op de Nederlandse huwelijksmarkt verdringen op zoek naar de bruid die hun de weg naar de arbeidsmarkt zal effenen.

Wij behoeven ook niet met bijstandsverlening te honoreren het geval van de voor een huwelijk naar Nederland komende jongeman die zich, al dan niet na illegaal verblijf, door zijn nieuwe echtgenote (en zijn schoonouders) laat onderhouden en bij hen intrekt, in afwachting van het moment waarop hijzelf het schrale gezinsinkomen kan suppleren. (...)

Gezinsvorming op zo wankele financiële poten behoeft de voor het vreemdelingenbeleid verantwoordelijke Minister van Justitie m.i. bepaald niet aan te moedigen, temeer gelet op de juist in deze gevallen zeer reële mogelijkheid van een schijnhuwelijk, althans de kans dat het welzijn van in Nederland in het kader van gezinshereniging toegelaten meisjes wordt opgeofferd aan het financieel gewin van haar eigen familie. ${ }^{255}$

Hier worden opnieuw twee inmiddels bekende argumentatiepatronen uit het vertoog van ambtelijk Justitie gebezigd: in de eerste plaats de verdenking van economische motieven bij mannelijke huwelijksmigranten en in de tweede plaats de perceptie dat huwelijkspraktijken van migranten vrouwen tot slachtoffer maken.

Dit stuk viel bij de collega's op het departement in zeer goede aarde. Binnen enkele maanden was de term 'gezinsvorming' opgenomen in het beleidsjargon van het ministerie van Justitie. In oktober 1981 werd besloten om in de volgende Vreemdelingencirculaire 'gezinsvorming afzonderlijk te behandelen'. Daarmee was niet alleen een nieuwe term, maar ook een nieuwe beleidscategorie geboren: een categorie die aan specifieke - stringente - beleidsregels kon worden onderworpen. Wat het inkomensvereiste

255 Nota DVZ, 9 juli 1981. NA IND 2629. Onderstreping in origineel. 
betrof werd in eerste instantie besloten ook voor jongeren vast te houden aan de bijstandsnorm. Garantstelling door derden - ouders - werd niet geaccepteerd. ${ }^{256}$

Dit kwam de staatssecretaris op kritiek van de kleine linkse partijen te staan. Opnieuw bleek hoezeer de positie van de vrouw deze partijen na aan het hart lag: PPR en PSP meenden dat vooral jonge Turkse en Marokkaanse vrouwen, die vaak jong trouwden, werden gedupeerd en vonden dat een 'uiterst onrechtvaardige zaak'. Staatssecretaris Scheltema (D66) antwoordde dat het niet om een wijziging maar om een verduidelijking van het beleid ging. Hij voegde daaraan toe:

Langs deze weg komen mensen binnen van wie wij niet in alle gevallen kunnen aannemen dat zij, in het kader van onze beperkte mogelijkheden, het beste tot ons land kunnen worden toegelaten. (...)

Ik mag erop wijzen dat hieronder ook mensen vallen die bij voorbeeld op hun $17^{\mathrm{e}}$ of $18^{\mathrm{e}}$ jaar hier zijn gekomen en zeer snel daarna huwen met iemand uit hun vaderland. Ik vind het dan niet voor de hand liggend, gezien de misschien geringe mate van integratie die bij hen is bereikt, dat zij met hun echtgenoot of echtgenote in Nederland zouden kunnen verblijven.

Bovendien is de wijze van partnerkeuze volgens de cultuur van vele betrokkenen soms niet helemaal in overeenstemming met de opvattingen die daarover in ons land bestaan. ${ }^{257}$

Opnieuw werden huwelijkspraktijken van migranten op normatieve gronden geproblematiseerd. Bovendien werd het argument geïntroduceerd, dat gezinsvorming onwenselijk was omdat de aanvrager onvoldoende geïntegreerd zou zijn in de Nederlandse maatschappij.

Naar aanleiding van de eerder geciteerde opmerking van Haas-Berger dat het gezinsherenigingsbeleid om 'bezinning' vroeg, had de staatssecretaris de Kamer beloofd om een notitie op te stellen die als basis kon dienen voor nadere discussie. ${ }^{258}$ In de ambtelijke voorbereiding van deze notitie werd onmiddellijk de vraag geopperd, of 'er grond [is] tot het stellen van strengere kriteria' voor gezinsvorming. ${ }^{259}$ Die vraag werd bevestigend beantwoord.

256 Nota DVZ aan Werkgroep Bijstelling Beleid, 21 oktober 1981. NA IND 2629; Bijlage bij uitnodiging vergadering Werkgroep Bijstelling Beleid, 4 december 1984. NA IND 2638.

257 TK 1981-1982 UVC 8 februari 1982: 39, 43; TK 1981-1982 UvC 1 maart 1982: 15, 18, 29.

258 TK 1981-1982 UVC, 1 maart 1982: 38.

259 Geannoteerde agenda beleidsbespreking DVZ met staatssecretaris, 31 maart 1982. NA IND 2775 . 
In juni 1983 presenteerde Korte-van Hemel (CDA), staatssecretaris van Justitie in het eerste kabinet Lubbers, de Notitie Gezinshereniging en verblijfsrechtelijke positie van kinderen van migranten aan de Tweede Kamer. Deze notitie werd over het algemeen goed ontvangen. Met name het feit dat de rechtspositie van migranten van de tweede generatie werd verduidelijkt en versterkt vond bijval in de Kamer. ${ }^{260}$ De notitie kondigde echter ook een andere beleidswijziging aan, die in minder goede aarde viel. Per 1 oktober 1983 zouden voor gezinsvorming door kinderen van migranten andere voorwaarden gelden dan voor gezinshereniging. In geval van gezinshereniging gold dat houders van een vestigingsvergunning, net als vluchtelingen en Nederlanders, vrijgesteld waren van het inkomensvereiste indien hen niet kon worden verweten dat zij over onvoldoende inkomen beschikten. Nieuw was de bepaling, dat bij gezinsvorming het inkomensvereiste onverkort zou worden toegepast, ongeacht of de aanvrager al dan niet over een vestigingsvergunning beschikte. Een migrant van de tweede generatie die minder dan f. 1445,- (de bijstandsnorm voor gehuwden) verdiende zou zijn huwelijkspartner niet mogen laten overkomen, ook als hij buiten zijn schuld werkloos was. ${ }^{261}$

De staatssecretaris gaf een aantal argumenten voor deze beleidswijziging. Zij ging uitgebreid in op de migratieprognoses van het Sociaal en Cultureel Planbureau (SCP), waaruit bleek dat gezinsvorming een steeds groter deel van de gezinsmigratie uit Turkije en Marokko uitmaakte. Het SCP verwachtte dat tussen 1982 en 1990 tussen de 15 en 17 duizend Turken en Marokkanen via gezinsvorming naar Nederland zouden komen. ${ }^{262}$ Gezinshereniging werd nog steeds als eindig en eenmalig beschouwd: de verwachting was dat deze migratiestroom eind jaren tachtig zou zijn 'afgerond' ${ }^{263}$ Voor gezinsvorming gold dat echter niet. Het feit dat de kinderen van migranten voor partners uit het land van herkomst kozen, opende het zicht op een potentieel oneindige kettingmigratie: een bron van nieuwe instroom waarvan de grenzen qua duur noch qua omvang konden worden overzien.

De vrijstelling van het inkomensvereiste van primaire migranten die een vestigingsvergunning bezaten en onvrijwillig werkloos waren, vond haar grondslag in

260 тк 1982-1983 17984 (2): 15; Van Walsum 2008: 173-174; Koens 1983b: 953, 955-956.

261 тк 1982-1983 17984 (2): 12-13.

262 тк 1982-1983 17984 (2): 10-11.

263 тк 1982-1983 17984 (2): 10. 
de overweging dat primaire migranten (...) deze vergunning vanwege hun gunstig arbeidspatroon hebben verkregen en een belangrijke bijdrage hebben geleverd aan de Nederlandse economie. Zij verblijven reeds lange tijd, met achterlating van hun gezin, hier te lande.

Voor huwelijkspartners van zonen en dochters van migranten lag de zaak volkomen anders:

Toelating voor gezinsvorming betekent toelating van vreemdelingen op een zodanige leeftijd, dat zij op tal van gebieden - arbeidsmarkt, opleiding, scholing - in een kansloze positie komen te verkeren. Met grote waarschijnlijkheid is te verwachten dat zij tot de structurele werklozen zullen gaan behoren, voor wie - ook in de toekomst - zeer weinig perspectieven zijn. Staat een bijna onvoorwaardelijke toelating van deze vreemdelingen al op gespannen voet met het restrictieve toelatingsbeleid, daar komt nog bij dat voorkomen moet worden dat de situatie van minderheidsgroeperingen in Nederland en het beleid dat de Nederlandse overheid terzake voert en zich voorneemt te voeren, door een voortdurende aanwas van deze kansarmen onder een nog zwaardere druk komt te staan. Extra verzwarend zal met name kunnen werken dat de aangeduide kansloze positie van hier te lande gevestigde groepen vreemdelingen zich kan voortzetten over toekomstige generaties. (...) In het spanningsveld tussen enerzijds het uitvoeren van een restrictief toelatingsbeleid en anderzijds een beleid gericht op een zo groot mogelijke versterking van de rechtspositie van vreemdelingen, in het bijzonder van hen die als minderjarige naar Nederland zijn gekomen, wordt, wat de toelating van huwelijkspartners betreft, het zwaartepunt gelegd bij de handhaving van het restrictieve toelatingsbeleid. Het zijn vooral de sombere toekomstverwachtingen voor deze categorie, die hier de doorslag geven. ${ }^{264}$

Het soepele gezinsmigratiebeleid dat Nederland tot dan toe voerde, hing nauw samen met het optimisme waarmee de maatschappelijke gevolgen van gezinsmigratie tegemoet werden gezien, niet alleen vanuit de verwachting dat die instroom in duur en omvang beperkt zou zijn, maar ook omdat men ervan overtuigd was de inpassing van migranten dankzij het

264 TK 1982-1983 17984 (2): 12-13. 
minderhedenbeleid binnen afzienbare tijd te kunnen bewerkstelligen. In de vroege jaren tachtig begon de dramatische stijging van de werkloosheid onder Turken en Marokkanen echter afbreuk te doen aan het vertrouwen in de effectiviteit van het minderhedenbeleid. Hier werd, ter onderbouwing van de nieuwe inkomenseis bij gezinsvorming, voor het eerst sinds de vroege jaren zeventig zorg geuit over mogelijke problematische consequenties van gezinsmigratie voor de Nederlandse samenleving. ${ }^{265}$

Staatssecretaris Korte-van Hemel voegde aan deze overwegingen nog één argument toe:

De partners maken deel uit van een andere samenleving en hebben geen band met Nederland, terwijl de buitenlandse jongeren in Nederland, blijkende uit hun partnerkeuze, kennelijk nog zoveel banden met hun land van herkomst hebben dat, wanneer niet aan de voorwaarden voor toelating wordt voldaan, vestiging aldaar een alternatief biedt. ${ }^{266}$

Het genereuze gezinsherenigingsbeleid kwam voort uit de nadrukkelijke keuze, eind jaren zeventig, tot insluiting van migrantengroepen in Nederland als permanente en volwaardige leden van de Nederlandse samenleving. Bij gezinsvorming stuitte deze insluiting op een grens. In de ogen van de regering plaatsten tweede generatie migranten die voor een partner uit het land van herkomst kozen zichzelf buiten de Nederlandse samenleving. Zij gaven blijk van onvoldoende binding met Nederland, hetgeen een stringenter huwelijksmigratiebeleid rechtvaardigde. ${ }^{267}$

In het parlement stuitte de mededeling dat voor migranten van de tweede generatie het inkomensvereiste onverkort zou worden toegepast onmiddellijk op fel protest van de partijen links van het midden. Niet alleen PSP en PPR maar ook D66 en PVdA vonden dat de nieuwe beleidslijn, die inmiddels

265 Dat was voor het laatst gebeurd in de Memorie van Antwoord van 1974. Zie paragraaf 2.8.

266 TK 1984-1985 17984 (7): 4.

267 Van Walsum wijst erop dat de verwachtingen met betrekking tot migranten van de tweede generatie hooggespannen waren. Van de eerste generatie werd verwacht en aanvaard dat zij vasthielden aan de waarden en gebruiken waarmee zij waren opgegroeid. De tweede generatie daarentegen werd verondersteld zich te oriënteren op de Nederlandse samenleving en zich te ontworstelen aan de tradities van de ouders. Volgens Van Walsum hingen die zo verschillende verwachtingen nauw samen met de notie van 'generatiekloof', waarmee ook scheidlijnen binnen de Nederlandse bevolking in de jaren zestig en zeventig werden geduid. In de onderbouwing van de versterking van het verblijfsrecht van migranten van de tweede generatie in 1979 werd inderdaad gesproken over jongeren 'wier banden met het land van herkomst vrijwel geslaakt zijn'. (Zie paragraaf 3.6) Gezien de hooggespannen verwachtingen zal de teleurstelling, toen deze jonge migranten voor partners uit het land van herkomst kozen, navenant groot zijn geweest. (Van Walsum 2008: 173) 
'1445-maatregel' werd genoemd, inbreuk maakte op het 'gelijkheidsbeginsel'. Vreemdelingen jonger dan 23 jaar zouden hun huwelijkspartner niet kunnen laten overkomen en werden daarmee ernstig achtergesteld, niet alleen ten opzichte van hun ouders, maar ook van Nederlandse jongeren. Het voorstel van de staatssecretaris kreeg echter steun van CDA en VVD. Krajenbrink (CDA) vond het toepassen van het inkomensvereiste 'humaan', omdat 'daarmee wordt voorkomen dat mensen in een kansloze en uitzichtloze positie komen'. Ook hij vroeg zich echter af of het onderscheid dat werd gecreëerd wel gerechtvaardigd was en of de tweede generatie niet juist 'extra bescherming bij de keuze van hun huwelijkspartner' verdiende. Krajenbrink besloot de staatssecretaris 'het voordeel van de twijfel te laten' maar vroeg wel om het beleid binnen een jaar te evalueren. Staatssecretaris Korte-van Hemel beloofde in het najaar van 1984 een evaluerende notitie te presenteren. ${ }^{268}$

Ook buiten het parlement stuitte de maatregel op weerstand. Redactionele commentaren in de landelijke pers waren 'vernietigend', de burgemeester en wethouders van Rotterdam stuurden een boze brief, de Raad voor het Jeugdbeleid publiceerde een kritisch rapport, in de juridische vakpers klonken afkeurende geluiden, duizenden jongeren kwamen in Ahoy in Rotterdam bijeen om te demonstreren en niet alleen belangengroepen van buitenlanders maar ook een groot aantal Nederlandse jongerenorganisaties - waaronder de JOVD en CDA-jongeren, zoals de PPR niet naliet in de Kamer te vermelden - tekenden protest aan tegen de 1445-maatregel. ${ }^{269}$

Het bericht van de staatssecretaris in oktober 1984 dat de evaluatie vertraging opliep ontlokte in het parlement dan ook emotionele reacties, niet alleen op links maar ook bij CDA en VVD. Jabaaij (PVdA) was 'boos en teleurgesteld': 'De staatssecretaris moet toch weten dat er met smart wordt gewacht op bespreking van het beleid door jonge mensen die vinden dat zij recht hebben op gelijke behandeling'. Ook Krajenbrink (CDA) en Wiebenga (VVD) waren 'ongelukkig' met de vertraging, 'zeker waar ook op het departement bekend is, hoe gevoelig deze materie ligt'. Jabaaij en Krajenbrink dienden samen een motie in, waarin werd gesteld dat geen huwelijksmigranten mochten worden uitgezet vanwege het niet voldoen aan het 1445-vereiste totdat een definitief besluit over het gezinsvormingsbeleid

268 TK 1983-1984 17984 (3): 1, 4-5; TK 1983-1984 Handelingen 28-29 september 1983: 180-181, 291.

269 Zijlstra 1988: 28; Brief burgemeester en wethouders van Rotterdam aan minister, 29 december 1983. NA IND 2747; Groenendijk 1989: 220; Groenendijk 1983; Koens 1983b; тK 1983-1984 UVC 27 februari 1984: 29; Tinnemans 1994: 245-246. 
zou zijn genomen. Hoewel staatssecretaris Korte-van Hemel met deze motie 'grote moeite' had, werd ze aangenomen en uitgevoerd. ${ }^{270}$

In april 1985 werd de evaluatie dan toch gepubliceerd. Het onderzoek leverde volgens staatssecretaris Korte-van Hemel twee belangrijke conclusies op. In de eerste plaats was gebleken dat veel minder kinderen van migranten een buitenlandse huwelijkspartner wilden laten overkomen dan in 1983 werd aangenomen. In de tweede plaats was aangetoond dat 83\% van de kinderen van migranten die gezinvorming had aangevraagd aan het 1445-vereiste voldeed. Het kwantitatieve effect van de maatregel op de instroom was dus zeer beperkt. ${ }^{271}$ Principieel hield de staatssecretaris vol, dat de 1445-maatregel noch een ongeoorloofd onderscheid tussen Nederlanders en vreemdelingen makte, noch een onevenredig beletsel van het recht op gezinsleven vormde. Zij wist zich hierin gesteund door de rechter: de Raad van State had in 1984 geoordeeld, dat het legitiem was om van tweede generatie migranten te verwachten dat zij zich in het land van herkomst van hun partner vestigden, indien zij niet aan de vereisten voor gezinsvorming konden voldoen. ${ }^{272}$ Aangezien de 'druk' op het restrictieve toelatingsbeleid en daarmee op het minderhedenbeleid 'zich niet in die verwachte mate' voordeed, was Korte-van Hemel echter toch bereid haar standpunt te herzien. Voortaan zouden voor gezinshereniging en gezinsvorming dezelfde voorwaarden gelden: houders van een vestigingsvergunning, of zij nu primaire migranten waren of kinderen van migranten, zouden worden vrijgesteld van het inkomensvereiste tenzij zij 'verwijtbaar' over onvoldoende inkomen beschikten. ${ }^{273}$ De staatssecretaris benadrukte dat zij haar beslissing niet op principiële maar op praktische gronden genomen had: de omvang van de instroom was doorslaggevend geweest. Hoewel zij het dus niet toegaf, heeft de bijzonder sterke druk vanuit het parlement echter beslist een zwaarwegende rol gespeeld in haar besluit.

Het parlement toonde zich dan ook verheugd dat het beleid was gewijzigd. PvdA, PSP en D66 verzochten de staatssecretaris zelfs om nog een stap verder te gaan en ook kinderen van migranten onder de 21 jaar, die

270 TK 1984-1985 17984 (7); TK 1984-1985 UVC 22 oktober 1984: 4, 9, 11, 32; тK 1984-1986 16102 (96), aangenomen op 22 oktober 1984. Tegen: VVD, SGP, RPF, GVP en CP; TK 1984-1985 16102 (109).

271 Zijlstra (1988: 29-30) trekt deze conclusie in twijfel: zij observeert na intrekking van de 1445-maatregel een scherpe stijging van gezinsvorming, die zij interpreteert als 'inhaaleffect': kennelijk hadden jonge vreemdelingen die te weinig verdienden gewacht met het aanvragen van een verblijfsvergunning voor hun partner.

272 Van Walsum 2008: 176.

273 TK 1984-1985 17984 (8). 
minderjarig waren en dus niet voor een vestigingsvergunning in aanmerking kwamen, vrij te stellen van het inkomensvereiste. Staatssecretaris Korte-van Hemel antwoordde eraan te hechten dat het onderscheid tussen verblijfsvergunning en vestigingsvergunning in stand bleef en niet 'op onderdelen (...) inbreuken [te] gaan maken op de systematiek van het vreemdelingenbeleid'. Zij wees de Kamer er echter op, dat de meerderjarigheidsgrens in de nabije toekomst verlaagd zou worden van 21 naar 18 jaar. Daarmee zouden migranten van de tweede generatie, die tenminste vijf jaar in Nederland hadden gewoond, op hun $18^{\mathrm{e}}$ in aanmerking komen voor een vestigingsvergunning en daarmee vrijgesteld zijn van het inkomensvereiste. De Kamer nam daarmee genoegen. ${ }^{274}$

De 1445-maatregel werd dus na minder dan twee jaar alweer afgeschaft. De staatssecretaris van Justitie had hem ingevoerd, omdat de overkomst van buitenlandse huwelijkspartners van kinderen van migranten als bijzonder problematisch werd beschouwd. Gezinsvorming was in potentie oneindig en zou een kwalijk effect op integratie hebben: huwelijksmigranten die in Turkije of Marokko waren opgegroeid waren 'kansloos' op de Nederlandse arbeidsmarkt en zouden hun achterstand bovendien doorgeven aan hun kinderen. Daarbij werd de keuze voor een buitenlandse partner niet alleen als een bron maar ook als een resultaat van gebrekkige integratie gezien: zij signaleerde onvoldoende binding met de Nederlandse maatschappij en kwam voort uit cultureel bepaalde huwelijkspraktijken die botsten met Nederlandse normen. Waar het kabinet Den Uyl zijn oordeel over wat een 'goed' gezin was in zoverre had opgeschort, dat verruimde gezinshereniging voorwaardelijk werd toegestaan om enige ruimte te maken voor alternatieve vormen van familieleven, werd onder de kabinetten Van Agt en Lubbers van de jaren tachtig een steeds scherpere afwijzing van afwijkende normen en gebruiken op het gebied van huwelijk en gezin zichtbaar.

In de jaren tachtig stuitten al deze argumenten nog op een onoverkomelijk principieel bezwaar: de norm van gelijke behandeling. Alles wat maar uit de verte naar racisme of discriminatie riekte lag bijzonder gevoelig. ${ }^{275}$ Dat het gelijkheidsbeginsel niet alleen voor Kamerleden maar ook voor een groot deel van het Nederlands publiek een uitzonderlijk gewicht in de schaal legde, blijkt wel uit de breedte van het maatschappelijk protest tegen de 1445-maatregel. De entree van de Centrumpartij van Janmaat

274 TK 1985-1986 17984 (9). Zie over de consequenties van de verlaging van de meerderjarigheidsgrens per 1 januari 1988 voor het vreemdelingenbeleid: Vessem 1986.

275 Hondius 2001: 173-174; Tinnemans 1994: 251-258; Scholten 2007: 126. 
in de Kamer in 1983 versterkte de behoefte van andere politieke partijen om zich te distantiëren van iedere vorm van discriminatie of vooroordeel. Een beperkende voorwaarde die uitsluitend op jonge migranten van toepassing was, was dan ook politiek onverteerbaar. In de discussies over de 1445-maatregel werden echter de fundamenten gelegd voor debatten in later jaren, die wel tot aanzienlijke aanscherpingen van het beleid zouden leiden.

\subsection{Besluit}

In de jaren tachtig was het Nederlands gezinsmigratiebeleid uitzonderlijk genereus. In de jaren zeventig en vroege jaren tachtig zijn tal van versoepelingen doorgevoerd. Zo werden niet-huwelijkse relaties, heteroseksueel èn homoseksueel, als toelatingsgrond aanvaard, niet alleen voor Nederlanders maar ook voor vluchtelingen en vestigingsvergunninghouders. Zowel Nederlandse als buitenlandse vrouwen kregen de mogelijkheid gezinsleden over te laten komen. Het inkomensvereiste werd voor Nederlanders en gevestigde vreemdelingen aanmerkelijk versoepeld: onvrijwillige werkloosheid vormde geen belemmering voor gezinshereniging. Ten slotte werd het verblijfsrecht van gezinsleden van migranten, zowel van kinderen als van echtgenoten, substantieel versterkt.

De verklaring voor dit open beleidsregime dient zeker niet gezocht te worden in de economische situatie, integendeel. De recessie van midden jaren zeventig deed de Nederlandse regering besluiten tot een restrictief vreemdelingenbeleid, maar weerhield haar er niet van om de voorwaarden voor gezinsmigratie te versoepelen. Op het dieptepunt van de crisis, rond 1983, kwam het gezinsmigratiebeleid weliswaar onder druk te staan, maar ook toen ketste de enige significante aanscherping van de voorwaarden die de regering tussen 1975 en 1989 doorvoerde - de 1445-maatregel - af op politiek en maatschappelijk protest.

Muus beweert dat 'family reunification and family formation became accepted back doors to the Dutch labor market after the main door closed to unskilled and low-skilled migrants' ${ }^{276} \mathrm{Bij}$ de ambtenaren van Justitie was de verdenking van verkapte arbeidsmigratie inderdaad voortdurend aanwezig. Van gelaten aanvaarding was echter geen sprake: zij probeerden

276 Muus 2004: 284. 
het beleid steeds zo in te richten dat een dergelijk 'misbruik' van het gezinsmigratiekanaal kon worden voorkomen. De stelling van Muus zou zelfs zo gelezen kunnen worden, dat gezinsmigratie werd aanvaard omdat laaggeschoolde gezinsmigranten in een behoefte op de arbeidsmarkt voorzagen. ${ }^{277}$ Dit was niet het geval. Wanneer arbeidsmarktoverwegingen een rol speelden in de beleidsdebatten, ging het steeds om zorg over de nadelige gevolgen van de toestroom van kansarme gezinsmigranten. Die zorg werd vanaf de jaren tachtig niet alleen door ambtenaren van Justitie maar ook breder geuit. Ze woog echter niet op tegen de politiek-ethische waarden die in het debat over gezinsmigratie op het spel stonden.

De versoepelingen van het gezinsmigratiebeleid vloeiden in de eerste plaats voort uit het openbreken van traditionele gezinsnormen en opvattingen over de rol en positie van man en vrouw in gezin en samenleving. Aangezien het traditionele gezin, met de man als gezinshoofd en kostwinner en de vrouw als huismoeder, niet langer normgevend was in de Nederlandse maatschappij, werd ook in het gezinsmigratiebeleid ruimte gemaakt voor andere vormen van gezinsleven. In de tweede plaats maakte de Nederlandse politiek eind jaren zeventig de fundamentele omslag van het 'gastarbeiders-paradigma' naar het 'minderheden-paradigma'. Migranten werden aanvaard als permanente leden van de Nederlandse maatschappij, die daarin volwaardig en gelijkwaardig moesten kunnen participeren. Zij hadden 'recht' op gelijke behandeling en 'recht' op gezinshereniging, waarbij de term 'recht' - het zij opnieuw met nadruk gesteld - veeleer verwees naar een politiek-ethische norm dan naar een juridische verplichting. Gevestigde vreemdelingen moesten dus, net als Nederlanders, hun buitenlandse gezinsleden kunnen laten overkomen. De maatschappelijke gevolgen van deze consequente toepassing van het gelijkheidsbeginsel baarden geen ernstige zorgen, omdat de verwachting was dat gezinsmigratie in duur en omvang beperkt zou blijven en dat het minderhedenbeleid spoedig zijn vruchten af zou werpen. Twijfel aan deze veronderstellingen deed de regering er in 1983 toe besluiten om het inkomensvereiste bij gezinsvorming aan te scherpen. Voor Kamerleden - en voor een groot aantal maatschappelijke organisaties - woog de norm van gelijke behandeling echter dusdanig zwaar, dat de 1445-maatregel na minder dan twee jaar alweer moest worden ingetrokken.

277 Messina (2007: 240-241) beweert dit expliciet, niet specifiek over de Nederlandse casus maar over 'many Western European governments'. 
In de jaren zeventig en tachtig trad een belangrijke verschuiving op in de invloedsverhoudingen in het beleidsveld van gezinsmigratie. De autonomie waarover ambtenaren in de jaren zestig en vroege jaren zeventig beschikten werd significant ingeperkt, doordat bewindslieden, Kamerleden en rechters een veel grotere rol gingen spelen in de beleidsvorming. De meningsvorming van ambtelijk Justitie werd, net als voorheen, bepaald door een restrictieve taakopvatting, waarin het controleren - lees: beperken - van immigratie voorop stond. Onder politieke, rechterlijke en maatschappelijke druk voerden zij met tegenzin aanzienlijke versoepelingen door. De ambtenaren behielden desalniettemin een niet te verwaarlozen discretionaire beleidsruimte: een groot deel van de in dit hoofdstuk besproken beleidswijzigingen zijn pas achteraf, vaak jaren later, aan het parlement meegedeeld. Daarbij speelde ook een rol dat de beleidsruimte van ambtelijk Justitie in één opzicht groter was dan in de jaren zestig en zeventig: het werd niet langer geconfronteerd met inmenging van andere ministeries. Er bestond consensus tussen de departementen over de noodzaak om een restrictief vreemdelingenbeleid te voeren en die taak werd aan Justitie overgelaten. Het is in dit opzicht veelzeggend dat het gezinsmigratiebeleid, op de toelating van Surinamers na, geen onderwerp van debat was in de ministerraad. Er was nauwelijks noodzaak tot interdepartementale coördinatie.

Overleg op kabinetsniveau kon bovendien achterwege blijven, omdat tussen de verschillende coalitiepartijen geen noemenswaardige verschillen in visie of benadering van het gezinsmigratievraagstuk bestonden. De 1445-maatregel was weliswaar een product van de centrum-rechtse regering Lubbers, maar onder het eveneens centrum-rechtse kabinet Van Agt waren enkele jaren eerder zeer wezenlijke versoepelingen van het gezinsmigratiebeleid doorgevoerd, waaronder de vrijstelling van de inkomenseis bij onvrijwillige werkloosheid voor gevestigde migranten. Veranderingen in de politieke kleur van de regeringscoalitie hadden geen zichtbaar effect op de beleidsontwikkeling. Uitzondering op die regel vormt het progressieve kabinet Den Uyl. De dominantie van de traditionele gezinsnorm in het gezinsmigratiebeleid zou niet in die mate en zeker niet zo vroeg zijn doorbroken zonder staatssecretaris van Justitie Glastra van Loon. Ook de staatssecretarissen die hem opvolgden spraken, anders dan de ministers van Justitie in de jaren zestig, geregeld het beslissende woord wanneer op ambtelijk niveau aarzeling of meningsverschil bestond. De lijn die zij daarin trokken was echter niet terug te voeren op partij-politieke herkomst. 
Dit is niet verwonderlijk, gezien het feit dat ook de verschillen tussen de politieke partijen in de Tweede Kamer zeer beperkt waren. ${ }^{278}$ De PvdA en de kleine partijen op haar linkerflank toonden zich de meest fervente behartigers van een genereus gezinsmigratiebeleid en een sterke rechtspositie voor migranten, terwijl CDA en VVD gevoeliger bleken voor de vrees van Justitie voor misbruik van het gezinsmigratiekanaal. Daarbij valt het verschil op met de partijpolitieke verhoudingen in de jaren zestig en vroege jaren zeventig, toen christendemocraten en liberalen nog voor soepele voorwaarden voor gezinsmigratie pleitten terwijl linkse partijen zich nauwelijks in die discussies mengden. Over het algemeen bestond echter Kamerbreed, op de Centrumpartij na, consensus over de wenselijkheid van een genereus gezinsmigratiebeleid.

De opkomst van de rechter als actor in het beleidsvormingsproces ten slotte, heeft de inhoudelijke ontwikkeling van het beleid slechts in beperkte mate beïnvloed. Rechterlijke druk heeft een belangrijke rol gespeeld in het opheffen van de wachttijd van een jaar voor overkomst van partners van vrouwelijke migranten en in het besluit om controle op schijnhuwelijken achterwege te laten. Over het geheel genomen gunden de rechtbanken de regering echter veel ruimte om in het algemeen belang voorwaarden te verbinden aan de overkomst van gezinsleden: met het inkomensvereiste of het huisvestingsvereiste hadden de rechters bijvoorbeeld geen moeite. Ongelijke behandeling van vreemdelingen en Nederlanders, mannen en vrouwen, of huwelijkse en niet-huwelijkse relaties stuitte evenmin op rechterlijk bezwaar. De rechtbanken zijn wel van doorslaggevende invloed geweest op de vorm van het vreemdelingenbeleid: zij dwongen openheid over de regelgeving en consistentie in de uitvoering af. Vrijwel alle inhoudelijke versoepelingen die in dit hoofdstuk zijn besproken zijn echter onafhankelijk van rechterlijke druk tot stand gekomen.

Dit betekent dat, net als in het besluit van het vorige hoofdstuk, de nodige kanttekeningen dienen te worden geplaatst bij de verklaringen die tot nu toe zijn geopperd voor het paradoxale feit dat westerse landen de grootschalige vestiging van migranten ongewenst achtten, maar desalniettemin hebben toegestaan. Een meerderheid onder de auteurs die zich over deze paradox hebben gebogen legt de nadruk op de invloed van de rechtbanken. Rechters zouden - op grond van nationaal recht of internationale verdragen - de rechten van migranten hebben verdedigd en zo de ruimte

278 Volgens Entzinger (1985: 82) gold die politieke consensus niet alleen het gezinsmigratiebeleid, maar ook het immigratiebeleid in het algemeen. 
hebben beperkt waarover regeringen beschikten om toelating en verblijf van vreemdelingen aan restricties te onderwerpen. ${ }^{279}$ Deze these is volstrekt onbevredigend waar het de ontwikkeling van het Nederlands gezinsmigratiebeleid tussen 1975 en 1989 betreft. Het genereuze beleid dat Nederland in deze periode voerde, was niet het resultaat van rechterlijke bemoeienis, maar van keuzen die ambtenaren en politici uit eigen beweging hebben gemaakt, op grond van hun perceptie en weging van de materiële en immateriële, individuele en collectieve belangen die bij het gezinsmigratiebeleid op het spel stonden.

De stelling van Guiraudon dat de rechten die in Europese samenlevingen aan migranten worden verleend omgekeerd evenredig zijn aan de openheid van het debat, omdat beleidsmakers alleen wanneer zij buiten zicht van het electoraat opereren versoepelingen van het beleid zullen kunnen en willen doorvoeren, gaat evenmin op voor de ontwikkeling van het Nederlands gezinsmigratiebeleid in de jaren zeventig en tachtig. ${ }^{280}$ In deze periode wordt het debat opengebroken: het is niet langer een besloten kring ambtenaren die de voorwaarden bepaalt. Bewindslieden, parlement, rechters en maatschappelijke organisaties gaan meespreken. Deze verruiming van het debat ten opzichte van de jaren zestig resulteert niet in aanscherping, maar in versoepeling van de voorwaarden voor gezinsmigratie. Het argument van Guiraudon is gebaseerd op de veronderstelling, dat de publieke opinie steeds de voorkeur geeft aan restrictie. ${ }^{281}$ In het debat over de 1445-maatregel zagen we echter dat, niet alleen voor Kamerleden maar ook voor een scala aan belangenorganisaties en voor de media, het belang van gelijke behandeling van jonge migranten zwaarder woog dan de wens om de huwelijksmigratie uit Turkije en Marokko aan banden te leggen. Dit zeer open debat resulteerde dan ook in liberalisering van het beleid.

De these van Freeman ten slotte, dat het soepele migratiebeleid van westerse staten begrepen moet worden als een resultaat van binnenlandse politieke processen, waarin het geconcentreerd belang van specifieke belangengroepen het overwicht heeft op diffuse maatschappelijke belangen, bood inzicht in de beleidsvormingsprocessen van vóór 1975, maar niet in die van de latere jaren zeventig en jaren tachtig. ${ }^{282} \mathrm{Nu}$ er eerder sprake is

279 Cornelius e.a. 1994: 7, 9; Joppke 1998: 270-271; 1999: 18-21; 2001: 340-342; Guiraudon 2000: 221-224; Guiraudon \& Lahav 2000: 189; Hollifield 2000: 148-150; Soysal 1994: 149-150; Sassen 1996: 11-12; 1999:181, 184-185; 2006: 351.

280 Guiraudon 2000: 238.

281 Guiraudon 2000: 22.

282 Freeman 1995: 881-887; 2002: 77-82. 
van overschot dan van tekort aan arbeidskrachten, heeft het bedrijfsleven niet langer belang bij een genereus gezinsmigratiebeleid. De tweede belangengroep waar Freeman op wijst zijn migrantenorganisaties: zij speelden in deze periode wel een grotere rol dan voorheen, maar hun invloed bleef over het geheel genomen beperkt. ${ }^{283}$ Het activisme van belangengroepen heeft er wel toe bijgedragen dat de Kamer de positie van vrouwen nadrukkelijk op de politieke agenda plaatste, en dat Kamerleden zich zo actief verzetten tegen de 1445-maatregel. Het ging hier echter niet alleen om migrantenorganisaties, maar ook om allerlei andere groepen en instanties, variërend van vakbonden, vrouwen- en jongerenorganisaties en de Raad van Kerken tot juristen, maatschappelijk werkers en gemeentes. Zij kwamen dan ook niet zozeer op voor materieel eigenbelang, zoals Freeman veronderstelt, als wel voor een immateriële norm waaraan zij allen een bijzonder belang hechtten: emancipatie en non-discriminatie van kwetsbare groepen in de samenleving.

De openheid van het Nederlands gezinsmigratiebeleid tussen 1975 en 1989 was primair het resultaat van een politieke keuze. Die keuze kwam voort uit morele overwegingen, waaronder zowel de verruiming van gezinsnormen als de nadrukkelijke insluiting van gevestigde migranten als volwaardige leden van de Nederlandse samenleving dienen te worden begrepen. De gevolgen van die keuze verwachtte men dankzij het minderhedenbeleid te kunnen opvangen. De paradox van het migratiebeleid van westerse staten kan niet inzichtelijk worden gemaakt, wanneer dergelijke ethische normen en gepercipieerde consequenties buiten beschouwing blijven. 


\section{De restrictieve wending in het Nederlands gezinsmigratie- beleid, 1989-2005}

\subsection{Inleiding}

Begin jaren negentig kwam een einde aan ruim tien jaar bijzonder liberaal gezinsmigratiebeleid. In een eerste voorzichtige hervorming werden de voorwaarden voor gezinshereniging en gezinsvorming aangescherpt. Daarmee werd een restrictieve beleidslijn ingezet, die uiteindelijk van het Nederlands gezinsmigratiebeleid één van de strengste in Europa zou maken.

Opmerkelijk genoeg vond deze ommekeer plaats in een relatief gunstige economische context. Eind jaren tachtig was het dieptepunt van de crisis al voorbij en in de jaren negentig klauterde de economie verder uit het dal. De groei van het BNP, de investeringen, de werkgelegenheid en de arbeidsparticipatie lagen tussen 1991 en 1996 in Nederland ruim boven het Europees gemiddelde. Vanaf het midden van de jaren negentig braken gouden tijden aan voor de Nederlandse economie. In de jaren tachtig gold Nederland nog als een 'schoolvoorbeeld' van 'welfare without work'. In de jaren negentig werd niet langer over de 'Dutch disease' gesproken, maar over de 'Dutch miracle'. Het Nederlandse model liet zien hoe men via consensuspolitiek stabiel economisch welvaren tot stand kon brengen. ${ }^{1}$ De politieke kleur van de kabinetten doet evenmin direct de verwachting van een streng migratiebeleid rijzen: de aanscherping van het gezinsmigratiebeleid werd ingezet door het centrum-linkse kabinet Lubbers III, en doorgezet door de Paarse kabinetten waarin weliswaar de VVD deelnam, maar waarin de PvdA de grootste partij was en de portefeuille Vreemdelingenzaken ook steeds in handen was van een sociaaldemocraat. De 'restrictieve periode' die hier wordt besproken beslaat zestien jaar, van 1989 tot 2005: pas in de laatste

1 Visser \& Hemerijck 1998: 21-23, 39. 
drie jaar namen centrum-rechtse kabinetten het roer over. Dit hoofdstuk beoogt inzichtelijk maken waarom op een moment dat dat politiek noch economisch voor de hand lag, gekozen is voor een restrictieve koers in het Nederlands gezinsmigratiebeleid.

Het is wellicht niet vanzelfsprekend om het tijdvak tussen 1989 en 2005 als één geheel te bespreken. Het 'lange jaar 2002'² is door velen als een keerpunt beleefd, voor de Nederlandse politiek in het algemeen en zeker voor de politieke omgang met het migratie- en integratievraagstuk. Het perspectief op het gezinsmigratievraagstuk en het type beleidsmaatregelen waarvoor gekozen werd waren na de 'Fortuyn-revolte' in een aantal opzichten inderdaad wezenlijk anders dan daarvoor. Om die breuklijnen tot uitdrukking te brengen, valt dit hoofdstuk uiteen in een deel over de jaren negentig en een deel over de jaren na de eeuwwisseling. Wanneer we de ontwikkeling van de beleidsvorming inzake gezinsmigratie van de jaren vijftig tot op heden bezien, heeft continuïteit in de periode van 1989 tot 2005 echter de overhand op discontinuïteit. ${ }^{3}$ Die continuïteit is in de eerste plaats inhoudelijk: er is sprake van een constante restrictieve beleidstendens, die voor een belangrijk deel steeds met hetzelfde soort argumenten wordt onderbouwd. $\mathrm{Zij}$ is ook institutioneel: de periode vanaf de jaren negentig onderscheidt zich van wat voorafging in een duidelijk overwicht van het politieke op het ambtelijke en in de opkomst van zowel het Europees Hof in Straatsburg als de instellingen van de Europese Unie als relevante actoren in de beleidsvorming. Juist omdat het beeld dat Fortuyn een revolutie teweeg heeft gebracht in het Nederlands migratie- en integratiebeleid nuancering behoeft, dient de beleidsvorming tussen 1989 en 2005 het onderwerp te zijn van één hoofdstuk.

\subsection{De institutionele structuur}

\section{Invloedsverhoudingen in Den Haag}

Van de late jaren tachtig tot het midden van het huidige decennium is het gewicht van de thematiek van instroom en inpassing van migranten in het Nederlandse publieke en politieke debat gestaag toegenomen. ${ }^{4}$ De toon van

2 Wansink 2004: 93.

3 Vgl. Vink 2007: 338-339, 343-344.

4 Roggeband \& Vliegenthart 2007: 533; Tinnemans 1994: 329-336, 356-363. 
discussies over de positie van migranten in de samenleving was er één van stijgende verontrusting. Die sfeer van urgentie werd aanzienlijk versterkt door de 'asielcrisis' van de jaren negentig. In de loop der tijd werd het migratie- en integratievraagstuk een thema dat politieke carrières en parlementaire verkiezingen kon maken of breken.

Naarmate het electoraal gewicht van het vraagstuk toenam, werd de grip van de politiek op de beleidsontwikkeling fermer. Er ging nauwelijks een week voorbij of er werd in het parlement over het migratie-, integratieof asielbeleid gesproken. Waar Kamerleden in de jaren zestig slechts van de grote lijnen van het vreemdelingenbeleid op de hoogte waren, werden wijzigingen van de regelgeving nu in detail gecommuniceerd en bediscussieerd. In de jaren tachtig ontwikkelden politieke partijen al steeds specifiekere standpunten inzake het vreemdelingenbeleid, die zij vertaalden in steeds concretere beleidsvoorstellen. Deze tendens zette zich in de jaren negentig en na de eeuwwisseling verder door.

Het meest opvallend kwam deze politisering van het migratievraagstuk echter tot uiting in de besluitvorming op het niveau van het kabinet. In de jaren zestig was het gezinsmigratiebeleid geregeld onderwerp van discussie in de ministerraad: de controverses kwamen toen echter niet voort uit ideologische, maar uit institutionele verschillen in beleidsperspectief, met name tussen de ministeries van Justitie en Sociale Zaken. In de jaren tachtig werd in de ministerraad niet over het gezinsmigratiebeleid gedebatteerd. Vanaf de jaren negentig vonden binnen het kabinet voor het eerst discussies plaats over gezinsmigratie die langs partijpolitieke lijnen verliepen. Bij het aantreden van het tweede Paarse kabinet onder premier Kok, in 1998, werden voor het eerst voornemens voor hervorming van het gezinsmigratiebeleid vastgelegd in een regeerakkoord. De coalitiepartijen die deelnamen in de eerste twee kabinetten onder Balkenende zouden dat in hun akkoorden van 2002 en 2003 ook doen. De sterk toegenomen invloed van partijpolitiek op de ontwikkeling van het gezinsmigratiebeleid kwam dus niet alleen tot uiting in intensivering van de parlementaire debatten, maar vooral ook in de besluitvorming op kabinetsniveau. 
In de loop van de jaren zeventig en tachtig was de beleidsruimte waarover ambtenaren beschikten om de voorwaarden voor toelating en verblijf van gezinsmigranten vast te stellen al significant verminderd. Door de politisering van het beleidsdebat vanaf de jaren negentig nam de autonome invloed van ambtenaren op het beleid nog veel verder af. In 1994 is de Immigratie- en Naturalisatiedienst (IND) ingesteld, om 'op afstand van het kerndepartement van Justitie' de uitvoering van het vreemdelingen- en naturalisatiebeleid op zich te nemen. ${ }^{5}$ Voor de ontwikkeling van wet- en regelgeving bleef een afdeling binnen het ministerie, de Directie Vreemdelingenbeleid (DVB) verantwoordelijk. Zoals al sinds de jaren zestig het geval was, bleef de inbreng van de ambtenaren die zich met vreemdelingenzaken bezig hielden gekenmerkt door een eigen, herkenbaar perspectief op het vraagstuk. Anders dan in de jaren tachtig botste dit institutioneel perspectief vanaf de jaren negentig weer vaker met de visies van andere departementen, met name met die van de ambtenaren die de verantwoordelijkheid droegen voor het integratiebeleid. Waar dergelijke institutionele controverses in de jaren zestig echter bepalend waren geweest voor de beleidsontwikkeling, gaven na 1989 niet de interdepartementale, maar de partijpolitieke verhoudingen de doorslag in de besluitvorming.

\section{Een nieuwe beleidsarena: het Europees asiel- en migratiebeleid}

Het EG-migratierecht dat in de jaren zestig is ontwikkeld betrof alleen het verkeer van werknemers tussen de lidstaten, dat als een fundamenteel onderdeel werd gezien van economische integratie. ${ }^{6}$ Dat de Gemeenschap bindend recht zou kunnen ontwikkelen voor toegang en verblijf van personen van buiten de EG, zogenaamde derdelanders, en zo inbreuk zou maken op het soevereine recht van haar lidstaten om vreemdelingen de toegang tot hun territorium te verlenen of te ontzeggen, was lange tijd ondenkbaar. Alleen gezinsmigratie van EG-werknemers viel dus onder het communautair recht: de voorwaarden voor gezinshereniging en -vorming van Nederlanders en derdelanders werden in Den Haag vastgesteld.

Pas met de opleving van het Europees integratieproces in de tweede helft van de jaren tachtig kreeg de ontwikkeling van een Europees asielen migratiebeleid een plaats op de Europese agenda. De lidstaten hadden zichzelf ten doel te gesteld om vóór 1992 de interne markt tot stand te

5 Berghuis e.a. 1994: 48-49.

6 Zie paragraaf 2.5 . 
brengen. Onderdeel daarvan was het streven naar vervolmaking van het vrij verkeer van personen. Dat betekende dat personencontroles aan de binnengrenzen zouden worden opgeheven, en dat niet alleen EG-burgers maar ook derdelanders zich vrij zouden kunnen bewegen binnen de Gemeenschap. Daarmee werd toelating van derdelanders op het grondgebied van elk van de lidstaten een zaak van gemeenschappelijk belang: wanneer het verkeer tussen de kamers van een huis wordt vrijgegeven, krijgen alle bewoners belang bij de regulering van de toegang tot de voordeur. De behoefte aan Europese beleidsvorming werd verder versterkt door de sterke stijging van de asielinstroom in de jaren negentig. De lidstaten met het soepelste asielbeleid merkten dat zij de grootste instroom te verwerken kregen: om een eerlijker verdeling van de 'last' te bereiken werd harmonisering op Europees niveau noodzakelijk geacht. In Nederland werden in de jaren negentig meer asielaanvragen ingediend per hoofd van de bevolking dan in enige andere lidstaat, op Zweden na. Nederland was dan ook een enthousiast voorstander van een gemeenschappelijk asiel- en migratiebeleid. ${ }^{7}$ Ook toen de asielinstroom in Nederland na 2000 sterk afnam, bleef de wens om te voorkomen dat het Nederlands beleid een 'grotere aanzuigende werking zou (...) hebben dan het beleid van de ons omringende landen', een belangrijke reden voor de Nederlandse politiek om naar Europese harmonisering te streven. ${ }^{8}$

Deze harmonisering ontwikkelde zich in eerste instantie buiten de kaders van de Gemeenschap om, in informele samenwerking tussen de lidstaten en in het kader van het Verdrag van Schengen. ${ }^{9}$ Een voorbeeld van dergelijke informele samenwerking is de resolutie inzake harmonisering van het nationaal gezinsherenigingsbeleid, die in juni 1993 - enkele maanden voor de inwerkingtreding van het Verdrag van Maastricht - werd aangenomen. In deze resolutie waren een aantal gemeenschappelijke principes neergelegd die de lidstaten 'in aanmerking zouden nemen' bij het vaststellen van nationale wet- en regelgeving voor gezinshereniging van gevestigde vreemdelingen. Deze principes waren echter zo ruim geformuleerd dat zij geen enkele aanpassing van het Nederlands beleid vergden. De resolutie was sowieso niet juridisch bindend. ${ }^{10}$ De bescheiden betekenis van de resolutie blijkt wel uit de woorden van staatssecretaris Kosto van

\footnotetext{
7 Bonjour 2005: 175-185.

8 TK 2001-2002 28198 (2): 45.

9 Geddes 2000: 69-84; Zwaan \& Bultena 2002: 7-16; Papademetriou 1996: 65-67.

10 Guild 1996: 251-259.
} 
Justitie, die haar beschreef als 'een eerste aanzet tot beleidsafstemming'. ${ }^{11}$

Het Verdrag van Maastricht van 1992, dat de Europese Unie in het leven riep, bracht het beleidsveld van asiel en migratie voor het eerst formeel binnen het bereik van de Europese instellingen. Het Europees asiel- en migratiebeleid kreeg echter een plaats in de zogenaamde 'derde pijler'. ${ }^{12}$ Beleid dat daar werd gemaakt was soft law, geen gemeenschapsrecht. Het was niet direct bindend voor de lidstaten en viel buiten de controle van het Europees Hof van Justitie in Luxemburg. De Commissie en het Europees Parlement speelden in de derde pijler nauwelijks een rol. Deze institutionele structuur weerspiegelde de terughoudendheid van lidstaten om zeggenschap over toegang en verblijf van derdelanders af te staan aan Brussel. ${ }^{13}$

Het Verdrag van Amsterdam (1997) integreerde Schengen in de Europese Unie en hevelde het Europees asiel- en migratiebeleid over naar de eerste pijler. Hoewel het Verdrag in een overgangsperiode voorzag waarin de lidstaten de ontwikkeling van het Europees asiel- en migratiebeleid nog grotendeels in eigen hand hielden, kan de betekenis van deze hervorming nauwelijks worden overschat. EU-maatregelen op het gebied van asiel en migratie zouden voortaan deel uitmaken van het communautair recht, dat direct toepasbaar is, boven nationaal recht gaat, en gecontroleerd wordt door de Commissie en het Europees Hof van Justitie. ${ }^{14}$

In 1999 presenteerde de Europese Commissie een eerste voorstel voor een Europese richtlijn 'inzake het recht op gezinshereniging'. Na ruim drie jaar onderhandelen werd de richtlijn door de Raad aangenomen. Daarmee is een zeer wezenlijke stap gezet in de overdracht van bevoegdheid over toelating en verblijf van gezinsmigranten in Nederland van de Haagse naar de Brusselse arena. Op de inhoud van de gezinsherenigingsrichtlijn van 2003 en haar betekenis voor beleid en beleidsvorming in Nederland ga ik in paragraaf 4.11 van dit hoofdstuk in.

11 TK 1992-1993 22809 (18). De resolutie is bij één gelegenheid door de regering als argument gebruikt om het beleid aan te passen, namelijk om af te zien van haar voornemen om een 'omgekeerde wachttijd' in te voeren. TK 1995-1996 24401 (21); zie paragraaf 4.5.

12 De Europese Unie bestaat uit drie zogenaamde 'pijlers'. De eerste pijler omvat de Europese Gemeenschappen, de tweede het Gemeenschappelijk Buitenlands en Veiligheidsbeleid, de derde - sinds het Verdrag van Amsterdam - Politiële en Justitiële Samenwerking. De bevoegdheden van de supranationale instituties - Commissie, Parlement en Hof - zijn in de eerste pijler aanzienlijk groter dan in de tweede en derde.

13 Papademetriou 1996: 50-53; Geddes 2000: 87-100; Dinan 1999: 443-444; Zwaan \& Bultena 2002: 17-28.

14 Bonjour 2005: 173-174; Geddes 2000: 120-126; Hailbronner 2000: 37; Zwaan \& Bultena 2002: 33-35. 
Als gevolg van deze geleidelijke ontwikkeling van een Europees beleidskader voor immigratie deed een nieuw argument zijn intrede in de debatten over het gezinsmigratiebeleid: steeds vaker werd het Nederlands beleid vergeleken met dat van omringende landen. De breed gedeelde wens om te komen tot een eerlijker verdeling van de 'last' van immigratie in Europa en dus tot harmonisering van het toelatingsbeleid van de lidstaten, maakte van de suggestie dat de Nederlandse regelgeving significant afweek van het Europees gemiddelde een krachtig motief voor hervorming.

\section{De rechtspraak: het Europees Verdrag voor de Rechten van de Mens}

Vanaf de tweede helft van de jaren tachtig ontwikkelde artikel 8 van het Europees Verdrag voor de Rechten van de Mens (EVRM), dat het recht op gezinsleven waarborgt, zich tot een factor van belang in de beleidsvorming op het gebied van gezinsmigratie. ${ }^{15}$ Het EVRM dateert uit 1950, maar tot 1985 gingen Nederlandse rechters en beleidsmakers ervan uit dat de bepalingen van het verdrag niet van toepassing waren op het vreemdelingenbeleid. ${ }^{16}$ Toelating en verblijf van vreemdelingen op het nationaal grondgebied werd als een zaak van nationale soevereiniteit gezien, waar de beleidsvrijheid van de staat niet kon worden ingeperkt.

In de zaak-Abdulaziz uit 1985 sprak het Europees Hof in Straatsburg voor het eerst uit dat artikel 8 EVRM van toepassing was op immigratiezaken. ${ }^{17}$ Dat betekende echter niet dat in alle gevallen een recht op gezinshereniging bestond: bij beslissingen over toelating en verblijf van vreemdelingen moest een redelijke afweging worden gemaakt tussen het individuele belang van betrokkenen om hun gezinsleven te kunnen uitoefenen, en het algemene belang van de staat. Daarbij blijft het uitgangspunt van het Hof tot op heden dat de staat het recht heeft om migratie te reguleren. Het Hof pleegt zich daarom terughoudend op te stellen om 'niet te veel afbreuk te doen aan de soevereiniteit van de deelnemende staten'. ${ }^{18}$ Vooral waar de openbare veiligheid of het sociaal-economisch beleid op het spel staan

15 Het EVRM was - tot de EU-gezinsherenigingsrichtlijn van 2003 - het enige internationaal rechtsinstrument dat effect had op het Nederlands gezinsmigratiebeleid. Van Walsum (2004b: 144-146) noemt ook de jurisprudentie van het Europees Hof van Justitie in Luxemburg en het vN-mensenrechtencomité als potentieel relevante rechtsbronnen, maar stelt dat deze nog geen neerslag hebben gevonden in de Nederlandse rechtspraak.

16 Groenendijk 1989: 223. Dit gold niet alleen voor Nederlandse maar ook voor Oostenrijkse, Belgische, Franse en Zwitserse rechters: Groenendijk 1996: 128-129; Guiraudon 1998: 665-666.

17 Groenendijk 1989: 223; Boeles 2004a: 98-99.

18 Van Walsum 2004b: 138, 141; Guiraudon 1998: 661. 
gunt het Hof staten veel ruimte om het nationaal belang te definiëren en te beschermen. ${ }^{19}$

Desalniettemin heeft het Hof grenzen gesteld aan wat als een 'redelijke afweging' van individuele en nationale belangen kan worden beschouwd. In de zaak-Berrehab van 1988, een klacht tegen Nederland, heeft het Hof uitgesproken dat het recht op gezinsleven zoals gewaarborgd door artikel 8 veel zwaarder weegt in gevallen van voortgezet verblijf dan bij eerste toelating. De staat heeft dan immers al ingestemd met het verblijf van de vreemdeling en zou actief ingrijpen in het gezinsleven door hem of haar uit te zetten. ${ }^{20}$ In de zaak-Gül van 1996 stelde het Hof vast dat artikel 8 EVRM de staat slechts verplichtte om een vreemdeling voor het eerst toe te laten op het nationaal grondgebied, wanneer toelating 'de enige manier' was om het gezinsleven uit te kunnen oefenen, dat wil zeggen wanneer 'objectieve belemmeringen' hereniging van het gezin elders onmogelijk maakten. ${ }^{21}$ In recente zaken - Sen (2001), Mehemi (2003), Tuquabo-Tekle (2005) - heeft het Hof bepaald dat van een verplichting tot eerste toelating ook sprake kan zijn wanneer gezinsleden zodanig in de Nederlandse samenleving geworteld zijn, dat van hen in redelijkheid niet kan worden gevraagd om zich bij hun gezinslid in het buitenland te voegen. ${ }^{22}$ Verder blijkt uit de jurisprudentie van het Hof dat artikel 8 EVRM in gevallen van gezinsvorming een veel beperktere rol speelt dan bij gezinshereniging, aangezien dan voorafgaand aan de beslissing nog geen gezinsleven bestond dat om bescherming vroeg. ${ }^{23}$

Het Hof van Straatsburg laat staten dus een ruime marge om te beoordelen welke voorwaarden aan gezinsmigratie dienen te worden gesteld bijvoorbeeld op het gebied van inkomen of huisvesting - om het nationaal belang te waarborgen. Daarbij komt dat de Afdeling Bestuursrechtspraak van de Raad van State - de hoogste vreemdelingenrechter in Nederland zich terughoudend op pleegt te stellen bij het toepassen van het EVRM in vreemdelingenzaken. Juist op een onderwerp dat politiek zo gevoelig ligt als gezinsmigratie is de Afdeling huiverig om op de stoel van het democratisch bestuur te gaan zitten. ${ }^{24}$ Hoewel Nederlandse besluitvormers dus

19 Van Walsum 2004b: 138; Steenbergen 1989: 35; Steenbergen 1990: 4-5.

20 Boeles 2004b: 103-104; Boeles 2004c: 114; Van Walsum 2004b: 143-144.

21 Boeles 2004c: 113-115.

22 Van Walsum 2004b: 141; Zaak Tuquabo-Tekle e.a. vs. Nederland, 1 december 2005, nr. 60665/00. Website EHRM, www.echr.coe.int.

23 Van Walsum 2004b: 138.

24 Van Walsum 2004c: 181-185, 188-190; Steenbergen 1989: 36. 
nog steeds over veel beleidsruimte beschikken, heeft de jurisprudentie op basis van artikel 8 EVRM zich wel ontwikkeld tot een factor waarmee zij in de beleidsvorming rekening moeten houden. Nadat Nederland in 1988 door het Hof van Straatsburg veroordeeld was in de zaak-Berrehab, werd voor het eerst in het Nederlands vreemdelingenbeleid vastgelegd dat in gezinsmigratiezaken getoetst moest worden of er sprake was van inbreuk op artikel 8 EVRM. ${ }^{25}$ Sindsdien is artikel 8 zowel in ambtelijke als in parlementaire beleidsdebatten een onontkoombaar referentiepunt: van ieder voorstel dient bezien en beargumenteerd te worden of het binnen de grenzen van het EVRM valt. In het vervolg van dit hoofdstuk zal blijken dat die grenzen ruim genoeg zijn om significante aanscherpingen van het gezinsmigratiebeleid toe te staan. In een tweetal specifieke gevallen heeft artikel 8 wel een belangrijke rol gespeeld in de beleidsontwikkeling. Dit betrof in de eerste plaats gezinshereniging van vluchtelingen, bij wie immers sprake is van 'objectieve belemmeringen' om naar het land van herkomst terug te keren, en in de tweede plaats de Nederlandse interpretatie van een 'feitelijke gezinsband' ${ }^{26}$

25 Steenbergen 1990: 3; Van Walsum 2008: 188. Zie ook Vc 1982 Deel B19/1.2 (supplement 7, december 1992). Documentatie Database CMR. 26 Zie respectievelijk paragraaf 4.5 en 4.11 . 


\section{DEEL I: DE JAREN NEGENTIG}

\subsection{Verantwoord burgerschap: een nieuwe kijk op migratie en integratie}

\section{Optimisme maakt plaats voor zorg}

Het liberaal gezinsmigratiebeleid dat Nederland in de jaren tachtig voerde was enerzijds gebaseerd op het moreel gewicht dat aan het recht op gezinshereniging werd toegekend, en anderzijds op optimistische verwachtingen inzake de maatschappelijke gevolgen van immigratie. Er was een groot vertrouwen dat migranten, dankzij het minderhedenbeleid, hun plaats zouden vinden in de Nederlandse samenleving. Dat optimisme begon in de tweede helft van de jaren tachtig te tanen, en sloeg in de vroege jaren negentig zelfs om in uitgesproken bezorgdheid. Gevolg was een wezenlijke verschuiving in het dominant perspectief van Nederlandse beleidsmakers op het migratie- en integratievraagstuk..$^{27}$

Die paradigmawisseling was in de eerste plaats een respons op een scherpe stijging van de immigratie. Het aantal immigranten dat in het buitenland was geboren bereikte, na een daling van ruim 90 duizend in 1980 tot ruim 55 duizend in 1985, opnieuw recordhoogten van rond de 95 duizend tussen 1990 en $1993 .^{28}$ Vooral de asielinstroom was zeer sterk gestegen, van iets meer dan duizend in 1980 en 5 duizend in 1985, tot jaarlijks ruim 20 duizend tussen 1990 en 1992 en zelfs meer dan 35 duizend in 1993. ${ }^{29}$ Ook de migratie uit Marokko en Turkije nam weer toe, van een kleine 10 duizend in 1985 tot zo'n 20 duizend per jaar in de vroege jaren negentig. ${ }^{30}$ De veronderstelling van de jaren tachtig, dat grootschalige immigratie een historisch unieke en eenmalige gebeurtenis was geweest, bleek een illusie. Voorlopig was het einde van de migratiestromen naar Nederland nog niet in zicht.

Bovendien bleven de resultaten van het minderhedenbeleid ver achter bij de verwachtingen. Waar de arbeidsparticipatie onder de autochtone

27 Scholten 2007: 82-84; Entzinger 2003: 69.

28 Website van het CBS, Historie bevolking, immigratie naar geboorteland, statline.cbs.nl. Totale immigratie minus personen die in Nederland geboren zijn.

29 Website van het CBS, Asielverzoeken, statline.cbs.nl. Cijfers uitgesplitst naar andere migratiemotieven, zoals arbeids- of gezinsmigratie zijn pas vanaf 1995 beschikbaar.

30 Website van het CBS, Historie bevolking, immigratie naar nationaliteit, statline.cbs.nl. 
Nederlandse beroepsbevolking na het dieptepunt van de economische crisis in 1983 weer steeg, nam ze onder migranten almaar verder af. In 1987 was meer dan $40 \%$ van de Turkse en Marokkaanse, en ongeveer $25 \%$ van de Surinaamse en Antilliaanse beroepsbevolking werkloos, tegen 13\% van de autochtone Nederlandse beroepsbevolking. De deelname aan het onderwijs liet een vergelijkbaar beeld zien: ruim 52\% van de autochtone jongeren ging naar het mbo, havo of vwo, tegen $24 \%$ van de Antillianen en Arubanen, $30 \%$ van de Surinamers en niet meer dan $17 \%$ van de Turkse en $11 \%$ van de Marokkaanse jongeren. Daarbij bleef de ruimtelijke segregatie toenemen: in 1985 was in dertig wijken in de vier grote steden meer dan $30 \%$ van de bewoners migrant of kind van een migrant. ${ }^{31}$ De inpassing van migranten in de Nederlandse maatschappij bleek een weerbarstiger vraagstuk dan de ontwerpers van het minderhedenbeleid begin jaren tachtig hadden voorzien.

Migratie en integratie waren niet alleen voor ambtenaren en politici een punt van zorg. Ook het publiek debat over de positie van migranten in de Nederlandse samenleving werd steeds levendiger en bovendien steeds kritischer en bezorgder van toon. In 1988 schreef de Marokkaan David Pinto in de Volkskrant dat etnische groepen in Nederland waren 'doodgeknuffeld', een term die veel navolging zou vinden. Datzelfde jaar lekte in Amsterdam een ambtelijke notitie uit over criminaliteit onder Marokkaanse jongeren. De teneur van het felle mediadebat dat volgde was dat deze 'ontsporingen' het failliet van het softe overheidsbeleid aantoonden. ${ }^{32}$ In 1991 verscheen een opiniestuk van Frits Bolkestein, voorzitter van de VvDfractie, in de Volkskrant. Bolkestein verzette zich tegen de vrijblijvendheid en het cultuurrelativisme die het minderhedenbeleid van de jaren tachtig hadden gekenmerkt en verklaarde dat de integratie van minderheden 'met lef' moest worden aangepakt. ${ }^{33}$ Zijn artikel maakte een publiek en politiek debat los dat meer dan een jaar zou duren en droeg ertoe bij dat het integratievraagstuk hoog op de politieke agenda kwam te staan. ${ }^{34}$ De intensiteit en de toon van de debatten die rond 1990 plaatsvonden laten zien dat er iets wezenlijks veranderd was. De jaren tachtig, met hun hoge morele norm van respect voor cultureel anders-zijn en zorg voor kwetsbare minderheden, en met hun 'verlammende harde norm om niet te discrimineren, ${ }^{35}$ waren

31 WRR 1989: 77-78, 184.

32 Tinnemans 1994: 329-331.

33 Prins 2002: 243; Prins 2004: 25-26; Tinnemans 1994: 362-363; Scholten 2007: 166-167.

34 Prins 2004: 26-27; Mariën 1992; Entzinger 2003: 71; Scholten 2007: 178, 187, 189.

35 Molleman, geciteerd in Tinnemans 1994: 331. 
voorbij. Het vertrouwen in de 'oplosbaarheid' van het integratievraagstuk maakte plaats voor een breed gedeeld gevoelen dat Nederland zich met een fundamenteel probleem geconfronteerd zag. Daarmee kreeg het integratievraagstuk een politieke urgentie die het voorheen niet had.

\section{Rechten en plichten}

De manier waarop de politiek op de toenemende zorg over de omvang van de migratiestroom en de maatschappelijke positie van migranten reageerde, werd sterk beïnvloed door een algemene herwaardering van de rol van de overheid ten opzichte van de burger en de maatschappij, die zich vanaf de tweede helft van de jaren tachtig voltrok. ${ }^{36}$ Het geloof in de maakbaarheid van de samenleving maakte plaats voor de overtuiging dat de verzorgingsstaat zijn doel voorbij was geschoten. ${ }^{37}$ Te veel overheidszorg maakte mensen passief en afhankelijk, waar hen de middelen zouden moeten worden aangereikt om actief en zelfredzaam te zijn. In de jaren negentig werd de inrichting van de Nederlandse verzorgingsstaat ingrijpend gewijzigd. Er werden 'prikkels' ingebouwd die 'activerend' dienden te werken, dat wil zeggen mensen ertoe moesten brengen zelfstandig in hun levensonderhoud te voorzien. Centraal stond de 'wederkerigheid van prestaties': het principe dat tegenover rechten ook plichten moesten staan. ${ }^{38}$

Het CDA had, al sinds het aantreden van het eerste kabinet Lubbers, 'het voortouw' genomen in deze 'neo-liberale koers', waarin 'marktstimulering, privatisering en deregulering' centraal stonden. ${ }^{39}$ Het nieuwe ideologische programma van het CDA, waarin een bescheidener rol voor de overheid was weggelegd en een beroep werd gedaan op de 'eigen verantwoordelijkheid' van burgers, markt en maatschappelijke organisaties, vond steeds bredere weerklank, niet alleen bij de VVD die deze principes van oudsher hoog in haar vaandel had staan, maar ook - tot op zekere hoogte - bij de PvdA. De sociaaldemocraten hadden het geloof in de maakbaarheid van de samenleving grotendeels laten varen. Hoewel zij nog steeds een belangrijker rol aan de overheid toeschreven dan VVD en CDA, werd ook binnen de PVdA nu meer nadruk gelegd op individuele verantwoordelijkheid en actieve participatie. ${ }^{40}$ Op krachtig aandringen van het CDA zou deze nieuwe 'rechten en

36 Scholten 2007: 151.

37 Tinnemans 1994: 328.

38 Van der Veen 1999: 46; Fermin 1997: 190-191.

39 Van Doorn 1996b: 131. Vgl. Hirsch Ballin 1992; Voerman \& Lucardie 1992: 31-33.

40 Voerman \& Lucardie 1992: 34-37. 
plichten'-benadering ook in de debatten over het migratie- en integratiebeleid een centrale rol gaan spelen.

In deze herijking van debat en beleid op het gebied van migratie en integratie speelde de WRR, onder voorzitterschap van de christendemocraat Wil Albeda, gewezen minister van Sociale Zaken, een belangrijke rol. Precies tien jaar na het WRR-rapport van 1979, dat aan de wieg van het minderhedenbeleid had gestaan, bracht de Raad een nieuw rapport uit over het overheidsbeleid ten aanzien van migranten in de Nederlandse samenleving, getiteld Allochtonenbeleid. ${ }^{41}$ De regering had de Raad verzocht om zich opnieuw over het minderhedenbeleid te buigen, omdat op de terreinen van 'wonen, weten en werken (...) ondanks de geleverde inspanningen te weinig vooruitgang [is] geboekt' ${ }^{42}$ Het rapport was opgesteld door een projectgroep onder leiding van Albeda, onder wiens voorzitterschap de WRR in 1987 en in 1990 eveneens rapporten uitbracht waarin werd gepleit voor een 'activerende verzorgingsstaat', waar plichten tegenover rechten moesten staan opdat mensen weerbaar werden gemaakt in plaats van 'apathisch' ${ }^{43}$ De agenda van de WRR kwam in deze periode dus nauw overeen met het programma van het CDA. Naar Albeda's eigen zeggen paste ook het rapport Allochtonenbeleid in deze nieuwe visie op de verhouding tussen overheid en burgers. ${ }^{44}$

Centraal uitgangspunt van het rapport was dat de Nederlandse regering niet alleen moest erkennen dat de aanwezigheid van migranten permanent was, zoals zij in 1980 had gedaan, maar ook dat 'de immigratie zelve blijvend is, ook bij handhaving van het huidige restrictieve toelatingsbeleid' ${ }^{45}$ De incorporatie van nieuwkomers in de Nederlandse maatschappij moest dus als een structurele opgave worden beschouwd. De Raad stelde daarom een grondige herziening van het minderhedenbeleid voor. Minderheden waren tot dan toe te veel als 'zorgcategorieeën' beschouwd. De Raad pleitte ervoor het beleid 'uit de huidige sfeer van vrijblijvendheid te halen': tegenover de moeite die de overheid zich getroostte om participatie mogelijk te maken diende een 'inspanningverplichting' van migranten te staan. De overheid zou minder aandacht moeten besteden aan collectieve cultuur- en identiteitsbeleving en meer aan individuele participatie in onderwijs en op

41 Scholten 2007: 188.

42 Brief minister-president aan WRR, 1 oktober 1987, in WRR 1989: 207.

43 Scholten 2007: 172-173.

44 Scholten 2007: 172-173; zie ook Mariën 1992: 12.

45 WRR 1989: 10, cursivering in origineel. 
de arbeidsmarkt. ${ }^{46}$

\section{Van minderhedenbeleid naar integratiebeleid}

Het WRR-rapport werd door de regering goed ontvangen. In 1990 verklaarde premier Lubbers, in een radio-interview dat veel stof deed opwaaien, dat hij 'zijn geduld begon te verliezen' met het minderhedenvraagstuk en een 'minder softe benadering' wilde, overeenkomstig de lijnen die door de WRR waren uitgezet. Volgens Scholten was Lubbers daarmee één van de eerste politici die het taboe op het uitspreken van zorg over het verloop van migrantenincorporatie doorbak. ${ }^{47}$ In zijn formele reactie op het rapport stemde het derde kabinet Lubbers in met een primair sociaal-economische benadering, waarin onderwijs en toegang tot de arbeidsmarkt centraal zouden staan en waarin een 'nieuw evenwicht' moest worden gevonden tussen rechten en plichten. ${ }^{48}$

In 1994 werd Wim Kok premier van het eerste 'Paarse' kabinet, waarin PVdA, VVD en D66 deelnamen. Voor het eerst sinds 1918 werden de christendemocraten naar de oppositiebankjes verwezen. Waar de regering onder Lubbers nog vasthield aan het model van collectieve emancipatie, en categoriale voorzieningen als onderwijs in eigen taal en cultuur en consultatiestructuren had gehandhaafd, ${ }^{49}$ omarmde het Paarse kabinet de individuele benadering die de WRR had bepleit. De Contourennota van 1994 markeerde een definitieve omslag in de benadering van het migrantenvraagstuk. ${ }^{50}$ De regering koos ervoor de term 'minderhedenbeleid' te vervangen door 'integratiebeleid'. Kernwoorden in de nieuwe benadering waren 'burgerschap' en 'eigen verantwoordelijkheid'. Het Paarse kabinet formuleerde het als volgt: 'Burgerschap als basisprincipe van het toekomstige beleid veronderstelt vrije, autonome en actieve burgers die verantwoordelijkheid dragen voor zichzelf en de samenleving en daarop aangesproken kunnen worden' ${ }^{9}{ }^{51}$ Participatie in onderwijs en arbeidsmarkt werd een plicht genoemd. Nieuwe migranten zouden zich de Nederlandse taal en

\footnotetext{
46 WRR 1989: 9-13, 17, 19-20, 24, 58; Scholten 2007: 159-162; Fermin 1997: 189-192; Entzinger 2003: 73.

47 Scholten 2007: 165-166; 187.

48 Fermin 1997: 193-194.

49 Fermin 1997: 193-194; Scholten 2007: 166.

50 Fermin 1997: 209-215; Scholten 2007: 83-85, 156.

51 TK 1993-1994 23684 (2): 24.
} 
een basiskennis van de Nederlandse samenleving eigen moeten maken: ${ }^{52}$ daartoe werd in 1998 de Wet Inburgering Nieuwkomers ingevoerd. Voor de Paarse coalitiepartijen was 'cultuur' een privézaak, waar de overheid zich niet mee zou bemoeien. Sociale cohesie en wederzijdse acceptatie moesten worden bereikt door iedereen aan het werk te zetten. ${ }^{53}$ Zo werd een algemeen activerend arbeidsmarktbeleid voorgesteld, waarvan gesubsidieerde arbeidsplaatsen - de Melkert-banen - het meest bekende voorbeeld zouden worden.

De nadruk op individuele sociaal-economische participatie als sleutel tot sociale samenhang, waarbij het cultureel aspect een zeer bescheiden plaats kreeg in het overheidsbeleid, weerspiegelt de standpunten van de PvdA en haar seculiere coalitiepartners. ${ }^{54}$ Met het CDA verdween ook de nadruk op collectieve emancipatie en cultuur- en identiteitsbeleving uit het repertoire van de regering. ${ }^{55}$ Daarnaast was deze pragmatische aanpak, waarin culturele conflicten ontzenuwd moesten worden door participatie op school en op de werkvloer, de 'Paarse' versie van de depolitiserende stijl die de omgang van de Nederlandse politiek met het migrantenvraagstuk al sinds de jaren tachtig kenmerkte. ${ }^{56}$ Vooral de PvdA bleef gebrand op 'zorgvuldig en duidelijk' taalgebruik, om stigmatisering van migranten te voorkomen. $^{57}$

De onwil om onvrede in de samenleving te voeden tekende ook de omgang van de Paarse kabinetten met het toelatingsbeleid. Enerzijds moest het restrictief vreemdelingenbeleid 'geïntensiveerd' worden, niet alleen omdat dat een 'randvoorwaarde' was voor een succesvol integratiebeleid, maar ook om het beeld te ontkrachten 'dat de overheid machteloos staat tegenover de instroom van vreemdelingen'. Anderzijds moest de regering uitdragen dat immigratie 'verrijkende en dynamiserende effecten' kon hebben en ervoor waken dat 'elke immigrant reeds bij voorbaat wordt geproblematiseerd' ${ }^{58}$

De politieke omgang met het migratie- en integratievraagstuk veranderde in de jaren negentig dus wezenlijk ten opzichte van de jaren tachtig. Waar

52 TK 1993-1994 23684 (2): 25

53 Fermin 1997: 211-212; Scholten 2007: 84-85.

54 De Beus 1998: 14-15.

55 Entzinger 2003: 77-78.

56 De Beus 1998; Guiraudon 2000: 139-153; Thränhardt 2002: 237.

57 Fermin 1997: 106-107.

58 тK 1993-1994 23684 (2): 17-18. 
het minderhedenbeleid draaide om collectieve emancipatie en identiteitsbeleving, versterking van de rechtspositie en toegang tot sociale voorzieningen, verplaatste de nadruk zich in de jaren negentig naar eigen verantwoordelijkheid, zelfredzaamheid en actief burgerschap. Daarmee werd ook het debat over gezinsmigratie in nieuwe termen gevoerd. In de jaren tachtig draaide dat debat om rechten: aan het recht op gezinshereniging en het recht op gelijke behandeling werd een bijzonder moreel gewicht toegekend. Over de maatschappelijke consequenties van gezinsmigratie was men optimistisch. In de jaren negentig daarentegen baarden die consequenties steeds meer zorgen, als gevolg van de stijgende migratiestromen en de weinig rooskleurige maatschappelijke positie van migranten. De balans tussen het individueel belang van een gezin bij hereniging enerzijds en het algemeen maatschappelijk belang bij migratiebeperking anderzijds sloeg geleidelijk om naar de andere kant. In de jaren tachtig was het recht op gezinshereniging vrijwel onaantastbaar: vanaf de jaren negentig zouden er aan dat recht voorwaarden worden gesteld. Dat paste ook in de neo-liberale visie, die breed opgang deed, dat tegenover rechten plichten dienden te staan.

\subsection{Een eerste restrictieve stap: de hervormingen van 1993}

In 1993 werden, voor het eerst in zeer lange tijd, de voorwaarden voor gezinsmigratie significant verzwaard. ${ }^{59}$ Het belangrijkste element van de hervormingen van 1993 was een aanscherping van het inkomensvereiste. In de jaren tachtig waren Nederlanders en vreemdelingen met een permanente verblijfsvergunning vrijgesteld van dat vereiste, indien zij buiten hun schuld over onvoldoende inkomen beschikten. Dat 'verwijtbaarheidscriterium' werd in 1993 afgeschaft. Daarmee brak de Nederlandse politiek met het liberale gezinsmigratiebeleid van de jaren tachtig en werd een restrictieve lijn ingezet, die tot de dag van vandaag de beleidsvorming bepaalt. Deze ommekeer kwam echter niet zonder slag of stoot tot stand. Er ging een bijzonder moeizaam proces van besluitvorming aan vooraf, niet alleen in de parlementaire arena, maar vooral ook binnen en tussen de ministeries.

59 Het inkomensvereiste was in 1989 als gevolg van een rechterlijke uitspraak wel in zoverre aangescherpt, dat het inkomen van de buitenlandse partner niet meer mocht worden meegerekend. De Hart 2003a: 108, 110. 


\section{Worsteling binnen de regering}

In het regeerakkoord van het derde kabinet Lubbers hadden de coalitiepartijen CDA en PvdA aangekondigd zich op het gezinsmigratiebeleid te willen bezinnen. Uitgangspunt bleef 'het recht op gezinsleven en non-discriminatie', maar:

[d] at betekent intussen wel dat een aanzienlijke stroom allochtonen op grond van de gezinshereniging naar Nederland zal blijven komen. De omvang van het vestigingsoverschot dwingt ertoe na te gaan hoe deze met inachtneming van de zojuist geformuleerde beginselen beheerst kan worden. Deze beheersing kan niet los gezien worden van de politiek morele plicht zorg te dragen voor reële integratiemogelijkheden in ons land en deze ook als uitgangspunt in het beleid te nemen. ${ }^{60}$

In 1989 was integratie een probleem geworden met een politieke urgentie die scherp contrasteerde met het vertrouwen in de oplosbaarheid van het minderhedenvraagstuk in de vroege jaren tachtig. Om de integratieproblematiek het hoofd te bieden werd een beperking van de omvang van de immigratie wenselijk geacht. Aangezien gezinsmigratie volgens berekeningen van het onderzoekscentrum van het ministerie van Justitie eind jaren tachtig $70 \%$ van de jaarlijkse instroom uitmaakte, bleef deze beleidscategorie niet langer buiten schot. ${ }^{61}$ Het kabinet gaf de opdracht om mogelijkheden voor restrictieve hervormingen van het gezinsmigratiebeleid te onderzoeken en het kwantitatieve effect van de beleidsopties te berekenen. ${ }^{62}$ Eind 1991 presenteerde de Interdepartementale Stuurgroep Immigratie (ISI), een ambtelijke werkgroep die als voorportaal van de ministerraad functioneerde, een rapport op basis van de onderzoeksresultaten.

De ISI was bezorgd over het verloop van de integratie van migranten, met name over 'hogere werkloosheid, vergrote huisvestingsproblematiek en toenemende spanningen tussen allochtonen en autochtonen'. De overheid diende 'de overlast van migratie' tegen te gaan, in de eerste plaats door een minder vrijblijvend integratiebeleid te voeren, zoals de WRR in 1989 had voorgesteld, en in de tweede plaats door in het toelatingsbeleid

60 TK 1989-1990 $21132(8 \mathrm{H}): 43$.

61 Naborn 1992: 2.

62 Overzicht activiteiten t.a.v. het gezinsherenigings- en vormingsbeleid in ISI-kader en MR, n.d. IND A92/7926. 
'een nog restrictievere koers' te kiezen. Daarbij zouden echter onvermijdelijk 'tot dusver als essentieel ervaren uitgangspunten van het beleid, ter discussie worden gesteld'. De soepele voorwaarden voor gezinsmigratie behoorden tot die essentiële uitgangspunten.

De ISI stelde dat uit het onderzoek bleek dat alleen het verbieden van gezinsvorming voor migranten van de tweede generatie 'forse kwantitatieve effecten' zou sorteren. Probleem was echter dat een dergelijke maatregel - zoals in de discussies rond de '1445-maatregel' in de jaren tachtig wel was gebleken ${ }^{63}$ - als discriminerend zou kunnen worden ervaren. De ISI deed daarom een alternatief voorstel: het stellen van een onverkorte inkomenseis zowel aan gevestigde vreemdelingen als aan Nederlands staatsburgers. Deze beleidsoptie was in het onderzoek niet meegenomen: alleen het kwantitatief effect van een verhoogde inkomenseis voor vreemdelingen was onderzocht en dat bleek verwaarloosbaar. De ISI verwachtte dat een onverkorte inkomenseis wel een significant beperkend effect zou hebben wanneer hij ook op Nederlanders werd toegepast. ${ }^{64}$

Dat aan het stellen van strengere eisen aan de overkomst van buitenlandse gezinsleden van Nederlanders in eerste instantie niet eens was gedacht, is veelzeggend. Tot de jaren zestig was het vanzelfsprekend dat een gezin één nationaliteit bezat, namelijk die van de echtgenoot en vader. Daarmee was het ook vanzelfsprekend dat een Nederlandse man en zijn vrouw en kinderen onvoorwaardelijk recht hadden op verblijf in Nederland. Een Nederlandse vrouw werd geacht haar buitenlandse echtgenoot te volgen in zijn nationaliteit en verblijfplaats. De opkomst van de norm van gelijke behandeling in de jaren zeventig leidde ertoe dat deze bevoorrechte positie van Nederlandse mannen ten opzichte van vrouwen en gevestigde vreemdelingen als onrechtvaardig werd ervaren. De eerste jaren bleef het principe dat een Nederlands staatsburger met zijn gezin op Nederlands grondgebied moest kunnen verblijven onbetwist. Gelijke behandeling werd dus bereikt door de voorwaarden voor Nederlandse vrouwen en gevestigde vreemdelingen te versoepelen. Begin jaren negentig was het gelijkheidsbeginsel een vanzelfsprekende politieke norm geworden. Tegelijkertijd werd de wens om de integratieproblematiek te verzachten door immigratie te beperken echter dermate dringend, dat dit gelijkheidsbeginsel een omgekeerde uitwerking kreeg: niet een verbetering voor wie tot dan toe achter-

63 Zie paragraaf 3.8 .

64 Tweede interim-rapport ISI, november 1991. IND A92/3429. 
gesteld was, maar een verslechtering voor wie voorheen bevoorrecht was. ${ }^{65}$ Er werd gebroken met het fundamentele uitgangspunt dat Nederlanders met hun gezinsleden een bijzondere aanspraak op verblijf in Nederland hadden. Daarbij speelde de constatering dat ruim een derde deel van de gezinsmigratiestroom uit partners en kinderen van Nederlanders bestond een cruciale rol. ${ }^{66}$

In reactie op de aanbevelingen van de ISI werden minister Ernst Hirsch Ballin (CDA) en staatssecretaris Aad Kosto (PvdA) van Justitie verzocht om de ministerraad een voorstel voor te leggen om, 'gelet op het hoge vestigingssaldo', gezinsmigratie aan verdere restricties te onderwerpen. ${ }^{67}$ Kosto was formeel verantwoordelijk voor het vreemdelingenbeleid. Uit het feit dat de opdracht om een voorstel te formuleren niet alleen aan hem maar ook aan minister Hirsch Ballin van Justitie werd toebedeeld, blijkt het politieke gewicht dat aan de hervorming van het gezinsmigratiebeleid werd toegekend. Het duurde niet minder dan vier maanden voordat een brief was opgesteld waar beide bewindslieden hun handtekening onder wilden zetten. Al in deze vroege fase van de beleidsvorming speelde partijpolitiek namelijk een cruciale rol. Lang voor de formele parlementaire behandeling liet de PvdA-fractie staatssecretaris Kosto weten een aanscherping van het inkomensvereiste pertinent te verwerpen als een 'beperking van de vrijheid van burgers', die 'met name de mensen die tot de laagste inkomensgroepen behoren' zou treffen. ${ }^{68}$ De CDA-fractie daarentegen gaf aan minister Hirsch Ballin als haar standpunt te kennen dat een regelmatig arbeidspatroon moest zijn aangetoond alvorens gezinshereniging werd toegestaan. ${ }^{69}$ Kosto en Hirsch Ballin hadden dus een heel verschillend politiek mandaat gekregen.

Hirsch Ballin hechtte groot belang aan het beperken van gezinsvorming, omdat uit onderzoek bleek dat gezinshereniging ten einde liep, terwijl ‘juist de gezinsvorming zorgt voor een grote toevloed van allochtonen'. Bovendien wenste hij, gezien de 'groeiende zwarigheid van integratie in de Nederlandse samenleving', gezinshereniging te beperken tot kinderen van

65 Ook in de wijziging van het nationaliteitsrecht in 1985 was al sprake van levelling down: zie paragraaf 3.7 .

66 Naborn 1992: 33; Notitie Brinkman aan minister-president, 7 oktober 1992. IND A92/3470-I.

67 Conclusies bewindsliedenoverleg 26 maart 1992. IND A92/3470.

68 Brief Apostolou aan staatssecretaris, 22 januari 1992. Zie ook brief Apostolou aan staatssecretaris, 28 oktober 1992. IND A92/3416.

69 Brief en notitie Brinkman aan minister, 24 juni 1992. Zie ook fax Krajenbrink aan hoofd DVZ, 24 september 1992. IND A92/3470. 
maximaal twaalf jaar. ${ }^{70}$ Kosto daarentegen voorzag 'geringe kwantitatieve effecten', 'ontduikingsgedrag' en 'politieke commotie' bij een aanscherping van het gezinsvormingsbeleid. ${ }^{71}$ In een handgeschreven briefje aan Hirsch Ballin stelde hij bovendien:

mij gaat het te ver als enig land in Europa de leeftijd van gezinshereniging te verlagen tot 12 jaar. Puur politiek: de opschudding daarover zal niet in de laatste plaats uit mijn politieke kring komen. En daarmee ben $\mathrm{ik}$ het dan ook nog eens. Dat maakt het voor mij onmogelijk de brief te tekenen, als daarin positief moet worden geoordeeld over dit aspect. ${ }^{72}$

Het voorstel dat de bewindslieden van Justitie in juni 1992 naar de ministerraad zonden was een compromis, waarbij echter vooral Kosto water bij de wijn lijkt te hebben gedaan. Zij pleitten voor een 'consequente toepassing' van de inkomenseis bij gezinsvorming. De maximum-leeftijd van 12 jaar bij gezinshereniging was vervangen door het voorstel om bij kinderen tussen de 12 en 18 jaar die naar Nederland kwamen 'integratie gerichte eisen' te stellen, zoals een aangepaste leerplicht. ${ }^{73}$

Dit laatste was zeer innovatief: voor het eerst werd overwogen om integratievereisten op te nemen in het immigratiebeleid. Dit voorstel weerspiegelt het nieuwe gewicht van het integratievraagstuk en de manier waarop dat doorwerkte in discussies over het vreemdelingenbeleid. In een later stadium zou zelfs worden voorgesteld om integratiefaciliteiten in het herkomstland aan te bieden. ${ }^{74}$ In de laatste fase van het besluitvormingsproces zouden de 'integratie gerichte eisen' echter sneuvelen vanwege juridische bezwaren - mogelijke strijd met het artikel 8 EVRM - maar vooral ook vanwege praktische bezwaren inzake de financiering. ${ }^{75}$ Pas na de eeuwwisseling zouden dergelijke voorstellen opnieuw ter tafel worden gebracht.

In een eerste reactie op het voorstel van Justitie betuigde Sociale Zaken zijn instemming en gaf het zelfs te kennen de onverkorte inkomenseis niet alleen op gezinsvorming maar ook op gezinshereniging toe te willen

70 Notitie minister aan ambtenaren en staatssecretaris, 13 april 1992; Fax minister aan hoofd DVZ, 14 april 1992; Aantekeningen minister op concept-brief aan ministerraad, 28 april 1992. IND A92/3470.

71 Aantekeningen staatssecretaris op concept-brief aan ministerraad, 28 april 1992. IND A92/3470.

72 Brief van staatssecretaris aan minister, 13 mei 1992. IND A92/3470. Onderstreping in origineel.

73 Brief minister en staatssecretaris van Justitie aan ministerraad, 11 juni 1992. IND A92/3470.

74 Ambtelijk compromis BiZa/DVZ, 1 oktober 1992. IND A92/3470-I.

75 Brief minister van Binnenlandse Zaken aan minister van Justitie, 12 augustus 1992. IND A92/3470; Nota secretaris-generaal AZ aan minister-president, 8 oktober 1992. IND A92/3470-I. 
passen. ${ }^{76}$ Sociale Zaken had er immers belang bij, zo stelde een ambtenaar van dat ministerie in een interne nota, de instroom te beperken en te voorkomen dat er door nieuwkomers een beroep op sociale voorzieningen werd gedaan: 'Vanuit deze invalshoek kan elke bijstelling van het beleid die de groep personen verkleint die voor toelating in aanmerking komt, worden ondersteund. ${ }^{77}$ Binnenlandse Zaken liet weten akkoord te gaan, met dien verstande dat de 'consequente' toepassing van het inkomensvereiste bij gezinsvorming niet meer dan een wijziging van de uitvoeringspraktijk mocht inhouden. ${ }^{78}$

Kosto en Hirsch Ballin interpreteerden deze reacties als steun voor het toekennen van een 'reële betekenis' aan het inkomensvereiste. ${ }^{79}$ In een nieuwe brief aan de ministerraad stelden zij voor om zowel bij gezinshereniging als gezinsvorming de vrijstelling bij niet-verwijtbare werkloosheid af te schaffen. Nederlanders en vreemdelingen met een permanente verblijfstitel zouden pas buitenlandse gezinsleden mogen laten overkomen wanneer zij duurzaam en zelfstandig beschikten over voldoende middelen van bestaan. Een beroep op bijstand zou leiden tot weigering, niet alleen van eerste toelating, maar ook van voortgezet verblijf. Dit voorstel werd als volgt onderbouwd:

Het recht op gezins- en familieleven in de zin van artikel 8 EVRM moet gerespecteerd worden. Wel dient er een evenwichtige afweging van de belangen van de vreemdeling en de Staat plaats te vinden. Dit leidt ertoe dat (...) de betrokkene hier te lande voor de zorg van zijn gezin, maar ook het overkomende gezinslid of de partner, gewezen dient te worden op een eigen verantwoordelijkheid. Deze verantwoordelijkheid geldt niet alleen voor mogelijke financiële consequenties van het verblijf maar strekt zich ook uit over het integratieproces na toelating tot Nederland. De toenemende gezinsvorming door secundaire migranten in plaats van gezinshereniging door primaire migranten rechtvaardigt onzes inziens deze nadruk op de eigen verantwoordelijkheid. ${ }^{80}$

76 Brief staatssecretaris SzW aan minister van Justitie, 24 juni 1992. IND A92/3470.

77 Interne nota szw, 18 juni 1992. IND A92/3470.

78 Nota DCM (BiZa) aan DVZ, 25 juni 1992. IND A92/3470.

79 Brief minister en staatssecretaris van Justitie aan ministerraad, 29 juni 1992. IND A92/3470.

80 Notitie staatssecretaris en minister van Justitie aan ministerraad, 23 juli 1992. IND A92/3470. 
Deze argumentatie was rechtstreeks afkomstig uit de koker van Hirsch Ballin. ${ }^{81}$ Ze zou cruciaal blijken voor de politieke aanvaarding van het voorstel. Met de nadrukkelijke verwijzing naar 'eigen verantwoordelijkheid' verbond Hirsch Ballin de hervorming aan de algemene norm van 'rechten en plichten', gericht op minder overheidszorg en zelfredzamer burgers, die centraal stond in het ideologisch programma van het CDA. De inpassing van migranten in de maatschappij kon alleen succesvol zijn wanneer de betrokkenen actief de verantwoordelijkheid op zich namen voor hun integratieproces: het stellen van een inkomenseis was een manier om hen daartoe aan te zetten. De verwijzing naar de stijgende omvang van de gezinsvorming laat zien hoezeer dit nieuwe ideologische perspectief verweven was met de wens om de migratiestroom in te perken.

Het voorstel stuitte echter op fel verzet van het ministerie van Binnenlandse Zaken, dat verantwoordelijkheid droeg voor het minderhedenbeleid en waar Ien Dales (PvdA) de scepter voerde. In dit verzet overlapten en versterkten institutionele en ideologische perspectieven elkaar. Voor zowel het Directoraat Coördinatie Minderhedenbeleid (DCM) als de PvdA stond - net als in de jaren tachtig - emancipatie van migranten door versterking van hun rechtspositie voorop, in het bijzonder in een moreel gewichtige kwestie als gezinshereniging. Dales schreef aan Hirsch Ballin dat de voorstellen 'de rechtspositie van minderheden en andere sociaal zwakkere groepen in de samenleving onevenredig zullen aantasten' en daardoor het minderhedenbeleid zouden ondermijnen. ${ }^{82}$ Het hoofd DCM constateerde dat waar Binnenlandse Zaken behoud van rechten als uitgangspunt nam, Justitie leek te streven naar een 'sterke vermindering' van de instroom van migranten, een 'zelfstandig uitgangspunt' dat voor hem 'nieuw' was en dat hij duidelijk niet onderschreef. ${ }^{83}$ Binnenlandse Zaken zou Nederlanders en gevestigde vreemdelingen geheel vrij willen stellen van de inkomenseis. ${ }^{84}$

Na maanden ambtelijk overleg kwamen Justitie en Binnenlandse Zaken tot een compromis-voorstel. ${ }^{85}$ Met betrekking tot het inkomensvereiste, het centrale twistpunt, werd voorgesteld om bij gezinsmigratie van

81 Nota minister aan hoofd DVZ, 17 juli 1992. IND A92/3470.

82 Brief minister van Binnenlandse Zaken aan minister van Justitie, 12 augustus 1992. IND A $92 / 3470$.

83 Brief hoofd DCM (BiZa) aan secretaris-generaal AZ, 22 oktober 1992. A92/3470-I.

84 Brief van hoofd DCM (BiZa) aan hoofd DVZ, 19 oktober 1992. IND A92/3470-I.

85 In dit stadium werd overeenstemming bereikt over de nieuwe voorwaarden voor gezinsvorming en de omgekeerde wachttijd, die in de brief van januari 1993 aan de Kamer zouden worden aangekondigd. 
Nederlanders, vluchtelingen en vestigingsvergunninghouders een inkomen van $70 \%$ van de bijstandsnorm voor gezinnen te vergen. Op het laatste moment werd, op aandringen van ambtenaren van Binnenlandse Zaken, echter nog een clausule toegevoegd die stelde dat wie meer dan 10 jaar in Nederland verbleef zou worden vrijgesteld van het inkomensvereiste. ${ }^{86}$ Dit was evenwel niet aanvaardbaar voor minister Hirsch Ballin, omdat zo vrijwel alle Nederlanders en het grootste deel van de vreemdelingen met een permanente verblijfsvergunning alsnog buiten het bereik van het inkomensvereiste zouden vallen. ${ }^{87}$

De ambtenaren waren zo ver gekomen als zij konden: nu was het woord aan de politiek, dat wil zeggen aan de leden van het kabinet. Dat bleek echter zeer verdeeld en wel langs partij-politieke lijnen. Premier Lubbers en minister Hirsch Ballin, beide christendemocraten, stonden lijnrecht tegenover de sociaaldemocratische kabinetsleden, met Kok van Financiën, Dales van Binnenlandse Zaken en Ter Veld van Sociale Zaken voorop. ${ }^{88} \mathrm{De}$ PvdA-bewindslieden spanden zich tot het uiterste in om te voorkomen dat het voor mensen in een zwakke economische positie definitief onmogelijk zou worden om buitenlandse gezinsleden te laten overkomen. Vice-premier Kok stelde voor om vrijstelling van het inkomensvereiste te verlenen aan mensen die een verklaring van de Sociale Dienst konden overleggen dat ze onvrijwillig werkloos waren. ${ }^{89}$ Dales en Ter Veld opperden om eenieder met een arbeidsverleden van tenminste twee jaar vrij te stellen van het inkomensvereiste, indien geen sprake was van verwijtbare werkloosheid. ${ }^{90}$ Beide voorstellen stuitten op bezwaar bij Justitie en bij minister-president Lubbers, primair omdat ze het kwantitatief effect van de hervorming teniet zouden doen. $^{91}$

In dit stadium van de besluitvorming liet staatssecretaris Kosto, die de hervorming zou moeten verdedigen in de Kamer, opvallend weinig meer

86 Nota DVZ bij concept-brief Tweede Kamer, 29 oktober 1992. A92/3470.

87 Nota secretaris-generaal AZ aan minister-president, 22 oktober 1992; interne nota AZ, 5 november 1992. IND A92/3470.

88 Dat staatssecretaris Ter Veld van Sociale Zaken zich zo nadrukkelijk opwierp als een tegenstander van een stringente inkomenseis is verrassend, aangezien haar ministerie er in een vroeger stadium met succes voor gepleit had niet alleen bij gezinsvorming maar ook bij gezinshereniging een onverkorte inkomenseis toe te passen. Blijkbaar wogen partijpolitieke overwegingen in deze laatste fase van de besluitvorming zwaarder voor Ter Veld dan institutionele belangenpercepties. 89 Brief minister van Financiën aan staatssecretaris en minister van Justitie, minister van Binnenlandse Zaken en staatssecretaris sZW, 5 november 1992. IND A92/4370-I.

90 Brief staatssecretaris szW aan minister van Financiën, 15 december 1992. IND A92/3470-I.

91 Nota DVZ aan minister, 3 december 1992; Nota DVZ aan minister en staatssecretaris, 15 december 1992. IND A92/3470-I. 
van zich horen. Hij verklaarde later 'hartstikke klem' te hebben gezeten tussen het CDA, dat 'zat te hameren', en zijn PvdA-collega's, van wie hij 'nou niet altijd de onverkorte steun' kreeg. Premier Lubbers daarentegen stelde hem gerust: 'Waar het hier om gaat is in wezen een discussie tussen Wim Kok en mij. Daar kom jij ook niet uit'. ${ }^{92}$ Uiteindelijk was het inderdaad premier Lubbers die, op initiatief van Hirsch Ballin en na overleg met Kok, de knoop doorhakte. Gezinsmigratie zou niet worden toegestaan aan mensen die van een bijstandsuitkering leefden, maar wel aan mensen met een werkloosheidsuitkering die tenminste drie jaar hadden gewerkt in de vijf jaar voor ontslag. ${ }^{93}$

Er was meer dan een jaar voor nodig geweest om binnen de regering overeenkomst te bereiken. Dit werd deels veroorzaakt door conflicterende institutionele doelstellingen, met name tussen het ministerie van Justitie dat naar migratiebeperking streefde en het ministerie van Binnenlandse Zaken dat bescherming van de rechtspositie van minderheden voorop stelde. Veel belangrijker echter was de fundamentele ideologische botsing tussen de coalitiepartijen. De PvdA bleef gezinshereniging zien als een gewichtig moreel recht: zij kon het nauwelijks rechtvaardigen om mensen in een kwetsbare sociaal-economische positie dat recht te ontzeggen. Voor de CDA-bewindslieden daarentegen was de integratieproblematiek dermate urgent dat inperking van de gezinsmigratiestroom noodzakelijk werd geacht. Binnen het nieuwe perspectief van 'rechten en plichten' vonden zij het niet alleen aanvaardbaar maar zelfs aanbevelenswaardig om financiële voorwaarden te stellen aan gezinsmigratie, om betrokkenen te stimuleren om verantwoordelijkheid te nemen voor de toekomst van hun gezin in Nederland. De PvdA voerde in zekere zin een achterhoedegevecht, zoals ze vaker deed sinds de uitbouw van de verzorgingsstaat op zijn grenzen was gestuit: ze streed voor behoud van verworven rechten. Gegeven dit wezenlijke ideologische meningsverschil is het niet verrassend dat een definitief besluit alleen op het hoogste politieke niveau kon worden genomen, door premier Lubbers en vice-premier Kok. Dat partijpolitieke conflicten een bepalende rol speelden in de besluitvorming binnen het kabinet was een novum in de geschiedenis van het Nederlands gezinsmigratiebeleid sinds de jaren vijftig, en een duidelijk signaal dat het migratie- en integratievraagstuk een tot dan toe ongekend politiek gewicht had gekregen.

92 Interview met Aad Kosto, in Rehwinkel \& Nekkers 1994: 32-33.

93 Handgeschreven briefje van minister van Justitie aan minister-president en minister van Financiën, n.d.; brief minister-president aan alle bewindslieden, 7 januari 1993. IND A92/3470-II. 


\section{De parlementaire behandeling}

In januari 1993 stuurden staatssecretaris Kosto van Justitie en minister Dales van Binnenlandse Zaken een brief naar de Tweede Kamer, waarin zij het voorstel voor hervorming van het gezinsmigratiebeleid uiteen zetten. Er werden drie nieuwe voorwaarden voor gezinsvorming geïntroduceerd: een minimumleeftijd van 18 jaar, een wachttijd van 3 jaar, en een minimale leeftijd op het moment van huwelijkssluiting van 16 jaar. Verder werd een 'omgekeerde wachttijd' ingevoerd: omdat het met name voor de integratie van kinderen van belang werd geacht dat zij zo jong mogelijk naar Nederland kwamen, moest gezinshereniging voortaan binnen drie jaar worden aangevraagd. Ten slotte werd het verwijtbaarheidscriterium afgeschaft. Nederlanders, vestigingsvergunninghouders en vluchtelingen dienden tenminste $70 \%$ van het bijstandsniveau te verdienen. ${ }^{94}$ Ouderen, alleenstaande ouders van kleine kinderen en arbeidsongeschikten waren vrijgesteld van het inkomensvereiste. Voor jongeren tussen de 18 en 23 jaar zou genoegen worden genomen met het minimumjeugdloon. Voor vreemdelingen met een tijdelijke verblijfsvergunning veranderde er niets: voor hen gold nog steeds een inkomensvereiste van tenminste de bijstandsnorm. ${ }^{95}$ De complexiteit van de regeling weerspiegelde het moeizame proces van compromisvorming dat eraan ten grondslag lag.

In de strategie van het kabinet om de Kamer te doen instemmen met zijn plannen vallen drie elementen op. Het eerste was de nadruk waarmee de hervorming in het perspectief van 'eigen verantwoordelijkheid' werd geplaatst. Met het inkomensvereiste werd een beroep gedaan op de verantwoordelijkheid van de betrokkenen om actief bij te dragen aan hun eigen integratieproces. ${ }^{96}$ Die nieuwe benadering werd expliciet afgezet tegen standpunten die in het verleden waren ingenomen. Toen GroenLinks ${ }^{97} \mathrm{de}$ regeringsvoorstellen bekritiseerde als een vorm van indirecte discriminatie, antwoordde premier Lubbers:

Ik zou zo graag eens hebben dat wij het eens werden over het feit dat wij iets mogen vragen van degene die aan gezinsvorming wil doen en dat dit niet discriminerend is. (...) Het is minderhedenbeleid oude stijl

94 Voor vluchtelingen gold de inkomenseis alleen bij gezinsvorming, niet bij gezinshereniging. 95 TK 1992-1993 22809 (10): 3-5

96 TK 1992-1993 22809 (10): 1.

97 GroenLinks was in 1990 opgericht als een fusie van CPN, EVP, PPR en PSP. 
- ik zeg het hard - als wordt gezegd: nou ja, laten we maar niet naar het inkomen kijken, dat is helemaal niet belangrijk. Dat is echt niet zuiver.

In datzelfde korte debat gebruikte Lubbers de woorden 'verantwoordelijk' en 'verantwoordelijkheid' niet minder dan vijftien keer. 98

De tweede politieke strategie, die vooral door de PvdA werd ingezet, bestond eruit de voorstellen te presenteren als een verbetering van de uitvoeringspraktijk, in plaats van een hervorming van het beleid. Sociaaldemocratische Kamerleden en bewindslieden benadrukten steeds opnieuw dat het inkomensvereiste niet werd ge ̈̈ntroduceerd. Het bestond altijd al, maar het was een 'lege huls' geworden door de manier waarop het verwijtbaarheidscriterium in de praktijk was toegepast. ${ }^{99}$ Hoewel de vreemdelingendiensten inderdaad moeite hadden met de interpretatie van 'verwijtbare' werkloosheid, is dit een onjuiste voorstelling van zaken. ${ }^{100}$ Tot 1993 kwam iemand die buiten zijn schuld van bijstand afhankelijk was volgens de formele regels zoals die in de Vreemdelingencirculaire waren neergelegd in aanmerking voor gezinsmigratie, daarna niet meer. Er was dus wel degelijk sprake van een restrictieve beleidswijziging. ${ }^{101}$ Voor de PvdA was beperking van de mogelijkheden voor gezinsmigratie echter zo moeilijk in overeenstemming te brengen met haar politieke waarden, dat zij verkoos te ontkennen dat het überhaupt om een hervorming ging, laat staan om een restrictieve hervorming.

In de derde plaats ten slotte verzweeg het kabinet de voornaamste doelstelling van zijn beleidsvoorstel. Van het begin tot het eind van de debatten binnen de regering was het duidelijk dat hervorming diende om het aantal gezinsmigranten dat naar Nederland kwam te beperken. ${ }^{102}$ In beleidsnotities die binnen het kabinet circuleerden stond 'beperking van de instroom' nog voorop. ${ }^{103}$ In de brief aan het parlement was daar 'consequente uitvoering van de regels voor migratie' van gemaakt. ${ }^{104}$ Dales en Kosto ontkenden zelfs expliciet dat de hervorming bedoeld was om de instroom van vreemdelingen terug te dringen, en werden daarin bijgevallen door PvdA-

98 TK 1992-1993 Handelingen 14 oktober 1992: 482-487.

99 тK 1992-1993 Handelingen 14 oktober 1992: 485; тK 1992-1993 22809 (10): 2-3; тK 1992199322809 (19): 12, 14.

100 Van den Bedem e.a. 1995: 4.

101 Vgl. Groenendijk \& Barzilay 2001: 6.

102 Het onderzoeksbureau van het ministerie van Justitie bevestigt dat migratiebeperking een primaire aanleiding voor de hervorming was. Van den Bedem e.a. 1995: 83.

103 Ambtelijk compromis Biza/DVZ, 1 oktober 1992. IND A92/3470-I.

104 тK 1992-1993 22809 (10): 3. 
Kamerleden. Het bevorderen van de integratie werd als doelstelling naar voren geschoven. ${ }^{105}$ Dit was een kwestie van politieke strategie: het verband dat het CDA legde tussen reductie van de gezinsmigratiestroom en verzachting van de integratieproblematiek werd door de linkse partijen niet aanvaard. Een hervorming gericht op migratiebeperking had geen kans op steun van links. Bovendien wilde het kabinet niet expliciet toegeven dat het de komst van nieuwe migranten problematisch vond, uit onwil om te stigmatiseren en onvrede in de samenleving te voeden. Zoals minister Ritzen ( $P v d A)$ van Onderwijs schreef, in een brief aan de ministerraad: 'Het is van het grootste belang om buitengewoon voorzichtig met deze onderwerpen om te gaan. Immers: elke wijziging in het beleid op deze terreinen kan licht steun geven aan gevoelens in de bevolking, die gericht zijn tegen vreemdelingen'. ${ }^{106}$ De ontkenning van de migratiebeperkende doelstelling van de hervorming was, net als de bewering dat het niet om een hervorming maar om een verbetering van de uitvoeringspraktijk ging, een typisch voorbeeld van de depolitiserende stijl die ook in de jaren negentig de omgang van de Nederlandse politiek - en vooral de PvdA - met het migratie- en integratievraagstuk bleef kenmerken.

Aangezien de politieke strijd al grotendeels binnen het kabinet was uitgevochten, leidde de parlementaire behandeling slechts tot kleine aanpassingen. De aanscherpingen van het gezinsvormingsbeleid en de invoering van de 'omgekeerde wachttijd' passeerden de Kamer vrijwel zonder commentaar. Van belang is dat alle politieke partijen behalve GroenLinks de onderbouwing van het voorstel in termen van 'eigen verantwoordelijkheid' onderschreven. Zelfs PvdA-woordvoerder Apostolou, die in eerdere informele communicatie met staatssecretaris Kosto zoveel nadruk had gelegd op bescherming van de rechtspositie van kwetsbare groepen, sprak nu over 'eigen verantwoordelijkheid' voor het integratieproces en omarmde 'het principe dat burgers in de Nederlandse samenleving (...) in het levensonderhoud van henzelf en hun gezin moeten kunnen voorzien door inkomen uit arbeid, een principe dat dan ook voor gezinshereniging geldt' ${ }^{107}$ Dat de PvdA deze nieuwe visie op het gezinsmigratievraagstuk had aanvaard vormde op zichzelf een cruciale politieke overwinning voor het CDA.

Desalniettemin was de VVD de enige partij in de Kamer die het aanvaardbaar vond dat het nieuwe inkomensvereiste ertoe kon leiden dat

105 тK 1992-1993 22809 (13): 3; тK 1992-1993 22809 (19): 3; тK 1992-1993 22809 (18): 5.

106 Brief minister o\&W aan ministerraad, 3 december 1992. IND A92/3470-I.

107 тK 1992-1993 22809 (19). 
gezinsmigratie voor sommige mensen definitief onmogelijk werd. ${ }^{108}$ Apostolou verklaarde: 'indien het buiten de schuld van betrokkene niet lukt om zo'n inkomen te verwerven, dan moet hem of haar het recht op een gezinsleven niet worden onthouden'. Zelfs Krajenbrink van het CDA, de partij die de stuwende kracht achter de hervorming was geweest, meende dat 'het niet [mag] voorkomen dat de zwakke economische positie van mensen blijvend een blokkade vormt voor het samenleven met een partner in huwelijksverband'. ${ }^{109}$ Staatssecretaris Kosto kwam aan deze zorgen van de Kamer tegemoet, door te wijzen op zijn bevoegdheid om in 'schrijnende gevallen' verblijf toe te staan ook als niet aan de formele voorwaarden was voldaan. Hij beloofde daarbij 'serieuze inspanningen (...) om in eigen levensonderhoud te voorzien' mee te wegen. ${ }^{110}$ Daarmee werd het verwijtbaarheidscriterium in wezen door de achterdeur teruggebracht in het vreemdelingenbeleid. Waar het voorheen echter ging om een formele beleidsregel, werd het nu aan het oordeel van de staatssecretaris overgelaten of iemand die vruchteloze pogingen had gedaan om werk te vinden al dan niet werd uitgezonderd van de inkomenseis. In de ogen van Rosenmöller (GroenLinks) was dit een schijnoplossing: die discretionaire bevoegdheid had de staatssecretaris voorheen immers ook al. PvdA en CDA waren door de toezegging van Kosto echter gerust gesteld. ${ }^{111}$

Een tweede punt van kritiek dat door PvdA, GroenLinks, CDA, SGP en VVD naar voren werd gebracht had betrekking op de rechtspositie van Nederlands staatsburgers in vergelijking met EG-onderdanen. ${ }^{112}$ De voorwaarden voor gezinshereniging voor EG-burgers die in een andere lidstaat woonden en werkten werden namelijk bepaald door het communautair recht en waren relatief soepel. Met deze hervorming werden Nederlands staatsburgers met buitenlandse gezinsleden voor het eerst aan significant strengere voorwaarden onderworpen dan Duitse, Spaanse of Belgische inwoners van

108 De centrum-democraten van Janmaat hadden daar ook geen moeite mee, maar die namen niet deel aan het mondeling overleg waar de hervorming werd besproken.

109 тK 1992-1993 22809 (19).

110 тк 1992-1993 22809 (18): 5.

111 тк 1993-1994 23409 (4); тк 1993-1994 Handelingen 16 september 1993: 6939-6947.

112 TK 1992-1993 22809 (19): 4-5, 8-11. 
Nederland. ${ }^{113}$ Voor een EG-burger gold een inkomenseis van $50 \%$ van de bijstandsnorm voor alleenstaanden; voor Nederlanders zou voortaan $70 \%$ van de bijstandsnorm voor gezinnen vereist zijn. ${ }^{114}$ In respons op kritiek vanuit de Kamer verklaarde de regering zich voor een 'lastig dilemma' gesteld te zien: 'Enerzijds is het wenselijk het hierbovengenoemde onderscheid tussen Nederlanders en EG-onderdanen zoveel mogelijk te beperken. Anderzijds is het streven erop gericht langdurig hier te lande legaal verblijvende derdelanders een zoveel mogelijk gelijke rechtspositie als Nederlanders te geven'. De regering koos ervoor om gelijke behandeling van Nederlanders en gevestigde vreemdelingen te laten prevaleren boven gelijkstelling van Nederlanders aan EG-onderdanen, omdat dat laatste 'een substantiële verruiming ten opzichte van het huidige beleid' zou betekenen. ${ }^{115}$

In zes van de twaalf lidstaten waren staatsburgers wel gelijk gesteld aan EG-burgers, en golden alleen voor vreemdelingen van buiten de Unie strengere voorwaarden voor gezinsmigratie. ${ }^{116}$ Aangezien de regering begin jaren negentig naturalisatie aanmoedigde, is in de debatten binnen het kabinet wel overwogen om Nederlands staatsburgers een bevoorrechte positie te verlenen in het gezinsmigratiebeleid. ${ }^{117}$ Dat daar uiteindelijk niet voor is gekozen, heeft te maken met de kwantitatieve doelstellingen van de hervorming. In een notitie van Justitie aan de ministerraad werd benadrukt dat $40 \%$ van de aanvragen voor gezinsvorming door Nederlanders werd gedaan. ${ }^{118}$ Bovendien wees Kosto er in handgeschreven briefjes aan Lubbers en Kok met klem op dat het merendeel van die Nederlanders van Surinaamse afkomst was en dat Nederland gemiddeld 15 duizend vreemdelin-

113 Voorheen was het belangrijkste verschil dat het EG-recht gezinshereniging met kinderen tot 21 jaar toe stond in plaats van 18 jaar, en dat de voorwaarden voor verruimde gezinshereniging soepeler waren. Met iedere volgende aanscherping van het beleid zou het verschil tussen EU-burgers en Nederlanders groter worden. In 2005 constateerden Kamerleden verontrust dat steeds meer Nederlandse allochtonen gebruik maakten van de zogenaamde 'België-route': zij verhuisden naar België om onder het soepel communautair gezinsmigratiebeleid te vallen in plaats van onder het strenge Nederlandse recht. TK 2004-2005 Aanhangsels van de Handelingen nrs. 334 en 425; TK 2004-2005 Handelingen 16 en 22 maart 2005. Zie ook Vanvoorden 2008.

114 TK 1992-1993 22809 (18); Nota hoofd DVZ aan staatssecretaris en minister, 15 december 1992. IND A92/3470-I.

115 тк 1992-1993 22809 (18): 1-3.

116 België, Spanje, Luxemburg, Portugal, Griekenland, Denemarken. TK 1992-1993 22809 (18): 3.

117 Nota hoofd DVZ aan staatssecretaris en minister, 24 september 1992. IND A92/3470; Interne nota AZ, 8 oktober 1992. IND A92/3470-I.

118 Notitie staatssecretaris en minister van Justitie aan ministerraad, 23 juli 1992. IND A92/3470. 
gen per jaar naturaliseerde. ${ }^{119}$ Kennelijk was het formeel staatsburgerschap, nu zoveel mensen van elders een Nederlands paspoort bezaten, een steeds minder relevant criterium om onderscheid te maken tussen 'wij' - die met ons gezin een bijzondere aanspraak hebben op verblijf in Nederland - en 'zij'. ${ }^{120}$

In de Kamer werd de keuze van de regering om vast te houden aan gelijke behandeling van Nederlanders en gevestigde vreemdelingen echter goed ontvangen. VVD-woordvoerder Wiebenga bleef van mening dat 'Nederlanders buiten dit beleid moeten vallen', omdat zij 'altijd vestigingsrecht in Nederland' en 'altijd het recht om een levensgezel te zoeken' hadden. ${ }^{121}$ Hij stond daarin echter alleen.

Op 17 september 1993 traden de nieuwe beleidsregels in werking. ${ }^{122}$ Daarmee was de eerste restrictieve hervorming van het Nederlands gezinsmigratiebeleid in lange tijd een feit. Het CDA had daarin een cruciale rol gespeeld. Voor de christendemocraten was het integratievraagstuk zo urgent geworden, dat zij krachtig aandrongen op aanscherping van het beleid, tegen hardnekkig verzet van de PvdA in. Door dat verzet werd het uiteindelijke resultaat aanmerkelijk gematigd: in plaats van volledig onafhankelijk inkomen was $70 \%$ van de bijstandsnorm vereist en op die regel bestond nog een hele reeks uitzonderingen. In het Nederlandse coalitiesysteem vereist besluitvorming compromissen. De Kamer omarmde weliswaar de nieuwe eis, maar had grote moeite met het logische gevolg van die eis dat gezinsmigratie voortaan onmogelijk was voor wie te weinig verdiende. Het moreel recht op gezinshereniging woog nog steeds zeer zwaar. Daarom moest staatssecretaris Kosto zijn discretionaire bevoegdheid benadrukken om de hervorming door het parlement te krijgen. De eerste stap richting een restrictiever gezinsmigratiebeleid was een kleine. De wezenlijke overwinning van het CDA zat hem echter in de aanvaarding door de Nederlandse politiek van een nieuw perspectief van 'eigen verantwoordelijkheid' op het gezinsmigratievraagstuk. Het recht op gezinshereniging was niet langer onaantastbaar. In het belang van het integratieproces van de betrokkenen

119 Handgeschreven brieven van staatssecretaris van Justitie aan minister van Financiën en minister-president, 25 september 1992. IND A92/3470.

120 Vgl. Spijkerboer (2007: 63) over de relativering van het belang van formeel burgerschap in het inburgeringsbeleid sinds 1998: allochtone staatsburgers 'hebben wel een Nederlands paspoort, maar zijn geen Nederlander'; Zie ook Schuster (1999: 222-223) over staatsburgers uit Suriname in de jaren zestig en zeventig als 'symbolische vreemdelingen': 'onechte' leden van de natie.

121 TK 1993-1994 23409 (4); TK 1993-1994 Handelingen 16 september 1993: 6939-6947.

122 De Lange 1997a: 47. 
en van de Nederlandse samenleving als geheel was het gerechtvaardigd om voorwaarden te verbinden aan gezinsmigratie. Dit zette de deur open naar verdere restrictieve hervormingen van het Nederlands gezinsmigratiebeleid.

Overige hervormingen in de jaren negentig: blauwe kaart, schijnhuwelijken en $m v v$

In de eerste helft van de jaren negentig vonden nog een aantal wijzigingen plaats in de regelgeving voor toelating en verblijf van buitenlandse gezinsleden. In de eerste plaats werd per 1 januari 1994 de zogenaamde '10 lid 2' - status afgeschaft, ook wel 'blauwe kaart' genoemd. Sinds 1967 kregen echtgenoten en kinderen van Nederlanders, vluchtelingen en vestigingsvergunninghouder na één jaar verblijf van rechtswege deze status. 'Van rechtswege' betekent hier automatisch: er was geen overheidsbesluit voor nodig. Het verblijfsrecht van vreemdelingen met een blauwe kaart was gewaarborgd zolang de gezinsband bleef bestaan. Vreemdelingen die in januari 1994 al een '10 lid 2'-status hadden, behielden deze. ${ }^{123}$ Voor nieuw binnengekomen buitenlandse gezinsleden betekende de afschaffing van de blauwe kaart dat zij net als andere vreemdelingen een tijdelijke verblijfsvergunning kregen, die elk jaar moest worden verlengd. Na vijf jaar konden zij in aanmerking komen voor een permanente vestigingsvergunning. De beleidswijziging was bedoeld om een effectiever toezicht op het verblijf van vreemdelingen mogelijk te maken. Voortaan kon de eerste vijf jaar, bij de jaarlijkse verlenging van de verblijfsvergunning, gecontroleerd worden of nog steeds aan de voorwaarden werd voldaan. Schijnhuwelijken of inmiddels ontwrichte huwelijken konden 'er uitgevist worden'. Op inbreuken op de openbare orde kon uitzetting volgen. ${ }^{124}$ Staatssecretaris Kosto beloofde de Kamer dat de inkomenstoets bij de jaarlijkse verlenging echter niet zou worden toegepast. ${ }^{125}$

Volgens Swart was de '10 lid 2 status' in 1965 in het leven geroepen om uitdrukking te geven aan de 'bijzondere waarde' die de wetgever aan het 'behoud van de gezinseenheid' hechtte. ${ }^{126}$ In 1993 werden het gewicht van gezinseenheid enerzijds en dat van migratiebeheersing anderzijds kennelijk

123 Groenendijk \& Barzilay 2001: 24-25.

124 Nota hoofd IND aan staatssecretaris, 15 februari 1994. IND A94/3412.

125 TK 1993-1994 19637 (10).

126 Swart 1978: 163. 
anders gewogen. In antwoord op een kritische brief van de Adviesraden van Amsterdam schreef staatssecretaris Kosto expliciet dat het morele gewicht dat de regering aan gezinsleven toekende gewijzigd was: 'Deze rechtspositie [van blauwe kaart houders] is alleen gebaseerd op de aanwezigheid van een gezinsband. De rechtspositie moet naar de mening van het kabinet echter gegrond zijn op de duur van het verblijf in Nederland en de mate van integratie'. ${ }^{127}$

Een tweede hervorming op het gebied van gezinsmigratie was de Wet Voorkoming Schijnhuwelijken, die in november 1994 in werking trad. Sinds 1986 werden, vanwege kritiek van de rechtbanken, geen preventieve controles meer uitgeoefend op de 'realiteit' van huwelijken op grond waarvan toegang tot Nederland werd verzocht. ${ }^{128}$ De nieuwe wet maakte dergelijke controles weer mogelijk. Een ambtenaar van de burgerlijke stand kon voortaan weigeren een huwelijk te sluiten, of een in het buitenland gesloten huwelijk te registreren, als hij ervan overtuigd was dat het een schijnhuwelijk betrof. Ieder paar waarvan tenminste één partner niet Nederlands was dat wilde trouwen of hun elders gesloten huwelijk in Nederland wilde laten registreren, diende een verklaring van de vreemdelingendienst te overleggen. Daarin zouden gegevens over de verblijfsrechtelijke status van de vreemdeling(en) worden opgenomen, evenals eventuele opmerkingen over de verdenking van een schijnhuwelijk. Er werd een lijst van 'objectieve indicaties' opgesteld aan de hand waarvan het schijnkarakter van het huwelijk kon worden vastgesteld, zoals de verblijfspositie van de buitenlandse partner, een groot leeftijdsverschil, gebrekkige kennis van elkanders taal, de duur van de relatie en de vraag of de Nederlandse partner bereid was naar het land van herkomst van de vreemdeling te verhuizen. ${ }^{129}$

Het wetsvoorstel werd goed ontvangen in de Kamer. Inmenging van de overheid in huwelijksvorming werd gerechtvaardigd geacht omdat het om huwelijken ging waar, in de woorden van staatssecretaris Kosto, 'iets wordt beoogd wat volstrekt buiten de huwelijksordening ligt, namelijk het verwerven van een verblijfsrecht'. Op basis van schattingen veronderstelde de regering dat $10 \%$ van de huwelijken waarbij één of beide partners

127 Brief staatssecretaris van Justitie aan Adviesraden gemeente Amsterdam, 11 februari 1994. IND A94/3412.

128 Van Walsum 2008: 186. Zie paragraaf 3.7.

129 De Hart 2000b: 246; Groenendijk \& Barzilay 2001: 34-35. Zie voor een kritische analyse van het schijnhuwelijkenbeleid vanuit gender-perspectief en van het 'romantisch huwelijksideaal' dat aan dat beleid ten grondslag ligt: De Hart 2000a; De Hart 2003a: 120-140. 
vreemdeling waren, een schijnhuwelijk betrof. ${ }^{130}$ Het zou dus gaan om 5 tot 10 duizend gevallen per jaar, waarin via het huwelijk werd geprobeerd 'onrechtmatig toegang [te] krijgen tot de voorzieningen van deze samenleving, die schaars zijn' en 'het vreemdelingenbeleid (...) te frustreren'. Deze argumenten werden in de Kamer met instemming begroet. Alleen bij D66 en GroenLinks stuitte het wetsvoorstel op weerstand. Wolffensperger noemde het namens D66 onjuist om het burgerlijk wetboek en de ambtenaar van de burgerlijke stand in te zetten in het vreemdelingenbeleid. GroenLinks had vooral principiële bezwaren tegen deze inmenging van de overheid in de bedoelingen waarmee mensen tot een huwelijk besluiten. ${ }^{131}$ Het wetsvoorstel werd op 19 oktober 1993 door de Tweede Kamer aangenomen met steun van alle partijen behalve D66 en GroenLinks. ${ }^{132}$

In de ogen van Van Walsum is de Wet Voorkoming Schijnhuwelijken een voorbeeld van de nieuwe assertiviteit waarmee de Nederlandse wetgever naar een restrictief vreemdelingenbeleid streefde. In de jaren tachtig legde de politiek zich nog neer bij een rechterlijk oordeel dat controle op schijnhuwelijken illegitiem was; in de jaren negentig pareerde zij met een wetswijziging. Een nog sprekender voorbeeld van deze veranderde politieke attitude was de aanscherping van het mvv-vereiste. ${ }^{133}$ In 1994 werd besloten dat een aanvraag voor een verblijfsvergunning alleen in behandeling zou worden genomen indien een vreemdeling in zijn land van herkomst een machtiging tot voorlopig verblijf (mvv) had verkregen. De regering wilde zichzelf zo in staat stellen vóór de binnenkomst van de vreemdeling te onderzoeken of hij aan de voorwaarden voldeed, om te voorkomen dat zij 'voor voldongen feiten' ${ }^{134}$ zou worden geplaatst. De overheid had al eerder - in 1972 en in 1980 - geprobeerd van de mvv een harde voorwaarde te maken. De rechter had echter geoordeeld dat een verblijfsvergunning niet mocht worden geweigerd alléén omdat een vreemdeling niet over een mvv beschikte. Tot 1994 werd het mvv-vereiste dus zeer soepel toegepast. In

130 Zie De Hart (2003a: 94-95) over de rol van de rol van niet gestaafde cijfers en ruwe schattingen in debatten over schijnhuwelijken.

131 TK 1993-1994 Handelingen 14 oktober 1993: 759-784.

132 тк 1993-1994 Handelingen 19 oktober 1993: 837. De Wet Voorkoming Schijnhuwelijken was niet van toepassing op ongetrouwde partners. In 1997 werd daarom de 'relatieverklaring' ingevoerd. Bij aanvraag van een verblijfsvergunning moesten partners een verklaring ondertekenen, waarin stond dat zij samenleefden en sinds wanneer. Mocht die verklaring later onjuist blijken te zijn, dan konden zij worden aangeklaagd wegens valsheid in geschrifte. Groenendijk \& Barzilay 2001: 35.

133 Van Walsum 2008: 229.

134 TK 2004-2005 Handelingen 19 april 2005: 4567. 
1995 werd de regering opnieuw door de rechterlijke macht teruggefloten: de Rechtseenheidskamer besloot dat weigering om een verblijfsaanvraag in behandeling te nemen omdat een mvv ontbrak strijdig was met de wet. Nog datzelfde jaar stelden De Hoop Scheffer en Verhagen (CDA) voor om het mvv-vereiste in de Vreemdelingenwet op te nemen. Dit wetsvoorstel is in december 1998 in werking getreden. ${ }^{135}$ Volgens De Hart blijkt uit de jurisprudentie en de literatuur dat de mvv-plicht en het inkomensvereiste 'de belangrijkste belemmeringen' vormen voor gezinsmigratie. ${ }^{136}$

\subsection{Evaluatie van het gezinsmigratiebeleid: het recht op gezins- hereniging ter discussie}

\section{De evaluatie}

Zoals in 1993 was beloofd, presenteerde Elisabeth Schmitz (PvdA), staatssecretaris van Justitie in het eerste kabinet Kok, in december 1995 een evaluatie van het gezinsmigratiebeleid aan de Kamer. Primair uitgangspunt van het gezinsmigratiebeleid bleef, zo stelde Schmitz, dat 'iedereen in Nederland zelf zoveel mogelijk verantwoordelijkheid draagt voor de overkomst van buitenlandse gezinsleden'. Zij stelde dan ook slechts een aantal kleine aanpassingen voor, die vooral bedoeld waren om de regelgeving te verduidelijken en om aansluiting te zoeken bij veranderingen in de sociale zekerheid en de arbeidsmarkt. ${ }^{137}$ Verder was gebleken dat het inkomensvereiste in de praktijk redelijk soepel werd toegepast door de uitvoerende diensten: wie een inkomen van een aantal tientjes onder het normbedrag had kreeg afhankelijk van de overige omstandigheden - vaak toch toestemming voor gezinshereniging. De staatssecretaris besloot dat de inkomenseis voortaan strikt moest worden gehanteerd, om te voorkomen dat een 'glijdende

135 Groenendijk \& Barzilay 2001: 11-15; Van Walsum 2008: 218-219.

136 De Hart 2003b: 60. Een derde belemmering die De Hart noemt is de legalisatie van documenten. Sinds 1992 moesten buitenlandse documenten die bij verzoek om gezinsmigratie werden overlegd worden gelegaliseerd. In 1996 werd die maatregel aangescherpt met een verificatieplicht van buitenlandse documenten betreffende de burgerlijke staat van personen uit 'probleemlanden'. (Groenendijk \& Barzilay 2001: 7; Van Walsum 2008: 223-224)

137 Zo werd een lijst opgesteld van wat als inkomensbestanddeel mocht worden meegeteld - kinderalimentatie niet, inkomen uit vermogen wel -, werd het mogelijk om tijdelijke contracten mee te wegen als duurzaam inkomen, en werden alleenstaande ouders van kinderen tot 5 jaar, in plaats van 6 jaar, vrijgesteld van de inkomenseis. Zie voor een gedetailleerde analyse van de inkomenseis bij gezinsmigratie in regelgeving en jurisprudentie: De Lange 1997a; 1997b; De Lange \& Depping 1999a; 1999 b. 
schaal' zou ontstaan en dat 'subjectieve oordeelsvorming' een rol zou gaan spelen. In 1993 had de Kamer pas ingestemd met het nieuwe inkomensvereiste, toen staatssecretaris Kosto beloofde om in individuele 'schrijnende' gevallen rekening te houden met inspanningen om werk te vinden. Over die individuele humanitaire toets schreef staatssecretaris Schmitz nu dat deze 'vrij strikt was toegepast'. ${ }^{138}$ Desalniettemin oordeelde de Kamer positief over de plannen van de staatssecretaris. ${ }^{139}$

De evaluatie leidde dus niet tot grote beleidswijzigingen, maar laat wel zien dat de norm van 'eigen verantwoordelijkheid', die het CDA begin jaren negentig met moeite had ingebracht in het debat over gezinsmigratie, inmiddels ferm verankerd was in het perspectief van de Nederlandse politiek. Waar de Kamer er in 1993 nog op aandrong dat de staatssecretaris zijn discretionaire bevoegdheid inzette om de scherpe kantjes van het inkomensvereiste af te halen, aanvaardde zij nu probleemloos dat Schmitz verklaarde zowel de inkomenseis als de humanitaire toets strikt te hanteren.

Een aantal maanden later besloot staatssecretaris Schmitz dat de 'omgekeerde wachttermijn', waartoe in 1993 besloten was, niet zou worden toegepast. Die 'omgekeerde wachttijd' hield in dat een aanvraag voor gezinshereniging uiterlijk drie jaar nadat aan de voorwaarden werd voldaan moest worden ingediend. Vanaf september 1996 - drie jaar na de inwerkingtreding van de nieuwe regels - zouden aanvragen op deze grond kunnen worden afgewezen. De staatssecretaris besloot daar echter van af te zien. Het criterium was in de praktijk moeilijk toe te passen en relatief gemakkelijk te omzeilen. Bovendien bood de in 1993 aangenomen Europese resolutie over harmonisatie van het gezinsmigratiebeleid geen ruimte voor een dergelijk criterium. ${ }^{140}$ Die resolutie was weliswaar niet bindend, maar Schmitz achtte het 'uit oogpunt van internationale samenwerking' toch wenselijk om het Nederlands beleid eraan te conformeren. ${ }^{141}$ Daarmee werd het Nederlands gezinsmigratiebeleid voor het eerst gewijzigd om te voldoen aan een op Europees niveau geformuleerde norm.

138 TK 1995-1996 24401 (6). Uit interne stukken van Justitie blijkt dat de humanitaire toets 'slechts voor weinig zaken positief heeft gewerkt'. Nota IND aan staatssecretaris, 7 maart 1996. MJ A95/3518.

139 тK 1995-1996 19637/24401 (189): 2.

140 Zie paragraaf 4.2 .

141 TK 1995-1996 24401 (21); zie ook nota hoofd DVB aan staatssecretaris, 24 juni 1996. MJ A96/3568. 
De Tweede Kamer kon zich in deze argumenten vinden. ${ }^{142}$ Bij minister Dijkstal (VVD) van Binnenlandse Zaken en zijn ambtenaren stuitte het besluit om de 'omgekeerde wachttijd' buiten toepassing te laten echter op bezwaar. De omgekeerde wachttermijn was het enige instrument waarmee snelle overkomst van gezinsleden, die van 'evident' belang werd geacht voor 'snelle integratie', kon worden gestimuleerd. Het besluit werd niet teruggedraaid, maar Dijkstal en Schmitz spraken wel af dat op ambtelijk niveau spoedig overleg zou worden gepleegd over 'mogelijkheden om de integratie-gedachte te verwerken in het gezinsherenigingsbeleid' ${ }^{143} \mathrm{De}$ overweging dat het migratiebeleid zo moest worden ingericht dat het bijdroeg aan het bereiken van de doelstellingen van het integratiebeleid, die ook in de hervormingen van 1993 al een belangrijke rol had gespeeld, won steeds verder terrein.

\section{De motie Verhagen/Rijpstra: gezinshereniging van vluchtelingen en} artikel 8 EVRM

In het kader van het debat over de evaluatie van de beleidsregels van 1993 was een nieuw discussiepunt opgekomen, dat nog jaren op de agenda zou blijven staan: de voorwaarden voor gezinshereniging van vluchtelingen. Het was voor het eerst dat dit aspect van het gezinsmigratiebeleid aanleiding gaf tot debat. Dit kwam in de eerste plaats doordat het aantal asielzoekers dat naar Nederland kwam sinds de late jaren tachtig dramatisch was gestegen. In de eerste helft van de jaren tachtig bedroeg het aantal asielaanvragen in Nederland minder dan 5 duizend per jaar. In 1990 waren dat er ruim 21 duizend, in 1994 zelfs meer dan 52 duizend. In 1995 en 1996 zakte de asielinstroom even onder de 30 duizend, om van 1998 tot 2000 weer jaarlijkse cijfers van meer dan 40 duizend te bereiken. In het tijdvak 1982-1991 vroegen 95 duizend mensen asiel aan in Nederland; in de periode 1992-2001 waren dat er ruim 358 duizend. ${ }^{144}$ Er ontstond al snel een sfeer van crisis rondom de asielinstroom. De vreemdelingendiensten raakten overbelast, opvangcentra overbevolkt. In de media verschenen beelden van asielzoekers die in tentenkampen moesten worden ondergebracht en in de publieke opinie ontstond de verontrustende indruk dat Nederland werd

142 TK 1996-1997 25001 (3).

143 Nota hoofd DVB aan staatssecretaris, 11 september 1996; Brief staatssecretaris van Justitie aan minister van Binnenlandse Zaken, 11 september 1996; Brief minister van Binnenlandse Zaken aan staatssecretaris van Justitie, 5 november 1996. MJ A96/3658.

144 Hovy 2002:112-113. 
'overspoeld' met vluchtelingen. ${ }^{145}$

In deze context werden de voorwaarden waaronder deze duizenden asielzoekers hun gezinsleden naar Nederland zouden mogen brengen onderwerp van debat. Daarbij speelde ook een rol dat de invloed van de rechtspraak op basis van artikel 8 EVRM zich bij de gezinshereniging van vluchtelingen veel sterker deed gelden dan bij andere aspecten van het gezinsmigratiebeleid. ${ }^{146}$ Het Hof in Straatsburg had in de zaak Gül van 1996 namelijk bepaald dat het recht op gezinsleven de staat niet verplichtte om buitenlandse gezinsleden toe te laten, tenzij het onmogelijk was om het gezinsleven elders uit te oefenen. Wanneer 'objectieve belemmeringen' zich tegen hereniging in het land van herkomst verzetten, moest het belang van het gezinsleven van het individu zwaarder wegen dan het belang van de staat. ${ }^{147}$ Deze jurisprudentie was direct relevant voor vluchtelingen, die immers in Nederland mochten blijven omdat zij hun leven in hun thuisland niet zeker waren.

In de jaren negentig konden aan asielzoekers drie soorten verblijfsvergunning worden verleend. Asielzoekers die gegronde reden hadden om te vrezen voor vervolging in de zin van het Vluchtelingenverdrag van 1951, kregen een A-status. Zij waren vrijgesteld van de normale voorwaarden voor gezinshereniging, zoals het inkomens- en huisvestingsvereiste, wanneer hun gezinsleden dezelfde nationaliteit hadden en direct met hen meereisden of binnen een 'redelijke termijn' volgden. ${ }^{148}$ Wanneer gezinsleden zich pas later bij de vluchteling voegden, of in geval van gezinsvorming, golden voor A-statushouders dezelfde versoepelde voorwaarden als voor Nederlanders en vestigingsvergunninghouders. Asielzoekers die niet onder het Vluchtelingenverdrag vielen maar toch niet konden worden teruggestuurd, kregen een 'vergunning tot verblijf-humanitair' (vtv-hum). Anders dan de A-status moest de vtv-hum jaarlijks worden verlengd. ${ }^{149}$ Voor houders van een vtv-hum bestond geen versoepeld gezinsmigratiebeleid. Voor hen golden dezelfde voorwaarden als voor andere vreemdelingen met een tijdelijke verblijfsvergunning: zij moesten aan de onverkorte inkomenseis voldoen. Asielzoekers die op grond van de 'algemene leefsituatie' niet

145 Bonjour 2005: 179.

146 Zie paragraaf 4.2 .

147 Boeles 2004c: 113-115.

148 Of de termijn waarbinnen gezinsleden nareisden 'redelijk' was, werd individueel beoordeeld aan de hand van het vluchtverhaal en de omstandigheden waarin het gezin was opgesplitst. TK 1995-1996 19637 (178).

149 Zie Holterman 1996: 177. 
terug naar hun land van herkomst konden ten slotte kregen een voorlopige vergunning tot verblijf (vvtv). Een vvtv kon worden ingetrokken zodra de situatie in het herkomstland zodanig was verbeterd dat terugkeer mogelijk was. Na drie jaar verblijf in Nederland kregen vvtv-houders een vtv-hum. Houders van een vvtv mochten hun gezinsleden niet laten overkomen. Uitgangspunt was immers dat zij Nederland op korte termijn weer zouden verlaten. Na drie jaar kregen zij een vtv-hum en was gezinshereniging mogelijk. ${ }^{150}$

In 1996 ontstond discussie over de voorwaarden voor gezinshereniging van vluchtelingen met een vtv-hum. PvdA, D66 en GroenLinks stelden dat, aangezien een vtv-hum in de praktijk zeer zelden werd ingetrokken en dus in feite een permanent karakter had, voor vreemdelingen met een vtv-hum hetzelfde soepele inkomensvereiste diende te gelden als voor gevestigde vreemdelingen en Nederlanders. Zij verwezen daarbij naar de werkloosheid van $75 \%$ onder vtv-hum-houders. ${ }^{151}$ Bovenop deze parlementaire kritiek kwam een reeks uitspraken van de Rechtseenheidskamer. Aangezien hereniging van het gezin in het land van herkomst voor houders van een vtv-hum onmogelijk was, oordeelde deze dat het in strijd was met het recht op gezinsleven om overkomst van achtergebleven gezinsleden te weigeren op grond van onvoldoende inkomen. ${ }^{152}$

Het voorstel om het inkomensvereiste voor vtv-hum-houders te verlagen tot $70 \%$ van de bijstandsnorm werd echter afgewezen door de ministerraad. ${ }^{153}$ De raad gaf wel zijn goedkeuring aan een andere versoepeling van het beleid, die staatssecretaris Schmitz had voorgesteld. Deze versoepeling was bedoeld om binnen de kaders die de rechtspraak had gesteld, ruimte te creëren voor de regering om de voorwaarden voor gezinsmigratie te blijven bepalen. De staatssecretaris meende dat de Rechtseenheidskamer onvoldoende rekening had gehouden met het uitgangspunt van eigen verantwoordelijkheid. Zij vond dat van iedereen gevraagd mocht worden om zich in te spannen om zelfstandig in het levensonderhoud van zijn gezin te voorzien. Mocht dat na een redelijke termijn van bijvoorbeeld drie jaar niet zijn gelukt, en terugkeer naar het herkomstland nog steeds onmogelijk

150 TK 1995-1996 19637 (178).

151 TK 1995-1996 19637/24401 (189); TK 1996-1997 25001 (3).

152 Notitie staatssecretaris van Justitie aan ministerraad, 4 april 1997. MJ A95/3518; Van Walsum 2008: 240.

153 Nota's hoofd DVB aan staatssecretaris en minister, 4 maart en 2 april 1997; Notitie staatssecretaris van Justitie aan ministerraad, 4 maart 1997; Nota DVB ter voorbereiding AO 18 juni 1997. MJ A95/3518. 
zijn, dan kon vrijstelling van het inkomensvereiste worden overwogen. Schmitz wilde dus tegenover de rechtbanken argumenteren, dat het economisch belang van de staat bij het inkomensvereiste de eerste drie jaar op mocht wegen tegen het belang van het individu bij gezinshereniging. ${ }^{154} \mathrm{Het}$ was, zoals een IND-ambtenaar aan zijn staatssecretaris schreef, 'noodzakelijk' om 'zelf nadere invulling' te geven aan deze 'redelijke termijn', 'want anders gaat de rechter de speelruimte bepalen'. ${ }^{155}$

Staatssecretaris Schmitz stuurde in mei 1997 een brief naar de Tweede Kamer, waarin zij meedeelde dat de inkomenseis voor vtv-hum-houders niet zou worden verlaagd. In diezelfde brief zette zij ook uiteen, dat zij voortaan in gevallen waar objectieve belemmeringen zich tegen terugkeer naar het land van herkomst verzetten, gedurende een 'redelijke termijn' van drie jaar zou vasthouden aan het inkomensvereiste. Wanneer de betrokkene zich drie jaar lang tevergeefs had ingespannen om een zelfstandig inkomen te verwerven, zou gezinshereniging alsnog worden toegestaan. Zo werd volgens staatssecretaris Schmitz 'enerzijds het uitgangspunt van de eigen financiële verantwoordelijkheid behouden en wordt anderzijds voldaan aan de internationale verplichtingen doordat gezinshereniging niet voor onbepaalde duur onmogelijk wordt gemaakt'. ${ }^{156}$

De Tweede Kamer reageerde uiterst verdeeld op de voornemens van de staatssecretaris. GroenLinks, PvdA en D66 waren teleurgesteld over de handhaving van de onverkorte inkomenseis en vonden de termijn van drie jaar te lang. CDA-woordvoerder Verhagen daarentegen vond het onacceptabel dat de inkomenseis na drie jaar buiten toepassing werd verklaard. Hij onderstreepte dat 'het recht op gezinsleven belangrijk' was, maar dat 'hieraan op goede gronden beperkingen worden gesteld'. Voor Verhagen was de zaak helder: 'De consequentie van het uitgangspunt dat men een eigen verantwoordelijkheid heeft voor het onderhoud van de gezinsleden, is dat sommigen niet voor gezinshereniging in aanmerking komen'. Anders dan in 1993 vond het CDA die ultieme consequentie nu wel aanvaardbaar.

De liberalen sloten zich bij de kritiek van Verhagen aan. ${ }^{157}$ Verhagen (CDA) en Rijpstra (VVD) dienden een motie in, waarin zij het criterium van de 'redelijke termijn' verwierpen als een vervanging van de inkomenseis door een 'inspanningseis' en waarin zij de regering verzochten ook in geval

154 Notitie staatssecretaris van Justitie aan ministerraad, 4 maart 1997. MJ A95/3518.

155 Nota IND, 4 juli 1997. IND A97/3643.

156 TK 1996-1997 25001 (26).

157 тк 1996-1997 25001 (30). 
van 'objectieve belemmeringen' slechts bij uitzondering af te wijken van het algemene inkomensvereiste. ${ }^{158}$ Deze motie kwam het CDA op felle kritiek te staan van Apostolou (PvdA), die het 'onbegrijpelijk' vond dat 'uitgerekend het CDA, dat zegt zoveel waarde te hechten aan het gezin, niet inziet dat het gescheiden leven van partner en kinderen alleen maar negatieve gevolgen heeft voor het functioneren van deze mensen in onze samenleving en hun tevens een fundamenteel mensenrecht ontzegt'. Verhagen reageerde op zijn beurt emotioneel door Apostolou te verwijten 'pertinente onwaarheden over het CDA' te verkondigen en 'weg te lopen' voor de gevolgen van de beleidskeuzes die in 1993 waren gemaakt vanuit het principe van eigen verantwoordelijkheid. Staatssecretaris Schmitz had moeite met de motie Verhagen/Rijpstra. Zij benadrukte dat haar geen beleidswijziging voor ogen stond, maar dat zij alleen 'invulling [gaf] aan wat de rechter vindt van artikel 8 EVRM'. De Kamer had een hoofdelijke stemming nodig om tot een uitspraak te komen: de motie Verhagen/Rijpstra werd aangenomen, met 69 stemmen voor en 68 stemmen tegen. ${ }^{159}$

Desalniettemin is de motie is nooit uitgevoerd. In eerste instantie liet de staatssecretaris weten dat zij gehoor zou geven aan de wens van de Kamer, ook al zou zij zich door gezinshereniging 'voor onbepaalde tijd' te weigeren aan mensen die niet terugkonden naar hun herkomstland om bij hun gezin te zijn 'op de grens van artikel 8 EVRM' begeven. Alleen in uitzonderlijk schrijnende gevallen zou op grond van de individuele humanitaire toets ontheffing van het inkomensvereiste worden verleend. Uit toekomstige jurisprudentie zou moeten blijken, 'of dit uitgangspunt houdbaar' was. ${ }^{160}$ PvdA, GroenLinks en D66 lieten het daar echter niet bij zitten. De PvdA was erop tegen dat 'de regering de grenzen van artikel 8 EVRM verkent'. Rabbae vroeg zich namens GroenLinks af of de staatssecretaris soms een 'kamikazepolitiek' voerde in de hoop 'dat de rechter haar terugfluit'? De VvD daarentegen was er blij mee dat de regering in haar reactie op de motie 'tot het uiterste was gegaan'. ${ }^{161}$ Een aantal maanden later kwam staatssecretaris Schmitz echter op haar toezegging terug. Vasthouden aan het middelenvereiste in geval van 'objectieve belemmeringen' was in strijd met artikel 8 EVRM en daarom kon zij de motie niet uitvoeren. Zij wenste deze beslissing niet aan de rechter over te laten want 'de rechter maakt geen beleid,

159 TK 1996-1997 Handelingen 26 juni 1997: 6928, 6932, 6980. Vóór stemden SGP, vVD, CDA, AOV, groep-Nijpels en CD.

160 TK 1997-1998 19637/25601 (285).

161 TK 1997-1998 19637/25601/25647 (312). 
maar behoort dat alleen maar te toetsen'. Verhagen liet weten zich met zijn fractie over dit besluit te zullen beraden. ${ }^{162}$

Het CDA kwam op de kwestie echter niet meer terug, en zo is de motie Verhagen/Rijpstra 'een stille dood gestorven'. ${ }^{163}$ Met de uitspraak van staatssecretaris Schmitz dat zij de motie niet zou uitvoeren, was de zaak voor haar ambtenaren afgedaan. ${ }^{164}$ De uitvoerende diensten werden geïnstrueerd om, wanneer objectieve belemmeringen zich tegen gezinshereniging in het herkomstland verzetten, na een 'redelijke termijn' ontheffing te verlenen van het inkomensvereiste indien betrokkene zich actief had ingespannen om zelfstandig in zijn levensonderhoud te voorzien. Als 'richtsnoer' diende een termijn van drie jaar te worden gehanteerd. ${ }^{165}$

In dit debat over de 'redelijke termijn' bij 'objectieve belemmeringen' wordt zichtbaar, hoe de Nederlandse regering manoeuvreerde om binnen de kaders die door de rechtspraak werden gesteld zoveel mogelijk grip op het toelatingsbeleid te houden. Het belangrijkste dat dit debat, dat bij momenten in emotionele termen werd gevoerd en uiteindelijk met een sisser afliep, laat zien is echter hoezeer de afweging verschoven was die het CDA maakte tussen het gewicht van gezinsleven en het belang van een restrictief toelatingsbeleid. In de jaren zestig stond geen enkele politieke partij zo consequent op de bres voor de gezinseenheid van arbeidsmigranten als de KVP, daarin gesteund door de andere confessionele partijen. Het strenge gezinsmigratiebeleid van de regering, dat resulteerde in 'gedwongen gezinsscheiding', lag toen voortdurend onder christendemocratisch vuur. Ook in de jaren tachtig werd aan wat toen het 'recht op gezinshereniging' was gaan heten een bijzonder moreel gewicht toegekend. In de jaren negentig was alles anders. De maatschappelijke problematiek rondom migratie en integratie werd door het CDA als zodanig ernstig ervaren en het belang van de Nederlandse samenleving bij migratiebeperking daarom als zodanig groot, dat het gezinsleven aan eisen onderworpen en zelfs ernstig belemmerd mocht worden. De asielcrisis zal aan deze verschuiving van het CDAstandpunt niet vreemd zijn geweest. Dat er voor het CDA wel degelijk sprake was van een moreel dilemma en dat het moeite kostte om daarin positie in te nemen, blijkt wel uit de emotionele manier waarop Verhagen reageerde toen hij door Apostolou op de morele betekenis van zijn standpunt werd

162 TK 1997-1998 19637 (361)

163 De Lange \& Depping 1999b: 201.

164 Brainstormsessie IND over artikel 8 EVRM, 30 juni 1998. IND A98/3663.

165 IND-werkinstructie nr. 181, 2 november 1998. IND A98/3663. 
aangesproken. Hij weigerde de discussie verder te voeren als Apostolou volhield dat het gezinsleven voor het CDA blijkbaar niet waardevol was. ${ }^{166}$

Dit debat roept de vraag op, welke rol de juridisering van dit morele vraagstuk heeft gespeeld. In de jaren zestig werd naar het moreel belang van gezinseenheid gewezen als naar een norm die eigen was, een fundamenteel element van het gedachtegoed van de christendemocratische partijen. In de jaren negentig werd niet meer direct naar die morele norm verwezen, maar naar een artikel uit een Europees verdrag. Daarbij leek dat artikel minder als de neerslag van een kernwaarde van de Nederlandse samenleving te worden beschouwd, dan als een beperking van de beleidsvrijheid van de Nederlandse staat, een beperking die van buitenaf werd opgelegd en waarvan de grenzen dus mochten worden opgezocht. ${ }^{167}$

\subsection{De Vreemdelingenwet 2000}

In september 1999 presenteerde Job Cohen (PvdA), staatssecretaris van Justitie in het tweede Paarse kabinet, een voorstel voor een nieuwe Vreemdelingenwet in de Tweede Kamer. Doel van de nieuwe wet, die de Vreemdelingenwet van 1965 verving, was 'de migratie naar Nederland - voor zover mogelijk - te reguleren en de gevolgen van deze migratie voor de Nederlandse samenleving zoveel mogelijk beheersbaar te houden'. De wetswijziging moest primair een oplossing bieden voor de asielcrisis waar Nederland zich sinds het begin van de jaren negentig voor gesteld zag. Zij betrof dus eerst en vooral de asielprocedure; op het gebied van reguliere migratie werden slechts enkele kleinere wijzigingen voorgesteld. ${ }^{168}$ Met de Vreemdelingenwet 2000 werd het gezinsmigratiebeleid op twee punten gewijzigd: in de eerste plaats werd het inkomensvereiste aangescherpt en in de tweede plaats werd het gezinsmigratieregime voor vluchtelingen herzien.

166 TK 1996-1997 Handelingen 26 juni 1997: 6928.

167 Wellicht is dit vergelijkbaar met de kritiek van VVD en CDA in de jaren negentig op het recht van vluchtelingen op bescherming zoals dat in het Vluchtelingenverdrag (1951) is vastgelegd, die Geuijen (2004: 185-186) beschrijft. 168 TK 1998-1999 26732 (3): 1-2. 


\section{De verhoging van het inkomensvereiste}

De wens om het inkomensvereiste te herzien werd in 1997 voor het eerst uitgesproken in een ambtelijke werkgroep van het ministerie van Justitie. Zij wilde de complexe regelgeving voor gezinsmigratie waartoe in 1993 besloten was 'vereenvoudigen', door 'het aantal uitzonderingen op de hoofdregels te beperken'. Het inkomensvereiste was $100 \%$ van de bijstandsnorm voor niet-huwelijkse partners en voor vreemdelingen met een tijdelijke vergunning, en $70 \%$ voor huwelijkse partners van Nederlanders en van vreemdelingen met een permanente vergunning. De ambtenaren pleitten ervoor, dat onderscheid op te heffen door de inkomenseis over de hele linie te verhogen of verlagen. In eerste instantie overwogen zij dat een verhoging naar $100 \%$ voor Nederlanders en voor het overgrote deel van de vreemdelingen in Nederland - 70 à $80 \%$ bezat een vergunning voor onbepaalde tijd - een 'aanzienlijke aanscherping' zou betekenen. ${ }^{169}$ In een notitie ten behoeve van de kabinetsformatie van 1998 pleitte de Directie Vreemdelingenbeleid toch voor een verhoging, omdat 'het ook thans geldende uitgangspunt, dat een ieder zoveel mogelijk zelf de financiële verantwoordelijkheid draagt voor de gezinsleden die hij of zij laat overkomen onverkort gehandhaafd [dient] te blijven' ${ }^{170}$

Dit ambtelijk voorstel werd overgenomen door de fractievoorzitters van PVdA, VVD en D66 die in 1998 het regeerakkoord van het tweede kabinet Kok opstelden. Dat regeerakkoord stipuleerde dat bij gezinsmigratie de 'hoofdregel' zou gaan gelden dat een inkomen van minimaal de bijstandsnorm vereist was. ${ }^{171}$ Voor het eerst in de geschiedenis werden specifieke beleidsvoornemens voor gezinsmigratie opgenomen in een regeerakkoord. Het feit dat de Paarse coalitie daarvoor koos weerspiegelt het toegenomen politieke gewicht van dit vraagstuk, en de ferme grip van partijpolitiek op het gezinsmigratiebeleid.

Net als in 1993 was ook deze tweede verhoging van de inkomenseis het resultaat van een compromis tussen de regeringspartijen. De vvD had in haar verkiezingsprogramma voor 1998 de wens opgenomen, gezinshereniging alleen toe te staan 'als degene die de partner wil laten overkomen, beschikt over een eigen inkomen dat tenminste gelijk is aan de

169 Memo's werkgroep gezinsherenigingsbeleid, 26 mei en 28 juli 1997. MJ A95/3518.

170 Notitie asielbeleid t.b.v. Kabinetsformatie 1998, n.d. MAZ 475093.

171 тK 1997-1998 26024 (9): 67. 
bijstandsnorm voor gehuwden'. ${ }^{172}$ De liberalen zaten op dit punt dus op één lijn met de ambtenaren van DVB. In Kamerdebatten verklaarde de PvdA later, daarmee te hebben ingestemd op voorwaarde dat de vrijstelling voor alleenstaande ouders werd gehandhaafd en dat inkomen uit gesubsidieerde arbeid mee werd gerekend als zelfstandig inkomen. ${ }^{173}$

Of het moeite heeft gekost om op dit punt overeenstemming te bereiken is moeilijk te zeggen. ${ }^{174}$ Anders dan begin jaren negentig duurde het in ieder geval niet meer dan een jaar voordat de coalitiepartijen op één lijn zaten. Het feit dat de PvdA, die slechts vijf jaar eerder met zoveel moeite had ingestemd met een inkomensvereiste van $70 \%$, nu bereid was nog strengere voorwaarden voor gezinsmigratie te accepteren, weerspiegelt niet alleen het feit dat de sociaaldemocraten in 1998 met een rechtsere coalitiepartner te maken hadden, maar ook de dominante positie die het perspectief van 'eigen verantwoordelijkheid' op het gezinsmigratiebeleid inmiddels had verworven, ook binnen de PvdA.

De verhoging van de inkomenseis van $70 \%$ naar $100 \%$ van de bijstandsnorm voor Nederlanders en gevestigde vreemdelingen werd opgenomen in de nieuwe Vreemdelingenwet. ${ }^{175}$ Misschien omdat hij al wist dat deze wijziging op de steun van een meerderheid in de Kamer kon rekenen, nam staatssecretaris Cohen nauwelijks de moeite om deze aanscherping in de memorie van toelichting te onderbouwen. Hij beperkte zich ertoe te stellen dat er 'thans zoveel uitzonderingen en vrijstellingen op de inkomenseis' bestonden, dat 'de hoofdregel was uitgehold'. ${ }^{176}$ Net als in 1993 werd de hervorming dus gedepolitiseerd door haar te presenteren als een correctie van de beleidspraktijk, in plaats van als een inhoudelijke politieke keuze.

172 Investeren in uw toekomst, Verkiezingsprogramma vVD 1998-2002: 23. Documentatiecentrum Nederlandse politieke partijen, www.rug.nl/dnpp.

173 тK 1999-2000 Handelingen 7 juni 2000: 5384.

174 De archieven van de kabinetsformaties op het ministerie van Algemene Zaken bevatten slechts formele notities van ministeries en bijvoorbeeld belangenorganisaties, geen verslaglegging van de onderhandelingen.

175 In de Vreemdelingenwet 2000 werd ook het huisvestingsvereiste, het enige criterium dat sinds de jaren tachtig wel voor vreemdelingen met een permanente verblijfsvergunning maar niet voor Nederlanders en vluchtelingen gold, afgeschaft. (Van Walsum 2008: 245) Die wijziging werd terloops aangekondigd door staatssecretaris Schmitz in 1997 en er is nooit enige politieke discussie over geweest. Schmitz gaf als argument dat het huisvestingsvereiste in strijd zou zijn met artikel 8 EVRM. (TK 1996-1997 25001 (30): 8) Voor zover mij bekend hebben het Hof in Straatsburg noch de Nederlandse rechters echter ooit geopperd dat het huisvestingsvereiste strijdig zou zijn met het recht op gezinsleven. In de memorie van toelichting op de Vreemdelingenwet 2000 wordt de afschaffing van het huisvestingsvereiste niet genoemd.

176 тк 1998-1999 26732 (3): 7. 
De nieuwe inkomenseis deed in de Kamer inderdaad weinig stof opwaaien. Het parlementair debat ging vrijwel uitsluitend over de asielbepalingen in het wetsvoorstel. GroenLinks protesteerde wel fel, zoals te verwachten was aangezien zij, zoals ze zelf schreven, 'al moeite hadden met de inkomenseis van 70\%'. GroenLinks vroeg om aandacht voor de gevolgen van de aanscherping voor vrouwen, jongeren en migranten, gezien hun kwetsbare positie op de arbeidsmarkt. ${ }^{177}$ Ook de sP vond de verhoging 'onredelijk', gegeven de hoge werkloosheid onder vluchtelingen. Het was niet juist om hen 'de dupe' te laten worden van het 'falende integratiebeleid' ${ }^{178}$ Door alle andere partijen in de Tweede Kamer werd het regeringsvoorstel echter met instemming begroet. ${ }^{179}$ Daaruit blijkt opnieuw, hoe breed het principe dat de overkomst van buitenlandse gezinsleden van inwoners van Nederland aan voorwaarden mocht en moest worden onderworpen, inmiddels aanvaard was door de Nederlandse politiek.

\section{Gezinshereniging voor vluchtelingen}

Om het aantal en de duur van de procedures te verkorten, verving de Vreemdelingenwet 2000 de A-status, de vtv-hum en de vvtv door één enkele asielstatus. Alle asielzoekers die in Nederland mochten blijven kregen voortaan in eerste instantie een vergunning die jaarlijks verlengd moest worden en na drie jaar een vergunning voor onbepaalde tijd. Zo zou worden voorkomen dat asielzoekers die een vvtv of vtv-hum kregen, doorprocedeerden voor een betere status. ${ }^{180}$

Dat had gevolgen voor het gezinsmigratiebeleid voor vluchtelingen. Houders van een vtv-hum moesten voorheen aan dezelfde strenge voorwaarden voldoen als vreemdelingen met een tijdelijke verblijfsvergunning. Voor houders van een vvtv was gezinshereniging niet toegestaan. Vanaf de inwerkingtreding van de nieuwe wet zou op alle vluchtelingen het soepele gezinsmigratieregime van toepassing zijn, dat tot die tijd alleen voor A-statushouders

177 TK 1999-2000 26732 (5): 39.

178 TK 1999-2000 Handelingen 7 juni 2000: 5423. De sP was sinds 1994 in de Kamer vertegenwoordigd, en bezette tussen 1998 en 20025 zetels.

179 TK 1999-2000 26732 (5); TK 1999-2000 27111 (8).

180 TK 1998-1999 26732 (3): 1-2. 
gold. ${ }^{181}$ Gezinsleden met dezelfde nationaliteit als de hoofdpersoon, die met hem meereisden of binnen een 'redelijke termijn' van drie maanden nareisden, kwamen in aanmerking voor een zelfstandige asielstatus, zonder dat aan de normale voorwaarden zoals het inkomensvereiste moest worden voldaan. ${ }^{182}$

Deze versoepeling viel bij het CDA niet in goede aarde. Vluchtelingen aan wie tijdelijk bescherming werd geboden kregen voorheen een vvtvstatus. Pas na drie jaar kregen zij een vtv-hum en konden zij hun gezin laten overkomen. Dankzij de Vreemdelingenwet 2000 zouden zij in de toekomst direct voor gezinshereniging in aanmerking komen. CDA-woordvoerder Wijn was daar pertinent op tegen, omdat 'gezinshereniging veel simpeler wordt en dus wel eens zou kunnen toenemen'. Net als in de debatten rondom de motie Verhagen/Rijpstra enkele jaren eerder, bleek dat beperking van de instroom voor de christendemocraten zoveel prioriteit had, dat zij zelfs voor vluchtelingen - die niet terug naar huis konden en dus een bijzonder belang hadden bij hereniging van hun gezin in Nederland - strenge voorwaarden wilden stellen aan gezinshereniging. Dit standpunt kwam het CDA opnieuw op forse kritiek te staan van links. Halsema zei namens GroenLinks niet te begrijpen hoe 'de gezinspolitiek die het CDA altijd koestert' zich verhield tot het feit dat het CDA 'ontwrichting van gezinnen voor een periode van bijvoorbeeld drie jaar (...) acceptabel' vond. Wijn antwoordde dat voor het CDA voorop stond dat 'zo'n gezin zich kan inbedden en een toekomstperspectief heeft'. ${ }^{183}$ Staatssecretaris Cohen poogde Wijn te overreden door erop te wijzen dat wanneer verschillen bleven bestaan tussen het gezinsmigratiebeleid voor tijdelijk beschermden en andere vluchtelingen, er opnieuw een grond zou ontstaan om door te procederen voor een betere status. Daarmee zou het voornaamste doel van de wetswijziging -

181 Zie paragraaf 4.5. In een notitie van DVZ ten behoeve van de kabinetsformatie 1998 is overwogen deze versoepelde toelating geheel af te schaffen. De Nederlandse eis dat binnen drie maanden moest worden nagereisd om vrijgesteld te zijn van de normale voorwaarden was echter al strenger dan het beleid van de meeste EU-landen, waar in het geheel geen inkomenseis werd gesteld bij gezinshereniging van vluchtelingen. Aangezien een dergelijke aanscherping bovendien op gespannen voet zou staan met artikel 8 EVRM, achtten de ambtenaren haar 'niet opportuun'. Nota asielbeleid t.b.v. Kabinetsformatie 1998, n.d. MAZ 475093.

182 Voorheen was de 'redelijke termijn' niet nader gedefinieerd in de regelgeving, maar werd in de praktijk een termijn van zes maanden gehanteerd. De staatssecretaris verklaarde dat nu voor een termijn van drie maanden gekozen was, omdat het met het oog op de integratie wenselijk was dat het gezin zo spoedig mogelijk overkwam. Voor verdragsvluchtelingen, die voorheen een A-status zouden hebben gekregen, werd het beleid dus iets strenger. Op GroenLinks na stemden alle politieke partijen daarmee in. Den Uyl 2007: 8; тK 1998-1999: 26732 (3): 6; тK 1999-2000 26732 (7): 48; TK 1999-2000 Handelingen 6 juni 2000: 5325, 5351; Handelingen 8 juni 2000: 5516.

183 тK 1999-2000 Handelingen 7 juni 2000: 5399-5400. 
het inperken van de procedures - teniet worden gedaan. ${ }^{184}$

Het CDA liet zich echter niet overtuigen. Van het hoge voorzieningenniveau dat voortaan aan alle toegelaten asielzoekers zou worden toegekend, waaronder de mogelijkheid tot gezinshereniging, verwachtten de christendemocraten een 'aanzuigende werking'. Het CDA stemde daarom tegen het wetsvoorstel. Ook sP en GroenLinks stemden tegen, omdat zij het wetsvoorstel te restrictief vonden. Alle andere partijen stemden echter voor, zodat de Vreemdelingenwet 2000 op 14 juni 2000 door de Tweede Kamer werd aangenomen. ${ }^{185}$

\subsection{Vrouwen in het vreemdelingenrecht}

In de jaren zeventig en tachtig was de positie van vrouwen een belangrijk thema in het debat over het gezinsmigratiebeleid. Na de formele gelijkstelling van mannen en vrouwen in het vreemdelingenrecht in1979 richtte de discussie zich vooral de op het verblijfsrecht van migrantenvrouwen wier huwelijk of relatie stuk liep. Die discussies werden vanaf de tweede helft van de jaren negentig voortgezet. Daarnaast werd herhaaldelijk de vraag opgeworpen, of de - steeds strengere - voorwaarden voor toelating van buitenlandse gezinsleden geen indirecte discriminatie van vrouwen opleverden. In beide gevallen ging het debat over mogelijk ongelijke gevolgen voor mannen en vrouwen van in formele zin gelijke regels. ${ }^{186}$

Zoals ook in de jaren tachtig het geval was geweest, werd de positie van vrouwen in het vreemdelingenbeleid steeds door het parlement op de politieke agenda gezet, waarbij met name de partijen links van het midden zich nadrukkelijk roerden. Vrouwenemancipatie blijkt een thema dat Nederlandse volksvertegenwoordigers na aan het hart ligt. Daarbij speelt ook een rol, dat belangenorganisaties van vrouwen en migranten, zoals het Clara Wichmann Instituut, het Komitee Zelfstandig Verblijfsrecht Migrantenvrouwen, E-Quality, Forum en de Stichting Lawine, actief aandacht bleven vragen voor de effecten van het vreemdelingenrecht voor Nederlandse en buitenlandse vrouwen.

184 TK 1999-2000 Handelingen 8 juni 2000: 5502-5503.

185 TK 1999-2000 Handelingen 14 juni 2000: 5545-5547.

186 Het idee dat het recht, ook wanneer formele gelijkheid is bereikt, de dominante sociaalculturele patronen weerspiegelt en daarmee vrouwen benadeelt, vormt de kern van een belangrijke stroming in feminist legal studies (Calavita 2006: 106) en is kernachtig verwoord door MacKinnon (1989: 248): 'When [law] is most ruthlessly neutral, it is most male'. 


\section{Voortgezet verblijf na verbreken van huwelijk of relatie}

Vreemdelingen aan wie verblijf werd toegekend op grond van hun gezinsband met een inwoner van Nederland, kregen een 'afhankelijke' verblijfstitel. Werd de gezinsband verbroken, dan verviel ook hun verblijfsrecht. $\mathrm{Na}$ vijf jaar kwamen buitenlandse partners, net als andere vreemdelingen, in aanmerking voor een zelfstandige vestigingsvergunning indien zij aan de inkomenseis voldeden. Sinds 1982 was voortgezet verblijf na verbreken van de huwelijksrelatie mogelijk, na drie jaar huwelijk en één jaar verblijf in Nederland, indien de vreemdeling zelfstandig en duurzaam in zijn levensonderhoud kon voorzien. ${ }^{187}$ Wie op het moment van relatiebreuk niet voldoende inkomen had, kreeg een jaar de tijd om werk te zoeken. Van deze voorwaarden kon worden afgeweken in geval van 'klemmende redenen van humanitaire aard'. ${ }^{188}$

In respons op kritiek van D66, GroenLinks en PvdA besloot staatssecretaris Schmitz in 1997 tot een aantal kleine aanpassingen van dit beleid. ${ }^{189}$ Voortaan zou inkomen uit tijdelijk werk als duurzaam inkomen kunnen worden beschouwd. ${ }^{190}$ Verder zou bij de beoordeling of sprake was van klemmende redenen van humanitaire aard worden meegewogen of de vreemdelinge de zorg droeg voor kinderen die in Nederland waren geboren of naar school gingen en of er sprake was geweest van misbruik binnen de relatie. $^{191}$

In 1999 zette Albayrak (PvdA) het afhankelijk verblijfsrecht opnieuw op de kaart. Zij meende dat de bestaande regelgeving soms 'onevenredig hard' uitpakte voor vrouwen en 'bovendien in strijd [was] met emancipatiedoeleinden'. Zij vroeg staatssecretaris Cohen daarom om een notitie. ${ }^{192}$ Op basis van de aanbevelingen van een expertmeeting waaraan vertegenwoordigers van verschillende vrouwen- en migrantenorganisaties en van de ministeries van Justitie, Sociale Zaken en Binnenlandse Zaken deel hadden genomen,

187 Bij niet-huwelijkse relaties was drie jaar verblijf in Nederland vereist. Anders dan bij eerste toelating waren alleenstaande ouders, ouderen en arbeidsongeschikten niet vrijgesteld van de inkomenseis.

188 тK 1997-1998 19637 (279); тK 1981-1982 17501 (2).

189 TK 1997-1998 19637/26237 (303).

190 Indien betrokkene tenminste drie jaar werkzaam was geweest en over een arbeidscontract van tenminste 6 maanden beschikte.

191 TK 1997-1998 19637 (306). Uit onderzoek van het Komité Zelfstandig Verblijfsrecht voor Migrantenvrouwen bleek dat 30 tot $40 \%$ van de buitenlandse vrouwen die binnen drie jaar scheidden, mishandeld waren door hun echtgenoot. Blokland \& De Vries 1992: 15.

192 TK 1998-1999 25453 (13): 2, 13. 
presenteerde Cohen een jaar later een voorstel om de voorwaarden voor voortgezet verblijf grondig te herzien. Het was uiterst ongebruikelijk dat het ministerie van Justitie een dergelijke bijeenkomst belegde ter voorbereiding van een hervorming van het gezinsmigratiebeleid. Hieruit blijkt hoezeer andere ministeries en - vooral - belangenorganisaties zich deden gelden in discussies over het verblijfsrecht van buitenlandse vrouwen.

Eén van de centrale conclusies van de expertmeeting was dat de procedures aanzienlijk moesten worden ingekort. Uit onderzoek van het instituut Clara Wichmann bleek dat niet meer dan 6\% van de aanvragen van vrouwen na scheiding of overlijden van hun partner meteen werd gehonoreerd. Uiteindelijk werd in $79 \%$ van de gevallen echter wel een verblijfsvergunning verleend. Gemiddeld duurde het twee jaar en drie maanden voordat de vrouwen zekerheid hadden omtrent hun verblijfsrecht. Staatssecretaris Cohen wilde hierin verbetering brengen door de regels te verduidelijken en versimpelen. Bovendien had Cohen geconstateerd dat het Nederlands beleid streng was in vergelijking met andere Europese lidstaten: nergens anders duurde het vijf jaar voordat een buitenlandse partner een zelfstandig verblijfsrecht werd toegekend. ${ }^{193} \mathrm{Na}$ het buiten toepassing blijven van de 'omgekeerde wachttermijn' in 1996 was dit de tweede keer dat de wens om tot Europese harmonisatie te komen leidde tot aanpassing van het Nederlands gezinsmigratiebeleid.

Voortaan zou voortgezet verblijf worden toegestaan, indien de buitenlandse partner drie jaar in Nederland verbleef en de relatie drie jaar had geduurd. De vereiste duur van het verblijf werd dus verlengd van één naar drie jaar. Tegenover deze aanscherping stond echter de aanzienlijke versoepeling, dat na drie jaar geen inkomenseis meer werd gesteld; een verblijfsvergunning zou dan alleen worden geweigerd als de vreemdeling een gevaar opleverde voor de openbare orde. Wanneer de relatie binnen drie jaar werd verbroken zou voortgezet verblijf net als voorheen uitsluitend op humanitaire gronden worden toegestaan. Er moest dan sprake zijn van een combinatie van de volgende factoren: de situatie van (alleenstaande) vrouwen in het land van herkomst, de zorg voor kinderen die hier geboren zijn of een opleiding volgen en aantoonbaar ondervonden geweld binnen de relatie. Bij overlijden van de partner zou altijd voortgezet verblijf worden toegestaan, omdat hier sprake was van 'een zodanig bijzondere en onbeïnvloedbare omstandigheid (...) die op zichzelf zodanig schrijnend is

193 тK 1999-2000 27111 (1): 7, 11. 
dat die grond voor verblijf hier te lande oplevert'. ${ }^{194}$ Volgens Groenendijk en Barzilay was deze laatste bepaling een reactie op 'ophef' in de pers in 1999 naar aanleiding van een Poolse weduwe die 'met uitzetting werd bedreigd'. 195

De progressieve partijen in de Kamer reageerden positief op deze beleidswijziging. Het voornaamste punt van kritiek van PvdA, GroenLinks, D66 en sP was dat huiselijk geweld alleen in combinatie met andere 'klemmende redenen' als grond voor een verblijfsvergunning werd beschouwd. Zij meenden dat misbruik, net als overlijden van de partner, altijd reden moest zijn om verblijf toe te staan. Staatssecretaris Cohen begaf zich op bijzonder glad ijs door daar tegenin te brengen dat men 'op het overlijden van de partner geen enkele invloed' had; 'op de situatie die voorafgaat aan de scheiding kan wel sprake zijn van enige invloed, zonder dan te spreken in termen van verwijtbaarheid'. ${ }^{196}$

Vanuit CDA en VVD klonk een heel ander geluid. CDA-woordvoerder Wijn maakte zich zorgen over schijnhuwelijken en stelde daarom voor om de verblijfstermijn van drie naar vijf jaar te verhogen. Hij zag ook niet in waarom het 'trieste weduwschap' automatisch zou betekenen dat terugkeer naar het herkomstland onmogelijk was. De vvD toonde zich bij monde van Kamp eveneens verontrust over het risico van misbruik, met name gezien de 'ruim geformuleerde' voorwaarden voor verblijf op humanitaire grond. Bovendien wierp Kamp de principiële vraag op, of het gezinsmigratiebeleid wel 'verantwoord' was, gezien de frequentie van scheiding en geweld in migrantengezinnen. Hij zag een direct oorzakelijk verband tussen de aantrekkelijkheid van het huwelijk als middel om een verblijfsvergunning te krijgen en de oververtegenwoordiging van migranten in de statistieken over huiselijk geweld. ${ }^{197}$

Van Walsum heeft erop gewezen dat advocaten, belangengroepen en politici die ijverden voor versterking van de rechtspositie van migrantenvrouwen en daarbij verwezen naar de patriarchale structuren in de landen van herkomst en naar de onderdrukking en geweld waarvan vrouwen in met name islamitische culturen het slachtoffer waren, onbedoeld hebben bijgedragen aan een beeldvorming die uiteindelijk als argument zou dienen voor

194 TK 1999-2000 27111 (1). Daarmee was het beleid - na 20 jaar debatten en hervormingen - weer vrijwel identiek aan dat van 1979. Zie Groenendijk \& Barzilay 2001: 21; TK 1999-2000 $27111(8): 6$.

195 Groenendijk \& Barzilay 2001: 21.

196 TK 27111 (8): 10.

197 TK 1999-2000 27111 (8): 3-5; TK 1999-2000 Handelingen 21 juni 2000: 5763-5764. 
restricties van het gezinsmigratiebeleid: '[i]f men originating from these countries were so abusive, their wives and children were better off staying separated from them'. 198 In het betoog van Kamp zien we hoe argumenten die door belangenbehartigers van migrantenvrouwen worden ingebracht, direct bijdragen aan een problematisering van de huwelijkspraktijken en gezinsverhoudingen van migranten als gewelddadig en vrouwonvriendelijk en hoe daaruit de conclusie wordt getrokken dat het beleid in restrictieve zin moet worden bijgesteld, om vrouwen te beschermen. In 2000 deed staatssecretaris Cohen deze redenering nog af met de opmerking dat hij 'deze veronderstellingen (...) graag voor de rekening van de heer Kamp' liet. ${ }^{199}$ De kabinetten Balkenende daarentegen die vanaf 2002 het regeringspluche bezetten zouden hun beleid met vergelijkbare argumenten onderbouwen.

In november 2002 dienden PvdA, GroenLinks, Leefbaar Nederland, SP en D66 een motie in, waarin gevraagd werd om vrouwen die slachtoffer waren van relationeel geweld altijd een verblijfsvergunning te verlenen, en niet alleen wanneer er ook andere 'klemmende redenen van humanitaire aard' in het spel waren. ${ }^{200}$ Minister Nawijn (LPF) van Vreemdelingenzaken en Integratie reageerde positief op de motie. ${ }^{201}$ De argumenten van staatssecretaris Cohen om weduwschap wel, maar geweld niet als toelatingsgrond te aanvaarden, waren in 2000 al niet zo sterk. 'Aantoonbaar ondervonden (seksueel) geweld binnen het gezin' werd als voldoende grond aanvaard om een verblijfsvergunning op humanitaire gronden te verlenen. ${ }^{202}$

Het afhankelijk verblijfsrecht is één van de weinige aspecten van het gezinsmigratiebeleid waarin sinds de jaren negentig tot versoepeling is besloten. Het activisme van parlement en belangengroepen heeft daarbij een belangrijke rol gespeeld. Dat de regering zich eind jaren negentig ontvankelijk toonde voor hun pleidooi, heeft wellicht te maken met de toenemende aandacht in het publiek debat voor verschillen tussen 'westerse' waarden en de cultuur van islamitische migranten. ${ }^{203}$ In de manier waarop die verschillen werden gedefinieerd speelde de positie van de vrouw een prominente rol, waarbij verwezen werd naar zaken als gedwongen huwelijken, huiselijk geweld, eerwraak en vrouwenbesnijdenis. Daarmee werd het politiek zeer wenselijk om dat aspect van het vreemdelingenrecht dat

198 Van Walsum 2008: 190.

199 TK 1999-2000 Handelingen 21 juni 2000: 5764.

200 TK 2002-2003 28600 VI (45).

201 TK 20002-2003 28600 VI (117).

202 IND Verblijfswijzer, website IND, www.ind.nl.

203 Roggeband \& Vliegenthart 2007: 536. 
direct van invloed was op de positie van migrantenvrouwen ten opzichte van hun echtgenoot, aan te passen aan de 'westerse' norm van emancipatie en onafhankelijkheid.

\section{Indirecte discriminatie}

In 1979 waren de voorwaarden voor de overkomst van buitenlandse gezinsleden voor mannen en vrouwen, mede dankzij een actieve lobby van linkse Kamerleden, in formele zin gelijkgesteld. Vanaf de eerste aanscherping van het inkomensvereiste in 1993 werd geregeld de kritiek geuit dat die formele gelijkstelling niet ver genoeg ging: de regels werkten in de praktijk negatiever uit voor vrouwen dan voor mannen en waren daarmee indirect discriminerend. Dit argument werd vooral door academici en belangenorganisaties naar voren gebracht. Wanneer het door Kamerleden werd overgenomen, betrof het altijd linkse politici.

Bij de evaluatie van het inkomensvereiste halverwege de jaren negentig wees een breed scala aan migranten- en vrouwenorganisaties - het Clara Wichmann Instituut, het Nederlands Centrum Buitenlanders, het Komitee Zelfstandig Verblijfsrecht Migrantenvrouwen en de Stichting Lawine - erop dat de aanscherping van het inkomensvereiste vrouwen onevenredig hard trof. ${ }^{204}$ Uit onderzoek van Lawine, de landelijke organisatie van Nederlandse vrouwen met een buitenlandse partner, bleek dat ruim de helft van de Nederlandse vrouwen niet aan het inkomensvereiste kon voldoen. ${ }^{205}$ De juriste Van Blokland wees er in een artikel op dat van de Marokkaanse vrouwen in Nederland zelfs minder dan tien procent voldoende verdiende om een buitenlandse partner te laten overkomen. Net als Lawine vond Van Blokland de inkomenseis daarom indirect discriminerend. ${ }^{206}$ Sipkes sloot zich namens GroenLinks aan bij deze kritiek en vroeg de staatssecretaris om een zogenaamde 'Emancipatie Effect Rapportage' te laten uitvoeren: een toets of de effecten van beleidsvoorstellen wel overeenstemden met de

204 TK 1995-1996 24401 (13): 6-7.

205 Het onderzoeksrapport verscheen onder de titel Kosto-kindjes en caissières. De term 'kostokindjes' verwees naar de bevinding van het onderzoek dat vrouwen die het niet lukte om aan het inkomensvereiste te voldoen soms voor het krijgen van een kind kozen, om zo te vallen onder de vrijstelling voor alleenstaande ouders van kleine kinderen, en natuurlijk naar de staatssecretaris van Justitie die de nieuwe inkomenseis had ingevoerd.

206 Brief Lawine aan staatssecretaris, 12 december 1995. MJ A95/5253; Van Blokland 1995: 110-111. 
emancipatiedoelstellingen van de regering. ${ }^{207}$

Staatssecretaris Schmitz (PvdA) vond een dergelijke toetsing van het vreemdelingenbeleid op mogelijk discriminerende effecten echter niet nodig. Uit gegevens van Justitie bleek dat het aantal mannen dat een vergunning aanvroeg of verkreeg sinds 1993 niet sterker gedaald was dan het aantal vrouwen. Er was dus geen indicatie dat het nieuwe inkomensvereiste het voor vrouwen moeilijker had gemaakt dan voor mannen om een partner over te laten komen. ${ }^{208}$ Later voegde zij daar nog aan toe, dat uit cijfers van de IND, het CBS en het ISEO $^{209}$ bleek dat mannen oververtegenwoordigd waren in de zeer hoge en zeer lage inkomensgroepen, 'maar dat vrouwen juist beter scoren in de modale inkomens'. Een modaal inkomen was voldoende om aan de inkomenseis te voldoen, dus was er geen enkele grond om aan te nemen dat vrouwen daar minder vaak in slaagden dan mannen. Het Clara Wichmann Instituut was niet overtuigd van de validiteit van de cijfers die Justitie presenteerde, maar aangezien andersom hetzelfde gold, werd besloten een punt te zetten achter de discussie. ${ }^{210}$

In 1999 werd het punt van indirecte discriminatie van vrouwen opnieuw aan de orde gesteld, ditmaal door Thomas Spijkerboer die toen verbonden was aan het Centrum voor Migratierecht in Nijmegen. Hij stelde in een rondetafelgesprek met Tweede Kamerleden dat de aanscherping van het inkomensvereiste tot $100 \%$ van de bijstandsnorm in de nieuwe vreemdelingenwet in strijd was met de standstill-bepaling van het vN-vrouwenverdrag, die stipuleert dat bestaande vormen van directe of indirecte discriminatie niet mogen worden verzwaard. D66 en GroenLinks stelden naar aanleiding van die opmerking vragen aan staatssecretaris Cohen, die er echter niet op in ging. ${ }^{211}$

In juli 2003 presenteerde de Adviescommissie Vreemdelingenzaken (ACVZ), als onderdeel van de periodieke nationale rapportage in het kader van het vN-vrouwenverdrag, een advies over de positie van vrouwen in het vreemdelingenrecht. ${ }^{212}$ Op verzoek van de ACVZ schreef Thomas Spijkerboer - inmiddels hoogleraar aan de vU - een discussiestuk, waarin hij het

207 TK 1995-1996 Handelingen 15 november 1995: 1820. Lawine en Van Blokland pleitten ook voor een Emancipatie Effect Rapportage.

208 TK 1995-1996 24401 (13).

209 Instituut voor Sociaal-Economisch Onderzoek van de Erasmus Universiteit

210 TK 1996-1997 25001 (7).

211 TK 1999-2000 26732 (4); TK 1999-2000 26732 (5).

212 Nederland had in 1991 het vN-vrouwenverdrag geratificeerd. Daarmee was het de verplichting aangegaan om eens in de vier jaar zowel aan het toezichthoudend comité als aan het parlement te rapporteren over de uitvoering van het verdrag. 
'aannemelijk' noemde dat vrouwen in het algemeen en allochtone vrouwen in het bijzonder 'minder vaak aan de inkomenseis kunnen voldoen dan mannen'. Als dat inderdaad klopte, dan was dat een 'niet gerechtvaardigd onderscheid'. Zou de regering het inkomensvereiste nog verder willen verhogen, dan rustte op haar een 'zeer zware motiveringsplicht'. ${ }^{213}$ De ACVZ adviseerde de regering om beleidsvoorstellen die de financiële drempel voor gezinshereniging of -vorming verder ophoogden, vóór inwerkingtreding te toetsen via een Emancipatie Effect Rapportage.

Het tweede kabinet Balkenende, dat voornemens was het inkomensvereiste bij gezinsvorming te verhogen, vond het echter niet nodig om te laten toetsen of dat in strijd zou kunnen zijn met de doelstellingen van het emancipatiebeleid. De aanscherping van de inkomenseis was vastgelegd in het regeerakkoord. Een Emancipatie Effect Rapportage had dus 'geen nut, aangezien de uitslag ervan geen effect zal hebben op de beleidswijziging'. ${ }^{214}$ Ondanks aandringen van GroenLinks en PvdA volhardde minister Verdonk in het standpunt dat een dergelijke rapportage niet nodig was, omdat 'de voorgestelde maatregelen sekseneutraal' waren. ${ }^{215}$

Juristen, belangenorganisaties en linkse politici vragen dus al meer dan tien jaar vergeefs om een onderzoek naar mogelijk discriminerende effecten van het inkomensvereiste in het gezinsmigratiebeleid. Waar staatssecretaris Schmitz nog inhoudelijk op het verwijt van indirecte discriminatie inging, hetgeen resulteerde in gesteggel over inkomens- en arbeidsmarktstatistieken, was voor minister Verdonk de vraag of sprake zou kunnen zijn ongerechtvaardigd onderscheid niet in de regelgeving zelf, maar in het effect van die regelgeving voor mannen en vrouwen, niet relevant. In haar ogen was aan het gelijkheidsbeginsel voldaan met formele gelijkstelling in de regelgeving.

213 Bijlage 3 bij ACVZ advies vN-Vrouwenverdrag november 2002: 10-14. TK 2002-2003 Just030524.

214 Kabinetsreactie Tweede nationale rapportage vN-Vrouwenverdrag, december 2003: 55. TK 2003-2004 Bijlage bij szw0400002.

215 тк 2004-2005 19637 (873): 8. 


\section{DEEL II: NA DE EEUWWISSELING}

\subsection{Cultuur, cohesie en 'zeggen wat je denkt'}

Begin jaren negentig was een fundamentele omslag gemaakt in debat en beleid in Nederland op het gebied van gezinsmigratie. Vanwege wat Hirsch Ballin beschreef als de 'groeiende zwarigheid van integratie in de Nederlandse samenleving ${ }^{216}$ moest de instroom van nieuwe migranten worden ingeperkt. Dat werd zo urgent gevonden, dat zelfs het moreel recht op gezinshereniging, dat in de jaren tachtig zo zwaar woog, aan voorwaarden werd onderworpen. De nieuwe norm van 'individuele verantwoordelijkheid' en 'rechten en plichten' speelde in de politieke aanvaarding van deze nieuwe beleidslijn een belangrijke rol. Waar de eerste restrictieve hervorming in 1993 nog in moeizame onderhandelingen tussen coalitiepartners PvdA en CDA tot stand kwam, en ook in de Kamer op aarzelingen stuitte, werd het in de loop van de jaren negentig vanzelfsprekend dat - steeds strengere - eisen werden gesteld aan mensen die buitenlandse gezinsleden wilden laten overkomen. De verhoging van de inkomenseis in 2000 ontmoette alleen bij de kleine linkse partijen nog weerstand.

Ook na de eeuwwisseling zouden de wens om de omvang van de instroom terug te dringen en de norm van 'individuele verantwoordelijkheid' een centrale rol blijven spelen in de debatten over het gezinsmigratiebeleid. Het 'lange jaar 2002' bracht echter in twee opzichten een wezenlijke verandering teweeg. In de eerste plaats gingen culturele verschillen, met name op het gebied van gezin, huwelijk en de positie van man en vrouw, een prominente plaats innemen in het politiek debat over de overkomst van buitenlandse gezinsleden. We hebben gezien dat de VVD reeds in de late jaren negentig pleitte voor aanscherping van het gezinsmigratiebeleid, vanuit een perceptie van de huwelijks- en gezinspraktijken van migranten als afwijkend en ongewenst. Dit pleidooi van de liberalen vond toen nog geen gehoor bij andere partijen, en zeker niet bij het Paarse kabinet. Na de eeuwwisseling werd dat anders. In de tweede plaats kreeg het gezinsmigratievraagstuk een groter politiek gewicht dan ooit tevoren.

Deze veranderingen in de omgang met het gezinsmigratievraagstuk in engere zin hingen nauw samen met ingrijpende wijzigingen in het politiek

216 Notitie minister aan ambtenaren en staatssecretaris, 13 april 1992. IND A92/3470. 
perspectief op het algemene migratie- en integratievraagstuk. Pellikaan, Van der Meer en De Lange hebben de standpunten van de parlementaire partijen over de multiculturele samenleving in de verkiezingsprogramma's van 1998 vergeleken met die van 2002 en 2003. Zij constateerden dat er in de tussenliggende jaren een 'meteoriet' leek te zijn ingeslagen in het Nederlandse politieke landschap. Standpunten die vijf jaar eerder alleen door de Centrumdemocraten van Janmaat werden ingenomen, waren in 2002 'gemeengoed'. In 1998 legden alle grote politieke partijen nog de nadruk op het opheffen van structurele achterstanden en het bestrijden van discriminatie, terwijl naast de Centrumdemocraten alleen de vvD pleitte voor het inperken van immigratie, en dan nog in heel voorzichtige termen. In 2002 en 2003 werd de achterstandspositie van minderheden toegeschreven aan gebrek aan inzet van allochtonen om te integreren, in plaats van aan racisme of discriminatie. Behoud van eigen cultuur en identiteit werd als een obstakel gezien voor het integratieproces. De nadruk lag nu op 'behoud van de Nederlandse identiteit en de daarbij behorende westerse waarden en normen'. ${ }^{217}$ Wat is er gebeurd in de jaren na de eeuwwisseling dat een zo radicale omslag kan verklaren?

\section{Nationale identiteit, culturele diversiteit en politieke legitimiteit}

In de jaren na de eeuwwisseling werd het migratie- en integratievraagstuk één van de meest urgente, zo niet hét meest urgente, thema op de politieke agenda in Nederland. ${ }^{218}$ Deze politisering was minder het gevolg van veranderingen in de materiële rol en positie van migranten in de Nederlandse maatschappij, dan van issue linkage, waarbij het migratie- en integratiebeleid onlosmakelijk verbonden raakte met abstractere thema's als nationale identiteit en de legitimiteit van het politiek bestel.

Dit betekent niet dat de incorporatie van migranten in de samenleving probleemloos verliep. Sommige migrantengroepen waren oververtegenwoordigd in de misdaadstatistieken, contacten tussen etnische groepen namen af en de segregatie in het onderwijs nam ongekende vormen aan. In Rotterdam en Amsterdam was meer dan 30\% van de bevolking allochtoon. ${ }^{219}$ Daartegenover stonden echter beduidende positieve ontwikkelingen. Mede dankzij de economische bloei was de sociaal-economische

217 Pellikaan e.a. 2003: 163-165.

218 Vgl. Scholten 2007: 203-204.

219 Scholten 2007: 205; Entzinger 2005: 127. 
positie van migranten en hun kinderen in de Nederlandse maatschappij in de loop van de jaren negentig aanzienlijk verbeterd. Waar in 1994 nog ongeveer een kwart van de Surinamers, Antillianen, Turken en Marokkanen werkloos was, zat in 2000 en 2002 nog maar 10\% zonder baan. Daarmee was de doelstelling van de regering om werkloosheid onder migrantengroepen te halveren bereikt, ook al was deze nog steeds twee keer zo hoog als onder de autochtone bevolking. De participatie van migranten van de tweede generatie in het hoger onderwijs nam toe, schooluitval liep terug. Op het gebied van huisvesting was de positie van migranten inmiddels vergelijkbaar met die van autochtone Nederlanders in dezelfde inkomensgroepen. ${ }^{220}$ In sociaal-economisch opzicht verging het migranten in Nederland dus steeds beter: desondanks zou na de eeuwwisseling een uitgesproken pessimisme gaan heersen over de inpassing van migranten in de samenleving.

Schnapper constateerde in 1994 al dat de 'passie' waarmee debatten over migratie en integratie in West-Europa werden gevoerd niet zozeer voortkwam uit - overigens reële - problemen met de integratie van migranten, als wel uit een 'crisis of national identity': de integriteit en soevereiniteit van Europese natiestaten was met steeds meer onzekerheid omgeven. ${ }^{221}$ Ook in Nederland werd de nationale identiteit in de loop van de jaren negentig onderwerp van discussie, als gevolg van globalisering en - vooral - de Europese integratie, die vanaf het Verdrag van Maastricht (1992) een doorstart maakte. De perceptie dat de Nederlandse staat de capaciteit verloor om een veilig kader te bieden werd versterkt door de herijking van de rol van de overheid in de jaren negentig. Ondanks de economische groei en de lage werkloosheid leek het leven in Nederland volgens Van Kersbergen en Krouwel veel minder zeker dan voorheen, als gevolg van privatisering en de neo-liberale, 'activerende' herinrichting van de verzorgingsstaat. ${ }^{222}$

De onrust en onzekerheid over de Nederlandse identiteit kwamen ook tot uiting in de toenemende aandacht in de media in de tweede helft van de jaren negentig voor de problematische aspecten van culturele verschillen tussen de autochtone bevolking en - islamitische - migranten. ${ }^{223}$ Daarbij deed zich een opmerkelijke paradox voor. Terwijl steeds vaker de vrees werd geuit dat de Nederlandse identiteit in gevaar was, stelt Duyvendak

220 Scholten 2007: 205-206; Entzinger 2005: 126-127.

221 Schnapper 1994: 129, 138.

222 Van Kersbergen \& Krouwel 2008: 402.

223 Roggeband \& Vliegenthart 2007: 536. 
vast dat Nederlanders juist een steeds uitgesprokener en eenvormiger identiteit bezitten. In opvattingen en gedrag op het gebied van godsdienst- en gewetensvrijheid, echtscheiding, homoseksualiteit en opvoeding van kinderen - thema's die in andere landen zeer controversieel zijn - wordt de Nederlandse bevolking gekenmerkt door een opvallende uniformiteit. Ook in de politiek bestaat vrijwel algehele consensus over deze progressieve waarden. $^{224}$

Van Walsum stelt eveneens dat de 'cacophony of contested norms' van de jaren zeventig en tachtig in de loop van de jaren negentig plaats had gemaakt voor een herkenbare en coherente nationale identiteit, die zij typeert als 'seculier individualisme'. Zij constateert bovendien dat die nieuwe collectieve norm werd gecontrasteerd met de waarden en gebruiken van niet-westerse migranten, met name moslims. ${ }^{225}$ Identiteit is relationeel: je weet wie je bent als je weet wie je niet bent: wie 'de Ander' is. ${ }^{226}$ Eind jaren negentig was de moslim-bevolking in Nederland die 'Ander' geworden. Juist de opvattingen die moslims geacht werden niet te delen, werden als kernwaarden van de Nederlandse identiteit gedefinieerd. De intieme leefsfeer - gezin, huwelijk, seksualiteit, verhouding tussen man en vrouw - speelde daarin een cruciale rol. ${ }^{227}$ In de dominante beeldvorming waren Islamitische culturen patriarchaal en vrouwonvriendelijk, in tegenstelling tot de Nederlandse of 'westerse' cultuur waarin gelijkheid van man en vrouw en een vrijzinnige kijk op gezin, huwelijk en seksualiteit voorop zouden staan. ${ }^{228}$ Niet voor niets vormden juist zaken als eerwraak, huiselijk geweld, gedwongen huwelijken, vrouwenbesnijdenis, kinderontvoeringen en boerka's aanleiding voor felle debatten. De aanwezigheid van grote aantallen 'niet-westerse' mensen, wier opvattingen en gebruiken zo wezenlijk afweken van de Nederlandse, werd in toenemende mate als problematisch en zelfs als een bedreiging van de Nederlandse identiteit ervaren.

Deze tendensen deden zich in de loop van de jaren negentig steeds sterker voelen, maar vonden nauwelijks weerklank in politiek en beleid, waar

224 Duyvendak 2004: 5-6, 11-12, 14.

225 Van Walsum 2008: 201-202, 205-206, 209-210, 212.

226 Vgl. Hall 1997: 234-238; zie ook Bauman (1992: 678-679), wiens interpretatie mijns inziens echter al te negatief en ongenuanceerd is: hij spreekt van 'we-talks', waarbij de wereld wordt verdeeld in 'vrienden' en 'vijanden'.

227 Vgl. Stoler 2002: 32-78, 112-139.

228 Saharso 1995: 244-245; 2002: 36-37; Roggeband \& Verloo 2006: 158, 165, 167-170, 172-

173; Lutz 1991: 5-28; Van Walsum 2004a: 124-125; Van Walsum 2008: 209-210. 
het pragmatisme van Paars overheerste. ${ }^{229}$ Achteraf zou je kunnen stellen dat de Paarse kabinetten onder Kok op deze gevoelens van onzekerheid en onveiligheid omtrent de Nederlandse identiteit en het sturingsvermogen van de overheid geen antwoord hadden. Beleid en vertoog van de Paarse kabinetten waren pragmatisch, gericht op het oplossen van sociaal-economische problemen: er was weinig ruimte voor thema's als identiteit, gemeenschap en collectieve zingeving. In de jaren negentig leek de tijd van fundamentele ideologische botsingen tussen politieke partijen voorbij. ${ }^{230}$ Van Doorn schreef in 1996 dat de 'ontideologisering' en 'professionalisering en verwetenschappelijking' van de politiek, waarin 'utopieën' en 'idealen' waren vervangen door 'technocratie' en 'beleid', onomkeerbare processen waren: 'In een gecompliceerde samenleving als de onze (...) kan politiek geen groots en meeslepend avontuur meer zijn'. ${ }^{231}$ Ook Schnabel constateert achteraf, en met veel ironie - dat onder Paars toekomstvisie en politiek debat overbodig leken: waar het op aankwam, was 'goed management' ${ }^{232}$ Typerend voor de pragmatische benadering van Paars was de nadruk die in de jaren negentig werd gelegd op verbetering van de sociaal-economische positie van migranten in de Nederlandse samenleving, waarbij culturele identiteit als een privé-zaak werd gezien waar de overheid zich niet mee diende te bemoeien. Dit bood een opening voor kritiek van publicisten als Scheffer en politici als Fortuyn.

\section{Scheffer, 9-11 en Fortuyn}

In 2000 schreef publicist en PvdA-lid Paul Scheffer in het NRC Handelsblad dat zich in Nederland een 'multicultureel drama' voltrok. Cultureel relativisme was ontaard in morele onverschilligheid: de politiek moest de Nederlandse identiteit veel krachtiger op de voorgrond plaatsen en minderheden door onderwijs in Nederlandse taal, maatschappij en geschiedenis een 'beschavingsoffensief' - deelgenoot maken van die identiteit. ${ }^{233}$ Negen jaar eerder had Bolkestein reeds aandacht gevraagd voor de spanning

229 Roggeband en Vliegenthart (2007: 530-536) observeren in de tweede helft van de jaren negentig een aanmerkelijk verschil tussen de termen waarin het debat over integratie enerzijds in de media en anderzijds in de politiek werd gevoerd. In de pers ging het primair over de plaats van de Islam in de Nederlandse samenleving; in Kamer en kabinet vooral over participatie op de arbeidsmarkt als sleutel tot emancipatie.

230 Voerman \& Lucardie 1992: 39.

231 Van Doorn 1996a 50-51.

232 Schnabel 2004: 6.

233 Prins 2004: 36-38; Scholten 2007: 215-216; Entzinger 2005: 128. 
tussen de 'westerse' kernwaarden en de normen en gebruiken van migranten uit islamitische landen, en gepleit voor een krachtig hooghouden van de Nederlandse grondbeginselen. Begin jaren negentig vond zijn pleidooi echter nog geen weerklank in het politiek debat. Het opiniestuk van Scheffer deed in 2000 veel stof opwaaien, maar leidde er evenmin direct toe dat de Nederlandse politiek haar bakens verzette.

Op 11 september 2001 boorden extremistische moslims echter twee vliegtuigen in het World Trade Center in New York, en één in het Pentagon in Washington. Deze terroristische aanslagen werden geïnterpreteerd als een aanval op de fundamentele normen en waarden van 'het Westen' en leken daarmee Hungtinton's these over de 'clash of civilisations' een geheel nieuwe relevantie te geven. Ook in Nederland werd 9-11 opgevat als een "aanval op "ons"'. Groot was dan ook de schok toen eind september uit verschillende opiniepeilingen bleek, dat een ruime meerderheid van de Nederlandse moslims begrip kon opbrengen voor de aanslagen. Daarmee gaapte plotseling ook een fundamentele culturele kloof midden in de Nederlandse samenleving. Niet alleen door commentatoren in de pers maar ook door premier Kok en minister Van Boxtel werd de goedkeuring van de aanslagen door moslims in Nederland beschouwd als een teken dat hun integratie schrikbarend faalde. ${ }^{234}$ Zelfs binnen het Paarse kabinet werd integratie niet langer in sociaal-economische termen gedefinieerd: plotseling stond het waardepatroon voorop.

Enkele maanden later maakte Pim Fortuyn zijn stormachtige entree in de Nederlandse politiek. In eerste instantie als lijsttrekker van Leefbaar Nederland, later als leider van zijn eigen Lijst Pim Fortuyn (LPF), werd hij in minder dan een jaar bijzonder populair door zich nadrukkelijk te presenteren als een nieuw soort politicus, die anders dan het politieke 'establishment' wel begreep wat er onder de mensen leefde. ${ }^{235}$ Hij wierp zich op als spreekbuis voor dat deel van de bevolking wiens onvrede, zorgen en angsten door de Paarse kabinetten niet werden erkend, laat staan verzacht. Geen onderwerp leende zich zo goed om het falen van de politieke elite aan te tonen als het migratie- en integratievraagstuk. Fortuyn zette zich krachtig af tegen de 'politiek correcte taboes' die Nederlandse politici zichzelf en hun kiezers oplegden, door over de Islam te spreken als een 'achterlijke cultuur', door te suggereren dat het beginsel van non-discriminatie uit de

234 Fennema 2002: 230, 236-238.

235 Prins 2004: 42-43; Wansink 2004: 131-147; Lucardie 2003: 188-192. 
grondwet kon worden geschrapt en door Nederland 'vol' te noemen. ${ }^{236} \mathrm{De}$ superioriteit van de Nederlandse waarden, juist op het gebied van scheiding van kerk en staat, vrouwenemancipatie, en seksualiteit stond voor Fortuyn, die van zijn homoseksualiteit geen geheim maakte, buiten kijf. Om die Nederlandse verworvenheden te behouden moest een rem worden gezet op de uitholling van de nationale soevereiniteit door Europese integratie, en op de bedreiging van de nationale identiteit door 'islamisering' van de samenleving. ${ }^{237}$

Met dit programma waarin kritiek op het politiek establishment, nadrukkelijke herwaardering van de Nederlandse identiteit en een uitgesproken harde lijn inzake migratie en integratie samensmolten, boekte Fortuyn een spectaculair succes in de gemeenteraadsverkiezingen in Rotterdam, waar Leefbaar Nederland in maart 2002 van 17 naar 45 zetels steeg en daarmee de grootste partij werd. ${ }^{238}$ Op 6 mei werd Pim Fortuyn vermoord door een extremistische milieu-activist. In de landelijke verkiezingen, negen dagen later, behaalde de LPF 26 zetels, en werd daarmee vanuit het niets de tweede grootste partij in de Tweede Kamer. Samen met CDA en VVD vormde de LPF het eerste kabinet Balkenende, dat door conflicten binnen de LPF echter niet langer dan 86 dagen aan de macht bleef. In de verkiezingen van 2003 kreeg de LPF nog maar 8 Kamerzetels en drie jaar later verdween de LPF uit de Kamer.

Het electorale succes van Fortuyn kan alleen worden begrepen tegen de achtergrond van een gevoel van crisis rond de nationale identiteit dat in de jaren negentig allengs toenam en van groeiende onvrede over het 'einde van de politiek' dat de Paarse kabinetten leken in te luiden. Juist daarom betekende de politieke mislukking van de LPF geenszins dat aan de invloed van de standpunten van Fortuyn op de Nederlandse politiek een einde kwam. De Fortuyn-revolte werd geïnterpreteerd als een motie van wantrouwen tegen het hele politieke bestel: er was een gapende kloof tussen politiek en burger blootgelegd. Door de manier waarop Fortuyn het migratie- en integratievraagstuk had verbonden niet alleen met kwesties rond nationale identiteit, maar ook met fundamentele vragen omtrent de representativiteit en legitimiteit van de Nederlandse politiek, behield dit vraagstuk ook na 2003 een ongekende politieke urgentie.

236 Interview met Fortuyn in de Volkskrant, 9 februari 2002. Annex in Wansink 2004: 285-293.

237 Prins 2004: 42.

238 Wansink 2004: 137-138. 


\section{De Nederlandse politiek en het migratie- en integratievraagstuk na de Fortuyn-revolte}

Aangezien migratie en integratie sleutelthema's waren geweest in de Fortuyn-revolte, werd dit ook bij uitstek het beleidsveld waarop de grote politieke partijen vanaf 2002 het vertrouwen van de kiezers probeerden te herwinnen. Voortaan moest alles anders.

In de eerste plaats werd nadrukkelijk afstand genomen van de depolitiserende stijl, die zo lang kenmerkend was geweest voor de omgang van Nederlandse politici met het migrantenvraagstuk. De vrees om xenofobe tendensen in de samenleving te voeden maakte plaats voor de wens om te laten zien dat de onvrede die klaarblijkelijk onder de bevolking leefde door de politiek werd erkend en serieus genomen. ${ }^{239}$ Het Verwey-Jonker Instituut spreekt in dezen van de 'articulatiefunctie' van de politiek..$^{240}$

In de tweede plaats werd, in tegenstelling tot de nadruk die in de jaren negentig op sociaal-economische aspecten als arbeid, onderwijs en huisvesting werd gelegd, integratie nu primair in culturele termen gedefinieerd. Scholten typeert deze ontwikkeling als een verschuiving van een 'universalistisch' naar een meer 'assimilationistisch' beleidsperspectief. ${ }^{241}$ Waar integratie voorheen als een achterstandsprobleem werd beschouwd en daarmee in de eerste plaats als een probleem van de migranten zelf, werd het nu een probleem van de samenleving als geheel. ${ }^{242} \mathrm{Te}$ veel culturele diversiteit zou de maatschappelijke samenhang kunnen ondermijnen. Het was daarom van groot belang gemeenschappelijke normen en waarden te benadrukken, en van nieuwkomers te vragen zich daaraan aan te passen. ${ }^{243}$ Typerend voor dit nieuwe dominante perspectief is de volgende passage uit het Regeerakkoord van het eerste kabinet Balkenende:

De integratie van veel immigranten verloopt moeizaam. Verschillen in etnische afkomst, leefgewoonten en gebruiken belasten de dagelijkse

239 Penninx 2006: 21; Scholten 2007: 231, 240.

240 Verwey-Jonker Instituut 2004: 201.

241 Scholten 2007: 86. Zie ook Entzinger 2005: 130. Deze Nederlandse verschuiving in integratiedebat en -beleid lijkt te passen in een bredere Europese tendens. Zowel Kofman als Joppke observeren een 'retreat from multiculturalism' in Europa. Waar Kofman (2005: 454) echter meent dat het multiculturalisme plaats maakt voor 'neo-assimilationist agendas', stelt Joppke (2004: 254) juist dat afstand wordt genomen van assimilationisme, ten faveure van een smal 'procedural commitment to liberal-democratic principles'.

242 Snel 2003: 13-14.

243 Bruquetas-Callejo e.a. 2006: 20; Scholten 2007: 86-88. 
omgang en het naast elkaar wonen, werken en leven. Verschillen in etnische afkomst gaan bovendien steeds meer samenvallen met verschillen in opleiding, arbeidsdeelname en ook betrokkenheid bij criminaliteit. Het zet middelpuntvliedende krachten in de samenleving aan en leidt tot fysieke, sociale en geestelijke scheiding van bevolkingsgroepen. Isolement leidt tot onbegrip, vervolgens tot wederzijdse afkeer en uiteindelijk tot steeds scherpere tegenstellingen.

Culturele verschillen werden gedefinieerd als 'middelpuntvliedende krachten' die dienden te worden gekeerd door 'te mobiliseren wat de samenleving bindt' ${ }^{244}$ Volgens het tweede kabinet Balkenende omvatte die gemeenschappelijke norm niet alleen respect voor wet- en regelgeving maar ook streven naar financiële zelfstandigheid en

zorg dragen voor de eigen omgeving, het respecteren van de lichamelijke integriteit van anderen, ook in een huwelijk, de aanvaarding van het recht van eenieder om zijn eigen mening te uiten, het accepteren van de seksuele voorkeuren van anderen, de gelijkheid van vrouwen en mannen. ${ }^{245}$

Aan sekseverhoudingen, huwelijk en seksualiteit werd een centrale plaats toegekend in het collectief waardepatroon.

In hun streven naar herstel van legitimiteit kozen politici ten slotte niet alleen voor klare taal, maar ook voor ferme actie. Zo werden niet alleen nieuwkomers maar ook 'oudkomers' verplicht om een inburgeringscursus te volgen, die de deelnemer voortaan zelf zou moeten betalen. ${ }^{246}$ Het integratiebeleid, dat al twee decennia door Binnenlandse Zaken werd gecoordineerd, verhuisde naar het ministerie van Justitie, onder een nieuwe minister van Vreemdelingenzaken en Integratie (VZI). Scholten en Timmermans interpreteren dit als 'een duidelijke uiting van de overgang naar een 'law and order'-benadering waarin de normen voor integratie worden aangescherpt' ${ }^{247}$ Ook in het vreemdelingenbeleid werd gekozen voor een restrictieve lijn. De aanscherpingen betroffen in de eerste plaats het gezinsmigratiebeleid, want:

244 TK 2001-2002 28375 (5): 15-16.

245 тK 2003-2004 29203 (1): 8-9.

246 Entzinger 2005: 131; Scholten 2007: 86-87.

247 Scholten \& Timmermans 2004: 19. 
Om integratie een kans van slagen te geven dient de toelating van vreemdelingen die bijdragen aan de integratieproblematiek zo veel mogelijk te worden beperkt. Dat het overgrote deel van de jongeren (ongeveer $75 \%$ ) uit twee van de drie grootste migrantengroepen een partner uit het land van herkomst laat overkomen baart in dat verband zorg. ${ }^{248}$

Huwelijksmigranten vormden in de ogen van het kabinet dus de meest problematische migratiecategorie.

\subsection{De nadagen van Paars: integratievereisten voor huwelijks- migranten?}

In de laatste maanden van de regeertermijn van het tweede Paarse kabinet vond een debat plaats, dat een voorloper was van de hervormingen die na de Fortuyn-revolte door het kabinet Balkenende zouden worden doorgevoerd. Er werden aanvullende eisen voor gezinsvorming geopperd en er werd overwogen om het toelatingsbeleid direct te koppelen aan het integratiebeleid. In de verantwoording van die voorstellen door de regering werd nadrukkelijk gerefereerd aan de 'afwijkende' huwelijkspraktijken van migranten, met name wanneer gekozen werd voor een partner uit het land van herkomst. Daarmee tekende zich een breuk af met de beleidsdebatten in de jaren negentig, toen culturele waarden en gebruiken in het vertoog van de regering over gezinsmigratie nog geen enkele rol speelden.

Dit was niet helemaal nieuw. Al sinds de vroege jaren tachtig werd immigratie van huwelijkspartners van kinderen van migranten in beleidskringen als een zorgwekkende vorm van gezinsmigratie beschouwd, omdat dergelijke 'ketenmigratie' in potentie oneindig was en omdat ze niet alleen als een indicatie van onvoldoende integratie van jonge migranten in Nederland maar ook als een bron van nieuwe integratieproblemen werd beschouwd. In 1983 had de regering daarom besloten om bij gezinsvorming door tweede generatie migranten een strenge inkomenseis aan te houden, maar die '1445-maatregel' was al na anderhalf jaar ingetrokken vanwege politiek en publiek protest. ${ }^{249}$ In 1993 waren voor gezinsvorming een minimumleeftijd van 18 jaar en een minimumverblijfstermijn van drie jaar ingevoerd, maar verder waren de voorwaarden voor gezinsvorming en gezinshereniging gelijk.

248 TK 2001-2002 28375: 16.

249 Zie paragraaf 3.8 . 
Ook het vermengen van de instrumenten van het integratiebeleid en die van het vreemdelingenbeleid was eerder overwogen. Zo was in de voorbereiding van de hervorming van 1993 geopperd om kinderen tussen 12 en 18 jaar een integratiecursus te laten volgen in hun land van herkomst, voordat zij naar Nederland mochten komen om zich bij hun ouders te voegen. Dat voorstel was toen afgeketst op praktische bezwaren. ${ }^{250}$ In 2000 had een ruime Kamermeerderheid van PvdA, CDA, D66 en VvD voorgesteld om alleen nog een permanente verblijfsvergunning te verlenen aan vreemdelingen die de inburgeringscursus volledig hadden afgerond. Staatssecretaris Cohen reageerde toen niet ronduit afwijzend, maar wel terughoudend op dit voorstel. ${ }^{251}$ Tot 2002 bleven het integratiebeleid en het vreemdelingenbeleid institutioneel strikt gescheiden.

In de herfst van 2001 initieerden Roger van Boxtel (D66), minister van Grote Steden en Integratiebeleid (GSI) en zijn ambtenaren een beleidsdebat over het Nederlands gezinsmigratiebeleid. Dat debat vond plaats in de nasleep van de aanslagen van 11 september, tegen de achtergrond van een publiek debat over de positie van migranten in de Nederlandse samenleving dat met de dag scherper van toon werd. In zijn zoektocht naar een antwoord op deze groeiende publieke onrust kwam GSI met voorstellen om het gezinsvormingsbeleid aan te scherpen. ${ }^{252}$ Die voorstellen zouden GSI in direct conflict brengen met het ministerie van Justitie.

\section{Het voorstel van GSI: een inburgeringsbijdrage bij gezinsvorming}

In de Nota Integratie in het perspectief van immigratie, die in januari 2002 aan de Kamer werd gepresenteerd, zette Van Boxtel uiteen waarom hij hervorming van het gezinsvormingsbeleid wenselijk achtte. In zijn ogen was gezinsvorming een bijzonder problematische migratiecategorie, omdat zich daarbij ernstige integratieproblemen zouden voordoen, niet alleen voor de buitenlandse maar ook voor de Nederlandse partner en voor toekomstige kinderen. ${ }^{253}$ Aangezien gezinsmigranten 'niet op grond van hun arbeidspotentie' werden toegelaten, was de 'economische bijdrage die zij kunnen

250 Zie paragraaf 4.4 .

251 TK 1999-2000 26732 (9): 29-31, 61; TK 1999-2000 26732 (42); тK 1999-2000 26732 (77);тK 1999-2000 Handelingen 8 juni 2000: 5506, 5524, 5534; Handelingen 14 juni 2000: 5547.

252 Nota Directie Jeugd en Criminaliteitspreventie (DJC) aan staatssecretaris, 12 december 2001. MJ A99/5253; тK 2001-2002 28198 (2): 4, 7.

253 Nota DVB aan staatssecretaris, 20 november 2001. MJ A99/5253; TK 2001-2002 29198 (2): 13-14. 
leveren ongewis'. Bovendien kwam huwelijksmigratie 'met name voor bij nietwesterse migranten' en 'naarmate de afstand tot de westerse cultuur groter' was zou het integratieproces langer duren en meer kosten met zich mee brengen. Met andere woorden, 'gezinsvorming (...) brengt toekomstige partners naar ons land wiens integratieperspectief vaak problematisch is'. Daarbij werd huwelijksmigratie niet alleen beschouwd als oorzaak, maar ook als gevolg van gebrekkige integratie, namelijk van 'het afwijzen van normen en waarden die in Nederland heersen, beperkt contact tussen autochtonen en allochtonen, de sociale controle van de omgeving, en een traditie die in de familie of het geloof is verankerd'. ${ }^{254}$ Dit alles was bijzonder verontrustend, omdat het om significante aantallen migranten ging: eind jaren negentig maakte gezinsmigratie $45 \%$ van de totale immigratiestroom uit en de helft daarvan bestond uit huwelijksmigranten. ${ }^{255}$ Dat GSI ondanks al deze bezwaren zocht naar een genuanceerde respons, blijkt uit de principiële stellingname dat 'het recht op gezinsleven (...) een fundamenteel recht' is en dat 'iedere ingezetene van Nederland in de gelegenheid moet zijn in gezinsverband te leven'. 256

In eerste instantie hadden minister Van Boxtel en zijn ambtenaren van het Directoraat Coördinatie Integratiebeleid Minderheden (DCIM) overwogen om deze problematiek het hoofd te bieden door het inkomensvereiste aan te scherpen. Later opperden zij om de wachttijd te verlengen of inburgeringseisen te stellen. ${ }^{257}$ Uiteindelijk viel de keus echter op een voorstel dat uit onverwachte hoek werd aangereikt. Het Nederlands Centrum Buitenlanders ( $\mathrm{NCB}$ ) had in de media vernomen dat Van Boxtel van zins was de voorwaarden voor gezinsvorming aan te scherpen. Het $\mathrm{NCB}$ vond dat iedere inwoner van Nederland vrij van enige overheidsbemoeienis een partner moest kunnen kiezen, in binnen- of buitenland, en kwam daarom met een tegenvoorstel, waarin de 'consistente aanpak van de integratie van nieuwkomers' voorop stond, in plaats van het 'belemmeren' van gezinsmigratie. Het NCB opperde om de Nederlandse partner in de verantwoordelijkheid voor de integratie te laten delen, door hem of haar vooraf de helft van de kosten van het inburgeringstraject te laten betalen. De buitenlandse partner zou pas een verblijfsvergunning krijgen, als de Nederlandse partner een

254 Vgl. Orobio de Castro 2003: 60-63.

255 TK 2001-2002 29198 (2): 13-14, 45-46.

256 тK 2001-2002 29198 (2): 45.

257 Nota hoofd DVB aan staatssecretaris, 21 november 2001; Nota hoofd DVB aan SG, 18 december 2001. MJ A99/5253. 
betalingsbewijs kon overleggen. ${ }^{258}$ Minister Van Boxtel vond het voorstel van het NCB 'interessant' en besloot het als 'vertrekpunt' te nemen voor 'te treffen maatregelen'. 259

De kosten van een individueel inburgeringstraject, dat uit Nederlandse les en maatschappelijke introductie bestond, bedroegen ruim 6000 euro. ${ }^{260}$ Sinds de invoering van het verplichte inburgeringstraject met de Wet Inburgering Nieuwkomers (WIN) in 1998 nam de overheid die kosten volledig op zich. Het is zeer de vraag of het NCB zich rekenschap heeft gegeven van het bedrag dat met zijn voorstel was gemoeid. Immers, een nieuwe financiële drempel van maar liefst 3000 euro zou voor menigeen wel degelijk een 'belemmering' kunnen vormen voor de overkomst van de huwelijkspartner. $^{261}$

\section{De bezwaren van Justitie}

Van het begin van het interdepartementaal overleg over herziening van het gezinsvormingsbeleid in de herfst van 2001 tot de presentatie aan de Kamer van het beleidsvoorstel in de lente van 2002 heeft Justitie zich fel verzet tegen de voorstellen van minister Van Boxtel en zijn ambtenaren. Die weerstand gold zowel de ambtenaren van de Directie Vreemdelingenbeleid (DVB) als hun bewindslid, staatssecretaris Ella Kalsbeek (PVdA) van Justitie.

Alleen al het feit dat GSI zich met zijn voorstellen zo ver op het terrein van het vreemdelingenbeleid begaf wekte de nodige irritatie op. Het hoofd DVB vroeg zich af "welke waarde moet worden gehecht aan de opmerking (...) dat de coördinerend minister voor integratie "geen inhoudelijke verantwoordelijkheid overneemt van zijn collegae"., ${ }^{262}$ Naast deze competentiestrijd liepen de meningen echter ook inhoudelijk ver uiteen.

258 Brief directeur NCB aan minister van GSI, 13 december 2001. MJ A99/5253. Zie ook interview met Ilhan Akel, directeur NCB, in Het importhuwelijk, aflevering Zembla 14 december 2001: www.zembla.vara.nl. Naar deze uitzending werd door minister Van Boxtel in zijn Nota aan de Kamer, en door CDA-woordvoerder Wijn in zijn debat met Kalsbeek expliciet verwezen.

259 Nota's DVB aan staatssecretaris, 18 december 2001 en 15 januari 2002. MJ A99/5253; TK 2001-2002 28198 (2): 46.

260 Nota hoofd DVB aan staatssecretaris, 27 februari 2002. MJ A99/5253.

261 In de laatste alinea's van zijn brief stelde het NCB wel voor om de inburgeringsbijdrage inkomensafhankelijk en fiscaal aftrekbaar te maken. Die aspecten van het NCB-voorstel zijn in het ambtelijke en politieke debat echter genegeerd.

262 Nota hoofd DVB aan staatssecretaris, 21 november 2001. MJ A99/5253. 
Binnen Justitie bestond überhaupt niet de behoefte om het gezinsmigratiebeleid te herzien. De voorwaarden waren met de Vreemdelingenwet 2000 nog aangescherpt en DVB zag 'geen enkele aanleiding om op dit moment die discussie opnieuw te gaan voeren' ${ }^{263}$ Daarbij kwam dat geen enkele andere Europese lidstaat eisen stelde die vergelijkbaar waren met de inburgeringsbijdrage. Justitie was bang dat Nederland daardoor in een moeilijke positie zou komen in de onderhandelingen over de Europese gezinsherenigingsrichtlijn, die op dat moment in volle gang waren. ${ }^{264}$

Bovendien leefden bij ambtelijk Justitie ernstige principiële bezwaren tegen verdere aanscherping van het gezinsvormingsbeleid. Het hoofd DVB verwees naar een recent rapport van de WRR, waarin werd opgemerkt dat het stellen van nog scherpere eisen aan gezinsmigratie niet zou passen in een rechtsstaat. ${ }^{265}$ Het invoeren van integratievereisten voor de binnenkomende partner, zoals dat in een vroeg stadium door GSI werd overwogen, verwierpen de ambtenaren van DVB als een inbreuk op de 'vrijheid van partnerkeuze' en het 'recht op gezinsvorming'. Alleen aan de Nederlandse partner mochten eisen worden gesteld. ${ }^{266}$ De inburgeringsbijdrage zoals die door het NCB werd voorgesteld zou 'de facto een verzwaring' van de toelatingsvoorwaarden betekenen en kon 'dan ook niet anders uitwerken dan als een verkapte maatregel om de toelating van vreemdelingen tot Nederland te belemmeren' ${ }^{267}$ DVB erkende dat de introductie van een inburgeringsbijdrage juridisch toelaatbaar was, zoals de ambtenaren van DCIM hadden benadrukt: artikel 8 EVRM legde alleen een verplichting tot toelating van huwelijkspartners op, indien uitoefening van het gezinsleven in het land van herkomst onmogelijk was. Desalniettemin vond ambtelijk Justitie het stellen van een dergelijke eis principieel onjuist. Er zou wel degelijk sprake zijn van discriminatie, aangezien gezinsvorming voor 'minder draagkrachtige personen' 'vrijwel illusoir' zou worden. ${ }^{268}$ Een financiële eis van enkele duizenden euro's, die 'alleen toegang [gaf] tot een overheidsvoorziening',

263 Nota hoofd DVB aan staatssecretaris, 21 november 2001. MJ A99/5253.

264 Nota DVB aan staatssecretaris, 15 januari 2002. MJ A99/5253. Zie paragraaf 4.12.

265 Het hoofd DVB verwijst hier naar WRR 2001: 225.

266 Nota hoofd DVB aan SG, december 2001. MJ A99/5253. Voor de binnenkomende partner gold dat hij of zij geen gevaar mocht opleveren voor de openbare orde: nadere voorwaarden mochten volgens DVB niet worden gesteld.

267 Nota's DVB aan staatssecretaris, 15 januari en 27 februari 2002. MJ A99/5253.

268 Datzelfde bezwaar zou natuurlijk ook tegen het inkomensvereiste kunnen worden ingebracht. Het hoofd DVB vond die vergelijking echter volstrekt niet op zijn plaats, omdat daar slechts het algemene principe werd toegepast dat een vreemdeling niet ten laste mocht komen van de openbare kas. Hoe dit punt van kritiek zich verhoudt tot de legeskosten, die per 1 april 2002 werden vervijfvoudigd, liet het hoofd DVB in het midden. 
vormde in de ogen van DVB een inbreuk op de vrijheid van partnerkeuze. ${ }^{269}$ Staatssecretaris Kalsbeek vond het opwerpen van een wellicht onoverkomelijke financiële drempel voor gezinsvorming eveneens nauwelijks verdedigbaar. ${ }^{270}$

Een laatste bezwaar ten slotte betrof het samenvoegen van integratie- en immigratievereisten. Het hoofd DVB schreef: 'Ik heb (...) zeer veel moeite met de redenering dat de mogelijkheden voor immigratie moeten worden beperkt, wanneer de integratie problematisch verloopt' ${ }^{271}$ Integratieproblemen bij gezinsvorming moesten worden opgelost met integratiemaatregelen, niet via het vreemdelingenbeleid. DVB zag nog voldoende mogelijkheden om het inburgeringsbeleid te verbeteren, bijvoorbeeld door 'daadwerkelijke toepassing van sancties' en door minder vaak ontheffing te verlenen van de inburgeringsplicht, vooral aan moeders met kleine kinderen. Met andere woorden: GSI moest eerst maar eens in eigen huis orde op zaken stellen, voordat het met allerlei restrictieve voorstellen voor het vreemdelingenbeleid kwam. De ambtenaren van DVB hadden geen onoverkomelijk bezwaar tegen een borgsom voor het inburgeringstraject van een buitenlandse partner. Zij waren er echter pertinent op tegen dat de inburgeringsbijdrage als voorwaarde voor toelating in het vreemdelingenbeleid zou worden opgenomen. ${ }^{272}$ Staatssecretaris Kalsbeek was het hier volkomen mee eens: zowel in communicatie met haar ambtenaren als in de Tweede Kamer gaf zij te kennen het 'geen goed idee' te vinden om toelatingseisen en inburgeringseisen 'door elkaar te klutsen'. ${ }^{273}$

Deze stellingname van niet alleen de staatssecretaris maar ook de ambtenaren van Justitie is opmerkelijk. Sinds de jaren vijftig hadden de ambtenaren die verantwoordelijkheid droegen voor het vreemdelingenbeleid steeds blijk gegeven van een restrictieve taakopvatting. Zij beschouwden het als hun opdracht de instroom van vreemdelingen binnen de perken te houden en streefden steeds naar behoud of uitbreiding van middelen om die opdracht te kunnen uitvoeren. Het was niet eerder voorgekomen dat Justitie ambtenaren afwijzend reageerden op een voorstel om de voorwaarden voor

269 Nota hoofd DVB aan staatssecretaris, 27 februari 2002. MJ A99/5253.

270 Gespreksnotitie bewindsliedenoverleg 1 maart 2002, met handgeschreven aantekeningen van de staatssecretaris. MJ A99/5253; TK 2001-2002 Handelingen 18 december 2001:2740.

271 Nota hoofd DVB aan staatssecretaris, 16 november 2001. MJ A99/5253.

272 Nota's hoofd DVB aan staatssecretaris, 20 november 2001 en 27 februari 2002. MJ A99/5253.

273 тK 2001-2002 Handelingen 18 december 2001: 2739; Nota hoofd DVB aan staatssecretaris, 14 februari 2002; Gespreksnotitie bewindsliedenoverleg 1 maart 2002; beide met aantekeningen van de staatssecretaris. MJ A99/5253. 
toelating en verblijf aan te scherpen. Waarschijnlijk speelde weerzin tegen bemoeienis van buiten met 'hun' vreemdelingenbeleid een belangrijke rol. Het verzet van Justitie was echter ook sterk inhoudelijk: er werd weliswaar geen juridische, maar wel een principiële grens overschreden. De wens van GSI om tegemoet te komen aan stijgende onvrede vanuit de samenleving, woog voor Justitie niet op tegen die principes.

\section{Justitie weggestemd}

In de Tweede Kamer werd het voorstel van minister Van Boxtel om een inburgeringsbijdrage te introduceren goed ontvangen. Nog voor de hervorming formeel aan het parlement was voorgelegd riep CDA-Kamerlid Wijn staatsscretaris Kalsbeek al naar de Kamer, omdat hij uit berichten in de pers had begrepen dat zij huwelijksmigratie minder 'stevig wil aanpakken' dan de minister van GSI. Wijn was het hartgrondig met Van Boxtel eens, dat de keuze van veel Turken en Marokkanen in Nederland voor een buitenlandse partner bijzonder problematisch was. ${ }^{274}$ Hij had de stellige indruk dat er hierbij nogal eens economische motieven in het spel waren. In zijn ogen ging het dus om schijnhuwelijken, met als resultaat 'veel ongelukkige levens en (...) een bovengemiddeld aantal scheidingen, al dan niet na huiselijk geweld'. Wijn wilde 'dit soort huwelijken, dat niet echt met liefde te maken heeft, (...) voorkomen'. Het CDA werd bijgevallen door VVD-woordvoerder Kamp, die het 'merkwaardig' vond dat zoveel migranten hun partner in het land van herkomst vonden in plaats van in hun eigen omgeving. In zijn ogen werd het gezinsvormingsbeleid 'misbruikt' om iemand uit het dorp of de familie naar Nederland te laten komen. ${ }^{275}$

In dit vertoog van CDA en VVD zien we hoe problematisering van de huwelijkspraktijken van Nederlandse Turken en Marokkanen als basis dient voor een pleidooi voor een restrictiever toelatingsbeleid. Deze problematisering is sterk normatief geladen: het beeld dat wordt neergezet is dat van gearrangeerde huwelijken, die strijdig zijn met de norm van het huwelijk als een individuele keus op romantische gronden en juist daarom vaak uitmonden in geweld tegen vrouwen. Huwelijken die niet voldoen aan die - Nederlandse norm zijn 'schijnhuwelijken' en moeten worden 'voorkomen'.

274 Uit het feit dat Wijn het expliciet heeft over partners van Turken en Marokkanen blijkt al dat er iets wezenlijks aan het veranderen is in de politieke omgang met het migratievraagstuk: tot dan toe verkozen politici veelal algemene termen als 'culturele minderheden', uit onwil om specifieke bevolkingsgroepen te stigmatiseren.

275 TK Handelingen 18 december 2001: 2737-2740. 
In haar antwoord koos staatssecretaris Kalsbeek een in normatieve zin meer neutrale lijn. Zij erkende de 'tragiek' van ‘jonge Nederlandse meiden, vaak van Turkse of Marokkaanse afkomst', die in hun hoop op een liefdevol huwelijk werden teleurgesteld. In juridische zin was van schijnhuwelijken echter geen sprake: bij beide partners bestond in de meeste gevallen de bedoeling om er een 'bestendige en duurzame relatie' van te maken. Zij zag dan ook geen reden om dergelijke huwelijken via het vreemdelingenbeleid te ontmoedigen. Kalsbeeks weigering om van de inburgeringsbijdrage een voorwaarde voor toelating te maken ontlokte felle kritiek, niet alleen aan CDA en VVD, maar ook aan D66. D66 had in 2000 al een motie geïnitieerd om pas een permanente verblijfsvergunning te verlenen wanneer de inburgeringscursus was afgerond en was nog steeds enthousiast voorstander van het koppelen van integratievereisten aan het verblijfsrecht. ${ }^{276}$ Wijn meende dat een succesvolle inburgering al bij toelating begon en dus in de Vreemdelingenwet geregeld moest worden: Kalsbeek mocht dat niet 'op het bordje van minister Van Boxtel gooien'. ${ }^{277}$

Ook in de ministerraad werd het voorstel van Van Boxtel positief ontvangen. ${ }^{278}$ Het protest van Justitie had in die zin enige invloed, dat waar GSI in eerste instantie aan een bijdrage van 5000 euro dacht, uiteindelijk voor een som van 3300 euro werd gekozen. ${ }^{279}$ Wellicht eveneens op aandringen van staatssecretaris Kalsbeek en haar ambtenaren opteerde Van Boxtel voor een borgsom: na voltooiing van het inburgeringsprogramma zou het bedrag worden teruggestort. Alle bezwaren van Justitie hadden echter niet kunnen voorkomen dat deze nieuwe financiële voorwaarde werd opgenomen in het vreemdelingenbeleid: in gevallen van gezinsvorming zou pas verblijf worden toegestaan nadat de Nederlandse partner 3300 euro had betaald. ${ }^{280}$

Vlak voordat de brief waarin Van Boxtel deze hervorming uiteenzette naar de Kamer werd gezonden vroeg een ambtenaar van Justitie nog aan zijn staatssecretaris of zij de brief mee zou willen ondertekenen, aangezien het ging om een wijziging van het Vreemdelingenbesluit die primair door Justitie zou moeten worden uitgevoerd. Staatssecretaris Kalsbeek had daar

276 TK 1999-2000 26732 (77).

277 TK 2001-2002 Handelingen 18 december 2001: 2737-2740.

278 Nota hoofd DVB aan staatssecretaris, 15 februari 2002. MJ A99/5253.

279 Nota hoofd DVB aan staatssecretaris, 27 februari 2002. MJ A99/5253; TK 2001-2002 28198

(4).

280 тк 2001-2002 28198 (4). 
naar eigen zeggen 'geen enkele behoefte aan!' ${ }^{281}$ Kalsbeek en haar ambtenaren bleven dus onvermurwbaar in hun afwijzing van de hervorming. Dit beleidsvoorstel werd tegen de zin van Justitie aan de Kamer voorgelegd.

Desalniettemin was een ruime meerderheid van de Kamer blij met het voorstel. De PvdA stelde wel de voorwaarde dat de borgsom bij een bank zou kunnen worden geleend en met rente teruggestort. Zij wilde zo zekerstellen dat de maatregel inderdaad alleen als een prikkel voor snelle integratie zou werken, en niet als een belemmering voor gezinsvorming. Alleen sP en Groenlinks wezen de invoering van de inburgeringsbijdrage af. Zij onderschreven het belang van snelle inburgering, zeker bij huwelijksmigratie, maar meenden dat het opwerpen van financiële drempels een ongeschikte en onrechtvaardige manier was om dat doel te bereiken. ${ }^{282}$

Ondanks deze brede politieke steun is de inburgeringsbijdrage nooit ingevoerd. Zes dagen nadat de Kamer over deze hervorming had gedebatteerd struikelde het kabinet Kok over de Srebrenica-affaire. Nog geen maand later werd Pim Fortuyn vermoord. Het eerste kabinet Balkenende dat in juli 2002 aantrad had geheel eigen plannen voor het gezinsmigratiebeleid. Het voorstel van Van Boxtel verdween geruisloos van de agenda.

Het debat liep dus met een sisser af, maar het maakt een drietal belangwekkende zaken zichtbaar. In de eerste plaats bleek een zeer brede meerderheid van de Nederlandse politici huwelijksmigranten als een inherent problematische categorie migranten te beschouwen, die moeilijk inpasbaar was in de Nederlandse samenleving. Voor het eerst werd een direct verband gelegd tussen het type migranten dat via gezinsmigratie naar Nederland kwam en de integratieproblematiek. ${ }^{283}$ Evenzeer nieuw was het samenvoegen van de tot dan toe gescheiden beleidsvelden van integratie en immigratie, dat eveneens brede politieke steun genoot. Dit beleidsdebat laat ten slotte zien dat de wending die het politieke debat over migratie en integratie aan het nemen was binnen het ministerie van Justitie op weerstand stuitte. Die weerstand was institutioneel van aard, niet ideologisch: de sociaaldemocraten in de Kamer deelden de bezwaren van hun partijgenoot Ella Kalsbeek immers niet. Kennelijk was het traditioneel sterk tot restrictie geneigde ministerie van Justitie 'rechts ingehaald', niet alleen door de publieke maar ook door de politieke opinie, en wellicht zelfs door de ambtenaren van

281 Nota hoofd DVB aan staatssecretaris, met aantekeningen staatssecretaris, 27 maart 2002. MJ A99/5253.

282 тк 2001-2002 28198 (5).

283 Dit gebeurde in de jaren tachtig ook, in het kader van discussies over de 1445-maatregel, maar in de jaren negentig niet meer. Zie paragraaf 3.8. 
DCIM die verantwoordelijkheid droegen voor het integratiebeleid en die in 1993 nog zo verontwaardigd hadden geprotesteerd tegen de inkomenseis van $70 \%$ van de bijstandsnorm. Wellicht is dit een vorm van institutionele padafhankelijkheid: een ambtelijke organisatie met een zo sterke institutionele traditie als de Directie Vreemdelingenbeleid van het ministerie van Justitie verandert minder snel van standpunt dan een politieke partij of de publieke opinie. Anders dan het publieke en politieke debat was het zware slagschip van Justitie door de ontwikkelingen in de wereld en in de maatschappij nauwelijks van zijn koers afgeslagen.

\subsection{Hervormingen onder het tweede kabinet Balkenende}

In 2002 kwam een einde aan acht jaar Paars bewind. CDA, LPF en VVD vormden samen het eerste kabinet Balkenende, dat echter na minder dan drie maanden alweer demissionair was. In 2003 trad het tweede kabinet Balkenende aan, waarin D66 de plaats van de LPF had ingenomen. Voor beide kabinetten was het aanscherpen van het gezinsmigratiebeleid een prioriteit. Daarbij speelde waarschijnlijk een rol, dat de Vreemdelingenwet 2000 haar effect op de asielinstroom niet had gemist. In 2000 werden nog ruim 43 duizend asielverzoeken ingediend: in 2001 waren dat er ruim 32 duizend, in 2002 bijna 19 duizend en in 2004 minder dan 10 duizend. ${ }^{284}$ De asielcrisis was voorbij en daarmee kwam ruimte voor politieke aandacht voor de gezinsmigratiestroom, die van 2001 tot 2004 rond de 32 duizend per jaar schommelde en ongeveer $40 \%$ van de totale immigratie naar Nederland uitmaakte. ${ }^{285}$

Bij de prioriteit die aan het gezinsmigratiebeleid werd toegekend speelde waarschijnlijk eveneens een rol, dat de Nederlandse politiek na de Fortuyn-revolte veel meer belang hechtte aan de sociaal-culturele dimensie van het migratie- en integratievraagstuk. In dit gewijzigd beleidsperspectief werd het voor het behoud van de maatschappelijke samenhang noodzakelijk geacht dat alle inwoners van Nederland een aantal fundamentele normen en waarden onderschreven. ${ }^{286}$ Cruciale elementen daarin waren individuele keuzevrijheid, gelijkheid van man en vrouw en een vrijzinnige kijk op seksualiteit, huwelijk en opvoeding. Omdat de huwelijkspraktijken

284 Website van het CBS, Asielverzoeken; Kerncijfers, statline.cbs.nl.

285 Website van het CBS, Immigratie naar migratiemotief, statline.cbs.nl.

286 Scholten 2007: 86-87. 
en gezinsverhoudingen van Turken en Marokkanen in Nederland met die waarden in strijd werden geacht, was het aanscherpen van het gezinsmigratiebeleid ook een manier om de sociale cohesie in Nederland te beschermen en om - in nauwe samenhang daarmee - de Nederlandse norm te markeren. ${ }^{287}$

De zorgen over de instroom van Marokkaanse en Turkse huwelijksmigranten en de maatschappelijke gevolgen van die instroom domineerden de debatten over het gezinsmigratiebeleid tussen 2002 en 2005 volledig. Daarbij was nauwelijks ruimte voor de erkenning, dat wellicht niet alle gezinnen en alle huwelijken van Turkse en Marokkaanse Nederlanders aan het patriarchale en vrouwonvriendelijke beeld voldoen. Er was nog minder ruimte voor het feit, dat gezinsmigranten uit Turkije en Marokko slechts een krappe $30 \%$ van de totale gezinsmigratie uitmaakten. Ruim $40 \%$ van de gezinsmigranten kwam uit Europa. De overige 30\% was uit de hele wereld afkomstig, van de vs, China of Indonesië tot Irak, Afghanistan, Thailand, Brazilië, Suriname of Japan. ${ }^{288}$

\section{Het probleem van gezinsmigratie volgens het tweede kabinet Balkenende}

In 2005 nam de Tweede Kamer de Wet Inburgering in het Buitenland (WIB) aan. Deze wet verplicht gezinsmigranten om aan te tonen dat zij over een basale kennis van de Nederlandse taal en maatschappij beschikken, alvorens zij toestemming krijgen om naar Nederland te komen. Daarnaast werden in 2004 de voorwaarden voor gezinsvorming aangescherpt: het inkomensvereiste werd verhoogd van $100 \%$ tot $120 \%$ van het minimumloon, de minimumleeftijd van 18 naar 21 jaar. Door deze hervormingen werd het Nederlands gezinsmigratiebeleid één van de meest restrictieve in de

287 Dit 'markeren van de norm' is wat Ringeling (1993: 247) de 'expressieve dimensie' van beleid noemt: het verdelen van symbolische waarden en tot uitdrukking brengen van overtuigingen door overheidsbeleid. Spijkerboer (2007: 49-50) constateert dat er in de Tweede Kamer consensus bestaat rondom een 'dikke' opvatting van de rol van de overheid: migranten moeten 'verlichte ideeën' worden bijgebracht en de 'publieke moraal', waarin de rol van de vrouw centraal staat, moet 'in de privé-sfeer van migranten (...) doordringen'.

288 Cijfers over 2003 en 2004 . Website van het CBS, Immigratie naar migratiemotief en geboorteland, statline.cbs.nl. 
Europese Unie. ${ }^{289}$

Het plan om de eisen voor gezinsvorming te verzwaren was al aangekondigd in het 'Strategisch Akkoord' van het eerste kabinet Balkenende, dat echter niet lang genoeg in het zadel bleef om die plannen uit te voeren. ${ }^{290}$ Het tweede kabinet Balkenende nam hervorming van het gezinsvormingsbeleid opnieuw op in zijn 'Hoofdlijnenakkoord' van 2003 en voegde daaraan toe dat het verwerven van een 'basisniveau' Nederlands een voorwaarde zou worden voor toelating. ${ }^{291}$

Aan de hervormingen van het gezinsmigratiebeleid in 2004 en 2005 lag een definitie van gezinsmigratie als beleidsprobleem ten grondslag, die in grote lijnen vergelijkbaar was met het beleidsperspectief waarop Van Boxtel in 2002 zijn voorstel voor een inburgeringsbijdrage had gebaseerd: gezinsmigranten werden als een inherent problematische categorie migranten beschouwd. Rita Verdonk (VVD), minister van Vreemdelingenzaken en Integratie in het tweede kabinet Balkenende, was echter veel uitgesprokener in haar negatieve evaluatie van de maatschappelijke gevolgen van gezinsmigratie dan Van Boxtel was geweest. In de argumenten die voor beide hervormingen werden gegeven wordt zeer duidelijk zichtbaar, dat de onwil om migranten of minderheden te stigmatiseren plaats had gemaakt voor de behoefte om klare taal te spreken. De kloof tussen kiezer en politiek die de Fortuyn-revolte had blootgelegd moest worden gedicht en daarom wilde de regering er geen twijfel over laten bestaan dat zij de ernst van de migratie- en integratieproblematiek onderkende. De onvrede die onder de kiezers leefde diende te worden gearticuleerd en dus diende iedere zweem van 'politieke correctheid' te worden vermeden.

Zo nam minister Van Boxtel van GSI in 2002 nog expliciet als uitgangspunt, dat het recht op gezinsleven een 'fundamenteel recht' was en

289 Met name de Nederlandse inkomens-, leeftijds- en integratievereisten zijn strenger dan die van de meeste andere Europese lidstaten. Nederland stelt het hoogste inkomensvereiste voor gezinsmigratie in de Unie. België en Zweden stellen geen inkomenseis: in andere landen sluit de inkomenseis aan bij het minimumloon of de bijstandsnorm. Denemarken vergt wel een borg van 7000 euro. Slechts vijf lidstaten stellen net als Nederland een minimumleeftijdseis van meer dan 18 jaar. Denemarken is op dit punt strenger dan Nederland: de minimumleeftijd is daar 24 jaar. Alleen Denemarken stelt net als Nederland integratie-eisen bij toelating van gezinsmigranten, namelijk bij kinderen van meer dan 12 jaar oud. Ook de Nederlandse eisen voor eigen staatsburgers zijn relatief streng. Nederland neemt daarentegen een liberale positie in waar het de toelating van niet-huwelijkse partners betreft en stelt - anders dan sommige lidstaten - geen eisen aan huisvesting of verblijfstermijn. Groenendijk e.a. 2007b: 12-14, 18-20, 23-28.

290 TK 2001-2002 28375 (5): 16. Het kabinet Balkenende I wilde het inkomensvereiste bij gezinsvorming verhogen tot $130 \%$ van het minimumloon: het kabinet Balkenende II maakte daar $120 \%$ van.

291 TK 2002-2003 28637 (19): 14. 
dat gezinsvorming bijdroeg aan 'het welzijn van de hier reeds wonende migrant' ${ }^{292}$ Sinds de jaren negentig werd in beleidsnota's steeds aangegeven dat de regering zocht naar een balans tussen het individueel belang bij gezinsleven en vrijheid van partnerkeuze enerzijds, en het belang van de Nederlandse maatschappij bij het verbinden van voorwaarden aan gezinsmigratie anderzijds. In de toelichting op de beleidsvoorstellen van minister Verdonk wordt aan dit dilemma niet gerefereerd. Aan het individueel belang van betrokkenen wordt wel aandacht besteed, maar dat wordt uitsluitend gedefinieerd in termen van de negatieve gevolgen van gezinsmigratie voor hun integratie in de Nederlandse samenleving. Over een positief persoonlijk belang bij toelating van buitenlandse gezinsleden, of over de morele betekenis die aan dat belang moet worden toegekend, geen woord. ${ }^{293}$ Het contrast met het moreel gewicht dat in de jaren tachtig aan het recht op gezinshereniging werd toegekend kon haast niet groter zijn.

Aanscherping van het gezinsmigratiebeleid was nodig, zo stelde minister Verdonk, vanwege de 'achterblijvende inburgering en het niet onbeperkte maatschappelijke draagvlak voor de opneming van nieuwe migranten'. Gezinsmigratie werd expliciet aangewezen als een belangrijke oorzaak van het problematisch verloop van de inpassing van migranten in de Nederlandse samenleving: 'de grootschalige gezinsmigratie [heeft] de integratie op groepsniveau in de afgelopen jaren ernstig belemmerd'. Dat gezinsmigratie zo'n negatief effect had op het integratieproces, kwam doordat vreemdelingen die als gezinsmigrant in Nederland werden toegelaten de verkeerde soort migranten waren: 'een belangrijk deel van de gezinsmigranten [heeft] kenmerken die ongunstig zijn voor een goede integratie in de Nederlandse samenleving. Het meest prominent - ook in omvang - is daarbij de groep gezinsmigranten uit Turkije en Marokko, die een slechte startpositie in de Nederlandse samenleving hebben.' Niet eerder had een Nederlands kabinet zo expliciet te kennen gegeven, een specifieke migrantengroep als ongewenst te beschouwen. De dagen van depolitisering en angst voor stigmatisering waren duidelijk voorbij. Turkse en Marokkaanse gezinsmigranten waren moeilijk inpasbaar, zo stelde minister Verdonk namens het kabinet, omdat hun opleidingsniveau laag was en hun kansen op de Nederlandse arbeidsmarkt gering. Hun sociaal-culturele kenmerken waren eveneens 'ongunstig', aangezien zij veelal weinig contacten hadden met Nederlanders, sterk georiënteerd waren op de eigen groep, taal en

292 TK 2001-2002 29198 (2): 45.

293 тK 2004-2005 19637 (852 Bijlage); TK 2003-2004 29700 (3). 
cultuur en traditionele opvattingen hadden met betrekking tot emancipatie. $^{294}$

Gezinsmigranten maakten ongeveer de helft uit van de totale immigratie naar Nederland, en de verwachting was dat 'de stroom van huwelijksmigranten de komende jaren zal aanhouden'. Zo zou het 'zichzelf repeterende verschijnsel van volgmigratie' kunnen uitmonden in een 'permanente aanwas van groepen etnische minderheden met een achterstand positie'. Dit proces van 'marginalisatie' bracht het risico op 'structurele afhankelijkheid van bijstandsuitkeringen en bijdragen op grond van andere uit de algemene middelen gefinancierde regelingen, op afkeer van de samenleving, antiwesterse gevoelens, segregatie en delinquentie' met zich mee en vormde daarom een bedreiging voor 'het economisch welzijn van Nederland, de openbare orde en de openbare veiligheid, en de rechten en vrijheden van anderen'. 295

Met andere woorden, het tweede kabinet Balkenende definieerde gezinsmigratie als de directe oorzaak van ernstige integratieproblemen die de maatschappelijke samenhang en veiligheid in gevaar brachten. Dit perspectief op het gezinsmigratievraagstuk werd onderschreven door alle politieke partijen in de Tweede Kamer, over het gehele politieke spectrum. ${ }^{296}$ Alleen GroenLinks zette kritische kanttekeningen bij de presentatie van huwelijksmigratie als 'een gevaar voor de nationale veiligheid en (...) voor fundamentele waarden als vrijheid van meningsuiting en godsdienst' en verwierp 'de suggestie dat Nederland overspoeld zou worden door analfabete buitenlanders', waardoor buiten beeld bleef dat het overgrote deel van de huwelijksmigranten zich bij een autochtone Nederlander of een goed geïntegreerde en hoog opgeleide allochtoon voegde. Zelfs GroenLinks was het echter met de regering eens, dat grootschalige gezinsvorming schadelijk was voor het integratieproces, met name voor de emancipatie van allochtone vrouwen. ${ }^{297}$

\section{Aanscherping van de voorwaarden voor gezinsvorming}

In september 2004 presenteerde minister Verdonk een beleidsvoorstel aan de Kamer, waarmee uitvoering werd gegeven aan de hervorming van het

294 TK 2004-2005 19637 (852 Bijlage); TK 2003-2004 29700 (3): 4-6.

295 TK 2004-2005 19637 (852 Bijlage); TK 2003-2004 29700 (3): 3, 17.

296 Zie noot 287 in hoofdstuk 4.

297 тк 2004-2005 19637 (873): 5; тK 2004-2005 Handelingen 16 maart 2005: 3894-3896; Spijkerboer 2007: 59. 
gezinsvormingsbeleid die in het regeerakkoord was aangekondigd. ${ }^{298}$ In de eerste plaats zou gezinsvorming pas worden toegestaan wanneer beide partners 21 jaar oud waren, in plaats van 18. Jongeren van 21 zouden beter dan 18-jarigen in staat zijn om zich 'desgewenst te onttrekken aan de invloed van het ouderlijk gezag en andere familiale of traditionele banden'. Aan dit argument ligt de veronderstelling ten grondslag, die ook in de debatten over de inburgeringsbijdrage in 2002 al een rol speelde, dat gezinsvorming geworteld is in niet-westerse tradities die individuele keuzevrijheid niet hoog in het vaandel dragen. De regering zag het als haar taak om de emancipatie van jongeren van die tradities te bevorderen.

In de tweede plaats werd het inkomensvereiste verhoogd tot $120 \%$ van het minimumloon. Pas op dat inkomensniveau was aanspraak op bijzondere bijstand of kwijtschelding van belastingen uitgesloten en kon dus werkelijk worden gesproken van financiële zelfstandigheid. Het integratieperspectief van de buitenlandse huwelijkspartner was 'beter gewaarborgd' indien de partner in Nederland 'zijn verantwoordelijkheid ook op financieel vlak kan waarmaken.' Tien jaar nadat het CDA het had geïntroduceerd in het debat, had het argument van 'eigen verantwoordelijkheid' nog niets van zijn gezag verloren. Het werd zelfs consequenter dan ooit toegepast: aangezien er 'geen reden [was] om categorieeën gezinsherenigers en -vormers op voorhand niet te houden' aan die verantwoordelijkheid zou de vrijstelling voor ouderen en alleenstaande ouders van kleine kinderen worden afgeschaft.

De regering verwachtte dat deze twee wijzigingen tezamen zouden leiden tot een daling van $45 \%$ van de ingewilligde aanvragen voor gezinsvorming. Ook in 1993 waren de doelstellingen van de regering bij het aanscherpen van het gezinsmigratiebeleid kwantitatief van aard: het kabinet Lubbers deed toen echter veel moeite om te ontkennen dat het om beperking van de migratiestroom te doen was, omdat het geen voedingsbodem wilde geven aan xenofobie. Het tweede kabinet Balkenende daarentegen kwam er rond voor uit dat het minder huwelijksmigranten wilde toelaten. ${ }^{299}$

Het beleidsvoorstel werd redelijk goed ontvangen in het parlement. Alle politieke partijen waren het met de regering eens, dat gezinsvorming

298 De vvD had voor het aantreden van het eerste kabinet Balkenende al gepleit voor verhoging van de leeftijds- en inkomenseis bij gezinsvorming. (TK 2001-2002 28198 (5): 5-6) Het zal dus vooral de VVD zijn geweest die op deze afspraak in het regeerakkoord heeft aangedrongen, maar ik verwacht niet dat dat bij de coalitiepartners op bezwaren is gestuit.

299 TK 2004-2005 19637 (852 Bijlage). Zie ook notitie minister aan informateurs, 24 februari 2003. MAZ 472520. 
problematische gevolgen had voor het integratieproces en dat daar iets aan moest worden gedaan. Ze onderschreven ook allemaal de impliciete stelling van het kabinet, dat gezinsvorming niet alleen oorzaak maar ook gevolg was van onvoldoende integratie van tweede en derde generatie migranten. Zo interpreteerde Sterk namens het CDA het feit dat tweederde van de Marokkaanse en Turkse jongeren 'nog steeds' met een buitenlandse partner trouwde als een teken 'dat deze burgers sterk op het land van herkomst zijn gericht en op [dat] van hun ouders'. VVD-woordvoerder Visser meende dat 'ook betrokkenen zelf behoefte hebben aan strengere regels' omdat die ze in staat stellen 'om weerstand te bieden aan ongewenste druk tot huwelijksvorming'. Ook sP en GroenLinks steunden de regering in haar streven naar emancipatie van jongeren van familiale en traditionele banden.

Over het probleem bestond dus politieke consensus, maar de meningen liepen uiteen waar het de oplossing betrof die de regering had gekozen. De coalitie-partijen CDA, VVD en D66 waren er blij mee. De linkse oppositiepartijen daarentegen uitten ernstige bezwaren tegen de verhoging van het inkomensvereiste. PvdA, SP en GroenLinks stelden dat deze maatregel leidde tot 'willekeur' en tot discriminatie van kwetsbare groepen, met name vrouwen en jongeren. In de woorden van de PvdA: 'een hogere financiële drempel betekent niet automatisch een snellere integratie'. ${ }^{300}$ De nieuwe voorwaarden voor gezinsvorming traden per 1 november 2004 in werking, met de steun van een relatief smalle politieke meerderheid. Volgens Groenendijk e.a. was het inkomensvereiste in Nederland daarmee het hoogste in de Europese Unie. Ook de nieuwe minimumleeftijd plaatste Nederland aan de restrictieve kant van het EU-spectrum: slechts vijf andere lidstaten hanteren een leeftijdsgrens van meer dan 18 jaar. ${ }^{301}$

\section{De Wet Inburgering in het Buitenland}

Eveneens in 2004 presenteerde minister Verdonk een wetsvoorstel waarmee uitvoering werd gegeven aan de tweede hervorming van het gezinsmigratiebeleid die in het regeerakkoord was aangekondigd. De Wet Inburgering in het Buitenland (WIB) incorporeerde een nieuwe toelatingsvoorwaarde in de Vreemdelingenwet: voortaan zouden gezinsmigranten pas worden toegelaten in Nederland indien zij over een basale kennis van de Nederlandse

300 тK 2004-2005 19637 (873).

301 Groenendijk e.a. 2007b: 20, 26. Zie noot 289 in hoofdstuk 4. 
taal en maatschappij beschikten. ${ }^{302}$ Die kennis werd getoetst in een examen op Nederlandse ambassades en consulaten in de landen van herkomst. Het examen zou in het Nederlands worden afgenomen via een directe telefonische verbinding met een computer. Vreemdelingen die geen machtiging tot voorlopig verblijf (mvv) nodig hadden om naar Nederland te komen, waaronder naast EU-burgers ook Amerikanen, Australiërs en Japanners, hoefden niet aan de nieuwe voorwaarde te voldoen. De Nederlandse overheid zou proefexamens beschikbaar stellen, maar geen cursussen of leermateriaal aanbieden. ${ }^{303}$ Het examen zelf zou 350 euro kosten. ${ }^{304}$

Integratie in het buitenland is niet bedacht door minister Verdonk. In 2000 opperde De Hoop Scheffer, fractievoorzitter van het CDA, al om gezinsmigranten te verplichten reeds in het land van herkomst een begin te maken met de inburgering. ${ }^{305}$ Deze suggestie wekte in eerste instantie weinig politiek enthousiasme, maar het CDA bleef er in de jaren die volgden geregeld op terugkomen. ${ }^{306}$ Zolang de Paarse coalities het regeringspluche bezetten vonden deze voorstellen geen gehoor bij het kabinet. Minister Van Boxtel meende dat inburgering in het buitenland 'bijna onuitvoerbaar' zou zijn. ${ }^{307}$ Staatssecretaris Kalsbeek van Justitie en haar ambtenaren waren bovendien op principiële gronden tegen een dergelijke maatregel gekant: door het stellen van integratievereisten aan buitenlandse gezinsleden zou 'het recht op gezinsleven geschaad en in geval van gezinsvorming ook de

302 Dat gezinsmigranten de doelgroep van de wet zijn is, in de woorden van Spijkerboer (2007: 29), zorgvuldig verpakt'. De memorie van toelichting definieert de doelgroep in eerste instantie als inburgeringsplichtige nieuwkomers, om via een uitgebreide kronkelredenering uit te komen op de conclusie dat het 'in de praktijk' 'overwegend' om gezinsvormers en gezinsherenigers gaat. Spijkerboer constateert terecht dat de nieuwe voorwaarde feitelijk uitsluitend op gezinsmigranten van toepassing is. De argumenten die worden gegeven ter onderbouwing van het wetsvoorstel hebben dan ook uitsluitend betrekking op gezinsmigranten.

303 Daarmee gaf het kabinet invulling aan haar standpunt, dat het 'aanbod-georiënteerde' inburgeringsbeleid tot dan toe van migranten 'zorgcategorieën' had gemaakt, 'die door de overheid bij de hand moeten worden genomen'. (TK 2003-2004 29700 (3): 2). In de jaren negentig werd het principe van 'eigen verantwoordelijkheid' nog zo geïnterpreteerd dat tegenover de inspanningsverplichting van migranten ook een inspanningsverplichting van de overheid stond. Het tweede kabinet Balkenende liet die visie varen. Groenendijk (2005: 25) interpreteert de weigering van de regering om migranten behulpzaam te zijn bij hun voorbereiding op de toets als een duidelijk signaal 'dat niet zozeer integratie maar beperking van de immigratie het voornaamste doel van deze maatregel is'.

304 TK 2003-2004 29700 (3): 12-14, 19.

305 TK 1999-2000 Handelingen 18 april 2000: 4713-4714; TK 1999-2000 Handelingen 20 april 2000: 4748.

306 TK 1999-2000 27111 (8): 4; TK 2001-2002 28198 (5): 7-8; TK 2001-2002 2800 VI (22).

307 TK 2001-2002 28198 (5): 17. 
vrijheid van partnerkeuze aangetast (...) kunnen worden' ${ }^{308}$ De christendemocraten lieten zich echter niet ontmoedigen: zij namen integratie in het buitenland op in hun verkiezingsprogramma voor 2002. ${ }^{309}$ In december 2002 initieerde Sterk namens het CDA een motie die door een zeer brede meerderheid in de Kamer werd aangenomen, waarin de regering werd verzocht om met 'concrete voorstellen' te komen om in het land van herkomst een begin te maken met de inburgering van gezinsmigranten. ${ }^{310}$ Diezelfde maand aanvaardde de Kamer een motie die was geïnitieerd door de VvD en die de regering opriep om 'het belang van de essentiële Nederlandse waarden, normen en grondrechten reeds tijdens de aanvraagprocedure voor een verblijfsvergunning in het land van herkomst onder de aandacht van de aanvrager te brengen'. ${ }^{311}$ Met de Wet Inburgering in het Buitenland gaf de regering dus uitvoering aan een wens die het CDA al lang koesterde en die inmiddels gesteund werd door een zeer brede meerderheid in de Kamer.

De doelstelling van de Wet Inburgering in het Buitenland was een 'efficiënter en effectiever' verloop van de integratie, dat moest worden bereikt door beide partners 'reeds voor komst naar Nederland' aan te spreken op hun 'verantwoordelijkheid in het integratieproces'. De wet was ook bedoeld als 'selectiemechanisme': degenen die er niet in slaagden zich een basale kennis van de Nederlandse taal en maatschappij eigen te maken, zouden ook bij de verdere integratie in Nederland 'grote problemen' ondervinden. Voortaan zouden deze mensen 'geen toestemming krijgen zich in Nederland te vestigen'. ${ }^{312}$

Juridisch lag het definitief onmogelijk maken van gezinshereniging en -vorming voor bepaalde groepen of personen echter moeilijk. ${ }^{313}$ Daarom moest het niveau van de toets zo bescheiden zijn, dat het 'redelijkerwijs

308 Deze passage uit de Nota 'Integratie in het perspectief van immigratie' is opgesteld door DVB. TK 2001-2002 28198 (2): 45; Brief hoofd DVB aan hoofd DCIM, 16 november 2001. MJ A99/5253. 309 Betrokken samenleving, betrouwbare overheid, verkiezingsprogram CDA 2002-2006: 68. Documentatiecentrum Nederlandse politieke partijen, www.rug.nl/dnpp.

310 TK 2002-2003 27083 (25); TK 2002-2003 Handelingen 17 december 2002: 2538. Alleen VVD stemde tegen, omdat de motie in het midden liet of de regering cursussen zou aanbieden en of er van een verplichting sprake zou zijn. Dat laatste was voor GroenLinks juist een reden om vóór te stemmen. De VVD verkoos het 'afnemen van examens zonder dat cursussen worden gegeven'. TK 2002-2003 Handelingen 3 december 2002: 2012.

311 TK 2002-2003 28600 VI (60); TK 2002-2003 Handelingen 10 december 2002: 2241. Alleen SP, ChristenUnie en SGP stemden tegen. SGP en Christenunie verschilden met de VVD van mening over de vraag of scheiding van kerk en staat een essentiële Nederlandse waarde was. TK 2002-2003 Handelingen 6 november 2002: 954-956.

312 тк 2003-2004 29700 (3): 4-6.

313 De ACVZ en de Raad van State hadden gewezen op mogelijke strijdigheid met artikel 8 EVRM. TK 2003-2004 29700 (4). Zie ook Groenendijk 2005: 24-25. 
door middel van zelfstudie in het land van herkomst' kon worden bereikt. De inburgeringstoets, zo stelde minister Verdonk, zou 'niet zozeer selecteren op opleidingsniveau als wel op motivatie en doorzettingsvermogen'. Aangezien de ervaringen met de inburgeringscursussen in Nederland hadden aangetoond dat niet alle immigranten voldoende gemotiveerd waren, werd van dit 'selectiemechanisme' een verlaging van de gezinsmigratiestroom van $25 \%$ verwacht. ${ }^{314}$

Deze beperking van de immigratie werd in de memorie van toelichting een 'neveneffect' genoemd. Hoewel het kabinet er geen twijfel over liet bestaan het zeer bezwaarlijk te vinden dat Turkse en Marokkaanse Nederlanders 'nog steeds massaal kiezen voor een partner uit het land van herkomst', werd het kennelijk zelfs in het hardere politiek klimaat na 2002 niet opportuun geacht het verminderen van het aantal gezinsmigranten als doelstelling van het wetsvoorstel te presenteren. ${ }^{315}$ In een radio-interview in november 2006 noemde Verdonk het 'gigantisch teruggelopen' aantal huwelijksmigranten uit Turkije en Marokko echter als voornaamste voorbeeld van 'de resultaten die we hebben bereikt'. 316

Zoals te verwachten was, werd het wetsvoorstel goed ontvangen in de Tweede Kamer. Wederom gingen de politieke discussies niet zozeer over de definitie van gezinsmigratie als beleidsprobleem die aan het voorstel ten grondslag lag, als wel over de beleidsrespons die de regering gekozen had. Zo stelde de PvdA voor om van migranten te vergen dat zij in hun eigen taal konden lezen en schrijven, in plaats van hun kennis van het Nederlands te toetsen. Zij meenden dat niet gebrek aan motivatie maar analfabetisme het voornaamste obstakel vormde voor integratie. Dit voorstel werd echter verworpen omdat het strijdig met artikel 8 EVRM zou zijn om analfabeten uit te sluiten van gezinsmigratie. De sp had ernstige bezwaren tegen het wetsvoorstel, die alle materieel van aard waren: de kosten van het examen waren te hoog en de toetsing met behulp van een spraakcomputer was onbetrouwbaar. GroenLinks ten slotte meende dat kennis van de Nederlandse taal en maatschappij veel gemakkelijker in Nederland dan in het buitenland kon worden verworven en dat 'de inperking van de vrije keuze door familieleden' niet moest worden 'vervangen door een inperking van de vrije partnerkeuze door de overheid'. Daarmee was GroenLinks de enige partij met principiële bezwaren tegen het vereiste van inburgering in het buitenland.

314 тK 2003-2004 29700 (3): 11, 14-16; тK 2003-2004 29700 (6): 6-7, 28, 34-44.

315 тк 2003-2004 29700 (3): 4-6, 15-16. Zie ook тк 2003-2004 29700 (6): 43.

316 De Ochtenden: Het Interview, 2 november 2006. Www.ochtenden.nl. 
De coalitiepartijen steunden het wetsvoorstel van harte. CDA-woordvoerder Sterk benadrukte daarbij dat zij verwachtte dat de positie van allochtone vrouwen in Nederland erdoor zou worden versterkt, aangezien zij voortaan al bij aankomst op de hoogte zouden zijn van de rechten die vrouwen hier hebben. Minister Verdonk zocht aansluiting bij dat argument door te stellen dat 'wij zijn begonnen met de Wet Inburgering in het Buitenland juist om de emancipatie van vrouwen te versterken', een doelstelling die in de memorie van toelichting nog niet werd genoemd..$^{317}$

De wet werd op 5 april 2005 door de Kamer aangenomen, met de steun van alle politieke partijen behalve GroenLinks en de SP. ${ }^{318} \mathrm{Ze}$ is op 15 maart 2006 in werking getreden. Daarmee werden voor het eerst in Nederland en in de wereld integratievereisten gekoppeld aan de overkomst van buitenlandse gezinsleden. ${ }^{319}$ Sinds de jaren negentig werd in het politiek debat een steeds nauwer verband gelegd tussen het vraagstuk van de inpassing van migranten in de Nederlandse samenleving en de voorwaarden voor toelating en verblijf van nieuwkomers. Zorgen over het verloop van het integratieproces vormden een primaire drijfveer voor de opeenvolgende restrictieve hervorming van het gezinmigratiebeleid. Met deze wet, waarmee bij toelating een schifting moet worden gemaakt tussen 'inpasbare' en 'niet-inpasbare' migranten, is de samensmelting van het integratiebeleid en het vreemdelingenbeleid naar een geheel nieuw plan getild. ${ }^{320}$

\section{Tentatieve interpretatie van de verhoudingen binnen het ministerie van Justitie}

Het ministerie van Justitie heeft mij toegestaan om de beleidsarchieven in te zien tot 2003, dat wil zeggen tot het aantreden van het tweede kabinet Balkenende. Ik heb dus geen kennis kunnen nemen van de ambtelijke voorbereiding van de aanscherping van het gezinsvormingsbeleid en de Wet Inburgering in het Buitenland. Het lijkt echter zeer waarschijnlijk dat beide hervormingen aanleiding hebben gegeven tot spanningen binnen het ministerie.

In de debatten over de inburgeringsbijdrage in 2002 hadden ambtenaren van de Directie Vreemdelingenbeleid (DVB) zich nog fel verzet tegen

317 TK 2004-2005 Handelingen 16 maart 2005: 3883-3906; TK 2004-2005 Handelingen 22 maart 2005: 4002-4041. Vgl. Spijkerboer 2007: 35-36.

318 TK 2004-2005 Handelingen 5 april 2005: 4283-4285.

319 Groenendijk 2005: 12.

320 Vgl. Bruquetas-Callejo 2006: 25-27. 
verdere aanscherping van de voorwaarden voor gezinsmigratie en tegen het stellen van integratievereisten aan buitenlandse gezinsleden. De overheid zou daarmee inbreuk plegen op het recht op gezinsleven en op vrije partnerkeuze. Ik acht het niet aannemelijk dat deze ambtenaren één of twee jaar later volkomen anders tegen de zaak aankeken.

In een telefonisch interview bevestigde Rita Verdonk dat er op individueel niveau meningsverschillen waren. Zij ontkende evenwel dat die bedenkingen van een specifieke afdeling afkomstig waren en benadrukte dat zij aan de samenwerking met haar ambtenaren een zeer plezierige herinnering overhoudt. Op mijn vraag of de bezwaren die werden geuit juridisch of principieel van aard waren antwoordde zij echter gedecideerd dat het om principiële tegenwerpingen ging: het stellen van eisen aan de binnenkomende partner werd als een inbreuk op de vrijheid van partnerkeuze beschouwd. ${ }^{321}$ Dit is exact het bezwaar dat enkele jaren eerder door de ambtenaren van DVB naar voren werd gebracht. Ik kan mij dan ook niet aan de indruk onttrekken dat de aanscherping van de voorwaarden voor gezinsvorming en met name de Wet Inburgering in het Buitenland ondanks verzet van DVB tot stand zijn gekomen. Dergelijke spanningen binnen het ministerie zouden ook verklaren, waarom het niet opportuun werd geacht mij de ambtelijke stukken te laten inzien.

Dat bezwaren van de meest betrokken ambtelijke afdeling werden overstemd, in ieder geval in 2002 en waarschijnlijk ook in 2004 en 2005, laat overtuigend zien dat partijpolitiek inmiddels bepalend was voor de beleidsontwikkeling op het gebied van gezinsmigratie. In de jaren zestig stelden ambtenaren, goeddeels buiten zicht van publiek en parlement, nog grotendeels naar eigen goeddunken vast aan welke voorwaarden de overkomst van buitenlandse gezinsleden werd onderworpen. Na 2001 was dat volkomen anders: de hervormingen waren door de coalitiepartijen vastgelegd in het regeerakkoord van 2003, en de Wet Inburgering in het Buitenland was een directe respons op twee moties van de Kamer. Een zo duidelijke en krachtige wens van de politieke meerderheid liet weinig ruimte voor ambtelijke invloed op het beleid.

Zoals ook in de jaren negentig het geval was geweest, waren de hervormingen van 2004 en 2005 het resultaat van een beslissing van de coalitiepartijen. Het is niet verrassend dat het centrum-rechtse kabinet Balkenende

321 Telefonisch interview SB met Rita Verdonk, 20 december 2007. 
daarbij een meer restrictieve lijn koos dan de Paarse regeringen onder de sociaaldemocraat Wim Kok. Daarbij mag echter niet uit het oog worden verloren dat alle politieke partijen sinds 2002 gezinsmigratie als schadelijk voor integratie en voor de maatschappelijke samenhang waren gaan beschouwen en dat ook de beleidsrespons van het kabinet Balkenende op dit probleem brede politieke instemming genoot. Vrijwel alle beleidswijzigingen die hier zijn besproken werden ondersteund door de hele Kamer, op GroenLinks en de sP na. Alleen de verhoging van het inkomensvereiste stuitte ook bij de PvdA op bezwaar. Het is deze brede politieke consensus die de weg heeft geopend naar innovatieve en radicale hervormingen van het Nederlands gezinsmigratiebeleid.

\subsection{Het criterium 'feitelijke gezinsband' in Europees perspectief}

Te midden van de verschillende aanscherpingen van het Nederlands gezinsmigratiebeleid na de eeuwwisseling, werd één aspect van het beleid significant versoepeld: het criterium dat minderjarige kinderen 'feitelijk' moesten behoren tot het gezin van de aanvrager om te worden toegelaten tot Nederland, werd afgeschaft. Dit gebeurde onder druk van het Europees Hof voor de Rechten van de Mens in Straatsburg en van de harmonisatie van het gezinsmigratiebeleid in de EU.

Sinds 1986 stipuleerde de Vreemdelingencirculaire dat toelating van een kind dat zich bij zijn ouder of ouders in Nederland wilde voegen moest worden geweigerd, indien het duurzaam was opgenomen in een ander gezin en de 'ouder(s) niet meer met het gezag zijn belast of niet (meer) in de kosten van opvoeding en verzorging voorzien'. ${ }^{322}$ Aan dit criterium 'feitelijke gezinsband' lag een scherp normatief oordeel ten grondslag met betrekking tot gezinsverhoudingen en de juiste invulling van het ouderschap: een kind kon maar tot één gezin tegelijk behoren, en een ouder die zijn kind voor langere tijd aan de zorg van een ander had overgelaten, kon geen aanspraak meer maken op een band met dat kind die zwaar genoeg woog om toegang tot Nederland te rechtvaardigen. ${ }^{323}$ Tot de invoering van deze toelatingsvoorwaarde was op ambtelijk niveau besloten en het zou meer dan tien jaar duren voordat er in het parlement over werd gediscussieerd. ${ }^{324}$

322 Vc 1982, B19 2.2.2 (Vc Suppl. 3 juni 1986). Documentatie Database CMR.

323 Van Walsum 1999: 148; Van Walsum (te verschijnen): 13-16.

324 Zie paragraaf 3.8. 


\section{De hervorming van 2001}

In 1997 stelden D66 en PvdA voor het eerst vragen over de manier waarop het criterium feitelijke gezinsband in de praktijk werd toegepast. PvdAwoordvoerder Apostolou gaf aan een 'groot aantal brieven met schrijnende gevallen' te hebben ontvangen. De Kamerleden stelden het criterium op zich niet ter discussie, maar vroegen zich af of er wel voldoende rekening werd gehouden met ouders die gevlucht waren voor oorlog en het contact met hun kinderen door de chaotische situatie in hun herkomstland lange tijd waren kwijt geraakt. De PvdA betwijfelde of het niet langer kunnen onderhouden van je kind altijd betekende dat de gezinsband verbroken was. Het CDA daarentegen benadrukte zoals gebruikelijk dat het doorslaggevend moest zijn of een ouder 'de financiële verantwoordelijkheid voor zijn kind is blijven dragen'. Staatssecretaris Schmitz verzekerde de Kamerleden dat met vlucht- en oorlogssituaties rekening werd gehouden. ${ }^{325}$

Volgens Van Walsum werd in de late jaren negentig steeds meer ruimte gelaten aan de uitvoerende ambtenaren om te bepalen of de gezinsband al dan niet verbroken was en lijkt het criterium dan ook steeds vaker tot weigering van de toelating van kinderen te hebben geleid. ${ }^{326}$ In 2000 stelde de PvdA bij monde van Albayrak dat het criterium feitelijke gezinsband in de praktijk te vaak leidde tot 'uiterst schrijnende situaties' en dat ze hierover graag verder zou discussiëren op basis van een regeringsnota. ${ }^{327}$

Staatssecretaris Kalsbeek presenteerde die nota in 2001. Zij had besloten het beleid te wijzigen en had daar drie redenen voor. In de eerste plaats was ze het met Albayrak eens dat het beleid in sommige gevallen onevenredig hard uitpakte. Ouders moesten schriftelijk bewijs overleggen dat ze bij de opvoeding van hun kind betrokken waren geweest en steeds de volledige kosten van het levensonderhoud hadden gedragen. ${ }^{328}$ Die bewijslast was te zwaar. Daarbij liet het beleid 'geen ruimte' voor het tijdelijk overdragen van de zorg voor een kind aan anderen, zonder de bedoeling te hebben 'de feitelijke gezinsband met het kind te verbreken'. In de tweede plaats hadden de rechtbanken zich kritisch over het beleid uitgelaten: de vage formulering van de regels liet te veel ruimte voor interpretatie in de uitvoeringspraktijk. In de derde plaats ten slotte was in onderhandelingen over harmonisatie

325 TK 1996-1997 25001 (30).

326 Van Walsum 1999: 147, 149.

327 TK 1999-2000 Handelingen 7 juni: 5383.

328 Van Walsum (te verschijnen): 5. 
van het gezinsmigratiebeleid in de EU gebleken dat Nederland de enige lidstaat was die een dergelijk criterium hanteerde. In de andere lidstaten had 'het recht op gezinshereniging van minderjarige kinderen met hun ouders (...) een absoluut karakter' en was het dus voldoende om aan te tonen dat er een familierechtelijke relatie bestond. ${ }^{329}$ Daarom wilde staatssecretaris Kalsbeek 'een ruimere en duidelijkere uitleg' geven aan het criterium feitelijke gezinsband. ${ }^{330}$

Voor Justitie woog het feit dat Nederland op dit punt een uitzonderingspositie innam in de onderhandelingen in Brussel het zwaarst. In eerste instantie was alleen dit argument in de nota opgenomen: pas op aandringen van ambtenaren van andere ministeries was de nota aangevuld met de twee andere punten. ${ }^{331}$ De wens om het Nederlands beleid in lijn te brengen met dat van de andere lidstaten werd een factor van steeds groter belang in de beleidsvorming.

Het streven naar Europese harmonisatie bracht Kalsbeek er echter niet toe het criterium feitelijke gezinsband te schrappen. Uitgangspunt was

dat kinderen en ouders in principe bij elkaar horen doch dat indien men in een reeks van jaren geen signaal heeft gegeven dat men gezinshereniging wil, hoewel aan de eisen daarvoor had kunnen worden voldaan, niet meer gesteld kan worden dat Nederland het meest aangewezen land is voor hereniging aangezien dan bij gezinshereniging hier te lande de integratie van die kinderen op grote problemen zal stuiten. ${ }^{332}$

Dit integratie-argument was nieuw: het had bij de invoering van het criterium feitelijke gezinsband in de jaren tachtig geen rol gespeeld. Het belang van snelle overkomst voor het integratieproces, met name voor kinderen, was in het ambtelijk overleg nadrukkelijk ingebracht door de ministeries van oc\&w en Binnenlandse Zaken, die 'aanzienlijke problemen' voorzagen bij de instroom van jongeren 'die geruime tijd in het buitenland hebben verbleven', een 'grote opleidings- en taalachterstand' hadden en dus 'vanuit integratieperspectief (...) een lastige groep' vormden. ${ }^{333}$

329 Alleen in Duitsland werd voor kinderen van 16 jaar en ouder in de overweging meegenomen of er een 'feitelijke gezinsband' bestond. Ook dan was het echter niet doorslaggevend. TK 2001200226732 (98): 3.

330 TK 2001-2002 26732 (98): 3.

331 Nota hoofd DVB aan staatssecretaris, 9 oktober 2001. MJ A01/5238.

332 тк 2001-2002 26732 (98): 4.

333 Nota hoofd DVB aan staatssecretaris, 9 oktober 2001. MJ A01/5238. 
Om zowel aan 'het principe dat ouders en kind in beginsel bij elkaar horen' als aan deze bezorgdheid over de integratieproblematiek recht te doen, stelde de staatssecretaris het volgende voor. Tot vijf jaar na het moment van scheiding zou zonder verder bewijs worden aangenomen, dat de band tussen ouder en kind niet was verbroken, tenzij het kind zelfstandig was gaan wonen of een eigen gezin had gesticht. Vijf jaar moest voldoende zijn voor de ouder om zijn plaats te vinden in Nederland en aan de voorwaarden voor gezinshereniging te voldoen, en voor het kind om een eventuele opleiding af te maken. Na vijf jaar zou 'er in principe van worden uitgegaan dat het kind geworteld is in het land van herkomst en dat hereniging in Nederland niet voor de hand ligt'. Alleen als voor het kind plotseling geen opvang meer aanwezig was in het land van herkomst, of als het kind 'door een oorlogssituatie onvindbaar' was geweest, zou verblijf in Nederland worden toegestaan. ${ }^{334}$

\section{De hervorming van 2006}

Ondanks deze versoepeling kwam het standpunt dat kinderen na meer dan vijf jaar gezinsscheiding zich niet meer met hun ouders in Nederland mochten verenigen, de Nederlandse regering op kritiek van het Europees Hof in Straatsburg te staan. Enkele maanden na het verschijnen van de hierboven beschreven notitie verloor Nederland de zaak Sen. Het ging om Sinem Sen, een Turks meisje van negen jaar wier aanvraag om een verblijfsvergunning was afgewezen omdat haar ouders te lang in gezinsscheiding hadden berust. Het Hof besloot dat gezien de lengte van het verblijf van de ouders in Nederland - de vader woonde al sinds hij twaalf was in Nederland - en het feit dat in Nederland inmiddels een broer en een zus waren geboren, van het gezin niet mocht worden verwacht dat het zich in Turkije herenigde. Ook met het oog op de jonge leeftijd van Sinem had Nederland inbreuk gepleegd op haar recht op gezinsleven door vast te houden aan het criterium feitelijke gezinsband. Dit was de eerste zaak waarin het Europees Hof een schending van artikel 8 constateerde bij weigering van eerste toelating. ${ }^{335}$

In eerste instantie meende de Nederlandse regering dat het in de zaak Sen om zodanig specifieke omstandigheden ging, dat een wijziging van de

334 тк 2001-2002 26732 (98): 4-5.

335 Van Walsum 2004d. Zie paragraaf 4.2. 
algemene regelgeving niet nodig was. ${ }^{336}$ In 2005 werd Nederland echter opnieuw door het Hof van Straatsburg in het ongelijk gesteld, ditmaal in de zaak Tuquabo-Tekle. Deze vrouw had bij haar vlucht uit Eritrea haar toen achtjarige dochter moeten achterlaten. Inmiddels was zij hertrouwd en waren uit dat huwelijk twee kinderen geboren. Anders dan de Nederlandse regering was het Hof van mening dat de vrouw wel degelijk moeite had gedaan om haar dochter zo snel mogelijk over te laten komen. Aangezien de vrouw gevlucht was en haar twee jongste kinderen in Nederland waren geboren en - net als hun ouders - de Nederlandse nationaliteit bezaten, kon redelijkerwijs niet van het gezin worden verlangd dat het zich in Eritrea vestigde. De dochter was al vijftien, hetgeen het belang van hereniging met haar ouders in beginsel minder zwaar deed wegen. De grootmoeder bij wie zij verbleef wilde haar echter, tegen de zin van haar moeder, uithuwelijken, zodat haar leeftijd in dit specifieke geval juist reden te meer was om gezinshereniging toe te staan. Opnieuw oordeelde het Hof dat het Nederlandse beleid inzake de feitelijke gezinsband een schending van artikel 8 EVRM opleverde. ${ }^{337}$

Deze uitspraak was voor minister Verdonk reden om te besluiten tot een versoepeling van het gezinsmigratiebeleid, die uit de toon viel tussen haar overige restrictieve beleidsbeslissingen. In september 2006 stuurde zij een nota naar de Tweede Kamer, waarin zij meedeelde dat het criterium feitelijke gezinsband zou worden afgeschaft. Uit de uitspraak van het Hof van Straatsburg in de zaak Tequabo-Tekle trok zij de conclusie dat 'de periode dat ouder en kind uit elkaar zijn, een bepalend criterium in het huidige beleid, internationaal anders wordt gewogen'. Er was sprake van een 'ongewenste spanning tussen nationaal recht enerzijds en internationale verplichtingen, waaronder met name de verplichtingen die voortvloeien uit artikel 8 EVRM, anderzijds'. Daarnaast was gebleken dat het criterium feitelijke gezinsband in de 'dagelijkse beslispraktijk' 'moeilijk uitvoerbaar' was, vanwege de 'indringende' individuele toets die het vereiste. Daarom zou voortaan worden aangenomen dat het kind feitelijk tot het gezin van zijn ouders behoorde, 'indien er sprake [was] van gezinsleven in de zin van artikel 8 EVRM'. Daarmee werd de 'feitelijke gezinsband' als apart toelatingscriterium afgeschaft, want '[g]ezinsleven in de zin van artikel 8 EVRM is er (...) tussen ouders en kinderen in beginsel altijd'. De gezinsband zou

336 Van Walsum (te verschijnen): 23.

337 Zaak Tuquabo-Tekle e.a. vs. Nederland, 1 december 2005, nr. 60665/00. Website EHRM, www.echr.coe.int. 
alleen nog als verbroken worden beschouwd als het kind zelfstandig ging wonen en in zijn eigen onderhoud voorzag, een eigen gezin vormde, of de zorg droeg voor buitenhuwelijkse kinderen. Deze nieuwe beleidslijn trad op 8 september 2006 in werking. ${ }^{338}$

Volgens juristen heeft bij deze beslissing nog een andere ontwikkeling een rol gespeeld, die in de brief van minister Verdonk niet wordt genoemd. In 2003 was de Europese gezinsherenigingsrichtlijn in werking getreden. Daarmee was het Nederlands gezinsmigratiebeleid voor het eerst aan het communautair recht en aan het toezicht van het Europees Hof in Luxemburg onderworpen. ${ }^{339}$ De vraag of het criterium feitelijke gezinsband in strijd was met de nieuwe Europese richtlijn was al enkele malen aan Nederlandse rechters voorgelegd. De richtlijn stelde dat toelating mocht worden geweigerd indien geen sprake meer was van 'werkelijk gezinsleven', maar het was de vraag of de invulling die de Nederlandse regering aan dat begrip gaf in overeenstemming was met het communautair recht. De Vreemdelingenkamers hadden al enkele malen geoordeeld van niet, maar die uitspraken waren in hoger beroep bij de Afdeling bestuursrechtspraak van de Raad van State steeds verworpen. ${ }^{340}$ Om de uniformiteit van het Gemeenschapsrecht te waarborgen, zijn nationale rechtbanken echter verplicht om wanneer onduidelijkheid bestaat over de interpretatie van het Europees recht een zogenaamd 'préjudicieel advies' te vragen bij het Europees Hof in Luxemburg en om dat advies te volgen in hun rechtspraak. ${ }^{341}$ Uiteindelijk zou ook de compatibiliteit van het criterium feitelijke gezinsband met de Europese richtlijn aan het Hof moeten worden voorgelegd. Lodder verwacht dat de Nederlandse regering in het ongelijk zou zijn gesteld. ${ }^{342}$ Volgens Groenendijk e.a. en Van Walsum moet de afschaffing van dit criterium dan ook mede als een uitwerking van het nieuwe EU-recht worden gezien, al repte minister Verdonk in de onderbouwing van haar beleidswijziging met geen woord over de Europese richtlijn. ${ }^{343}$ Baldinger vermeldt dat ambtenaren van Justitie in de rechtszaal wel eens hebben gesuggereerd dat de gezinsherenigingsrichtlijn bij die beslissing een rol heeft gespeeld. ${ }^{344}$ Lodder veronderstelt dat de minister niet wilde erkennen dat ze in strijd met de

338 тк 2006-2007 19637 (1089).

339 Zie paragraaf 4.12 .

340 Groenendijk e.a. 2007a: 23; Baldinger 2007: 289-290.

341 Barkhuysen 2007: 327-332.

342 Lodder 2007: 28-29.

343 Groenendijk e.a. 2007a: 22-23; Van Walsum (te verschijnen): 25-28.

344 Baldinger 2007: 290. 
richtlijn had gehandeld, omdat Nederland in dat geval zou kunnen worden verplicht tot het betalen van een schadevergoeding. ${ }^{345}$

\subsection{Enkeltje Brussel? De Europese gezinsherenigingsrichtlijn}

In 2003 heeft de Raad van Ministers van de Europese Unie een richtlijn aangenomen inzake het recht op gezinshereniging. ${ }^{346}$ Deze richtlijn maakt onderdeel uit van het Gemeenschapsrecht en is dus direct toepasbaar. Ze gaat boven Nederlands recht - waar communautair en nationaal recht botsen moet de nationale regelgeving buiten toepassing blijven - en de Europese Commissie en het Europees Hof van Justitie in Luxemburg zien toe op haar implementatie. Daarmee is de zeggenschap over het Nederlands gezinsmigratiebeleid voor een belangrijk deel overgeheveld van Den Haag naar Brussel.

In het Verdrag van Amsterdam (1997) hadden de lidstaten hun voornemen vastgelegd om binnen vijf jaar tot gemeenschappelijke regelgeving te komen op het gebied van 'voorwaarden voor toegang en verblijf (...), met name met het oog op gezinshereniging'. ${ }^{347}$ In 1999 presenteerde de Europese Commissie een eerste voorstel voor een Europese gezinsherenigingsrichtlijn. De Commissie had zich laten leiden door de uitspraak van de Europese Raad in Tampere datzelfde jaar, dat de EU ernaar streefde derdelanders 'rechten en verplichtingen te geven die vergelijkbaar zijn met die van de EU-burgers' ${ }^{348}$ Het Commissievoorstel zocht daarom aansluiting bij het communautair recht op gezinshereniging voor EU-burgers, dat relatief soepel was. Dit viel niet in goede aarde bij de lidstaten en de onderhandelingen liepen in eerste instantie vast. In 2002 kwam de Commissie met een gewijzigd voorstel en op 22 september 2003, ruim drie jaar na het begin van de onderhandelingen, werd de gezinsherenigingsrichtlijn door de Raad aangenomen. De richtlijn trad op 3 oktober 2003 in werking. De lidstaten hadden twee jaar de tijd om de maatregel te implementeren: vanaf

345 Lodder 2007: 29.

346 Richtlijn 2003/86 EG van de Raad van 22 september 2003 inzake het recht op gezinshereniging. Publicatieblad EU 2003 L251/12.

347 Verdrag van Amsterdam (Verdrag tot oprichting van de Europese Gemeenschap, Publicatieblad Nr. C 340 van 10 november 1997), artikel 63 lid 3 onder a. Zie over de ontwikkeling van het Europees asiel- en migratiebeleid tot het Verdrag van Amsterdam: paragraaf 4.2.

348 Conclusies van het voorzitterschap van de Europese Raad van Tampere, 15 en 16 oktober 1999: paragraaf 18. 
3 oktober 2005 was de richtlijn bindend en konden individuen er direct rechten aan ontlenen. ${ }^{349}$

De richtlijn is van toepassing op derdelanders die in de Europese Unie gevestigd zijn en gezinsleden willen laten overkomen. Zij heeft dus geen betrekking op gezinshereniging voor Nederlanders of andere EU-burgers die in Nederland wonen. Vreemdelingen met een tijdelijke verblijfsvergunning vallen eveneens buiten het bereik van de richtlijn. Gezinshereniging of -vorming is toegestaan als de aanvrager beschikt over een verblijfsdocument voor tenminste één jaar met uitzicht op permanent verblijf, stabiel en regelmatig inkomen om zijn gezin te onderhouden, normale huisvesting en een ziektekostenverzekering voor zichzelf en zijn gezinsleden. Buitenlandse gezinsleden die een bedreiging vormen voor de openbare orde kunnen worden geweigerd. Lidstaten hebben de mogelijkheid om deelname in integratieprogramma's te eisen en kunnen een wachttijd van maximaal twee jaar en een minimumleeftijd bij huwelijkspartners van maximaal 21 jaar hanteren. Na één jaar hebben gezinsleden recht op dezelfde toegang tot onderwijs en arbeidsmarkt als de reeds gevestigde migrant. Voor gezinsleden van vluchtelingen geldt een soepeler regime. De bepalingen in de richtlijn zijn minimumnormen: het staat lidstaten vrij om gunstiger bepalingen aan te nemen. ${ }^{350}$

\section{De Nederlandse inbreng in de onderhandelingen}

De onderhandelingen in Brussel over de gezinsherenigingsrichtlijn zijn namens Nederland gevoerd door drie opeenvolgende kabinetten: het tweede kabinet Kok en de eerste twee kabinetten Balkenende. In het algemeen was de Nederlandse inbreng erop gericht de richtlijn zo nauw mogelijk te laten aansluiten bij het Nederlands beleid. ${ }^{351}$ Uit onderzoek van Groenendijk en Minderhoud blijkt dat Nederland twintig voorstellen voor wijzigingen heeft gedaan, waarvan er zeventien een restrictief karakter hadden. ${ }^{352}$ Daarbij was de lijn die de kabinetten Balkenende kozen logischerwijs restrictiever dan de lijn van het Paarse kabinet.

Op een aantal punten nam het kabinet Kok echter ook al een restrictief standpunt in. Zo heeft het er tevergeefs op aangedrongen het criterium

349 Groenendijk e.a. 2007a: 18; Groenendijk e.a. 2007b: 2-3; Niessen 2004: 8.

350 Groenendijk 2006: 217-218; Niessen 2004: 8-9.

351 Groenendijk 2006: 220.

352 Groenendijk \& Minderhoud 2004: 144-145. 
'feitelijke gezinsband' in de richtlijn op te nemen, een strengere inkomenseis te stellen en het hanteren van gunstiger voorwaarden door individuele lidstaten te verbieden. ${ }^{353}$ Het Paarse kabinet was wel succesvol in zijn protest tegen het voorstel van de Commissie om een verbod op discriminatie van eigen onderdanen ten opzichte van andere EU-burgers in de richtlijn vast te leggen. Sinds 1993 was het Nederlands gezinsmigratiebeleid voor Nederlands staatsburgers en derdelanders significant stringenter dan het intra-Europees migratieregime. Gelijke behandeling van staatsburgers en EU-burgers zou 'een aanzienlijk versoepeling van het bestaande nationaal beleid' betekenen: zo zouden de inkomenseis en de mvv-verplichting moeten worden afgeschaft. ${ }^{354}$ Voor de Nederlandse delegatie was dit een 'breekpunt' in de onderhandelingen. Denemarken, Duitsland en het Verenigd Koninkrijk vielen Nederland bij, waarop de Commissie deze omstreden bepaling heeft geschrapt. ${ }^{355}$

De overkomst van buitenlandse gezinsleden van Nederlanders valt dus buiten het bereik van de richtlijn: Den Haag behoudt voorlopig exclusief zeggenschap over de voorwaarden die hieraan worden gesteld. Bij de presentatie van haar gewijzigde voorstel in 2002 heeft de Commissie echter nadrukkelijk aangegeven deze richtlijn als een 'eerste stap' in de ontwikkeling van een Europees gezinsmigratiebeleid te zien en op korte termijn met voorstellen voor verdere harmonisering te zullen komen. Europese regelgeving voor de overkomst van gezinsleden van eigen onderdanen staat daarbij hoog op het prioriteitenlijstje. ${ }^{356}$

Een punt waarop Nederland zich steeds sterk heeft gemaakt voor een soepele benadering, is de erkenning van het recht op gezinshereniging voor ongehuwde partners. Voor de Nederlandse delegatie was gelijke behandeling van homoseksuele koppels van bijzonder belang. ${ }^{357}$ Dit voorstel stuitte echter op fel verzet van de vier zuidelijke lidstaten. Uiteindelijk is in de richtlijn opgenomen dat lidstaten de mogelijkheid hebben om 'ongehuwde levenspartners' toe te laten. Deze bepaling is van weinig praktische betekenis, aangezien het lidstaten sowieso vrijstaat om soepeler beleid te voeren. Nederland had liever een recht op gezinshereniging gezien, maar nam met

353 Groenendijk \& Minderhoud 2004: 144; Nota hoofd DVB aan staatssecretaris, 22 augustus 2001. MJ A01/5238.

354 TK 2001-2002 28198 (2): 12-13; Nota Directie Jeugd- en Criminaliteitspreventie aan staatssecretaris, 12 december 2001. MJ A99/5253.

355 Groenendijk 2006: 228; Lodder 2007: 26.

356 Lodder 2007: 31; Groenendijk e.a. 2007b: 3.

357 Nota hoofd DVB aan staatssecretaris, 21 november 2001. MJ A99/5253. 
dit compromis genoegen, blij dat toelating van niet-huwelijkse partners in ieder geval niet uitgesloten was. ${ }^{358}$

Het kabinet Balkenende voegde een aantal elementen toe aan het Nederlands verlanglijstje, om ruimte te maken voor de uitvoering van zijn regeerakkoord. ${ }^{359}$ Zo wist Nederland de overige lidstaten ervan te overtuigen om verhoging van de minimumleeftijd voor huwelijkspartners tot 21 jaar mogelijk te maken. Eveneens succesvol was het voorstel van de Nederlandse, Duitse en Oostenrijkse delegaties om lidstaten toe te staan integratie-eisen te stellen aan gezinsmigranten, eventueel al vóór de overkomst. ${ }^{360}$ Overigens doet zich hier een interessant verschijnsel voor: de Nederlandse tekst van de richtlijn wijkt af van die in de andere talen van de Unie. Zij spreekt over 'integratievoorwaarden', waar in alle andere vertalingen de term 'integration measures' wordt gebruikt. Volgens Groenendijk e.a. is het verschil substantieel: de Nederlandse tekst laat ruimte voor het invoeren van een toets én een slaagplicht. Alle andere teksten staan slechts toe gezinsleden te verplichten tot deelname aan integratiemaatregelen, niet om te eisen dat ze slagen voor een toets. ${ }^{361}$ Het is aan de rechter om te bepalen of de Nederlandse interpretatie in strijd is met de richtlijn: zo ja, dan zal de Wet Inburgering in het Buitenland in haar huidige vorm niet langer kunnen worden toegepast. ${ }^{362}$ Een laatste Nederlands voorstel dat door de andere lidstaten is aanvaard betreft de beperking van de toepassing van versoepelde voorwaarden voor gezinshereniging van vluchtelingen tot gezinsleden die zich binnen drie maanden bij de vluchteling voegen, het zogenaamde 'nareis-criterium'. Wanneer meer dan drie maanden verlopen tussen de binnenkomst van de vluchteling en de overkomst van zijn gezin, zijn de normale voorwaarden voor gezinshereniging, zoals de inkomenseis, van toepassing. ${ }^{363}$

Groenendijk en Minderhoud hebben laten zien, dat het Nederlandse parlement nauwelijks invloed heeft uitgeoefend op de totstandkoming van

358 Nota hoofd DVB aan staatssecretaris, 3 juli 2002. MJ A99/5253; Groenendijk \& Minderhoud 2004: 145 .

359 Groenendijk \& Minderhoud 2004: 154.

360 De regering-Balkenende heeft samen met Oostenrijk en Duitsland eveneens met succes voorgesteld om de toelating van kinderen boven de 12 of 15 jaar te beperken op grond van integratieoverwegingen. De richtlijn stipuleert echter dat dit in de nationale wetgeving moet zijn vastgelegd op het moment dat de richtlijn in werking trad. In Nederland is dat voor 3 oktober 2005 niet gebeurd: deze bepaling kan dus niet worden toegepast.

361 Groenendijk e.a. 2007a: 23.

362 Zie Baldinger 2007: 292.

363 Groenendijk \& Minderhoud 2004: 144-145. 
de gezinsherenigingsrichtlijn. Geen van de - schaarse - vragen en opmerkingen die Kamerleden stelden hebben geleid tot 'een zichtbare verandering in de opstelling van de Nederlandse regering in Brussel'. ${ }^{364}$ De Eerste Kamer heeft de regering wel gedwongen om bij het instemmen met de richtlijn formeel te verklaren, dat artikel 8 EVRM de ondergrens moest zijn bij de interpretatie van de richtlijn. ${ }^{365}$ Deze verklaring lijkt echter vooral van symbolische betekenis, aangezien de nationale rechter en het Hof van Luxemburg er sowieso op toezien dat Europese regelgeving in overeenstemming met mensenrechtelijke verdragen wordt toegepast. Van directe parlementaire invloed is dus geen sprake, maar wel is heel duidelijk zichtbaar dat de verschuiving in de politieke meerderheid in de Tweede Kamer en daarmee in de regeringscoalitie na de verkiezingen van mei 2002 tot aanzienlijke wijzigingen heeft geleid in de standpunten die Nederland in Brussel verdedigde.

\section{Invloed op beleidsvorming en beleid in Nederland}

In de jaren zestig leidde de totstandkoming van het Europees migratierecht voor EG-werknemers al tijdens de onderhandelingsfase tot verschuivingen in de machtsverhoudingen in Den Haag. In de strijd tussen de ministeries over het al dan niet toelaten van gezinnen van arbeidsmigranten werd de positie van Sociale Zaken versterkt, ten koste van die van Justitie. ${ }^{366}$ Een vergelijkbaar proces deed zich tijdens de onderhandelingen in Brussel over de gezinsherenigingsrichtlijn niet voor.

GroenLinks en PvdA beriepen zich bij hun verzet tegen de verhoging van het inkomensvereiste bij de invoering van de Vreemdelingenwet 2000 weliswaar op de uitspraak van de Europese Raad in Tampere dat de rechtspositie van derdelanders moest worden versterkt, maar zonder succes. ${ }^{367}$ Ook in de discussies in 2002 over de invoering van een borgsom voor inburgering vroeg de PvdA zich af hoe een dergelijke voorwaarde zich zou verhouden tot het Europees gezinsmigratiebeleid in wording. ${ }^{368}$ In de ambtelijke discussies tussen Binnenlandse Zaken en Justitie over diezelfde inburgeringsborgsom bracht Justitie als tegenargument in, dat deze voorwaarde

364 Groenendijk \& Minderhoud 2004: 151-155.

365 TK 2002-2003 23490 (282): 16.

366 Zie paragraaf 2.5 .

367 TK 1999-2000 Handelingen 6 juni 2000: 5350; Handelingen 7 juni 2000: 5383-5384; EK 2000-2001 Handelingen 14 november 2001: 9.

368 тк 2001-2002, 28198 (5): 3. 
uniek in Europa zou zijn en de Nederlandse onderhandelingspositie dus zou bemoeilijken. ${ }^{369}$ Noch de PvdA, noch Justitie boekte met deze redenering succes. De bescheiden parlementaire inbreng in de totstandkoming van de Europese richtlijn zou de indruk kunnen wekken dat de positie van de regering ten opzichte van de volksvertegenwoordiging is versterkt door de opkomst van de Europese beleidsarena. De voorstellen die de regering deed betroffen echter steeds elementen uit het Nederlands beleid die de steun genoten van een meerderheid in de Kamer. ${ }^{370}$ Het Brussels onderhandelingsproces heeft dus geen significant effect gehad op de machtsverhoudingen in Nederland, dat wil zeggen op de relatieve invloed van politieke partijen, bewindslieden of ministeries op het besluitvormingsproces.

Ook de invloed van de Europese richtlijn op het Nederlands gezinsmigratiebeleid zelf blijft tot nu toe beperkt. De Nederlandse regering is dan ook vrij succesvol geweest in haar streven, de richtlijn zo te formuleren dat de bestaande regelgeving zo min mogelijk zou moeten worden aangepast. Eén belangrijk punt waarop dat niet is gelukt, betreft het criterium 'feitelijke gezinsband'. De uitzonderingspositie die Nederland met dit criterium in Brussel innam was voor staatssecretaris Kalsbeek al in 2001, nog voor de richtlijn was aangenomen, reden om het beleid te versoepelen. In 2006 besloot minister Verdonk zelfs tot afschaffing van de regel dat gezinshereniging met kinderen die langdurig aan de zorg van anderen waren toevertrouwd moest worden geweigerd, omdat van een 'feitelijke gezinsband' met de ouders geen sprake meer was. Hoewel de minister aangaf tot dit besluit te zijn gekomen op grond van een uitspraak van het Europees Hof in Straatsburg en daarbij met geen woord repte over de Europese gezinsherenigingsrichtlijn, zijn veel juristen ervan overtuigd dat deze beleidswijziging tenminste deels als een effect van de nieuwe richtlijn moet worden beschouwd. $^{371}$

Sinds de inwerkingtreding in 2003 is nog één andere wijziging van het Nederlands gezinsmigratiebeleid doorgevoerd onder expliciete verwijzing naar de richtlijn. Voortaan hebben alleenstaande minderjarige vluchtelingen het recht om hun ouder of ouders naar Nederland te laten komen. ${ }^{372}$ Ten slotte hebben zowel CDA als VVD zich de laatste jaren voorstander getoond

369 Nota DVB aan staatssecretaris, 15 januari 2002. MJ A99/5253.

370 Anders dan Guiraudon \& Lahav (2000: 175-190) veronderstellen, was het ontsnappen aan 'domestic constraints' dus geen drijfveer voor de Nederlandse regering om Europees beleid te ontwikkelen. Zie paragraaf 5.3.

371 Zie paragraaf 4.10.

372 Groenendijk e.a. 2007a: 22. 
van een verhoging van de minimumleeftijd bij gezinsvorming van 21 tot 24 jaar. ${ }^{373}$ Voor een dergelijke aanscherping zou waarschijnlijk de steun van een politieke meerderheid kunnen worden gevonden, maar de Europese richtlijn staat geen hogere leeftijdsgrens toe dan 21 jaar. Hier laat de invloed van het communautair recht op het Nederlands beleid zich dus gelden, doordat een hervormingsvoorstel in de kiem wordt gesmoord. ${ }^{374}$

\section{De toekomst van het Nederlands gezinsmigratiebeleid}

In eerste instantie waren belangenorganisaties en juristen teleurgesteld over de Europese richtlijn, die derdelanders bij lange na niet dezelfde rechten op gezinshereniging geeft als EU-burgers en die de lidstaten veel ruimte biedt om aanvullende voorwaarden te stellen. ${ }^{375}$ Inmiddels zijn zij daarvan teruggekomen. ${ }^{376}$ De kracht van de richtlijn zit hem in het feit dat hij deel uitmaakt van het communautair recht. Dit betekent dat de Commissie en het Europees Hof van Justitie in Luxemburg toezien op de correcte en uniforme toepassing van de richtlijn in alle lidstaten. In het verleden is vaker gebleken dat de rechtspraak een belangrijke eigen rol speelt in het vorm geven van Europees beleid: Europese wetgeving is immers steeds het resultaat van een compromis tussen de lidstaten en de Europese instellingen en bevat daarom vaak formuleringen die ruimte laten voor interpretatie. Het vrij verkeer van werknemers is een goed voorbeeld van een beleidsterrein waar het Hof, samen met de Commissie, een actieve rol heeft gespeeld en daarbij een invulling heeft gegeven die wellicht verder ging dan wat de lidstaten in eerste instantie voor ogen stond. ${ }^{377}$

Het Europees Hof heeft zich inmiddels een eerste keer uitgesproken over de richtlijn, naar aanleiding van een klacht van het Europees Parlement dat een aantal bepalingen uit de richtlijn in strijd zouden zijn met artikel 8

373 TK 2004-2005 19637 (873); Nota Immigratie en Integratie van vVD-Kamerlid Henk Kamp, 12 november 2007. Website VvD, www.vvd.nl.

374 Op 4 juli 2008 bepaalde de rechtbank in Roermond dat het inkomensvereiste van $120 \%$ van het minimumloon bij gezinsvorming in strijd is met de Europese gezinsherenigingsrichtlijn. (Website van de Rechtspraak en de Hoge Raad der Nederlanden, LJ Nummer: BD6637, www. rechtspraak.nl) Het ministerie van Justitie is in hoger beroep gegaan. (NRC Handelsblad, 'Looneis vervalt bij importbruid', 22 juli 2008) Mocht het ministerie ook in hoger beroep in het ongelijk worden gesteld, dan kan voortaan alleen nog bij toelating van buitenlandse gezinsleden van Nederlands staatsburgers - die buiten het bereik van de richtlijn vallen - een inkomenseis van meer dan $100 \%$ van het minimumloon worden gesteld.

375 Zie bijvoorbeeld Schaffrin 2005; Walter 2004.

376 Groenendijk 2006: 221.

377 Zie Groenendijk 2006: 221; Joppke 2001: 354-355. 
EVRM. ${ }^{378}$ Het Hof achtte die klacht in 2006 ongegrond, maar heeft van de gelegenheid gebruikt gemaakt om de betekenis van de richtlijn te verduidelijken. Deze kent, zo stelde het Hof, een subjectief recht op gezinshereniging toe aan derdelanders. Dit betekent dat lidstaten verplicht zijn om de overkomst van leden van het kerngezin toe te staan wanneer de aanvrager voldoet aan de voorwaarden zoals gestipuleerd in de richtlijn. Lidstaten hebben op dit punt 'geen beoordelingsmarge'. Ook als lidstaten gebruik maken van de uitzonderingen die de richtlijn toestaat, zoals de mogelijkheid om integratie te verplichten of een wachttijd te hanteren, valt hun handelen onder de controle van het Hof. Verder heeft het Hof verklaard dat de algemene beginselen van de communautaire rechtsorde ook op de richtlijn van toepassing zijn. Groenendijk e.a. verwachten daarom dat lidstaten geen ruimte meer zullen krijgen om een eigen invulling te geven aan begrippen als 'openbare orde', 'voldoende inkomen' ${ }^{379}$ of 'werkelijk gezinsleven': dit zijn bestaande begrippen in het communautair recht en het Hof zal, in zijn streven naar coherentie in het Europees recht, van de lidstaten eisen dat zij zich aan de jurisprudentie confirmeren. ${ }^{380}$

De status van de Europese richtlijn is dus een geheel andere dan die van artikel 8 EVRM en de jurisprudentie van het Hof in Straatsburg. Uitgangspunt daarin was steeds dat staten soeverein zijn in het toelaten of weigeren van vreemdelingen. Het recht op gezinsleven stelt grenzen aan die vrijheid en verplicht tot een afweging tussen de belangen van de staat en die van het individu. Staten krijgen veel ruimte om die afweging te maken en om het staatsbelang te definiëren. De gezinsherenigingsrichtlijn werkt volgens het Hof van Luxemburg andersom: derdelanders hebben een recht op gezinshereniging, waarop lidstaten slechts in beperkte gevallen inbreuk kunnen maken. ${ }^{381}$

Groenendijk e.a. constateren dat sinds de inwerkingtreding van de gezinsherenigingsrichtlijn "praktisch alle beslissingen van nationale instanties van de lidstaten over visa of verblijfsvergunningen voor gezinshereniging (...) besluiten ter uitvoering van EG-recht' zijn. ${ }^{382}$ Europese regelgeving bepaalt welke eisen kunnen worden gesteld aan de overkomst van gezinsleden van in Nederland gevestigde vreemdelingen die geen EU-burgers zijn.

378 Zaak C-540/03 (Parlement/Raad) van het Hof van Justitie, 27 juni 2006.

379 Zie noot 374 in hoofdstuk 4.

380 Groenendijk 2006: 221, 226-227; Groenendijk e.a. 2007a: 28.

381 Groenendijk e.a. 2007a: 21, 28; Groenendijk e.a. 2007b: 9; zie ook Groenendijk 2006: 225-

226.

382 Groenendijk e.a. $2007 \mathrm{a}: 17$. 
De richtlijn biedt weliswaar de nodige ruimte aan lidstaten om aanvullende voorwaarden te stellen, zoals integratievereisten of een wachttijd, maar Nederland maakt op dit moment al vrijwel maximaal gebruik van deze ruimte. Aanscherping van het gezinsmigratiebeleid voor derdelanders is nauwelijks meer mogelijk, althans niet in Den Haag: dat kan alleen nog in Brussel. ${ }^{383}$ Het staat de Nederlandse overheid wel te allen tijde vrij om het beleid te versoepelen. Verder beslist de Nederlandse politiek voorlopig nog zelf aan welke voorwaarden Nederlanders moeten voldoen om zich met buitenlandse gezinsleden te mogen herenigen, maar de Commissie is voornemens daar spoedig verandering in te brengen.

De jurist Günter Renner schreef in 2005 dat de Duitse wetgever na aanname van de verschillende Europese richtlijnen over asiel en migratie op het gebied van vreemdelingenbeleid 'weitgehend nur noch die Funktion der Ausführung und der Lückenfüllung' toeviel. ${ }^{384}$ Hetzelfde geldt voor de Nederlandse wetgever. Volgens Groenendijk hebben niet alleen Nederlandse politici en ambtenaren maar ook hun Europese collega's de gevolgen van de richtlijn ernstig onderschat. Zij waren er vrijwel uitsluitend op gericht om de tekst van de richtlijn zo te formuleren dat het bestaande nationale beleid ongewijzigd kon blijven en gaven zich er te weinig rekenschap van dat het Europees beleidsvormingsproces vaak niet ophoudt als er een besluit van de Raad ligt. De Commissie en het Hof willen immers nogal eens een actieve, autonome rol spelen bij het interpreteren van Europese regelgeving, die dan ook pas bij de implementatie en de controle daarop concreet en definitief vorm krijgt. De onderhandelaars in Brussel waren overwegend experts in vreemdelingenrecht, niet in Europees recht. Daardoor overzagen zij niet welke gevolgen de toepassing van algemene principes van het communautair recht op de interpretatie van de richtlijn zouden hebben. ${ }^{385}$

De belangrijkste consequenties van de gezinsherenigingsrichtlijn liggen dus in de toekomst. De beleidsruimte waarover Nederlandse beleidsmakers beschikken om het gezinsmigratiebeleid te hervormen is reeds zeer

383 De Nederlandse overheid beschikt nog wel over ruimte om de overkomst van niet-huwelijkse partners aan strengere voorwaarden te onderwerpen, het gezinsmigratiebeleid voor subsidiaire vluchtelingen aan te scherpen, het huisvestingsvereiste opnieuw in te voeren of de wachttijd te verhogen. De inkomens- en leeftijdseis kunnen echter niet verder worden verhoogd. Evenmin kunnen volkomen nieuwe voorwaarden worden ingevoerd, die in de richtlijn niet worden genoemd. 384 'in vérgaande mate slechts nog de taak om uit te voeren en hiaten op te vullen'. Renner 2005: 19.

385 Groenendijk 2006: 220-221. 
significant ingeperkt en zal in de toekomst waarschijnlijk nog kleiner worden, als gevolg van jurisprudentie van het Europees Hof in Luxemburg en van voorstellen voor verdere harmonisatie door de Europese Commissie. Dit boek beschrijft de geschiedenis van de Haagse besluitvorming inzake gezinsmigratie vanaf de jaren vijftig: de Europese richtlijn luidt het begin van het einde van die geschiedenis in. De voorwaarden voor toelating en verblijf van buitenlandse gezinsleden in Nederland worden voortaan primair in Brussel en Luxemburg vastgesteld.

\subsection{Besluit}

In 1993 werd het Nederlands gezinsmigratiebeleid voor het eerst in lange tijd aangescherpt. De vrijstelling van de inkomenseis in geval van onvrijwillige werkloosheid werd vervangen door een inkomenseis van $70 \%$ van de bijstandsnorm. Met deze bescheiden eerste stap werd een restrictieve lijn ingezet: geleidelijk werd de inkomenseis verder verhoogd en werden strengere leeftijdseisen gesteld. Na de eeuwwisseling werd de overkomst van buitenlandse gezinsleden bovendien voor het eerst onderworpen aan integratievereisten. Als gevolg van de restrictieve wending die begin jaren negentig is ingezet behoort het Nederlands gezinsmigratiebeleid in 2005 tot de strengste in Europa.

Continuïteit en discontinuïteit in het perspectief op het gezinsmigratievraagstuk

In de jaren tachtig was de overkomst van buitenlandse gezinsleden slechts aan minimale voorwaarden onderworpen; tegenwoordig zijn de eisen zeer streng. Aan deze ommekeer lag een wezenlijke veranderingen in het perspectief van Nederlandse beleidsmakers op het gezinsmigratievraagstuk ten grondslag.

Begin jaren tachtig leefde bij politici en ambtenaren nog het vertrouwen dat migranten, met behulp van gericht overheidsbeleid, binnen afzienbare tijd hun plaats zouden vinden in de Nederlandse samenleving. Eind jaren tachtig was dat optimisme aangetast: de positie van minderheden op de arbeidsmarkt en op school verbeterde niet, maar verslechterde. 
Het integratievraagstuk werd het onderwerp van bezorgde discussies, niet alleen onder politici maar ook in het bredere publieke debat. Daarmee werden migratie en integratie ook electoraal steeds gewichtiger thema's. Daarbij kwam dat de politiek begin jaren negentig erkende, dat immigratie naar Nederland ook bij handhaving van een restrictief toelatingsbeleid als een permanent fenomeen moest worden beschouwd. De integratie van immigranten was dus een structureel en zorgwekkend probleem, dat dringend om een beleidsrespons vroeg.

Alle aanscherpingen van het gezinsmigratiebeleid die tussen 1993 en 2005 zijn doorgevoerd dienden om deze integratieproblematiek het hoofd te bieden en wel op twee manieren. ${ }^{386}$ Eerst en vooral moest het probleem kleiner worden gemaakt door de omvang van de immigratie terug te dringen. Anders dan in de jaren tachtig bleven gezinsmigranten, die een aanzienlijk deel van de instroom uitmaakten, nu niet langer buiten schot. Het moreel recht op gezinshereniging woog niet meer op tegen het maatschappelijk belang bij migratiebeperking. De voorwaarden die aan gezinsmigratie werden gesteld dienden echter niet alleen om toegang tot Nederland te bemoeilijken: zij dienden ook om betrokkenen te stimuleren om hun toekomst in Nederland en die van hun gezin in eigen hand te nemen. Hun integratieproces was veel meer gebaat bij participatie en zelfredzaamheid dan bij een al te zorgzame overheid. Deze nieuwe visie op de verhouding tussen overheid en burger werd gevangen in het principe van 'eigen verantwoordelijkheid' dat het CDA begin jaren negentig krachtig inbracht in het debat en dat sindsdien in iedere beleidsnota over gezinsmigratie als centraal uitgangspunt geldt.

In de kwantitatieve doelstellingen van het gezinsmigratiebeleid en in de nadruk op het principe van 'eigen verantwoordelijkheid' is er dus sprake van continuiiteit over het tijdvak dat in dit hoofdstuk besproken is. Daarnaast bestaan ook wezenlijke verschillen tussen de perspectieven die vóór en na de eeuwwisseling de beleidsvorming bepaalden. In de late jaren negentig raakte het migratie- en integratievraagstuk in het publiek debat allengs verweven enerzijds met vragen rondom de Nederlandse identiteit

386 Bruquetas-Callejo e.a. (2006: 26) constateren net als ik dat er sprake is van een 'more systemic connection between immigration and integration' sinds de jaren negentig. Zij stellen echter dat het integratiebeleid vooral sinds 2000 steeds meer wordt gebruikt als 'tool for restricting immigration'. Hoewel de integratievereisten die in de WIB aan gezinsmigranten worden gesteld inderdaad dienen om het aantal migranten terug te dringen, meen ik dat het verband primair andersom moet worden gelegd: het steeds restrictiever toelatingsbeleid is een middel om integratiedoeleinden te bereiken. 
en sociale samenhang en anderzijds met kritiek op het functioneren van de Nederlandse politiek. Deze 'issue linkage,387 culmineerde in de Fortuynrevolte: sindsdien stond de legitimiteit en representativiteit van Nederlandse politieke partijen op het spel in debatten over migratie en integratie. Politici benadrukten dat zij net als een groot deel van de kiezers de ernst van de integratieproblematiek inzagen en de oplossing zochten in een krachtig uitdragen van de progressieve normen die de kern van de Nederlandse identiteit uitmaakten, zoals individuele keuzevrijheid, gelijkheid van man en vrouw en een vrijzinnige kijk op seksualiteit, huwelijk en gezin. Gezinsmigratie werd gezien als resultaat én bron van gezinsverhoudingen en huwelijkspraktijken die met die normen in strijd waren, en daarmee als een directe oorzaak van het problematisch verloop van de integratie van minderheden in Nederland. Gezinsmigranten werden zowel in sociaal-economisch als in cultureel opzicht als een inherent problematische categorie migranten beschouwd.

Hier tekent zich een breuk af met de politieke debatten van de jaren negentig, waarin nauwelijks werd gesproken over normatieve of culturele aspecten van het gezinsmigratievraagstuk. Het type vreemdeling dat als gezinsmigrant in Nederland werd toegelaten speelde toen geen enkele rol: het waren er simpelweg te veel. Het kabinet Balkenende zag dat anders en voegde aan de kwantitatieve doelstellingen van de kabinetten onder Lubbers en Kok kwalitatieve oogmerken toe. Het vreemdelingenbeleid werd zo ingericht dat bij toelating een schifting kon worden gemaakt tussen migranten die inpasbaar waren en migranten met 'kenmerken die ongunstig zijn voor een goede integratie'. Daarmee werd het verband tussen de doeleinden van het immigratiebeleid en die van het integratiebeleid nauwer dan ooit.

\section{Continuïteit in de invloedsverhoudingen: de politiek beslist}

Sinds de jaren negentig is het migratie- en integratievraagstuk politiek gewichtiger en urgenter dan het in de na-oorlogse periode ooit is geweest; in de verkiezingsstrijd van 2002 bleek het doorslaggevend. ${ }^{388}$ In deze context namen politieke partijen de besluitvorming over het gezinsmigratiebeleid in eigen hand en was de invloed van ambtenaren op de beleidsvorming gering. In de jaren tachtig kwam het nog voor dat ambtenaren buiten de 
politiek om besloten tot significante wijzigingen van de voorwaarden voor gezinsmigratie: dat gebeurde vanaf de jaren negentig niet meer. Ambtelijke organisaties hadden wel degelijk hun eigen visies op het vraagstuk en brachten die ook te berde in beleidsdebatten: zo stuitten de hervormingen van 1993 op bezwaar bij de Directie Coördinatie Minderhedenbeleid van Binnenlandse Zaken, en de beleidwijzigingen na de eeuwwisseling op protest van de Directie Vreemdelingenbeleid van Justitie. Met name dit laatste geval zou erop kunnen wijzen dat institutionele beleidsperspectieven minder veranderlijk zijn dan de publieke of politieke opinie en dus in principe een remmende werking kunnen hebben op radicale beleidsherziening. Het laat echter ook zien dat zelfs bezwaren van hoge ambtenaren van de meest direct betrokken ambtelijke afdeling terzijde werden geschoven. Het politieke gewicht van het gezinsmigratievraagstuk liet geen ruimte voor substantiële ambtelijke inbreng.

Voor het eerst sinds de jaren vijftig speelde partijpolitiek een doorslaggevende rol in de beleidsvorming. De voornaamste beslissingen zijn genomen door de politieke partijen die het regeringspluche bezetten. Die besluitvorming vond niet in de Tweede Kamer plaats, maar buiten zicht van het publiek, in 1993 nog in kabinetsberaad en daarna in onderhandelingen tussen de fractievoorzitters over de regeerakkoorden. ${ }^{389}$ Ook in 1993 al oefenden de Kamerfracties van PvdA en CDA aanzienlijke invloed uit op de besluitvorming in het kabinet door 'hun' bewindslieden over hun politieke voorkeuren te informeren. Een dergelijke inmenging van Kamerleden voorafgaand aan het formele parlementaire debat kwam tot de jaren negentig niet voor. De sterk toegenomen invloed van politieke partijen op de beleidsvorming weerspiegelt het grotere electorale gewicht van het gezinsmigratievraagstuk. Waarschijnlijk wordt hier ook het veelbesproken gebrek aan dualisme in het Nederlands politiek bestel zichtbaar: de coalitiefracties en het kabinet zijn zodanig met elkaar verweven, dat de vraag of de regering dan wel de Kamer meer invloed uitoefent op de besluitvorming niet meer te beantwoorden is. ${ }^{390}$ Wellicht is het juister om te stellen dat de besluitvorming werd bepaald door 'coalitiepolitiek', dan door

389 Wat dit betreft lijkt er sprake te zijn van continuïteit in de Nederlandse politieke cultuur. Lijphart (1979: 124) schrijft over de jaren vijftig en zestig: 'Wat tenslotte in het openbaar in de Kamers werd behandeld was het resultaat van de onderhandelingen tussen de zuilen en dus meestal een uitgemaakte zaak; de Kamers moesten er alleen nog hun formele goedkeuring aan hechten'.

390 Mijn bevindingen lijken erop te duiden, dat dit afnemend dualisme een relatief recent fenomeen is, dat vanaf de jaren negentig van belang wordt. Tot nog toe is naar dualisme in de Nederlandse politiek vanuit historisch perspectief helaas geen onderzoek gedaan. 
'partijpolitiek'.

Het besluitvormingsproces mag zich echter grotendeels binnen de coalities hebben afgespeeld, het resultaat van die besluitvorming mocht vervolgens veelal rekenen op zeer brede steun in de Kamer. ${ }^{391}$ De schaarste van afwijkende meningen in parlementaire debatten is opmerkelijk. Vrijwel steeds stemden alle politieke partijen, op GroenLinks en de sP na, in met de voorstellen van de regering. Alleen de Wet Schijnhuwelijken van 1993, het gezinsherenigingsbeleid voor vluchtelingen van staatssecretaris Cohen en de verhoging van het inkomensvereiste bij gezinsvorming door minister Verdonk stuitten bij respectievelijk D66, CDA en PvdA op bezwaar. Vanaf 1993 waren alle politieke partijen behalve GroenLinks het erover eens dat het principe van 'eigen verantwoordelijkheid' centraal moest staan in het beleid. Na de eeuwwisseling bestreed geen enkele politieke partij de definitie van gezinsmigratie als directe oorzaak van culturele en sociaaleconomische integratieproblemen zowel voor de betrokkenen als voor de Nederlandse maatschappij als geheel. Givens en Luedtke veronderstellen dat 'high salience', i.e. veel belangstelling voor het migratievraagstuk in media en publieke opinie, leidt tot een 'high-conflict mode of immigration politics', ${ }^{392}$ De beleidsvorming inzake gezinsmigratie in Nederland sinds de jaren negentig laat echter een heel ander beeld zien: hoe 'salient' het thema ook was, er was minder sprake van conflicten dan van een opvallend brede en constante politieke consensus.

$\mathrm{Er}$ is dan ook geen eenduidige één-op-één relatie tussen de politieke kleur van het kabinet en het restrictieve gehalte van de gekozen beleidslijn, ook al speelden de coalitiepartijen een cruciale rol in de besluitvorming. ${ }^{393}$ De restrictieve wending in het gezinsmigratiebeleid is in de jaren negentig ingezet en doorgevoerd onder de directe verantwoordelijkheid van vier opeenvolgende staatssecretarissen van sociaaldemocratische signatuur. De aanscherpingen die na de eeuwwisseling werden doorgevoerd vloeiden weliswaar direct voort uit reeds jaren gekoesterde wensen van de grootste coalitiepartners CDA en VVD, maar zij genoten - op de verhoging van het inkomensvereiste na - de steun van de PvdA.

Wel valt op, dat het CDA zowel in de jaren negentig als na de eeuwwisseling een invloedrijke rol heeft gespeeld in de beleidsvorming. Het waren

391 Opnieuw een element van continuïteit: volgens Lijphart (1979: 129) bestond tot de late jaren zestig evenmin een 'scherpe grens tussen regerings- en oppositiepartijen'. Zie paragraaf 5.2.

392 Givens \& Luedtke 2004: 150.

393 Vgl. Vink 2007: 343-344. 
de christendemocraten die begin jaren negentig besloten dat het problematisch verloop van de integratie een breuk met het liberale gezinsmigratiebeleid van de jaren tachtig noodzakelijk maakte en die de PvdA ervan wisten te overtuigen dat het legitiem was om een beroep te doen op financiële 'eigen verantwoordelijkheid' van degenen die gezinshereniging wensten. Het principe van 'eigen verantwoordelijkheid' rechtvaardigt tot de dag van vandaag de voorwaarden die aan gezinsmigratie worden gesteld. Ook de invoering van inburgering in het buitenland als toelatingseis voor gezinsmigranten, een zeer innovatieve beleidswijziging, is door het CDA op de politieke agenda gezet.

\section{De hypothese van de 'control gap'}

Indien de beleidsvorming in Nederland inzake gezinsmigratie tussen 1989 en 2005 één ding laat zien, dan is het dat staten over ruime mogelijkheden beschikken om immigratie aan beperkingen te onderwerpen, als de politieke wil er maar is. Anders dan Cornelius e.a., Joppke, Guiraudon, Sassen en Soysal veronderstellen werd de capaciteit van staten om migratie te controleren - althans tot voor kort - niet significant ondermijnd door nationale of internationale rechtspraak. ${ }^{394}$

Vanaf de tweede helft van de jaren tachtig wordt de jurisprudentie van het Hof van Straatsburg, met name op grond van artikel 8 EVRM dat het recht op gezinsleven beschermt, wel een factor van belang in de beleidsvorming inzake gezinsmigratie. Bij ieder beleidsvoorstel wordt bezien of en hoe het binnen de grenzen valt die het Hof van Straatsburg stelt. In parlementaire debatten onderbouwen vooral linkse politici hun betoog geregeld met een verwijzing naar artikel 8 . Daarbij valt echter op dat Kamerleden zelden blijk geven van inzicht in de complexe en voorzichtige manier waarop het Hof in Straatsburg het belang van individuen bij gezinshereniging en het belang van de staat bij migratiebeheersing weegt. Ook de Nederlandse rechter is huiverig om 'op de stoel van het democratisch bestuur te gaan zitten'. De rechtspraak laat het bestuur veel ruimte om te bepalen welke voorwaarden in het algemeen belang aan gezinsmigratie mogen worden gesteld.

Op twee punten heeft de jurisprudentie op grond van artikel 8 EVRM wel een rol van belang gespeeld in de beleidsvorming. In de eerste plaats betrof het de wens van een - smalle - Kamermeerderheid halverwege de 
jaren negentig om ook bij vluchtelingen die niet zonder gevaar voor lijf en leden terug konden naar het land van herkomst om zich bij achtergebleven gezinsleden te voegen, vast te houden aan de inkomenseis bij gezinshereniging. Aangezien uit jurisprudentie van het Hof bleek dat het weigeren van toelating van gezinsleden een inbreuk op het recht op gezinsleven opleverde wanneer terugkeer objectief onmogelijk was, werd deze motie niet uitgevoerd. In de tweede plaats werd het criterium 'feitelijke gezinsband' afgeschaft, nadat het Hof tot twee keer toe had geoordeeld dat de manier waarop Nederland dit criterium toepaste in strijd was met artikel 8 EVRM.

De verhoging van het inkomensvereiste, de aanscherping van de leeftijdseisen en de introductie van inburgeringsvoorwaarden zijn echter bij de Nederlandse noch bij de Straatsburgse rechter op bezwaar gestuit, evenmin als de invoering van een harde mvv-eis en van controle op schijnhuwelijken. ${ }^{395}$ Met name de hervormingen van 2004 en 2005 lijken hun effect op de instroom niet te hebben gemist. ${ }^{396}$ Het totaal aantal gezinsmigranten is gedaald van ruim 32 duizend in 2003 tot bijna 28 duizend in 2006. Gezinsvorming laat een nog sterkere daling zien: van bijna 21 duizend in 2003 tot ruim 10 duizend in 2006. Het aantal huwelijksmigranten uit Marokko en Turkije, in de ogen van het kabinet Balkende de meest ongewenste migratiecategorie, is gedaald van 5440 in 2003 tot 2992 in $2006 .{ }^{397}$ Hoewel het bepaald niet zonder risico is om een exclusief causaal verband te veronderstellen tussen het toelatingsbeleid en de omvang van de instroom, lijkt hier toch de conclusie gerechtvaardigd dat het aantal gezinsmigranten door

395 De rechter achtte voor de invoering van het mvv-vereiste wel een wetswijziging noodzakelijk. Op 15 juli 2008 oordeelde de rechtbank in Amsterdam bovendien, dat het inburgeringsvereiste bij toelating dat met de WIB was ingevoerd, buiten toepassing moest blijven. Grond hiertoe was echter niet strijd met het recht op gezinsleven volgens artikel 8 EVRM, met de Europese gezinsherenigingsrichtlijn, of met enige andere inhoudelijke norm. Probleem was een 'kennelijke misslag van de wetgever'. In het Vreemdelingenbesluit staan de voorwaarden voor gezinsmigratie limitatief opgesomd: indien aan die voorwaarden is voldaan is de overheid verplicht een verblijfsvergunning te verlenen. De inburgeringseis staat in het Vreemdelingenbesluit echter niet genoemd. (Website voor de Rechtspraak en de Hoge Raad der Nederlanden, LJ nummer BD7 I 89, www.rechtspraak.nl) Een Kamermeerderheid - PVdA, CDA, VVD en PVV - blijft evenwel groot voorstander van inburgering in het buitenland. (NRC Handelsblad, 'Kamer wil inburgeringstoets in buitenland behouden', 17 juli 2008) Het probleem kan dus worden opgelost door het Vreemdelingenbesluit te wijzigen. 396 In de jaren negentig is de instroom, ondanks de restrictieve hervormingen, niet gedaald. Het CBS beschikt vanaf 1995 over migratiecijfers per migratiemotief. Dat jaar kwamen ruim 24 duizend gezinsmigranten naar Nederland; in 1998 waren dat er bijna 32 duizend; in 1999 en 2000 zakt de instroom even onder de 30 duizend om van 2001 tot 2003 weer boven de 32 duizend uit te stijgen. De vraag is natuurlijk of de instroom zonder de restrictieve hervormingen nog hoger zou zijn geweest. Website CBS, Immigratie naar migratiemotief, statline.cbs.nl.

397 Website CBS, Immigratie naar migratiemotief en geboorteland, statline.cbs.nl; INDIAC 2007: $42-43,47-48$. 
strengere toelatingseisen kan worden teruggebracht. De toetsing van de rechter was in de jaren tachtig niet stringenter dan nu: ook toen stond het de Nederlandse overheid vrij om gezinsmigratie aan dergelijke voorwaarden te verbinden. Anders dan in de jaren negentig ontbrak daartoe toen evenwel de politieke wil.

De these van Sassen, dat natiestaten als gevolg van globalisering zeggenschap over immigratie zijn kwijtgeraakt aan supranationale actoren, 'such as the institutions of the European Union, the newly formed World Trade Organisation, or the international human rights code', ${ }^{398}$ heeft recentelijk echter ten dele een nieuwe relevantie gekregen. Met de inwerkingtreding van de eerste Europese richtlijn inzake gezinshereniging is de bevoegdheid om de voorwaarden voor toegang en verblijf van buitenlandse gezinsleden in Nederland te bepalen inderdaad voor een aanzienlijk deel overgeheveld naar de instellingen van de Europese Unie. De Nederlandse soevereiniteit in deze zou in de toekomst nog verder kunnen worden ingeperkt, als gevolg van nieuwe harmonisatievoorstellen van de Commissie en van de jurisprudentie van het Europees Hof van Justitie in Luxemburg. In een eerste uitspraak heeft dat Hof inmiddels te kennen gegeven veel minder behoedzaam om te springen met de soevereiniteit van lidstaten inzake toelating en verblijf van gezinsmigranten dan het Hof van Straatsburg pleegt te doen. Tien jaar nadat Sassen haar hypothese van soevereiniteitsverlies aan supranationale actoren formuleerde, wordt deze - althans voor zover het de Europese Unie betreft - dan toch nog bevestigd.

398 Sassen 1999: 177; zie ook Sassen 1996: 12. 



\section{Besluit}

De ontwikkeling van de beleidsvorming in Nederland op het gebied van gezinsmigratie van de jaren vijftig tot op heden lijkt op een muziekstuk als de Bolero van Ravel: wat begon met een tromroffel en een enkele ijle fluit eindigt met een meerstemmig symfonieorkest, dooreenlopende melodielijnen en dreunende pauken. In de jaren vijftig en zestig was gezinsmigratie een relatief marginaal beleidsveld, dat in vérgaande mate aan een besloten kring ambtenaren werd overgelaten. Beslissingen werden genomen binnen de ministeries, grotendeels buiten zicht van parlement en publiek. In de loop der jaren werd de dynamiek van de besluitvormingsprocessen geleidelijk complexer. De spelers op het veld werden talrijker en diverser. Inhoudelijk raakte het gezinsmigratievraagstuk in de ogen van politiek en publiek steeds nauwer verweven met fundamentele kwesties rond maatschappelijke samenhang, collectieve identiteit en politieke legitimiteit.

\subsection{De ontwikkeling van het Nederlands gezinsmigratiebeleid, 1955-2005}

De voorwaarden die de Nederlandse overheid aan de overkomst van buitenlandse gezinsleden stelt hebben de laatste vijf decennia een slingerbeweging gemaakt: streng in de jaren vijftig en zestig, soepel in de jaren zeventig en tachtig, en weer steeds strenger vanaf de jaren negentig.

In de allereerste jaren van de grootschalige werving van arbeidsmigranten, tussen 1955 en 1960, was het buitenlandse werknemers niet toegestaan hun gezin naar Nederland te laten komen. In de loop van de jaren zestig werd het beleid geleidelijk versoepeld, maar de criteria bleven relatief streng: een vreemdeling diende minimaal een jaar in Nederland te hebben gewoond en gewerkt en daarnaast te beschikken over passende huisvesting en een arbeidscontract voor tenminste een jaar.

In de tweede helft van de jaren zeventig werden de criteria aanzienlijk verruimd. Niet alleen huwelijkse maar ook niet-huwelijkse heteroseksuele én homoseksuele relaties werden erkend als grond voor toelating en verblijf. Vrouwen kregen net als mannen de mogelijkheid om buitenlandse gezinsleden te laten overkomen. Nederlanders en vreemdelingen met een 
permanente verblijfstitel werden vrijgesteld van het inkomensvereiste, indien zij buiten hun schuld werkloos waren. ${ }^{1}$ Het gezinsmigratiebeleid bleef gedurende de gehele jaren tachtig soepeler dan het op enig ander moment in de naoorlogse periode is geweest. De enige significant aanscherping van de voorwaarden - de inkomenseis van 1445 gulden voor partners van migranten van de tweede generatie die in 1983 werd ingevoerd - werd na minder dan twee jaar alweer ingetrokken.

Vanaf de jaren negentig werd het gezinsmigratiebeleid stap voor stap aangescherpt. Het 'verwijtbaarheidscriterium' werd vervangen door een harde inkomenseis die geleidelijk werd verhoogd. Er werd structurele controle op schijnhuwelijken ingevoerd, evenals een stringente mvv-verplichting. Recentelijk is de minimumleeftijd voor huwelijksmigranten verhoogd van 18 naar 21 jaar. De Wet Inburgering in het Buitenland van 2005 bepaalt tenslotte dat verblijf alleen wordt toegestaan indien een gezinsmigrant heeft aangetoond over voldoende kennis van de Nederlandse taal en samenleving te beschikken. Daarmee is het huidig Nederlands gezinsmigratiebeleid uitzonderlijk stringent, niet alleen in historisch perspectief, maar ook in vergelijking met andere Europese landen. ${ }^{2}$

Hoe dient deze slingerbeweging van het Nederlands gezinsmigratiebeleid, van streng naar soepel en weer naar streng, te worden geduid? Intuïtief ligt het voor de hand, een verband te zoeken met de sociaal-economische situatie in Nederland. In Meyers' theoretische interpretatie van liberale en restrictieve tendensen in vreemdelingenbeleid is dit een primaire verklarende factor: landen sluiten hun grenzen voor vreemdelingen in tijden van recessie, en voeren een open migratiebeleid wanneer de economie bloeit. ${ }^{3}$ De ontwikkeling van het Nederlands gezinsmigratiebeleid laat echter een volstrekt tegengesteld beeld zien. De voorwaarden voor de overkomst van gezinsmigranten zijn nooit soepeler geweest dan in de jaren tachtig, op het dieptepunt van de economische crisis, bij een werkloosheid van $14 \%$ van de beroepsbevolking. In de jaren zestig daarentegen, toen de economische groei grenzeloos leek en bedrijven vochten om werknemers, was het gezinsmigratiebeleid relatief streng. Ook de restrictieve wending van het beleid vanaf de jaren negentig vond plaats in een gunstige - vanaf midden

1 Op buitenlandse echtgenotes van Nederlandse mannen waren de voorwaarden van het vreemdelingenbeleid tot 1985 niet van toepassing: zij konden toen direct opteren voor de Nederlandse nationaliteit. Zie paragraaf 5.3 voor een discussie van de ontwikkeling van de status van het Nederlands staatsburgerschap in het gezinsmigratiebeleid.

2 Zie noot 289 in hoofdstuk 4.

3 Meyers 2004: 202-203. 
jaren negentig zelfs zeer gunstige - economische context. Ter verdediging van de these van Meyers zou daar tegenin kunnen worden gebracht, dat de hervormingen die de kabinetten Lubbers en Kok hebben doorgevoerd als een vertraagde reactie op de crisis van de jaren tachtig moeten worden beschouwd. In een dergelijke redenering moeten echter zoveel tussenkomende factoren worden meegewogen - niet in de laatste plaats het effect van de recessies van de jaren zeventig en tachtig op de opkomst van neoliberale visies op de verzorgingsstaat - dat de economische situatie als verklarende factor an sich vrijwel betekenisloos wordt.

Een tweede verklaring die Meyers oppert en die op het eerste gezicht plausibel lijkt, relateert de beleidstendens aan de omvang en het type van de immigratiestromen: wanneer grootschalige immigratie 'of dissimilar racial/ethnic/cultural composition' plaatsvindt is de kans op restrictieve hervorming van het vreemdelingenbeleid groot. ${ }^{4}$ Dit causaal verband ontbreekt echter eveneens in de ontwikkeling van het Nederlands gezinsmigratiebeleid. Tussen 1975 en 1990 nam de Nederlandse bevolking met een Surinaamse, Turkse en Marokkaanse achtergrond respectievelijk toe van ruim 87 duizend tot bijna 233 duizend, van ruim 55 duizend tot ruim 203 duizend en van ruim 30 duizend tot ruim 163 duizend. Het totaal aantal niet-westerse allochtonen - een statistische categorie die nauw overeenkomt met wat Meyers onder 'dissimilar immigration' verstaat - nam toe van bijna 251 duizend in 1975 tot bijna 476 duizend in 1980 en bijna 866 duizend in 1990. ${ }^{5}$ Tussen 1975 en 1980 was het aantal niet-westerse allochtonen in Nederland dus bijna verdubbeld: desalniettemin werd in die jaren het gezinsmigratiebeleid significant versoepeld. In de tien jaar die volgden zette de grootschalige immigratie zich voort, grotendeels via het gezinsmigratiekanaal; het liberale gezinsmigratiebeleid werd desondanks gehandhaafd.

Externe materiële omstandigheden als de stand van de economie en de omvang van de migratiestromen kunnen op zichzelf niet verklaren, waarom Nederlandse beleidsmakers voor soepele of restrictieve benaderingen van gezinsmigratie hebben gekozen. Die verklaring vinden we wel in de manieren waarop betrokken actoren gezinsmigratie construeerden als beleidsprobleem: in hun perceptie van de materiële en immateriële, individuele en

4 Meyers 2004: 203. Meyers formuleert nog vijf andere algemene causale hypotheses, over oor$\log$, internationale betrekkingen, en general racist attitudes. Vervolgens spitst hij zijn hypotheses nog toe op specifieke categorieën: arbeidsmigratie, asiel, permanente 'dissimilar' en permanente 'similar' migratie.

5 Website van het CBS, Allochtonen op 1 januari; herkomstgroepering, statline.cbs.nl. 
collectieve belangen die op het spel stonden en het relatief gewicht dat zij aan die belangen toekenden.

Het gezinsmigratiebeleid dat Nederland tussen 1955 en 1975 voerde kwam voort uit drie botsende beleidsperspectieven. Vanuit een economisch perspectief, waarvan het ministerie van Sociale Zaken in beleidskringen de belangrijkste pleitbezorger was, stond het belang van het Nederlands bedrijfsleven bij de tewerkstelling van buitenlandse werknemers voorop. Om Nederland een aantrekkelijk land van bestemming te maken, moest arbeidsmigranten de mogelijkheid tot gezinshereniging worden geboden. Dit pleidooi vond bijval in de Tweede Kamer, waar met name de confessionele partijen het uit moreel oogpunt onaanvaardbaar achtten om vaders en echtgenoten jarenlang van hun gezinnen te scheiden. Voor de Kamer noch voor Sociale Zaken vormden de maatschappelijke gevolgen van arbeids- en gezinsmigratie op de langere termijn een bron van zorg, omdat zij veronderstelden dat het verblijf van de mediterrane migranten in Nederland van tijdelijke aard was. Het ministerie van Justitie daarentegen verwachtte dat wanneer gezinshereniging eenmaal had plaatsgevonden, van terugkeer naar het land van herkomst geen sprake meer zou zijn. Aangezien Justitie vreesde dat de grootschalige en permanente vestiging van vreemdelingen - zeker wanneer hun culturele achtergrond 'afwijkend' was - verontrustende consequenties zou hebben voor de sociale samenhang in Nederland, had het de overkomst van buitenlandse gezinnen liefst verboden. Het resultaat was een compromis, dat in de loop van de jaren zestig steeds verder opschoof richting de wensen van Sociale Zaken en de Tweede Kamer. Er werden wel voorwaarden gesteld aan gezinshereniging, met name op het gebied van werkzaamheid, verblijfsduur en huisvesting, maar die voorwaarden werden geleidelijk versoepeld. De bezwaren van Justitie wogen niet op tegen het economisch en moreel belang dat aan gezinshereniging werd toegekend, en tegen de overtuiging dat de migranten Nederland spoedig weer zouden verlaten.

De liberale beleidstendens die de periode van 1975 tot 1989 kenmerkte kwam primair voort uit normatieve overwegingen. In de eerste plaats mondde de culturele revolutie van de late jaren zestig, en de fundamentele verandering in de dominante gezinsmoraal waarmee deze gepaard ging, uit in een streven naar gelijke behandeling van mannen en vrouwen, homo's en hetero's, en getrouwde en ongetrouwde stellen, ook in het gezinsmigratiebeleid. In de tweede plaats erkende de Nederlandse politiek eind jaren zeventig dat de migranten die vanuit (voormalige) koloniën en 
wervingslanden hun weg naar Nederland hadden gevonden in overgrote meerderheid niet meer terug zouden keren naar hun herkomstland. Ook hier deed de norm van gelijke behandeling zijn invloed gelden: gevestigde migranten moesten als volwaardige leden van de Nederlandse maatschappij worden beschouwd en dus diende hun rechtspositie waar mogelijk gelijk te worden getrokken met die van Nederlands staatsburgers. Die rechtspositie omvatte ook het recht op gezinshereniging, waaraan een bijzonder moreel gewicht werd toegekend.

De maatschappelijke gevolgen van de versoepelingen van het gezinsmigratiebeleid werden met vertrouwen tegemoet gezien. Men veronderstelde dat het nieuwe minderhedenbeleid spoedig zijn vruchten af zou werpen en dat de inpassing van migranten in de Nederlandse maatschappij dus binnen afzienbare tijd zou zijn verwezenlijkt. Daarbij speelde ook een rol, dat de grootschalige migratiestromen die de voorgaande decennia hadden plaatsgevonden als een eenmalig accident of history werden beschouwd. Reeds in het begin van de jaren tachtig werden daar al wel de eerste vraagtekens bij gezet: zorgen over het aantal jeugdige migranten dat voor een buitenlandse partner koos en de gevolgen daarvan voor het integratieproces brachten het eerste kabinet Lubbers ertoe voor tweede generatie migranten een inkomenseis van 1445 gulden in te voeren. Deze maatregel botste echter met de norm van gelijke behandeling, die bij politiek en publiek zoveel gewicht in de schaal legde dat ze na minder dan twee jaar alweer werd afgeschaft.

Begin jaren negentig maakte het optimisme over de maatschappelijke gevolgen van immigratie plaats voor een toenemende bezorgdheid, niet alleen onder beleidsmakers maar ook in de publieke opinie. Immigratiestromen namen in omvang toe in plaats van af, en de resultaten van het minderhedenbeleid bleven ver achter bij de verwachtingen, met name waar het participatie op de arbeidsmarkt en in het onderwijs betrof. Om de integratieproblematiek de verzachten werd het noodzakelijk geacht om de instroom van nieuwe migranten, met inbegrip van gezinsmigranten, te beperken. Tegelijkertijd maakte een nieuwe ideologische visie op de verhouding tussen overheid en burger opgang, waarin plichten tegenover rechten dienden te staan en waarin de overheid zelfredzaamheid moest stimuleren, in plaats mensen door te veel zorg passief en afhankelijk te maken. Gezinsmigratie werd dus geleidelijk aan strengere voorwaarden onderworpen, niet alleen om de instroom te verminderen, maar ook om een beroep te doen op de 'eigen verantwoordelijkheid' van betrokkenen om zich een 
plaats te verwerven in de Nederlandse maatschappij.

Waar het migratie- en integratievraagstuk in de jaren negentig primair als een sociaal-economisch vraagstuk werd gedefinieerd, kwamen na het 'lange jaar 2002' de problematische aspecten van culturele diversiteit centraal te staan. De veronderstelling van de ambtenaren van Justitie in de jaren zestig, dat een zekere mate van homogeniteit in waarden en gebruiken een noodzakelijke voorwaarde was voor sociale cohesie, werd nu over de volle breedte van het politiek spectrum onderschreven. Gezinsmigratie werd als oorzaak èn gevolg van gebrekkige integratie beschouwd, niet alleen op sociaal-economisch maar juist ook op sociaal-cultureel vlak. Daarom werden de kwantitatieve doelstellingen die het beleid ook in de jaren negentig al kenmerkten aangescherpt en aangevuld met kwalitatieve beleidsoogmerken: de hervormingen van na de eeuwwisseling dienden ook om bij toelating een selectie te maken tussen 'inpasbare' en 'niet-inpasbare' gezinsmigranten.

De keuze voor aanscherping dan wel versoepeling van de voorwaarden voor gezinsmigratie vloeide dus voort enerzijds uit verwachtingen omtrent het verloop van de migratiestromen en de maatschappelijke effecten daarvan en anderzijds uit het gewicht dat aan politiek-ethische normen als gelijke behandeling of eigen verantwoordelijkheid werd toegekend. Daarnaast en in nauwe samenhang daarmee - speelden normen en waarden op het gebied van gezin, huwelijk en verhoudingen tussen mannen en vrouwen in twee opzichten een belangrijke rol. In de eerste plaats bepaalde het morele oordeel over wat een goed gezin was, welke familiebanden als grond voor toelating en verblijf werden beschouwd. In de jaren vijftig en zestig was het traditionele kostwinnersmodel onomstreden, met als gevolg dat het algemeen als evident werd beschouwd dat alleen de wettige echtgenote en minderjarige kinderen voor toelating in aanmerking kwamen. Lange tijd bestond er niet eens beleid voor de toelating van buitenlandse gezinsleden van vrouwen: zo vanzelfsprekend was het dat de man de verblijfsplaats van zijn gezin bepaalde en een vrouw dus haar echtgenoot volgde en niet andersom. In de jaren zeventig vertaalde de revolutie in de zeden zich in de gelijkstelling van mannen en vrouwen in het vreemdelingenrecht, de aanvaarding van heteroseksuele en homoseksuele niet-huwelijkse relaties als toelatingsgrond en voorwaardelijke instemming met de overkomst van familieleden die niet tot het kerngezin behoorden.

In de tweede plaats maken gezinsnormen een cruciaal onderdeel uit van de manier waarop collectieve identiteiten worden gedefinieerd: van de 
constructie van het onderscheid tussen 'Wij' en 'Zij'. Percepties van en normatieve oordelen over de gezins- en sekseverhoudingen van migranten spelen een belangrijke rol in de visie op de inpassing van migrantengroepen in de Nederlandse maatschappij. In de jaren zeventig maakte de dominante norm van het kostwinnersmodel plaats voor een weerzin tegen iedere beperking van de individuele keuzevrijheid. Dit betekende niet alleen voor Nederlanders maar ook voor migranten dat zij, binnen de grenzen van het wettelijk toegestane, hun privé-leven naar eigen goeddunken moesten kunnen inrichten zonder dat daar door de overheid of anderen een moreel oordeel over werd geveld. Het is geen toeval dat deze normatieve openheid samenviel met een periode van optimisme over de inpassing van migranten in de Nederlandse samenleving en van een liberaal gezinsmigratiebeleid. Open gezinsnormen hangen samen met een open collectieve identiteit, met een onscherpe, doordringbare grens tussen 'ons' en 'de ander' en daarmee met een minder bezorgde kijk op de aanwezigheid van vreemdelingen in ons midden. In de late jaren negentig ontstond opnieuw een scherp omlijnde en breed gedeelde normatieve consensus, waarin individuele keuzevrijheid, gelijkheid van mannen en vrouwen en een vrijzinnige kijk op seksualiteit en opvoeding centraal stonden. Juist op deze punten werden gezinsverhoudingen en huwelijkspraktijken van migranten geacht af te wijken van de Nederlandse norm. Daarom werd hun maatschappelijke integratie als problematisch beschouwd en werd het gezinsmigratiebeleid aangescherpt.

Philip Muus heeft de Nederlandse beleidsvorming op het gebied van immigratie als volgt gekenschetst:

The Netherlands has developed its immigration control policies by accepting immigration as an inevitable outcome of economic needs and humanitarian considerations. This pragmatic approach to policymaking led to a long series of policy adjustments. Most responded to specific migration events - or fear of future migration events - making decision making on immigration policy largely ad hoc, a process that followed what was happening in practice than proactively shaping the conditions for immigration. ${ }^{6}$

Bruquetas-Callejo e.a. schetsen een vergelijkbaar beeld, wanneer zij het

6 Muus 2004: 265-266. 
Nederlands migratiebeleid karakteriseren als 'formulated ad hoc, in response to actual influxes of migrants. Immigration policies thus have long been considered "quasi non-policies", ${ }^{7}$ Het beeld van de beleidsvorming inzake gezinsmigratie dat uit mijn onderzoek naar voren komt, wijkt in belangrijke opzichten af van dergelijke typeringen. Weliswaar was de overkomst van gezinsmigranten een vorm van migratie die de Nederlandse overheid 'overkwam', in die zin dat de vestiging van buitenlandse gezinnen nooit is aangemoedigd uit sociaal-economische of demografische overwegingen. Zo bezien zou het Nederlands gezinsmigratiebeleid veeleer als reactief dan als pro-actief betiteld kunnen worden. Ook is het zo, dat de perspectieven die aan het gezinsmigratiebeleid ten grondslag lagen in het relatief korte tijdbestek van vijftig jaar aanzienlijke veranderingen hebben ondergaan. Bij een oppervlakkiger beschouwing zou dat de indruk kunnen wekken van 'ad hoc' geformuleerd beleid. Het moge echter inmiddels duidelijk zijn dat de beleidsvorming inzake gezinsmigratie veel meer inhield dan een directe en eenduidige respons op fluctuaties in migratiestromen. Termen als 'pragmatisch', 'ad hoc' en zelfs 'non-beleid' doen geen recht aan de visies op individuele en collectieve, materiële en ethische, korte én lange termijn belangen waarop beleidsmakers hun besluiten baseerden: wat ons oordeel achteraf over hun overwegingen en inschattingen ook moge zijn, er was wel degelijk sprake van visies. Wellicht is het beeld dat Muus en Bruquetas-Callejo e.a. schetsen beter van toepassing op subvelden van het migratiebeleid die buiten dit onderzoek vallen, zoals arbeidsmigratie, asiel of post-koloniale migratie. Ik acht het echter niet onwaarschijnlijk dat zich hier in algemene zin de schaarste van wetenschappelijke studies van de beleidsvorming op het gebied van immigratie wreekt, waar Penninx e.a. reeds op wezen, ${ }^{8}$ en dat verder empirisch en historisch onderzoek aanleiding zou geven tot wezenlijke bijstelling van het bestaand beeld van besluitvormingsprocessen inzake toelating en verblijf van vreemdelingen in Nederland.

Ik zie uit naar politiek-historische studies van beleid en beleidsvorming inzake gezinsmigratie in andere Europese landen, waarmee de bevindingen van dit onderzoek in internationaal perspectief kunnen worden geplaatst. Volgens Entzinger is het migratiebeleid in Nederland - anders dan het integratiebeleid, 'where there is much more room for national traditions and specificities' - niet zo heel anders dan in buurlanden, doordat de Europese

7 Bruquetas-Callejo e.a. 2006: 24.

8 Penninx e.a. 2005: 2. 
Unie weinig ruimte laat om af te wijken van de gemeenschappelijke lijn. ${ }^{9}$ Over de afgelopen vijftig jaar hebben Nederlandse beleidsmakers, zoals inmiddels duidelijk zal zijn, echter nauwelijks met Europese beperkingen te maken gehad op het gebied van gezinsmigratie. Het is zeer wel mogelijk dat de naoorlogse ontwikkeling van het Nederlands gezinsmigratiebeleid evenzeer is gekenmerkt door 'nationale tradities en specificiteit'. Nederlandse ambtenaren en politici hadden in de jaren zestig zelf de indruk, dat het gezinsmigratiebeleid dat zij voerden strenger was dan dat van omringende landen. De uitzondering die Nederland bedong op het Europees gezinsherenigingsbeleid voor migrerende werknemers wijst eveneens in die richting. Wat de gunstige voorwaarden betreft die in de jaren tachtig aan gezinsmigratie werden gesteld, zou de observatie van Thränhardt dat het 'tolerante politieke klimaat' en de 'beschaafde stijl van politieke omgang' in Nederland positief afstaken tegen de uitspraken die Duitse, Franse of Engelse politici over het vreemdelingenvraagstuk deden ${ }^{10}$, kunnen duiden op een Nederlandse bijzonderheid. Wellicht was het perspectief van beleidsmakers in andere landen in die jaren niet zo sterk normatief geladen als in Nederland, hetgeen zou kunnen passen in het zelfbeeld van Nederland als 'gidsland' dat toen sterk aanwezig was. ${ }^{11}$ In recente jaren ten slotte, is het Nederlands gezinsmigratiebeleid, blijkens uit onderzoek van Groenendijk e.a., juist stringent in vergelijking met dat van de andere Europese lidstaten. ${ }^{12}$ Mijn vermoeden is dus dat er wel degelijk substantiele verschillen bestaan in de ontwikkeling van het gezinsmigratiebeleid in Europese landen.

\subsection{Haagse machten ${ }^{13}$}

Er is tot op heden opmerkelijk weinig empirisch onderzoek verricht naar de manier waarop de verschillende actoren die betrokken zijn bij het vormgeven van het Nederlands overheidsbeleid zich tot elkaar verhouden; vooral de vraag wie meer of minder invloed weet uit te oefenen op de besluitvorming is wel het onderwerp van uitgebreid academisch én politiek en

\footnotetext{
9 Entzinger 2004: 289.

10 Thränhardt 2002: 237.

11 Kennedy 2005: 17-19.

12 Groenendijk e.a. 2007b: 20, 26; Groenendijk 2005: 12.

13 Dit is de titel van een veel geciteerde studie van Van Putten uit 1980 naar beleidsvorming in Nederland.
} 
publiek debat, maar werd zelden empirisch onderzocht. ${ }^{14}$ Historisch onderzoek dat, zoals de onderhavige studie, continuïteit en discontinuïteit in de inbreng van parlement, bewindslieden en Kamerleden in de beleidsvorming over meerdere decennia in kaart brengt, is nog schaarser. De analyse van de beleidsvorming inzake gezinsmigratie van 1955 tot 2005 biedt daarom interessante inzichten in de historische ontwikkeling van de rol van en verhouding tussen de actoren die in Nederland beleid maken.

\section{De rol en invloed van ambtenaren}

De bevinding die, wanneer wij de inbreng van ambtenaren in de beleidsvorming inzake gezinsmigratie over de afgelopen vijftig jaar bezien, het meest prominent naar voren treedt, is deze: hoe groter het electoraal gewicht van het gezinsmigratievraagstuk, hoe fermer de grip van de politiek op de beleidsontwikkeling en hoe minder ruimte er is voor ambtelijke invloed op de besluitvorming. ${ }^{15}$ In de jaren vijftig en zestig was het gezinsmigratiebeleid - zeker in vergelijking met later jaren - nauwelijks onderwerp van politiek of publiek debat. Noch voor de partijen in de Tweede Kamer, noch voor de politiek gezagdragers in het kabinet was het een thema waarop politiek hoog spel moest of kon worden gespeeld. In deze politieke luwte kregen de ambtenaren van Justitie en Sociale Zaken alle ruimte: zij bepaalden in vérgaande mate welke voorwaarden aan toelating en verblijf van buitenlandse gezinsleden werden gesteld.

Vanaf de jaren zeventig kwam hierin verandering. Immigratie en integratie werden vraagstukken met een brede maatschappelijke en politieke relevantie: Surinaamse, Marokkaanse en Turkse migranten werden zichtbaar in de wijk, op school, in het ziekenhuis en op het werk. De verschijning van

14 Peters 1999: 18-19. Uitzonderingen op deze regel zijn met name Van Putten 1980; Koppenjan e.a. 1987; Visscher 1994; Peters 1999. Zie ook't Hart e.a. (2002), in wier onderzoek naar politiekambtelijke verhoudingen de invloedsvraag niet centraal staat, maar wel zijdelings aan bod komt. 15 In de academische literatuur bestaat discussie over de vraag of de invloed van ambtenaren en hun bewindspersoon een 'zero sum game' is: hoe meer invloed voor ambtenaren, hoe minder voor de minister, en omgekeerd. Peters (1999: 246-247) komt tot de voorzichtige conclusie, dat bewindslieden en ambtenaren elkaar veeleer wederzijds versterken: hoe krachtiger de bewindspersoon, hoe invloedrijker zijn ambtenaren, en andersom. De bevindingen van deze studie daarentegen duiden wel degelijk op een zero sum game. Daarbij dient echter te worden aangetekend, dat de negatieve correlatie tussen politieke en ambtelijke invloed die hier wordt geobserveerd voortvloeit uit het politiek en maatschappelijk gewicht van het beleidsthema in een specifieke historische context: dit laat onverlet dat op individueel niveau de positie van ambtenaren in interdepartementaal overleg kan worden versterkt door een minister met prestige of sterke politiek-strategische vaardigheden, en andersom. 
de Nederlandse Volksunie, de eerste anti-immigrantenpartij, op het politiek toneel in 1974 tekende de toenemende politieke urgentie van het migratieen integratievraagstuk. Vanaf de tweede helft van de jaren zeventig ging de Tweede Kamer zich dan ook steeds intensiever met het gezinsmigratiebeleid bezig houden. Met de aanstelling in 1971 van een staatssecretaris op het ministerie van Justitie, belast met vreemdelingenzaken, werd ook de inbreng van de bewindspersoon in de beleidsvorming vergroot. Ambtenaren speelden in de jaren zeventig en tachtig dan ook een minder bepalende rol dan in de jaren zestig. Binnen het kabinet was het gezinsmigratiebeleid echter nog steeds geen onderwerp van politieke strijd. Er bleef dan ook ruimte voor ambtelijke inbreng: de controle op schijnhuwelijken en schijnrelaties in de jaren zeventig weerspiegelde het wantrouwen van de ambtenaren van Vreemdelingenzaken jegens mannelijke gezinsmigranten, en de 1445-maatregel van 1983 de wens van diezelfde ambtenaren om gezinsvorming door kinderen van migranten aan banden te leggen. Voor een aantal maatregelen, zoals het criterium 'feitelijke gezinsband' geldt zelfs, dat zij op ambtelijk niveau, zonder inbreng van het parlement, zijn ingevoerd.

Voor dergelijke ambtelijke autonomie was vanaf de jaren negentig geen ruimte meer. Het migratie- en integratievraagstuk was inmiddels een dermate saillant thema in het politiek én publiek debat, dat ook voor de besluitvorming binnen het kabinet partijpolitiek beslissend werd. De voornaamste hervormingen van het gezinsmigratiebeleid die sinds de jaren negentig zijn doorgevoerd zijn het resultaat van overleg tussen de coalitiepartijen, binnen het kabinet in 1993 en in de onderhandelingen over het regeerakkoord in 1998 en 2003. Wanneer politieke wensen zo uitgesproken en specifiek zijn, rest ambtenaren weinig anders dan die opdrachten uit te voeren. Na de eeuwwisseling was het overwicht van het politieke op het ambtelijke zelfs zo groot, dat tot hervormingen werd besloten die bij de direct verantwoordelijke ambtelijke afdeling op pertinent en principieel verzet stuitten. Het contrast met de autonomie waarmee ambtenaren in de jaren zestig opereerden kan nauwelijks groter zijn.

De invloed van ambtenaren op de Nederlandse beleidsvorming inzake gezinsmigratie is van de jaren vijftig tot op heden dus gestaag afgenomen: waar zij in de jaren vijftig en zestig grotendeels naar eigen goeddunken het beleid bepaalden, moesten zij in recente jaren - soms met veel tegenzin buigen voor de wens van de politiek. Deze bevinding staat lijnrecht tegenover het beeld van de politiek-ambtelijke verhoudingen in Nederland sinds de Tweede Wereldoorlog, zoals dat in de academische literatuur bestaat. 
Peters stelt dat onder politicologen en bestuurskundigen 'onomstreden' is, dat 'in de twintigste eeuw een verschuiving in de machtsverhoudingen heeft plaatsgevonden ten gunste van ambtenaren'. ${ }^{16}$ Prominente onderzoekers als Hoppe en Bekke veronderstellen dat het ambtelijk apparaat tot halverwege de jaren zestig 'klassiek weberiaans' functioneerde, in die zin dat het een 'volgende' rol speelde, en de besluiten uitvoerde die door de politiekbestuurlijke elites werden genomen. In de loop van de tweede helft van de jaren zestig en de jaren zeventig zouden ambtenaren een autonome rol zijn gaan spelen in het beleidsvormingsproces, als gevolg van een toegenomen inhoudelijke expertise en van hun contacten met belangengroepen. ${ }^{17}$ Ook Bovens e.a. stellen dat de rol van ambtenaren 'in de late twintigste eeuw' is veranderd, 'van loyale uitvoerders tot mondige meedenkers'. Deze 'verschuiving van de machtsbalans' zou het gevolg zijn van de uitbreiding van het ambtelijk apparaat, de toegenomen vrijheden en hogere scholing van ambtenaren, en de verandering van de aard van het beleidsvormingsproces van 'government' naar 'governance'. ${ }^{18}$

Van der Meer en Roborgh hebben zich scherp uitgelaten over de weinig tot empirie geneigde attitude van Nederlandse bestuurswetenschappers: 'Wat betreft de bestuurswetenschappen is het opvallend hoe al te gemakkelijk allerlei uitspraken worden gedaan, en nog erger, klakkeloos van elkaar worden overgenomen zonder dat deze denkbeelden op (de mate van) hun empirische houdbaarheid worden onderzocht'. ${ }^{19}$ Mijn bevindingen geven voeding aan deze kritiek. De ambtelijke invloed op het gezinsmigratiebeleid is sinds de jaren vijftig niet toe- maar afgenomen; er was niets 'klassiek-weberiaans' aan de manier waarop de ambtenaren van Sociale Zaken en Justitie in de jaren vijftig en zestig opereerden. Het is zeer wel mogelijk dat deze ontwikkeling specifiek is voor dit beleidsveld en dient te worden begrepen als een gevolg van de uitzonderlijke politisering van het gezinsmigratievraagstuk in de loop der tijd. Desalniettemin doet het beeld van de modus operandi van ambtenaren in de eerste naoorlogse decennia dat uit mijn archiefonderzoek naar voren komt, de vraag rijzen of het Nederlands ambtelijk apparaat ooit een zuiver 'volgende' rol heeft gespeeld. De historische ontwikkeling van de politiek-ambtelijke verhoudingen in Nederland is dringend toe aan nader empirisch onderzoek.

16 Peters 1999: 36.

17 Bekke 1994: 14-19; Hoppe 1998: 15-19.

18 Bovens e.a. 2007: 360-361, 371-374.

19 Van der Meer \& Roborgh 1993: 3. 
Het is onder onderzoekers van het openbaar bestuur in Nederland een algemeen aanvaard gegeven dat 'de' overheid niet bestaat: fragmentatie wordt zelfs een belangrijk kenmerk van het Nederlands openbaar bestuur genoemd. ${ }^{20}$ De uitkomsten van mijn onderzoek vormen een treffende illustratie van de pluraliteit van de overheid. Verschillende ambtelijke organisaties bezien het gezinsmigratievraagstuk vanuit sterk uiteenlopende perspectieven en nemen daardoor onderscheiden en soms botsende standpunten in. ${ }^{21}$ Dit is het duidelijkst zichtbaar in de conflicten tussen de ambtenaren van Justitie en Sociale Zaken tussen 1955 en 1975: waar voor Sociale Zaken het verzachten van het acute tekort aan werknemers op de Nederlandse arbeidsmarkt voorop stond, wierpen de ambtenaren van Vreemdelingenzaken zich op als beschermers van de orde en samenhang van de Nederlandse maatschappij, die in hun ogen stond of viel met een zekere mate van culturele en religieuze homogeniteit. Ook in later jaren deden zich echter wrijvingen tussen ambtelijke afdelingen voor: zo bleek begin jaren negentig het op restrictie gerichte beleidsperspectief van ambtelijk Justitie te conflicteren met de denkwijzen van de ambtenaren van Binnenlandse Zaken, die verantwoordelijk waren voor het minderhedenbeleid en wier prioriteit lag bij bescherming van de rechtspositie van minderheden. Het is opvallend dat niet zozeer 'neutrale' expertise bepalend is voor de standpunten die ambtelijke organisaties innemen, als wel de manier waarop de maatschappelijke opdracht van de organisatie wordt geïnterpreteerd: deze institutionele taakopvatting vormt de 'bril' waardoor ambtenaren naar een beleidsvraagstuk kijken en bepaalt welke belangen en waarden in hun ogen op het spel staan en wat de beleidsrespons zou moeten zijn. ${ }^{22}$

Rosenthal brak in zijn oratie in 1988 een lans voor 'bureaupolitiek', ofwel competitie binnen het overheidsbestel, die in zijn ogen bijdroeg 'tot een afgewogen toe- en verdeling van waarden in de maatschappij' ${ }^{23}$ Ook Ringeling stelt dat aangezien 'organisatie-onderdelen van de overheid (...) de institutionalisering van bepaalde waarden en belangen' vormen, het 'niet verwerpelijk' is dat zij bij het uitoefenen van hun maatschappelijke taak bij gelegenheid met andere ambtelijke afdelingen botsen. ${ }^{24} \mathrm{Bij}$ een pluriforme samenleving past een pluriforme overheid. De bevindingen van

20 Koppenjan e.a. 1987: 279. Zie ook Glasbergen 1984: 91; Van Putten 1980: 250; Visscher 1994: 765-765; Veenswijk 1996: 252-253.

21 Vgl. De Lange 2007: 414.

22 Vgl. Ringeling 1993: 161-162; Veenswijk 1996: 58; Glasbergen 1984: 89-92.

23 Rosenthal 1988: 8.

24 Ringeling 1993: 162, 164, 166. 
dit onderzoek ondersteunen in mijn ogen dit positief oordeel. In interdepartementale conflicten worden inderdaad verschillende maatschappelijke belangen en waarden ingebracht en tegen elkaar afgewogen.

Over de periode van de jaren vijftig tot op heden bezien, kan de taakopvatting van de ambtenaren van het ministerie van Justitie die verantwoordelijkheid dragen voor het vreemdelingenbeleid worden gekenmerkt als het binnen de perken houden van de instroom van vreemdelingen in Nederland, hetgeen uitmondt in een voortdurend streven om de beheersingsmiddelen die de overheid ter beschikking staan te behouden of uit te breiden. Het verzet van de Directie Vreemdelingenzaken tegen de invoering van de inburgeringsbijdrage in 2001 vormt in dit opzicht een opvallende breuk met een tenminste vijftig jaar oude institutionele praktijk.

Volgens Peters blijkt uit de literatuur dat op 'oude' beleidsterreinen, zoals Justitie, maatschappelijke organisaties relatief weinig invloed uitoefenen op de beleidsvorming. ${ }^{25}$ De stukken van het ministerie van Justitie die ik heb ingezien roepen inderdaad een beeld op van een institutionele cultuur waarin belangenorganisaties niet zozeer als gesprekspartners worden gezien, wier betrokkenheid in het beleidsvormingsproces kan bijdragen aan het maatschappelijk draagvlak voor het beleid of wier expertise nuttig kan worden ingezet, als wel als opponenten die van de redelijkheid van de gekozen beleidslijn dienen te worden overtuigd. Noch de werkgeversorganisaties die zich in de jaren zestig nadrukkelijk roerden, noch het brede scala aan actie- en belangengroepen dat zich sinds de jaren zeventig betrokken toont bij het gezinsmigratiebeleid, lijken erin geslaagd te zijn enig wezenlijk effect te sorteren op de standpuntbepaling binnen het ministerie van Justitie.

Ambtelijk Justitie laat zich niet gemakkelijk van zijn institutioneel verankerde beleidsvisies afbrengen. Van de jaren vijftig tot na de eeuwwisseling nemen de ambtenaren van Vreemdelingenzaken geregeld posities in, die haaks staan op het meerderheidsstandpunt: zij verzetten zich in de jaren vijftig en zestig het dominant economisch perspectief dat versoepeling van het beleid voorschreef, in de jaren zeventig en tachtig tegen het gelijkheidsideaal dat in uitbreiding van het recht op gezinsmigratie voor vrouwen en migranten uitmondde, en recentelijk tegen de koppeling van het gezinsmigratiebeleid aan de integratieproblematiek waarop de restrictieve hervormingsvoorstellen van na de eeuwwisseling zijn gebaseerd. In

25 Peters 1999: 49-50. 
dit opzicht lijkt een zekere tegendraadsheid de rode draad te vormen die de huidige Directie Vreemdelingenbeleid met haar naoorlogse voorgangers verbindt. Zolang zij politieke opdrachten - indien die worden geformuleerd - loyaal uitvoeren, lijkt het mij een vertrouwenwekkend gegeven dat de ambtenaren die ons land helpen besturen zich niet laten meeslepen door de waan van de dag.

\section{De rol en invloed van bewindspersoon en kabinet}

In de jaren vijftig en zestig hadden ambtenaren het overwicht in de besluitvorming, ook ten opzichte van politiek gezagdragers. De ministers van Justitie lieten het bepalen van de voorwaarden voor gezinshereniging vrijwel geheel aan hun ambtenaren over. Daarbij speelt wellicht ook een rol, dat het gezinsmigratiebeleid onderwerp was van interdepartementale strijd. Op basis van haar onderzoek naar invloed op de rijksbesluitvorming in Nederland heeft Klaartje Peters geconcludeerd dat ambtelijke 'stammenstrijd' de invloed van ambtenaren op de beleidsvorming vergroot. Wanneer zich ernstige conflicten tussen departementen of afdelingen voordoen, wordt de aandacht van ambtenaren zozeer in beslag genomen door de 'interne strijd', dat externe actoren en het parlement er niet meer 'tussen (...) komen' ${ }^{26}$ In de jaren vijftig en zestig lijken de interdepartementale conflicten de positie van Justitie ambtenaren inderdaad te hebben versterkt, maar niet zozeer ten opzichte van de Kamer of externe actoren, als wel ten opzichte van hun bewindspersoon. Beleidsvoorstellen die aan de minister van Justitie werden voorgelegd waren veelal het resultaat van maanden ambtelijk overleg: in een zo moeizaam bereikt compromis konden moeilijk nog wijzigingen worden aangebracht, zelfs als de minister zich er niet in kon vinden. Het feit dat de bewindslieden zich pas zo laat in de besluitvorming mengden, geeft echter ook aan dat het onderwerp voor hen niet de hoogste prioriteit had.

Tussen 1955 en 1975 had de politieke kleur van de bewindslieden van Sociale Zaken of Justitie geen invloed op de standpunten die door de departementen werden ingenomen. ${ }^{27}$ Wisselingen in de politieke samenstelling van het kabinet als geheel hadden evenmin effect op de ontwikkeling van het gezinsmigratiebeleid. Meestentijds werd de regelgeving in interdepartementaal overleg vastgesteld en kwam de ministerraad er ofwel in het

26 Peters 1999: 245-246.

27 Vgl. De Lange 2007: 235. 
geheel niet aan te pas, ofwel alleen om zijn goedkeuring te verlenen aan een ambtelijk compromis. Bij uitzondering gaf het oordeel van de ministerraad wel de doorslag: ook dan gold echter dat de scheidslijnen binnen de raad geenszins langs partijpolitieke lijnen verliepen, maar langs institutionele. De posities die bewindslieden innamen kwamen naadloos overeen met de standpunten die hun ambtenaren in interdepartementaal overleg inbrachten. Waarschijnlijk wordt hier een element van de Nederlandse politieke cultuur van de jaren zestig zichtbaar, dat Daalder in 1964 beschreef als 'de gedachte aan een regering, staande boven de partijen', waarbij ministers 'veelal een bewuste afstand tot het parlement en de fracties' behouden, 'het politieke spel bewust afdempend': 'het ministersambt krijgt een sterk ambtelijke kleur' ${ }^{28}$ Het overwicht van het ambtelijke en institutionele op het politieke in de besluitvorming binnen en tussen de ministeries tekent echter evenzeer het geringe politieke gewicht dat in de jaren vijftig en zestig aan het gezinsmigratievraagstuk werd toegekend.

In 1971 werd Hans Grosheide de eerste staatssecretaris van Justitie, belast met vreemdelingenzaken. Het feit dat aan het ministerie een staatssecretarispost werd toegevoegd, is indicatief voor het grotere gewicht dat aan het migratiebeleid werd toegekend, en droeg ertoe bij dat bewindslieden een actiever en invloedrijker rol gingen spelen in de beleidsvorming. De staatssecretaris die, wellicht meer dan al zijn voorgangers of opvolgers, een stempel heeft gedrukt op de beleidsontwikkeling, was Jan Glastra van Loon. Dit lid van het kabinet Den Uyl bracht de aanpassing van het Nederlands gezinsmigratiebeleid aan de nieuwe progressieve normen op het gebied van huwelijk en gezin in een stroomversnelling. Geen andere staatssecretaris heeft zo duidelijk en voortvarend - en wellicht weinig diplomatiek ten opzichte van zijn ambtenaren - een eigen koers uitgezet. Ook voor de opvolgers van Glastra van Loon gold evenwel dat zij - veel meer dan ministers van Justitie in de jaren vijftig en zestig deden - de beleidsvorming op de voet volgden en in geval van ambtelijke meningsverschillen een doorslaggevend oordeel gaven. Met uitzondering van Glastra van Loon, wiens inbreng duidelijk de liberale ideologie van D66 weerspiegelde, had de politieke kleur van de staatssecretarissen echter geen zichtbaar effect op de standpunten die zij innamen, of op de beleidstendens. Hetzelfde gold voor de partijpolitieke samenstelling van het kabinet. In de ministerraad is tussen 1976 en 1984 dan ook alleen de toelating van

28 Daalder 1995: 25, 35. 
Surinaamse familieleden onderwerp van discussie geweest: verder is over het gezinsmigratiebeleid niet op kabinetsniveau gesproken. ${ }^{29}$ De gunstige voorwaarden die Nederland in de tweede helft van de jaren zeventig en in de jaren tachtig aan gezinsmigratie verbond gaven institutioneel - tussen departementen - noch ideologisch - tussen politieke partijen - aanleiding tot meningsverschillen die in de ministerraad zouden moeten worden beslecht.

In de jaren negentig ging partijpolitiek voor het eerst een rol spelen in de besluitvorming binnen de regering. Naarmate het electoraal gewicht van het gezinsmigratievraagstuk toenam, werd het een politiek strijdpunt waarop parlementaire partijen specifieke en onderscheiden voorkeuren formuleerden, die zij steeds vaker opnamen in hun verkiezingsprogramma's en waartussen op kabinetsniveau compromissen moesten worden gesloten. In vergelijking met de late jaren zeventig en jaren tachtig nam de invloed op de beleidsvorming van de direct verantwoordelijke bewindspersoon daardoor af ten gunste van het kabinet als geheel. Het is echter opvallend dat uiteenlopende wensen van coalitiepartijen niet op het publieke toneel met elkaar in overeenstemming werden gebracht, maar achter de gesloten deuren van kabinetsberaad of coalitieonderhandelingen. De neiging tot geheimhouding die volgens Daalder en Lijphart typerend was voor de Nederlandse politiek in de jaren zestig, blijkt een element van continuïteit in de Nederlandse politieke cultuur dat zich tot de dag van vandaag doet gelden. ${ }^{30}$

\section{De rol en invloed van het parlement}

Uit onderzoek van zowel Peters als Visscher is reeds gebleken, dat de invloed van de Eerste Kamer op beleidsvorming zeer beperkt is, in vergelijking met die van de Tweede Kamer. ${ }^{31}$ Dat geldt ook voor de beleidsvorming inzake gezinsmigratie. Wellicht mede doordat het gezinsmigratiebeleid - met uitzondering van de Wet Schijnhuwelijken en de Wet Inburgering in het Buitenland - niet in de wet maar in lagere regelgeving is vastgelegd, is de Eerste Kamer als actor in de besluitvorming van de jaren vijftig tot op heden zelfs zo goed als irrelevant geweest.

29 De archieven van de ministerraad van na 1984 zijn nog niet beschikbaar voor inzage.

30 Daalder 1995: 19-20; Lijphart 1979: 124.

31 Peters 1999: 227; Visscher 1994: 773. 
Tot de jaren zeventig bleef ook de bemoeienis van de Tweede Kamer met het gezinsmigratiebeleid beperkt. Het werd slechts incidenteel aan de orde gesteld, voornamelijk in het kader van de jaarlijkse begrotingsdebatten of een enkele keer in schriftelijke vragen, veelal naar aanleiding van mediaberichten. De linkse politieke partijen lieten zich zelden uit over het gezinsherenigingsbeleid. De confessionele partijen daarentegen, met name de KVP, uitten het meest veelvuldig en het felst bezwaar tegen de in hun ogen te stringente voorwaarden voor gezinshereniging en de jarenlange scheiding van gezinnen die daarvan het gevolg was. Ook de VvD trok regelmatig van leer tegen het strenge gezinsmigratiebeleid, dat het bedrijfsleven belemmerde bij het werven en behouden van buitenlandse arbeidskrachten. De inbreng van Kamerleden beperkte zich tot de grote lijnen, tot de principes die in de beleidsvorming te doorslag moesten geven. Met de specifieke formulering van de regelgeving bemoeiden zij zich niet: zij waren daarvan zelfs niet altijd op de hoogte. Volgens Lijphart is een dergelijke attitude kenmerkend voor de Nederlandse politiek tot de late jaren zestig. Hij spreekt van het principe dat 'de regering regeert': het kabinet is verantwoordelijk voor het bestuur en dient van de Kamer de ruimte te krijgen om zich van die taak te kwijten. ${ }^{32}$ Tot de jaren zeventig had de regering - hier begrepen als de bewindslieden én hun ambtenaren - dus duidelijk het overwicht op de Kamer. Dat betekent echter niet dat Kamerleden geen invloed hebben uitgeoefend op de beleidsvorming: hun kritiek versterkte de positie van het ministerie van Sociale Zaken ten opzichte van het ministerie van Justitie en heeft er zo toe bijgedragen dat de voorwaarden voor gezinshereniging in de loop van de jaren zestig geleidelijk werden versoepeld.

De Nota Buitenlandse Werknemers van 1970, waarin de regering voor het eerst haar arbeidsmigratiebeleid omvattend uiteen zette en daarover de discussie aanging met het parlement, vormde een keerpunt in de betrokkenheid van de Tweede Kamer bij het migratie- en integratiebeleid. Vanaf de late jaren zeventig werd ook het gezinsmigratiebeleid regelmatig onderwerp van regeringsnota's en van debat in de Kamer. Kamerleden waren nu veel beter op de hoogte van het beleid en formuleerden specifieke en gedetailleerde standpunten over de regelgeving. Deze actievere rol van het parlement in de vorming van het gezinsmigratiebeleid past in een algemene tendens van toenemend 'parlementair activisme' sinds de late jaren zestig, maar reflecteert ook het stijgend maatschappelijk en politiek gewicht van het gezinsmigratievraagstuk.

32 Lijphart 1979: 127. 
Van Putten constateerde in 1980 dat het parlement weliswaar actiever was, maar er nog minder dan voorheen in slaagde invloed uit te oefenen op het beleid. ${ }^{33}$ Visscher daarentegen observeert tussen 1963 en 1982 een toenemende parlementaire invloed. ${ }^{34}$ Uit Peters' onderzoek naar invloedsverhoudingen tussen 1988 en 1995 blijkt dat regering en parlement elkaar 'aardig in evenwicht' houden. ${ }^{35}$ In de beleidsvorming op het gebied van gezinsmigratie was, vooral na 1980, inderdaad sprake van een zeker evenwicht tussen kabinet en Kamer. Belangrijke hervormingen uit de jaren zeventig, zoals de toelating van niet-huwelijks partners en Surinaamse gezinsleden, of de vrijstelling van het inkomensvereiste voor gevestigde vreemdelingen, zijn tot stand gekomen zonder dat het parlement erbij betrokken was. Bij de formele gelijkstelling van mannen en vrouwen in het vreemdelingenrecht in 1979 hebben linkse Kamerleden echter een belangrijke rol gespeeld. Ook in de jaren tachtig bleef de positie van vrouwen in het vreemdelingenrecht, op initiatief van linkse Kamerleden maar met steun van CDA en VVD, hoog op de politieke agenda staan. Dat de 1445-maatregel van 1983 na minder dan twee jaar alweer werd ingetrokken, was in belangrijke mate het gevolg van parlementair verzet, niet alleen van de oppositie- maar ook van de coalitiepartijen.

Vanaf de jaren negentig speelde partijpolitiek een doorslaggevende rol in de beleidsvorming. Dat betekent echter niet dat de Tweede Kamer de belangrijkste besluitvormingsarena werd: beleidsvoorstellen kwamen tot stand in overleg tussen de coalitiepartijen, buiten de Kamerdebatten om. In de vroeg jaren negentig deelden de fracties van PvdA en CDA hun beleidsvoorkeuren al lang voor de parlementaire behandeling mee aan 'hun' bewindslieden in het kabinet. Dergelijke informele inmenging van coalitiepartijen in het formuleren van kabinetsvoorstellen heb ik vóór de jaren negentig niet aangetroffen. Vanaf 1998 werden hervormingsvoornemens zelfs door de fractievoorzitters vastgelegd in regeerakkoorden. Deze vermenging van de rol van coalitiefracties en kabinet in de beleidsvorming maakt de vraag of parlement of regering de grootste invloed had moeilijk te beantwoorden: de vraag is in deze formulering zelfs niet meer relevant. Of deze ontwikkeling specifiek is voor het beleidsveld van gezinsmigratie en als gevolg van het sterk toegenomen politiek gewicht van het thema moet worden begrepen, of een algemene tendens in de verhouding tussen politiek en bestuur weerspiegelt, is grond voor verder onderzoek.

33 Van Putten 1980: 270.

34 Visscher 1994: 784.

35 Peters 1999: 228. 


\section{De invloed van partijpolitieke verhoudingen}

Wanneer we het tijdvak van 1955 tot 2005 bezien valt op, dat verschuivingen in de tendens van het gezinsmigratiebeleid niet of nauwelijks te relateren zijn aan wijzigingen in de partijpolitieke verhoudingen in de Kamer of in het kabinet. Meestentijds bestond, zeker onder de grote partijen CDA, VVD, PvdA en D66, voldoende consensus over de waarden en belangen die bij het gezinsmigratievraagstuk op het spel stonden, om in te kunnen stemmen met de beleidskeuzes van het kabinet, wat de politieke kleur van dat kabinet ook was.

De verschillen tussen politieke partijen waren wellicht nog het duidelijkst in de jaren zestig. Door de stabiliteit van de verhoudingen in de Kamer en de geringe invloed van partijpolitiek op de besluitvorming leidde dit echter niet tot fluctuaties in de beleidsontwikkeling. Het liberale gezinsmigratiebeleid van de jaren tachtig genoot zeer brede parlementaire steun. Er waren wel nuanceverschillen: de PvdA en de partijen op haar linkerflank, die tot de jaren zeventig weinig aandacht besteedden aan het gezinsmigratiebeleid, toonden zich nu zeer betrokken bij het belang van migranten bij gezinshereniging en gelijke behandeling. De linkse partijen bleken relatief ontvankelijk voor de inbreng van migranten- en vrouwenorganisaties en lijken nauwe contacten te hebben onderhouden met geëngageerde vreemdelingenjuristen: zij waren dan ook veelal goed op de hoogte van ontwikkelingen in vreemdelingenrecht en -praktijk. ${ }^{36} \mathrm{CDA}$ en VVD daarentegen, tot het midden van de jaren zeventig nog fervent voorstanders van een soepel gezinsherenigingsbeleid, uitten in de jaren tachtig steeds vaker zorgen over mogelijk misbruik van het gezinsmigratiekanaal, zonder daar echter de conclusie aan te verbinden dat het beleid in restrictieve zin hervormd moest worden.

Vanaf de jaren negentig tekenden de verschillen tussen CDA en VVD enerzijds en PvdA, GroenLinks en SP anderzijds zich bij momenten wat scherper af dan in de jaren tachtig: dat was bijvoorbeeld het geval in de discussies over het recht op gezinshereniging voor vluchtelingen. Met name het CDA heeft in de afgelopen vijftien jaar een invloedrijke rol gespeeld in

36 De standpuntbepaling van belangenorganisaties en hun invloed op de ontwikkeling van het vreemdelingenbeleid verdienen verder onderzoek: mijn indruk is dat die invloed over het algemeen beperkt was, met uitzondering van werkgeversorganisaties in de jaren zestig en - wellicht - van vrouwenorganisaties sinds de jaren zeventig. Daarnaast biedt de rol en inbreng van juristen, die zich op het snijvlak van wetenschap en maatschappelijk engagement bewegen, vruchtbare grond voor wetenschapssociologisch onderzoek. 
de vorming van het gezinsmigratiebeleid: de christendemocraten hebben de eerste restrictieve hervorming in 1993 geïnitieerd, evenals de inburgering in het buitenland; zij hebben bovendien het uitgangspunt van 'eigen verantwoordelijkheid' geïntroduceerd dat tot op heden aan iedere aanscherping van de voorwaarden ten grondslag ligt. Deze voorstellen en argumenten werden echter aanvaard, zelfs overgenomen, door de PvdA. Ook in de jaren negentig en na de eeuwwisseling kon het regeringsbeleid over het algemeen rekenen op de steun van een brede Kamermeerderheid.

Daalder constateerde in 1964 al dat het verschil tussen de rol van oppositiepartij en coalitiepartij in Nederland niet zo groot was. Hij weet dat toen aan de afstand die regering en parlement ten opzichte van elkaar bewaarden. ${ }^{37}$ Lijphart kwam in 1979 tot dezelfde conclusie. ${ }^{38}$ Sinds de jaren negentig is die afstand tussen kabinet en coalitiepartijen echter aanzienlijk kleiner geworden: desalniettemin blijft over het gezinsmigratiebeleid brede parlementaire consensus bestaan. De cruciale elementen van het beleidsperspectief dat op een zeker moment dominant was - zoals de veronderstelling van tijdelijk verblijf in de jaren zestig, de norm van gelijke behandeling in de jaren tachtig, of de norm van eigen verantwoordelijkheid vanaf de jaren negentig - werden steeds door alle grote politieke partijen onderschreven. In die zin was de partijpolitieke consensus over het gezinsmigratievraagstuk geworteld in de 'tijdgeest'.

Daarmee is het ook begrijpelijker dat de politieke kleur van het kabinet, van de jaren vijftig tot op heden, niet bepalend is voor het restrictieve dan wel liberale karakter van het Nederlands gezinsmigratiebeleid. ${ }^{39}$ Tussen 1955 en 1975 maakte het voor de voorwaarden die aan gezinsmigratie werden gesteld geen enkel verschil of de confessionele partijen met de PvdA of met de VVD het regeringspluche bezetten, aangezien partijpolitieke posities in discussies binnen het kabinet geen rol speelden. Het meest liberale gezinsmigratiebeleid dat Nederland ooit heeft gekend werd gevoerd door de kabinetten Van Agt en Lubbers I en II, dat wil zeggen door VVD en CDA. De restrictieve wending van het gezinsmigratiebeleid in de jaren negentig daarentegen vond plaats toen de PvdA regeringsverantwoordelijkheid droeg, samen met CDA en later VVD en D66: de post van staatssecretaris van Justitie was van 1989 tot 2002 in handen van een sociaaldemocraat. De meest recente restrictieve hervormingen, onder het centrum-rechtse

37 Daalder 1995: 27.

38 Lijphart 1979: 129.

39 Vgl. De Lange 2007: 413. 
kabinet Balkenende II, werden - op de verhoging van het inkomensvereiste bij gezinsvorming na - gesteund door de PvdA. Dit paradoxale verband tussen restrictieve en liberale tendensen in het Nederlands gezinsmigratiebeleid en de ideologische samenstelling van de regering toont aan hoezeer 'consensus government' 40 tot de dag van vandaag kenmerkend blijft voor de Nederlandse politiek.

\subsection{De these van de control gap}

Eén van de drijfveren om dit onderzoek te verrichten was de vraag, hoe kan worden verklaard dat in Nederland, een land dat nooit een immigratieland heeft willen zijn, gezinsmigratie heeft plaats gevonden op een zodanig grote schaal dat het aanzien van de Nederlandse maatschappij voorgoed veranderd is. Deze vraag sluit aan bij een theoretisch debat dat reeds vijftien jaar woedt in het internationale veld van migratiestudies. Centraal in dit debat staat de paradox die, in de beroemde formulering van Cornelius e.a., kan worden samengevat als de 'gap hypothesis': er gaapt een kloof tussen de restrictieve doelstellingen van het immigratiebeleid van geïndustrialiseerde, democratische landen en de resultaten van dat beleid, dat wil zeggen de voortdurende en omvangrijke immigratiestromen in die landen. ${ }^{41}$ Deze studie van de beleidsvorming in Nederland inzake gezinsmigratie tussen 1955 en 2005 werpt een nieuw licht op de hypotheses die tot op heden ter verklaring van deze paradox naar voren zijn gebracht.

\section{Macht of onmacht van nationale beleidsmakers}

In de these die tot nu toe de grootste aanhang geniet onder onderzoekers van migratiebeleid, wordt een doorslaggevende rol toegekend aan de rechtspraak. Nationale en Europese rechters zouden - op grond van nationale, Europese of mondiale rechtsnormen - de belangen van individuele migranten hebben verdedigd, en zo de beleidsruimte hebben verkleind waarover de uitvoerende en de wetgevende macht beschikken om toelating en verblijf van vreemdelingen aan banden te leggen. Nationale beleidsmakers wilden immigratie wel remmen, maar stuitten daarbij op de grenzen die in een democratische rechtsstaat aan legitiem overheidsingrijpen worden

40 Andeweg \& Irwin 2005: 220-235.

41 Cornelius e.a. 1994: 3. 
gesteld door de individuele rechten van staatsburgers én vreemdelingen; grenzen die door de rechtbanken voortvarend zouden zijn verdedigd. ${ }^{42}$

Het feit dat de Nederlandse overheid in de halve eeuw die achter ons ligt de vestiging van honderdduizenden gezinsmigranten heeft toegestaan is echter niet het gevolg van wat Joppke heeft beschreven als 'agressief' optreden van 'activistische rechtbanken'. ${ }^{43}$ In het veld van gezinsmigratie kan de rol van de Nederlandse rechters noch het Europees Hof in Straatsburg 'agressief' of 'activistisch' worden genoemd. Integendeel, deze rechters toonden zich over het algemeen terughoudend, uit respect voor de beslissingen van het democratisch gelegitimeerd bestuur en van de soevereiniteit van de staat over toelating en verblijf van vreemdelingen op het nationaal grondgebied. De rechtspraak is wel degelijk een belangrijker rol gaan spelen in de beleidsvorming, maar niet op een manier die het onmogelijk maakte om de overkomst van gezinsmigranten aan beperkingen te onderwerpen.

In de jaren vijftig en zestig speelde de rechtspraak geen rol van enige betekenis in het Nederlands gezinsmigratiebeleid. Hierin kwam in de jaren zeventig verandering, toen de mogelijkheden tot beroep bij de rechter werden uitgebreid en betaalbare en deskundige rechtshulp beschikbaar kwam. De invloed van de rechtspraak op het gezinsmigratiebeleid is misschien wel het grootst geweest in de jaren zeventig en vroege jaren tachtig: deze betrof toen echter niet primair de inhoud, maar de vorm van het beleid. Op grond van algemene principes van behoorlijk bestuur, zoals rechtszekerheid, zorgvuldigheid en gedegen motivatie, dwongen rechters publicatie van de regelgeving en consistentie in de uitvoering af. De Vreemdelingencirculaire veranderde van een geheime interne instructie in formele regelgeving waaraan burgers rechten konden ontlenen, en de beleidsruimte waarover ambtenaren beschikten bij de interpretatie en implementatie van die regelgeving werd aanzienlijk ingeperkt. Ook wat de inhoud van het beleid betrof hebben rechterlijke uitspraken gevolgen gehad, met name waar het de controle op schijnhuwelijken, de toepassing van het mvv-vereiste en de aanvullende eisen voor gezinshereniging door buitenlandse vrouwen betrof. Vanaf de

42 Cornelius e.a. (1994: 7, 9), Joppke (1998: 270-271; 1999: 18-21; 2001: 340-342), Guiraudon (2000: 221-224), Guiraudon \& Lahav (2000: 189), Guiraudon \& Joppke (2001: 9-10) en Hollifield (2000: 148-150, 163-164) leggen de nadruk op nationale constitutionele en algemene rechtsprincipes als bron van beperking door rechtbanken van mogelijkheden van natiestaten om immigratie te beheersen; Soysal (1994: 149-151) en Sassen (1996: 11-12; 1999: 181, 184-185; 2006: 351) daarentegen kennen internationale rechtsnormen een beslissende rol toe.

43 Joppke 2001: 359. 
late jaren tachtig ging ook de jurisprudentie van het Hof van Straatsburg op grond van artikel 8 EVRM een rol spelen in de Nederlandse rechtspraak: dit had met name gevolgen voor het beleid inzake voortgezet verblijf van buitenlandse gezinsleden en het gezinsherenigingsbeleid voor vluchtelingen. Het meest directe effect van de rechterlijke interpretatie van artikel 8 EVRM voor het Nederlands gezinsmigratiebeleid was de afschaffing van het criterium feitelijke gezinsband in 2006, in respons op twee veroordelingen van de Nederlandse staat door het Hof van Straatsburg. Sinds 1989 worden beslissingen in individuele gevallen bovendien steeds getoetst op mogelijke inbreuk op artikel 8 EVRM.

De invloed die de rechtspraak sinds de jaren zeventig op het Nederlands gezinsmigratiebeleid heeft uitgeoefend is dus niet verwaarloosbaar. Zij is echter ook zeker niet van dien aard, dat beleidsmakers wezenlijk werden beperkt in hun mogelijkheden om gezinsmigratie aan banden te leggen. ${ }^{44}$ Rechters zien erop toe dat de Nederlandse overheid een redelijke afweging maakt tussen enerzijds het individueel belang bij gezinshereniging of -vorming in Nederland en anderzijds het algemeen belang bij een restrictief of selectief migratiebeleid. Daarbij krijgt het bestuur veel ruimte om dat algemeen belang te definiëren en om te bepalen welke voorwaarden op grond daarvan aan gezinsmigratie dienen te worden gesteld. Het verbod op overkomst van niet-huwelijkse partners is in de jaren zeventig niet op aandringen van de rechtbanken opgeheven; rechters hebben evenmin gelijke behandeling van mannen en vrouwen, of van Nederlands staatsburgers en gevestigde vreemdelingen afgedwongen. ${ }^{45} \mathrm{Al}$ deze versoepelingen in de tweede helft van de jaren zeventig waren het gevolg van beslissingen die politici en ambtenaren uit eigen beweging hebben genomen. De legitimiteit van inkomens-, huisvestings- en leeftijdsvereisten bij gezinsmigratie is door rechtbanken nooit in algemene zin in twijfel getrokken: de restrictieve hervormingen die sinds de jaren negentig zijn doorgevoerd zijn dan ook niet op rechterlijk bezwaar gestuit. ${ }^{46}$ De inkomenseis van 1445 gulden voor migranten van de tweede generatie uit 1983 werd door de rechtbank evenmin verworpen; de introductie van inburgeringsvereisten bij toelating

44 Vgl. De Lange 2007: 408.

45 Rechtbanken hebben wel een rol gespeeld in de gelijkstelling van man en vrouw in het vreemdelingenrecht, maar zonder direct een beroep te doen op het principe van non-discriminatie: zij achtten de eis van één jaar wachttijd illegitiem, niet omdat die wel voor vrouwen en niet voor mannen gold, maar omdat het een ondeugdelijk middel werd gevonden om te toetsen of het om een 'reëel' huwelijk of om een schijnhuwelijk ging.

46 Zie noot 374 in hoofdstuk 4. 
in 2005 ook niet. ${ }^{47}$ De conclusie moet zijn dat de rechtspraak het Nederlands bestuur veel ruimte liet en laat om gezinsmigratie aan voorwaarden te onderwerpen, maar dat Nederlandse ambtenaren en politici er lang niet altijd voor hebben gekozen maximaal van die ruimte gebruik te maken.

In de inleiding van de eerste editie van het veel geciteerde boek van Cornelius, Martin en Hollifield uit 1994 werden rechtbanken nadrukkelijk naar voren geschoven als de drijvende kracht achter de beperking van de zeggenschap van nationale beleidsmakers over toelating en verblijf van vreemdelingen. ${ }^{48}$ In de inleiding op de tweede editie, die in 2004 verscheen, wordt de gap hypothesis gehandhaafd, maar wordt aan de rechtspraak in de verklaring van die kloof een veel bescheidener rol toegekend: de auteurs stellen slechts voorzichtig dat 'draconische' maatregelen door rechters kunnen worden verworpen en dat belangengroepen en juristen het nationaal vreemdelingenbeleid 'in sommige gevallen' met succes hebben aangevochten bij de rechtbank. ${ }^{49}$ De bevindingen van dit onderzoek ondersteunen de tweede interpretatie: de grenzen die de rechterlijke macht aan het overheidsoptreden heeft gesteld zijn geenszins zodanig krap bemeten, dat zij de paradox van het Nederlands gezinsmigratiebeleid kunnen verklaren. Joppke had, in ieder geval voor zover het de Nederlandse casus betreft, ongelijk toen hij stelde dat in Europe, the legal rather than the political process explains why states accepted unwanted (family) migration. ${ }^{50}$

Het zou kunnen dat de Nederlandse casus in internationaal perspectief uitzonderlijk is: Guiraudon stelde vast dat de Nederlandse rechtspraak in de versterking van de rechtspositie van migranten een minder belangrijke rol heeft gespeeld dan in Duitsland en Frankrijk het geval was, ook al zijn de bevoegdheden van de Nederlandse bestuursrechter niet minder groot. ${ }^{51}$ Wellicht stelt de Nederlandse rechter zich in vreemdelingenzaken bescheidener op ten opzichte van het bestuur dan zijn collega's in andere Europese landen plegen te doen. Het zou ook kunnen dat Nederlandse politici en ambtenaren minder radicale beleidskeuzes hebben gemaakt dan Franse en Duitse beleidsmakers en daardoor minder op rechterlijke weerstand zijn

47 Zie noot 395 in hoofdstuk 4.

48 Cornelius e.a. 1994: 9.

49 Cornelius \& Tsuda 2004: 13-14.

50 Joppke 1998: 271.

51 Guiraudon 2000: 220-221. 
gestuit. ${ }^{52}$ In beide gevallen zou de vraag zijn, hoe deze 'afwijkende' handelwijze van Nederlandse rechters dan wel beleidsmakers kan worden verklaard.

Allereerst dient echter empirisch te worden onderzocht of de casus van het Nederlands gezinsmigratiebeleid inderdaad uitzonderlijk is. Messina heeft recentelijk namelijk betoogd dat de rechtspraak in de ontwikkeling van het migratiebeleid in Duitsland, de casus die de grondslag vormt van Joppke's these van de rechtbanken als primaire bron van 'self-limited sovereignty', helemaal geen doorslaggevende rol heeft gespeeld. ${ }^{53} \mathrm{Ik}$ acht het niet onwaarschijnlijk dat, zoals ook Cornelius en Tsuda impliciet suggere$\operatorname{ren}^{54}$, de rechtspraak beduidend minder invloed heeft gehad op het migratiebeleid van westerse landen dan tot nu toe werd verondersteld. Nadere empirische studie van de beleidsvorming in andere landen is noodzakelijk om deze hypothese te onderbouwen. Daarbij dient niet alleen gezocht te

52 Gedetailleerde studies van beleidsvorming inzake gezinsmigratie in Duitsland en Frankrijk, of de rol van de rechter daarin, zijn niet voorhanden. Guiraudon en Joppke geven wel voorbeelden van uitspraken waarin de Franse en Duitse rechters het recht op gezinsleven hebben verdedigd; anders dan de Nederlandse rechter beriepen zij zich daarbij niet alleen op artikel 8 EVRM, maar ook op nationaal recht. Het recht op gezinsleven is vastgelegd in artikel 6 van de Duitse grondwet en wordt in Frankrijk als een principe général du droit beschouwd. (Guiraudon 1998: 665, 668-669; Joppke 1998: 284-286) De beleidsregel die door het Duits grondwettelijk hof werd verworpen, in 1987, was de eis dat vreemdelingen pas een huwelijkspartner mochten laten overkomen als het huwelijk tenminste drie jaar bestond, zoals die in Bavaria voor tweede generatie migranten en in Baden-Württemberg voor alle migranten werd toegepast. (Joppke 1998: 285-286; Huber 1985: 28). In 1981 had de federale regering reeds als richtsnoer voor de Bundesländer vastgelegd, dat kinderen alleen over mochten overkomen als zij ten hoogste zestien jaar oud waren en als beide ouders in Duitsland verbleven. Tweede generatie migranten mochten volgens de federale (niet bindende) richtlijnen alleen een huwelijkspartner naar Duitsland laten komen indien zij tenminste acht jaar in Duitsland verbleven en indien het huwelijk tenminste een jaar had bestaan. (Herbert 2001: 247; Huber 1985: 28) Deze beleidsregels werden door het Grondwettelijk Hof goedgekeurd. (Joppke 1998: 285-286) Het Duits gezinsmigratiebeleid lijkt in de jaren tachtig dus significant strenger te zijn geweest dan het Nederlandse, hoewel er belangrijke verschillen bestonden tussen de Bundesländer. In Frankrijk werden reeds in de jaren zeventig een aantal stringente maatregelen genomen: van juli 1974 tot mei 1975 was gezinsmigratie in het geheel niet toegestaan. In september 1977 kondigde staatssecretaris Stoléru een nieuwe opschorting van gezinsmigratie aan, die dit keer drie jaar zou moeten duren. Publiek en politiek protest tegen die maatregel was zo fel dat Stoléru terugkrabbelde en in november 1977 verordonneerde dat gezinsmigranten zouden worden toegelaten, maar geen toegang kregen tot de arbeidsmarkt. In 1978 werd die ordonnance geannuleerd door de Conseil d'Etat, met verwijzing naar het grondwettelijk recht op gezinsleven. (Viet 1998: 361, 376, 381-383, 387) In de jaren zeventig en tachtig zijn in Nederland vérgaande maatregelen als een stop op gezinsmigratie of arbeidsverbod voor gezinsmigranten nooit voorgesteld. Voor zover ik weet is noch in Frankrijk, noch in Duitsland ooit sprake geweest van een vrijstelling van de inkomenseis zoals die in Nederland werd toegepast. In één opzicht was het Frans gezinsmigratiebeleid in ieder geval soepeler dan het Nederlandse: tot 1994 was de overkomst van polygame gezinnen toegestaan. (Viet 1998: 458, 483) In Nederland is steeds alleen een vergunning verleend aan één echtgenote en aan háár kinderen.

53 Messina 2007: 235-237.

54 Cornelius \& Tsuda 2004: 13-14. 
worden naar voorbeelden van invloed van rechterlijke uitspraken op het beleid: dergelijke voorbeelden vinden we immers ook in de Nederlandse casus. Vooral dient in kaart te worden gebracht, hoeveel ruimte de rechtbanken aan beleidsmakers lieten en hoe van die ruimte gebruik is gemaakt.

De tweede these die veronderstelt dat nationale regeringen zeggenschap over het immigratiebeleid hebben verloren en die met name door Sassen naar voren wordt gebracht, legt de nadruk op 'the relocation of various components of state authority to supranational organizations such as the institutions of the European Union' ${ }^{55}$ Als gevolg van het vrij personenverkeer binnen de interne markt werd het onvermijdelijk om ook bevoegdheden over toegang en verblijf van derdelanders over te dragen aan de Europese instellingen. ${ }^{56}$ Sassen laat in het midden, op welk moment in de halve eeuw die achter ons ligt dit soevereiniteitsverlies precies zou hebben plaatsgevonden. Zij spreekt zich evenmin uit over de vraag, of de grootschalige immigratiestromen waarmee West-Europese landen zijn geconfronteerd, als een gevolg van de overdracht van nationale bevoegdheden moeten worden begrepen. Wanneer wij deze beide vragen wel aan de orde stellen, dan moet de conclusie zijn dat de instellingen van de Europese Unie pas uiterst recentelijk zeggenschap hebben gekregen over het nationaal gezinsmigratiebeleid en dat de grootschalige gezinsmigratie die de afgelopen decennia in Nederland heeft plaatsgevonden dus niet het resultaat is van het Europees integratieproces.

Dit proces heeft de ontwikkeling van het Nederlands gezinsmigratiebeleid wel beïnvloed, vooral in de vroege jaren zestig. De onderhandelingen in de EEG over het vrij verkeer van werknemers hadden weliswaar alleen betrekking op de voorwaarden voor gezinshereniging voor arbeidsmigranten die EEG-burgers waren, dat wil zeggen voor Italianen. Doordat het in die beginjaren van de Europese integratie echter nog niet vanzelfsprekend was om EEG-burgers een voorkeursbehandeling toe te kennen, had de totstandkoming van de eerste richtlijnen over het vrij werknemersverkeer ook effect op het Nederlands gezinsmigratiebeleid voor arbeidsmigranten van buiten de Europese Gemeenschap. Door de onderhandelingen in Brussel werd de positie van Justitie in het interdepartementaal overleg in Den Haag verzwakt, ten gunste van Sociale Zaken, en daardoor werd de opheffing van het verbod op gezinshereniging voor Spanjaarden en andere arbeidsmigranten van buiten de EEG versneld.

55 Sassen 1999: 177; zie ook Sassen 1996: 9, 12; 2006: 351-352.

56 Sassen 1999: 186-187. 
In de jaren zeventig en tachtig speelden de Europese instellingen geen rol in de beleidsvorming inzake gezinsmigratie in Nederland. Pas toen in de jaren negentig, in het kader van de vervolmaking van het vrij verkeer binnen de interne markt, de personencontroles aan de binnengrenzen werden opgeheven, werd toelating en verblijf van derdelanders geleidelijk een zaak van gemeenschappelijk belang. In eerste instantie gebeurde dat echter in een strikt intergouvernementele setting, vrijwel zonder betrokkenheid van de Europese Commissie, het Europees Parlement of het Europees Hof. De instrumenten die door de Raad van Ministers werden aangenomen, zoals de resolutie van 1993 over gezinshereniging, waren 'soft law': aanbevelingen of intentieverklaringen, geen bindende wetgeving. De wens om Europese harmonisatie van het migratiebeleid tot stand te brengen ging wel een rol spelen in de Nederlandse beleidsdebatten: het feit dat de Nederlandse regelgeving afweek van die van omringende landen werd een argument voor beleidswijziging. Van overdracht van bevoegdheden was echter nog geen sprake. Pas na het Verdrag van Amsterdam (1997) werd een begin gemaakt met het tot stand brengen van een Europees asiel- en migratiebeleid, dat onderdeel uit zou maken van het communautair recht en dat onderwerp zou zijn van toezicht door de Europese Commissie en het Europees Hof. In dat kader werd in 2003 de gezinsherenigingsrichtlijn aangenomen, het eerste communautaire beleidsinstrument in dit beleidsveld dat direct bindend is en boven nationale wet- en regelgeving gaat.

Pas zeer recentelijk zijn dus daadwerkelijk bevoegdheden over toelating en verblijf van gezinsmigranten overgeheveld van Den Haag naar Brussel. Tot 2003 hebben de Nederlandse autoriteiten niets van hun zeggenschap over het gezinsmigratiebeleid afgestaan aan de Europese instellingen. Voor de paradox van het Nederlands gezinsmigratiebeleid biedt het Europees integratieproces dan ook geen verklaring. Indien juristen als Groenendijk gelijk hebben, zou de gezinsherenigingsrichtlijn in dit opzicht een keerpunt betekenen. Zij verwachten dat de richtlijn veel vérstrekkender gevolgen zal hebben dan de nationale delegaties hebben voorzien, en dat Den Haag in de toekomst, als gevolg van verdere harmonisatievoorstellen van de Commissie maar vooral ook van de jurisprudentie van het Europees Hof van Justitie in Luxemburg, dat veel minder voorzichtig met de soevereiniteit van lidstaten pleegt om te springen dan het Hof in Straatsburg, weinig meer in te brengen zal hebben waar het toelating en verblijf van gezinsmigranten in Nederland 
betreft. Wellicht krijgt Sassen op dit punt dus toch nog gelijk. ${ }^{57}$

Overigens vind ik nog minder bewijs voor de stelling van Guiraudon en Lahav, dat verplaatsing van de beleidsvorming inzake toelating en verblijf van vreemdelingen naar het Europees niveau juist moet worden beschouwd als een strategie van de uitvoerende macht van de lidstaten om controle over het migratiebeleid te behouden, dat wil zeggen om politieke, juridische of maatschappelijke weerstand die zij op nationaal niveau ontmoeten te omzeilen. ${ }^{58}$ De doelstelling van de Nederlandse delegatie in de onderhandelingen in Brussel was een zodanige formulering van de gezinsherenigingsrichtlijn, dat het Nederlands gezinsmigratiebeleid ongewijzigd kon blijven en dat hervormingsplannen die reeds op tafel lagen konden worden uitgevoerd. De beleidslijnen die de Nederlandse kabinetten in Brussel verdedigden genoten de steun van een parlementaire meerderheid en stuitten bij de Nederlandse rechtbanken niet op bezwaar. Er was dus geen sprake van 'constraints' waaraan de regering door 'shifting up'59 probeerde te ontsnappen.

Dat in Nederland de afgelopen vijftig jaar grootschalige vestiging van gezinsmigranten heeft plaatsgevonden, is dus niet het gevolg van machtsverlies van Nederlandse beleidsmakers ten gunste van de rechtspraak of de Europese instellingen. De bevoegdheid en de capaciteit om de voorwaarden voor gezinsmigratie te bepalen berustte bij Nederlandse ambtenaren en politici. Het zijn hun keuzes die een verklaring behoeven.

\section{De keuzes van politici en ambtenaren}

Cornelius en Tsuda noemen 'ambiguous policy intentions' als een deelverklaring voor de 'kloof' die gaapt tussen formele beleidsdoelstellingen en feitelijke immigratiestromen in westerse landen. Deze ambiguïteit wijten zij aan de fragmentatie van staten, die immers 'do not speak with one voi$c e \cdot{ }^{60}$ Dit is een belangrijk punt dat, zoals Guiraudon reeds constateerde,

57 Joppke (1999: 22) spreekt over Europese beperkingen van zeggenschap over immigratie als 'self-induced', dat wil zeggen het resultaat van vrijwillige overeenkomsten van lidstaten: van externe beperkingen is in zijn ogen dus geen sprake. Indien Groenendijk c.s. gelijk hebben, zal het soevereiniteitsverlies van de lidstaten echter een onvoorzien en onbedoeld gevolg zijn van de dynamiek van het integratieproces, met name van de autonome en actieve rol die het Europees Hof in Luxemburg nog wel eens wil spelen bij de interpretatie van het communautair recht. (Groenendijk 2006: 218-221, 225-227; Groenendijk e.a. 2007a: 28) Het verlies van zeggenschap over het gezinsmigratiebeleid zou dan weliswaar 'self-induced' zijn, maar niet bewust gekozen.

58 Guiraudon \& Lahav 2000: 175-190; zie ook Guiraudon 2001.

59 Guiraudon \& Lahav 2000: 178.

60 Cornelius \& Tsuda 2004: 14. 
meer aandacht verdient in het internationaal academisch debat over migratiebeleid dan het tot nu toe gekregen heeft. ${ }^{61}$ 'De' staat bestaat niet, zo min als 'de' Nederlandse overheid bestaat. Migratiebeleid komt, in Nederland zoals in andere landen, tot stand in een wisselwerking tussen ambtenaren, bewindslieden en parlementariërs, die op basis van eigen institutionele of ideologische perspectieven op het migratievraagstuk onderscheiden standpunten innemen. De paradox van het Nederlands gezinsmigratiebeleid kan niet worden verklaard zonder deze wisselwerking in ogenschouw te nemen; naar alle waarschijnlijkheid geldt hetzelfde voor de paradox van het migratiebeleid in andere westerse landen.

De fragmentatie van de Nederlandse overheid tekende zich het duidelijkst af in de periode tussen 1955 en 1975. Twintig jaar lang werd het Nederlands gezinsmigratiebeleid bepaald in conflictueus overleg tussen de ambtenaren van Sociale Zaken en van Justitie. Dat Justitie in de loop der tijd meer water bij de wijn moest doen dan Sociale Zaken, en de voorwaarden voor gezinshereniging van arbeidsmigranten dus geleidelijk werden versoepeld, kan grotendeels inzichtelijk worden gemaakt met behulp van de theorieën van Freeman. Deze Amerikaanse onderzoeker stelt dat migratiebeleid in westerse landen moet worden beschouwd als 'client politics'. Doordat de maatschappelijke kosten van immigratie 'diffuus' zijn, en het profijt daarentegen 'geconcentreerd', zal de stem van de voorstanders van een liberaal migratiebeleid, zoals goed georganiseerde werkgeversorganisaties die nauwe banden met overheidsinstanties onderhouden, zwaarder wegen in de besluitvorming dan de stem van de tegenstanders. ${ }^{62}$ De weerstand van Justitie tegen versoepeling van het gezinsmigratiebeleid kwam inderdaad voort uit vrees voor de maatschappelijke gevolgen op de lange termijn, voor kosten die in die zin 'diffuus' waren dat zij moeilijk concreet te benoemen, of aan een specifieke groep toe te schrijven waren. Het pleidooi van Sociale Zaken voor soepele voorwaarden daarentegen was gebaseerd op de concrete belangen op de korte termijn van het Nederlands bedrijfsleven. Zeker in de eerste decennia na de Tweede Wereldoorlog, toen het wederom op de rails zetten van de Nederlandse economie een nationaal project was waar vrijwel al het andere voor moest wijken, woog het pleidooi van Sociale Zaken, dat krachtig ondersteund werd door de werkgeversorganisaties, zwaarder dan het verzet van Justitie.

61 Guiraudon 2001: 57.

62 Freeman 1995: 881-887; 2002: 77-82. 
Freeman blokkeert echter het zicht op een aantal cruciale aspecten van beleidsvorming inzake gezinsmigratie in Nederland, wanneer hij stelt dat 'immigration policy is not a morality play; it is interest driven like most everything else'. ${ }^{63}$ Ook tussen 1955 en 1975 speelden ethische overwegingen een rol van betekenis: de confessionele partijen in het parlement verzetten zich tegen al te stringente voorwaarden voor gezinshereniging omdat zij het moreel verwerpelijk achtten om arbeidsmigranten jarenlang gescheiden te houden van hun gezinnen. Dit parlementair verzet versterkte de positie van Sociale Zaken in interdepartementaal overleg. In later jaren speelden immateriële waarden een minstens zo belangrijke rol in de beleidsvorming: met denke aan het gewicht van de norm van gelijke behandeling vanaf de jaren zeventig, van eigen verantwoordelijkheid vanaf de jaren negentig, en van individuele keuzevrijheid en vrijzinnigheid inzake seksualiteit, huwelijk en opvoeding na de eeuwwisseling.

Freemans exclusieve focus op materiële belangen schiet tekort. Hetzelfde geldt voor Messina's analyse, waarin hij het migratiebeleid van West-Europese landen van de Tweede Wereldoorlog tot op heden definieert als 'interest-driven'. Ook na de het einde van de grootschalige werving in de vroege jaren zeventig bleef er op de Europese arbeidsmarkten vraag naar goedkope en flexibele arbeidskrachten, zelfs als er onder de autochtone bevolking werkloosheid heerste. Regeringen verklaarden formeel immigratie tot een minimum te willen beperken, maar waren werkgevers die belang hadden bij voortdurende immigratie in feite graag ter wille, zo stelt Messina, ook al omdat migratie een positief effect had op de demografische ontwikkeling. ${ }^{64}$

Messina's verklaring snijdt volstrekt geen hout waar het de ontwikkeling van het Nederlands gezinsmigratiebeleid betreft. Vanaf de tweede helft van de jaren zeventig hebben werkgeversorganisaties geen enkele rol meer gespeeld in de beleidsvorming. Wanneer arbeidsmarktoverwegingen te berde werden gebracht in de beleidsdebatten, binnen de ministeries of in het parlement, ging het steeds om bezorgdheid over de toestroom van kansarme gezinsmigranten en de nadelige gevolgen daarvan voor de sociale cohesie en de sociale zekerheid, nooit om profijt dat het Nederlands bedrijfsleven van gezinsmigratie zou kunnen hebben. Dat de Nederlandse regering grootschalige gezinsmigratie heeft toegestaan, heeft met de belangen van de Nederlandse

63 Freeman 2002: 94.

64 Messina 2007: 239-241, 
arbeidsmarkt niets te maken, integendeel. ${ }^{65}$ Mijn onderzoeksbevindingen duiden erop dat inzicht in de dynamiek van beleidsvormingsprocessen op het gebied van immigratie alleen mogelijk is wanneer wij, anders dan Freeman en Messina, erkennen dat in migratievraagstukken niet alleen materiele belangen op het spel staan, maar dat de vorming van migratiebeleid wel degelijk ook een 'morality play' is.

Een andere auteur die de verklaring voor liberale en restrictieve tendensen in nationaal migratiebeleid in binnenlandse politieke processen heeft gezocht, is Virginie Guiraudon. Op basis van haar onderzoek naar de toekenning van rechten aan migranten in Duitsland, Frankrijk en Nederland sinds de jaren zeventig, concludeert zij dat de rechtspositie van migranten wordt versterkt wanneer beleidsvorming zich afspeelt in besloten institutionele kaders, zoals de rechtbanken of ambtelijke organisaties, of in parlementaire debatten die weinig aandacht krijgen in de media. Hoe meer beleidsmakers zich kunnen onttrekken aan het zicht van het publiek, hoe groter de kans op liberale hervormingen. Hoe opener daarentegen de beleidsarena, hoe waarschijnlijker de keuze voor een restrictieve beleidslijn. ${ }^{66}$ In de periode die Guiraudon heeft onderzocht, namelijk van de jaren zeventig tot het einde van de jaren negentig, ontwikkelde de beleidsvorming inzake gezinsmigratie in Nederland zich inderdaad volgens deze lijn. Naarmate in het publiek debat en in de media meer aandacht kwam voor het immigratie- en integratievraagstuk in het algemeen en het gezinsmigratiebeleid in het bijzonder, werden de voorwaarden voor gezinsmigratie steeds verder aangescherpt. Wanneer wij echter verder teruggaan in de tijd, en het tijdvak van de jaren vijftig tot op heden bezien, dienen bij de analyse van Guiraudon de nodige vraagtekens te worden gezet. In de jaren zeventig werd de arena waarin de beleidsvorming inzake gezinsmigratie plaats vond opengebroken: waar de regelgeving voorheen achter gesloten deuren door een handvol ambtenaren werd vastgelegd, gingen politieke partijen, belangengroepen, juristen en rechtbanken zich steeds intensiever in de beleidsvorming mengen. Anders dan Guiraudon voorspelt, resulteerde dit veel opener institutioneel kader echter niet in restrictieve hervormingen: integendeel, het gezinsmigratiebeleid was in de jaren tachtig veel soepeler dan in de jaren zestig.

65 Messina (2007: 241) meent zelfs dat de massale instroom van asielzoekers sinds de jaren negentig als gevolg van voortdurende vraag naar buitenlandse arbeidskrachten dient te worden beschouwd. Gezien de dramatische werkloosheidscijfers onder in Nederland gevestigde vluchtelingen is dat echter uiterst discutabel.

66 Guiraudon 2000: 239. 
Aan Guiraudons analyse ligt de veronderstelling ten grondslag dat er sprake is van 'biais systématiquement négatifs du débat public'. ${ }^{67} \mathrm{Zij}$ is beslist niet de enige die ervan uitgaat, dat de publieke opinie steeds afwijzend staat tegenover liberale hervormingen van het migratie- of integratiebeleid. Joppke schrijft: 'it seems to be an Iron Law of the mass public in immigrant-receiving states to be negatively disposed to new immigration'. ${ }^{68}$ Freeman is nog stelliger: 'it appears normal, indeed it approaches a social law, that the citizens of liberal democracies are sceptical, if not hostile, toward immigration'. ${ }^{69}$ Mijn onderzoeksbevindingen roepen echter de nodige twijfels op over de validiteit en bruikbaarheid van deze 'wet' als analytische vooronderstelling.

Zo gold in de jaren zestig dat steeds wanneer publieke ruchtbaarheid werd gegeven aan voornemens van Justitie om Spaanse echtgenotes het land uit te zetten, de weerstand zo groot was dat uiteindelijk van uitzetting werd afgezien. Op basis van de krantenknipsels in de archieven van het ministerie en van wat in ambtelijke nota's over berichtgeving in de pers werd gezegd, is mijn stellige indruk dat niet alleen in het parlement, maar ook in de media kritisch werd gereageerd op stringent overheidsoptreden en beleid, en een scherp normatief oordeel werd geveld over de gezinsscheiding waarin het Nederlands gezinsmigratiebeleid resulteerde. Ook in de jaren tachtig gold dat het sterk gemediatiseerde conflict tussen regering en parlement over de inkomenseis van 1445 gulden voor kinderen van migranten uitmondde in de herroeping van de restrictieve beleidswijziging. De afwijzing van de 1445-maatregel door Kamerleden als een schending van de norm van gelijke behandeling werd ondersteund door een zeer breed scala aan maatschappelijke organisaties, die met massale demonstraties de aandacht van het publiek vroegen. Het is mogelijk dat de Nederlandse media tot de jaren negentig progressiever waren dan de brede publieke opinie, en dat de actiegroepen die zich in de jaren zeventig en tachtig roerden de 'zwijgende meerderheid' overstemden. Zowel de media als belangenorganisaties oefenen echter invloed uit op de publieke opinie; de posities die zij innemen passen in een 'tijdgeest' die ook de 'gewone burger' niet onberoerd laat. Jammer genoeg is tot op heden geen onderzoek gedaan naar publieke opinievorming of mediaberichtgeving in Nederland

67 'systematisch negatieve tendensen in het publiek debat'. Guiraudon 2000: 22.

68 Joppke 2002: 262.

69 Freeman 2002: 78. 
over migratie en integratie vóór de jaren negentig. ${ }^{70}$ Nadere studie van de historische ontwikkeling van de wisselwerking tussen mediaberichtgeving, publieke opinievorming en beleidsvorming inzake migratie en integratie is uiterst wenselijk.

In de Nederlandse beleidsvorming hebben dus niet alleen materiële maar ook immateriële belangen en waarden een rol gespeeld: waarden zoals gezinseenheid en gelijke behandeling, die een brede maatschappelijke weerklank vonden. Auteurs die voor dergelijke elementen ruimte maken in hun analyse van het migratiebeleid van westerse landen, zijn Joppke en Cornelius e.a. Joppke benoemt weliswaar de invloed van de rechtspraak als primaire verklaring voor de aanvaarding door Europese landen van ongewenste migratie, maar voegt daar een tweede factor aan toe: de 'morele verplichtingen' die politici ervaren jegens specifieke groepen migranten, zoals buitenlandse arbeiders of (post)koloniale migranten. ${ }^{71}$ In de Nederlandse debatten heeft dit argument twee keer een rol gespeeld: het is met kracht ingebracht door de Surinaamse delegatie in de onderhandelingen over de vestigingsakkoorden van 1975 en 1980 en het is door het kabinet in de vroege jaren tachtig naar voren geschoven als argument om migranten van de eerste generatie niet, en migranten van de tweede generatie wél aan een inkomenseis van 1445 gulden te onderwerpen. Deze these van Joppke verklaart de ontwikkeling van het Nederlands gezinsmigratiebeleid dus slechts in zeer beperkte mate. Desalniettemin is hij één van de weinige auteurs die oog heeft voor de mogelijke betekenis van moraliteit in de vorming van migratiebeleid.

Andere auteurs die zich in die richting begeven zijn Cornelius e.a., die in hun verklaring van het falen van westerse landen om immigratie aan banden te leggen een centrale rol toekennen aan 'rights-based liberalism'. Vanuit de burgerrechtenbeweging in de vs zien zij in de gehele westerse wereld een nieuw type 'liberal republicanism' ontstaan, dat 'has taken shape at many levels of the democratic polity: in legislative acts, partisan and interest group (especially ethnic) politics, and most important of all, in

70 Uitzonderingen zijn Emmerik-Levelt en Teulings (1967), die echter slechts berichtgeving in de geschreven pers in het jaar 1965 hebben geanalyseerd; het lopend onderzoek van Schrover (2008) naar de invloed van media-hypes op het Nederlands migratiebeleid; en de analyse van de 'Tamil crisis in de pers' van Teun van Dijk (1988: 215-254). De framing van migratie en integratie enerzijds in de media en anderzijds door parlement en regering is voor de periode 1995-2004 in kaart gebracht in het proefschrift van Rens Vliegenthart (2007). Zie ook Boomgaarden \& Vliegenthart 2007; Vliegenthart e.a. 2008; Roggeband \& Vliegenthart 2007.

71 Joppke 1998: 271. 
judicial rulings' ${ }^{72}$ De uitbreiding van de rechten van minderheden heeft de mogelijkheden waarover westerse regeringen beschikken om hun grenzen te sluiten en migranten uit te sluiten significant ingeperkt. ${ }^{73}$ We hebben reeds vastgesteld dat van de centrale rol die Cornelius e.a. hierbij aan de rechtspraak toekennen in Nederland geen sprake was. Desalniettemin raakt hun analyse aan een wezenlijk punt. Vanaf de jaren zeventig wordt het politiek debat over gezinsmigratie inderdaad steeds vaker in termen van 'rechten' gevoerd. Kamerleden spreken over het 'recht op gezinshereniging' en het 'recht op gelijke behandeling'. De opkomst van dit 'rechten-vertoog' houdt nauw verband met de juridisering van de verhouding tussen burger en overheid ${ }^{74}$, en kan wellicht indirect worden teruggevoerd op de indruk die Martin Luther King en de zijnen ook in Nederland hebben gemaakt. Het is echter cruciaal om te beseffen dat formuleringen als het 'recht op gezinshereniging' en het 'recht op gelijke behandeling' niet zozeer naar een juridische norm verwijzen als wel naar een politiek-ethische of ideologische norm. Er bestond en bestaat geen ongeclausuleerd recht op gezinshereniging, noch in het Nederlands noch in het internationaal recht. De afweging die rechters maken tussen het recht van een individu op een gezinsleven en het recht van de staat om vreemdelingen te weigeren of toe te laten is gecompliceerd, en valt in de regel in het voordeel van de staat uit. De gelijke behandeling van mannen en vrouwen, en de - vrijwel - gelijke behandeling van gevestigde vreemdelingen en Nederlandse staatsburgers is in de tweede helft van de jaren zeventig niet tot stand gekomen omdat de rechtspraak respect voor die norm afdwong. Ongelijke behandeling op grond van nationaliteit is juridisch zeer wel mogelijk. Wanneer Nederlandse politici over 'rechten' spraken en spreken, geven zij zelden blijk van inzicht in de complexe manier waarop de normen waaraan zij refereren door rechtbanken worden geïnterpreteerd en toegepast. Door over 'rechten' te spreken, geven zij echter wel het politiek-ethisch gewicht aan van normen als gelijke behandeling en respect voor gezinsleven. In die zin heeft 'rights-based politics ${ }^{75}$ inderdaad een cruciale rol gespeeld in de Nederlandse beleidsontwikkeling: zij vormde de drijvende kracht achter het liberale gezinsmigratiebeleid dat Nederland in de jaren tachtig voerde.

72 Cornelius e.a. 1994: 9.

73 Cornelius e.a. 1994: 9-10; Hollifield 2000: 146-150.

74 Dijkstra 1996: 49, 61-62.

75 Cornelius e.a. 1994: 10. 
Wellicht kan 'rights-based politics', of de juridisering van het beleidsdebat, ook in zijn tegendeel verkeren. Waar het spreken over 'rechten' in de jaren zeventig en tachtig als onderbouwing diende voor de versoepeling van de voorwaarden van gezinsmigratie, nam het debat midden jaren negentig een geheel andere wending. CDA en VVD dienden toen een motie in die de regering dwong in haar gezinsherenigingsbeleid voor vluchtelingen 'de grenzen van artikel 8 EVRM op te zoeken'. De christendemocraten, die in de jaren zestig nog zo krachtig pleiten voor versoepeling op grond van het moreel gewicht van het gezinsleven, achtten deze ethische norm in de jaren negentig minder zwaarwegend dan het belang van de Nederlandse samenleving bij migratiebeperking. De context waarin deze debatten zich afspeelden was in de jaren negentig natuurlijk wezenlijk anders dan in de jaren zestig. Wellicht speelt in deze omslag echter ook een rol dat de morele waarde van het gezin, door de opkomst van internationaal recht en rechtbanken, was veranderd van een norm die tot de kern van het confessioneel gedachtegoed behoorde en dus eigen was, in een artikel uit een Europees verdrag, een juridische verplichting die van buitenaf werd opgelegd en waarvan de grenzen dus mochten worden opgezocht.

Een vergelijkbare ontwikkeling lijkt zich te hebben voltrokken waar het de status van het Nederlands staatsburgerschap in het gezinsmigratiebeleid betreft. Zowel Soysal als Sassen menen dat de betekenis van nationaal burgerschap, als gevolg van processen van globalisering, wezenlijk is veranderd. Soysals these is dat zich sinds de Tweede Wereldoorlog een nieuw, postnationaal concept van burgerschap heeft ontwikkeld, gebaseerd op 'universal personhood rather than national belonging' . Waar individuele rechten voorheen hun grond vonden in nationaal staatsburgerschap, zijn zij nu geworteld in de transnationale gemeenschap, dat wil zeggen in internationale conventies en mensenrechtenverdragen. De natiestaat is nog steeds het kader waarin individuele rechten materieel worden verwezenlijkt, maar vormt niet langer de bron van legitimiteit van die rechten. Die legitimiteit vloeit nu voort uit een transnationaal vertoog waarvan mensenrechten het organiserend principe vormen. Daardoor legt nationaal staatsburgerschap volgens Soysal steeds minder gewicht in de schaal. ${ }^{76}$ Sassen onderschrijft de hypothese van Soysal ten dele. Naast de opkomst van post-nationaal burgerschap, dat zijn rechtvaardiging buiten de natiestaat vindt, observeert Sassen ook een proces van 'de-nationalisering' van burgerschap: een bur-

76 Soysal 1994: 1-3, 142-143, 164-165. 
gerschap dat geworteld is in de natiestaat, maar een nieuwe betekenis aanneemt als gevolg van de effecten van globalisering op 'the national' sinds de jaren tachtig. De loyaliteit die cruciaal was voor het in stand houden van massalegers is nu voor de natiestaat minder van belang dan de mobiliteit en flexibiliteit die de competitie op de globale wereldmarkt van burgers vergt. Diezelfde competitie zet staten onder druk om de rechten en privileges die zij hun burgers toekenden terug te schroeven en verzwakt zo de band tussen staat en burger verder. Sassen is weinig uitgesproken in haar evaluatie van deze veranderingen, maar lijkt net als Soysal te veronderstellen dat nationaal staatsburgerschap aan waarde aan het inboeten is. ${ }^{77}$

Mijn onderzoeksbevindingen onderschrijven deze hypothese, maar op een heel andere manier dan met name Soysal voorspelt. Tot halverwege de jaren vijftig was het vanzelfsprekend en onomstreden dat een Nederlandse man met zijn gezin op Nederlands grondgebied mocht verblijven. Die geprivilegieerde status kwam tot uiting in het feit dat de buitenlandse vrouw die een Nederlander huwde direct de Nederlandse nationaliteit kreeg. De consequente toepassing van het kostwinnersmodel betekende dat de Nederlandse vrouw daarentegen bij haar huwelijk met een vreemdeling haar Nederlanderschap verloor: zij werd geacht haar echtgenoot in zijn nationaliteit en verblijfplaats te volgen. De opkomst van de norm van gelijke behandeling in de jaren zeventig leidde er in eerste instantie toe dat vrouwen en gevestigde vreemdelingen gingen delen in de geprivilegieerde status van Nederlandse mannen: vrouwen verloren niet langer hun staatsburgerschap bij huwelijk met een buitenlander en kregen de mogelijkheid om hun Nederlanderschap over te dragen op hun kinderen en om buitenlandse gezinsleden naar Nederland te laten overkomen. Gevestigde vreemdelingen werden, net als Nederlandse vrouwen, vrijgesteld van het inkomensvereiste in geval van niet-verwijtbare werkloosheid en hun gezinsleden kregen, net als de partners en kinderen van Nederlanders, een vrijwel onaantastbaar verblijfsrecht. Vanaf de tweede helft van de jaren tachtig krijgt de norm van gelijke behandeling echter een omgekeerd effect: er wordt niet langer gekozen voor levelling-up, maar voor levelling-down. De echtgenotes van Nederlandse mannen kunnen sinds 1985 niet langer direct opteren voor het Nederlanderschap, maar moeten net als partners van Nederlandse vrouwen drie jaar wachten voordat zij voor

77 Sassen 2003: 45-47, 55-57. 
naturalisatie in aanmerking komen. ${ }^{78}$ Sinds de hervormingen van 1993 is iedere aanscherping van de voorwaarden voor gezinsmigratie gelijkelijk op Nederlands staatsburgers en op gevestigde vreemdelingen van toepassing geweest. Enerzijds woog de norm van gelijke behandeling zo zwaar, dat een voorkeursbehandeling van staatsburgers boven vreemdelingen met een permanente verblijfstitel nauwelijks verdedigbaar was. Anderzijds was de doelstelling van migratiebeperking alleen te verwezenlijken indien ook Nederlanders die buitenlandse gezinsleden wilden laten overkomen aan strengere voorwaarden werden onderworpen: bijna de helft van de aanvragers was immer Nederlands staatsburger. In informele communicatie tussen bewindslieden begin jaren negentig werd er bovendien expliciet op gewezen, dat het in veel gevallen om genaturaliseerde Surinamers ging. Dit wekt de indruk dat het staatsburgerschap tenminste deels aan waarde heeft ingeboet als onderscheidend criterium, doordat zoveel mensen van elders inmiddels een Nederlands paspoort bezitten. ${ }^{79}$

In de afgelopen decennia zijn de privileges die aan het Nederlands staatsburgerschap - van mannen - waren gekoppeld uit het gezinsmigratiebeleid verdwenen. Soysal en Sassen hebben gelijk: nationaal burgerschap heeft aan betekenis verloren. Het doet er voor de overheid niet langer toe of de persoon die met buitenlandse gezinsleden in Nederland wil leven al dan niet het Nederlands staatsburgerschap bezit. Het voornaamste criterium om onderscheid te maken is nu de vraag, of de aanvrager tijdelijk of permanent toestemming is verleend om op Nederlands grondgebied te verblijven. Anders dan Soysal suggereert heeft dit echter niet zozeer geleid tot een opwaardering van de status van status van buitenlandse ingezetenen als 'post-nationale' burgers, als wel tot een devaluatie van de status van Nederlands staatsburger, dat wil zeggen van de voorkeursbehandeling die hij genoot in het gezinsmigratiebeleid.

78 De wijziging van het nationaliteitsrecht in 1985 betekende zowel een levelling down voor Nederlandse mannen en hun buitenlandse echtgenotes, als een levelling up voor Nederlandse vrouwen en hun buitenlandse gezinsleden: vrouwen kregen net als mannen de mogelijkheid om hun Nederlands burgerschap aan hun kinderen door te geven. Echtgenoten van Nederlandse vrouwen kwamen na drie, in plaats van na vijf jaar, in aanmerking voor naturalisatie.

79 In politiek en maatschappelijk debat, evenals in de sociale wetenschappen, is staatsburgerschap als grond om onderscheid te maken binnen de Nederlandse bevolking vrijwel volkomen vervangen door herkomst: er wordt niet gesproken over Nederlanders en vreemdelingen, maar over autochtonen en allochtonen. 'Autochtoon' of 'allochtoon' zijn echter juridisch geen bruikbare begrippen en kunnen in het vreemdelingenbeleid dus niet worden toegepast. De veranderende status van staatsburgerschap in het gezinsmigratiebeleid hangt echter wel nauw met deze bredere tendens in het politiek, maatschappelijk en wetenschappelijk vertoog samen. 


\section{Kritische reflecties op de vraagstelling van een academisch debat}

Cornelius e.a. beschouwen de grootschalige immigratie die in westerse landen heeft plaats gevonden als het resultaat van het onvermogen van liberale staten om migratie te beheersen. Aan hun gap hypothesis ligt de veronderstelling ten grondslag, dat staten ernaar streven immigratie te beperken of zelfs een halt toe te roepen, maar daarin falen. Die veronderstelling is onjuist. In Nederland waren politici het er in de jaren tachtig bijna Kamerbreed over eens dat de algemene restrictieve doelstellingen van het vreemdelingenbeleid niet op het gezinsmigratiebeleid dienden te worden toegepast. Zij hebben niet gepoogd om gezinsmigratie in te perken: er was geen sprake van onvermogen, maar van een politieke keuze. De vraagstelling van Cornelius e.a., die een zo centrale rol heeft gespeeld in het academisch debat van de afgelopen vijftien jaar, is niet vrij van een zekere vooringenomenheid, dat wil zeggen tijdgebondenheid: zij weerspiegelt de sfeer van crisis en indruk van falend overheidsbeleid die in de jaren negentig rond het migratievraagstuk bestonden, vooral als gevolg van de plotselinge en aanzienlijke stijging van asielmigratie.

In de inleiding op de tweede editie van het standaardwerk, Controlling Migration, dat in 2004 verscheen, handhaven de auteurs de beroemde 'gap hypothesis' die zij tien jaar eerder formuleerden: 'singificant and persistent gaps exist between official immigration policies and actual policy outcomes'. Zij menen zelfs dat niet zozeer van een hypothese sprake is, als van een empirisch feit: weinig landen hebben 'migration control policies that are perfectly implemented or do not result in unintended consequences'. ${ }^{80}$ Zo geformuleerd is deze stelling een waarheid als een koe, maar verliest daarmee ook grotendeels haar waarde als paradox die een zo vruchtbare voedingsbodem bood voor academische reflectie en debat. Immers, in welk beleidsveld is wel sprake van een naadloze aansluiting tussen beleidsdoeleinden en resultaten? Het idee van een dergelijk sturingsvermogen van de overheid, van een maakbare samenleving, is achterhaald. De beleidsstrategieën die westerse landen sinds de jaren negentig hebben ontwikkeld en ingezet hebben veel onderzoekers tot de conclusie doen komen, dat er van een 'controle crisis' geen sprake is en dat overheden wel degelijk in staat zijn een effectief migratiebeleid te voeren.$^{81}$ De meest recente ontwikkelingen van het Nederlands gezinsmigratiebeleid tonen inderdaad aan dat

80 Cornelius \& Tsuda 2004: 4-5.

81 Guiraudon \& Joppke 2001: 12; Joppke 2002: 262-263; Messina 2007: 241. 
wanneer de politieke wil er is, toelating en verblijf van vreemdelingen aan stringente voorwaarden kunnen worden onderworpen.

De paradox van het westers migratiebeleid is in recenter jaren ook anders geformuleerd. Freeman observeert een kloof niet zozeer tussen de doeleinden en resultaten van migratiebeleid, als wel tussen 'public opinion and public policy': 'immigration policy in most countries is more liberal than public preferences as expressed in surveys and by other means suggest that it should be if policy closely tracked popular sentiments' ${ }^{82}$ Dit is een vruchtbaarder benadering dan die van Cornelius e.a., in die zin dat de veronderstelling wordt losgelaten dat overheidsbeleid gericht was op migratiebeperking, maar faalde. Uitgangspunt is hier dat staten toelating en verblijf van migranten toestaan: de vraag is dan waarom. Dit is mijns inziens de juiste vraagstelling. De paradox zoals Freeman die schetst is echter wederom gebaseerd op een veronderstelling waarbij, zoals reeds geconstateerd, op grond van dit onderzoek vraagtekens moeten worden gesteld. Ik betwijfel of er op enig moment gedurende de afgelopen vijftig jaar sprake is geweest van een wezenlijke discrepantie tussen het gezinsmigratiebeleid dat de Nederlandse regering voerde, en de standpunten die in het publiek debat werden ingenomen.

Joppke maakte in 2002 een onderscheid tussen drie categorieën van migratie, dat een goed startpunt biedt voor een nauwkeuriger en vooral opener formulering van de paradox van het westers migratiebeleid. Migratie kan 'solicited' zijn, dat wil zeggen bewust bevorderd vanwege het profijt dat overheden ervan verwachten: dat geldt bijvoorbeeld voor de Mediterrane arbeidsmigranten die tot 1974 in grote getale naar Nederland kwamen, en voor de kennismigranten wier komst de regering dezer dagen wil stimuleren. Tegenover 'soliciting policies' staan 'stemming policies', gericht op het inperken of stoppen van bestaande maar ongewenste immigratiestromen. In de derde plaats ten slotte onderscheidt Joppke 'as-of-right immigration': immigratie die in wezen ongewenst is, in die zin dat overheden ze liever niet zouden zien plaatsvinden, maar die wel legitiem en legaal is. Deze derde categorie, waartoe asiel- en gezinsmigratie behoren, beschouwt Joppke als 'the true subject of the scholarly debate over the resilience or decline of state sovereignty in immigration control'. ${ }^{83}$

In Joppkes woordkeus - 'as-of-right' - komt opnieuw de term 'recht' terug: Joppke blijft, net als in zijn eerder werk, meer nadruk leggen op de

82 Freeman 2002: 78; zie ook Boswell 2007: 75.

83 Joppke 2002: 260-263. 
rol van rechters en juristen in de beleidsdynamiek dan ik gerechtvaardigd acht. Ook zijn bestempeling van asiel- en gezinsmigratie als 'ongewenst' is wat kort door de bocht. Joppke maakt echter wel een sterk analytisch punt, door gezinsmigratie te typeren als niet bewust gezocht of uitgenodigd, maar wel aanvaard. De Nederlandse regering heeft gezinsmigratie nooit actief gestimuleerd: de vestiging van buitenlandse gezinnen of gezinsleden is nooit bevorderd omdat daarvan demografische of sociaal-economische voordelen werden verwacht, zoals dat in 'settler countries' als de Verenigde Staten of Australië of in Europese koloniën soms wel het geval is geweest. Desalniettemin heeft Nederland gezinsmigratie sinds 1960 toegestaan, onder meer of minder strenge voorwaarden. De grootschalige gezinsmigratie van de afgelopen vijftig jaar heeft legaal plaatsgevonden, dat wil zeggen binnen de kaders die door Nederlandse ambtenaren en politici, vrij van externe druk of dwang, zijn vastgesteld.

Of en onder welke voorwaarden Nederlandse ambtenaren en politici de vestiging van gezinsmigranten hebben toegestaan, was afhankelijk van de manier waarop zij de voor- en nadelen wogen. In die afweging speelden sociaal-economische belangen een rol, evenals verwachtingen omtrent migratiestromen en de maatschappelijke gevolgen daarvan, en - niet in de laatste plaats - morele en ideologische waarden. Hoe die afweging uitviel was afhankelijk van de invloedsverhoudingen tussen de betrokken beleidsactoren.

Ik pleit ervoor de paradox van het migratiebeleid in West-Europa als volgt te formuleren: landen die zichzelf niet als immigratieland beschouwden en die geenszins aspiraties koesterden om immigratielanden te worden, hebben sinds de Tweede Wereldoorlog de vestiging van migranten toegestaan op een schaal, die het aanzien van West-Europa voorgoed heeft veranderd. De vraag dient te zijn, waarom overheden immigratie hebben toegestaan: op grond van welke overwegingen ambtenaren en politici tot die beleidskeuze zijn gekomen. Het antwoord op die vraag dient in de eerste plaats gezocht te worden in onvoorziene ontwikkelingen in migratiestromen, zoals de vestiging van de 'gastarbeiders' of de grootschalige keuze van tweede generatie migranten voor een buitenlandse huwelijkspartner. In de tweede plaats is van belang, hoe de maatschappelijke gevolgen van immigratie worden gepercipieerd. Men denke hierbij aan het economisch profijt dat in de jaren zestig van arbeidsmigratie werd verwacht, of aan het optimisme over de maatschappelijke inpassing van migranten in de jaren tachtig. In de derde plaats ten slotte dient het gewicht van morele of 
ideologische normen als respect voor gezinsleven of gelijke behandeling - een aspect dat tot nu toe verwaarloosd is in het academisch debat - een centrale plaats te krijgen in de analyse. In het Nederlands beleidsvormingsproces speelden dergelijke normen een doorslaggevende rol, zonder dat de rechter daaraan te pas kwam.

De bevindingen van deze studie laten zien, dat ons inzicht in de dynamiek van migratiebeleid in West-Europa gebaat is bij onderzoek dat in kaart brengt welke actoren invloed hebben uitgeoefend op de beleidsvorming, hoe deze actoren zich tot elkaar verhielden, en op grond van welke materiële én immateriële belangen, percepties en verwachtingen zij tot hun besluiten zijn gekomen. Internationaal comparatief onderzoek om de specificiteit dan wel algemene geldigheid van onderzoeksbevindingen vast te stellen is zeer gewenst, maar niet ten koste van de zorgvuldigheid en volledigheid van onze kennis van de dynamiek van beleidsvormingsprocessen.

Wellicht betekent dit een stap 'terug' naar empirie en single case studies voor het academisch veld van migratiestudies, dat zichzelf stilaan als zelfstandige discipline aan het vestigen is en waar in dat kader de roep om theorievorming reeds jaren dringend klinkt. Ik meen echter dat de inzichten die deze studie van de Nederlandse beleidsvorming inzake gezinsmigratie biedt de waarde aantonen van een meer inductieve benadering, die onderzoekers beter in staat stelt de valkuilen van tijd- en plaatsgebonden vooronderstellingen te vermijden. 


\section{English summary}

\section{Borders and families. The making of family migration policies in the Netherlands, 1955-2005}

This book is about the ways in which Dutch politicians and civil servants have determined the conditions for entry and stay of family migrants in the Netherlands between 1955 and 2005. It traces the development of Dutch family migration policies and seeks to explain this development by analysing the dynamic of the decision-making processes in which these policies were established.

Starting from a constructivist approach to the study of policy-making, I investigate change and continuity in the institutional structure, that is in the actors involved in the decision-making process, the ways in which these actors framed family migration as a policy problem, and the extent to which the different actors influenced the outcome. Furthermore, I identify phases and turning points in the development of family migration policies, and examine how these policy trends relate to the broader political and cultural context.

This book aims to contribute to the academic debate in three ways. First, it fills a void in existent knowledge about migration and migration policies in the Netherlands. Penninx et al. have recently observed that the Dutch field of migration studies is short of 'literature that analyses the making of policies itself: that is analyses, not of the content of policies per se, but of the process that has led to these policies, the actors involved and the levels at which they are made'. ${ }^{1}$ Dutch students of policy and politics have but recently directed their attention to the field of migration and integration. Since the 1990s, academic accounts of policies regarding entry and stay of labour migrants, refugees and (post)colonial migrants in the Netherlands have been more forthcoming. The history of the making of Dutch family migration policies however has not yet been written.

1 Penninx e.a. 2005: 2. 
Second, this book is a case study of Dutch policy-making. Empirical analyses of the interaction between Parliament, cabinet and civil servants in the decision-making process and the relative influence of these actors on the policy output are fairly scarce in the Netherlands. Historical accounts, identifying change and continuity in these influence structures over the longer term, are even sparser.

Finally, this study engages with the ongoing debate in the international field of migration studies regarding the paradox of migration policy in liberal democratic countries. In the famous wording of Martin, Cornelius and Hollifield, this paradox is defined as a 'control gap': 'the gap between the goals of national immigration policy (...) and the actual results of policies in this area (...) is wide and growing wider' ${ }^{2}$ The Netherlands are one of these countries where large-scale settlement migration was far from welcome, but took place all the same, for a significant part through the family migration channel. This case study of the decision-making processes in which the conditions for family migration were set thus offers the opportunity to test existent hypotheses explaining this paradox.

\section{The making of Dutch family migration policies, 1955-2005}

From 1955 to 1975 , during the years of large scale labour recruitment, Dutch family migration policy was the result of three conflicting policy perspectives. The economic point of view, represented in policy circles by the ministry of Social Affairs, focused on the urgent need of Dutch companies for foreign labour. To ensure the attractiveness of the Netherlands as a country of destination, foreign workers should be offered the possibility to bring their families over. This plea found support in Parliament, where the confessional parties in particular deemed it morally inadmissible to keep fathers and husbands separated from their families. As both Social Affairs and Parliamentarians assumed the stay of labour migrants in the Netherlands to be temporary, the long term social consequences of labourand family migration were no cause for concern. The ministry of Justice however was convinced that once reunited with their family in the Netherlands, foreign workers would not return to their home countries. Since Justice feared that the large-scale and permanent settlement of foreigners - especially if their cultural background was 'different' - would have a

2 Cornelius e.a. 1994: 3. 
detrimental effect on the cohesion of Dutch society, it would have preferred to deny entry to labour migrants' families. Between 1955 and 1960, family reunification was indeed forbidden. In the course of the 1960s however, the economic and moral perspectives put forward by Social Affairs and Parliament came to outweigh the ministry of Justice's concerns, and policies were gradually relaxed. By 1970, labour migrants from recruitment countries were allowed to bring their family members over after one year of residence, provided they disposed of sufficient housing and a labour contract for another year.

In the second half of the seventies and the early eighties, the conditions for family migration were significantly relaxed. The cultural revolution of the late 1960s brought about fundamental changes in the dominant norms regarding family and gender relations. As a result, non-marital relationships, both heterosexual and homosexual, were admitted as ground for entry and stay, and women were allowed to bring foreign family members over under the same conditions as men. In addition, Dutch politicians acknowledged that the large majority of the migrants who had found their way to the Netherlands from recruitment countries and (former) colonies would not be returning to their home countries. The norm of equal treatment - a prominent norm in Dutch political discourse since the late 1960s - prescribed that wherever possible, settled migrants should be treated on a par with Dutch nationals. With regard to family migration, this led to the exemption of resident migrants from the income requirement in case of involuntary unemployment, and to a substantial strengthening of the residence rights of their partners and children. Throughout the post-war period, Dutch family migration policies have not been more liberal than in the 1980s. Optimism reigned where the social consequences of these policy choices were concerned: thanks to the new minorities policy, migrants would soon find their place in Dutch society. This optimism was reinforced by the assumption that the large scale immigration flows the Netherlands had known since the Second World War had been an accident of history, which would not repeat itself.

In the early nineties, optimism gave way to increasing concern about the effects of migration on Dutch society, not only among policymakers but also in public opinion. Immigration flows increased instead of decreasing, and the integration process proved more problematic than expected, particularly with regard to participation in education and on the labour market. To ease migrant incorporation problems, it was deemed necessary to 
reduce immigration flows, including family migration. At the same time, a new ideological vision gained currency, stating that the state should stimulate its citizens to be active and autonomous, rather than rendering people dependent and passive by too much state care. Family migration was therefore gradually subjected to more stringent conditions, not only to reduce inflow, but also to appeal to the 'personal responsibility' of applicants to build a future for themselves and their families in the Netherlands. The income requirement was gradually raised, structural control on marriages of convenience introduced, and the visa requirement was tightened.

Where the migration and integration issue had been defined primarily as a socio-economic issue in the nineties, the political debate after the turn of the century centred on the problematic aspects of cultural diversity. Across the political spectrum, it was assumed that a certain measure of homogeneity in values and customs was a necessary precondition for social cohesion. Family migration was considered both a result and a cause of failing integration, in socio-economic as well as in cultural terms. The quantitative policy goals of the nineties were therefore reinforced and supplemented with qualitative goals: the reforms most recently implemented in the Netherlands were designed to make a selection at entry between desirable and undesirable migrants. The income and age requirements for family formation were sharpened in 2004. In addition, the Law on Integration Abroad of 2005 stipulates that entry will only be granted to family migrants who have proved to possess sufficient knowledge of Dutch language and society. Currently, Dutch family migration policies are highly restrictive, not only in contrast to earlier periods, but also in comparison to other European countries.

\section{The powers that be in The Hague}

It is broadly assumed among students of Dutch politics and policy that civil servants have come to play a more influential role in the policy-making process in the second half of the twentieth century: whereas up until the mid-1960s, their role was limited to executing political decisions, civil servants have become autonomous actors in recent decades, due to their increased expertise and to changes in the nature of policy-making processes. ${ }^{3}$ In the field of family migration policies however, the evolution of

3 Peters 1999: 36; Bekke 1994: 14-19; Hoppe 1998: 15-19; Bovens e.a. 2007: 360-361, 371374. 
power relations between civil servants and politics was exactly the opposite. In the 1950s and 1960s, the conditions for family reunification were to a very large extent decided by the civil servants of Justice and Social Affairs, without much interference from Parliament or even from members of government, for whom family migration was not a priority issue. In the 1970s and 1980s, Parliament became more involved in the policy debate and a deputy minister for Immigration was appointed. The autonomous influence of civil servants on the policy-making process was substantially reduced, but still not insignificant. As of the 1990s however, as family migration became a highly salient electoral issue, political parties took a firm hold on the decision-making process, leaving little if any room for the input of civil servants. There are strong indications that the reforms implemented after the turn of the century were adopted in spite of emphatic opposition from the responsible administrative department. ${ }^{4}$ The contrast with the autonomy with which civil servants operated in the 1960 s could hardly be sharper.

The influence of the members of cabinet on the making of family migration policy has increased gradually: it was small in the 1950s and 1960s, and became decisive from the 1990s onwards. Up until the 1990s, the political colour of neither the minister responsible for Foreigner Affairs, nor the cabinet as a whole had any visible influence on the positions adopted in the policy debate. Glastra Van Loon, deputy minister of Justice in the Den Uyl cabinet of the seventies, was the sole exception to this rule: his progressive views on family norms influenced family migration policies significantly. From the 1990s onwards however, party politics became decisive for decision-making within the cabinet.

The input of Parliament also increased steadily. In the 1950s and 1960s, MPs addressed the issue of family migration only incidentally, and limited their comments to the broad outlines of policy. From the 1970s onwards, the House of Representatives engaged ever more actively in the policy debate, discussing regulations in detail. Since the 1990s, political parties have even become the dominant actors in the decision-making process. Decisions are not primarily made in the House of Representatives however, but behind the closed doors of cabinet deliberations and - from 1998 onwards - in the negotiations about coalition agreements. The distance between coalition parties in Parliament and members of governments has become very small:

4 I have been granted permission to consult the archives of the ministry of Justice up until 2003: hence my tentativeness. 
coalition politics are now the main decision-making mechanism in the field of family migration.

Nevertheless, throughout the period between 1955 and 2005, shifts in the trend of family migration policies cannot be related to changes in party political dominance, either in Parliament or in the cabinet. The most liberal conditions for family migration were applied in the 1980s, by centre-right cabinets. The restrictive turn in the 1990s was implemented when the Social Democrats were in power, first in coalition with the Christian Democrats, then with the Liberals. Over the past fifty years, there has typically been sufficient consensus about the stakes of the family migration issue among the main political parties - Christian Democrats, Social Democrats and Liberals - to subscribe to the policies implemented by the government, regardless of the political colour of that government.

\section{The thesis of the control gap}

In the debate among European and North American migration scholars as to how to explain the paradoxical fact that large scale settlement migration has taken place in Western countries against the express wishes of their publics and governments, many have ascribed a crucial role to the judicial system. Domestic and international courts, so it is argued, have actively defended the rights attributed to individual migrants in liberal democracies, thus limiting the possibilities of governments to control the entry and stay of foreigners on their territory. ${ }^{5}$

However, while the courts have come to play an increasingly important role in the making of Dutch family migration policies since the 1970s, they have hitherto proved reticent to encroach upon the sovereignty of the Dutch government in the field of immigration policies. On the whole, they have acknowledged the right of democratic governments to set conditions to the entry of family members so as to protect the general interest of the public they represent. The general legitimacy of housing, income, age, or integration requirements has not been called into question by the courts. If Dutch policymakers applied very liberal conditions to family migration in the 1980s, it was not because the courts compelled them to do so, but out of their own free choice.

5 Cornelius e.a. 1994: 7, 9; Joppke 1998: 270-271; 1999: 18-21; 2001: 340-342; Guiraudon 2000: 221-224; Guiraudon \& Lahav 2000: 189; Hollifield 2000: 148-150, 163-164; Soysal 1994: 149151; Sassen 1996: 11-12; 1999: 181, 184-185; 2006: 351. 
One of the few authors who does not refer to the courts to explain the paradox of migration in liberal democracies is Gary Freeman. He posits that migration policy in Western countries should be understood as client politics: the benefits of migration are concentrated and lie with well organised groups with good access to policymakers, such as employer organisations. As the costs on the other hand are diffuse and less well articulated, migration policies will tend to be liberal in spite of the restrictive preferences of the general public. ${ }^{6}$ This distinction between concentrated and diffuse interests goes a long way to explaining the making of Dutch family migration policies in the sixties, that is why the economic interests represented by the ministry of Social Affairs outweighed the concerns for the long term social consequences expressed by the ministry of Justice. However, Freeman obstructs the view to an important factor in the policy-making process, when he states that 'immigration policy is not a morality play; it is interest driven like most everything else'. ${ }^{7}$ Already in the 1960s, the input of Parliamentarians in the policy debate was a highly normative one. From the 1970s onwards, ethical and ideological norms - such as the norm of equal treatment as of the 1970s, or of 'personal responsibility' as of the 1990s came to play an even more important role in the decision-making process. The distribution of interests can not explain the family migration policies in the Netherlands from the 1970s onwards: immigration policy is undeniably, in part, a morality play.

Like Freeman, Guiraudon has analysed the mechanisms of domestic politics in the field of migration and migrant policies. Her research of policy-making in France, Germany and the Netherlands from the 1970s to the late 1990s has led her to conclude that rights will be granted to migrants when policymakers are shielded from public scrutiny. The more open the arena where decision-making takes place, the more restrictive the policy output will tend to be. ${ }^{8}$ The development of Dutch family migration policies from the 1970s onwards indeed follows these lines. However, when considering the period from 1955 until 2005, a different dynamic is apparent. Family migration policies were made by a closed circle of civil servants in the 1960 s, operating almost entirely out of the public's view. The 1970s witnessed a significant opening up of the decision-making arena, with Parliament, interest groups and media actively engaging in the debate.

6 Freeman 1995: 881-887; 2002: 77-82.

7 Freeman 2002: 94.

8 Guiraudon 2000: 239. 
This did not result in more restrictive policies, as Guiraudon would predict, but in the most liberal family migration policies the Netherlands have known throughout the post-war period. My findings lead me to question the analytical validity and usefulness of the hypothesis which underlies Guiraudon's argument and which is broadly accepted in academic circles, namely that the general public is always, in all historical circumstances, in favour of restrictive migration policies. ${ }^{9}$

Underlying the thesis of the 'control gap' as formulated by Cornelius, Martin and Hollifield in 1994 is the assumption that states strive to control migration, but fail. In my view, the paradox should be approached differently. The question ought to be: why have states which in no way aspired to be immigration countries accepted large scale settlement migration, although they had the possibility not to do so. The answer to this question should be sought in the considerations that have led civil servants and politicians to their policy choices: in their expectations regarding the development of migration flows, in their perceptions of the social consequences of immigration, and in the ethical and ideological norms that they deemed to be at stake. This study reveals the ways in which our insight in the dynamics of migration policies in Western Europe may benefit from case studies which set out to identify the actors involved in the policy-making, the relations between these actors, and the interests, value-judgements, perceptions and expectations they based their decisions upon.

9 Guiraudon 2000:22; Joppke 2002: 262; Freeman 2002: 78. 


\section{Geraadpleegde archieven}

Nationaal Archief - Den Haag

- Ministerie van Justitie: Beleidsarchief Immigratie- en Naturalisatiedienst (IND), 1956-1985. Toegangsnummer 5.023.5027. In voetnoten afgekort als: 'NA IND'.

- Ministerie van Justitie: Beleidsarchief Immigratie- en Naturalisatiedienst (IND), 1945-1955. Toegangsnummer 5.023.5026. In voetnoten afgekort als: 'NA IND 5.023.5026'.

- Raad van Ministers, 1823-1984. Toegangsnummer 2.02.05.02. In voetnoten afgekort als 'NA MR'.

Ministerie van Justitie - Den Haag

- Beleidsarchief 1985-2003. In voetnoten afgekort als 'MJ'.

Immigratie- en Naturalisatiedienst - Rijswijk

- Beleidsarchief 1985-2005. In voetnoten afgekort als 'IND'.

Ministerie van Algemene Zaken - Den Haag

- Archief kabinetsformaties 1998, 2002 en 2003. In voetnoten afgekort als 'MAZ'.

Centrum voor Migratierecht - Nijmegen

- Documentatie Database: Vreemdelingencirculaires en Tussentijdse Berichten Vreemdelingencirculaires van vóór 2001. http://cmr.jur.ru.nl/cmr/. 



\section{Literatuur}

Ahmad Ali, H.A. (1998). De Toescheidingsovereenkomst inzake nationaliteiten tussen Nederland en Suriname. Den Haag: Sdu Uitgevers.

Alink, F. (2006). Crisis als kans? Over de relatie tussen crises en hervormingen in het vreemdelingenbeleid van Nederland en Duitsland. Amsterdam: Vossiuspers UvA.

Amersfoort, H. v. (1973). 'Opbouwwerk en immigratie'. In: Tijdschrift voor maatschappijvraagstukken en welzijnswerk, 27 (9): 211-218.

Amersfoort, H. v. (1974). Immigratie en minderheidsvorming. Een analyse van de Nederlandse situatie 1945-1973. Alphen aan den Rijn: Samsom Uitgeverij.

Amersfoort, H. v. (1987). 'Van William Kegge tot Ruud Gullit. De Surinaamse migratie naar Nederland: Realiteit, beeldvorming en beleid.' In: Tijdschrift voor Geschiedenis, 100 (3): 475-490.

Amersfoort, H. v. (1999). 'Migration Control and Minority Policy: The Case of the Netherlands'. In: G. Brochmann \& T. Hammar (Red.), Mechanisms of Immigration Control. A Comparative Analysis of European Regulation Policies, (135-167). Oxford/New York: Berg.

Amersfoort, H. v. \& H. v. d. Wusten (1975). Marokkaanse arbeiders in Nederland. Amsterdam: Sociaal-Geografisch Instituut, UvA.

Amersfoort, H. v. \& B. Surie (1987). 'Immigratieland tegen wil en dank. Nederland 1970-1985'. In: H. v.d. Wusten (Red.), Postmoderne aardrijkskunde. De sociografische traditie voortgezet, (180-194). Muiderberg: Coutinho.

Amersfoort, H. v. \& R. Penninx (1993). 'Migratieontwikkeling en Migratiebeheersing'. In: H. v. Amersfoort (Red.), Migratie, bevolking en politiek. Nederland als immigratieland in een West-Europese context, (57-84). Amsterdam: Instituut voor Sociale Geografie, UvA.

Andeweg, R.B. \& G.A. Irwin (2005). Governance and politics of the Netherlands. Second Edition. Basingstoke/New York: Palgrave Macmillan.

Anthias, F. \& N. Yuval-Davis (1989). 'Introduction'. In: N. Yuval-Davis \& F. Anthias (Red.), Woman - Nation - State, (1-15). Basingstoke: Macmillan.

Baldinger, D. (2007). 'The Family Reunification Directive: A survey of jurisprudence in the Netherlands'. In: Migrantenrecht, 22 (7): 289-293.

Barkhuysen, T. (2007). 'De inpassing van de prejudiciële procedure in het Nederlands bestuursrecht'. In: T. Barkhuysen, W. den Ouden \& E. Steyger (Red.), Europees recht effectueren. Algemeen bestuursrecht als instrument voor de effectieve uitvoering van EG-recht, (325-350). Alphen aan den Rijn: Kluwer.

Barnard, C. (2004). The substantive law of the EU. The four freedoms. Oxford: Oxford University Press.

Bauman, Z. (1992). 'Soil, blood and identity'. In: The Sociological Review, 40: 675701.

Bedem, R.F.A. v. d., J.C. v. d. Brink \& E. J. Verhagen. (1995). Grenzen aan hereniging: de regels met betrekking tot het bestaansmiddelenvereiste per september 1993. Arnhem: Gouda Quint.

Bekke, A.J.G.M. (1990). De betrouwbare bureaucratie. Over veranderingen van bureaucratische organisaties en ontwikkelingen in het maatschappelijk bestel. Alphen aan den Rijn: Samsom H.D. Tjeenk Willink. 
Bekke, A.J.G.M. (1994). 'Verschuivende functies'. In: A.J.G.M. Bekke, J.L.M. Hakvoort \& J.M. d. Heer ( Red.), Departementen in beweging, (11-26). Den Haag: Vuga.

Berg, E.L. (1967). 'Economische achtergronden van het verschijnsel der buitenlandse arbeiders in Nederland'. In: R. Wentholt (Red.), Buitenlandse arbeiders in Nederland. Een veelzijdige benadering van een complex vraagstuk, (15-29). Leiden: Spruyt, Van Mantgem \& De Does.

Berg-Eldering, L. v. d. (1978). Marokkaanse gezinnen in Nederland. Alphen aan den Rijn: Samsom Uitgeverij.

Berghuis, C.K. (1999). Geheel ontdaan van onbaatzuchtigheid. Het Nederlandse toelatingsbeleid voor vluchtelingen en displaced persons van 1945 tot 1956. Amsterdam: Thela Thesis.

Berghuis, C.K., W. Hoffstädt \& W.D. Küller. (1994). De toelating van vreemdelingen. Een institutioneel onderzoek naar het beleidsterrein toelating van vreemdelingen, 1945-1993. PIVOT-rapport nr. 23. Den Haag: Rijksarchiefdienst/PIVOT, Ministerie van OCenW.

Beus, J. d. (1998). De cultus van vermijding. Visies op migrantenpolitiek in Nederland. Utrecht: Forum.

Blokland, E. v. (1995). 'Onverantwoord (vreemdelingen)beleid. Evaluatie gezinshereniging getoetst'. In: Nemesis, 11 (5): 109-111.

Blokland, E. v. \& M. de Vries (1992). De afhankelijke verblijfstitel van migrantenvrouwen. Nijmegen: Wetenschapswinkel Nijmegen, KUN.

Blom, J.H.C. (1999). 'Nederland sinds 1830'. In: J. H. C. Blom \& E. Lamberts (Red.), Geschiedenis van de Nederlanden, (308-365). Baarn/Meerhout: Nijgh \& Van Ditmar Universitair/Infoboek.

Blom, J.H.C. (1993). Een harmonisch gezin en individuele ontplooiing. Enkele beschouwingen over veranderende opvattingen over de vrouw in Nederland sinds de jaren dertig. In: $B M G N, 108$ (1): 28-50.

Böcker, A. (1994). 'Op weg naar een beter bestaan. De ontwikkeling van de maatschappelijke positie van Turken in Nederland'. In: H. Vermeulen \& R. Penninx (Red.), Het democratisch ongeduld. De emancipatie en integratie van zes doelgroepen van het minderhedenbeleid, (145-176). Amsterdam: Het Spinhuis.

Boeles, P. (1984). Vreemdelingenrecht en Nederlanderschap. Zwolle: W.E.J. Tjeenk Willink.

Boeles, P. (2004a). 'Noot bij Uitspraak Europees Hof voor de Rechten van de Mens 28 mei 1985: Abdulaziz; art. 8 EVRM'. In: T. P. Spijkerboer (Red.), Rechtspraak vreemdelingenrecht. Jurisprudentie 1974-2003, (98-100). Nijmegen: Ars Aequi Libri.

Boeles, P. (2004b). 'Noot bij Europees Hof voor de Rechten van de Mens 21 juni 1988: Berrehab; art. 8 EVRM'. In: T.P. Spijkerboer (Red.), Rechtspraak vreemdelingenrecht. Jurisprudentie 1974-2003, (103-104). Nijmegen: Ars Aequi Libri.

Boeles, P. (2004c). 'Noot bij Europees Hof voor de Rechten van de Mens 19 februari 1996: Gül; art. 8 EVRM'. In: T.P. Spijkerboer (Red.), Rechtspraak vreemdelingenrecht. Jurisprudentie 1974-2003, (113-115). Nijmegen: Ars Aequi Libri.

Boeles, P. (2005). 'De aanval op de gezinshereniging en de rol van het internationale recht'. In: Migrantenrecht, 20 (4): 116-126.

Boeles, P. (2007). 'Het gezin als hoeksteen van de wereld'. In: Migrantenrecht, 22 (1-2): 4-6.

Boeles, P. \& G.G. Lodder (2005). 'Inleiding'. In: P. Boeles \& G.G. Lodder ( Red.), Integratie en uitsluiting, (1-8). Den Haag: Sdu Uitgevers. 
Bolten, J.J. (1981). 'Het schijnhuwelijk tussen vreemdelingenrecht en gelijkberechtiging van vrouwen'. In: Ars Aequi, 30 (10): 603-617.

Bonjour, S. (2005). 'Explaining Ambition: The Elaboration of the Working Program for the European Asylum Policy, 1996-1999'. In: H. Schneider (Red.), Migration, Integration and Citizenship. A Challenge for Europe's Future, (167-186). Maastricht: Forum.

Bonjour, S. (2007). 'Gezin en grens. Debat en beleidsvorming op het gebied van gezinsmigratie in Nederland sinds de jaren vijftig. ' In: Migrantenstudies, 23 (1): $2-23$.

Boomgaarden, H. \& R. Vliegenthart (2007). 'Explaining the rise of anti-immigrant parties: The role of news media content'. In: Electoral Studies, 26 (2): 404-417.

Boswell, C. (2007). 'Theorizing Migration Policy: Is There a Third Way?' In: International Migration Review, 41 (1): 75-100.

Bovenkerk, F. (1979). 'The Netherlands'. In: R.E. Krane (Red.), International Labor Migration in Europe, (118-132). New York (etc.): Praeger.

Bovens, M.A.P., P. 't Hart \& M. v. Twist. (2007). Openbaar bestuur: beleid, organisatie en politiek. Alphen aan den Rijn: Kluwer.

Brochmann, G. (1999). 'Controlling Immigration in Europe'. In: Brochmann, G. \& T. Hammar (Red.), Mechanisms of immigration control : a comparative analysis of European regulation policies, (297-334). Oxford/New York: Berg.

Bruquetas-Callejo, M., B. Garcés-Mascareñas, R. Penninx \& P. Scholten (2006). 'Policymaking related to immigration and integration. The Dutch Case'. Imiscoe working paper $\mathrm{nr} 15$.

Calavita, K. (2006). 'Gender, Migration, and Law: Crossing Borders and Bridging Disciplines'. In: International Migration Review, 40 (1): 104-132.

Campo, S. d. (1979). 'Spain'. In: R. E. Krane (Red.), International Labor Migration in Europe, (156-163). New York: Praeger.

Carlier, J.-Y. (2007). La condition des personnes dans l'Union Européenne. Brussel: Larcier.

Chotkowski, M. (2000). “"Baby's kunnen we niet huisvesten, moeder en kind willen we niet scheiden". De rekrutering door Nederland van vrouwelijke arbeidskrachten uit Joegoslavië, 1966-1979'. In: Tijdschrift voor Sociale Geschiedenis, 26 (1): 76-100.

Cornelius, W.A., P.L. Martin \& J.F. Hollifield (1994). 'Introduction: The Ambivalent Quest for Immigration Control'. In: W.A. Cornelius, P.L. Martin \& J.F. Hollifield (Red.), Controlling Immigration: A Global Perspective, (3-41). Stanford: Stanford University Press.

Cornelius, W.A. \& T. Tsuda (2004). 'Controlling Immigration: the Limits of Government Intervention'. In: W.A. Cornelius, T. Tsuda, P.L. Martin \& J.F. Hollifield (Red.), Controlling Immigration: A Global Perspective. Second Edition, (3-48). Stanford: Stanford University Press.

Daalder, H. (1995). Van oude en nieuwe regenten: politiek in Nederland. Amsterdam: Bakker.

Dew, E. (1978). The difficult flowering of Surinam: ethnicity and politics in a plural society. Den Haag: Martinus Nijhoff.

Dijk, T. v. (1988). News analysis: case studies of international and national news in the press. Hillsdale: Erlbaum.

Dijkstra, G.S.A. (1996). 'Juridisering van de verhouding tussen bestuur en burger'. In: C.L. Baljé (Red.), De ontzuiling voorbij: openbaar bestuur en individualistisch 
burgerschap: essay-bundel, (47-66). Den Haag: Sdu.

Dinan, D. (1999). Ever Closer Union. An introduction to European Integration. Hampshire: MacMillan Press

Doesschate, J.W. 't. (1993). Asielbeleid en Belangen. Het Nederlandse toelatingsbeleid ten aanzien van vluchtelingen in de jaren 1968-1982. Hilversum: Verloren.

Doorn, J. v. (1996a). 'Schets van de Nederlandse politieke traditie'. In: J. d. Beus, J. v. Doorn \& P. d. Rooy (Red.), De ideologische driehoek. Nederlandse politiek in historisch perspectief, (9-51). Amsterdam: Uitgeverij Boom.

Doorn, J. v. (1996b). 'De onvermijdelijke presentie van de confessionelen'. In: J. d. Beus, J. v. Doorn \& P. d. Rooy (Red.), De ideologische driehoek. Nederlandse politiek in historisch perspectief, (98-135) Amsterdam: Uitgeverij Boom.

Duyvendak, J.W. (2004). Een eensgezinde, vooruitstrevende natie. Over de mythe van 'de' individualisering en de toekomst van de sociologie. Amsterdam: Vossiuspers UvA.

Eijl, C. v. (2005). Al te goed is buurmans gek: het Nederlands vreemdelingenbeleid 1840-1940. Amsterdam: Aksant.

Ellemers, J.E. \& R.E.F. Vaillant (1987). 'Indische Nederlanders en gerepatrieerden: de grootste categorie naoorlogse immigranten'. In: Tijdschrift voor Geschiedenis, 100 (3): 412-431.

Emmerik-Levelt, H. \& A.W.M. Teulings (1967). 'Buitenlandse arbeiders in de pers'. In: R. Wentholt (Red.), Buitenlandse arbeiders in Nederland. Een veelzijdige benadering van een complex vraagstuk, (167-182). Leiden: Spruyt, Van Mantgem \& De Does.

Entzinger, H.B. (1975). 'Nederland immigratieland? Enkele overwegingen bij het overheidsbeleid inzake allochtone minderheden'. In: Beleid en Maatschappij, 2 (12): 326-336.

Entzinger, H.B. (1984). Het minderhedenbeleid. Dilemma's voor de overheid in Nederland en zes andere immigratielanden in Europa. Amsterdam: Boom Meppel.

Entzinger, H.B. (1985). 'The Netherlands'. In: T. Hammar (Red.), European immigration policy. A comparative study, (50-88). Cambridge (etc.): Cambridge University Press.

Entzinger, H.B. (2003). 'The Rise and Fall of Multiculturalism: The Case of the Netherlands'. In: C. Joppke \& E. Morawska (Red.), Towards Assimilation and Citizenship: Immigrants in Liberal Nation-States, (59-86). Basingstoke/New York: Palgrave Macmillan.

Entzinger, H.B. (2004). 'Commentary'. In: W.A. Cornelius, T. Tsuda, P.L. Martin \& J.F. Hollifield (Red.), Controlling Immigration: A Global Perspective. Second Edition, (289-292). Stanford: Stanford University Press.

Entzinger, H.B. (2005). 'Changing the rules while the game is on: from multiculturalism to assimilationism in the Netherlands'. In: M. Bodemann \& G. Yurkadul (Red.), Migration, citizenship, ethnos. Incorporation regimes in Germany, Western Europe and North America, (121-145). New York: Palgrave Macmillan.

Erpecum, I. (1998). Naar eer en geweten. De geschiedenis van Justitie in vogelvlucht, 1798-1998. Den Haag: Ministerie van Justitie.

Faassen, M. v. (2001). 'Min of meer onmisbaar. Naoorlogse emigratie vanuit Nederland: achtergronden en organisatie, particuliere motieven en overheidsprikkels, 1946-1967'. In: S. Poldervaart, H. Willemse \& J.W. Schilt (Red.), Van hot naar her. Nederlandse migratie vroeger, nu en morgen, (50-67). Amsterdam: Stichting beheer IISG.

Federici, N. (1979). 'Italy'. In: R. E. Krane (Red.), International Labor Migration in Europe, (147-155). New York: Praeger. 
Fennema, M. (2002). 'Het publieke debat na 11 september'. In: De Gids, 165 (3): 229-244.

Fermin, A.M.E. (1997). Nederlandse politieke partijen over minderhedenbeleid 19771995. Amsterdam: Thesis Publishers.

Fernández Vicente, M.J. (2004). Émigrer sous Franco. Politiques publiques et stratégies individuelles dans l'émigration espagnole vers l'Argentine et vers la France (1945-1965). Proefschrift, Université Paris 7.

Fischer, F. (2003). Reframing public policy : discursive politics and deliberative practices. Oxford (etc.): Oxford University Press.

Freeman, G.P. (1995). 'Modes of Immigration Politics in Liberal Democratic States'. In: International Migration Review, 29 (4): 881-902.

Freeman, G.P. (2002). 'Winners and Losers: Politics and the Costs and Benefits of Migration'. In: A. Messina (Ed.), West European Immigration and Immigrant Policy in the New Century, (77-95). Westport/Londen: Praeger.

Gaikhorst, L., M. Hartman \& A. v. Keulen (Red.) (1978). Buitenlandse vrouwen in Nederland: Gesprekken en ervaringen, landen van herkomst, situatie en praktijk in Nederland. Amersfoort: De Horstink.

Geddes, A. (2000). Immigration and European integration. Towards fortress Europe? Manchester: Manchester University Press.

Geddes, A. (2003). The politics of migration and immigration in Europe. London (etc.): Sage.

Geuijen, K. (2004). De asielcontroverse : argumenteren over mensenrechten en nationale belangen. Amsterdam: Dutch University Press.

Givens, T. \& A. Luedtke (2004). 'The Politics of European Union Immigration Policy: Institutions, Salience, and Harmonization'. In: The Policy Studies Journal, 32 (1): 145-165.

Glasbergen, P. (1984). Visies op beleid. Sociaal-wetenschappelijke analyse van overheidsbeleid. Amsterdam: Kobra.

Glastra van Loon, J. F. (1976). Kanalen graven. Baarn: In den Toren.

Goedings, S. (2005). Labor migration in an integrating Europe. National migration policies and the free movement of workers. 1950-1958. Den Haag: Sdu.

Grillo, R. (2007). 'The Family at Issue: The Forced Marriage Debate in the UK'. Paper gepresenteerd op conferentie Gender, Generation and the Family in International Migration, EUI, Florence, 14-16 juni 2007.

Groenendael, T. v. (1986). Dilemma's van regelgeving. De regularisatie van illegale buitenlandse werknemers 1975-1983; een case studie naar het functioneren van regels als instrument van overheidsbeleid. Alphen aan den Rijn/Utrecht: Samsom H.D. Tjeenk Willink/NCB.

Groenendijk, K. (1978). 'Legal aid to immigrants in the Netherlands or: how lawyers discovered a new branch of law and provided representation to a new class of clients'. In: K. Groenendijk, E. Thomas \& B. Endresen (Red.), Flere Emner Fra Fremmedretten, (1-19). Oslo: Institutt for offentlig rett.

Groenendijk, K. (1980). 'The Working Group on Legal Aid for Immigrants: A Public Interest Law Organization in the Netherlands'. In: E. Blankenburg (Red.), Innovations in the Legal Services, (165-176). Cambridge/Königstein: Oelgeschlager, Gunn \& Hain/Verlag Anton Hain.

Groenendijk, K. (1981). 'Minderhedenbeleid in een onwillig immigratieland'. In: Ars Aequi, 30 (10): 531-546.

Groenendijk, K. (1983). 'Trouwbeperking voor tweede generatie immigranten. Minderhedenbeleid en mensenrechten dicht bij huis'. In: Nederlands Juristenblad, 58 
(41): 1311-1318.

Groenendijk, K. (1989). 'Mensenrechten tussen retoriek en praktijk: gebruik van het klachtenrecht in Straatsburg en de bescherming van vreemdelingen'. In: L. Heyde, J. Leijten, T. Mertens \& B.P. Vermeulen (Red.), Begrensde vrijheid. Opstellen over mensenrechten aangeboden aan Prof. dr. D.F. Scheltens bij zijn afscheid als hoogleraar aan de Katholieke Universiteit Nijmegen, (191-229). Zwolle: W.E.J. Tjeenk Willink.

Groenendijk, K. (1990). 'Verboden voor Tukkers. Reacties op rellen tussen Italianen, Spanjaarden en Twentenaren in 1961'. In: A.J.F. Köbben (Red.), Wetenschap en partijdigheid: opstellen voor André J.F. Köbben, (55-95). Assen: Van Gorcum.

Groenendijk, K. (1996). 'De wisselende rol van de rechter in vreemdelingenzaken'. In: C.H. Brants (Red.), Er is meer. Opstellen over mensenrechten in internationaal en nationaal perspectief, (119-133). Deventer: Gouda Quint.

Groenendijk, K. (2005). 'Integratie en uitsluiting in het Nederlands vreemdelingenrecht'. In: P. Boeles \& G. G. Lodder (Red.), Integratie en Uitsluiting, (9-32). Den Haag: Sdu Uitgevers.

Groenendijk, K. (2006). 'Family Reunification as a Right under Community Law'. In: European Journal of Migration and Law, 8: 215-230.

Groenendijk, K. \& A.H.J. Swart (1979a). Rechtspraak vreemdelingenrecht 1968 t/m 1977. Alphen aan den Rijn: Samsom Uitgeverij.

Groenendijk, K. \& A.H.J. Swart (1979b). Rechtspraak vreemdelingenrecht 1978. Alphen aan den Rijn: Samsom Uitgeverij.

Groenendijk, K. \& A.H.J. Swart (1980). Rechtspraak vreemdelingenrecht 1979. Alphen aan den Rijn: Samsom Uitgeverij.

Groenendijk, K. \& A.H.J. Swart (1982). Rechtspraak vreemdelingenrecht 1981. Nijmegen: Ars Aequi Libri.

Groenendijk, K. \& R. Barzilay (2001). Verzwakking van de rechtspositie van toegelaten vreemdelingen (1990-2000). Utrecht: Forum.

Groenendijk, K. \& P. Minderhoud (2004). 'De Nederlandse invloed op nieuwe Europese regels betreffende migratie en asiel'. In: W. Asbeek Brusse, D. Broeders \& R. Griffiths (Red.) Immigratie en asiel in Europa. Een lange weg naar gemeenschappelijkheid?, (137-161). Utrecht: Lemma.

Groenendijk, K., R. v. Oers \& T. Strik (2007a). 'De betekenis van de Gezinsherenigingsrichtlijn voor vluchtelingen en andere migranten'. In: Nieuwsbrief asiel- en vluchtelingenrecht 23 (1): 17-29.

Groenendijk, K., R. Fernhout, D.v. Dam, R. v. Oers \& T. Strik (2007b). The Family Reunification Directive in EU Member States. The First Year of Implementation. Nijmegen: Wolf Legal Publishers.

Groeneveld, H.A. (1989). De staatssecretaris in Nederland 1948-1988. Deventer: Kluwer.

Guild, E. (1996). 'Resolution on the Harmonization of national policies on family reunification'. In: E. Guild \& J. Niessen (Red.), The Developing Immigration and Asylum Policies of the European Union. Adopted Conventions, Resolutions, Recommendations, Decisions and Conclusions, (251-273). Den Haag (etc.): Kluwer Law International.

Guiraudon, V. (1998). 'Third Country Nationals and European law: Obstacles to Rights Expansion'. In: Journal of Ethnic and Migration Studies, 24 (4): 657-674.

Guiraudon, V. (2000). Les politiques d'immigration en Europe : Allemagne, France, Pays-Bas. Paris: L'Harmattan. 
Guiraudon, V. (2001). 'De-nationalizing control. Analyzing state responses to constraints on migration control'. In: V. Guiraudon \& C. Joppke (Red.), Controlling a New Migration World, (31-64). London: Routledge.

Guiraudon, V. \& G. Lahav (2000). 'A Reappraisal of the State Sovereignty Debate: The Case of Migration Control'. In: Comparative political studies 33 (2): 163195.

Guiraudon, V. \& C. Joppke (2001). 'Controlling a new migration world'. In: V. Guiraudon \& C. Joppke (Red.), Controlling a new migration world, (1-27). London/ New York: Routledge.

Hailbronner, K. (2000). Immigration and Asylum Law and Policy of the European Union. Den Haag (etc.): Kluwer Law International.

Hajer, M. (1989). 'Discours-coalities in politiek en beleid: De interpretatie van bestuurlijke heroriënteringen in de Amsterdamse gemeentepolitiek'. In: Beleidswetenschap, 3 (3): 242-263.

Hall, P.A. (1993). 'Policy Paradigms, Social Learning, and the State. The Case of Economic Policymaking in Britain'. In: Comparative Politics, 25 (3): 275-296.

Hall, S. (1997). 'The Spectacle of the 'Other'. In: S. Hall (Red.), Representation. Cultural Representations and Signifying Practices, (223-279). London/Milton Keynes: Sage/The Open University.

Hart, B. d. (1997). 'Vrouwen wier toekomst wordt misbruikt'. Nederlandse vrouwen met een niet-Nederlandse partner in het nationaliteitsrecht en het vreemdelingenrecht (1849-1996). Doctoraalscriptie, Faculteit der Rechtsgeleerdheid, Universiteit van Amsterdam.

Hart, B. d. (2000a). 'Echte Liefde - De constructie van het schijnhuwelijk'. In: Lover, 27 (3): 14-18.

Hart, B. d. (2000b). 'De Goede Lobbes en de Onbezonnen Vrouw: gemengde relaties en het schijnhuwelijk'. In: Migrantenstudies, 16 (4): 246-259.

Hart, B. d. (2003a). Onbezonnen vrouwen. Gemengde relaties in het nationaliteitsrecht en het vreemdelingenrecht. Amsterdam: Aksant.

Hart, B. d. (2003b). 'Onbezonnen vrouwen - Gemengde relaties in het nationaliteitsrecht en het vreemdelingenrecht'. In: Nemesis, 19 (3): 54-62

Hart, B. d. \& B. Prins (2005). 'De onderzoeker tussen wetenschap en beleid. Rondetafelgesprek'. In: Migrantenstudies, 21 (4): 178-193.

Hart, P. 't. (1992). 'Politiek-bestuurlijke besluitvorming in Nederland. Een decennium van onderzoek in beeld'. In: Beleidswetenschap, 6 (3): 199-227.

Hart, P. 't, A.C. Wille, R.A. Boin, G.S.M. Dijkstra, F.M. v.d. Meer, W.J. v. Noort \& M. Zannoni (2002). Politiek-ambtelijke verhoudingen in beweging. Amsterdam: Boom.

Heijs, E.J.M. (1995). Van vreemdeling tot Nederlander : de verlening van het Nederlanderschap aan vreemdelingen 1813-1992. Amsterdam: Het Spinhuis.

Hekma, G. (2004). Homoseksualiteit in Nederland van 1730 tot de moderne tijd. Amsterdam: Meulenhoff.

Herbert, U. (2001). Geschichte der Ausländerpolitik in Deutschland: Saisonarbeiter, Zwangsarbeiter, Gastarbeiter, Flüchtlinge. München: Beck.

Hirsch Ballin, E. (1992). 'Bakens voor een cultuur van verantwoordelijkheid'. In: Christen Democratische Verkenningen, 12 (10): 470-476.

Hisschemöller, M. (1993). De democratie van problemen. De relatie tussen de inhoud van beleidsproblemen en methoden van politieke besluitvorming. Amsterdam: vU Uitgeverij. 
Hollifield, J.F. (2000). 'The Politics of International Migration. How Can We "Bring the State Back In"?' In: C. Brettell \& J.F. Hollifield (Red.), Migration Theory. Talking Across Disciplines, (137-186). New York/London: Routledge.

Holterman, T. (1996). Vreemdelingenrecht: toelating en verblijf van vreemdelingen in Nederland. $4^{\mathrm{e}}$ Druk. Zwolle: Tjeenk Willink.

Hondius, D. (2001). Gemengde huwelijken, gemengde gevoelens. Hoe Nederland omgaat met etnisch en religieus verschil. Den Haag: Sdu uitgevers.

Hooghiemstra, E. (2003). Trouwen over de grens. Achtergronden van partnerkeuze van Turken en Marokkanen in Nederland. Den Haag: Sociaal en Cultureel Planbureau.

Hoppe, R. (1987). 'Veertig jaar minderhedenbeleid: van onbedoelde beleidsevolutie tot gefrustreerde beleidsopvolging.' In: R. Hoppe (Red.) Etniciteit, politiek en beleid in Nederland, (23-70). Amsterdam: vu Uitgeverij.

Hoppe, R. (1998). 'De onafwendbaarheid van de argumentatieve wending'. In: R. Hoppe \& A. Peterse ( Red.), Bouwstenen voor argumentatieve beleidsanalyse, (13-52). Den Haag: Elsevier Bedrijfsinformatie.

Horst, E. v. d. (2005). Deventer Blik. Geschiedenis van arbeidsmigranten in een Nederlandse industriestad (1945-1990). Kampen: IJsselacademie.

Hovy, B. (2002). Statistical Yearbook 2001. Refugees, Asylum-seekers and Other Persons of Concern - Trends in Displacement, Protection and Solutions. Genève: UNHCR.

Huber, B. (1985). 'Europäische Menschenrechtskonvention und Familiennachzug'. In: K. Barwig, K. Lörcher \& C. Schumacher (Red.), Familiennachzug von Ausländern auf dem Hintergrund völkerrechtlicher Verträge, (27-52). Baden-Baden: Nomos Verlagsgesellschaft.

Imbos, J. (2006) Gender in overheidsbeleid. Het beleid met betrekking tot gezinshereniging in de periode 1955-1983. Masterscriptie Social and Economic History, Universiteit van Leiden.

IND Informatie- en Analysecentrum (INDIAC) (2007). Small Scale Study IV. Gezinshereniging en gezinsvorming in Nederland in de periode 2002-2006. Rijswijk: IND.

Jansen, J. (2006). Bepaalde huisvesting. Een geschiedenis van opvang en huisvesting van immigranten in Nederland, 1945-1995. Amsterdam: Aksant.

Jones, G. (2007). Tussen onderdanen, rijksgenoten en Nederlanders. Nederlandse politici over burgers uit Oost \& West in Nederland, 1945-2005. Amsterdam: Rozenberg Publishers.

Joppke, C. (1998). 'Why liberal states accept unwanted migration'. In: World politics 50 (2): 266-293.

Joppke, C. (1999). Immigration and the nation-state : the United States, Germany, and Great Britain. Oxford/New York: Oxford University Press.

Joppke, C. (2001). 'The legal-domestic sources of immigrant rights. The United States, Germany, and the European Union'. In: Comparative political studies 34 (4): 339-366.

Joppke, C. (2002). 'European Immigration Policies at the Crossroads'. In: P. Heywood, E. Jones \& M. Rhodes (Red.), Developments in West European Politics, (259-276). Basingstoke (etc.): Palgrave.

Joppke, C. (2004). 'The retreat of multiculturalism in the liberal state: theory and policy'. In: The British Journal of Sociology, 55 (2): 237-257.

Kennedy, J. (1995). Nieuw Babylon in aanbouw: Nederland in de jaren zestig. Amsterdam: Boom. 
Kennedy, J. (2005). De deugden van een gidsland. Amsterdam: Uitgeverij Bert Bakker.

Kersbergen, K. v. \& A. Krouwel (2008). 'A double-edged sword! The Dutch centreright and the "foreigners issue"'. In: Journal of European Public Policy, 15 (3): 398-414.

Koens, M.J.C. (1983a). Jeugdige vreemdelingen in Nederland. Een onderzoek naar enige aspekten van vreemdelingenrecht en jeugd(beschermings)recht betreffende de komst naar en het voortgezet verblijf in Nederland van jeugdige vreemdelingen. Arnhem: Gouda Quint.

Koens, M.J.C. (1983b). 'De toelating en het voortgezet verblijf van buitenlandse jeugdigen in Nederland'. In: Nederlands Juristenblad, 58 (29): 949-957.

Kofman, E. (2004). 'Family-related migration : a critial review of European Studies'. In: Journal of Ethnic and Migration Studies, 30 (2): 243-262.

Kofman, E. (2005). 'Citizenship, Migration and the Reassertion of National Identity'. In: Citizenship Studies, 9 (5): 453-467.

Koppenjan, J.F.M., A.B. Ringeling \& R.H.A. te Velde (1987). Beleidsvorming in Nederland: een vergelijkende studie naar de totstandkoming van wetten. Den Haag: VUGA.

Lange, T. d. (1997a). 'Voldoende middelen van bestaan bij gezinshereniging (I). Een jurisprudentie-overzicht 1995/1996'. In: Migrantenrecht, 12 (3): 47-54.

Lange, T. d. (1997b). 'Voldoende middelen van bestaan bij gezinshereniging (II). Een jurisprudentie-overzicht 1995/1996'. In: Migrantenrecht, 12 (4): 81-87.

Lange, T. d. (2007). Staat, markt en migrant. De regulering van arbeidsmigratie naar Nederland, 1945-2006. Den Haag: Boom Juridische Uitgevers.

Lange, T. d. \& R. Depping (1999a). 'Voldoende middelen van bestaan bij gezinshereniging. Een jurisprudentie-overzicht 1997-juli 1999'. In: Migrantenrecht, 14 (7): 171-178.

Lange, T. d. \& R. Depping (1999b). 'Voldoende middelen van bestaan bij gezinshereniging (deel II). Een jurisprudentie-overzicht 1997-juli 1999'. In: Migrantenrecht, 14 (8): 199-205.

Leenders, M. (1993) Ongenode gasten. Van traditioneel asielrecht naar immigratiebeleid, 1815-1938. Hilversum: Verloren.

Lijphart, A. (1979). Verzuiling, pacificatie en kentering in de Nederlandse politiek. Amsterdam: J. H. de Bussy.

Lindo, F. (1994). 'Het stille succes. De sociale stijging van Zuideuropese arbeidsmigranten in Nederland'. In: H. Vermeulen \& R. Penninx (Red.), Het democratisch ongeduld: de emancipatie van zes doelgroepen van het minderhedenbeleid, (117144). Amsterdam: Het Spinhuis.

Lodder, G.G. (2007). 'De gezinsherenigingsrichtlijn: legitimering van of keerpunt voor het restrictieve Nederlandse beleid?' In: Migrantenrecht, 22 (1-2): 26-31.

Lucardie, P. (1989). ' 'Met de Franse slag'. De symbolische revolutie van de jaren zestig'. In: R.A. Koole (Red.), Van Bastille tot Binnenhof. De Franse Revolutie en haar invloed op de Nederlandse politieke partijen, (115-135, 185-189). Houten: Fibula.

Lucardie, P. (1998). 'Een geschiedenis van vijftien jaar Centrumstroming'. In: J. v. Holsteyn \& C. Mudde (Red.), Extreem-rechts in Nederland, (17-30). Den Haag: Sdu Uitgevers.

Lucardie, P. (2003). 'Populismus im Polder: Von der Bauernpartei bis zur Liste Pim Fortuyn'. In: N. Werz (Red.), Populismus. Populisten in Übersee und Europa, (177-194). Opladen: Leske und Budrich Verlag. 
Lucassen, L. (1990). En men noemde hen zigeuners: de geschiedenis van Kaldarasch, Ursari, Lowara en Sinti in Nederland: 1750-1944. Amsterdam: Stichting beheer IISG.

Lucassen, L. (2005). The immigrant threat. The integration of old and new migrants in western Europe since 1850. Urbana: University of Illinois Press.

Lutz, H. (1991). Welten verbinden. Türkische Sozialarbeiterinnen in den Niederlanden und der Bundesrepublik Deutschland. Frankfurt: Verlag für Interkulturelle Kommunikation.

MacKinnon, C.A. (1989). Toward a feminist theory of the state. Cambridge: Harvard University Press.

Mak, C.D. (Red.) (1976). De vrouw in het gezin van de buitenlandse werknemer. Verslag van een colloquium gehouden onder de auspiciën van de Nationale Unesco Commissie, 8-11 december 1976, Helvoirt. Den Haag: Staatsuitgeverij.

Manuhutu, W. (1987). 'Molukkers in Nederland. Migranten tegen wil en dank'. In: Tijdschrift voor Geschiedenis, 100 (3): 432-445.

Mariën, M.H. (1992). Het maatschappelijk debat over integratie van minderheden in de pers. Den Haag: Directie Coördinatie Minderhedenbeleid, Ministerie van Binnenlandse Zaken.

Meer, F.M. v.d. \& L.J. Roborgh (1993). Ambtenaren in Nederland. Omvang, bureaucratisering en representativiteit van het ambtelijk apparaat. Alphen aan den Rijn: Samsom H.D. Tjeenk Willink.

Messina, A. (2007). The logics and politics of post-WWII migration to Western Europe. Cambridge: Cambridge University Press.

Meyers, E. (2004). International immigration policy : a theoretical and comparative analysis. New York (etc.): Palgrave Macmillan.

Molleman, H. (1978). 'Culturele minderheden en overheidsbeleid'. In: Socialisme en democratie, 35 (7-8): 328-345.

Molleman, H. (2004). 'Het minderhedenbeleid in historisch perspectief: leren van gemaakte fouten'. In: M. Dijkstra (Red.), Kleur bekennen. Integratiebeleid, denkstijlen en bestuursstijlen, (37-50). Den Haag: Sdu.

Muus, P. (2004). 'The Netherlands: A Pragmatic Approach to Economic Needs and Humanitarian Considerations'. In: W.A. Cornelius, T. Tsuda, P.L. Martin \& J.F. Hollifield (Red.), Controlling Immigration: A Global Perspective. Second Edition, (263-288). Stanford: Stanford University Press.

Naborn, E.M. (1992). Gezinshereniging. De overkomst van gezinsleden van migranten en Nederlanders. Den Haag: WODC, Ministerie van Justitie.

Niessen, J. (2004). 'Five years of EU migration and asylum policy-making under the Amsterdam and Tampere mandates'. MPG Occasional Paper. Brussel: Migration Policy Group.

Obdeijn, H. (1987). 'Van internationale forens tot immigrant. Marokkaanse en Turkse migranten in Nederland'. In: Tijdschrift voor Geschiedenis, 100 (3): 460-474.

Orobio de Castro, I. (2003). 'Hoeksteen des aanstoots? Marokkaanse en Turkse huwelijksmigratie'. In: C. Kohlmann, S. Kraus \& I. Orobio de Castro (Red.), Vrouwen in het migratiebeleid, (59-73). Den Haag: E-Quality.

Papademetriou, D.G. (1996). Coming Together or Pulling Apart? The European Union's Struggle with Immigration and Asylum. Washington: Carnegie Endowment for International Peace.

Pellikaan, H., T. v. d. Meer \& S. de Lange (2003). 'De positie van politieke partijen in het vraagstuk van de multiculturele samenleving'. In: H. Pellikaan \& M. Trappenburg (Red.), Politiek in de multiculturele samenleving, (160-187). Amsterdam: Boom. 
Penninx, R. (1979). Naar een algemeen etnisch minderhedenbeleid? Schets van de sociale positie in Nederland van Molukkers, Surinaamse en Antilliaanse Nederlanders en mediterrane werknemers en een inventarisatie van het Nederlandse overheidsbeleid. Bijlage bij WRR-rapport 17. Den Haag: Staatsuitgeverij.

Penninx, R. (1988). Minderheidsvorming en emancipatie. Balans van kennisverwerving ten aanzien van immigranten en woonwagenbewoners 1967-1987. Alphen aan den Rijn/Brussel: Samsom Uitgeverij.

Penninx, R. (2006). 'Après les assassinats de Fortuyn et de Van Gogh: le modèle d'intégration hollandais en déroute?' In: Critiques Internationales, 9 (33): 9-26.

Penninx, R., B. Garcés-Mascareñas \& P. Scholten. (2005). 'Policymaking related to immigration and integration: a review of the literature of the Dutch case'. Imiscoe working paper nr. 8 .

Peters, K. (1999). Verdeelde macht. Een onderzoek naar invloed op rijksbesluitvorming in Nederland. Amsterdam: Boom.

Polak, J.E.M. (2006). 'Bestuursrechtspraak'. In: E.R. Muller \& C.P.M. Cleiren (Red.), Rechterlijke macht. Studies over rechtspraak en rechtshandhaving in Nederland, (335-360). Deventer: Kluwer.

Prins, B. (2002). 'Het lef om taboes te doorbreken. Nieuw realisme in het Nederlandse discours over multiculturalisme'. In: Migrantenstudies, 18 (4): 241-254.

Prins, B. (2004). Voorbij de onschuld: het debat over integratie in Nederland. Amsterdam: Van Gennep.

Prins, M.C.J. (1989). Emancipatie van vrouwen in beweging. Emancipatie als (be) sturingsvraagstuk (1974-1989). Groningen: PP \& Styx Publications.

Putten J. v. (1980). Haagse machten. Verslag van een politicologisch onderzoek naar de totstandkoming van acht regeringsmaatregelen. Den Haag: Sdu.

Rath, J. (1991). Minorisering: de sociale constructie van 'etnische minderheden'. Amsterdam: Sua.

Rehwinkel, P. \& J. Nekkers (1994). Regerenderwijs. De PvdA in het kabinet-Lubbers/ Kok. Amsterdam: Uitgeverij Bakker.

Renner, G. (2005). 'Das Zuwanderungsgesetz - Ende des deutschen Ausländerrechts?' In: IMIS-Beiträge (27): 9-24.

Righart, H. (1995). De eindeloze jaren zestig: geschiedenis van een generatieconflict. Amsterdam: De Arbeiderspers.

Ringeling, A.B. (1978). Beleidsvrijheid van ambtenaren: het spijtoptantenprobleem als illustratie van de activiteiten van ambtenaren bij de uitvoering van beleid. Alphen aan den Rijn: Samsom.

Ringeling, A.B. (1993). Het imago van de overheid. De beoordeling van prestaties van de publieke sector. Den Haag: Vuga.

Roggeband, C. \& M. Verloo (2006). 'Nederlandse vrouwen zijn geëmancipeerd, allochtone vrouwen zijn een probleem'. In: Migrantenstudies, 22 (4): 158-178.

Roggeband, C. \& R. Vliegenthart (2007). 'Divergent Framing: The Public Debate on Migration in the Dutch Parliament and Media, 1995-2004'. In: West European Politics, 30 (3): 524-548.

Roosblad, J. (2002). Vakbonden en immigranten in Nederland. Amsterdam: Aksant.

Rooy, P. d. (2005). Republiek van rivaliteiten. Nederlands sinds 1813. Amsterdam: Mets\&Schilt.

Rosenthal, U. (1988). Bureaupolitiek en bureaupolitisme. Om het behoud van een competitief overheidsbestel. Alphen aan den Rijn: Samsom H.D. Tjeenk Willink.

Saharso, S. (1995). 'Een koperen bruiloft: Twaalf en een half jaar sekse en etniciteit in het gecombineerde vrouwen- en minderhedenbeleid'. In: Migrantenstudies, 11 (4): 241-257. 
Saharso, S. (2002). 'Over de grens. Zmv-vrouwen in het debat over multiculturaliteit'. In: R. Holtmaat (Red.), Eén verdrag voor alle vrouwen. Verkenningen van de betekenis van het VN-Vrouwenverdrag voor de multiculturele samenleving, (29-38). Den Haag: E-Quality.

Sassen, S. (1996). 'Beyond Sovereignty: Immigration Policy Making Today'. In: Social Justice, 23 (3): 9-20.

Sassen, S. (1999). 'Beyond Sovereignty: De-Facto Transnationalism in Immigration Policy'. In: European Journal of Migration and Law, 1 (2): 177-198.

Sassen, S. (2003). 'The Repositioning of Citizenship. Emergent Subjects and Spaces for Politics'. In: Centennial Review, 3 (2): 41-66.

Sassen, S. (2006). 'Immigratiebeleid: feitelijke en juridische transnationale tendensen'. In: Internationale Spectator, 60 (7-8): 351-353.

Schaffrin, D. (2005). 'Which Standards for Family Reunification of Third-Country Nationals in the European Union?' In: J.-Y. Carlier \& P. De Bruycker (Red.), Immigration and Asylum Law of the EU: Current Debates, (90-143). Brussel: Bruylant.

Schendelen, M.P.C.M. v. (1974). 'Groei en achtergronden van parlementair activisme'. In: Beleid \& Maatschappij, 1 (4): 111-120.

Schnabel, P. (2004). Een eeuw van verschil. Van achterstelling tot zelfontplooiing: de dynamiek van het gelijkheidsideaal. Den Haag: SCP.

Schnapper, D. (1994). 'The Debate on Immigration and the Crisis of National Identity'. In: West European Politics, 17 (3): 127-139.

Scholten, P. (2007). Constructing Immigrant Policies: research-policy relations and immigrant integration in the Netherlands (1974-2004). Enschede: Ipskamp.

Scholten, P. \& A. Timmermans (2004). 'Doorbraken en zachte landingen in het Nederlandse immigrantenbeleid. Een theoretische analyse van beleidsdynamiek'. In: Beleidswetenschap, 18 (1): 3-30.

Schön, D.A. \& M. Rein (1994). Frame reflection : toward the resolution of intractable policy controversies. New York: BasicBooks.

Schrover, M. (2008). 'Migration policy and media-hypes, the Netherlands 19452000'. Paper gepresenteerd op European Social Science and History Conference. Lissabon, 26 februari - 1 maart 2008.

Schuster, J. (1999). Poortwachters over immigranten : het debat over immigratie in het naoorlogse Groot-Brittannië en Nederland. Amsterdam: Het Spinhuis.

Schuyt, K. \& E. Taverne (2000). 1950. Welvaart in zwart-wit. Den Haag: Sdu.

Sewandono, I. (1998). Werknemersverkeer en gezinsleven. Deventer: Kluwer.

Snel, E. (2003). De vermeende kloof tussen culturen. Enschede: Universiteit Twente.

Snel, E. \& P. Scholten (2005). 'Integratie: van gastarbeiders tot het multicultureel drama'. In: M. Arentsen (Red.), Moderniteit en overheidsbeleid: hardnekkige beleidsproblemen en hun oorzaken, (155-183). Bussum: Coutinho.

Soysal, Y. (1994). Limits of citizenship. Migrants and postnational membership in Europe. Chicago (etc.): University of Chicago.

Spijkerboer, T. (2002). Discussiestuk. Het VN-Vrouwenverdrag en het Nederlandse vreemdelingenrecht. Bijlage 3 bij ACVZ-advies vN-vrouwenverdrag. TK 20022003, Just030524.

Spijkerboer, T.P. (2007). Zeker weten. Inburgering en de fundamenten van het Nederlandse politieke bestel. Den Haag: Sdu.

Steenbergen, J.D.M. (1989). 'Family life' en de Raad van State'. In: Migrantenrecht, 4 (2): 35-39. 
Steenbergen, J.D.M. (1990). 'De Raad van State en artikel 8 EVRM'. In: Migrantenrecht, 5 (1): 3-8.

Stoler, A. L. (2002). Carnal Knowledge and Imperial Power. Race and the Intimate in Colonial Rule. Berkeley (etc.) : University of California Press.

Streek, H. v. (1993). 'Moeder in het gezin. De invloed van opvattingen over vrouwen op beleid en samenleving'. In K. v. Kersbergen, H.-M. t. Napel \& P. Lucardie (Red.), Geloven in macht: de christen-democratie in Nederland, (187-208). Amsterdam: Het Spinhuis.

Swart, A. H. J. (1978). De toelating en uitzetting van vreemdelingen. Deventer: Kluwer.

Thränhardt, D. (2000). 'Conflict, Consensus, and Policy Outcomes: Immigration and Integration in Germany and The Netherlands'. In: P. J. Statham \& R. Koopmans (Red.), Challenging immigration and ethnic relations politics : comparative European perspectives, (162-186). New York: Oxford University Press.

Thränhardt, D. (2002). 'Einwanderungs- und Integrationspolitik in Deutschland und den Niederlanden'. In: Leviathan : Zeitschrift für Sozialwissenschaft, 30 (2): 220249.

Tielman, R. (1982). Homoseksualiteit in Nederland. Studie van een emancipatiebeweging. Amsterdam/Meppel: Boom.

Tinnemans, W. (1994). Een gouden armband: een geschiedenis van mediterrane immigranten in Nederland (1945-1994). Utrecht: NCB.

Toner, H. (2004). 'Partnership rights, migration and EC law'. In: T. Tridimas \& P. Nebbia (Red.), European Union Law for the Twenty-First Century. Rethinking the New Legal Order. Volume 2. Internal Market and Free Movement Community Policies, (349-370). Oxford \& Portland: Hart Publishing.

Tuskan, E. \& J. Vogel (2004). Lied uit den vreemde. Brieven en foto's van Turkse migranten, 1964-1975. Amsterdam: Aksant.

Uyl, A. d. (2007). 'Gezinsleven van vluchtelingen steeds meer in de knel'. In: Migrantenrecht, 22 (1-2): 7-11.

Vanvoorden, K. (2008). 'Betekenen de arresten Jia en Eind het einde van de Belgiëroute?' In: Migrantenrecht, 23 (3): 84-93.

Veen, R. v.d. (1999). 'De ontwikkeling en recente herziening van de Nederlandse verzorgingsstaat'. In: W. Trommel \& R. v.d. Veen (Red.), De herverdeelde samenleving. Ontwikkeling en herziening van de Nederlandse verzorgingsstaat, (23-47). Amsterdam: Amsterdam University Press.

Veenswijk, M. (1996). Departementale cultuur. IJzeren kooi, bron van versplintering of politiek werktuig? Delft: Eburon.

Verwey-Jonker Instituut (2004). Bruggen bouwen. Bronnenonderzoek Verwey-Jonker Instituut. Den Haag: Sdu. TK 2003-2004 28689 (11).

Vessem, I. v. (1986). 'Verlaging van de meerderjarigheidsgrens'. In: Migrantenrecht, 1 (9): 246.

Viet, V. (1998). La France immigrée. Construction d'une politique 1914-1997. Paris: Fayard.

Vink, M. (2007). 'Dutch 'Multiculturalism' Beyond the Pillarisation Myth'. In: Political Studies Review, 5 (3): 337-350.

Visscher, G. (1994). Parlementaire invloed op wetgeving. Inventarisatie en analyse van de invloed van de beide Kamers der Staten-Generaal op de wetgevende activiteiten van de kabinetten-Marijnen tot en met-Lubbers I. Den Haag: Sdu. 
Visser, J. \& A.C. Hemerijck (1998). Een Nederlands mirakel. Beleidsleren in de verzorgingsstaat. Amsterdam: Amsterdam University Press.

Vliegenthart, R. (2007). Framing immigration and integration: facts, parliament, media and anti-immigrant support in the Netherlands. Dissertatieserie. Amsterdam: Faculteit der Sociale Wetenchappen, Vrije Universiteit.

Vliegenthart, R., C. Roggeband \& H. Boomgaarden. (2008). 'Wie leidt en wie volgt? Invloedsrelaties tussen parlement en media in het Nederlandse integratiedebat'. In: Migrantenstudies, 24 (1): 23-39.

Voerman, G. \& P. Lucardie (1992). 'Ideologie en individualisering. De grondslagendiscussie bij CDA, PVdA en VVD'. In: Beleid en Maatschappij, 19 (1): 31-41.

Vreede-de Stuers, C. (1979). De vrouw onder de buitenlandse werknemers: een beschrijvende bibliografie. Amsterdam: Averroès Stichting.

Vuijsje, H. (1986). Vermoorde onschuld. Etnisch Verschil als Hollands taboe. Amsterdam: Uitgeverij Bert Bakker.

Walsum, S.K. v. (1997). 'Het machtskarakter van het cultuurdebat'. In: T.P. Spijkerboer \& S.K. v. Walsum (Red.), Grensoverschrijdingen. Opstellen over vreemdelingen en recht, (32-42). Utrecht: NCB.

Walsum, S.K. v. (1999). 'Gezinshereniging van twee kanten belicht - De feitelijke gezinsband onder de loep genomen (deel I)'. In: Migrantenrecht, 14 (6): 147-152.

Walsum, S.K. v. (2002). 'Transnationale gezinsbanden in een individualistisch tijdperk'. In: S. Grotenhuis, T. Knijn, T. Korver, E. Tonkens \& J. v.d. Zwaard (Red.), Hoeksteen of Zwerfkei. Het moderne gezin tussen individualisering en pedagogisering. Amsterdam: De Balie/NGR.

Walsum, S. v. (2004a). 'The Dynamics of Emancipation and Exclusion. Changing Family Norms and Dutch Family Migration Policies'. In: IMIS-Beiträge, (24): 119-128.

Walsum, S.K. v. (2004b). 'Recente ontwikkelingen - Vreemdelingenrecht en gezinsleven. Deel I: internationaal recht'. In: Migrantenrecht, 19 (4): 136-146.

Walsum, S.K. v. (2004c). 'Receptie jurisprudentie EHRM - Vreemdelingenrecht en gezinsleven. Deel II : nationaal recht'. In: Migrantenrecht, 19 (5): 180-190.

Walsum, S.K. v. (2004d). 'Noot bij Europees Hof voor de Rechten van de Mens 21 december 2001: Sen; Art. 8 EVRM'. In: T. P. Spijkerboer (Red.), Rechtspraak vreemdelingenrecht. Jurisprudentie 1974-2003, (124-126). Nijmegen: Ars Aequi Libri.

Walsum, S.K. v. (2005). 'Dutch rules on family regulation: restyling the Empire's old clothes'. Unpublished paper presented at the joint seminar of the Nijmegen/ vU research group on new approaches to immigration law, Bergen, 11 December 2005.

Walsum, S.K. v. (2008). The Family and the Nation. Dutch Family Migration Policies in the Context of Changing Family Norms. Newcastle Upon Tyne: Cambdridge Scholars Publishers.

Walsum, S.K. v. (te verschijnen). 'Transnational Mothering, National Immigration Policy, and European Law: The Experience of the Netherlands'. In: S. Benhabib \& J. Resnik (Red.), Migrations and Mobilities. Gender, Citizenship, Borders, (?). New York: New York University Press.

Walter, A. 2004. 'The New EC Directive on the Right to Family Reunification'. In: IMIS-Beiträge (24): 111-118.

Wansink, H.A. (2004). De erfenis van Fortuyn. De Nederlandse democratie na de opstand van de kiezers. Amsterdam: Meulenhoff. 
Wentholt, R. (1967a). 'Maatschappelijke achtergronden en factoren'. In: R. Wentholt (Red.), Buitenlandse arbeiders in Nederland. Een veelzijdige benadering van een complex vraagstuk, (83-115). Leiden: Spruyt, Van Mantgem \& De Does.

Wentholt, R. (1967b). 'Slotbeschouwing'. In: R. Wentholt (Red.), Buitenlandse arbeiders in Nederland. Een veelzijdige benadering van een complex vraagstuk, (185211). Leiden: Spruyt, Van Mantgem \& De Does.

Wetenschappelijke Raad voor het Regeringsbeleid (WRR) (1979). Etnische Minderheden. Rapport nr. 17. Den Haag: Staatsuitgeverij.

Wetenschappelijke Raad voor het Regeringsbeleid (WRR) (1989). Allochtonenbeleid. Rapport nr. 36. Den Haag: Sdu.

Wetenschappelijke Raad voor het Regeringsbeleid (WRR) (2001). Nederland als immigratiesamenleving. Rapport nr. 60. Den Haag: Sdu.

Willems, W. \& L. Lucassen (1990). Ongewenste vreemdelingen. Buitenlandse Zigeuners en de Nederlandse overheid: 1969-1989. Den Haag: Sdu.

Zanden, J.L. v. (1998). The Economic History of the Netherlands. A small open economy in the 'long' twentieth century. Londen/New York: Routledge.

Zijlstra, B. (1988). 'De $f$ 1445,- maatregel: sociologisch onderzoek en beleidsbepaling'. In: Migrantenstudies, 4 (4): 28-33.

Zwaan, J.W. d. \& A.J. Bultena. (2002). Ruimte van vrijheid, veiligheid en rechtvaardigheid. De samenwerking op het gebied van Justitie en Binnenlandse Zaken in de Europese Unie. Den Haag: Sdu. 



\section{Bijlagen}

\section{Kabinetten, betrokken bewindslieden en hervormingen gezinsmigratiebeleid, 1955-2005}

\begin{tabular}{|c|c|c|c|}
\hline & Kabinetten* & Betrokken bewindslieden* & Beleidswijzigingen \\
\hline 1952-1956 & $\begin{array}{l}\text { Kabinet Drees III: } \\
\text { PVdA, KVP, ARP, CHU }\end{array}$ & $\begin{array}{l}\text { Premier: Drees (PvdA) } \\
\text { Justitie: Donker (PvdA), } \\
\text { Beel (KVP),Van Oven (PvdA) } \\
\text { SoZa: } \text { Suurhoff (PvdA) } \\
\text { Stas SoZa: Van Rhijn (PvdA) } \\
\text { en Muntendam (PvdA) }\end{array}$ & $\begin{array}{l}\text { 1955: Gezinshereniging verboden } \\
\text { voor arbeidsmigranten. }\end{array}$ \\
\hline 1956-1958 & $\begin{array}{l}\text { Kabinet Drees IV } \\
\text { PVdA, KVP, ARP, CHU }\end{array}$ & $\begin{array}{l}\text { Premier: Drees (PvdA) } \\
\text { Justitie: } \text { Samkalden (PvdA) } \\
\text { SoZaV: Suurhoff (PvdA) } \\
\text { Stas SoZa: } \text { Van Rhijn (PvdA) } \\
\text { MaWe: Klompé (KVP) }\end{array}$ & \\
\hline 1958-1959 & $\begin{array}{l}\text { Kabinet Beel II } \\
\text { KVP, ARP, CHU }\end{array}$ & \begin{tabular}{|l|} 
Premier: Beel (KVP) \\
Justitie: Struycken (KVP) \\
SoZaV: Beel (KVP) \\
MaWe: Klompé (KVP) \\
\end{tabular} & \\
\hline $1959-1963$ & $\begin{array}{l}\text { Kabinet De Quay } \\
\text { KVP, VVD, ARP, CHU }\end{array}$ & $\begin{array}{l}\text { Premier: De Quay (KVP) } \\
\text { Justitie: } \text { Beerman (CHU) } \\
\text { SoZa: Van Rooy (KVP) } \\
\text { Stas SoZa: Roolvink (ARP) } \\
\text { MaWe: Klompé }\end{array}$ & $\begin{array}{l}\text { 1960: gezinshereniging toegestaan } \\
\text { voor EEG-burgers } \\
\text { 1961: gezinshereniging toegestaan } \\
\text { voor niet-EEG-burgers. } \\
\text { 1961: Wachttijd van } 2 \text { naar } 1 \text { jaar } \\
\text { voor EEG-burgers, en van } 3 \text { naar } 2 \\
\text { jaar voor niet-EEG-burgers. } \\
\text { 1962: kinderloze echtgenotes die } \\
\text { werkzaam zijn in sociale sector } \\
\text { vrijgesteld van wachttijd } \\
\text { 1963: kinderloze echtgenotes die } \\
\text { werkzaam zijn in sociale of winst- } \\
\text { gevende sector vrijgesteld van } \\
\text { wachttijd. } \\
\text { 1963: alle Spaanse echtgenotes die } \\
\text { zich op } 15 \text { juli in Nederland bevin- } \\
\text { den krijgen verblijfsvergunning }\end{array}$ \\
\hline
\end{tabular}




\begin{tabular}{|c|c|c|c|}
\hline & Kabinetten* & Betrokken bewindslieden* & Beleidswijzigingen \\
\hline 1963-1965 & $\begin{array}{l}\text { Kabinet Marijnen } \\
\text { KVP, VVD, ARP, CHU }\end{array}$ & $\begin{array}{l}\text { Premier: Marijnen (KVP) } \\
\text { Justitie: Scholten (CHU) } \\
\text { SoZa: Veldkamp (KVP) } \\
\text { Stas SoZa: Bartels en De } \\
\text { Meijer (KVP) } \\
\text { MaWe: Schouwenaar-Frans- } \\
\text { sen (VVD) }\end{array}$ & $\begin{array}{l}\text { 1964: wachttijd van } 2 \text { naar } 1 \text { jaar } \\
\text { voor Spanjaarden. } \\
\text { 1965: echtgenotes van arbeidsmi- } \\
\text { granten die zich op } 1 \text { januari in } \\
\text { Nederland bevinden en aan alle } \\
\text { voorwaarden voldoen behalve het } \\
\text { huisvestingsvereiste, krijgen ver- } \\
\text { blijfsvergunning } \\
\text { 1965: nieuwe Vreemdelingenwet } \\
\text { introduceert vestigingsvergunning } \\
\text { en '10-lid } 2 \text { status' }\end{array}$ \\
\hline $1965-1966$ & $\begin{array}{l}\text { Kabinet Cals } \\
\text { KVP, PVdA, ARP }\end{array}$ & $\begin{array}{l}\text { Premier: Cals (KVP) } \\
\text { Justitie: Samkalden (PvdA) } \\
\text { SoZa: Veldkamp (KVP) } \\
\text { Stas SoZa: Bartels en De } \\
\text { Meijer (KVP) } \\
\text { CRM: Vrolijk (PVdA) }\end{array}$ & $\begin{array}{l}\text { 1966: wachttijd van } 2 \text { naar } 1 \text { jaar } \\
\text { voor Grieken, Portugezen en } \\
\text { Turken }\end{array}$ \\
\hline $1966-1967$ & $\begin{array}{l}\text { Kabinet Zijlstra } \\
\text { KVP, ARP }\end{array}$ & $\begin{array}{l}\text { Premier: Zijlstra (ARP) } \\
\text { Justitie: Struycken (KVP) } \\
\text { SoZa: Veldkamp (KVP) } \\
\text { Stas SoZa: Bartels en De } \\
\text { Meijer (KVP) } \\
\text { CRM: Klompé (KVP) } \\
\end{array}$ & \\
\hline $1967-1971$ & $\begin{array}{l}\text { Kabinet De Jong } \\
\text { KVP, ARP, CHU, VVD }\end{array}$ & $\begin{array}{l}\text { Premier: De Jong (KVP) } \\
\text { Justitie: Polak (VVD) } \\
\text { SoZa: Roolvink (ARP) } \\
\text { Stas SoZa: Kruisinga (CHU) } \\
\text { CRM: Klompé (KVP) }\end{array}$ & $\begin{array}{l}\text { 1968: wachttijd afgeschaft voor } \\
\text { EEG-burgers } \\
\text { 1970: wachttijd van } 2 \text { naar } 1 \text { jaar } \\
\text { voor Joegoslaven en Marokkanen }\end{array}$ \\
\hline 1971-1972 & $\begin{array}{l}\text { Kabinet Biesheuvel I } \\
\text { KVP, ARP, CHU, VVD, } \\
\text { DS'70 }\end{array}$ & $\begin{array}{l}\text { Premier: } \text { Biesheuvel (ARP) } \\
\text { Stas Justitie: Grosheide } \\
\text { (ARP) } \\
\text { SoZa: } \text { Boersma (ARP) } \\
\text { Stas SoZa: Rietkerk (VVD) } \\
\text { CRM: Engels (KVP) }\end{array}$ & \\
\hline $1972-1973$ & $\begin{array}{l}\text { Kabinet Biesheuvel II } \\
\text { KVP, ARP, CHU, VVD }\end{array}$ & $\begin{array}{l}\text { Premier: } \text { Biesheuvel (ARP) } \\
\text { Stas Justitie: Grosheide } \\
\text { (ARP) } \\
\text { SoZa: Boersma (ARP) } \\
\text { Stas SoZa: Rietkerk (VVD) } \\
\text { CRM: Engels (KVP) }\end{array}$ & \\
\hline 1973-1977 & $\begin{array}{l}\text { Kabinet Den Uyl } \\
\text { PvdA, PPR, D66, KVP, ARP }\end{array}$ & $\begin{array}{l}\text { Premier: Den Uyl (PvdA) } \\
\text { Stas Justitie: Glastra van } \\
\text { Loon (D66), Zeevalking } \\
\text { (D66) } \\
\text { SoZa: Boersma (ARP) } \\
\text { Stas SoZa: Mertens (KVP) } \\
\text { CRM: Van Doorn (PPR) }\end{array}$ & $\begin{array}{l}\text { 1975: niet-huwelijkse homo- of } \\
\text { heteroseksuele relatie met Neder- } \\
\text { lands staatsburger als toelatings- } \\
\text { grond aanvaard } \\
\text { 1975: Nederlandse vrouw vrij- } \\
\text { gesteld van inkomensvereiste bij } \\
\text { overkomst buitenlandse gezinsle- } \\
\text { den, tenzij verwijtbaar werkloos } \\
\text { 1975: buitenlandse vrouw mag } \\
\text { gezinsleden laten overkomen }\end{array}$ \\
\hline
\end{tabular}




\begin{tabular}{|c|c|c|c|}
\hline & Kabinetten* & Betrokken bewindslieden* & Beleidswijzigingen \\
\hline 1977-1981 & $\begin{array}{l}\text { Kabinet Van Agt I } \\
\text { CDA, VVD }\end{array}$ & $\begin{array}{l}\text { Premier: Van Agt (CDA) } \\
\text { Stas Justitie: Haars (CDA) } \\
\text { BiZa: Wiegel (VVD) }\end{array}$ & $\begin{array}{l}\text { 1978: vluchtelingen en vestigings- } \\
\text { vergunninghouders vrijgesteld van } \\
\text { inkomenseis, tenzij verwijtbaar } \\
\text { werkloos. } \\
\text { 1978: vluchtelingen en vesti- } \\
\text { gingsvergunninghouders mogen } \\
\text { niet-huwelijkse partners laten } \\
\text { overkomen. } \\
\text { 1979: mannen en vrouwen formeel } \\
\text { gelijkgesteld in vreemdelingen- } \\
\text { recht (aanvullende eis } 1 \text { jaar huwe- } \\
\text { lijk voor buitenlandse vrouwen } \\
\text { afgeschaft) } \\
\text { 1979: gezinslid krijgt na } 3 \text { jaar } \\
\text { zelfstandig verblijfsrecht }\end{array}$ \\
\hline 1981-1982 & $\begin{array}{l}\text { Kabinet Van Agt II } \\
\text { CDA, PvdA, D66 }\end{array}$ & $\begin{array}{l}\text { Premier: Van Agt (CDA) } \\
\text { Stas Justitie: Scheltema } \\
\text { (D66) } \\
\text { BiZa: Van Thijn (PvdA) } \\
\end{array}$ & $\begin{array}{l}\text { 1982: zelfstandig verblijfsrecht na } \\
\text { drie jaar huwelijk en één jaar ver- } \\
\text { blijf, indien voldoende inkomen. }\end{array}$ \\
\hline 1982 & $\begin{array}{l}\text { Kabinet Van Agt III } \\
\text { CDA, D66 }\end{array}$ & $\begin{array}{l}\text { Premier: Van Agt (CDA) } \\
\text { Stas Justitie: Scheltema } \\
\text { (D66) } \\
\text { BiZa: Rood (D66) } \\
\end{array}$ & \\
\hline 1982-1986 & $\begin{array}{l}\text { Kabinet Lubbers I } \\
\text { CDA, VVD }\end{array}$ & $\begin{array}{l}\text { Premier: Lubbers (CDA) } \\
\text { Stas Justitie: Korte-van } \\
\text { Hemel (CDA) } \\
\text { BiZa: Rietkerk (VVD), Kort- } \\
\text { hals Altes (VvD), De Korte } \\
\text { (VvD) }\end{array}$ & $\begin{array}{l}\text { 1983: Inkomenseis van f. } 1445,- \\
\text { bij gezinshereniging door tweede } \\
\text { generatie migranten } \\
\text { 1985: } 1445 \text {-maatregel ingetrokken } \\
\text { 1986: criterium 'feitelijke gezins- } \\
\text { band' ingevoerd }\end{array}$ \\
\hline 1986-1989 & $\begin{array}{l}\text { Kabinet Lubbers II } \\
\text { CDA, VVD }\end{array}$ & $\begin{array}{l}\text { Premier: Lubbers (CDA) } \\
\text { Stas Justitie: Korte-van } \\
\text { Hemel (CDA) } \\
\text { BiZa: Van Dijk (CDA), } \\
\text { Koning (CDA) } \\
\end{array}$ & $\begin{array}{l}\text { 1988: meerderjarigheid van } 21 \\
\text { naar } 18 \text { jaar: maximumleeftijd voor } \\
\text { overkomst van buitenlandse kinde- } \\
\text { ren dus ook. }\end{array}$ \\
\hline 1989-1994 & $\begin{array}{l}\text { Kabinet Lubbers III } \\
\text { CDA, PvdA }\end{array}$ & $\begin{array}{l}\text { Premier: Lubbers (CDA) } \\
\text { Stas Justitie: Kosto (PvdA) } \\
\text { BiZa: Dales (PVdA), Hirsch } \\
\text { Ballin (CDA), Van Thijn } \\
\text { (PvdA), De Graaff-Nauta } \\
\text { (CDA) }\end{array}$ & $\begin{array}{l}\text { 1993: inkomensvereiste naar } 70 \% \\
\text { bijstandsnorm } \\
\text { 1993: bij gezinsvorming minimum- } \\
\text { leeftijd van } 18 \text { en minimumverblijf } \\
\text { van } 3 \text { jaar } \\
\text { 1993: Wet Voorkoming Schijnhu- } \\
\text { welijken } \\
\text { 1994: '10-lid 2'-status afgeschaft }\end{array}$ \\
\hline 1994-1998 & $\begin{array}{l}\text { Kabinet Kok I } \\
\text { PvdA, vVD, D66 }\end{array}$ & $\begin{array}{l}\text { Premier: Kok (PvdA) } \\
\text { Stas Justitie: } \text { Schmitz (PvdA) } \\
\text { BiZa: Dijkstal (VvD) }\end{array}$ & \\
\hline 1998-2002 & $\begin{array}{l}\text { Kabinet Kok II } \\
\text { PvdA, VVD, D66 }\end{array}$ & $\begin{array}{l}\text { Premier: Kok (PvdA) } \\
\text { Stas Justitie: Cohen (PvdA), } \\
\text { Kalsbeek (PvdA) } \\
\text { GSI: Van Boxtel (D66) }\end{array}$ & $\begin{array}{l}\text { 1998: mvv-verplichting aange- } \\
\text { scherpt } \\
\text { 2000: zelfstandig verblijfsrecht na } \\
\text { drie jaar verblijf en drie jaar huwe- } \\
\text { lijk (geen inkomenseis) } \\
\text { 2001: inkomensvereiste van } 70 \% \\
\text { naar } 100 \% \text { bijstandsnorm }\end{array}$ \\
\hline
\end{tabular}




\begin{tabular}{|l|l|l|l|}
\hline & Kabinetten* & Betrokken bewindslieden* & Beleidswijzigingen \\
\hline 2002-2003 & $\begin{array}{l}\text { Kabinet Balkenende I } \\
\text { CDA, VVD, LPF }\end{array}$ & $\begin{array}{l}\text { Premier: Balkenende (CDA) } \\
\text { VZI: Nawijn (LPF) }\end{array}$ & \\
\hline 2003-2006 & $\begin{array}{l}\text { Kabinet Balkenende II } \\
\text { CDA, VVD, D66 }\end{array}$ & $\begin{array}{l}\text { Premier: Balkenende (CDA) } \\
\text { VZI: Verdonk (VVD) }\end{array}$ & $\begin{array}{l}\text { 2004: bij gezinsvorming inkomens- } \\
\text { vereiste naar 120\% minimumloon, } \\
\text { en minimumleeftijd naar 21 jaar } \\
\mathbf{2 0 0 5 : ~ W e t ~ I n b u r g e r i n g ~ i n ~ h e t ~ B u i - ~} \\
\text { tenland } \\
\text { 2006: criterium 'feitelijke gezins- } \\
\text { band' afgeschaft }\end{array}$ \\
\hline
\end{tabular}

Stas $=$ staatssecretaris

soza $=$ Sociale Zaken

sozav = Sociale Zaken en Volksgezondheid

Mawe $=$ Maatschappelijk Werk

CRM $=$ Cultuur, Recreatie en Maatschappelijk Werk

Biza $=$ Binnenlandse Zaken

GSI $=$ Grote Steden- en Integratiebeleid

$\mathrm{VZI}=$ Vreemdelingenzaken en Integratie

* Bron: 'Parlement en Politiek', website onder redactie van het Parlementair Documentatiecentrum van de Universiteit Leiden, in samenwerking met het Documentatiecentrum Nederlandse Politieke Partijen (DNPP) van de Rijksuniversteit Groningen en het Centrum voor Parlementaire Geschiedenis (CPG) van de Radboud Universiteit Nijmegen. (www.parlement.com) 


\section{Bevolking van Nederland naar nationaliteit en herkomstgroepering, 1955-2007}

\begin{tabular}{|c|c|c|c|c|c|c|c|c|c|c|c|c|}
\hline \multicolumn{13}{|c|}{ Bevolking van Nederland op 1 januari $(x$ 1000) } \\
\hline \multirow[b]{2}{*}{ Totale bevolking } & 1955 & 1960 & 1965 & 1970 & 1975 & 1980 & 1985 & 1990 & 1995 & 2000 & 2005 & 2007 \\
\hline & 10680 & 11417 & 12212 & 12958 & 13599 & 14091 & 14454 & 14893 & 15424 & 15864 & 16306 & 16358 \\
\hline \multicolumn{13}{|l|}{ Naar nationaliteit* } \\
\hline Totaal niet-Nederlands & . & 107 & 142.5 & 212.1 & 316.3 & 473.4 & 558.7 & 641.9 & 757.1 & 651.5 & 699.4 & 681.9 \\
\hline Belgisch & 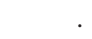 & 20.2 & 20.4 & 20.2 & 20.7 & 23 & 23.6 & 23.3 & 24.1 & 25.4 & 26.1 & 26 \\
\hline Duits & . & 25.4 & 25.9 & 31.3 & 40.1 & 42.7 & 44.8 & 41.8 & 53.4 & 54.3 & 57.1 & 60.2 \\
\hline Italiaans & . & 5.2 & 11.4 & 16.3 & 19.7 & 20.9 & 20.3 & 16.7 & 17.5 & 17.9 & 18.4 & 18.6 \\
\hline Voorm. Joegoslavisch & . & 0.9 & 1.3 & 4.3 & 12.9 & 13.7 & 12.2 & 12.8 & 29.9 & 15.6 & 11.1 & 10 \\
\hline Marokkaans & . & 0.1 & 1.7 & 17.4 & 33.2 & 71.8 & 111.3 & 148 & 158.7 & 119.7 & 91.6 & 80.5 \\
\hline Spaans & . & 0.3 & 13.1 & 22.6 & 31.3 & 23.5 & 20.7 & 17.4 & 16.8 & 16.9 & 17.1 & 16.5 \\
\hline Turks & . & 0.1 & 4.3 & 23.6 & 62.6 & 119.6 & 155.6 & 191.5 & 182.1 & 100.7 & 100.6 & 96.8 \\
\hline Brits & & 5.7 & 7.9 & 9.8 & 19.5 & 35.4 & 40.7 & 37.5 & 43 & 39.5 & 42.5 & 40.3 \\
\hline Amerikaans & & 4.2 & 6.5 & 7.4 & 9.6 & 10.7 & 10.4 & 10.5 & 12.8 & 14.1 & 14.8 & 14.6 \\
\hline \multicolumn{13}{|c|}{ Naar herkomstgroepering** } \\
\hline Suriname & . & . & . & . & 79.2 & 145.7 & 181.4 & 219.0 & 276.0 & 302.5 & 329.4 & 333.5 \\
\hline Nederlandse Antillen & . & . & . & . & 23.9 & 36.2 & 46.2 & 71.2 & 86.2 & 107.2 & 130.5 & 130.0 \\
\hline
\end{tabular}

* De gegevens van de jaren 1969 tot 1973 zijn gedeeltelijk geschat. De gegevens over de jaren 1956 tot 1969 en 1973 tot 1976 zijn afkomstig van het Ministerie van Justitie.

Nationaliteit: Het wettelijk onderdaan zijn van een bepaalde staat staatsburgerschap. Personen kunnen meerdere nationaliteiten hebben. Om dubbeltellingen te voorkomen wordt in statistische overzichten aan personen die meerdere nationaliteiten hebben, slechts één nationaliteit toegekend. Daartoe worden prioriteringsregels gesteld. Die komen erop neer dat iemand met de Nederlandse nationaliteit in de statistiek steeds Nederlander is. Voor mensen die niet de Nederlandse nationaliteit bezitten, geldt de volgorde: nationaliteit van één van de Benelux-landen, nationaliteit van een staat binnen de Europese Unie, andere Europese nationaliteit, niet-Europese nationaliteit. Personen die geen nationaliteit hebben, zijn staatloos.

**Herkomstgroepering: Kenmerk dat weergeeft met welk land een persoon verbonden is op basis van het geboorteland van de ouders of van zichzelf.

Voor de periode tot en met 1994 geldt: In Suriname of op de Nederlandse Antillen (inclusief Aruba) geboren personen en de in Nederland geboren kinderen uit een in Suriname of op Nederlandse Antillen (inclusief Aruba) geboren moeder. Deze gegevens zijn gedeeltelijk geschat.

Vanaf 1995 geldt: persoon van wie ten minste één ouder in het buitenland is geboren.

Bron: Website van het CBS, Historie bevolking, huishoudens en bevolkingsontwikkeling (http://statline.cbs.nl). 


\section{Buitenlandse immigratie per jaar naar nationaliteit, geboorteland en herkomst- land, 1950-2005}

\begin{tabular}{|c|c|c|c|c|c|c|c|c|c|c|c|c|}
\hline $\begin{array}{l}\text { Buitenlandse immigratie* } \\
\text { per jaar }(x \text { 1000) }\end{array}$ & 1950 & 1955 & 1960 & 1965 & 1970 & 1975 & 1980 & 1985 & 1990 & 1995 & 2000 & 2005 \\
\hline Totaal immigratie & 70.6 & 52.1 & 45.4 & 76.6 & 90.8 & 127.3 & 112.5 & 79.4 & 117.4 & 96.1 & 132.9 & 92.3 \\
\hline $\begin{array}{l}\text { Naar nationaliteit } \\
\text { Nederlands } \\
\text { Totaal niet-Nederlands } \\
\text { Europese Unie (excl. Nederland) } \\
\text { Marokkaans } \\
\text { Turks }\end{array}$ & $\begin{array}{r}64.8 \\
5.8\end{array}$ & $\begin{array}{r}44 \\
8.1\end{array}$ & $\begin{array}{r}32.3 \\
13.1 \\
5.8\end{array}$ & $\begin{array}{r}30.8 \\
45.8 \\
7.7 \\
5.3 \\
5.4 \\
\end{array}$ & $\begin{array}{r}38.8 \\
52.1 \\
8.7 \\
5.9 \\
9 \\
\end{array}$ & $\begin{array}{r}72 \\
55.2 \\
16 \\
7.9 \\
12.7 \\
\end{array}$ & $\begin{array}{l}32.7 \\
79.8 \\
16.2 \\
10.4 \\
17.5 \\
\end{array}$ & $\begin{array}{r}33.2 \\
46.2 \\
13 \\
5.8 \\
6 \\
\end{array}$ & $\begin{array}{r}36.1 \\
81.3 \\
17.8 \\
9.8 \\
12.8 \\
\end{array}$ & $\begin{array}{r}29.1 \\
67 \\
14.8 \\
3.1 \\
4.8 \\
\end{array}$ & $\begin{array}{r}41.5 \\
91.4 \\
22.1 \\
4.2 \\
4.5 \\
\end{array}$ & $\begin{array}{r}28.9 \\
63.4 \\
26.6 \\
2.1 \\
3.1 \\
\end{array}$ \\
\hline $\begin{array}{l}\text { Naar geboorteland } \\
\text { Nederland } \\
\text { Europese Unie (excl. Nederland) } \\
\text { Indonesië } \\
\text { Suriname } \\
\text { Nederlandse Antillen } \\
\text { Marokko } \\
\text { Turkije } \\
\text { Specifieke emigratiegebieden } * * \\
\end{array}$ & $\cdot$ & $\begin{array}{r}19.6 \\
20.4\end{array}$ & 20.5 & 20.7 & $\begin{array}{r}24.5 \\
10.1 \\
2.8 \\
. \\
. \\
6 \\
9 \\
.\end{array}$ & $\begin{array}{r}25.7 \\
15.9 \\
2.8 \\
38 \\
2.5 \\
7.9 \\
12.6 \\
5.1 \\
\end{array}$ & \begin{tabular}{r|}
22.3 \\
16.1 \\
3 \\
18.3 \\
4.5 \\
10.4 \\
17.1 \\
3.8 \\
\end{tabular} & $\begin{array}{r}22.2 \\
13.6 \\
1.7 \\
5 \\
5 \\
5.7 \\
5.6 \\
3.8 \\
\end{array}$ & $\begin{array}{r}23.5 \\
18.2 \\
2 \\
8.1 \\
6.8 \\
9.6 \\
12.1 \\
4.7 \\
\end{array}$ & $\begin{array}{r}21.4 \\
16.1 \\
1.2 \\
2.6 \\
3.3 \\
3.2 \\
4.7 \\
4.2 \\
\end{array}$ & $\begin{array}{r}23.8 \\
21.8 \\
1.9 \\
3.6 \\
10.2 \\
4.5 \\
5.4 \\
6.9 \\
\end{array}$ & $\begin{array}{r}20.2 \\
26.3 \\
1.4 \\
2.2 \\
2.4 \\
2.4 \\
3.4 \\
5.1 \\
\end{array}$ \\
\hline $\begin{array}{l}\text { Naar land van herkomst } \\
\text { Europese Unie (excl. Nederland) } \\
\text { Indonesië } \\
\text { Suriname } \\
\text { Nederlandse Antillen } \\
\text { Marokko } \\
\text { Turkije } \\
\text { Specifieke emigratiegebieden** }\end{array}$ & $\begin{array}{r}56.1 \\
0.5 \\
1.2\end{array}$ & $\begin{array}{r}26 \\
1 \\
2.6\end{array}$ & $\begin{array}{r}14.1 \\
8.1 \\
1.4 \\
3.1\end{array}$ & $\begin{array}{r}36.1 \\
5.3 \\
3.1 \\
4.1 \\
4.1 \\
3.8 \\
10.3\end{array}$ & $\begin{array}{r}36.5 \\
1.6 \\
7.4 \\
3.8 \\
4.1 \\
8.4 \\
12.6\end{array}$ & $\begin{array}{r}32.9 \\
1.8 \\
39.7 \\
4.1 \\
7.8 \\
12.6 \\
10.2\end{array}$ & $\begin{array}{r}29.6 \\
2.6 \\
19 \\
5.5 \\
10.4 \\
17.4 \\
7.7\end{array}$ & $\begin{array}{r}25.2 \\
1.4 \\
5.3 \\
6.6 \\
5.8 \\
5.9 \\
8.1\end{array}$ & $\begin{array}{r}31.9 \\
1.8 \\
8.4 \\
8.2 \\
9.5 \\
12.8 \\
9.2 \\
\end{array}$ & $\begin{array}{r}29.1 \\
1.1 \\
2.7 \\
5.1 \\
3.2 \\
5.3 \\
7.5\end{array}$ & $\begin{array}{r}35.8 \\
1.8 \\
3.4 \\
13.1 \\
4.4 \\
5.8 \\
10.6\end{array}$ & $\begin{array}{r}41.3 \\
1.3 \\
2.1 \\
4.4 \\
2.4 \\
3.6 \\
7.8 \\
\end{array}$ \\
\hline
\end{tabular}

* Buitenlandse immigratie: Vestiging van personen vanuit het buitenland in Nederland. Om als immigrant te kunnen worden geteld dienen deze personen ingeschreven te worden in de gemeentelijke bevolkingsregisters.

** Specifieke emigratiegebieden: Totaal immigratie van personen afkomstig uit Australië, Canada, Nieuw-Zeeland, Republiek van Zuid-Afrika of de Verenigde Staten van Amerika.

Bron: Website van het CBS, Historie bevolking, huishoudens en bevolkingsontwikkeling (http://statline.cbs.nl). 


\section{Index van namen}

Agt, Dries van 135, 163

Akel, Ilhan 249

Albayrak, Nebahat 230, 268

Albeda, Wil 195

Amersfoort, Hans van 136

Ancona, Hedy d' 149

Andriessen, Koos 83

Apostolou, Thanasis 201, 209, 210, 222, 223, 268

Baeten, Fons 70, 82

Beckers-de Bruijn, Ria 150, 155, 156

Beerman, Albert 68, 70, 81, 94, 95

Berkhouwer, Cees 80

Bolkestein, Frits 193, 241

Boxtel, Roger van 242, 247-249, 252-254, 257, 262

Brinkman, Elco 201

Broek, Hans van den 147, 152

Brouwer, Tiemen 70

Buikema, Jan 157, 158, 160

Buurmeijer, Flip 156

Cohen, Job 224, 226, 228, 230233, 235, 247, 286

Corver, Han 71

Dales, Ien 204, 205, 207, 208

Dijkstal, Hans 218

Doorn, Harry van 148

Entzinger, Han 136

Es, Andrée van 160

Fortuyn, Pim 15, 184, 241-243, 254

Gaay Fortman, Wilhelm de 150

Glastra van Loon, Jan 60, 91, 114, 116-119, 121-123, 125, 128, 179,306

Glimmerveen, Joop 112

Grosheide, Hans 87, 91, 306
Haars, Bert 142, 146, 150, 155, 157, 163

Haas-Berger, Ineke 150, 152, 156, 164,170

Halsema, Femke 228

Hermsen, Ben 93

Hirsch Ballin, Ernst 201-206, 237

Hoop Scheffer, Jaap de 216, 262

Jabaaij, Wijnie 174

Janmaat, Hans 138, 176, 210, 238

Kalsbeek, Ella 249, 251-254, 262, 268, 269, 278

Kamp, Henk 232, 233, 252, 279

Kappeyne van de Coppello, Annelien 147

Klompé, Marga 89

Kok, Wim 196, 205, 206, 211, 242

Korte-van Hemel, Virginie 160, 171, 173-176

Kosto, Aad 187, 201-203, 205, 207-214, 217, 234

Krajenbrink, Jan 174, 210

Lubbers, Ruud 196, 205-208, 211

Maarseveen, Johannes van 94

Maenen, Jan 70

Marijnen, Victor 72

Meijer, José de 72

Mertens, Jan 135

Molleman, Henk 137, 141, 193

Nawijn, Hilbrand 233

Nijpels, Ed 157

Penninx, Rinus 136

Pinto, David 193

Polak, Carel 74, 87-89, 119

Quay, Jan de 81

Rabbae, Mohamed 222

Rijpstra, Jan 229, 221-223, 228

Ritzen, Jo 209 
Roolvink, Bauke 69, 73, 81, 87

Rosenmöller, Paul 210

Samkalden, Ivo 73, 120

Scheffer, Paul 241, 242

Scheltema, Michiel 158-160, 170

Schmitz, Elisabeth 216-218, 220222, 230, 235, 236, 268

Scholten, Ynso 72

Schwarz, Bert 135

Sipkes, Leoni 234

Spijkerboer, Thomas 235

Sterk, Mirjam 261, 263, 265

Stoléru, Lionel 316

Suurhoff, Ko 64

Veld, Elske ter 205

Veldkamp, Gerard 71-73

Verdonk, Rita 236, 257-259, 261, 262, 264-266, 271, 272, 278, 286

Verhagen, Maxime 216, 218, 221223, 228

Visser, Arno 261

Wentholt, Rob 58, 78, 98, 99

Wessel-Tuinstra, Elida 156, 159

Wiebenga, Jan-Kees 174, 212

Wiegel, Hans 137, 163

Wijn, Joop 228, 232, 249, 252, 253

Wolffensperger, Gerrit Jan 215

Zeevalking, Henk 132

Zwanikken, Johan 70 


\section{Over de auteur}

Saskia Bonjour is geboren op 26 juni 1980 in Mauguio, aan de Franse kust. Haar vwo-diploma behaalde ze in juni 1998 aan het St.-Willibrord Gymnasium in Deurne. Ze studeerde cultuur- en wetenschapsstudies aan de Faculteit der Cultuurwetenschappen van de Universiteit Maastricht. Als onderdeel van haar specialisatie in politieke cultuur studeerde ze een jaar aan het Institut d'Etudes Politiques in Grenoble en liep ze vier maanden stage bij de Adviesraad Internationale Vraagstukken in Den Haag. Ze studeerde in januari 2004 cum laude af. Haar doctoraalscriptie, Paradoxale ambities. De totstandkoming van het werkprogramma voor het Europees asiel- en migratiebeleid, 1996-1999, is beloond met de Scriptieprijs 2005 van de Universiteit Maastricht.

Van februari 2004 tot september 2008 was Saskia Bonjour als promovendus aangesteld bij de capaciteitsgroep geschiedenis van de faculteit die inmiddels was omgedoopt tot Faculteit der Cultuur- en Maatschappijwetenschappen van de Universiteit Maastricht, en bij het Duitsland Instituut Amsterdam. Van september 2008 tot mei 2009 was ze werkzaam bij het International Center for Migration Policy Development in Wenen. Sinds mei 2009 werkt ze als onderzoeker bij de Université Libre de Bruxelles. 
